The Urban Book Series

Daniel Baldwin Hess. Tiit Tammaru Maarten van Ham Editors
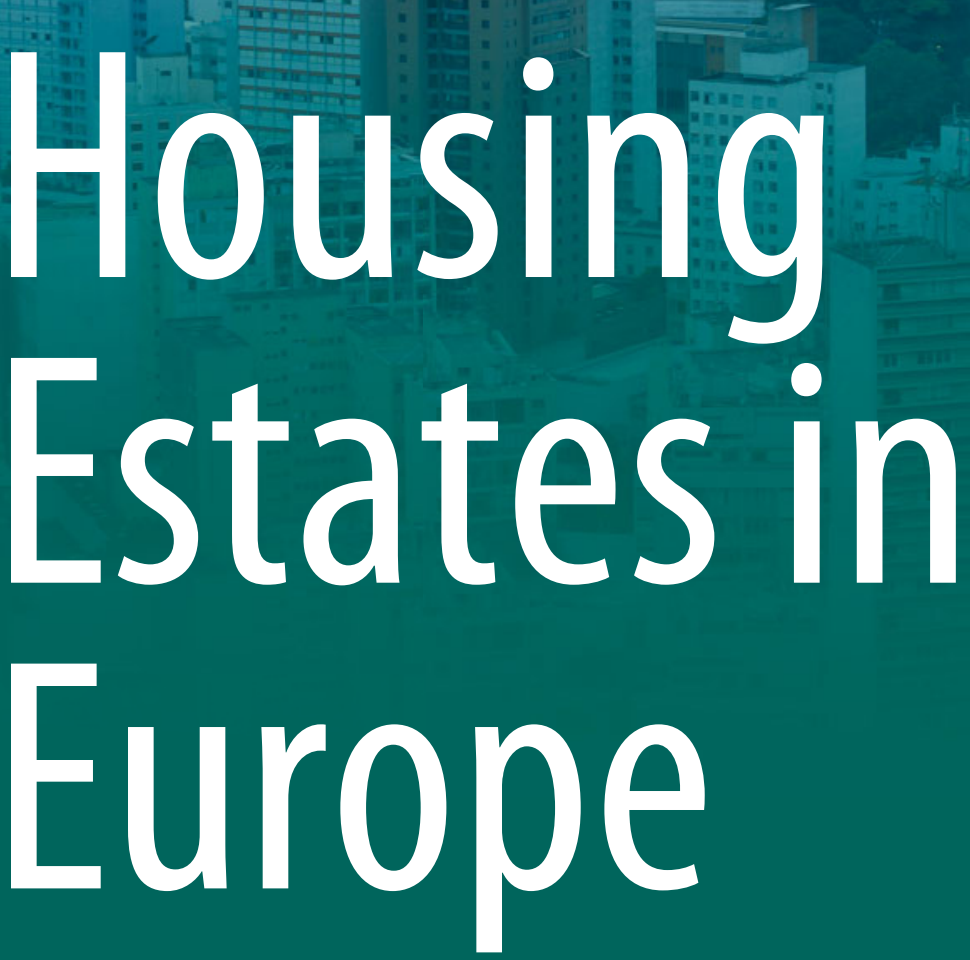

Poverty, Ethnic Segregation and Policy Challenges

Springer Open 


\section{The Urban Book Series}

\section{Series Advisory Editors}

Fatemeh Farnaz Arefian, University College London, London, UK Michael Batty, University College London, London, UK

Simin Davoudi, Newcastle University, Newcastle, UK

Geoffrey DeVerteuil, Cardiff University, Cardiff, UK

Karl Kropf, Oxford Brookes University, Oxford, UK

Marco Maretto, University of Parma, Parma, Italy

Vítor Oliveira, Porto University, Porto, Portugal

Christopher Silver, University of Florida, Gainesville, USA

Giuseppe Strappa, Sapienza University of Rome, Rome, Italy

Igor Vojnovic, Michigan State University, East Lansing, USA

Jeremy Whitehand, University of Birmingham, Birmingham, UK 


\begin{abstract}
Aims and Scope
The Urban Book Series is a resource for urban studies and geography research worldwide. It provides a unique and innovative resource for the latest developments in the field, nurturing a comprehensive and encompassing publication venue for urban studies, urban geography, planning and regional development.

The series publishes peer-reviewed volumes related to urbanization, sustainability, urban environments, sustainable urbanism, governance, globalization, urban and sustainable development, spatial and area studies, urban management, urban infrastructure, urban dynamics, green cities and urban landscapes. It also invites research which documents urbanization processes and urban dynamics on a national, regional and local level, welcoming case studies, as well as comparative and applied research.

The series will appeal to urbanists, geographers, planners, engineers, architects, policy makers, and to all of those interested in a wide-ranging overview of contemporary urban studies and innovations in the field. It accepts monographs, edited volumes and textbooks.
\end{abstract}

More information about this series at http://www.springer.com/series/14773 
Daniel Baldwin Hess · Tiit Tammaru

Maarten van Ham

Editors

\section{Housing Estates in Europe}

Poverty, Ethnic Segregation and Policy

Challenges

照 Springer Open 


\section{Editors}

Daniel Baldwin Hess

Department of Urban and Regional Planning,

School of Architecture and Planning

University at Buffalo, State University of New York

Buffalo, NY

USA

\section{Tiit Tammaru}

Department of Geography,

Centre for Migration and Urban Studies

University of Tartu

Tartu

Estonia

and

OTB - Research for the Built Environment

Delft University of Technology

Delft, Zuid-Holland

The Netherlands
Maarten van Ham

OTB-Research for the Built Environment

Delft University of Technology

Delft, Zuid-Holland

The Netherlands

and

School of Geography and Sustainable

Development

University of St Andrews

St Andrews

UK

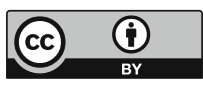

ISSN 2365-757X

The Urban Book Series

ISBN 978-3-319-92812-8

https://doi.org/10.1007/978-3-319-92813-5

Library of Congress Control Number: 2018943382
ISSN 2365-7588 (electronic)

ISBN 978-3-319-92813-5 (eBook)

(C) The Editor(s) (if applicable) and The Author(s) 2018. This book is an open access publication.

Open Access This book is licensed under the terms of the Creative Commons Attribution 4.0 International License (http://creativecommons.org/licenses/by/4.0/), which permits use, sharing, adaptation, distribution and reproduction in any medium or format, as long as you give appropriate credit to the original author(s) and the source, provide a link to the Creative Commons license and indicate if changes were made.

The images or other third party material in this book are included in the book's Creative Commons license, unless indicated otherwise in a credit line to the material. If material is not included in the book's Creative Commons license and your intended use is not permitted by statutory regulation or exceeds the permitted use, you will need to obtain permission directly from the copyright holder.

The use of general descriptive names, registered names, trademarks, service marks, etc. in this publication does not imply, even in the absence of a specific statement, that such names are exempt from the relevant protective laws and regulations and therefore free for general use.

The publisher, the authors, and the editors are safe to assume that the advice and information in this book are believed to be true and accurate at the date of publication. Neither the publisher nor the authors or the editors give a warranty, express or implied, with respect to the material contained herein or for any errors or omissions that may have been made. The publisher remains neutral with regard to jurisdictional claims in published maps and institutional affiliations.

This Springer imprint is published by the registered company Springer Nature Switzerland AG

The registered company address is: Gewerbestrasse 11, 6330 Cham, Switzerland 
We dedicate this book to our patient and loving spouses-Alex, Kaidi, and Peteke. We also dedicate our work to those who designed, constructed, and have resided in Europe's vast collection of housing estates. From them we have learned much about communal living, urban progress, and social change. 


\section{Preface}

Our scholarly engagement with housing estates began in 2012, when we first talked in depth about planned residential districts and their place and function in cityscapes in Europe and, following two decades in the post-transition era, in Estonia, our research home base. A successful application for a Marie Skłodowska-Curie international fellowship funded Daniel Hess' academic stay at the University of Tartu (during 2016 and 2017) and sponsored a collaborative research programme with Tiit Tammaru, who already worked with Maarten van Ham on the ERC funded DEPRIVEDHOODS project. During the course of the fellowship, various publications were produced that dealt centrally with modernist housing estates, with topics ranging from the historical evolution of housing estates, ambitions for transport and access components of housing estates, and outcomes of housing estate renovation programmes and social and ethnic segregation. We were joined at the University of Tartu by Coline Dalimier, from Lille University 1 in France, a motivated student who participated in an internship with us in Estonia as part of her master's degree studies. She delivered a seminar to the research group in April 2016 about the evolution and afterlife of housing estates in France. This presentation inspired us to think more deeply about comparing the condition of housing estates across various urban centres in Europe, and thus the idea for the book was born.

As we proceeded working on this book, tragedy struck in June 2017 when the Grenfell Tower in a London housing estate caught fire killing 71 people, and only a few months earlier, officials in Moscow had announced large-scale demolition of Soviet-time khrushchëvka apartment buildings, resulting in a projected loss of 10 percent of the urban housing stock. But we also knew that various other newsworthy events were linked with housing estates in Europe over the last 2 decades, including a series of riots in 2015 in the banlieues of Paris. In reaction, local and state governments in Paris (and in other cities and countries) have poured billions of euros into renovation programmes. Through our work on this book, we therefore seized the opportunity to assess the current status of housing estates - and to measure changes since 1990 - in their physical condition and social status. We especially wanted to characterise the trajectory of housing estates in various national settings and in various conditions related to their establishment in the 
decades following World War II. This book thus offers a timely overview of the current status of large housing estates in Europe, their trajectories and future outlook, which we have summarised in ten takeaway lessons.

The book would not have been possible without contributions from author teams from Athens, Berlin, Birmingham, Brussels, Bucharest, Budapest, Helsinki, Madrid, Milan, Moscow, Paris, Prague, Stockholm and Tallinn, along with two key subject-area specialists. We are indebted to Annika Väiko for her expert assistance and endless patience in preparing the final manuscript and Alex Bitterman, Susan June, Brendan Seney and Diane Ivancic for editing. Our research approach was developed through conversations with Kadri Leetmaa, Anneli Kährik, Petra Špačková and Coline Dalimier. Our progress benefitted from presentations of work-in-progress by the co-editors at the Seventh International Urban Geographies of Post-Communist States Conference (in Kiev, Ukraine, September 2017), the Dorpater Dozentenabend Lecture Series at the University of Tartu (in Tartu, Estonia, December 2017) and presentations in Helsinki linked to the URMI project, and presentations at Delft University of Technology as part of Tiit Tammaru's Visiting Professorship. During the effort to produce this edited volume, Daniel Hess was Visiting Scholar and Director in the Centre for Migration and Urban Studies, University of Tartu.

The research leading to this work has received funding from the European Union's Horizon 2020 research and innovation programme under Marie Skłodowska-Curie grant agreement number 655601. Support also came from three grants from the Estonian Research Council: Institutional Research Grant IUT2-17 on Spatial Population Mobility and Geographical Changes in Urban Regions, Infotechnological Mobility Observatory, and RITA-Ränne. The European Research Council funded this research under the European Union's Seventh Framework Programme (FP/2007-2013)/ERC [Grant Agreement No. 615159] (ERC Consolidator Grant DEPRIVEDHOODS, Socio-spatial inequality, deprived neighbourhoods and neighbourhood effects). Delft University of Technology University supported this research through the Visiting Professors programme of the Faculty of Architecture and the Built Environment.

Buffalo, NY, USA

Tartu, Estonia/Delft, The Netherlands

Delft, The Netherlands/St Andrews, UK

April 2018
Daniel Baldwin Hess Tiit Tammaru Maarten van Ham 


\section{Contents}

\section{Part I Introduction}

1 Lessons Learned from a Pan-European Study of Large Housing Estates: Origin, Trajectories of Change and Future Prospects .

Daniel Baldwin Hess, Tiit Tammaru and Maarten van Ham

\section{Part II Thematic Lenses for Scholarly Inquiry}

2 Beyond an Ugly Appearance: Understanding the Physical Design and Built Environment of Large Housing Estates . . . . . . . . . . 35 Frank Wassenberg

3 Who Is to Blame for the Decline of Large Housing Estates? An Exploration of Socio-Demographic and Ethnic Change . . . . . . 57 Gideon Bolt

Part III Case Studies of Housing Estates in European Metropolitan Areas

4 Exceptional Social Housing in a Residual Welfare State: Housing Estates in Athens, Greece . . . . . . . . . . . . . . . . . . . . . . George Kandylis, Thomas Maloutas and Nikolina Myofa

$5 \quad$ Large Housing Estates of Berlin, Germany. Florian Urban

6 Decline and Response? Lifecycle Change and Housing Estates in Birmingham, England.

Alan Murie

7 Sprouted All Around: The Emergence and Evolution of Housing Estates in Brussels, Belgium

Rafael Costa and Helga de Valk 
8 The Many (Still) Functional Housing Estates of Bucharest, Romania: A Viable Housing Provider in Europe's Densest Capital City

Vera Marin and Liviu Chelcea

9 Persistence or Change: Divergent Trajectories of Large Housing Estates in Budapest, Hungary .

Zoltán Kovács, Tamás Egedy and Balázs Szabó

10 Experience of a Preventive Experiment: Spatial Social Mixing in Post-World War II Housing Estates in Helsinki, Finland

Mari Vaattovaara, Anssi Joutsiniemi, Matti Kortteinen,

Mats Stjernberg and Teemu Kemppainen

11 The Diversity of Trajectories of Large Housing Estates in Madrid, Spain .

Pedro Uceda, Daniel Sorando and Jesús Leal

12 Social and Ethnic Transformation of Large Social Housing

Estates in Milan, Italy: From Modernity to Marginalisation . . . . . 265

Petros Petsimeris

13 Path-Dependent Development of Mass Housing

in Moscow, Russia . . . . . . . . . . . . . . . . . . . . . . . . . . . . . . 289

Maria Gunko, Polina Bogacheva, Andrey Medvedev

and Ilya Kashnitsky

14 Impoverishment and Social Fragmentation in Housing Estates of the Paris Region, France.

Christine Lelévrier and Talia Melic

15 Long-term Development and Current Socio-Spatial Differentiation of Housing Estates in Prague, Czechia

Martin Ouředníček, Petra Špačková and Lucie Pospíšilová

16 The Stockholm Estates-A Tale of the Importance of Initial Conditions, Macroeconomic Dependencies, Tenure and Immigration

Roger Andersson and Åsa Bråmå

17 Population Shifts and Urban Policies in Housing Estates

of Tallinn, Estonia.

Kadri Leetmaa, Johanna Holvandus, Kadi Mägi and Anneli Kährik

Index 


\section{Editors and Contributors}

\section{About the Editors}

Daniel Baldwin Hess is Professor and Chairperson of the Department of Urban and Regional Planning in the School of Architecture and Planning at the University at Buffalo, State University of New York. He earned a doctoral degree in urban planning from the University of California, Los Angeles. While this book was in progress, he was Visiting Scholar and Director of the Centre for Migration and Urban Studies at the University of Tartu, Estonia, where he was a Marie Skłodowska-Curie International Fellow funded by the European Commission. His research addresses interactions between housing, transportation, land use and other public concerns, and he develops new pathways for understanding the complex socio-economic and ethnic landscape of cities and spatial inequalities. In his scholarship, he explores metropolitan form and urban planning practice and policy, sometimes interactively and sometimes separately, but always as a means to improve city functions and urban life. He is a former Fulbright Scholar at Tallinn University of Technology in Estonia, a National Endowment for the Humanities Fellow at Columbia University, and winner of an Eisenhower Fellowship.

Tiit Tammaru is Professor of Urban and Population Geography in the Department of Geography, University of Tartu. He leads the development of longitudinal linked censuses and registers data for urban and population geographic studies in Estonia. He was trained in human geography and received a doctoral degree from the University of Tartu in 2001. Since then, he has worked as a Lecturer, Researcher, Senior Researcher and Professor at the Department of Geography, University of Tartu. He has also worked as a Guest Researcher at the Department of Geography, University of Utah, and Department of Geography, Umeå University. Currently, he is a Visiting Professor at the Neighbourhood Change and Housing research group at the Department OTB - Research for the Built Environment, Faculty of Architecture and the Built Environment, Delft University of Technology. 
Maarten van Ham is Professor of Urban Renewal at Delft University of Technology in the Netherlands, and Professor of Geography at the University of St Andrews in the UK. In Delft, he is Head of the Urban and Neighbourhood Change research group at the Department OTB-Research for the Built Environment, Faculty of Architecture and the Built Environment. He studied economic geography at Utrecht University, where he obtained his Ph.D. with honours in 2002. In 2011, he was appointed Full Professor in both St Andrews and Delft. He has published over 80 academic papers and 8 edited books. He is a highly cited academic with research projects in the UK, the Netherlands, Germany, Sweden, Lithuania, Estonia, Spain and China. He has expertise in the fields of urban poverty and inequality, segregation, residential mobility and migration; neighbourhood effects; urban and neighbourhood change; housing market behaviour and housing choice; geography of labour markets; spatial mismatch of workers and employment opportunities. In 2014, he was awarded a 2 million Euro ERC Consolidator Grant for a 5-year research project on neighbourhood effects (DEPRIVEDHOODS).

\section{Contributors}

Roger Andersson Chair in Human Geography, Institute for Housing and Urban Research, Uppsala University, Uppsala, Sweden

Polina Bogacheva Glorax Development, Moscow, Russia

Gideon Bolt Department of Human Geography and Spatial Planning, Utrecht University, Utrecht, The Netherlands

Åsa Bråmå Institute for Analytical Sociology, Linköping University, Linköping, Sweden

Liviu Chelcea Professor and Chair, Department of Sociology, University of Bucharest, Bucharest, Romania

Rafael Costa Interface Demography, Vrije Universiteit Brussel, Brussels, Belgium

Helga A. G. de Valk Theme group leader of Migration and Migrants, Netherlands Interdisciplinary Demographic Institute; Professor of Migration and Life Course, University of Groningen, Groningen, The Netherlands

Tamás Egedy Senior Research Fellow, Geographical Institute of the Hungarian Academy of Sciences, Budapest, Hungary; Associate Professor, Budapest Business School, University of Applied Sciences, Budapest, Hungary

Maria Gunko Institute of Geography, Russian Academy of Sciences, Moscow, Russia 
Maarten van Ham Professor of Urban Renewal, Delft University of Technology, Delft, The Netherlands; Professor of Geography, University of St Andrews, St Andrews, Scotland, UK

Daniel Baldwin Hess Professor and Chair, Department of Urban and Regional Planning, University at Buffalo, State University of New York, NY, USA

Johanna Holvandus Doctoral Student, Centre for Migration and Urban Studies, University of Tartu, Tartu, Estonia

Anssi Joutsiniemi Aalto University, Helsinki, Finland

George Kandylis National Centre for Social Research, Athens, Greece

Anneli Kährik Senior Researcher, Centre for Migration and Urban Studies, University of Tartu, Tartu, Estonia

Ilya Kashnitsky University of Groningen and Netherlands Interdisciplinary Demographic Institute, Groningen, The Netherlands; National Research University Higher School of Economics, Moscow, Russia

Teemu Kemppainen Doctoral Candidate, University of Helsinki, Helsinki, Finland

Matti Kortteinen Professor of Urban Sociology, Faculty of Social Sciences, University of Helsinki, Helsinki, Finland

Zoltán Kovács Research Professor, Geographical Research Institute, Hungarian Academy of Sciences, Budapest, Hungary; Professor, Human Geography, University of Szeged, Budapest, Hungary

Jesús Leal Professor and Chair, Department of Applied Sociology, Universidad Complutense de Madrid, Madrid, Spain

Kadri Leetmaa Senior Researcher, Centre for Migration and Urban Studies, University of Tartu, Tartu, Estonia

Christine Lelévrier Director, Lab'urba Research Centre; Professor, Paris Urban School of Planning, University Paris-Est-Créteil, Marne-la-Vallée, France

Kadi Mägi Doctoral Student, Centre for Migration and Urban Studies, University of Tartu, Tartu, Estonia

Thomas Maloutas Professor of Social Geography, Department of Geography, Harokopio University, Kallithea, Greece

Vera Marin Department of Urbanism, University of Architecture and Urban Planning Ioan Mincu, Bucharest, Romania

Andrey Medvedev Institute of Geography, Russian Academy of Sciences, Moscow, Russia 
Talia Melic Doctoral Student, University of Melbourne, Melbourne, Australia; Lab’urba Research Centre, University Paris-Est-Créteil, Marne-la-Vallée, France

Alan Murie Emeritus Professor of Urban and Regional Studies, University of Birmingham, Birmingham, England

Nikolina Myofa Doctoral Candidate, Harokopio University, Kallithea, Greece

Martin Ouředníček Associate Professor, Department of Social Geography and Regional Development, Faculty of Science, Charles University, Prague, Czech Republic

Petros Petsimeris Professor of Geography, University Paris 1 Panthéon-Sorbonne, Paris, France

Lucie Pospíšilová Assistant Professor, Department of Social Geography and Regional Development, Faculty of Science, Charles University, Prague, Czech Republic

Daniel Sorando Researcher, Department of Applied Sociology, Universidad Complutense de Madrid, Madrid, Spain

Petra Špačková Assistant Professor, Department of Social Geography and Regional Development, Faculty of Science, Charles University, Prague, Czech Republic

Mats Stjernberg Senior Researcher, City of Helsinki Urban Facts, Finland; doctoral candidate, University of Helsinki, Helsinki, Finland

Balázs Szabó Research Fellow, Geographical Institute of the Hungarian Academy of Sciences, Budapest, Hungary

Tiit Tammaru Professor of Urban and Population Geography, University of Tartu, Tartu, Estonia

Pedro Uceda Lecturer and Researcher, Department of Applied Sociology, Universidad Complutense of Madrid, Madrid, Spain

Florian Urban Professor and Head of Architectural History and Urban Studies, Mackintosh School of Architecture, Glasgow School of Art, Glasgow, Scotland

Mari Vaattovaara Professor of Urban Geography, University of Helsinki, Helsinki, Finland

Frank Wassenberg Senior Project Leader, Platform31; Guest Researcher, OTB Research Institute for the Built Environment, Delft University of Technology, Delft, The Netherlands 


\section{Part I \\ Introduction}




\title{
Chapter 1 \\ Lessons Learned from a Pan-European Study of Large Housing Estates: Origin, Trajectories of Change and Future Prospects
}

\author{
Daniel Baldwin Hess, Tiit Tammaru and Maarten van Ham
}

\begin{abstract}
Mid-twentieth-century large housing estates, which can be found all over Europe, were once seen as modernist urban and social utopias that would solve a variety of urban problems. Since their construction, many large housing estates have become poverty concentrating neighbourhoods, often with large shares of immigrants. In Northern and Western Europe, an overlap of ethnic, social and spatial disadvantages have formed as ethnic minorities, often living on low incomes, settle in the most affordable segments of the housing market. The aim of this introductory chapter is to synthesise empirical evidence about the changing fortunes of large housing estates in Europe. The evidence comes from 14 citiesAthens, Berlin, Birmingham, Brussels, Budapest, Bucharest, Helsinki, Madrid, Milan, Paris, Moscow, Prague, Stockholm and Tallinn - and is synthesised into 10 takeaway messages. Findings suggest that large housing estates are now seen as more attractive in Eastern Europe than in Western Europe. The chapter also provides a diverse set of visions and concrete intervention measures that may help to improve the fortunes of large housing estates and their residents.
\end{abstract}

D. B. Hess ( $\square)$

Department of Urban and Regional Planning, School of Architecture and Planning,

University at Buffalo, State University of New York, Buffalo, NY, USA

e-mail: dbhess@buffalo.edu

T. Tammaru

Department of Geography, Centre for Migration and Urban Studies,

University of Tartu, Tartu, Estonia

e-mail: tiit.tammaru@ut.ee

T. Tammaru $\cdot$ M. van Ham

OTB-Research for the Built Environment, Delft University of Technology,

Delft, Zuid-Holland, The Netherlands

e-mail: m.vanham@tudelft.nl

M. van Ham

School of Geography and Sustainable Development,

University of St Andrews, St Andrews, UK

(C) The Author(s) 2018

D. B. Hess et al. (eds.), Housing Estates in Europe, The Urban Book Series,

https://doi.org/10.1007/978-3-319-92813-5_1 
Keywords European cities - Housing estates - Neighbourhood planning Residential planning - Urban change

\subsection{Point of Departure for Scholarly Inquiry}

It has been nearly 15 years since a large European Union-funded project called Restate explored challenges in housing estates throughout several European countries and served as a clearinghouse for the exchange of ideas about counteracting negative trends in large housing estates (van Kempen et al. 2005). Since that time, a series of riots in the Paris banlieues and in the 'million home programme' suburbs in Stockholm have revealed that many problems remain. Major European newspapers, including The Guardian, frequently publish articles about deep social problems in housing estates, the poor image from which they suffer, and dissident groups that reside in them. Families with resources often move away from large housing estates, and housing estates contribute to increasing segregation levels in European cities (Tammaru et al. 2016a). Immigration currently introduces new groups to European cities whose initial places of settlement are low-cost neighbourhoods, often in large housing estates (Wessel 2016). Moreover, new challenges arise, such as the ongoing ageing of both buildings and their environments, which necessitates new investments and raises challenges related to sustainability, energy reduction and ageing populations. With many cities operating on austerity budgets and lacking cash to invest in improving housing and neighbourhoods, now is a good time to revisit the challenges faced by large housing estates in European cities.

There are three major pathways for responding to the many challenges that are faced by large housing estates. First is to not intervene and to leave potential changes to markets with little public involvement. Many European countries have in fact operated in this way by allowing stronger market functioning in the housing sector (Andersson and Bråmå 2018). A second option, from the other extreme, is wholesale demolition of apartment buildings and housing estates. For example, leaders in Moscow announced the demolition of a staggering 7,900 1950s- and 1960s-era apartment buildings (causing displacement of 1.6 million people) and replacing the obsolete residences with new modern apartment towers (Luhn 2017; Gunko et al. 2018). Third, selective demolition can take place, as has been common in many Western European countries in the last decade including the United Kingdom (Murie 2018). This third option falls between the first two strategies and focuses on more integrated interventions and measures aimed at upgrading housing estates both physically and socially, including building renovations, upgrading the flats, improving neighbourhoods and accompanying all tasks with supportive social, economic and safety enhancements. The French government has made perhaps the largest investments among European countries in improving housing estates by significantly upgrading their built environments (Chrisafis 2015; Lelévrier and Melic 2018). With this complexity in mind, our central research question asks: 
Given the potential for urban policy and planning interventions, what role do large housing estates play in the reproduction of inequalities, poverty, and segregation in European cities today?

To explore this question, we present new evidence about changes in large housing estates from 14 European cities-Athens, Berlin, Birmingham, Brussels, Budapest, Bucharest, Helsinki, Madrid, Milan, Paris, Moscow, Prague, Stockholm and Tallinn (Fig. 1.1) - thus enlarging and updating findings from the Restate study (Dekker and Van Kempen 2004; van Kempen et al. 2005; Rowlands et al. 2009; Turkington et al. 2004). The Restate study found a great deal of diversity in the formation and development trajectories of housing estates, strongly influenced by factors such as context, building period and size, location and connectedness, maintenance, obsolescence, population structure, stigmatisation, the local economy, public space, and livability. Broadly, European experiences with regard to housing

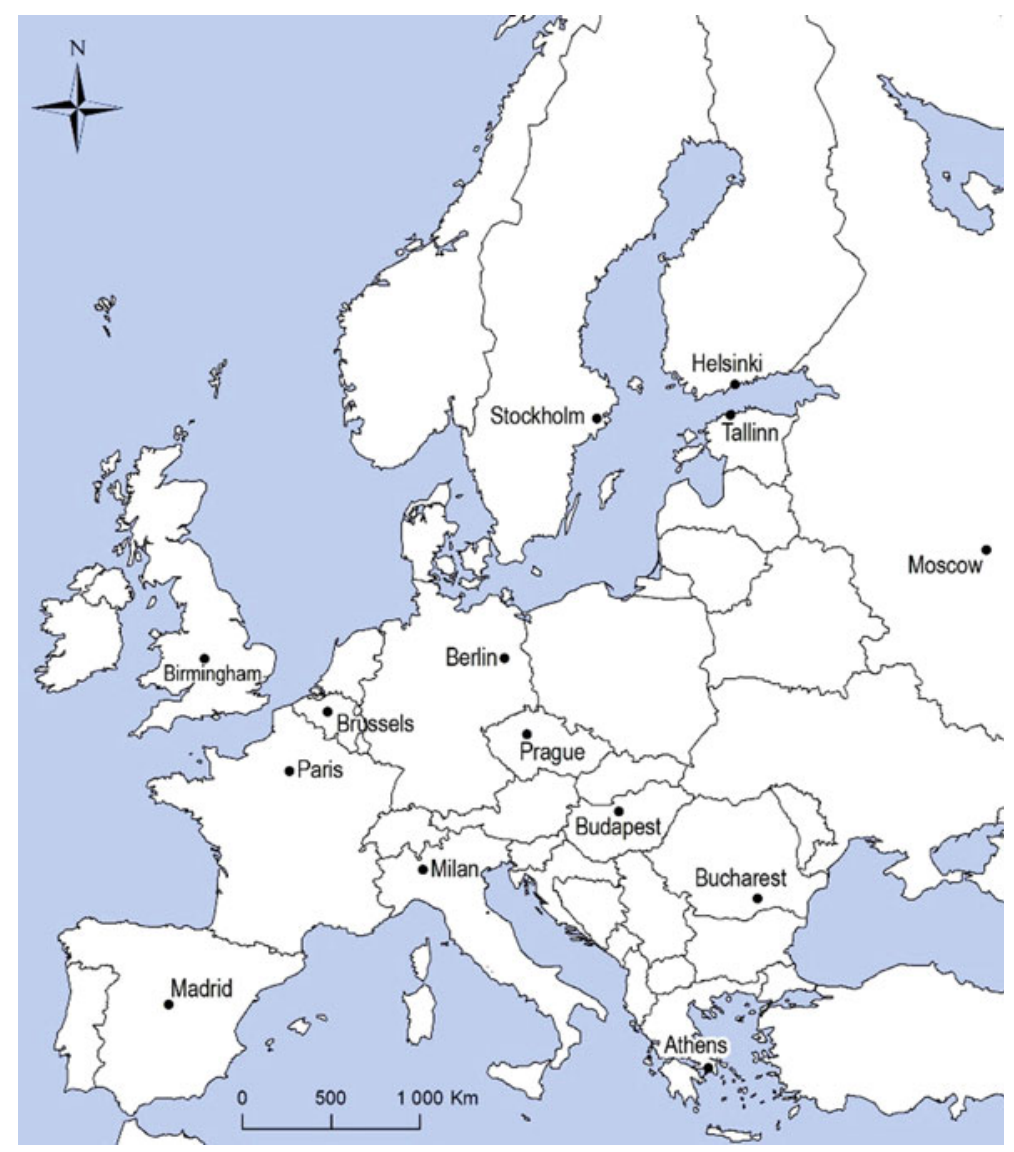

Fig. 1.1 Location of 14 case study cities. Source Annika Väiko 
estates differ in Northern/Western and Southern/Eastern European countries. The construction of housing estates took place in a relatively short time period in Northern and Western Europe as a response to rapid post-War population growth and subsequent housing demand. The construction of large housing estates in Eastern Europe began later and lasted longer. In Southern Europe, there was a strong private involvement in the construction of large housing estates unlike in other parts of Europe. These differences launched housing estates along different development trajectories, with the problem of spiralling social status still a major problem with many housing estates in Northern and Western Europe, while the prestige of housing estates remains higher in Eastern Europe.

The concluding chapter of the Restate project (van Kempen et al. 2005) is ominously titled "Deepening the Crises or Homes for the Future?" For a brighter future to emerge, the authors strongly advocate for diversified tenure and social mix in more problematic housing estates; this should be undertaken to provide opportunities for housing careers within the districts, more social contact and social cohesion in housing estates, increased social capital, providing more positive role models and reduced stigma in large housing estates. Now, since more than 10 years have passed since the last major publication from the Restate project, it is timely to make a thorough investigation of the changes that have taken place in large housing estates across Europe. In this context, we develop several penetrating research questions that guide the content of the chapters of this book:

- Have large housing estates remained differentiated or begun to follow more similar pathways? Have housing estates followed similar trajectories as they age? Are key differences related to time of construction, location, scale, density or other factors?

- Does the role housing estates play in social stratification and segregation depend on broader tenure and residualisation patterns and trends? Has it become apparent that privatisation has contributed to social and physical problems and to different trajectories of large housing estates?

- What is the success of various intervention measures applied in different European contexts? What works best? Are there different patterns of demolition and renovation across Europe? What are the key characteristics that could help large housing estates to become homes of the future?

The remainder of this introductory chapter is organised as follows. We first provide an overview of the common origins of large housing estates in Europe. We provide a definition of housing estates and present evidence about the variations in scale and timing of housing estate formation in Europe. This is followed by a synthesis of key findings from the chapters in this book, which are structured around ten takeaway messages. These messages convey that few substantial changes have occurred in large housing estates in Europe since the Restate project on the one hand, but they also carefully clarify some of the strategies for improvement that might help to secure a solid future for the dwellings and inhabitants of Europe's large housing estates. Many housing estates still embody social democratic welfare ideals of state involvement in the lives of working-class people, and they still represent a buffer between downward mobility and homelessness. It 
may be an important reason why levels of socio-economic and ethnic segregation are still lower in European cities compared to US cities since high-rise public housing in the US never became popular, as it was considered to be socialist and anti-capitalist and, as a consequence, un-American. The more prominent the share of large housing estates in an urban housing stock, the more appreciated housing estates are by the population, as is the case in many Eastern European cities.

\subsection{Formation of Large Housing Estates in Europe}

Mid-twentieth-century large housing estates were to greater and lesser extents envisioned as modernist urban and social utopias that would solve various urban problems at times of rapid industrialisation and urbanisation in most of Europe during the post-World War II baby boom (Rowlands et al. 2009). In one extreme, in Eastern Europe, large housing estates were carefully planned at the apartment, building, and neighbourhood levels, with an aim to provide working and middle-class families with quality living environments in a cost-efficient manner. At the other extreme, large housing estates are almost absent in Athens, where they were never seen as an instrument to solve urban housing problems. Most countries in Western, Southern, and Northern Europe fall somewhere between these extremes. Many housing estates established during the post-World War II decades are now 30, 40, 50 and even 60 years old, and the built environment and infrastructure has decayed, since cheap building materials and economical construction techniques were often used to build housing estates inexpensively and quickly.

Physical decay in housing estates today is matched by a lowering of social status and ethnic segregation. Especially in Western and Northern European cities, social problems tend to cluster spatially, and housing estates are often the domain of such clustering since they provide affordable housing (relative to other segments of the housing sector). Consequently, many housing estates have over time become sites of problems - including social dysfunction, poverty, ethnic concentration and isolation-amid deteriorating buildings and public spaces (Bolt 2018). While some housing estates eventually became dysfunctional places for desperate people, not all housing estates are obsolete, because they currently house tens of millions of Europeans and they remain vital parts of cities' housing stocks, especially in Eastern European countries. Not all of these housing estates in Europe are problematic, but serious problems occur far more in housing estates than on average in Europe, and especially Northern and Western European cities.

The appeal of housing estates to Europeans in the post-World War II period is understandable, because housing estate programmes offered an inexpensive model for expanding housing supplies during a time of rapid industrialisation and urbanisation. Establishing housing estates also helped address several urgent problems: providing shelter to people relocating to cities (including a workforce supporting industrialisation, as was often the case in Eastern Europe); meeting housing needs for immigrants and guest workers (that was more common in 
Western Europe); and providing replacement housing when slum clearance projects were needed (Hess and Hiob 2014). Governments in Europe assumed responsibility for housing provision after World War I because it was evident that market-based housing solutions proved inadequate (Wassenberg 2018). In many countries, especially in Northern Europe (Andersson and Bråmå 2018) and Eastern Europe (Leetmaa et al. 2018), egalitarian housing production and housing provision became one of the central elements of the welfare state. New master-planned residential communities (often for tens of thousands of residents) were established on the periphery of urban centres where land was readily available. Housing estates were often meant to function as semi-autonomous neighbourhoods that catered to the daily needs of residents, including day care/kindergartens, elementary schools, sports halls, culture/community centres, and shops and services all within easy reach. Protection from traffic was usually a guiding principle so that internal neighbourhood services were within comfortable walkable distance (Hess 2018).

Although the first modernist apartment buildings and housing estate-like neighbourhoods appeared in Europe during the inter-War period (Wassenberg 2018), we focus in this book on an intense period of post-World War II housing estate construction between the 1950s and 1980s. A well-known 'million home programme' in Sweden characterises the ambition of the period: one million new homes in modern apartment towers were built in Sweden between the early 1960s and mid-1970s (Andersson and Bråmå 2018). 'One million homes' became a magical target in other European countries, including Hungary (Kovács et al. 2018), France (Lelévrier and Melic 2018) and Spain (Leal et al. 2018). In Northern Europe, national governments funded and constructed housing estates, also acting as landowner, while in Southern Europe, housing estates were often a product of commercial real estate markets and, as a consequence, targeted to different income groups. Housing estates in city centres often targeted higher income groups while housing estates on urban peripheries targeted lower income groups. Housing estates for high-income residents were more centrally located than housing estates for low-income groups, which were geographically distributed where land values were lower (Leal et al. 2018; Lelévrier and Melic 2018).

The evolution of large housing estates in Europe demonstrates the tension between short-term versus long-term strategies for developing an urban housing stock. In the short-term, housing estates helped to solve the problem of urgent demand for housing at times of large-scale industrialisation and urbanisation. Housing estates also introduced vast improvements in the quality of living space, allowing many people to leave behind inadequate pre-World War II housing and take up residence in new, modern apartments (Lelévrier and Melic 2018). Large numbers of working-class people had access to better-quality housing in new housing estates, either as renters (more commonly in Northern Europe) or as homeowners (more commonly in Southern Europe) (Wassenberg 2018; Andersson and Bråmå 2018; Leal et al. 2018). Housing estates were developed to offer long-term housing solutions, but optimism faded as soon as alternative forms of housing became available. The usually well-planned housing estates did not survive as ideal living environments; they eventually transformed into problematic and undesirable living areas. 
High densities, priority of cost-efficient construction, attractive alternative housing and many other factors quickly downgraded housing estates to the bottom of the housing ladder (Petsimeris 2018; Andersson and Bråmå 2018).

\subsection{Large Housing Estates Defined}

It is challenging to construct a consistent definition for large housing estates, and we recognise that housing estates contain various types of residences: social housing, privatised apartments and condominiums. In some European cities, especially in Eastern and Northern Europe, housing estates were thoroughly planned as coherent socio-spatial ensembles. In other European cities, especially in Western Europe, the focus was on social housing that is more scattered in urban space. Housing estates thus have different connotations in various European countries, and this is also reflected by differences in terminology (Wassenberg 2018).

Nevertheless, we attempt a universal definition in this book in order to clarify the meaning of the term 'housing estate'. Following Wassenberg (2018), large housing estates are composed of groups of apartment buildings that are (a) distinct in form, (b) constructed as a planned, single development on a large scale for a local context, (c) situated in high-rise towers in vertical space, and (d) tall enough (usually five or more floors) that an elevator may legally be required. For empirical purposes, we define housing estates as areas containing at least 1,000 residences in high-rise buildings, established by a developer or development process between the $1950 \mathrm{~s}$ and the 1980 s as a coherent and compact planning unit. In most European countries, however, it is impossible to strictly apply this definition using population data, since national datasets lack geographic and housing detail; nevertheless, we have carefully attempted to adhere to this analytical definition. Cities with comparable data provide evidence that the share of people living in large housing estates ranges from less than $5 \%$ in Athens to $80 \%$ in Bucharest, with higher shares generally found in Eastern Europe than in other parts of Europe.

\subsection{Key Findings}

Findings from past studies including High-rise Housing in Europe (Turkington et al. 2004) and the Restate project (van Kempen et al. 2005) provide in-depth evidence of the varieties of change in large housing estates in Europe through the mid-2000s. A recent book entitled Socio-economic Segregation in European Capital Cities (Tammaru et al. 2016b) documents growing levels of segregation across Europe, suggesting an increasing overlap of ethnic and social segregation, often to be found in large housing estates. Our current book focuses on the formation and later socio-spatial trajectories of large housing estates in Europe. The long-term growth in social inequalities in Europe, a growing number of immigrants in European cities 
seeking affordable housing, as well as the physical ageing of apartment buildings form key policy challenges related to large housing estates in Europe.

This book provides comparative city- and metropolitan-level evidence of the origins, trajectories of change and future prospects of large housing estates. We are specifically interested in the actions needed to realistically improve the fortunes of housing estates experiencing downward trends and enhance life for the residents living in them. Part 2 of the book includes two pan-European views on (a) built environments and planning, and (b) social and ethnic change in large housing estates, focusing on the challenges that relate both to their physical characteristics and residents living in them. Part 3 is composed of targeted case studies of housing estates in 14 European cities-Athens, Greece; Berlin, Germany; Birmingham, United Kingdom; Brussels, Belgium; Budapest, Hungary; Bucharest, Romania; Helsinki, Finland; Madrid, Spain; Milan, Italy; Paris, France; Moscow, Russia; Prague, Czechia; Stockholm, Sweden; and Tallinn, Estonia - in which authors address the following five questions:

- Are housing estates spatially clustered or scattered?

- Which social groups originally had access to residential space in housing estates?

- What is the size and scale of housing estates, their architectural and built environment composition, their position on the local housing market, the level of services and neighbourhood amenities, and connections between housing estates and the rest of the city (in terms of work and leisure-time activities)?

- How did or how do housing estates contribute to the urban mosaic of neighbourhoods by ethnic and socio-economic status?

- Which policies and planning initiatives have been implemented to prevent the lowering of the social status of housing estates?

The remainder of the introductory chapter is organised around ten synthesised takeaway messages distilled from the 16 chapters of the book.

1. Although large housing estates are a common phenomenon in Europe, large variations exist between countries. There were wide variations in the initial conditions and contexts of housing estates, and these placed housing estates along different trajectories of change.

2. Housing estates are often viewed as universally problematic, but this characterisation is too simplistic and there are varieties of trajectories of change, even within the same cities. Some housing estates have downgraded significantly, while others have been more successful in maintaining or even improving their status.

3. Interventions that aim to reduce densities and improve the relative location of housing estates-investments in transport infrastructure, including the expansion of subway systems, construction of pathways for pedestrians and cyclists - can substantially improve access to housing estates.

4. The position of housing estates on the housing ladder is unclear. Housing estates could have a better-defined role-for example, either as a final housing destination or as an interim position in a family's housing career-which could make it easier to clarify goals and design concrete interventions. 
5. Privatisation of collective space should be handled with care. The function of housing estates, originally built by a central authority and intended for collective ownership, is strained when structural changes cause housing units to be placed in private hands. The often-grandiose physical configuration and social structure of housing estates require thoughtful management of common spaces also when apartments get privatised.

6. It is critical to improve the perception and elevate the reputation of housing estates. People have a tendency to create images in their mind that may or may not match reality, but a poor reputation for large housing estates can further hurt their future performance.

7. Intervention strategies for reversing the fortunes of large housing estates are complex. The focus is usually on area-based interventions with an aim to improve the physical qualities of neighbourhoods, or on access- and connectivity-based interventions with an aim to link large housing estates originally located in peripheral urban space. More attention is needed, however, on people-based improvement strategies.

8. Many ideas about contemporary urban life - including sustainability, ecological footprints, communal life and the sharing economy, and social equityalign well with the underlying principles of housing estates, which offers chances for the future.

9. Reliable, up-to-date and comparable data are needed about the residents of large housing estates across Europe. We cannot expect city governments and other actors to define effective intervention strategies if they cannot accurately diagnose problems and challenges.

10. Past mistakes made with large modernist housing estates could help guide the way current and future cities are planned in Europe and beyond. A lesson can be offered from twentieth-century experiences in Europe with housing estates: the larger, higher density and the more peripherally located housing areas are at higher risk of concentrating poverty and producing and reproducing triple disadvantages - social, ethnic and spatial — through a vicious circle of poverty and segregation.

\subsection{Takeaway Messages}

\section{Message 1}

Although large housing estates are a common phenomenon in Europe, large variations exist between countries. There were wide variations in the initial conditions and contexts of housing estates, and these placed housing estates along different trajectories of change.

The standardised grand structures of housing estates in Europe are the children of post-World War II urban growth, industrialisation and urban renewal. Housing estates often formed a high-density urban-industrial circle around the historic cores of cities (Petsimeris 2018; Lelévrier and Melic 2018) but in some cases they were 
built to facilitate the redevelopment of inner-city neighbourhoods of slum housing (Murie 2018). Many housing estates were built outside the urban core on peripheral greenfield spaces where land was cheap and where it was easy to reap economies of scale, i.e. to provide a large amount of housing units at a single construction site (Wassenberg 2018). In some cases, the ease of movement of cranes on construction sites determined the way housing estates were planned (Meuser and Zadorin 2016).

Although there are fewer housing estates in some cities, for example, in Athens (Kandylis et al. 2018) or Brussels (Costa and de Valk 2018) and even if they have been built outside the city central areas as in Paris (Lelévrier and Melic 2018), they are still a common characteristic in virtually all European cities. Despite many similarities in form and function, large variations among housing estates exist between European cities. The number of apartment buildings built, as well as the social and physical conditions in housing estates today, relate in part to the welfare regime that was prevalent in the countries at the time housing estates were established. In some countries - the former Soviet Union, of course, but also the social democratic welfare states of Northern Europe - collective visions prevailed and communal living and egalitarian social conditions were consistent with societal expectations. In other countries-notably in Southern Europe-collective vision promoted private homeownership, even through a period of expansion of social housing and collective housing estates. Both societal visions shaped the formation of housing estates as well as set the tone for their long-term development.

The peak of large-scale housing construction varies by European region as well. In Northern, Southern and Western Europe, the main construction period occurred in the 1960s and 1970s. Turkington et al. (2004) identify peaks in high-rise construction in several countries. Construction slowed quickly thereafter when the problems of housing estates - such as mono-functionality (residence), low construction quality, spatial isolation of housing built on the periphery of cities, deprivation, lack of safety, problematic public spaces, etc.- - were quickly recognised. An alarm bell rang after a gas explosion in Ronan Point tower in Newham, London, in 1968. Critical public debates began in France around the same time. After the 1981 riots, the term 'deprived neighbourhoods' entered the French public discourse (Lelévrier and Melic 2018). Likewise, critical public debates about housing quality in large housing estates began in Sweden in the 1970s, soon after the 'million home programme' (1965-1974) housing was completed.

The construction of new high-rise housing estates began decreasing in the 1970s in Western Europe. In the socialist countries of Eastern Europe, their construction increased rather than decreased in the 1970s, and the growth trend continued in many countries until the fall of the Berlin Wall in 1989 and the demise of the Soviet Union in 1991. The provision of free-of-charge public housing was one of the cornerstones of the egalitarian ideology in communist Europe. The ideals of large housing estates were modelled from Northern Europe (rather than from Western Europe) because central planners were inspired by the grand socio-spatial structures of Northern European cities, notably Sweden. Central planners were less impressed by the public housing-based approaches to housing estate formation that prevailed in Western Europe. They developed various templates for planning the internal 
spatial structures of modernist neighbourhoods. These templates included a (a) surround-type where a square inner-courtyard is formed between apartment buildings, (b) a canyon-type formation with grand roads with tall apartment buildings along both sides and (c) a parallel blades formation featuring long rows of parallel buildings (Marin and Chelcea 2018). The neighbourhoods, which were planned to deliver necessary daily services within a walkable reach, became the foci of daily life for people despite the fact that oftentimes not all planned service facilities were actually built.

Some of the most grandiose modernist urban structures can be found in Eastern Europe. Moscow (Gunko et al. 2018) and Bucharest (Marin and Chelcea 2018) consist of endless housing estates that are home to hundreds of thousands of people. For example, the number of people living in Balta Alba estate $(300,000)$ in Bucharest and in the Lasnamäe estate $(125,000)$ in Tallinn is comparable to the size of the second largest cities in these countries. In Berlin (Urban 2018), housing estates grew larger in the eastern part of the city (the largest, Marzahn, with 100,000 people) compared to the western part (Märkisches Viertel, the largest, with 35,000 people). In many Western European cities, only about $10 \%$ of urban residents live in large housing estates. For example, in the Paris region around $11 \%$ of people live in housing estates (Lelévrier and Melic 2018), and in Stockholm this figure is $15 \%$ (Andersson and Bråmå 2018), while more than $80 \%$ of the residents of Bucharest live in large housing estates (Marin and Chelcea 2018). Interestingly, though, higher shares of people living in large housing estates do not necessarily correspond to larger social problems. In cities with a high share of the population living in housing estates, these estates are accepted as a normal part of life (Marin and Chelcea 2018).

\section{Message 2}

Housing estates are often viewed as universally problematic, but this characterisation is too simplistic and there are varieties of trajectories of change, even within the same cities. Some housing estates have downgraded significantly, while others have been more successful in maintaining or even improving their status.

Characteristics and features of housing estates vary not only between countries but also within cities. Construction methods for large housing estates changed over time. The first housing estates were smaller in size, strongly influenced both by modernist housing aims as well as by the ideals of the Garden City concept (Urban 2018). As mass production techniques improved and in order to meet the growing demand for new housing units, apartment buildings became taller and housing estates became denser from the 1960s onward. This change is especially evident in Eastern European cities where the construction of large housing estates lasted longer (until the early 1990s) compared to West European cities (Urban 2018; Marin and Chelcea 2018; Ouředníček et al. 2018).

The metropolitan location of new housing estates changed over time as well. The first housing estates were often built either as in-fill in city centres or close to city centres, while later housing estates were usually built further away, on plots of land still available for large-scale construction. This implies that high densities and spatial isolation are often combined in newer housing estates, making them less 
attractive in today's housing market compared to older housing estates (Kovács et al. 2018). However, older housing estates face problems too. These problems relate to their older age and consequent higher investment needs, fewer amenities, and, in some cases, the small size of the apartments. In some cities, apartments increased in size and quality over time, better meeting families' needs (Ouředníček et al. 2018; Leal et al. 2018).

Figure 1.2 depicts the relative size (measured by current or recent residential population) and spatial arrangement of housing estates as detailed in the chapters in the book. High-density arrangements of housing estates (in Moscow and Bucharest, for example) can be identified, and largely peripheral locations for housing estates (in Milan and Brussels, for example) can be contrasted with central locations for

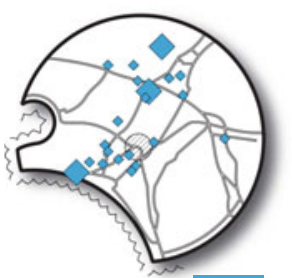

Athens

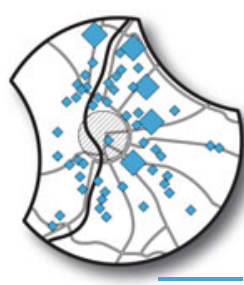

Budapest

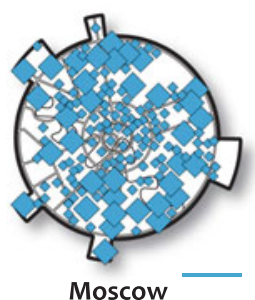

Moscow

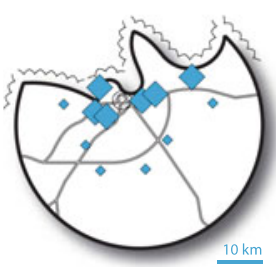

Tallinn

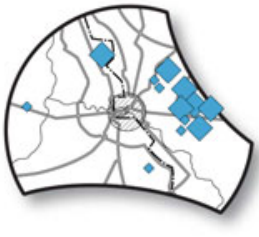

Berlin

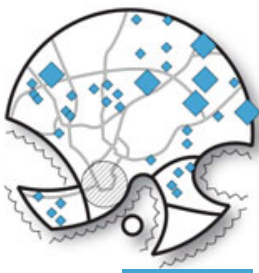

Helsinki

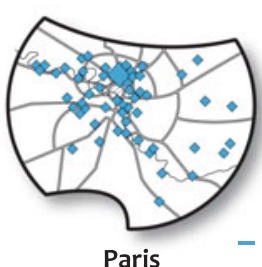

Paris

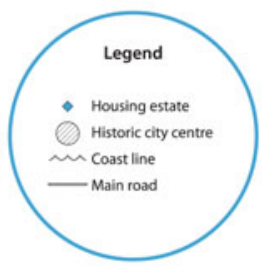

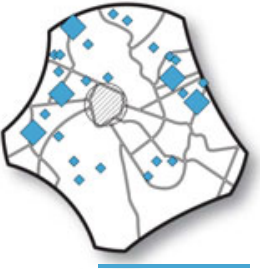

Brussels

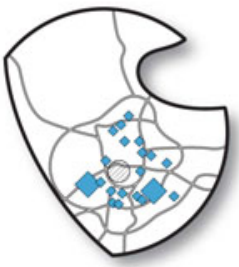

Madrid

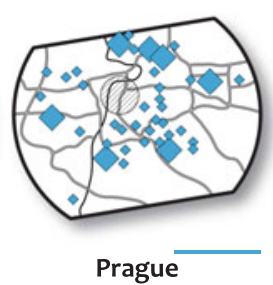

Prague

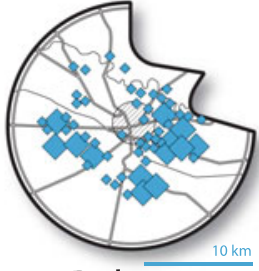

Bucharest
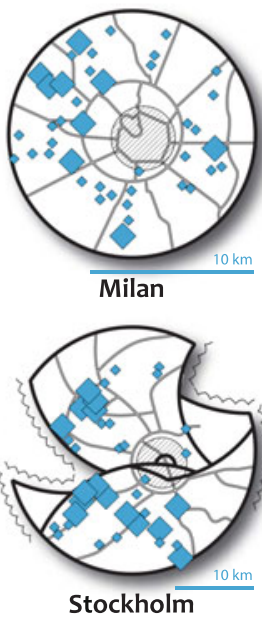

Fig. 1.2 Distribution of housing estates in metropolitan space in case study cities. Source Figure prepared by Raivo Aunap 
housing estates (in Paris, for example) and evenly-distributed housing estates (in Budapest and Prague, for example). Underlying political contexts at the time of housing estates construction explain the concentration of housing estates in East Berlin (but not West Berlin), and the socialist system explains a fewer number of housing estates that are nonetheless large in size (in Tallinn, for example, and elsewhere in Eastern Europe).

Once established, the built environment is slow to change due to inertia. Initial choices made about the physical characteristics of housing estates-location, size, design and construction - have had a crucial impact on the long-term trajectory and performance of housing estates, even if social and housing values have changed since then. As a rule of thumb, immense housing estates and those located in more peripheral locations face higher risks for social and physical downgrading than smaller housing estates (Andersson and Bråmå 2018; Kovács et al. 2018; Leetmaa et al. 2018), while smaller building types in housing estates within the urban core tend to perform better over the long run (Kovács et al. 2018; Vaattovaara et al. 2018).

While the absolute location of housing estates cannot be changed once established, in many cities, their relative location has changed; where European cities have sprawled further since large housing estates were built, housing estates now often form a middle zone between urban cores and lower density outer rings. Transportation connections have often improved as well (Hess 2018). The relative spatial position of housing estates can be improved more by focusing on their better integration with opportunities elsewhere in the city through transport networks (Lelévrier and Melic 2018). For example, in Tallinn, some housing estates face the challenge of a lowering social status, but people are not trapped in these neighbourhoods, thanks to free public transport (Leetmaa et al. 2018; Hess 2017).

\section{Message 3}

Interventions that aim to reduce densities and improve the relative location of housing estates-investments in transport infrastructure, including the expansion of subway systems, construction of pathways for pedestrians and cyclists - can substantially improve access to housing estates.

High-density per se is not necessarily a source of problems and dissatisfaction for residents; other related factors may be more detrimental, such as poor environmental quality, noise, lack of community involvement or lack of safety (Howley et al. 2009; Andersson and Bråmå 2018). Since gentrification has elevated housing prices in central cities beyond the reach of large numbers of dwellers in many European cities, people seek alternatives in the housing market, and that could gear choice towards housing estates. For this to happen, measures need to be taken to downplay the negative aspects of high-density residential space, to improve the relative location of housing estates in urban housing markets and to invest in the built environments within housing estates.

There are many aspects of housing estates that contribute to differences in the trajectories of change. Housing estates that are functionally more diverse and provide good jobs, services and leisure-time activity can be relatively attractive. For 
example, Mustamäe, a housing estate in Tallinn, Estonia built between 1962 and 1973, is remarkable for the level of land-use and functional mixing that was originally achieved and has been maintained. Situated only five kilometres from the city centre and possessing good transport connections, it houses approximately 65,000 people. Its interior is focused on kindergartens and schools, and it also contains a university, an industrial quarter, shops and services, and other workplaces (Metspalu and Hess 2018). Functional diversification is an important way to increase the attractiveness of large housing estates.

The initial social composition matters, too. In Brussels (Costa and de Valk 2018) and Madrid (Leal et al. 2018), for example, the initial social composition of housing estates varied significantly depending on the developer and location. In Madrid, housing estates in the city centre were constructed by private developers for higher income groups while those constructed by the public sector were located mainly on the urban periphery and targeted for low-income people. Likewise, the current ability of residents to fund basic building maintenance may differ according to ownership structure. In Brussels (Costa and de Valk 2018), private owners are less capable of large-scale renovations and publicly owned apartments are therefore better maintained. In Tallinn, ethnicity (in the majority group, Estonian) rather than income predicts residents' willingness to afford large-scale housing renovations (Leetmaa et al. 2018).

Private ownership of apartments combined with poverty and high shares of minorities may exacerbate the downward spiral of housing estates. The trend towards an overlap of ethnic, social and spatial disadvantage is growing in Western and Northern European cities, and an increasing share of the housing stock is privatised. Certain risk factors call for caution when it comes to the future of particular housing estates in Eastern Europe as well, since there is some evidence of high-income groups moving away from the less attractive housing estates built in the 1980s (Kovács et al. 2018; Leetmaa et al. 2018). Similar risks also apply to many Southern European housing estates located on urban peripheries, which are characterised by high densities and tall buildings and private ownership combined with mainly low-income groups (Petsimeris 2018; Leal et al. 2018).

An alternative way to intervene is to demolish less attractive housing estates. Demolition of apartment buildings has been undertaken in three of our case study cities: Birmingham, Moscow and Paris. In Paris, social aims drive housing demolition and renovation schemes (Lelévrier and Melic 2018). There is an ambition to provide one new housing unit for each one demolished and to reduce housing density through the removal of high-rise towers. The opposite takes place in Moscow, where an immense demolition plan of 1960s housing departs from an entrepreneurial way of thinking. Profit-driven developers operate within a rather ruthless real estate market and social considerations are unimportant (Gunko et al. 2018). The demolished area will be significantly densified through the addition of clusters of taller towers. Although their physical configuration thus becomes similar to the most problematic housing estates in South European cities, the social structure would be different since in Moscow, a respectable income is needed to buy an apartment in new tower blocks to compete in the dynamic housing market 
with limited choice for new housing. In Birmingham, density has been increased with new private and social rented housing alongside new investment to improve the standard of existing housing (Murie 2018).

In short, vital neighbourhoods adjust to changing circumstances in complex ways. These may include refurbishments, replacements of housing and people, physical and social upgrading, modernising the built environment, adding new facilities, changing the housing stock when necessary, and altering individual dwellings (by combining, splitting or enlarging them). There is no single measure that can neatly apply to all countries, cities and housing estates.

\section{Message 4}

The position of housing estates on the housing ladder is unclear. Housing estates could have a better-defined role-for example, either as a final housing destination or as an interim position in a family's housing career-which could make it easier to clarify goals and design concrete interventions.

The original aim of the housing estates programme was to provide modern apartments for working-class families. These apartments were often seen as a final destination in the housing career; they were carefully and scientifically designed to meet the expectations of families and then replicated in large numbers. In many European countries, the first residents were middle-class or affluent working-class families (Andersson and Bråmå 2018; Murie 2018); in others, the profile of residents was more diverse and included large shares of immigrants (Lelévrier and Melic 2018; Kandylis et al. 2018). The subsequent trajectory of change-lowering of social status and increase of immigrant population - bares more similarities, although the pace of these changes yet again varies from country to country and from housing estate to housing estate. Families with children have opted for low-rise housing alternatives as well. The lowering of social status, departure of native families and increase in immigrant population have been most rapid in Western European cities (Andersson and Bråmå 2018; Lelévrier and Melic 2018). Higher income people have left housing estates and for them, this housing segment is either out of the question altogether or considered only for temporary housing; for many low-income groups, housing estates still form a final and permanent housing destination (Lelévrier and Melic 2018).

However, new population groups are on the rise in European cities for whom large housing estates would serve as an attractive option on the housing market. As the second demographic transition evolves, in most countries, the highest growth is predicted for small households - composed of young singles, elderly, divorced people, foreign students and temporary workers-not families. In the meantime, there are plenty of apartment buildings built during the last decades for families with children, and these are located in the suburbs, away from central cities. Not all groups look automatically towards a single-family house in the suburbs with a garden and a parking place. Instead, they prefer centrally located and easy-to-reach apartments with shared services, ease of maintenance, smaller dwelling units and (for the elderly) one-level units. Many apartments in large housing estates meet these requirements. 
The social composition of housing estates has been more stable in Eastern European cities (Leetmaa et al. 2018; Kovács et al. 2018; Ouředníček et al. 2018; Gunko et al. 2018) than other parts of Europe for two main reasons. First, there was little lowering of the social status of housing estates during the socialist period. There was less life cycle related mobility in socialist countries and housing estates aged simultaneously with people who moved into them. Housing allocation was centrally administered; people waited in housing queues for years or even decades, and once an apartment was received, there were few opportunities for further residential moves. Second, housing estates became a dominant housing segment and they still provide shelter to a significant share of urban dwellers, slowing the pace of social change. However, there is some evidence of the lowering of the social status as well as increasing shares of immigrants in housing estates in Eastern European cities in the last two decades.

To conclude, lower socio-economic groups and ethnic minorities have become increasingly concentrated in large housing estates and in other areas where social, ethnic and spatial disadvantage overlaps and intensifies (Hess et al. 2012; Leetmaa et al. 2015; Bolt 2018). In this context, it is critical to better conceptualise the current role of housing estates in urban housing markets, especially in light of the second demographic transition and an increase of mobile people without families. Large housing estates are ideal for many of these groups. However, if the role of housing estates on the housing market is unclear, it is difficult to devise suitable intervention measures. Since the origins, size, location and current condition of housing estates vary from country to country and housing estate to housing estate (Lelévrier and Melic 2018), it is difficult to universally conceptualise their role in the housing market. Increased marketisation makes this complex too. Still, planning interventions could help to influence the choices made by specific population groups like students, families or older people through planning of public spaces and services. Various innovations - such as setting up the best school in the city, locating a ministry office, establishing a centre with diverse and sophisticated services for older people, providing land free of charge for a leisure-time centre and other measures - could potentially shape the main function, social vibe and population composition in certain housing estates.

\section{Message 5}

Privatisation of collective space should be handled with care. The function of housing estates, originally built by a central authority and intended for collective ownership, is strained when structural changes cause housing units to be placed in private hands. The often-grandiose physical configuration and social structure of housing estates require thoughtful management of common spaces when individual apartments become privatised.

The construction of large housing estates was usually publicly financed, resulting in publicly owned and publicly managed housing complexes. Public financing occurred to a lesser degree in Southern Europe and especially Athens, where housing estates have always been under private ownership (Kandylis et al. 2018). Governance structures were devised that were regarded as appropriate for 
public ownership and management. A common contemporary trend across Europe, however, is increased private ownership (Murie 2018; Petsimeris 2018; Lelévrier and Melic 2018) or semi-private ownership (Andersson and Bråmå 2018) of housing units (both in the general housing stock and in large housing estates). In the U.K. (Murie 2018), private owners are leaseholders and the freeholder (usually the local authority) retains key legal responsibilities for maintenance and repair of the external fabric and common areas of buildings; private owners are consulted and charged for these services. In many Eastern European countries, most apartments became privately owned in the 1990s, usually through 'right-to-buy' or 'pure give away' strategies to sitting tenants, resulting in the formation of super-homeownership societies (Kovács et al. 2018; Marin and Chelcea 2018; Leetmaa et al. 2018). In Prague, the transformation period (housing restitution, privatisation, rent regulation, administrative and legal changes) was top-down and overseen by municipal governments, but now the private and commercial sector influences the development of residential and commercial space of large housing estates (Ouředníček et al. 2018; Liepa-Zemeša and Hess 2016). In Berlin, large numbers of apartments have been sold to international investors (Urban 2018).

Today, redevelopment of many of the publicly constructed and formerly state-managed housing complexes thus sometimes lies in the hands of private owners. Although private ownership is usually related to better housing maintenance, it does not always work this way in large housing estates for various reasons (Kandylis et al. 2018; Marin and Chelcea 2018). First, private ownership of apartments puts them morally outside the realm and responsibility of local and central governments. Second, owners do not always possess the culture, knowledge or resources for property management to effectively upgrade housing themselves. Third, area-based coordination and management of common spaces is needed in housing estates. Privatisation with no eye on the grand spatial structures, private management of apartments and management of common spaces can easily lead to eclectic arrangements; individual improvements and care at the apartment - or even apartment building-level do not necessarily contribute to improved overall quality of living environments in housing estates. The selling of properties to large private development companies does not necessarily work, either. For example, Berlin sold 100,000 apartments to international investors; setting high rents for earning high profits tends to be more important for such investors than investing into the quality of the housing units and built environment (Urban 2018).

Although apartment associations are common in Eastern Europe, the management of renovation programmes is often chaotic. In Tallinn (Leetmaa et al. 2018) or Moscow (Gunko et al. 2018), for example, apartment owners who are dissatisfied with apartment association practices often pursue un-coordinated efforts to improve their apartments. The outcome of these improvements often leads to aesthetic compromises in buildings; for example, when windows are replaced by individual owners, every apartment may look different on the building facade. Even more radical developments, falling under the umbrella term 'do-it-yourself urbanism' can be found in less-wealthy post-socialist cities in the form of balcony construction or unregulated building additions (Bouzarovski et al. 2011). Again, the outcome is an 
eclectic building facade. Better coordination and management does not necessarily mean costly public investments; reasonable-cost renovations have been conducted in France (Lelévrier and Melic 2018). Poland is a good example of a healthy combination of privatisation and management, with large housing associations responsible for large numbers of apartment buildings and collecting modest maintenance fees from residents. The outcome is a fully renovated housing stock in large housing estates that is still attractive for socially diverse urban residents without creating burdens for public finances (Szafrańska 2014).

Productive management structures may not help if differential residential mobility has already produced significant population dynamics, leaving low-income groups in large housing estates. As the social status of residents of housing estates downgrades, it may be more difficult to reverse trends (Lelévrier and Melic 2018). Consequently, well-structured management programmes in Czechia and Poland are effective since there is still a relatively high social mix in housing estates in those countries. If high-income and low-income groups sort into different housing segments, the financial capacity for housing upkeep in low-income housing estates could fall short of investment needs. It follows that management structures should be revised in some countries before it is too late, since the differential sorting of various income groups is in an advanced state (Ouředníček et al. 2018).

To conclude, any action that increases private or semi-private ownership - and this is a pronounced and growing trend across Europe-in housing estates that are designed as grand macro-structures should be connected to effective systems of area-based urban management. This simple rule seems self-evident but is often violated in everyday life in many European countries; in no other housing segment can the violation of this rule create more harm than in large housing estates.

\section{Message 6}

It is critical to improve the perception and elevate the reputation of housing estates. People have a tendency to create images in their mind that may or may not match reality, but a poor reputation for large housing estates can further hurt their future performance.

At the time of the construction of housing estates, people had high hopes for them. There was great excitement, since new apartments in modernist housing estates offered major improvements in living quality. Many of the previous residential units were without running water (or cold water only), without showers or baths, without indoor toilets and without central heating. This made people enthusiastic about newly constructed housing estates, which offered a modern living style. Since social mixing within housing estates was a common aim of policymakers and planners, both working-class and middle-class families had the chance to live in a new modern apartment. However, the public perception of housing estates in Western Europe reversed quickly as the negative qualities of housing estates or the high concentration of low-income people were acknowledged. For example, the term 'deprivedhoods' was coined in France in 1981, referring to neighbourhoods in which large social problems were readily apparent (Lelévrier and Melic 2018). 
Large housing estates today tend to house people with lower than average incomes, but this is not always regarded as problematic (Urban 2018). As a rule of thumb, there is more stigma attached to large housing estates in Western European cities (e.g. Costa and de Valk 2018) than in Eastern and Southern European cities. Stereotyping by the media has contributed to the poor reputation of housing estates and has diminished their chances for success. For example, the public tends to have a distorted image of housing estates in Milan, based in part on media coverage of certain negative events. People think that housing estates are overrun with foreigners, but in reality, the share of ethnic minorities is small there (Petsimeris 2018). Likewise, residents of large housing estates find it shocking when media depicts them as criminals living in ghettos (Urban 2018). In Paris, large-scale investments have significantly improved the built environments of large housing estates, but their reputation has not increased among middle-class families, especially when riots and delinquency are emphasised in the media (Lelévrier and Melic 2018). Meanwhile, housing estates in Finland are well-managed and often beautifully landscaped with fully renovated modern housing (Vaattovaara et al. 2018). Hence, there is nothing substantially wrong with housing estates in many cities of Western and Northern Europe, and the negative perception towards them, especially among people not living there, does not always fully reflect the objective reality.

There is less stigma towards large housing estates in Eastern Europe (Ouředníček et al. 2018; Kovács et al. 2018; Marin and Chelcea 2018; Gunko et al. 2018), probably because they form a much more important segment in the housing sector and because there are fewer alternatives. The formation of large housing estates was closely linked with urbanisation and industrialisation. Eastern European cities industrialised rapidly, and, despite attempts to limit large city growth, grew rapidly as well, maintaining high demand for new housing construction (Marin and Chelcea 2018; Gunko et al. 2018). This high demand for new housing overshadowed the possible problems related to building large housing estates. In East Berlin, the critique of housing estates was surprisingly blunt as early as 1960 , when the housing blocks were depicted as 'monotonous', 'uniform' and 'carelessly designed' (Urban 2018). The state was responsible for housing development and since the costs of new housing construction are high $-8 \%$ of the GDP in Romania was spent on housing construction (Marin and Chelcea 2018)—new housing developments grew both in terms of height and density until the late 1980s, despite significant criticism. Furthermore, as new housing construction was almost absent in many Eastern European countries in the 1990s and early 2000s and during the period of major social transformation that impoverished people (Sýkora and Bouzarovski 2012) - there is little choice in the form of new housing, and the reputation of large housing estates has suffered less as well. In short, as large housing estates form the most important segment of housing in many Eastern European cities, their relative reputation has suffered less and they still form a well-appreciated segment of the housing stock.

A poor reputation for housing estates can certainly jeopardise their success. People often judge various segments of housing in relative terms, and the perception of each individual tends to follow the perceptions of the crowd. For 
example, the reputation of inner-city neighbourhoods is high across Europe today, but not long ago these neighbourhoods were sites of poor quality housing and low social status (Hess et al. 2017). This suggests that changes in perception could significantly alter the development trajectories of residential neighbourhoods. Policy and planning interventions at all levels - places, people and connectivitycan help to improve all aspects of housing estates and also the image of them. The latter is as crucial as the first. Changing the reputation, once damaged, is not an easy task, though. It only succeeds when supported with a range of related measures, including real, visible improvements for the residents ('the internal image') and newcomers to the city; it is most difficult to change reputation for those living outside housing estates (Wassenberg et al. 2004).

\section{Message 7}

Intervention strategies for reversing the fortunes of large housing estates are complex. The focus is usually on area-based interventions with an aim to improve the physical qualities of neighbourhoods, or on access- and connectivity-based interventions with an aim to link large housing estates originally located in peripheral urban space. More attention is needed, however, on people-based improvement strategies.

There is little wrong with large housing estates in many parts of Europe either because they have never experienced significant physical decline and lowering of social status or they have been subject to large-scale renovation. What is problematic is their negative public reputation and relative position at the bottom of the housing ladder. The consequences are, however, unfavourable since social, ethnic and spatial problems are often intermixed in a vicious circle of poverty and segregation (van Ham et al. 2018; Bolt 2018). This cycle has turned large housing estates into poverty traps where delinquency can readily develop. As a consequence, a lack of safety is one of the major challenges in large housing estates (Wassenberg 2018; Petsimeris 2018). Poor quality of the built environment is another important issue. Many policymakers have clearly understood this, and a majority of investments have consequently been channelled to improving the physical conditions of apartment buildings and surrounding built environments. Political rewards can be tied to physical improvements. In Eastern Europe, the requirement to comply with European Union energy directives is the most common way of improving large housing estates (Marin and Chelcea 2018; Lihtmaa et al. 2018).

Another important issue - especially in West European cities - pertains to quality of schools. Since schools often draw their students from surrounding residential districts (and in many countries, children must attend the nearest neighbourhood school); when low-income families begin to concentrate in certain areas of cities, higher income parents leave these places (and avoid moving into them in the first place) due to school quality (Bernelius 2013). This may deepen and hasten the lowering of the social status of large housing estates. The lowering of the social status of residents is partly related to changes in the economy in Northern and Western European countries. Middle-class families affected by the loss of jobs due to globalisation and de-industrialisation often become trapped in the most affordable 
parts of the housing sector, usually within large housing estates. As middle-income families leave (or avoid) such areas, unemployment levels are high in large housing estates (Lelévrier and Melic 2018; Andersson and Bråmå 2018). Children raised in these social environments often have low motivation to do well in school, lack positive role models and lack resources for getting good education and jobs; consequently, poverty tends to pass from parents to children (van Ham et al. 2018).

We identify three types of policy interventions - related to segregation and poverty - that can be pursued in large housing estates: place-based policies, people-based policies and connectivity-based policies. The place-based policies have been most popular in European cities and they mainly focus on upgrading the physical environments of large housing estates. This is achieved, for example, by demolishing low-quality (social) housing, by building higher quality social housing, by establishing more expensive rental and owner-occupied housing, and by enhancing neighbourhood amenities. Such measures have been extensive in the UK (Murie 2018), France (Lelévrier and Melic 2018) and Russia (Gunko et al. 2018). Place-based policies often require enormous investments, but within a relatively short period of time the physical layout can be upgraded by renovating and replacing buildings. Interestingly, though, the physical outcomes of demolition differ-in terms of densities and other factors. In Western European cities, the outcome is often reduced density (e.g. Lelévrier and Melic 2018), while in Eastern Europe, the outcome is often increased density, either as a result of in-fills as new apartment buildings are inserted among existing ones (Marin and Chelcea 2018) or existing apartment buildings are replaced with denser and taller housing blocks (Gunko et al. 2018).

While uniformity, repetition and equality were original guiding principles for large housing estates, diversity, individualism and choice are important for changing the future fortunes of large housing estates (Wassenberg 2018). Area-based intervention policies can only be successful if more affluent households can be attracted to large housing estates or in situ social mobility of existing residents occurs, driven by changes in built environments and local services, improved local school quality, and employment opportunities. It is a challenge to keep the socially upward climbers within housing estates; it would require a parallel renewal of dwellings and upgrading of neighbourhood facilities and amenities.

While some progress has been made in improving the quality of built environments and services, there has been less success in attracting middle-class families to large housing estates once social decline has advanced to a certain extent or 'tipping point' (Lelévrier and Melic 2018). Recent evidence from the Moving to Opportunity project suggests that mixing in situ works better than relocation (to better neighbourhoods) for low-income people (Chetty et al. 2016). An important lesson that follows is that it is never too early to intervene into the physical degradation and lowering of the social status of large housing estates, but it may be too late to intervene in an effective way.

People-based policies focus on reducing poverty and creating opportunities for residents in the areas of education and employment. People-based policies require a long-term perspective as it might take a generation or longer to reduce (intergenerational) poverty. An important realm that could have important spill-over effects 
in local communities pertains to primary and secondary education. Investing not only in the physical qualities of schools but attracting well motivated and good teachers in pre-schools and schools located in large housing estates could be a crucial catalyst for positive change. Especially when a share of residents of large housing estates is of immigrant background, their better integration in European societies hinges on policies that adjust to specific local contexts and day-to-day activities. A large pan-European project shows that across Europe, central governments tend to pursue naïve and value-based integration policies that poorly relate to people living in housing estates who experience everyday challenges (Tasan-Kok et al. 2014). More context-sensitive approaches are thus needed. A good example is the halving of class size in French housing estates in order to pay more attention to each child.

The success of people-based policies is not always visible in local communities, since success might be masked or it might dissipate. Hence, people-based policies should be combined with place-based policies to effectively improve housing and neighbourhoods. If the focus is on only people-based or place-based policies, the interventions will likely fail. If people-based policies are successful, children may perform well in school and advance to higher education and employment, eventually earning higher incomes and allowing themselves to consider wider choices in the housing market and consequently move to better neighbourhoods. A way to intervene is to motivate companies to locate their offices in or near large housing estates (using tax incentives) and to also locate public institutions and jobs there (similar to the way that institutions such as universities are sometimes located in peripheral locales as part of regional policy measures). Locating an art university (or a branch of an art university), for example, within a large housing estate could invigorate its surroundings, bring new people to the area and contribute to an improved reputation for large housing estates. Other potential additions to housing estates include local libraries, museums, football stadiums, concert halls, or regional shopping malls; it is important to bring outsiders to housing estates for functional reasons. This would also help improve the perception of housing estates. However, the juxtaposition of various social groups is only successful when social links between social groups form as well.

Place-based policies do not necessarily reduce poverty and inequality, and people-based policies might not have desired local effect; therefore, a full set of interventions should ideally also focus on connectivity. Interventions to improve connectivity are aimed at reducing spatial separation of poor groups from opportunities, leisure-time facilities, services, suitable jobs and, in particular, education. For example, segregation levels have risen quickly in Tallinn compared to other European capital cities (Tammaru et al. 2016b) but free public transport in the city helps to overcome the problems of socio-spatial isolation of residents living in large housing estates (Leetmaa et al. 2018; Hess 2017). But the effect also works in the opposite direction. When better connected to the rest of the city, other urban dwellers can have easier access to large housing estates. If private companies are attracted to large housing estates and if some public institutions and jobs are located there, good connectivity is crucial for facilitating inward mobility to large housing 
estates. In other words, new policies are needed to promote investments that link large housing estates with other parts of cities and wider metropolitan regions. Such linking includes public transport, improving road access (often large estates are poorly accessible by roads, or easy to avoid), and creating bicycle routes, with each travel mode providing convenient access to the city centre.

Place-based policies can also lead to the gentrification of housing estates, similar to events in central cities in which higher socio-economic groups replace lower socio-economic groups, or fragmentation of large housing estates into smaller subdistricts where people with different social statuses still live parallel lives. Intervention strategies should thus have an eye on such changes in large housing estates as well.

\section{Message 8}

Many ideas about contemporary urban life-including sustainability, ecological footprints, communal life and the sharing economy, and social equity-align well with the underlying principles of housing estates, which offers chances for the future.

The reputation of large housing estates tends to be poor, due to either real or perceived problems related to their physical decline and spiralling social status. The original formation of large housing estates was driven by a need to provide new housing in large quantities, but there was also a belief that modernist housing and urban planning could produce a more equal and fair society (Wassenberg 2018). In Sweden, modernist housing was intended to become the core element of the welfare state (Andersson and Bråmå 2018) and in the former Soviet Union, large housing estates acted as the spatial manifestations of egalitarian ideology (Leetmaa et al. 2018). Contemporary social and urban discussions also revolve around the topics of equality and justice, especially in light of growing levels of income inequality (World Inequality Report 2018) and residential segregation (Tammaru et al. 2016b).

The problems tend to be larger in the most grandiose housing estates with high densities and tall apartment towers. However, recent studies challenge the assumption that higher densities per se are harmful to community life or to local social interaction, suggesting that the specific urban form of neighbourhoods is more important (Arundel and Ronald 2017). In some cities where high-rise housing is almost ubiquitous, high densities are not perceived as a large problem; in Moscow, for example, high urban density is a norm and new urban regeneration programmes increase rather than decrease housing densities (Gunko et al. 2018). In cities with a more diverse choice set for housing, i.e. with more alternatives to large housing estates, high densities tend to correlate more strongly with poor reputations (Andersson and Bråmå 2018). It is thus important to avoid the formation of stigma towards high-rise buildings and to create social mix and change within them (Lelévrier and Melic 2018).

Although differences exist in the perception towards high densities in large housing estates that might lead to different intervention strategies, a compact city strategy was not necessarily misguided. It aligns well with contemporary urban ideals that celebrate community life, urban sustainability and the sharing economy. What has proved to be terribly wrong, rather, was confidence in an assumption that 
planners and architects know what is good for people, especially the replication of the idea en masse. Design weaknesses of housing estates can be changed to a certain degree-modifying urban densities, diversifying housing through retrofitting, introducing elements of smart cities and the sharing economy - which can help bring about important change. In housing estates with high shares of elderly people, sharing of out-of-home obligations (like daily errands and shopping) might be useful. Likewise, shared usage of bicycles or electric vehicles might be another option, not to speak of common laundry and leisure facilities. When well-managed and cared for, shared activity spaces and activities might be attractive for younger people who have difficulties entering the labour market and achieving a good starting salary, who care about sustainability, and are comfortable with the idea of resource sharing.

Measures that connect housing estates efficiently to the rest of the city - to jobs, leisure-time activity sites, urban parks, suburban and rural greenery-not only by public transport but also by well-designed pathways for non-motorised travel are also an attractive option for young people who value environmental sustainability and cost efficiency. There are various ways to be creative and to try to match housing estates better to contemporary urban ideals, thinking in a very concrete way about the needs of people living in large housing estates by acknowledging the variety of living contexts, tenure structures and trajectories of change that they represent in European cities.

\section{Message 9}

Reliable, up-to-date and comparable data are needed about the residents of large housing estates across Europe. We cannot expect city governments and other actors to define effective intervention strategies if they cannot accurately diagnose problems and challenges.

In the current age of information and big data, there is, most surprisingly, little solid, reliable and comparable data about European housing estates and their residents. The diversity of housing estates and their urban contexts pose challenges to amassing relevant data. However, the problem explicitly relates to the flexibility of using data at fine-grained geographic scale by important population segments (such as ethnic groups) and data that can be longitudinally analysed over time. Without adequate and fine-grained data that can be flexibly used to fit a variety of definitions, it is difficult to quantify and understand urban problems and, as a consequence, it is challenging to design appropriate interventions addressing confirmed problems. Non-existence of detailed data, making it impossible to accurately delineate housing estates (Marin and Chelcea 2018; Lelévrier and Melic 2018) is the norm; fortunately, however, relevant detailed data exists in a few places such as Sweden (Andersson and Bråmå 2018). Since there are few problems in many housing estates in Europe and negative public perceptions often emerge from media coverage of specific events, it is also difficult to overcome prejudice and stigma attached to housing estates and to their residents, as evidenced in Milan (Petsimeris 2018). It follows that the reputation of large housing estates in European cities unfortunately hinges more on media reports than on solid scientific evidence. 
A lack of detailed geographical data in Europe is often grounded on a privacy argument. However, the good intentions of data protection often produce negative outcomes, since poor knowledge about population characteristics in large housing estates can exacerbate problems associated with their downgrading. Therefore, census data and population register data should be adjusted so that they can be used to study housing estate residents, and new data sources should be developed that reflect changing realities, such as data from smartphones (Silm and Ahas 2014). As more research on various aspects of challenges related to large housing estates is conducted in European cities, we can better measure, understand and compare contributors to successes and failures that shape the trajectories of large housing estates. Such research would also generate more evidence and new ideas for designing better and smarter policy interventions that ultimately improve the lives of people living in housing estates.

\section{Message 10}

Past mistakes made with large modernist housing estates could help guide the way current and future cities are planned in Europe and beyond. A lesson can be offered from twentieth-century experiences in Europe with housing estates: the larger, higher density and the more peripherally located housing areas are at higher risk of concentrating poverty and producing and reproducing triple disadvantages - social, ethnic, spatial—-through a vicious circle of poverty and segregation.

Housing estates in Europe were established during the post-World War II period of rapid industrialisation and urbanisation, providing cost-efficient housing for rapidly expanding urban populations. There is a risk, however, in succumbing to short-term thinking in attempts to solve housing crises, because this strategy is attached to long-term societal costs. The sequence of events is as follows for reproducing a vicious cycle of poverty and segregation (van Ham et al. 2018): lower income people cluster into large housing estates; schools are often neighbourhood-based, and thus children in less affluent families living in large housing estates attend the same schools, resulting in the transmission of social and spatial disadvantage from parents to children; these differences are carried on to the labour market and result in income inequalities; the vicious circle of poverty closes when labour market outcomes shape residential choice. The signs of the formation of segregation cycles are most clear in Northern and Western European cities (Lelévrier and Melic 2018; Andersson and Bråmå 2018), but can also be traced elsewhere (Leetmaa et al. 2018). Focusing on teachers and school outcomes in large housing estates is a potential strategy for breaking the cycle of segregation.

Although the fortunes of housing estates and their residents can be changed, the main lesson is that city leaders should conscientiously avoid the formation of such quickly and cheaply constructed housing areas on inexpensive land in urban peripheries - where migrants, immigrants, guest workers and low-income people become highly concentrated-since this would most likely produce long-term challenges. While the phase of large-scale industrialisation and urbanisation in Europe is in the past and will not be repeated, these processes are at their peak today 
in other places across the globe. The number of people living in cities increased from 0.75 to 3.9 billion between 1950 and 2014, and an additional 2.5 billion people will move to cities worldwide by 2050, a third of them in India, China and Nigeria (United Nations 2014). To accommodate this contemporary urban population growth, large tower block districts continue to grow.

It is not imperative to completely avoid high population densities in urbanising countries today since it would be a nearly impossible aim to achieve; the population size in countries urbanising today is larger than in Europe and lower population densities would consume a great deal of valuable land. High densities per se are often not a problem in European cities. Problems emanate, however, from (1) the relative position of high-density housing estates at the bottom of the housing hierarchy; (2) a 'one-size-fits-all' way of thinking in urban planning and (3) new housing districts with deleterious features including cost-efficient planning and construction, repetition, spatial isolation, an undeveloped sense of community and place attachment, and a lack of safety. To overcome these issues, planning for new residential areas should instead focus on creating human-scale environments and avoid density-related problems. Eastern European cities demonstrate that large housing estates can be desirable living spaces for many and provide a considerable share of the urban housing stock.

It is undoubtedly tempting for city planners to build cheap mass-produced housing on urban peripheries because the living conditions provided are better (at least at the time of construction) compared to most existing housing units in a city's housing stock. Based on the twentieth-century European experience, however, grandiose cost-efficient housing estates should be avoided in favour of more human-scale urban models. Although more expensive at the time of construction, traditional and human-scale residential environments would last longer and produce fewer social problems for future generations to solve. Moreover, good connectivity, an abundance of neighbourhood amenities and a sustainable social mix supporting interaction across social groups are important for avoiding poverty concentrations in large housing estates like those in Northern and Western European cities.

Acknowledgements We are grateful to all authors in this volume for their valuable input to this introductory chapter. We are especially indebted to Frank Wassenberg and Alan Murie for thorough feedback and suggestions that helped to significantly improve the chapter, as well as to Thomas Maloutas, Liviu Chelcea, Christine Lelévrier and Martin Ouředníček. Annika Väiko provided invaluable research support and Raivo Aunap provided cartographic assistance. The authors are responsible for the contents of the chapter.

The research leading to this work has received funding from the European Union's Horizon 2020 research and innovation programme under Marie Skłodowska-Curie grant agreement number 655601. Support also came from three grants from the Estonian Research Council: Institutional Research Grant IUT2-17 on Spatial Population Mobility and Geographical Changes in Urban Regions, Infotechnological Mobility Observatory, and RITA-Ränne. The European Research Council funded this research under the European Union's Seventh Framework Programme (FP/ 2007-2013)/ERC [Grant Agreement No. 615159] (ERC Consolidator Grant DEPRIVEDHOODS, Socio-spatial inequality, deprived neighbourhoods, and neighbourhood effects). 


\section{References}

Andersson R, Bråmå $\AA$ (2018) The Stockholm estates - a tale of the importance of initial conditions, macroeconomic dependencies, tenure and immigration. In: Hess DB, Tammaru T, van Ham M (eds) Housing estates in Europe: poverty, segregation, and policy challenges. Springer, Dordrecht, Netherlands

Arundel R, Ronald R (2017) The role of urban form in sustainability of community: The case of Amsterdam. Environ Plann B Urban Anal City Sci 44(1):33-53

Bernelius V (2013) Eriytyvät kaupunkikoulut. Helsingin peruskoulujen oppilaspohjan erot, perheiden kouluvalinnat ja oppimistuloksiin liittyvät aluevaikutukset osana kaupungin eri-ytymiskehitystä. Tutkimuksia, vol 1. Helsingin kaupungin tietokeskus, Helsinki

Bolt G (2018) Who is to blame for the decline of large housing estates? An exploration of socio-demographic and ethnic change. In: Hess DB, Tammaru T, van Ham M (eds) Housing estates in Europe: poverty, segregation, and policy challenges. Springer, Dordrecht, Netherlands

Bouzarovski S, Salukvadze J, Gentile M (2011) A socially resilient urban transition?: The contested landscapes of apartment building extensions in two post-communist cities. Urban Stud 48(13):2689-2714

Chetty R, Hendren N, Katz L (2016) The effects of exposure to better neighborhoods on children: new evidence from the moving to opportunity project. Am Econom Rev 106(4)

Chrisafis A (2015) 'Nothing's changed': 10 years after French riots, Banlieues remain in crisis. The Guardian

Costa R, de Valk H (2018) Sprouted all around: The emergence and evolution of housing Estates in Brussels, Belgium. In: Hess DB, Tammaru T, van Ham M (eds) Housing estates in europe: poverty, segregation, and policy challenges. Springer, Dordrecht, Netherlands

Dekker K, Van Kempen R (2004) Large housing estates in Europe: cur-rent situation and developments. Tijdschrift voor Economische en Sociale Geografie 95(5):570-577

Gunko M, Bogacheva P, Medvedev A, Kashnitsky I (2018) Path-Dependent development in mass housing in Moscow, Russia. In: Hess DB, Tammaru T, van Ham M (eds) Housing estates in europe: poverty, segregation, and policy challenges. Springer, Dordrecht, Netherlands

Hess DB (2017) Decrypting fareless public transport in Tallinn, Estonia. Case Stud Trans Policy 5 (4):690-698

Hess DB, Evan I, Annika V (2017) Network connections and neighborhood perception: using social media postings to capture attitudes among twitter users in Estonia. J Archit Urban Plan 13:67-77. doi: https://doi.org/10.1515/aup-2017-0010

Hess DB (2018) Transport in mikrorayons: accessibility and proximity in centrally planned residential districts during the socialist era, 1957-1989. J Plann Hist 17(3):184-204. doi: https://doi.org/10.1177/1538513217707082

Hess DB, Hiob M (2014) Preservation by neglect in soviet-era town planning in Tartu, Estonia. J Plann Hist 13(1):24-49. doi: https://doi.org/10.1177/1538513213512254

Hess DB, Tammaru T, Leetmaa K (2012) Ethnic differences in housing in post-Soviet Tartu, Estonia. Cities 29(5):327-333

Howley P, Scott M, Redmond D (2009) Sustainability versus liveability: an investigation of neighbourhood satisfaction. J Environ Plann Manag 52(6):847-864

Kandylis G, Maloutas T, Myofa N (2018) Exceptional social housing in a residual welfare state: housing estates in Athens, Greece. In: Hess DB, Tammaru T, van Ham M (eds) Housing estates in Europe: poverty, segregation, and policy challenges. Springer, Dordrecht, Netherlands

Kovács Z, Egedy T, Szabó B (2018) Persistence or change: divergent trajectories of large housing estates in Budapest, Hungary. In: Hess DB, Tammaru T, van Ham M (eds) Housing estates in Europe: poverty, segregation, and policy challenges. Springer, Dordrecht, Netherlands

Leal J, Sorando D, Uceda P (2018) The diversity of trajectories of large housing estates in Madrid, Spain. In: Hess DB, Tammaru T, van Ham M (eds) Housing estates in Europe: poverty, segregation, and policy challenges. Springer, Dordrecht, Netherlands 
Leetmaa K, Holvandus J, Mägi K, Kährik A (2018) Population shifts and urban policies in housing estates of Tallinn, Estonia. In: Hess DB, Tammaru T, van Ham M (eds) Housing estates in Europe: poverty, segregation, and policy challenges. Springer, Dordrecht, Netherlands

Leetmaa K, Tammaru T, Hess DB (2015) Preferences towards neighbor ethnicity and affluence: evidence from an inherited dual ethnic context in post-soviet Tartu, Estonia. Ann Assoc Am Geogr 105(1):162-182

Lelévrier C, Melic T (2018) Impoverishment and Social Fragmentation in Housing Estates of the Paris Region, France. In: Hess DB, Tammaru T, van Ham M (eds) Housing estates in europe: poverty, segregation, and policy challenges. Springer, Dordrecht, Netherlands

Liepa-Zemeša M, Hess DB (2016) Effects of public perception on urban planning: evolution of an inclusive planning system during crises in Latvia. Town Plann Rev 87(1):71-92

Lihtmaa L, Hess DB, Leetmaa, K (2018) Intersection of the global climate agenda with regional development: Unequal distribution of energy efficiency-based eenovation subsidies for apartment buildings. Energy Policy 119:327-338. doi: https://doi.org/10.1016/j.enpol.2018. 04.013

Luhn A (2017) Moscow's big move: is this the biggest urban demolition project ever? Guardian Cities

Marin V, Chelcea L (2018) Housing estates in Bucharest, Romania: a viable housing provider in Europe's densest capital city. In: Hess DB, Tammaru T, van Ham M (eds) Housing Estates in Europe: poverty, segregation, and policy challenges. Springer, Dordrecht, Netherlands

Metspalu P, Hess DB (2018) Revisiting the role of architects in planning large-scale housing in the USSR: the birth of three large housing estates in Tallinn, Estonia. Plann Perspect 33(3):335-361. doi: https://doi.org/10.1080/02665433.2017.1348974

Meuser P, Zadorin D (2016) Towards a typology of soviet mass housing: Prefabrication in the USSR, 1955-1991. DOM Publishers, Berlin

Murie A (2018) Decline and response: lifecycle change of housing estates in Birmingham, England. In: Hess DB, Tammaru T, van Ham M (eds) Housing estates in Europe: poverty, segregation, and policy challenges. Springer, Dordrecht, Netherlands

Ouředníček M, Špačková P, Pospíšilová L (2018) Long-term development and current socio-spatial differentiation of housing estates in Prague, Czechia. In: Hess DB, Tammaru T, van Ham M (eds) Housing estates in Europe: poverty, segregation, and policy challenges. Springer, Dordrecht, Netherlands

Petsimeris P (2018) Social and ethnic transformation of large social housing estates in Milan, Italy: from modernity to marginalisation. In: Hess DB, Tammaru T, van Ham M (eds) Housing estates in Europe: poverty, segregation, and policy challenges. Springer, Dordrecht, Netherlands

Rowlands R, Musterd S, van Kempen R (2009) Mass housing in Europe, multiple faces of development, change and response. Palgrave Macmillan, Basingstroke

Silm S, Ahas R (2014) The temporal variation of ethnic segregation in a city: evidence from a mobile phone use dataset. Soc Sci Res 47:30-43

Szafrańska E (2014) Transformations of Large housing estates in post-socialist city: the case of Łódź. Poland. Geographia Polonica 87(1):77-93

Sýkora L, Bouzarovski S (2012) Multiple transformations: conceptualising post-communist urban transition. Urban Studies 49(1):41-58

Tammaru T, Kährik A, Mägi K, Novák J, Leetmaa K (2016a) The 'market experiment': Increasing socio-economic segregation in the inherited bi-ethnic context of Tallinn. In: Tammaru T, Marcińczak S, van Ham M, Musterd S (eds) Socio-economic segregation in European capital cities: East meets West. Routledge, New York/ London, pp 333-357

Tammaru T, Marcińczak S, van Ham M, Musterd S (2016b) Socio-economic segregation in European capital cities: East meets West. Routledge, New York/ London

Tasan-Kok T, Van kempen R, Raco M, Bolt G (2014) Towards hyper-diversified European Cities. Utrecht University, Utrecht, A critical Literature Review

Turkington R, van Kempen R, Wassenberg F (2004) High-rise housing in Europe: current trends and future prospects. In. Delft University Press, Delft 
United Nations (2014) World's population increasingly urban with more than half living in urban areas

Urban F (2018) Large Housing Estates of Berlin, Germany. In: Hess DB, Tammaru T, van Ham M (eds) Housing estates in Europe: Poverty, segregation, and policy challenges. Springer, Dordrecht, Netherlands

Vaattovaara M, Joutsiniemi A, Kortteinen M, Stjernberg M, Kemppainen T (2018) Experience of a preventive experiment: spatial social mixing in post-world war ii housing estates in Helsinki, Finland. In: Hess DB, Tammaru T, van Ham M (eds) Housing estates in Europe: poverty, segregation, and policy challenges. Springer, Dordrecht, Netherlands

van Ham M, Tammaru T, Janssen HJ (2018) A multi-level model of vicious circles of socio-economic segregation. In: Divided cities: understanding intra-urban disparities. OECD, Paris

van Kempen R, Dekker K, Hall S, Tosics I (2005) Restructuring large housing estates in EuropeRestructuring and resistance inside the welfare industry. Policy Press, University of Bristol, Bristol

Wassenberg F (2018) Beyond an ugly appearance: understanding the physical design and built environment of large housing estates. In: Hess DB, Tammaru T, van Ham M (eds) Housing estates in Europe: poverty, segregation, and policy challenges. Springer, Dordrecht, Netherlands

Wassenberg R, Turkington R, van Kempen R (2004) High-rise housing estates in Europe. In: Turkington R, van Kempen R, Wassenberg F (eds) High-rise housing in Europe: current trends and future prospects. University Press, Delft, pp 1-14

Wessel $\mathrm{T}$ (2016) Economic segregation in Oslo: polarisation as a contingent outcome. In: Tammaru T, Musterd S, van Ham M, Marcinczak S (eds) Socio-economic segregation in european capital cities: East Meets West. Routledge, New York/London, pp 132-155

Open Access This chapter is licensed under the terms of the Creative Commons Attribution 4.0 International License (http://creativecommons.org/licenses/by/4.0/), which permits use, sharing, adaptation, distribution and reproduction in any medium or format, as long as you give appropriate credit to the original author(s) and the source, provide a link to the Creative Commons license and indicate if changes were made.

The images or other third party material in this chapter are included in the chapter's Creative Commons license, unless indicated otherwise in a credit line to the material. If material is not included in the chapter's Creative Commons license and your intended use is not permitted by statutory regulation or exceeds the permitted use, you will need to obtain permission directly from the copyright holder. 


\section{Part II \\ Thematic Lenses for Scholarly Inquiry}




\title{
Chapter 2 \\ Beyond an Ugly Appearance: \\ Understanding the Physical Design \\ and Built Environment of Large \\ Housing Estates
}

\author{
Frank Wassenberg
}

\begin{abstract}
Large housing estates - and high-rise blocks in particular-are well-known for their problems. This chapter explores the extent to which physical form is responsible for causing the eventual failure of many large housing estates. Although the process of planning large housing estates in the post-World War II era is considered to have been well-thought out, it is also worth exploring how the design, size, form and appearance of these housing estates affected their negative perception and outcomes. The chapter investigates the relationships between the built environment of large housing estates, their local contexts and negative social outcomes commonly associated with estates. To understand this relationship, the chapter examines why high-rise apartment blocks and large housing estates were built the way they were, why problems are concentrated there and what is being done to combat the problems commonly experienced in large residential districts.
\end{abstract}

Keywords Large housing estates - High-rise - Urban renewal policies Physical appearance $\cdot$ Neighbourhood development

\subsection{Large Housing Estates Are Intriguing}

Everyone has an opinion about large housing estates. This could be an opinion about their most visible shapes, which are often high-rise blocks, characterised by a uniform repetition of cells. However, most opinion makers, nor scientists, nor policymakers do not live on such large estates themselves, and never visit them unless strictly necessary. Surprisingly, most of these large-scale estates have been carefully planned. Planners, scientists, architects and other experts have spent far

\author{
F. Wassenberg $(\bowtie)$ \\ Platform31, The Hague, The Netherlands \\ e-mail: frank.wassenberg@platform31.nl \\ F. Wassenberg \\ Delft University of Technology, Delft, The Netherlands \\ (C) The Author(s) 2018 \\ D. B. Hess et al. (eds.), Housing Estates in Europe, The Urban Book Series, \\ https://doi.org/10.1007/978-3-319-92813-5_2
}


more time studying ideas, design and construction than was the case with most other neighbourhoods, but this has not lead to the intended satisfaction and popularity of these estates.

Why is it that large housing estates, and high rises in particular, attract all this attention? Is it the failure of the form? Are they just considered ugly - not so by me, but by many citizens? Do most people prefer other types of dwellings, once they get choice? Is it the scale, the monotonous repetition, the (lack of) colour ('fifty shades of grey') or the one-size-fits-all appearance?

Large housing estates, particularly high rises, can be considered one of the most shining examples of well-thought-out urban designs ever: 'housing of tomorrow for the people of today'. However, since then tremendous problems have been observed, receiving particular attention from policymakers, urban practitioners and scientists. Sometimes, rigorous measures were inescapable, often soon after construction.

In this chapter, I focus on the physical perspective, realising that other points of view are just as important, but these are dealt with in other chapters of this book. Within the country chapters, all perspectives will be combined. I make use of my doctoral dissertation, in which I describe my experience with over 20 years interference with the issue (Wassenberg 2013).

Problematic or not, it is a fact that large housing estates do exist; in some countries, they are up to half of the housing stock. We have to cope with them and make them functional as an ordinary urban neighbourhood. When necessary, we have to consider ways to improve them. Sometimes to a lesser degree, but elsewhere major renewal approaches are inescapable. Fortunately, fine examples of minor and major renewals of large estates do exist.

This chapter describes both the glorious designs and expectations from when large housing estates were first built, the convergent fortunes of the estates once built, the numerous problems in the years following, and integrated approaches to renewing failing estates. The chapter starts with some general thoughts about large housing estates and high-rise blocks in particular. Afterwards, we elaborate on the roots of the construction of large housing estates, followed by their promising start. However, problems soon started occurring, mostly in Western European countries. Western Europe has had the most experience with integrated approaches for sustainable renewal of those estates.

\subsection{Reflections on Large Housing Estates}

The first question to raise is: 'What is a large housing estate?' Earlier studies pointed out that there is no universal definition for a housing estate, nor for a large housing estate (see: Power 1997; Dunleavy 1981; Turkington et al. 2004; van Kempen et al. 2005; Rowlands et al. 2009).

The British phrase 'housing estate' is not easily and equally translated into other languages, providing different connotations. In Germany and Austria, we can find many 'Siedlungen' or 'Wohnsiedlungen', but these have a connotation of their 
socialist advocates in the 1920s. The French 'cité's' or 'ensembles' are associated with remote post-war constructions in the notorious banlieue. The Dutch 'complex' associates with the administration unit of the owning housing associations. In Spanish, 'poligonos de vivienda' is the closest, which is clearly associated with Franco's dictatorship strategy of building large housing estates for blue-collar workers in major cities. 'Housing estate' is more a British English term, as in the United States and Australia, 'housing developments' and 'tract housing' are more widely used.

\subsubsection{Features of Housing Estates}

We distinguish ten features of housing estates:

1. Planned development: A housing estate is the result of urban planning, not of the organic growth of cities.

2. Urbanity: Housing estates can be found in urban or suburban areas, where houses have been built in large quantities.

3. Appearance: Housing estates are usually built by a single contractor in a limited period of time and according to one prevailing design, resulting in a uniform and distinct appearance.

4. Economy: The construction of adjoining similar dwellings in large amounts provides more housing at lower costs.

5. Building periods: Although the history of housing estates starts in the nineteenth century, most estates were built in the post-World War II decades. This is the period we focus on.

6. Housing types: Housing estates vary from single-family developments to large high-rise blocks.

7. Tenure: Housing estates can be owner-occupied, public (or social) housing and privately rented housing. A mix is possible.

8. Social equality: In the post-war decades, egalitarianism and uniformity prevailed over individualism and diversity: 'What is good for one, is good for all'.

9. Function: Housing estates usually contain dwellings. Only in large developments are support functions like neighbourhood centres, community services and schools included. Often, housing is clearly separated from other functions.

10. Location: Most housing estates were developed outside the then-existing city limits, where sufficient land was available and affordable. Some of these once-peripheral spots became central within cities, while others have remained isolated.

Next to these spatial characteristics, we can add one more, concerning the size, as we are talking about large housing estates. Estates may contain thousands of dwellings, depending on the local context; so, an average housing estate in Moscow or London will be larger than one in the provinces. However, housing estates are 
quite large scale within the local context. The larger the city, the larger an estate has to be to be considered as 'large' by locals.

\subsubsection{Defining Large Housing Estates and High Rises}

Combining all these thoughts, we can define a large housing estate as a group of housing distinct in form, built together as a single development on a large scale for the local context. High rises form an important and clearly visible part of large housing estates. High rises are commonly defined as when the number of floors is high enough that an elevator is legally required; in most cases, this is five or more. Most high rises were built in a limited time period. The country-specific chapters will illustrate this. Sometimes, disguised post-war estates do have very fundamental origins. The next section provides some background into this.

\subsection{The Roots of Large Housing Estates}

Any organised country in history has provided large housing estates. Increasing civilisation has historically led to urbanisation, and to upscaling of housing provision. The Romans built six storey high blocks, which must have been considered as mass housing by locals, as did other cultures like the Persians, Maya's and Chinese to name a few. Much later, industrialisation in the nineteenth century attracted masses of job seekers to expanding urban areas where new industries were being concentrated. Cities grew rapidly, providing housing for the masses and providing large housing estates. Vienna grew from 400,000 to 2 million over the second half of the nineteenth century. Here, the masses were housed in poorly equipped, large blocks, often rented by the bed. Up to $20 \%$ of all tenants rented a bed by the hour, sharing it with others during the day. Paris grew from 1 million in 1850 to almost 3 million by World War I. Glasgow saw its demographic base increase between 1801 and 1861 from 77,000 to 400,000, before exceeding 1 million by 1911. Emerging cities were not equipped for such large migrant inflows, which led to poverty, overcrowding, poor hygienic conditions, diseases and a host of other social miseries (Lévy-Vroelant et al. 2008). To combat the misery, housing conditions had to be improved. Several distinctive developments led to the construction of mass housing. We consider five of these.

\subsubsection{Philanthropists Take Action}

The first housing estates in the late 1800 s were built on a small scale by philanthropic aristocrats and utopian industrialists, in order to combat social injustice, 
provide healthy workforces, control urban diseases and reduce the risk of uprisings. Enlightened rich entrepreneurs provided decent housing for deserving workers and their families. Examples are New Lanark in Scotland, Agnetapark in Delft, the Netherlands, Lever's Port Sunlight in England, the Krupp estate in Berndorf, Austria and Le Creusot and Dolfus in Mulhouse, France. These examples are quite different from what we now consider to be large housing estates.

\subsubsection{Governments at Last Got Involved}

Gradually, but very slowly, governments became involved in housing (Pooley 1992). It was not until the late 1800s that increased concern about public health put housing on the national political agendas and led to housing acts being passed in many European countries around 1900. National governments got involved only after the World War I. The building industry had collapsed, and moreover, there was fear of uprising socialist parties, which were stimulated by the Russian revolution in 1917. State involvement only grew after 1945.

\subsubsection{Healthy Garden Cities}

Concerns about slum conditions stimulated the search for healthier urban and housing environments. Ebenezer Howard's influential 1898 plan for a 'Garden City' combined the best of 'town' and 'country' in small, low-density developments away from the overcrowded city. The 'garden suburb' of the 1920s and 1930s constituted a genuine housing form, built in response to the excesses of unregulated urbanisation. Renowned garden cities in England are Welwyn and Letchworth. Howard became the inspiration for the New Town Movement, which as a form of urban planning has had large impacts all around the world.

\subsubsection{Modern CIAM Architects}

Most dwelling construction followed traditional ideas in the inter-war years, but by the 1930s a more radical philosophy began to emerge. Das Neue Bauen had its roots in Germany, but was to be of great international influence, especially in the USSR. Stalin's Soviet Union provided a model with collective rental housing for workers on a large scale. This model was used in European countries under Communism and provided inspiration for Western European architects and planners, both between the world wars and in the first years after World War II. According to the principles of Modernism, architects and urban planners believed it 
was possible to construct a new and egalitarian society by providing dramatically improved housing and environmental conditions for the working classes.

From 1928 onwards, the Congrès Internationaux d'Architecture Moderne (CIAM) organised international congresses that were to have a major influence on the construction of large housing estates. Probably, its most prominent member was the Swiss architect Le Corbusier.

\subsubsection{A Housing Estate as a Planned Neighbourhood}

Architects and urban planners had thought not only about better housing units but also about better living environments than the slums with small, overcrowded and unhygienic housing on stuffy streets hidden from the daylight. Hall called the nineteenth-century slums the 'City of dreadful night', after the late nineteenthcentury poet James Thomson (Hall 1988). Polasky (2001) spoke of 'teeming, chaotic and congested cities, where the ever increasing number of workers who huddled in blind alleys and rookeries threatened urban order'.

Urban planning reformers embraced the neighbourhood unit planning idea of American planner Clarence Perry and the human ecologists of the Chicago School. Urban planning of the post-war large housing estates leaned heavily on these important neighbourhood planning ideas (Nyström 2006). Many post-war housing estates were built with the ideas that the neighbourhood was a unit; it would flourish by itself when houses and all the necessary services, like schools and neighbourhood centres were within the same unit or area. Post-war large housing estates were very orderly and well planned, contrary to the chaotic urban planning of the pre-war years, as depicted in Fig. 2.1.

\subsection{Glorious Estates}

\subsubsection{Mass Housing for Millions}

The three decades following the World War II are often considered the golden age of social housing, les trentes glorieuses, as the French call it. Millions of homes were built, the majority in large housing estates. Social housing estates were no longer aimed only at the working classes, but also at the middle classes, key workers and, otherwise, the lowest classes. Social housing policy allowed the majority of the population to share the wealth of the economic boom and was a key factor in the establishment of national welfare states, following Scandinavian examples (Scanlon et al. 2014).

It is interesting to note that the modern architects in Western Europe tested their first concepts of mid-rise blocks in the colonies of northern Africa. Avermaete and 

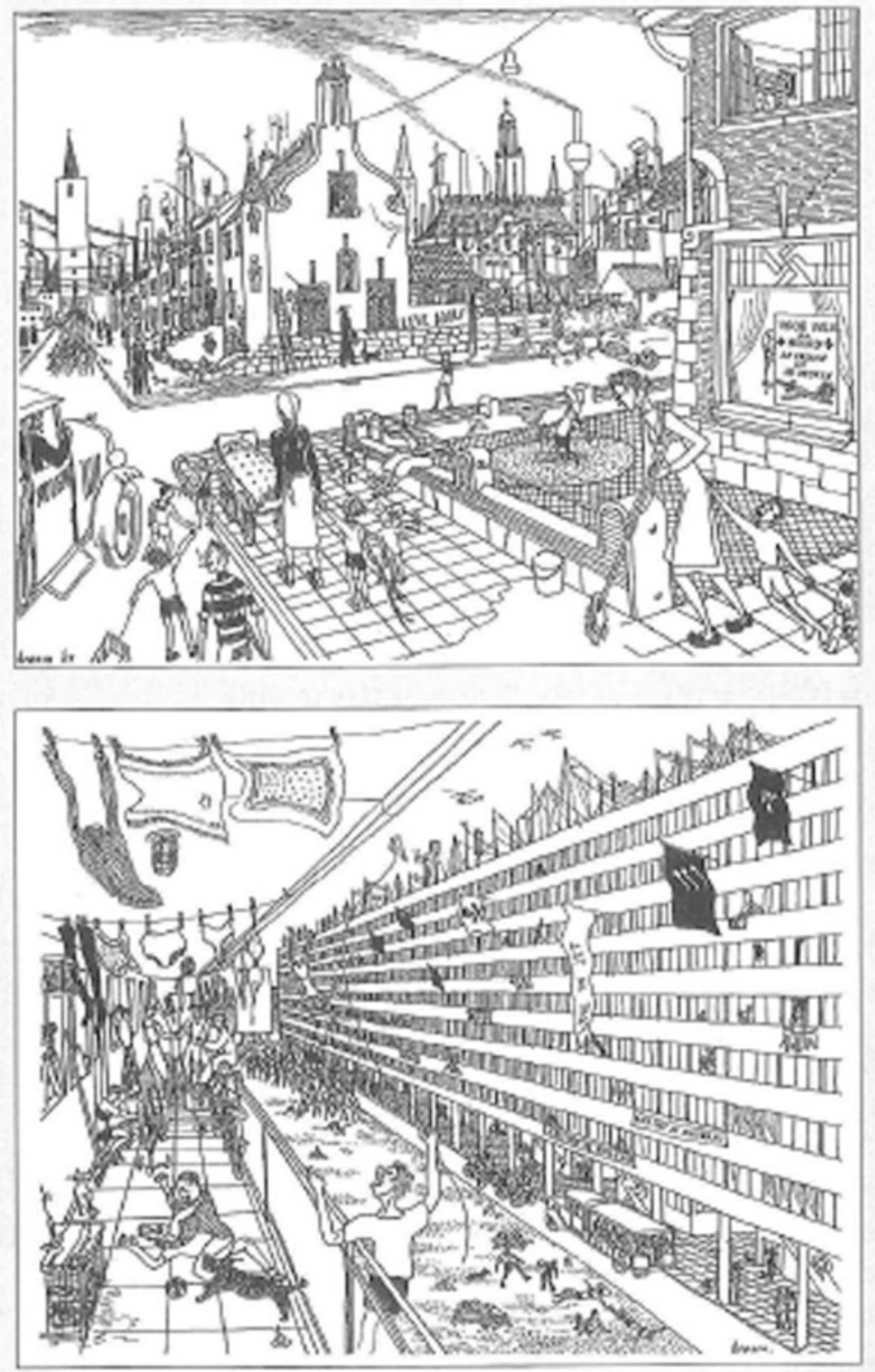

Fig. 2.1 Belgian architect Renaat Braem illustrates strikingly different views of modernist and traditional urbanists (1953, in: Declerck 2004); top: modern architects' view of traditional neighbourhoods. bottom: traditional views of modernistic estates

colleagues (2010) formulated this as follows: 'Modern modes of mass construction which were tested in North Africa in the 1940s and 1950s soon migrated to the peripheries of Western European cities where the all-too-familiar suburbs arose to 
accommodate hundreds of thousands of people. In many cases, the inhabitants living in the outskirts of Paris and London originated from the former colonies. Colonial history thus returned home to the European metropolises'. We can observe that many North Africans ended up in the modernist blocks, however, not in North Africa but in Western Europe's large housing estates.

Large housing estates have been constructed for a number of reasons. The origins of such estates can be found in the miserable living conditions found about four generations ago. Architects and urban planners knew what to do, and they designed spectacular solutions, but it was not until after the great devastations of World War II that governments developed a willingness to be involved in housing issues. The post-war baby boom and migration patterns increased housing scarcity tremendously, and housing received top political priority in many countries. Under government control, large housing estates were the result.

\subsubsection{Seven Motives for Building Large Housing Estates}

By the 1960s, a series of influences and pressures had coincided that can be regarded as the seven motives for building large mass housing estates across European countries (Turkington et al. 2004). These are as follows:

(1) reducing housing shortages caused by war damages, high birth rates, migration from the countryside to the cities, international migration and growing prosperity.

(2) technological improvements and labour-saving techniques that enabled homes to be built in volume and at speed. Building in concrete, the use of large prefabricated components, establishing housing factories on site and the rationalisation of the building process all made high-rise technically possible.

(3) the belief that architecture would contribute to a fair society. There was great confidence that 'Modernism' applied to housing and urban planning could deliver a more equal and fair society. The achievement of the egalitarian functional city represented a powerful expression of the belief that social development could be controlled more effectively than ever before.

(4) to save the countryside from mass sprawl, the belief that the new high-density housing would protect nature from urban sprawl associated with single-family houses (Mentzel 1989). Building high rises would provide more open space and reduce the pressure on agricultural land.

(5) a higher standard of living. It is often forgotten that in the early 1960s, the new flats were relatively luxurious and spacious, provided with such modern amenities as a hot and cold water supply, a shower or bath, central heating and a rubbish disposal system. Collective amenities such as childcare, laundry, shops and recreation facilities made high-rise living both comfortable and convenient. 
(6) status and competition, related to symbolism of high-rise housing. High-rise blocks were landmarks reflecting a town's urbanism and modernity. Municipal authorities and social housing providers competed with each other to acquire such symbolic buildings, and as a result, high-rise blocks can be found in almost every city in Europe. This status motive still exists in the form of the present competition to build the tallest skyscraper.

(7) governmental support. In Britain, large housing estates were associated with slum clearance and additional subsidies were provided to support building costs. In the Netherlands, 25\% extra subsidy was given in 1963 for prefab housing systems.

\subsection{Large Housing Estates: Similar Start, Divergent Outcomes}

Similar motives for the production of high-rise housing produced similar outcomes. The outcomes of the golden years for the construction of large housing estates are evident. Housing production peaked in the late 1960s and early 1970s, not coincidentally the same era where the construction of high-rise housing peaked. Mass housing on large estates was definitely supply-side construction; arguments had to do with production numbers. Research had determined what residents should want. This resulted in 'the ideal dwelling', to be produced in limited types and large quantities. Some figures illustrate this. In Hungary, the 15-Year Housing Development Plan of 1960 resulted in the construction of 1 million new homes, mostly in mass-produced high-rise blocks. In Sweden, high-rise housing dominated the famous Million Programme in 1964. The speed of construction tripled. In the Netherlands, it took $2000 \mathrm{~h}$ to build a traditional house, compared to only $600 \mathrm{~h}$ for a system-built construction (De Vreeze 1993). Figures on France show that the average time taken to produce a dwelling dropped from nearly two man-years in 1950 to 7 months in 1960. As a result, between 1960 and 1980, France built nine million dwellings, and it is evident that in any 4-year period from these decades, more homes were produced than in the 1920s and 1930s combined. Between 1966 and 1973, over $60 \%$ of all social-sector housing built in the Netherlands, and two-thirds of social housing in France consisted of high-rise blocks (Fig. 2.2).

An important feature of large housing estates was the provision of collective space for communal use, based on high expectations of people's mutual and collective behaviour (see Fig. 2.3). Such ideas fit particularly well with the Nordic welfare model, in which state-organised systems were designed to take care of their citizens, and with communist principles of communal provision practiced in eastern European countries.

Housing estates were produced in large quantities, at high speed and to uniform standards. Key elements were standardisation and repetition of construction 


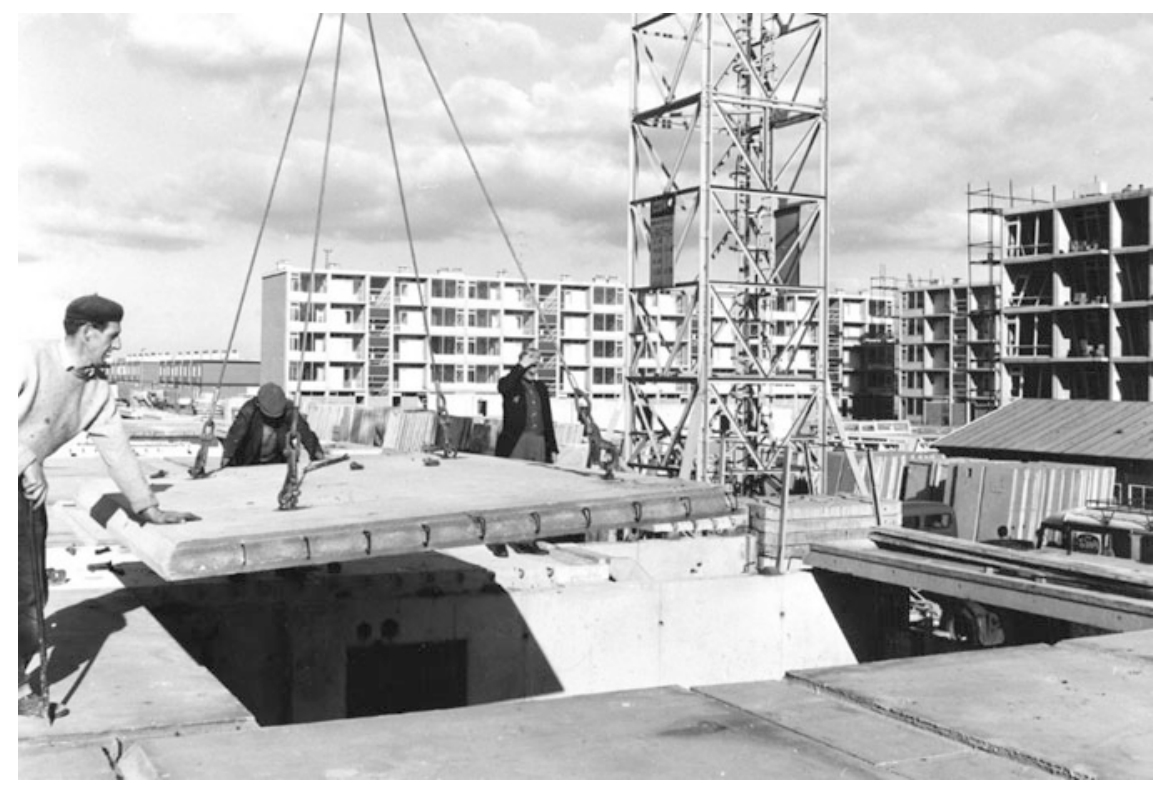

Fig. 2.2 New production methods sped up housing construction Photo by Fas Keuzenkamp, courtesy Delft University of Technology archives

patterns, with the use of prefabricated constructions from housing factories on the site. In Germany and Eastern Europe, post-war estates are often called Plattenbau, referring to the concrete panels used. One can say that traditional houses are 'built', while mass housing on large estates was 'produced'.

Post-war large housing estates were built at easy to acquire and inexpensive locations, namely on the outskirts of cities. Since then, siting has depended on local urban development; some housing estates are still far out of town, while others have been swallowed up by further urban expansions. In many countries, large housing estates are not limited to larger cities: many smaller cities and towns have their own large housing estates-large, that is, for their local context.

\subsubsection{The High-Rise Wave}

High-rise estates in western countries were built in a concentrated period, a high-rise wave, starting somewhere in the 1960s, and stopping rather suddenly some 10 years later. The period ended in England after a horrifying gas explosion (Ronan Point in East London) in the late 1960s, in the USA after a major debacle in St. Louis in the early 1970s (Pruitt-Igoe), and in the Netherlands, Western Germany and Sweden in the mid-1970s after it became clear that the market demanded something else. The wave of northern and western European countries peaked around 1970. 

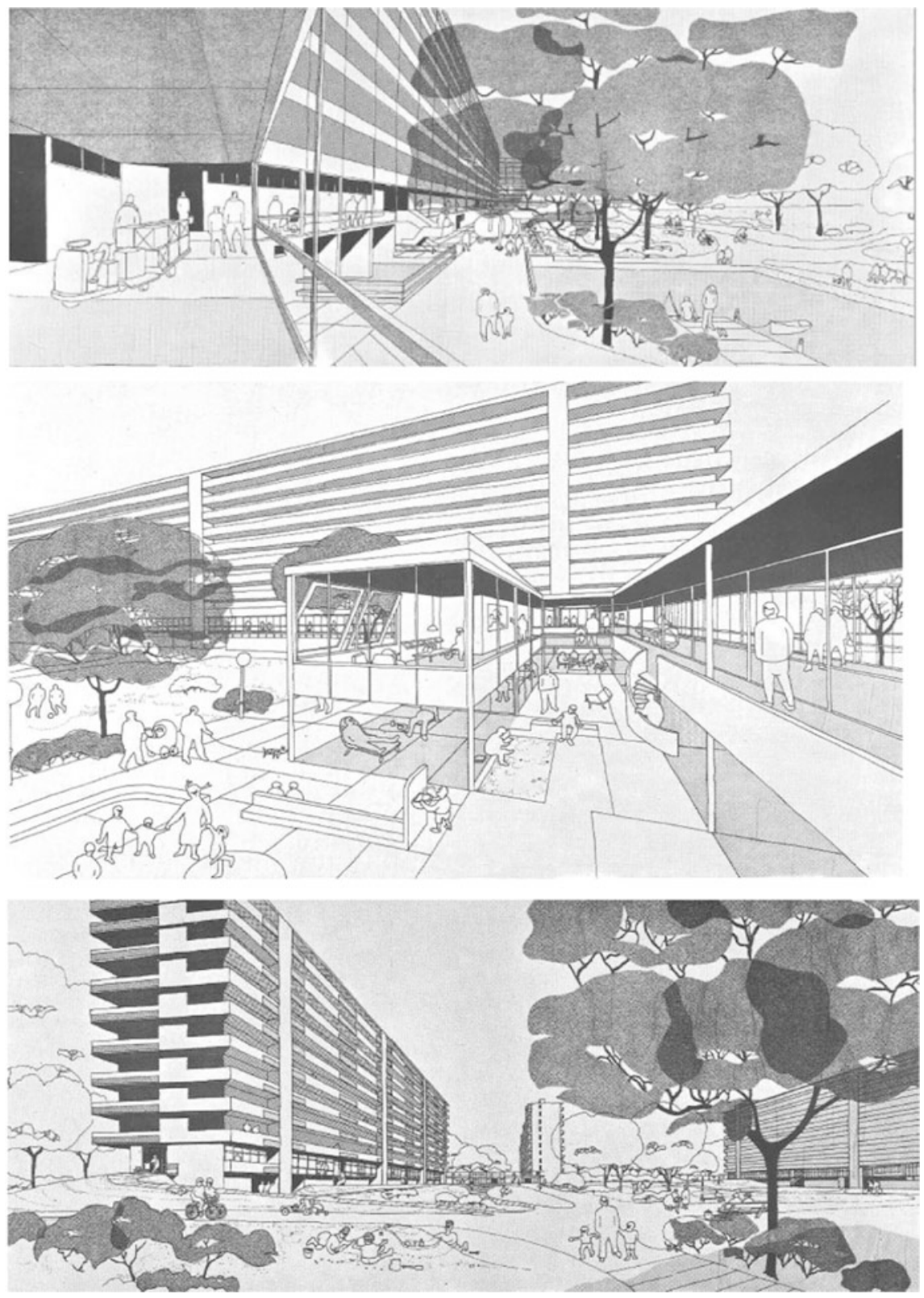

Fig. 2.3 Three depictions of social space in modernist housing estates. Source Gemeente Amsterdam, 1968 
After these respective waves, there was a remarkably sharp decline, caused by a radical anti-establishment shift in society, resulting in more demand-oriented planning. However, by that time, millions of dwellings on mass housing estates had been built. A commonality is the way they were planned: top-down, by planning departments and according to (sometimes scientific) research into what would be best for residents - but without consulting residents, who were (supposed to be) happy simply to get any dwelling in times of everlasting housing shortages.

In Eastern Europe, the construction of high-rise housing estates continued until the fall of the Berlin Wall in 1989, and in Southern Europe and Southeast Asia, there has been continuous construction of high-rise estates for the last 50 years. This is why more high-rise estates can be found in countries such as Spain, Italy, Ukraine and Hong Kong, than in Scandinavia, Germany, Britain and the USA.

After a standstill between the mid-1970s and the 1990s, new high-rise housing is again being constructed in western countries, following Asian initiatives in the Pacific and in Arab countries. This new high-rise housing, however, is no longer built on large housing estates, but mostly in separated tower blocks. What is remarkable is that these modern high-rise blocks are promoted with the same advantages and features as their predecessors: private living, extensive views, security and luxurious common facilities. Moreover, they are aimed at another population group, namely wealthy young or elderly urban-oriented citizens, not the working or middle-class families as in the 1960s. And the location differs: not on the outskirts of town, but in central and attractive locations: in the city centre, near transit stations or at the riverfront.

Post-war housing estates, culminating in the high-rise estates of the 1960s and early 1970s, represented the ideal housing of their era, egalitarian and modern dwellings that were spacious, comfortable and well designed. However, these qualities would be questioned in the subsequent era.

\subsubsection{There Were Critics, but No One Listened}

Considering the mass of criticism and problems that finally arose, did no one give criticism before mass housing construction? Criticism is easy when history has already shown you to be right, but what were the opinions beforehand? High-rise housing might appear to have been planned without any critics, but that was not the case.

The large housing estates, high rises in particular, were the ultimate culmination of the modern architecture of CIAM. The city of tomorrow for the people of today. One characteristic of CIAM was the emphasis on leadership. The architect, the urban planner and the politician had to decide what is best for mankind, so they did (or rather, they tried). One of the most famous critics of the top-down planned neighbourhood is, without a doubt, Jane Jacobs. In 1961, she published The Death and Life of Great American Cities, but it would be a decade or so before her work, and followers, became more mainstream. Jacobs would later be considered one of 
the most influential urban thinkers, with her plea for livelier urban areas, attractive streets and a concentration of activities, functions, inhabitants and passers-by. Cities should not be planned, but grow in an organic way. Seeing the obvious failure of too many planned, top-down, large neighbourhoods, it is not difficult to understand why she later acquired a wide range of followers. Nevertheless, early criticism was not enough, considering the seven motives were just too strong during the period of the high-rise wave, especially the everlasting housing shortage.

Did high rises meet people's demands? A constant factor during post-war urban planning was the almost total neglect of consumers' wishes. Planners and architects thought they knew what was good for people. Early critics like Dunleavy and Jephcott stated that the intended families with children did not want to live in flats at all. In the 1960s, Pearl Jephcott studied inhabitants of the well-known (and just finished) new towers of 'the Gorbals' in Glasgow and concluded that 'local authorities should discontinue this form of housing except for a limited range of carefully selected tenants' (Jephcott 1971 in; Mentzel 1989). Cooper Marcus and Hogue (1977), Gifford (2007) and Stewart (2009) provided an extensive literature overview that clearly shows that children are better off in low rises rather than high-rise housing. However, in the early years of high-rise construction, consumers' opinions were not heard, and the views of professionals held sway.

\subsubsection{Different Outcomes}

While similarities between countries in ideas and the construction of large housing estates were greater than their differences, developments afterwards followed more divergent outcomes. A clear geographical distinction across Europe can be drawn. Northern and Western European countries have developed a negative critique of high-rise living and estates, compared with Southern Europe where such housing is experienced as conventional. In both North and South, dwellings more often are owner occupied, or in cooperative housing, while in Western Europe more dwellings are rented, often in the social housing sector. This makes it easier for inhabitants to move away instead of staying and investing in the area. In Eastern European countries, living on a large housing estate is experienced as a 'normal' form of housing, but is increasingly problematic, especially in its technical quality and energy efficiency. It does not help that most dwellings have been sold to the then-inhabitants during the 1990s, without any maintenance experiences nor structures.

Most problems, analysis and interventions have been carried out in Western European countries. There, the problems turned out to be most dramatic. In these countries, there existed a series of so-called 'sink estates', where numerous and often terrible problems occurred. 


\subsection{Sink Estates}

\subsubsection{All Areas Develop, but Some Areas Get Deprived}

Estates are not static entities. They change when used by residents, visitors and local entrepreneurs. They age, wear out and need maintenance and renewal. Some neighbourhoods are always doing well, while others decline and become branded as a 'problem', 'disadvantaged', 'deprived' or 'concentrated' area. This refers to a downward process in which people who can afford it move out and make room for people in the lower social strata, whereby dwellings and streets deteriorate, crime and anti-social behaviour increase, services and businesses leave or go out of business, and the image of the neighbourhood worsens.

Cities are characterised by differences and inequalities. Variety and differentiation are part of urban life. However, when differences are too large, problems accumulate in too large and too heavy concentrations: such deprived areas exist in many forms (Fig. 2.4).

There is abundant literature explaining area developments and providing causes for deterioration. Van Beckhoven and colleagues (2009) provided an overview, including the findings of earlier scholars. They mentioned processes that are considered to happen more naturally and automatically (like the ecological school of succession, filtering and downgrading), while others emphasised the influence of human behaviour (with preferences, social cohesion, constraints and possibilities)

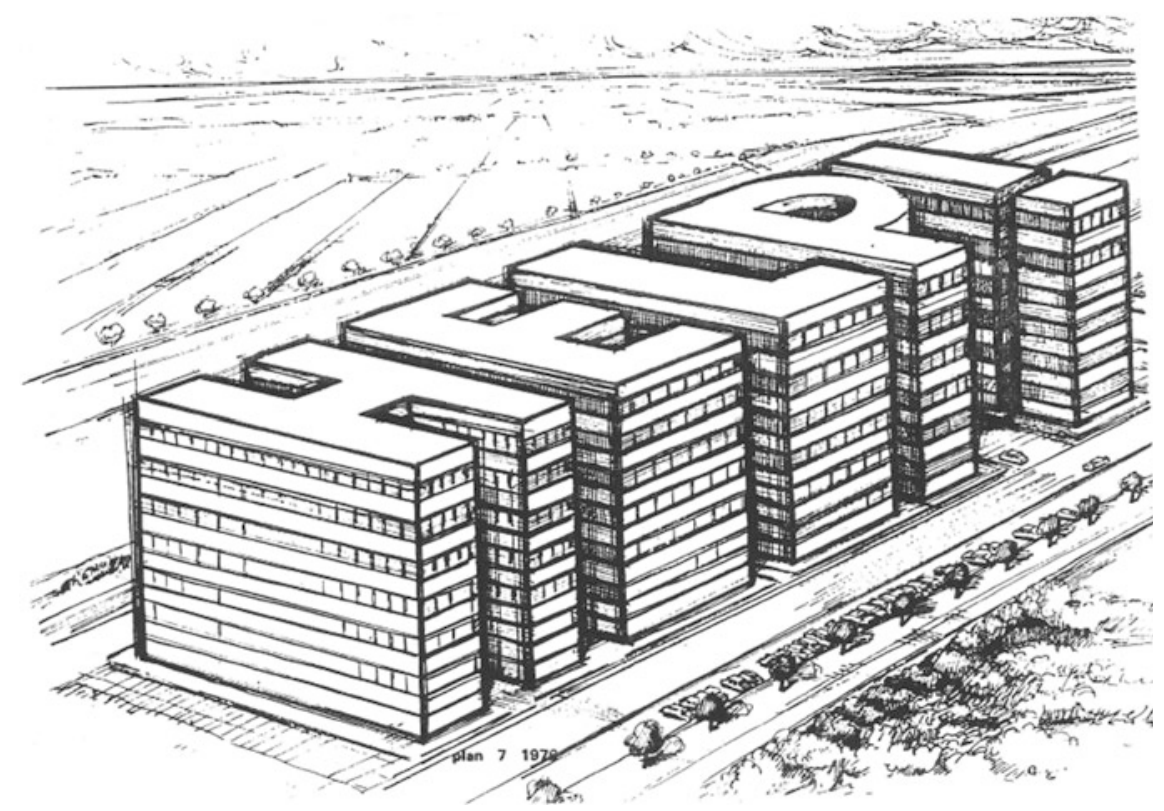

Fig. 2.4 High-rise housing in trouble. Source Figure in Plan 7, 1970 
or physical appearance (ugly buildings that cause social deterioration). Others focused on institutions and organisations (like management and processes of allocation).

\subsubsection{Cycles of Decline}

Large housing estates are best known by many observers for their problematic image, less popular housing, high crime rates, safety issues, broader quality-of-life issues, deprivation and decline. These are all well-known problems. Professionals and academics hurry to state that there are plenty of large estates that work well, where residents are satisfied, and problems are limited. In 'Mass housing in Europe' (2009), Rowlands et al. focus on these differences. Every estate has its own history and follows its own path. Nevertheless, there are plenty of similarities, on which I focus.

Problems do not occur on all estates, at least not at the same time and with the same intensity. Developments are dependent on factors of supply (initial quality, character and use), demand (preferences, resources and constraints), the available alternatives, external trends in society and policies that are possibly adopted or ignored. When all factors turn out negative, estates develop into sink estates, where increasing problems of all kinds become downward spirals of further deterioration. In most cases, neither a single problem nor a single cause can be indicated, but rather intricate combinations of causes and effects are responsible. Prak and Priemus (1986) developed a comprehensive model to explain why a process of decline, once it has begun, apparently leads of its own accord to further decline. They identified three cycles of decline: technical decline (affecting the estate), social decline (affecting tenants) and financial decline (affecting the operation of the estate). All three cycles may influence and reinforce each other and are also affected by external factors including government policies, wider social and economic trends and the policies of owners.

\subsubsection{Is It the Design?}

Similar spirals of decline have been analysed by other authors, including Power (1997) and Temkin and Rohe (1996). One of the most controversial questions concerns the impact of the urban form itself. Coleman's (1985) study 'Utopia on Trial' accused the architects and developers of mass housing estates of generating problems through bad design. However, while large high-rise estates were generally considered unattractive, the case for physical design determinism was unproven.

The question was also raised by Rowlands et al. (2009): Why are mass housing estates a problem? One obvious reason is that they provide - en masse - a housing type that does not reflect contemporary household preferences. However, the 
authors were reluctant to blame the physical layout of the mass housing estates and referred to many large estates that have satisfied residents. Adriaanse (2011) elaborated on some well-functioning large housing estates that are doing well in their local housing markets, despite their appearance. One of the main explanations she found lies in the set of mostly unwritten norms and values among inhabitants, tacit rules that maintain the quality of living.

Urban (2012) compared mass housing in seven metropolises around the world. He stated that differences show that design alone is not to blame for mass housing's mixed achievements. The buildings did not produce the social situations they came to stand for, but acted as vessels, conditioning rather than creating social relations. Similar buildings function well in one city but are catastrophic in another. This functioning is dependent on a range of factors.

\subsubsection{At Least, Design Plays a Role}

One estate is not the other, and the local context will always be different. It is a combination of housing-type, large-scale, urban design and location that make particular estates less popular places to live. When alternatives are available, people choose 'with their feet', and stay out or move out. Hirschman (1970) was among the first to elaborate on the conceptualisation of customers' choice, and how increasing choices affect behaviour.

Urban design causes problems like insecurity and lack of social control, due to the way the area was built (large, monotonous blocks, separate lanes for pedestrians, bikes and cars, and bushes beside the pavements). Newman (1972) came up with the often-cited idea of the (failing) defensible space in many of semi-public spaces: no-man's areas between home and the street. Moreover, the competitive position of high rises on the housing market is often not good. Once the reputation is low, social problems are on the increase. This might be a consequence of the allocation process, whereby households with little choice on the urban housing market end up in the least popular estates. These households may cause conflicts. Crime, vandalism and feelings of insecurity occur frequently precisely in this type of post-war district (Elsinga and Wassenberg 1991).

\subsection{Urban Renewal Policies}

Measures will usually be taken to combat problems. In some situations, early measures do the job. This usually happens only when there are favourable external circumstances, like a tightening housing market (limiting alternatives), supportive national policies (reshuffling of police forces, national subsidy schemes, employment support programmes, etc.) or general trends in society (economic growth, 
increasing employment, demographic shifts, etc.). However, these forces might also turn out to have a detrimental effect.

\subsubsection{Urban Renewal Policies}

Most European countries developed policies to renew cities and neighbourhoods (see Turkington and Watson 2015; Scanlon et al. 2014; Wassenberg 2015). Urban regeneration gradually became an integrated policy during the 1990s: City Policy (Politique de la Ville) in France, the National Strategy for Neighbourhood Renewal in England, Big City Policy (Grote Steden Beleid) in the Netherlands, the Metropolitan Development Initiative in Sweden and the Socially Integrative City (Soziale Stadt) in Germany. These territorial and integrative programmes combined physical, economic and social goals and strategies. Policies developed in a new way, towards a social mix of the population, to be achieved by a differentiated housing stock.

Moreover, years of urban centre upgrading paid out, resulting in more shops, cafés and restaurants, car-free streets, and festivals and attractions than twenty years ago. City life has just grown more pleasant. Urban popularity coincides with major trends like an increasing number of small households and small-scale service-oriented entrepreneurs, groups that often prefer city life.

The object of urban renewal differs per country. When global forces changed the worldwide industrial landscape, former heavily industrialised countries such as Britain, Germany and Belgium had to cope more with vacant industrial plots, which obviously needed transformation and restructuring. In France, Sweden and the Netherlands, a relatively large amount of social housing was produced in the decades following World War II. When prosperity rose and people could afford other types of housing, these mass housing neighbourhoods increasingly proved to be unpopular. In Southern European countries, owner occupancy rules and urban renewal activities focus on upgrading central districts. In Eastern Europe, all changes started only from the 1990s onwards after the political turnover. Despite general trends across Europe, local and national circumstances, histories and interests influence outcomes of the process of urban renewal (Lévy-Vroelant et al. 2008).

An interesting debate among scientists is whether urban renewal policies should be area-based, focusing on a better place to live, or people-based, focusing on better lives for residents. Physical renewal upgrades the area but offers no guarantee that residents' daily lives will improve, a situation that was found during the 1980s in Western European countries. Otherwise, socio-economic measures may improve residents' personal situations, but if successful people continuously move out, the area will stay deprived. This we can call the paradoxical relationship between territorial action and residential mobility. The challenge is to find the right balance between the two approaches, given the particular context of each area. 


\subsection{Renewing Large Housing Estates}

\subsubsection{Large Housing Estates: One Size Fits All}

Large housing estates were produced in big series and at high speed. Their contribution to alleviating housing shortages was substantial. They were planned by experts who followed general top-down planning ideas. These were uniform, corresponding to ideals of an egalitarian society. It was well-studied what the ideal dwelling should look like. The results of these studies were copied thousands of times, implemented by increasing technology and standardised labour-saving methods. People would easily feel at home. The location of work, leisure, recreation, school, housing or traffic was clear: every function was located on its own specific piece of land. Large housing estates anticipated the future; for everyone. One size fits all.

\subsubsection{From One Size to More Flavours}

However, society developed in another direction. People became educated and emancipated, many household types other than 'standard families' developed, prosperity grew and more room was needed for individual demands and styles of living. Uniformity, repetition and equality were the basic characteristics of the post-war society, the period in which many large housing estates were built. Diversity, individualism and choice would be the features of the following decades.

The larger and more one-size-fits-all the housing, the more vulnerable it is. This is exactly what happened with large housing estates: limited inconveniences became major problems, exacerbated by large size and uniformity.

All across Europe, restricted measures that prevailed in the 1980s and 1990s gradually made way for a more integrated urban renewal approach, in which several sectors are incorporated, major and minor measures are combined, long-term prospects for the area are mingled with the day-to-day worries of residents, and a range of participants are involved.

Policies are aimed at improving the quality of life for inhabitants and other users (safety, crime, pollution, vandalism and social cohesion), individual mobility (empowerment, education, jobs, language and debt control) and a financially sound exploitation of the housing stock. Achieving a social mix of groups within society is often also targeted. Policies are aimed at bringing ecological (energy, waste), social and economic sustainability. 


\subsubsection{Three Ingredients for an Integrated Approach}

Recovering estates can be characterised by three categories of ingredients. They have to differentiate the original one-size-fits-all character of the estate, which has proven to be vulnerable to changing circumstances. The ingredients for an integrated approach are based on creating more 'flavours' than provided by the one-size-fits-all model. Three categories of ingredients can be distinguished.

The first is bringing more differentiation within the area. This can be achieved by changing physical appearances, as well as by a better exploitation of positive current qualities, namely specific features that the area can be proud of and that outsiders often do not know about. The combination of brand new buildings and refurbished high rises may be another quality. More differentiation also can be achieved by allowing more room for the private initiatives of market actors and residents, such as residents who improve their (rented) homes themselves.

The second group of improvements is strengthening the relationships between residents and their housing environment, their neighbourhood and each other. Room for residents' initiatives can reinforce those relationships, just like the use of cultural values within the area. Another strategy is to keep the social climbers in the area by offering attractive housing alternatives.

The third group is more coherence in measures, through combinations of types of measures, both long-term and short-term major operations and day-to-day actions. It can also be achieved by using moments of communication (e.g. when rehousing) to deal with individual problems. More coherence is also necessary to limit spill-over effects, of which there will always be some. And more coherence is an ingredient for creating a broad social base to guarantee a long-term commitment. Major recovery schemes will easily last 20 years or more.

The successful recovery of large housing estates should lead to sustainable results. Once sustainable, an estate has enough internal vitality and flexibility to adjust to changing circumstances, uses and preferences. A sustainable urban area gradually adjusts to changing needs, uses and preferences of inhabitants and other users. Then, drastic renewal activities will no longer be necessary.

\subsection{Conclusion}

Physical design is never the only reason why a particular estate functions well or not. It is an ongoing debate whether physical elements contribute to this functioning. This chapter focused on these physical elements. At least, design matters, although it is more complicated than just the question of, 'Does it look ugly or not?'. This chapter explained why mass housing estates exist, including the most prominent type, the high-rise blocks. Seven strong motives contributed to the construction of millions of these kinds of dwellings across Europe. 
These high rises and other large housing estates exist and will be there for the next few decades. Whether we like them or not, we have to deal with this pan-European legacy. This chapter also showed prospects for large housing estates. They can be improved, if necessary. I want to end with an opportunity. During the 1960s-1980s, the large housing estates were developed to house working or middle-class families with children, as an appealing alternative for the small and outdated apartments of those days. However, when alternative family housing was built, these families did not opt for high rises. Nowadays, the situation is different. There are plenty of family houses in the suburbs, while most of the new households are small in size, often preferring urban life. A growing number of households are elderly, opting for ground floor flats instead of houses with stairs. Once improved, existing high rises and other large housing estates could meet the changing needs of households, offering all floors as 'ground floors' with elevator access, and a central location for services and jobs. Practices have shown that the sometimes 'ugly appearance' of estates can be transformed into aesthetically pleasing blocks. In this way, once-disguised large housing estates can transform into community assets.

\section{References}

Adriaanse C (2011) On measuring and explaining neighbourhood success. A behavioural economic approach. IOS Press, Amsterdam

Avermaete T, Karakayali S, Osten M (2010) Colonial modern, aestetics of the past-rebellions for the future. Black Dog Publishing, London

Coleman A (1985) Utopia on trial. Hilary Shipman, London

Cooper Marcus C, Hogue L (1977) Design guidelines for high-rise family housing. In: Stroudsburg P (ed) Human response to tall buildings. Dowden, Hutchinson \& Ross

De Vreeze N (1993) Woningbouw, inspiratie en ambities. Nationale Woningraad, Almere

Declerck N (2004) Belgium, impact of modernism in a divided country. In: Turkington R, van Kempen R, Wassenberg F (eds) High-rise housing in Europe. Delft University Presss, Delft

Dunleavy P (1981) The politics of mass housing in Britain, 1947-1975. Clarendon Press, Oxford

Elsinga M, Wassenberg F (1991) Tackling crime and vandalism on post-war housing estates: the Dutch approach. Netherlands J Hous Built Environ 6(2):159-175

Gifford R (2007) The consequences of living in high-rise buildings. Arch Sci Rev 50(1):2-17

Hall P (1988) Cities of tomorrow. An intellectual history of urban planning and design in the twentieth century. Basil Blackwell, Oxford

Hirschmann A (1970) Exit, voice and loyalty. Cambridge University Press, Cambridge

Jephcott P (1971) Homes in high flats. Some of the human problems in-volved in multi-storey housing. In Edinburgh

Lévy-Vroelant C, Reinprecht C, Wassenberg F (2008) Learning from history, changes and path dependency. Housing Strategies in Europe. LSE, London

Mentzel M (1989) Bijlmermeer als grensverleggend ideaal. Delft University Press, Delft

Newman O (1972) Defensible space: crime prevention through urban design. Macmillan, New York

Nyström L (2006) Neighbourhood centres in Europe: yesterday, today and tomorrow. Special Issue Built Environ 32(1):1-102

Polasky J (2001) Transplanting and rooting workers in London and Brussels: a comparative study. J Mod Hist 73:528-560 
Pooley CG (1992) Housing strategies in Europe, 1880-1930. Leicester University Press, Leicester, London, New York

Power A (1997) Estates on the edge: the social consequences of mass housing in Northern Europe. Macmillan, London

Prak NL, Priemus H (1986) A model for the analysis of the decline of post-war housing. Int J Urban Reg Res 10(1):1-17

Rowlands R, Musterd S, van Kempen R (2009) Mass housing in Europe, multiple faces of development, change and response. Palgrave Macmillan, Basingstroke

Scanlon K, Whitehead C, Fernández Arrigoitia M (2014) Social housing in Europe. Wiley, Blackwell

Stewart BT (2009) Inhabiting towers on the edge; creating a livable land-scape in Toronto's tower neighbourhoods. University of Berkeley, Berkeley

Temkin K, Rohe WM (1996) Neighbourhood change and urban policy. J Plan Educ Res 15:159170

Turkington R, van Kempen R, Wassenberg F (2004) High-rise housing in Europe: current trends and future prospects. Delft University Press, Delft

Turkington R, Watson C (2015) Renewing Europe's housing. The Policy Press, Bristol

Urban F (2012) Tower and slab, histories of global mass housing. Routledge, London/New York van Beckhoven E, Bolt G, van Kempen R (2009) Theories of neighbour-hood change and decline. In: Rowlands R, Musterd S, van Kempen R (eds) Mass housing in Europe. Palgrave Macmillan van Kempen R, Dekker K, Hall S, Tosics I (2005) Restructuring large housing estates in Europerestructuring and resistance inside the welfare industry. Policy Press, University of Bristol, Bristol

Wassenberg F (2013) Large housing estates: ideas, rise, fall and recovery. TU Delft, IOS Press, Amsterdam

Wassenberg F (2015) Meeting the British housing challenge: Dutch experiences and reflections. In: Crookston M (ed) Built environment, meeting the housing challenge: British experience, European lessons, vol 41, pp 211-226

Open Access This chapter is licensed under the terms of the Creative Commons Attribution 4.0 International License (http://creativecommons.org/licenses/by/4.0/), which permits use, sharing, adaptation, distribution and reproduction in any medium or format, as long as you give appropriate credit to the original author(s) and the source, provide a link to the Creative Commons license and indicate if changes were made.

The images or other third party material in this chapter are included in the chapter's Creative Commons license, unless indicated otherwise in a credit line to the material. If material is not included in the chapter's Creative Commons license and your intended use is not permitted by statutory regulation or exceeds the permitted use, you will need to obtain permission directly from the copyright holder. 


\title{
Chapter 3 \\ Who Is to Blame for the Decline of Large Housing Estates? An Exploration of Socio-Demographic and Ethnic Change
}

\author{
Gideon Bolt
}

\begin{abstract}
In the 1960s and 1970s, all over Europe housing estates emerged that were very similar with respect to construction methods and urban design. At the same time, housing estates across Europe did not all follow the same trajectory after their completion. This divergence occurred because the main reasons for their deterioration and social degradation are exogenous factors, not internal factors. Of course, it makes a difference whether the physical quality of the dwellings was good and whether the spatial planning was adequate. But even well-designed housing estates are subject to social degradation due to competition with newer neighbourhoods that are usually added at the top of the market and more geared to contemporary housing preferences. In Western Europe, this process of relative depreciation is further exacerbated by the prioritisation of owner-occupation leading to residualisation of the social rented sector. The social and ethnic transformation of large housing estates is not only the consequence of planning and housing policies but also of external factors like immigration and economic decline. Most European countries have witnessed a substantial inflow of immigrants in the previous decades, and many of these find their way to large housing estates. Next to that, the social decline of housing estates is often related to a shrinking local economy. Policies aimed at reversing the decline hurt the sitting population more often than it helped them.
\end{abstract}

Keywords Relative depreciation - Urban design - Social decline Ethnic segregation - Urban renewal

\footnotetext{
G. Bolt $(\bowtie)$

Faculty of Geosciences, Department of Human Geography and Planning, Utrecht, The Netherlands

e-mail: G.S.bolt@uu.nl 


\subsection{Introduction}

Inevitably, the large housing estates that were built in earlier decades now suffer from the competition of newly built dwellings. In many cases, newer dwellings are of a higher quality and can also be more attractive in terms of location, which seduces those households who can afford it to move to this new housing stock, leaving less attractive estates behind for those who do not have the financial means to move to attractive new dwellings and places.

This process of social transformation often goes hand in hand with ethnic transformation. In many European cities, more and more newcomers in large housing estates are from an ethnic minority background. This is due to the increasing diversification of cities as a consequence of immigration. Moreover, immigrants and their descendants are disproportionally distributed over urban space and are most likely to end up in a neighbourhood with a relatively weak position in the urban housing market.

This chapter focuses on the causes of the changing social and ethnic profile of housing estates and will offer explanations for the variations in this process across European cities. According to Hoogvliet and Hooimeijer (1988), the dynamics in population composition of neighbourhoods depends mainly on four factors:

(1) The original situation: Many physical characteristics of a neighbourhood, like dwelling types, urban design, and physical quality, as well as its relative location have been fixed from the time of realisation. New neighbourhoods are usually different from the existing housing stock as they are built to address the needs of housing seekers that cannot be satisfied by the existing stock. Post-war housing estates were built to solve the enormous housing shortage after World War II, which was caused by a combination of demolition and low new housing production during the war and high population growth. Although the emphasis was more on the production of quantity than of quality, moving to a housing estate was a major improvement for those who left inner-city slum areas.

(2) Relative depreciation: In many theories of neighbourhood change, the concept of filtering has a central place (van Beckhoven et al. 2009). The general idea is that as dwelling units grow old, they tend to depreciate. This is not only due to physical deterioration or obsolescence but also relative depreciation. Even if neighbourhoods remain in good condition, they will have more and more trouble over time competing with new neighbourhoods that are usually added to the market at the top of the quality and price hierarchy and are more geared to contemporary housing preferences. Therefore, dwellings and neighbourhoods filter from higher status to lower status populations. The construction of new homes starts a chain of residential moves. This creates the filtering of households up the housing scale and consequently the filtering of dwellings (that is, estates) down the social scale. 
(3) The management of the housing stock: The pace of relative depreciation is to some extent determined by how the housing estate is managed. Management comprises a wide range of activities, including maintenance of dwellings and public spaces, housing allocation policies and mediation in case of tensions between neighbours.

(4) Renewal and reappraisal: Downgrading of a neighbourhood can be reversed by processes of renewal. These processes of renewal may be more or less spontaneous and led by private actors, like in the many western inner-city neighbourhoods that were the target of gentrification, but renewal processes in post-war housing estates were usually characterised by a more direct involvement of the (local) government.

These four factors form the structure of this chapter. Additionally, the role of macro developments, like immigration and economic restructuring, are discussed. While the tendency in most literature about neighbourhood decay is to look for explanations within the dynamics of a neighbourhood, the role of external factors should not be underestimated (Grigsby et al. 1987; Murie et al. 2003).

\subsection{Initial Conditions}

Turkington et al. (2004) identify a wide range of problems (to be discussed in the next sections) that high-rise estates across Europe are confronted with. While most of these problems have an impact on the functioning of high-rise estates in the longer term, poor design and inadequate planning may lead to a spiral of decline very soon after the completion of the estates.

\subsubsection{Poor Physical Design}

Many estates malfunctioned from the beginning due to physical shortcomings: elevators were too few and often did not work, there were problems with waste disposal systems and with condensation and leaking, and many high rises had bad acoustics (De Decker and Newton 2009; Hall 2014).

Of course, not all high-rise housing estates had the same physical problems. There are differences in the quality of construction within countries, between countries and between different time periods. In the UK, for instance, there was a substantial difference in the quality of design between London on the one hand and the rest of England and Scotland on the other hand. In London, top architects took the lead in the design of large housing estates, whereas elsewhere architects had to work within the strict requirements of housing departments, which were mainly focused on realising the maximum number of units in the minimum possible time (Glendinning and Muthesius 1994). In Eastern Europe, the quality of design tends to be lower than in Western Europe, mainly for economic reasons (Kährik and Tammaru 2010; Monclús and Díez Medina 2016). 


\subsubsection{Weaknesses in Urban Design and Inadequate Spatial Planning}

One of the planning flaws of many large housing estates was that they were located on the fringes of cities, far away from any amenities and job opportunities. Functions like schooling, shopping and recreational opportunities were underdeveloped (De Decker and Newton 2009). In Southern European housing estates, the public transport connections to the rest of the city are often underdeveloped (Dekker and Van Kempen 2004). Peripheral locations were chosen to reduce costs. For instance, Quarto Cagnino in Milan (1964-1973) was built as 'marginal appendix to the city', as the legal framework limited the development of public housing estates to the availability of less expensive plots of land (Monclús and Díez Medina 2016, p. 542).

Another shortcoming of the modernist housing estates is that their monotony stands in the way of the residents' need to express their lifestyle and to acquire their status through their dwelling. De Decker and Newton (2009) criticise Le Corbusier for the ignorance of the symbolic meaning of housing. To Le Corbusier, a house was une machine à habiter, designed to serve the function of a dwelling and nothing more. However, people have the need to show who they are through their homes. The extreme standardisation of the modernist housing estate does not facilitate its appropriation by the new inhabitants. This standardisation tends to be the most problematic in the largest housing estates. The 'drab monotony' in Eastern Europe is even more extreme than in Western Europe (Monclús and Díez Medina 2016). In Western Europe, large-scale projects like Sarcelles at the outskirts of Paris or the Bijlmer in Amsterdam are faced with extreme standardisation. In Gran San Blas in Madrid (1958-1963), the largest housing estate of the period in Spain, monotony was avoided by dividing the district into neighbourhood units. A considerable variation between the units was created, as the designs varied in the degree of sticking to modernist prescriptions, as documented in the Athens Charter (Monclús and Díez Medina 2016).

Hall (2014) argues that Le Corbusier, as well as his followers, had no real feeling for the way of life of working-class families. The famous housing complex Unite in Marseille, designed by Le Corbusier himself, is a completely different world compared to the British council tower blocks or the French grand ensembles. That is not so much due to the quality of the design, which in Hall's view makes the complex resemble 'a medium-quality hotel', but due to the fact that it is occupied by middle-class professionals. For working-class families, the suburbs offer great advantages in terms of privacy and freedom from noise. There, they have their own garden where they can relax and where their children can play safely. Hall (2014) concludes that high-rise estates may work well for rich people, due to the access to high-quality services and the amount of time they spend outside their homes, but that these kinds of places are not fit for working-class families. 
Modernist housing estates are also criticised for the negative impacts of the built environment on social life. Research in Scotland revealed high-rise estates score worse than other areas in social and psychosocial outcomes, like frequency of contact with neighbours and a number of aspects of (perceived) control (Kearns et al. 2012). The design of space in many large-scale housing estates was often too fluid and open with no well-defined spaces and no clear hierarchy. There was a lack of attention for the connection of common space and private space. Residents did not feel responsible for public spaces, which soon became desolated and dilapidated (Monclús and Díez Medina 2016). Oscar Newman (1972) uses the term indefensible space to describe the discouraging effect of physical design of these estates on collective community actions, which makes these neighbourhoods susceptible to crime.

Newman has been criticised for his architecturally deterministic position, but nevertheless his ideas have been adopted in Europe. Alice Coleman argues in her book Utopia on Trial (1985) that the design of high-rise public housing estates is responsible for anti-social behaviour. Although her ideas have not been taken seriously in academic circles, her work had a high impact on housing policy in the UK. Her critique of modernist architecture was compatible with the neoliberal agenda of Thatcher's government (1979-990) and-as we shall see laterThatcher's policy has led to the depreciation of council housing estates (Jacobs and Lees 2013).

\subsubsection{Recruitment of Initial Residents}

The problematic start of some housing estates is in several cases not only due to the poor quality and design of the buildings and the environment but also to the recruitment of the first residents. Van Kempen and Musterd (1991) compared several ill-functioning and well-functioning post-war housing estates in two middle-sized Dutch cities. The differences between these estates could not be attributed to physical and management characteristics. Instead, the initial population composition appeared to be crucial for the performance of the high-rise blocks. Estates where the poverty level was already high among the initial population experienced a process of decline very soon after the estate was built. The problem is not only that poor people have more problems in paying their rent but also that the concentration of poverty led to a bad reputation among outsiders (Murie et al. 2003).

Some housing estates in Western Europe also faced an influx of immigrants. When the Bijlmer (1968-1975) in Amsterdam was completed, the expected influx of residents from within the city did not materialise. Families in the older parts of the city did not consider the Bijlmer as a suitable environment to raise their children (which is in line with Peter Hall's point of view discussed above) and opted for neighbourhoods in the new towns and suburbs outside Amsterdam. The huge number of vacancies were filled to a large extent by immigrants from Surinam who 
left their country in the period around the independence of this former Dutch colony (Aalbers 2011).

In former communist countries, the initial population of housing estates had a different ethnic and socio-economic profile. While housing estates in Western Europe were mainly inhabited by blue-collar workers and immigrants, housing estates in Eastern Europe were dominated by the middle class. In Hungary, for instance, there was much less equality in housing allocation than what might be expected from a communist state. Bureaucrats, intellectuals, the military and workers in high-priority sectors were over-represented in the state-built housing estates, whilst members of the working class often had to rely on the self-build housing sector (Herfert et al. 2013). This allocation policy leads to a spatial division between the cities and their hinterland, with a much stronger presence of people with a high level of education and income in the former than in the latter (Kährik and Tammaru 2010).

In several Eastern European countries, like Hungary and the Czech Republic, some housing estates carried a bad reputation due to the policy to segregate Roma (Temelová et al. 2011; Váradi and Virág 2014). For instance, the Roma ghetto of Chanov, located at the edge of the city of Most in northern Bohemia (Czech Republic), was a housing estate constructed on the city periphery with the aim to accommodate the Roma population, which was displaced as the consequence of the opening of a coal mine. Chanov was a stigmatised neighbourhood from the onset and was avoided not only by the Czech population but also by better-off Roma (Temelová et al. 2011).

In most of Central and Eastern Europe, large housing estates did not see an inflow of immigrants. In the 1990s, some countries attracted guest workers from other socialist countries, but the numbers were much lower than in Western Europe. At the end of the 1980s, 50,000 foreign citizens were working in Czechoslovakia, including about 35,000 Vietnamese and 5,000 Cubans. In Bulgaria (40,000 guest workers), the majority came from Vietnam (Grečic 1991). The German Democratic Republic (the former East Germany) hosted more than 100,000 guest workers, with Vietnamese again forming the largest group $(59,000)$, followed by immigrants from Poland and Mozambique. These guest workers did not get access to state housing estates but were housed in hostels where they were excluded from German Democratic Republic society (Dennis 2007). Most of them were forced to leave immediately after the political upheaval in 1989/1990.

With respect to immigration, the countries of the former Soviet Union have a distinct history. In Kazakhstan (Gentile and Tammaru 2006) and the Baltic states (Kährik and Tammaru 2010), there is a considerable amount of segregation between the native population and the large number of Russian-speaking immigrants. These immigrants, who arrived through organised channels, tended to be housed in the new panel housing districts. In contrast to the Western European situation, these immigrants did not live in worse housing conditions (and in some cities even in better housing conditions) compared to the native population. 


\subsection{Relative Depreciation}

Relative depreciation refers to the decline of social status in neighbourhoods due to competition with newly built neighbourhoods. The size of the housing stock, characteristics of the local housing market and tenure distribution play a role in the depreciation of a large housing estate.

\subsubsection{Size of the Housing Stock}

In Western Europe, the scale of large housing estates is seen as one of the reasons that these areas are degrading. A comparison of Oslo and Stockholm, two cities situated in countries with strong welfare states, reveals that income segregation is much higher in the latter city. Whereas Oslo did not build a huge amount of multifamily public housing and dispersed these projects in small pockets over the city, Stockholm chose for large-scale public housing estates which since the Million Homes Programme (from the mid-1960s to the mid-1970s) cover many suburban areas (Musterd et al. 2017). This concentration led, in combination with the residualisation of public housing, to an accumulation of lower income groups and non-Western immigrants in these estates.

Whereas the concentration of public housing in large housing estates is seen as one of the factors explaining the social downgrading in Western Europe, the sheer size of large housing estates in post-socialist cities will ensure these neighbourhoods will never be seen as places to exclusively house the poor. Large housing estates provide $30-50 \%$ of the urban housing stock, as opposed to at the most $10 \%$ in Western European cities (Herfert et al. 2013; Grossmann et al. 2017; Murie et al. 2003). As a consequence, large housing estates as a whole have never been stigmatised in Eastern Europe. Many middle-income households live in a large housing estate and almost everyone will have family and friends that live in the same or similar housing estates. Surveys in Leipzig and Prague revealed that housing estates are still considered as an ideal residential environment by a wide range of households (Grossmann et al. 2017).

\subsubsection{Characteristics of Local Housing Markets}

The competitive position of large housing estates depends on the pressure on the local housing market. Van Gent (2010) compared four housing estates in Birmingham, Amsterdam, Barcelona and Stockholm. Although the four neighbourhoods were similar in their urban design, Birmingham was much more stigmatised as a slum area. Residents there are seen by outsiders as people that only 
stay there because they have no choice to move to a better place. The other three housing estates could benefit from spillover demand due to high pressure on the regional housing market.

High pressure on housing markets can be alleviated by new housing production. In segregation literature, it is often overlooked that this can be a factor that exacerbates the spatial division between the rich and the poor. In Dutch cities, post-war housing estates face tough competition from greenfield developments built at the edges of the big cities. These developments attract middle- and high-income households, many of whom move out of the relatively deprived housing estates. This resulted in an increasing concentration of low-income people in post-war housing estates. The spatial division between the rich and the poor is increasing in all six cities that were investigated, but the trend was strongest in cities where greenfield developments were the most extensive (Bolt and van Kempen 2013).

The lack of new housing production was one of the reasons that large housing estates in Eastern Europe did not end up in a downward spiral after the collapse of communism. Herfert et al. (2013) compared large housing estates in five Eastern European cities (Leipzig, St. Petersburg, Sofia, Budapest and Vilnius) and found that the housing shortage became more severe in the 1990s due to a lack of new construction. The only exception was Leipzig, where outmigration to the western part of Germany led to an oversupply at the large housing estates. The lack of new housing production, combined with the deterioration of the inner city (especially in St. Petersburg and Sofia) meant that the competitive position of large housing estates remained quite good. In two cities, St. Petersburg and Sofia, the socio-economic composition in the large housing estates does not differ from the inner city. In the other three cities, however, there is a tendency of a growing socio-economic segregation and a declining social status of social housing estates.

Riga (Latvia) and Tallinn (Estonia) also did not experience a sharp increase in residential segregation in the first decade after the transition (Musterd et al. 2017). Like in other post-socialist countries, rapidly increasing income inequality did not translate into spatial divisions (Marcińczak et al. 2015). Again, this is partly due to the lack of new housing. However, in the second decade after the transition, new housing kept up with the demand. New housing was mainly built in suburban areas and aimed at the better-off. This led to increasing socio-economic segregation, which in the case of Tallinn was also amplified by ethnic divisions (Musterd et al. 2017). Although both Riga and Tallinn have a very large Russian-speaking community, Estonians are much more segregated from the Russian-speaking minority than Latvians. Compared to the situation in Riga, members of the Russian minority are much more concentrated at the bottom of the social hierarchy and they are also more clustered in large housing estates from the socialist period. The better-off Estonian-speaking residents tend to leave these estates and move into suburban areas that are dominated by members of their own group. 


\subsubsection{Tenure}

Ownership structures of large housing estates differ between the various parts of Europe (Dekker and Van Kempen 2004). In Southern and Eastern Europe, owner-occupation is most prevalent, while most dwellings in large housing estates in Western and Northern Europe can be found in the social rented sector. Due to the dominance of owner-occupation in most Southern European housing estates, the residential turnover is lower than in Northern and Western Europe and, consequently, the pace of social degradation is also slower (Turkington et al. 2004). In Italy, however, some social housing estates were built in the 1970s. Neighbourhoods like Vele in Naples and Corviale in Rome have experienced rapid social degradation, suffering from a high rate of school drop-outs and the infiltration of mafia (Boeri and Longo 2012).

Owner-occupation in Eastern Europe has become prevalent since the transition, which led to a privatisation of the housing market. It took some time for financial markets to adapt to the new situation leading to limited access to mortgage credit. Combined with the low level of new housing production, this resulted in a low level of mobility in the first decade after the transition (Herfert et al. 2013; Musterd et al. 2017).

In Western and Northern Europe, where the share of social rented dwellings is much higher, a distinction can be made between a universalist approach, which emphasises provision for all households, and a dual approach focused on the provision for lower income households (Scanlon et al. 2015). In a dual system, social housing is more marginalised and therefore it seems reasonable to expect that the level of segregation will be higher than in a universal system (Arbaci 2007). However, Skifter Andersen et al. (2016) show that the opposite applies for Nordic countries. Copenhagen and Stockholm operate within a universal housing system, but the social housing estates are characterised by high concentrations of immigrants. In Oslo and Helsinki, access to social housing is restricted to the lowest-income households. However, the concentration of immigrants in this sector does not lead to high levels of segregation. In Oslo, the social housing sector is very small and spatially dispersed, and in Helsinki social housing is much more mixed with other tenures than in Copenhagen and Stockholm. Apparently, the size and the spatial distribution of the social/public sector are more important determinants of segregation than the type of approach used. In Copenhagen and Stockholm, the public sector is accessible for all income groups, but the concentration of these dwellings on large housing estates engenders a high concentration of immigrants.

Within Western and Northern Europe, there is a trend towards a residualisation of the social rented sector. Residualisation is the trend that the social rented sector gradually becomes the exclusive domain of low-income households (Bolt and van Kempen 2013). The term first appeared in UK, where the social rented sector has declined due to privileging of the owner-occupied sector (Murie et al. 2003). The introduction of the Right-to-Buy Act in 1980 led to a decline in the share of social rented households from 31\% in 1981 to $19 \%$ in 2012 in England (Fenton et al. 2013). 
As economic incentives are much larger to buy in popular areas (where the gap between buy-out price and value was much bigger), the proportion of social rented dwellings in large housing estates remains relatively high and the proportion of low incomes is increasing due to a lack of affordable alternatives. In large housing estates where social dwellings are sold, the effects on the neighbourhood tend to be negative. Permentier et al. (2013) performed a large-scale evaluation of the selling off of social housing in the Netherlands and found a positive effect on livability indicators (like social cohesion and safety) only for higher status neighbourhoods. In low-status neighbourhoods, the effects were negative. In Bijlmer, for instance, a housing association decided to terminate their selling project, as too many sold dwellings were sublet to other people and/or used for criminal activities.

In London, the Right-to-Buy Act led (in combination with other policies strengthening the commodification of housing) to the dispersion and suburbanisation of the urban poor over the 2000s (Fenton et al. 2013). The same trend can be seen in Stockholm, although the Right-to-Buy policy there is more recent. Between 1990 and 2010, the proportion of public housing declined from 32 to $18 \%$ and the decline was even sharper in the inner city (from 19 to 7\%). This resulted in a residualisation process in the multifamily outer suburbs (where large housing estates dominate the housing stock). In 1990, the income distribution there was very similar to Stockholm as a whole: $21 \%$ of residents were in the lowest disposable income quintile. By 2010, this number had risen to $32 \%$ while the proportion of non-western immigrants grew from 17 to $47 \%$. In Stockholm as a whole, the growth (from 6 to 16\%) was much more moderate (Andersson and Turner 2014).

\subsection{Management}

According to Glendinning and Muthesius (1994), the majority of high-rise blocks are attractive places to live with good management. The problem is that many housing estates are faced with flaws in management, both in terms of maintenance and housing allocation.

\subsubsection{Maintenance}

The maintenance budgets of large housing estates tend to be too limited, especially in Eastern Europe (Murie et al. 2003). In Tallinn, Estonia, for instance, the lack of resources for the maintenance of the housing stock led to significant deterioration over time (Kährik and Tammaru 2010). The privatisation process in Eastern Europe did not automatically improve the maintenance of large housing estates. While investment in renovation and maintenance increased in better-off neighbourhoods, new homeowners in lower status neighbourhoods often could not afford the 
necessary maintenance costs. This led to further physical degradation (and as a consequence also a social degradation) in the latter areas (Temelová et al. 2011).

Lack of maintenance is not a typically Eastern European issue but a problem that can be found all across Europe. In Sant Roc (an estate in the Barcelona region dominated by owner-occupation), for example, the housing stock is in a dismal state due to minimal investments in maintenance (Van Gent 2010) and the same applies to social housing estates such as Vele in Naples (Vele) and Corviale in Rome (Boeri and Longo 2012). In Glasgow, large housing estates have to cope with a harsh climate on top of the limited resources for maintenance. Wet weather conditions led to problems with dampness and water penetration, which would not have occurred if the same buildings would have been located in other parts of Europe (Kearns et al. 2012).

\subsubsection{Housing Allocation}

According to Kenneth and Forrest (2003, p. 51), it was in part the '... active exclusion of the poorest or those deemed to be less deserving which gave the social housing of the early post-war period its social status'. In the course of time, however, the social profile of incoming tenants started to change in countries like the Netherlands (Van Kempen 2000) and Britain (Goodchild and Cole 2001). In the popular imagination, large housing estates are nowadays seen as concentrated enclaves of poor people (Kennett and Forrest 2003). The timing of social degradation is very much dependent on the regional housing context. Problems started in the 20-storey John Russell Court block in Edinburgh only 5 or 10 years after the opening in 1964 when problem families were moved in, which quickly led to the deterioration of the image of the estate (Hall 2014). The reason for this change in allocation policy was the housing surplus that occurred in the UK at the end of the 1960s, which was the result of the 1960s production 'success' in building unprecedented numbers of new dwellings (Glendinning and Muthesius 1994, p. 320).

As explained above, the housing allocation process was completely different in Eastern Europe. The intellectual, cultural and political had better access to the housing estates at the most desirable locations (in the central cities), which meant that the socialist society was much less egalitarian than what could be expected on the basis of the dominant ideology (Kährik and Tammaru 2010; Kovács and Herfert 2012). After the transition, the differences in social status between more and less desirable locations have increased. 


\subsection{Renewal}

As explained in the introduction, Hoogvliet and Hooimeijer (1988) mentioned renewal as the fourth factor (next to the original situation, relative depreciation and management) that impacts the population composition of the neighbourhood. In Western Europe, there is strong involvement of the (local) state in the renewal of high-rise estates. This renewal is aimed at attracting middle-class residents by transforming tenure structure. Social transformation policies tend to be most radical in neighbourhoods where most dwellings are in the hands of the municipality or housing associations. Van Gent (2010) found in his comparison of four housing estates that in Barcelona (Sant Roc), social transformation was least drastic, as most residents were owner-occupiers and therefore had a quite strong bargaining position. They were granted the right to be relocated within the neighbourhood after the demolition of their dwelling. In Stockholm (Tensta), a failed attempt was made to change the social composition by the privatisation of part of the housing stock in the late 1990s. Large-scale restructuring was not an option in Stockholm, as the Swedish policy framework does not cover the costs of the demolition of municipal dwellings. In Amsterdam (Bijlmer) and Birmingham (Central Estates), where most dwellings were social rented, the restructuring of the housing stock was much more focused on changing the socio-economic profile of the population.

In the Netherlands, neighbourhoods with a high proportion of dwellings built in the post-war period (1945 to 1970) and a high proportion of low-income households are most likely to be targeted for large-scale restructuring. While targeting poor neighbourhoods is consistent with a philosophy of creating more social mix, it is perhaps surprising that the ethnic composition of a neighbourhood also seems to play a role in the targeting of neighbourhoods. Even when housing stock characteristics and the proportion of low-income households are controlled for, the proportion of members of minority ethnic groups is a strong predictor for the probability of an intervention aimed at replacement of social housing by owner-occupied homes (Permentier et al. 2013). Although changing the ethnic composition of the neighbourhood is not part of the formal policy, there are many indications that it is no coincidence that immigrant-dense neighbourhoods have a high chance to be targeted. A policymaker in Amsterdam, quoted by Van Gent (2010, pp. 73-74), argues 'We are diluting problems and by doing so making them more manageable. ... This means that if you have $80 \%$ immigrants (in a neighbourhood) and you lower it to 60 or $40 \%$, the problem will be easier to manage'. This is certainly not unique for the Dutch situation. For instance, one of the motives for the regeneration of Sant Roc in Barcelona is the policymakers fear of 'ghettoisation' and the negative consequences of the concentration of immigrants for the housing prices in the area (Van Gent 2010), and in Montreuil (France) the high proportion of immigrants is considered a problem by a local planners as it supposedly presents a bad image (Kipfer 2016).

In France, redevelopment has a disproportionate effect on immigrants as renewal projects are predominantly located in Zones Urbaines Sensibles which tend to be 
areas with high concentrations of immigrants and their descendants. To Kipfer (2016), social mixing is not only racialised in terms of targeting immigrant-dense areas but also in the practices of the allocation of social housing. Responsible commissions are biased in their attempts to prevent the recreation of 'ghettos' or the concentration of 'large families'.

In the Scottish context, the ethnic composition of the neighbourhood is much less of an issue (due to their lesser presence) than in France, but also here housing estates are stigmatised on the basis of the population composition. Estates like Craigmillar in Edinburgh (Kallin and Slater 2014) and Glasgow's East End (Gray and Mooney 2011) are defamed by media and politicians, because of the concentration of poverty and the pathological effects (like criminality and the culture of poverty) that are believed to result from this concentration. The territorial stigmatisation in British cities is connected to the residualisation of public housing discussed before. The stimulation of home ownership and the Right-to-Buy policy has led to normalising ownership and delegitimising council housing (Kallin and Slater 2014). In combination with an allocation policy which located the most deprived tenants in the most deprived estates, it can be argued that it is the state that has created the 'concentrated poverty' that it laments.

\subsection{Macro Developments}

\subsubsection{Population Change}

Within Europe, there are large differences with regard to the proportion of immigrants in the population. In 2014, foreign-born people accounted for $10.2 \%$ of the total population in the EU (Eurostat 2015). Roughly two-thirds came from outside an EU member state. The seven EU member states where the foreign-born population accounted for less than $5 \%$ of the total population are all post-socialist countries: Lithuania, Hungary, the Czech Republic, Slovakia, Poland, Bulgaria and Romania. In Southern Europe, the proportion of immigrants is slightly above (Spain, Greece) or below (Italy, Portugal) the EU average, while Western European countries have a higher than average proportion of immigrants (with the exception of Denmark). Estonia and Latvia are the post-socialist countries with the highest proportion of immigrants (most of whom are born in Russia), but these countries face emigration, like most Eastern European countries, while Western European countries experience a migration surplus (Musterd et al. 2017).

Immigrants tend to move to large cities, and within these cities they are often concentrated in large housing estates. In Amsterdam, about $80 \%$ of the population of Bijlmer has a non-Dutch ethnicity (Aalbers 2011). Tensta, a housing estate at the periphery of Stockholm, is one of the areas that suffered from the Right-to-Buy policy. It was stigmatised more and more and is increasingly avoided by native Swedish households; 85\% of residents are foreign-born (Van Gent 2010). 
In Athens, there is a low level of segregation of immigrants, which can be attributed to the absence of large housing estates. In the 1990s, Athens experienced a substantial inflow of immigrants (Albanians being the largest group), but they were relatively evenly dispersed over the central areas if Athens. Most immigrants moved into affordable low-quality apartments in neighbourhoods around the city centre (Maloutas 2016).

On the basis of a comparison of the four Nordic capital cities, Skifter Andersen et al. (2016) suggests that the degree of segregation is linked to the level of immigration. The level of segregation appears to be highest in Stockholm, which has the largest immigrant population, while segregation in Helsinki (with the smallest immigrant population) is lowest. This may be explained by a stronger tendency for 'white flight and avoidance' in the context of a large immigrant population (see also Andersson and Hedman 2016).

\subsubsection{Declining Employment}

One of the reasons that the heydays of large housing estates in Western Europe were relatively short-lived was that they very soon got a bad reputation among the public (Hall 2014; Turkington et al. 2004). The disastrous collapse of Ronan Point (an East London tower block) in 1968 as a consequence of a gas explosion and the demolition of Pruitt-Igoe in 1972 received a lot of media attention. Pruitt-Igoe was an American modernist public housing estate in St. Louis, Missouri completed in 1956. Physical deterioration, rent arrears and vacancy rates of $30 \%$ led to the decision to raze the entire complex. Hall (2014) comes up with the usual suspects to explain the failure of Pruitt-Igoe: poor physical quality, indefensible space leading to vandalism and criminality, lack of maintenance, and the admission of poor (black) family households.

The Pruitt-Igoe Myth, a 2011 (Freidrichs 2011) documentary film, argues that most explanations focus too much on internal factors. The social downgrading of the Pruitt-Igoe complex should be seen as a result of the economic restructuring of St. Louis. Pruitt-Igoe was a declining housing estate in a declining region. Employment opportunities were shrinking, and incomes were declining. As a consequence, renters were getting poorer and often could not pay their rents anymore. As a consequence, the funds available for maintenance and security of the buildings were reduced.

The story of Pruitt-Igoe has been replicated in European cities many times. The decline of the Park Hill housing project in Sheffield (1954-1961), which initially was one of the most praised public housing schemes of the post-war period, can be explained to a large extent by the collapse of the steel industry (Monclús and Díez Medina 2016). Craigmillar in Edinburg suffered from the closure of local breweries, the creamery and the coal pits (Kallin and Slater 2014). In Malmö (Sweden), poor neighbourhoods suffered much more from the economic recession in the early 1990s than other neighbourhoods. This led to sharp increases in both income 
inequality and income segregation (Andersson and Hedman 2016). This underlines that not only selective mobility but also in situ change plays a large role in segregation trends. In segregation literature, there is much more attention for the former process than for the latter. Temelová et al. (2011) also argue that, in the case of Czech housing estates, the decline in socio-economic status in situ is equally important as an explaining factor for social degradation as the inflow of poor people from outside to the housing estates. This in situ decline in socio-economic status is intertwined with the ageing process, since the elderly generally become poorer.

Some Eastern European housing estates suffered even more from the deindustrialisation process than their western counterparts. In contrast to the rest of Europe, new cities were constructed at sites where new factories emerged. When factories closed, these cities were abandoned, as they were too dependent on a single employer (Monclús and Díez Medina 2016).

\subsection{Conclusion}

In the traditional literature on neighbourhood decline, neighbourhood trajectories are portrayed as a natural, apolitical process. All neighbourhoods are supposed to go through a certain life cycle in which the number and order of the different stages are fixed (van Beckhoven et al. 2009). Although life cycle theories are not supported in academic circles anymore, policy documents still present the decline of housing estates as the outcome of 'inevitable processes of impersonal quasi-natural forces' (Gray and Mooney 2011, p. 11). Nothing could be further from the truth. There is nothing natural about neighbourhood decline. The decline of neighbourhoods is the outcome of economic forces and of political decisions. The concentration of poor households in housing estates is the result of political choices with regard to (among others) the planning of new neighbourhoods, the prioritisation of homeownership and austerity measures. Even the stigmatisation that often goes hand in hand with the social and ethnic transformation of housing estates is partly produced by state actors. The rationale for creating a worse reputation is that it widens the rent gap (opportunity for profit), which facilitates state-led gentrification focused on displacing the poor to make space for the middle class (Kallin and Slater 2014).

State-led gentrification may lead to an upgrading of a neighbourhood, but it will not help the residents of housing estates and it will not reduce the level of segregation within the city as displaced households tend to move to other poor neighbourhoods. What is needed is a new kind of housing policy which does not prioritise homeownership over renting. Social housing should not be residualised and stigmatised. Paris and Zurich set good examples here as they plan to expand the social sector in more expensive neighbourhoods (Bolt 2017). Converting social rented dwellings to owner-occupation should be restricted as it leads to a higher socio-economic as well as ethnic segregation (Boterman and Gent 2014), as shown in the Amsterdam case. New housing should preferably be built within existing 
cities. Building new housing at greenfield locations not only has ecological disadvantages but also leads to higher levels of segregation (Bolt and van Kempen 2013). Paradoxically, many high-rise housing estates are characterised by low density and offer plenty of opportunities for new housing projects which do not necessarily lead to the displacement of the sitting population.

With regard to interventions within housing estates, the focus should be on people rather than on the built environment. Stimulating social cohesion would help to create more stability in these areas. Of course, this policy has a physical aspect (creating meeting opportunities), but it is mainly about recognising the value of bottom-up efforts in the community. The numerous initiatives that exist in large housing estates can play an important role in the support of marginalised groups and contribute to social cohesion. Policymakers could support local initiatives financially and should stimulate the cooperation between these initiatives. Furthermore, policymakers should focus on increasing the social mobility of sitting residents. Language courses for immigrants and educational programmes for people with a low level of education could help people to find a job. Moreover, residents could be encouraged to start new firms through offering micro-credits and counselling. Rather than trying to attract the middle class, in situ upward mobility would be the best way forward to reverse social decline.

\section{References}

Aalbers MB (2011) The revanchist renewal of yesterday's city of tomorrow. Antipode 43(5): $1696-1724$

Andersson R, Hedman L (2016) Economic decline and residential segregation: a Swedish study with focus on Malmö. Urban Geogr 37(5):748-768

Andersson R, Turner LM (2014) Segregation, gentrification, and residualisation: from public housing to market-driven housing allocation in inner city Stockholm. Int J Hous Policy 14(1): $3-29$

Arbaci S (2007) Ethnic segregation, housing systems and welfare regimes in Europe. Int J Hous Policy 7(4):401-433

Boeri A, Longo D (2012) High density suburbs redevelopment and so-cial housing retrofitting for cities regeneration. Sustain City VII Urban Regener Sustain 155(1):133-144

Bolt G (2017) Governing diversity and social cohesion in European cities. Adj Open Access e-book

Bolt G, van Kempen R (2013) Neighbourhood based policies in the Netherlands: counteracting neighbourhood effects? In: Manley D, van Ham M, Bailey N, Simpson L, Maclennan D (eds) Neighbourhood effects or neighbour-hood based problems? A policy context. Springer, Dordrecht, pp 195-213

Boterman WR, Gent WP (2014) Housing liberalisation and gentrification: the social effects of tenure conversions in Amsterdam. Tijdschrift voor Economische en Sociale Geografie 105(2): $140-160$

De Decker P, Newton C (2009) At the fall of Utopia. Urban izziz/Urban Challenge 20:74-82

Dekker K, Van Kempen R (2004) Large housing estates in Europe: current situation and developments. Tijdschrift voor Economische en Sociale Geografie 95(5):570-577

Dennis M (2007) Working under hammer and sickle: vietnamese workers in the German Democratic Republic 1980-89. German Polit 16(3):339-357 
Eurostat (2015) People in the EU: who are we and how do we live? European Union, Brussels

Fenton A, Lupton R, Arrundale R, Tunstall R (2013) Public housing, commodification, and rights to the city: The US and England compared. Cities 35:373

Freidrichs C (2011) The Pruitt-Igoe myth: an urban history

Gentile M, Tammaru T (2006) Housing and ethnicity in the post-soviet city: Ust'-Kamenogorsk. Kazakhstan Urban Stud 43(10):1757-1778

Glendinning M, Muthesius S (1994) Tower block: modern public housing in England, Scotland, Wales, and Northern Ireland. Paul Mellon Centre for Studies in British Art, London

Goodchild B, Cole I (2001) Social balance and mixed neighbourhoods in Britain since 1979: a review of discourse and practice in social housing. Environ Plann D Soc Space 19:103-121

Gray N, Mooney G (2011) Glasgow's new urban frontier: 'civilising' the population of 'Glasgow East', City 15(1):4-24

Grečic V (1991) East-West migration and its possible influence on South-North migration. Int Migr 29(2):241-252

Grigsby W, Baratz M, Glaster G, Maclennan D (1987) The dynamics of neighborhood change and decline. Prog Plann 28:1-76

Grossmann K, Kabisch N, Kabisch S (2017) Understanding the social development of a post-socialist large housing estate: the case of Leipzig-Grünau in eastern Germany in long-term perspective. Eur Urban Region Stud 24(2):142-161

Hall P (2014) Cities of tomorrow: an intellectual history of urban planning and design since 1880. Wiley, Chicester

Herfert G, Neugebauer CS, Smigiel C (2013) Living in residential satisfaction? Insights from large-scale housing estates in Central and Eastern Europe. Tijdschrift voor Economische en Sociale Geografie 104(1):57-74

Hoogvliet A, Hooimeijer P (1988) Population change in early-twentieth century neighbourhoods. J Hous Built Environ 3(2):133-147

Jacobs JM, Lees L (2013) Defensible space on the move: revisiting the urban geography of Alice Coleman. Int J Urban Reg Res 37(5):1559-1583

Kallin H, Slater T (2014) Activating territorial stigma: gentrifying marginality on Edinburgh's periphery. Environ Plann A 46(6):1351-1368

Kearns A, Whitley E, Mason P, Bond L (2012) Living the high life? Residential, social and psychosocial outcomes for high-rise occupants in a deprived context. Hous Stud 27(1):97-126

Kennett P, Forrest R (2003) From planned communities to deregulated spaces: social and tenurial change in high quality state housing. Hous Stud 18(1):47-63

Kipfer S (2016) Neocolonial urbanism? La Rénovation Urbaine in Paris. Antipode 48(3):603-625

Kovács Z, Herfert G (2012) Development pathways of large housing estates in post-socialist cities: an international comparison. Hous Stud 27(3):324-342

Kährik A, Tammaru T (2010) Soviet prefabricated panel housing estates: areas of continued social mix or decline? Case Tallinn Hous Stud 25(2):201-219

Maloutas T (2016) Socio-economic segregation in Athens at the beginning of the twenty-first century. In: Tammaru T, Marcińczak S, van Ham M, Musterd S (eds) Socio-economic segregation in European capital cities. East Meets West, Routledge, London and New York, pp 156-185

Marcińczak S, Tammaru T, Strömgren M, Lindgren U (2015) Changing patterns of residential and workplace segregation in the Stockholm metropolitan area. Urban Geogr 36(7):969-992

Monclús J, Díez Medina C (2016) Modernist housing estates in European cities of the Western and Eastern blocs. Plann Perspect 31(4):533-562

Murie A, Knorr-Siedow T, van Kempen R (2003) Large housing estates in Europe: general developments and theoretical backgrounds. Utrecht University, Utrecht, Faculty of Geosciences

Musterd S, Marcińczak S, van Ham M, Tammaru T (2017) Socioeconomic segregation in European capital cities. Increasing separation between poor and rich. Urban Geogr 38(7):1062-1083

Newman O (1972) Defensible space: crime prevention through urban design. Macmillan, New York

Permentier M, Kullberg J, Van Noije L (2013) Werk aan de wijk. SCP, Den Haag 
Scanlon K, Fernández Arrigoitia M, Whitehead CM (2015) Social housing in Europe. Eur Policy Anal 17:1-12

Skifter Andersen H, Andersson R, Wessel T, Vilkama K (2016) he impact of housing policies and housing markets on ethnic spatial segregation: comparing the capital cities of four Nordic welfare states. Int J Hous Policy 16(1):1-30

Temelová J, Novák J, Ouředníček M, Puldová P (2011) Housing estates after socialism: various trajectories and inner differentiation. Urban Stud 48(9):1811-1834

Turkington R, van Kempen R, Wassenberg F (2004) High-rise housing in Europe: current trends and future prospects. In: Delft University Press, Delft

Van Beckhoven E, Bolt G, van Kempen R (2009) Theories of neighbour-hood change and decline. In: Rowlands R, Musterd S, van Kempen R (eds) Mass housing in Europe. Palgrave, Macmillan, pp 20-50

Van Gent WP (2010) Housing context and social transformation strategies in neighbourhood regeneration in Western European cities. Int J Hous Policy 10(1):63-87

Van Kempen R (2000) Big cities policy in the Netherlands. Tijdschrift voor Economische en Sociale Geografie 91(2):197-203

Van Kempen R, Musterd S (1991) High rise housing: some research and policy implications. Hous Stud 6(1):83-95

Váradi MM, Virág T (2014) Faces and causes of roma marginalization: experiences from Hungary. In: Szalai J, Zentai V (eds) Faces and causes of Roma marginalization in local contexts: Hungary, Romania, Serbia. Central European University, Budapest, pp 35-65

Open Access This chapter is licensed under the terms of the Creative Commons Attribution 4.0 International License (http://creativecommons.org/licenses/by/4.0/), which permits use, sharing, adaptation, distribution and reproduction in any medium or format, as long as you give appropriate credit to the original author(s) and the source, provide a link to the Creative Commons license and indicate if changes were made.

The images or other third party material in this chapter are included in the chapter's Creative Commons license, unless indicated otherwise in a credit line to the material. If material is not included in the chapter's Creative Commons license and your intended use is not permitted by statutory regulation or exceeds the permitted use, you will need to obtain permission directly from the copyright holder. 
Part III

Case Studies of Housing Estates in European Metropolitan Areas 


\title{
Chapter 4 \\ Exceptional Social Housing in a Residual Welfare State: Housing Estates in Athens, Greece
}

\author{
George Kandylis, Thomas Maloutas and Nikolina Myofa
}

\begin{abstract}
This chapter describes housing estates in Athens, Greece in terms of their number, the periods in which they were produced, the public agencies involved in their production, the profile of their beneficiaries and the changes they have undergone since they were produced. It also provides a map of housing estates in the Athens Metropolitan Region depicting their various spatial patterns. Housing estates are a rather exceptional form of social housing in Athens. The fact that rented social housing has never been developed in Greece has limited housing estates not only in terms of their number but also in their social function. Thus, housing estates in Athens have never formed a sector of the housing stock serving the needs of the most vulnerable population groups. Instead, housing estates followed the dominant trend of the local housing provision system-i.e. the promotion of socially diffused homeownership — but played a relatively minor role in the whole process.
\end{abstract}

Keywords Athens, Greece - Housing estates • Housing policy

Interwar refugees $\cdot$ Working-class homeownership

\subsection{Introduction}

Housing estates in Athens were primarily developed to cater to the housing needs of victims of wars or natural disasters. Housing for the massive wave of refugees from Asia Minor in the early 1920s led to the first batch of housing estates in the city's

\footnotetext{
G. Kandylis

National Centre for Social Research (EKKE), Athens, Greece

e-mail: gkandyli@ekke.gr

T. Maloutas $(\bowtie) \cdot$ N. Myofa

Department of Geography, Harokopio University, Kallithea, Greece

e-mail: tmaloutas@gmail.com; maloutas@hua.gr

N. Myofa

e-mail: nikolmyofa@hua.gr

(C) The Author(s) 2018

D. B. Hess et al. (eds.), Housing Estates in Europe, The Urban Book Series, https://doi.org/10.1007/978-3-319-92813-5_4
} 
periphery, which only accommodated a small portion of the immigrant's needs. The second group of estates was produced after World War II and the Greek Civil War (1946-1949) to address the needs of refugees that continued to live in slums and other segments of the working class. Again, housing estates only covered a very small share of housing needs and not the most pressing ones. They exclusively provided access to homeownership, a political strategy of authoritarian regimes aimed at gaining political support from a broad stratum of social groups.

In more recent years, housing estates became even more scarce, while the motive for their production was even less focused on specific social housing objectives. Two projects at the fringes of the urban tissue-including the 2004 Olympiako Chorio (Olympic Village) that eventually transformed into social housing-were the last housing estates to be constructed in Athens. Newer projects were abandoned after the recent abolition of the Workers' Housing Organization (OEK), the biggest public housing constructor of the post-war period.

Housing estates are a rather exceptional form of social housing in Athens. The fact that rented social housing has never been developed in Greece not only limited the number of housing estates but also restricted their social function. Thus, housing estates followed the dominant trend of the housing provision system-i.e. the social diffusion of homeownership - and, despite some sporadic, ambitious plans, they played a relatively minor role in the whole system due to their small aggregate size. Moreover, the transfer of ownership to beneficiaries without any provision for future maintenance and renewal throughout the post-war period resulted in gradually deteriorating residential areas and the stigmatisation of housing estates.

\subsection{Periodisation of Policies, Priorities and Forces at Work}

\subsubsection{The 1920s and 1930s}

Housing estates first appeared in 1922 at the end of the war between Greece and Turkey, which ceased the short-lived Greek occupation of territories in Asia Minor inhabited by ethnic Greeks. Following the massive ethnic cleansing imposed by the Lausanne Treaty (1923), over one million Greeks were deported from Turkey to Greece and about half a million Turks were deported from Greece to Turkey. The brutal displacement of such a large population created a humanitarian crisis, especially since the newcomers had to be integrated into a state whose population was about 5 million, representing an increase of about 20\% (Guizeli 1980; Leontidou 1989).

The overwhelming increase in housing needs was only partially addressed through active policies and the construction of public housing. Initially, refugees settled in camps, and most of them eventually had to find housing solutions on their own with limited assistance from the relevant authorities. A significant share of refugees ended up in urban areas; 230,000 settled in Athens, representing a 50\% 
population increase. In the next census (1928), the city's population rose to 740,000 , including refugees (Leontidou 1989, p. 159). The first encampments in Athens were placed outside the existing urbanised area (see maps in: Papaioannou and Vasilikioti 1975; Leontidou 2017).

A large majority of Asia Minor refugees eventually found housing solutions with little or no direct provision from public authorities (Leontidou 1990). Several factors - including the occupation of public land and the creation of slums, the public provision, or more frequently, the purchase of cheap land lots for self-promotion and self-construction-influenced the way housing for vulnerable groups was addressed in Greece over the long term. Moreover, the abrupt settlement of many poor refugees at the city's periphery radically reshaped its social geography. Both temporary encampments and different types of permanent settlements - including housing estates - accentuated the divide between the relatively affluent centre and the poor peripheral neighbourhoods which, to some extent, corresponded to the division between newcomers and the native population.

Housing estates for Asia Minor refugees were initially constructed between 1922 and 1925 by the Refugee Care Fund (TPP), an ad hoc public body established by the government (Vasiliou 1944; Leontidou 1990). The Refugee Care Fund constructed the first four refugee settlements in Athens, at the margins of the existing urban tissue. After 1925, the Refugee Care Fund was replaced by the Refugee Rehabilitation Committee (EAP), another state authority that undertook the task to allocate the loan that the League of Nations granted to Greece. The Refugee Rehabilitation Committee constructed about 13,500 new dwellings in Athens, covering about $20 \%$ of the refugee population's needs (assuming that the average dwelling corresponds to a family of four). Different types of housing were provided and only some of those were dwellings in apartments buildings (Papaioannou and Vasilikioti 1975; Papadopoulou and Sarigiannis 2006). Housing estates in Athens and Piraeus were located in the undeveloped areas at the margins or clearly outside the limits of the urban tissue, but were eventually engulfed by the city's expansion, especially after World War II (Fig. 4.3). Even refugees with a bourgeois background settled outside the city, but not in housing estates.

By the end of the 1920s and during the 1930s, the Ministry of Social Care also began constructing temporary settlements and dwellings to address the continuously growing housing needs, since refugees often relocated to large cities from the rural areas where they were originally driven. Many of these settlements were of very poor quality and brought about the emergence of vast urban slums in their surroundings. After 1930, the Ministry became the exclusive provider for the needs of urban refugees and adopted slum clearance as its basic strategy (Vasiliou 1944) (Figs. 4.1 and 4.2).

Under those extraordinary conditions, state authorities clearly opted for promoting homeownership instead of establishing a social rented housing sector, which never developed in Greece. The option of social rent was soon discarded, and refugees were granted subsidised loans for the purchase of their dwellings. The only restriction to private ownership that remained for some time was the prohibition of selling housing units to non-refugee households, even after repayment of the loan. 


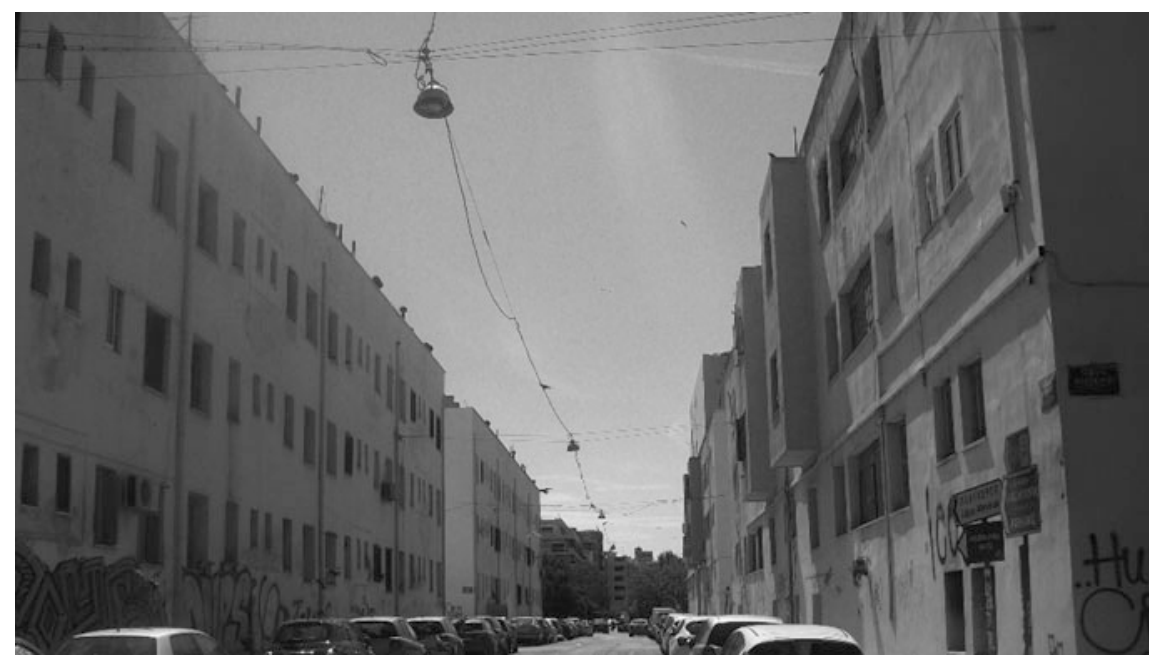

Fig. 4.1 The first four condominiums in Dourgouti, part of the old public housing stock for refugees constructed between 1935 and 1936 by the Ministry of Social Care, 2016. Source Myofa, personal archive, 2016

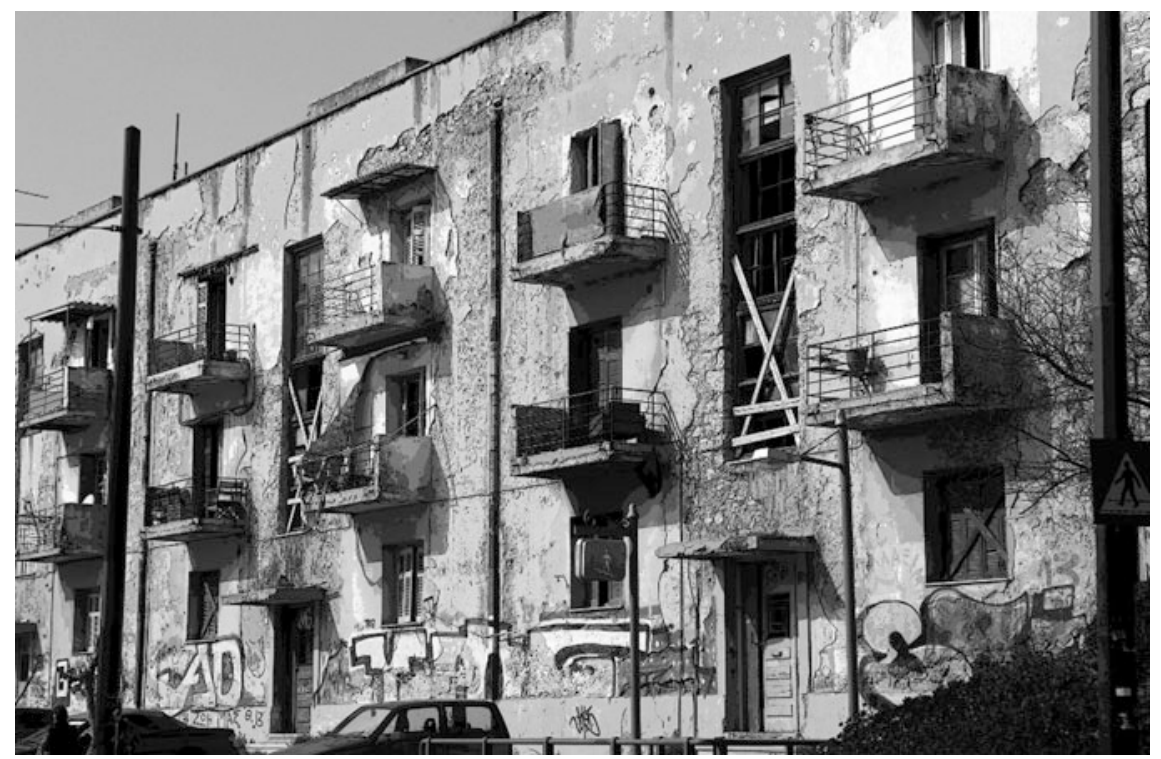

Fig. 4.2 View of the refugee housing estate on Alexandras Avenue, central Athens, 1933-1935. Source Maloutas, personal archive, 2009 


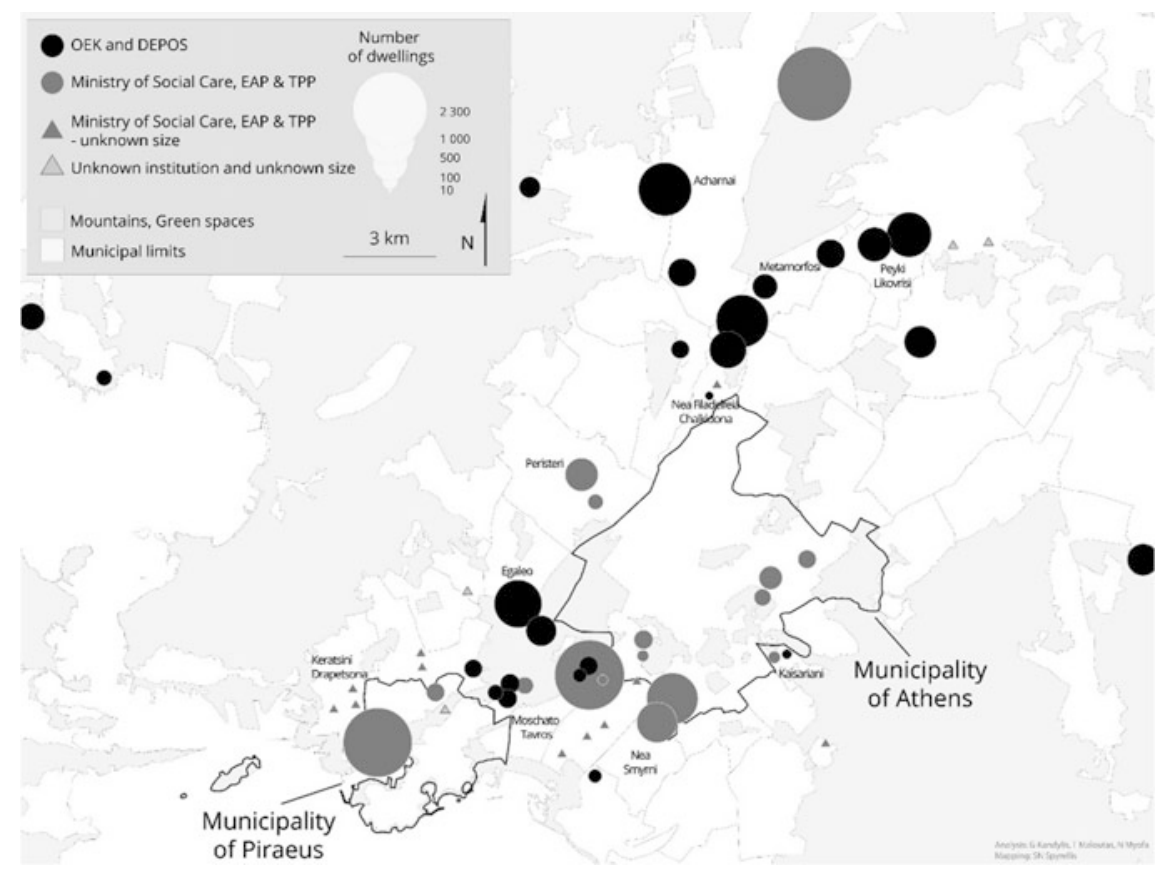

Fig. 4.3 Housing estates in the Athens metropolitan region by size and public agency, 2017. Source Compiled information from Papaioannou and Vasilikioti (1975); Papadopoulou and Sarigiannis (2006); Stavridis et al. (2009); Gouvousi (2011) and local visits by the authors

\subsubsection{From the 1950s to the Late 1970s}

The destruction caused by World War II, the Occupation (1941-1944) and the Civil War (1946-1949) caused a new very serious housing shortage in Athens, as in the rest of Greece (Doxiadis 1947). Apart from the already impoverished urban population, the metropolitan area now had to accommodate internal migrants fleeing poverty and political persecutions in rural areas (Kyriazi-Alisson 1998). The extraordinary housing needs created by wars, ethnic cleansing and natural disasters took precedence over the needs of industrial development created in other countries. The following decades (until the late 1970s) were a period of intense economic development and impressive population growth for Athens. Yet, at the same time, the contribution of public construction in the impressive reconstruction and urban expansion of those decades was of limited importance.

In place of public construction, state policies prioritised homeownership through self-promotion - often involving self-construction - by various means. This option, coming from the interwar period, was adopted even more eagerly since it was considered a way to gain political support or at least to neutralise the resistance of the electorate of the left who were vanquished in the Civil War. A decisive measure 


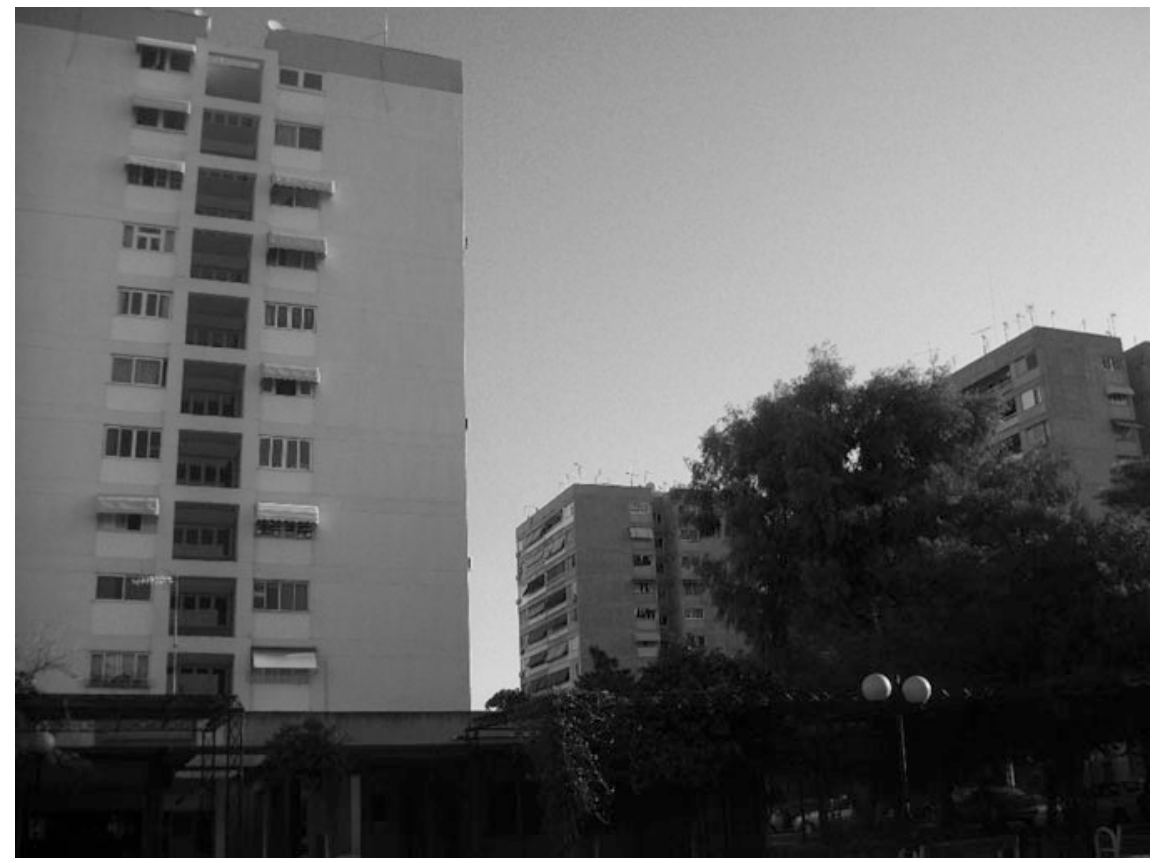

Fig. 4.4 Ten-storey condominiums in Tavros built between 1969 and 1971 by the Ministry of Social Care, 2016. Source Myofa, personal archive, 2016

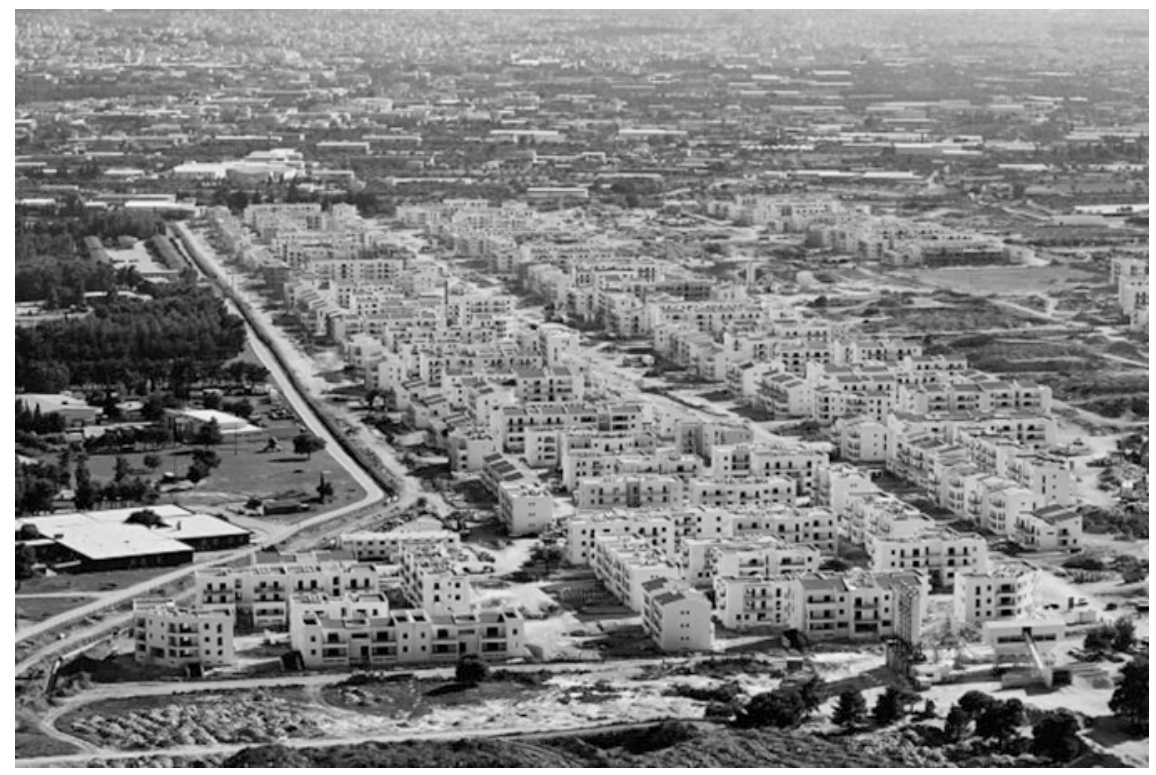

Fig. 4.5 View of the Olypiako Chorio estate, 2004. Source Acharnes web page, 2017 
permitted the segmentation of large peri-urban properties and their sale as small plots officially destined for gardening, which ended up in irregular construction by buyers. Eventually, the latter had to become part of the clientelist regime, exchanging their political support against the legalisation of their construction. Unlike in other countries of the Southern European region, homeownership was boosted mainly through the initiative of the final users (i.e. self-promotion) and through the legal provision of a land-for-flats system (antiparochi ${ }^{1}$ ) that enabled non-monetary exchanges between small landowners and small size building firms.

Most public housing projects in Athens were undertaken by the Ministry of Social Care, carrying on the refugee slum clearance programme of the preceding period. This activity culminated in the 1960s and early 1970s (Papaioannou and Vasilikioti 1975). The Ministry adopted the same policy model used for the refugees of the 1920s to address housing needs of other groups, such as victims of natural disasters. The first post-World War II housing estate was constructed in 1955 in the area of Asyrmatos, in the city centre not far from the Acropolis. It comprised 150 dwellings in detached and four-storey houses, replacing the shacks of a refugee settlement from the 1920s in the same area (Saliveros 1961).

The Workers' Housing Organization (OEK), established as an independent agency by the Ministry of Employment and Social Security in 1954 (Leontidou 1990), was the first institution meant to initiate a more comprehensive housing policy. The Workers' Housing Organization was a sui generis obligatory partnership of salaried workers, directed by the government. Workers had to contribute $1 \%$ of their salaries to fund its activity. Employers also had to contribute an additional $0.5 \%$ of labour cost. The objective of the Workers' Housing Organization was to provide housing options for its members, under certain preconditions. As with other public housing construction initiatives, the policy of the Workers' Housing Organization was to promote homeownership, in this case for working-class and employee families. Like the Ministry of Social Care, the Workers' Housing Organization constructed projects of identical condominiums and blocks of flats in different urban areas throughout Greece. Construction activities escalated towards the end of the period, but mainly outside Athens (Gouvousi 2011) (Fig. 4.4).

During this first post-war period, the number of people who catered to their housing needs through self-promotion-mostly legal, but often illegal—was incomparably larger than those who benefited from direct housing provision by the relevant state agencies. If we also take into account those who accessed housing through the private market - especially those who bought apartments during the building frenzy of the 1960s and 1970s - the share of direct housing provision by state agencies becomes much smaller.

\footnotetext{
${ }^{1}$ The system of antiparochi permits joint ventures between landowners and builders, whereby the latter gets a share of the building at the end of the operation (Antonopoulou 1991; Katsikas 2000).
} 


\subsubsection{From the Early 1980s to the Present}

After 1980, the Workers' Housing Organization attempted to renew and enrich its construction activities. One of the main targets was to improve quality and reduce aesthetic distance between its projects and the average housing standards of the day (Gouvousi 2011). This attempt was implemented especially in specific cases of innovative new settlements. For example, smaller housing blocks on a large land plot and low-density settlement, allegedly preferred by the beneficiaries, were constructed in the mid-1980s in the north-western part of the suburban ring of Athens (in the working-class municipality of Acharnai), equipped with local centres for commerce and recreation.

In the northern suburbs (municipality of Pefki), the settlement of Iliako Chorio (Solar Village) was constructed in the same period, in proximity to middle-class residential areas. It was planned to use solar energy for heating but the renewable energy system collapsed a few years later. More recently, the settlement of Olympiako Chorio was constructed for the 2004 Olympic Games to serve as the accommodation centre for athletes during the Games. As initially planned, it was transformed into a social housing residential compound after the Games, albeit facing several problems regarding the completion of public and private amenities that should accompany its residential function.

A total of 62 settlements were built by the Workers' Housing Organization in metropolitan Athens since the mid-1950s, with a total of 610 settlements throughout Greece. ${ }^{2}$ The Workers' Housing Organization remained the main public housing constructor in Greece until its abolition in 2012 (Gouvousi 2011), following policies to reduce the size of the state after the burst of the sovereign debt crisis. The abolition of the Workers' Housing Organization, apart from the negative impact on other housing policies such as subsidised rent, led to the abandonment of new construction projects. No other institution has taken over the Workers' Housing Organization's function (Fig. 4.5).

\subsection{Physical Form}

Most housing estates in Athens are rather small areas in the midst of more important residential areas that surround them. Only four estates exceed a population of 3,000 people: two of the more recent estates at the peri-urban fringe (Olympiako Chorio and Acharnai) and two older estates in the working-class western suburbs (Nea Filadelphia and Tavros) that were initially constructed to house refugees from the

\footnotetext{
${ }^{2}$ The Workers' Housing Organization's activity has been targeted much more towards mid-sized Greek cities. The number of settlements produced in Athens represents about $10 \%$ of the total, while the share of Athens in the country's population was about $31 \%$ in 1981 when the activity of this agency culminated.
} 
slum areas around Athens. No estate exceeds a population of 10,000, and from this perspective Athens is a marginal case among the other cities in this book. However, their average size of 1,340 residents is significant for a city where there are no private housing estates and the only comparable unit is the much smaller typical Athenian residential building. The Greek term sygrotima that is used to describe estates can be translated as both compound and estate, and denotes their 'big' size in relative terms. Moreover, there are no considerable urban zones exclusively characterised by public housing. This is compatible with the very small portion that housing estates account for in the city's total housing stock (about 1.5\%, see the section on the demographics of housing estates). The small size of the estates may also mark an effort to construct coherent local communities.

Different types of estates had already emerged in the pre-war period, including independent and semi-detached houses (either with one or with two storeys), rows of two-storey houses and larger estates consisting of multilevel condominiums (Papaioannou and Vasilikioti 1975). The latter prevailed especially after the war, although never entirely, since clusters of two-storey houses continued to be produced in the first years of the Workers' Housing Organization's activity. Influences of garden city planning and modern architecture (CIAM, Bauhaus, ville radieuse) were clear on street layouts and on buildings' forms (Filippidis 1984; Stavridis et al. 2009).

Most of the blocks of independent and semi-detached houses do not exist anymore, as they were demolished and replaced by privately built blocks of flats during the decades that followed, as their owners eventually had the opportunity to exploit the land and increase their property's size and value through the land-for-flats system (antiparochi) mentioned above. However, some of those houses were either abandoned or (more rarely) renovated and continue to appear occasionally among other higher buildings. In a few cases, relatively large remnants of the initial blocks of independent and semi-detached houses have been transformed to commercial or recreation spots, aided by their rare architectural form.

Pioneer Greek architects found the opportunity, especially in the 1930s, to implement the functionalist principles of modernist architecture in the layout of the buildings and the new settlements. In the case of blocks of condominiums, the provision of common open and green space marked a difference from the dominant pattern of continuous construction, which prevailed in the vast majority of privately constructed residential areas of the city. However, these advantages were increasingly compromised. Many among the settlements are situated at the borders between municipal authorities, witnessing the peripherality of their initial position. The production of housing estates often led to creating isolated areas, poorly connected with the rest of the city. With time, these disadvantages decreased as public housing areas were rapidly engulfed by the expanding city, but other disadvantages emerged.

In several cases, especially in older settlements where architectural innovation was more 'tolerated', some building characteristics mark a clear difference between the estates and the regular building types considered acceptable by the same social strata. For example, the absence of the provision of very small balconies was a 
sacrifice in order to increase common space, but an important disadvantage for Athens's climatic conditions. Lacking domestic space led to the closing of small balconies and their incorporation into the apartment interior. Open and/or common spaces were often appropriated by residents situated next to them for private use (addition of rooms, private gardens) simulating similar practices in the surrounding areas. At the same time, some features like the small common entrances of the buildings or the open staircases tended to create a kind of symbolic inferiority, as well as feelings of insecurity.

Various plans have been experimented for the common-use space of the estates (Stavridis et al. 2009). Some of them adopted innovative (for Athens) ways to promote community life, especially through the creation of community markets, the provision of space for indoor and outdoor community activities and experimental solutions to promote the relationship between private and public use of space. These attempts have mostly led to failures and progressive abandonment of such innovations. This outcome can be mainly explained by the fact that all housing estates in Athens were rapidly turned to condominiums, where the low-means beneficiaries who were able to become apartment owners did not have the resources or any assistance to maintain and upgrade the quality of their property, let alone that of the common spaces of the estates. In recent years, maintaining and upgrading housing properties was not a priority, especially for low-means households, since many Athenian households have been struggling to even pay for heating their apartments during the winter.

\subsection{Allocation Process and Tenure}

Housing estates in Athens were initially produced under exceptional conditions which contributed to their particular character. Providing housing units and settlements for victims of various disasters, especially for Asia Minor refugees and their descendants, initially produced a homogeneous profile of housing estates, especially since state authorities tended to segregate different strata of the refugee population (Guizeli 1980). The policy decision to promote homeownership over home rental made this initial homogeneity a more permanent feature, further sustained by restrictions to selling outside the refugee population.

The process of housing allocation by the Ministry of Social Care comprised initially the inventory of families who lived in shacks. The allocation of apartments to beneficiaries was based on the number of their family members and on the condition that the beneficiaries' families were not homeowners or landowners in some other area. During the demolition of the shacks and the building of the new estate, beneficiaries were given a rent subsidy. Allocation of apartments was implemented through a lottery among potential beneficiaries, who did not have the option to choose apartments according to the features they wanted. In many cases, households were relocated from the neighbourhood in which they used to live. The transition from shacks to apartment buildings, in spite of the improvement of 
housing conditions, brought about significant changes in other aspects of everyday life affecting the neighbourhoods' social cohesion and the sense of solidarity among residents.

The establishment of the Workers' Housing Organization in the 1950s marked a significant turn in public housing policy. Focusing on providing housing for salaried workers, it followed what happened in industrial countries in Europe and elsewhere and, by that, became a symbol of modernization. Eligibility for beneficiaries depended always on their work record, which they had to prove. This meant that a large part of workers and employees working informally or with interrupted contracts were excluded. It was salaried workers and employees with the higher potential of repaying for their access to homeownership that were eligible; in other words, the part of these groups with relatively high and steady income. Different types of lottery were used, since a much larger number of potential beneficiaries applied for the relatively small number of housing units supplied. Restrictions for transferring the apartments to third parties applied until repayment, and subletting was also restricted, but the rule about the latter has often been transgressed.

It took many years or even decades before homogeneity started to decline as a consequence of new major demographic changes combined with the progressive decline of living conditions in housing estates. The large internal migratory movement of the $1950 \mathrm{~s}$ to the $1970 \mathrm{~s}$ and, more recently, the settlement of transnational immigrants since the early 1990s brought new low-means households to the city. The latter found shelter in the most affordable sector of the existing housing stock, including in apartments in declining housing estates, rented by their initial owners or their descendants.

Like housing estates in other cities around the world, the Athenian ones were initially desirable residential spaces for the upper layers of salaried workers and employees, but their desirability declined rapidly in parallel with the fast improvement of housing conditions throughout the city and their own rapid deterioration. Today, despite the existence of estates produced in different periods and characterised by different standards, housing estates in Athens are marked by their residual character and stigmatisation, especially due to their very limited and haphazard maintenance and improvement. Residents generally have limited capacity to undertake such tasks by their own means. Estates are further affected negatively by the presence of abandoned dwellings and dwellings with ambiguous legal status (for example, due to non-repayment, bureaucratic obstacles in the procedure of legal transfer or disagreements among multiple inheritors).

Public housing projects in Athens were always meant to produce dwellings that would end up as owner-occupied - either destined to satisfy the housing needs of the victims of natural and human disasters or destined to house salaried workersafter a subsidised housing loan was paid off by the beneficiary household. After repayment, the beneficiaries became homeowners of their dwellings with full rights and were also generally free to rent or sell them in the market. In this way, distributed dwellings became an asset for the beneficiaries or their descendants who were able to use them to generate money income, if they decided not to live in 
them. This has been a widespread practice, especially in the older and deteriorating estates, among households that experienced upward social mobility (mainly intergenerational) and relocated outside the estates. In some cases, the apartments were rented to non-beneficiaries in the shadow private rented sector even before repayment (and before beneficiaries became full owners).

As a result of these processes, tenure structure in the census tracts that contain housing estates is almost identical with the tenure structure in the entire metropolitan area (Table 4.1). Households in owner-occupied dwellings account for $70 \%$ and households in privately rented dwellings for $25 \%$ of the total. The similar tenure structure in and outside housing estate areas is enough evidence that the privately owned dwellings in housing estates are generally integrated into the housing market in a similar way to other parts of the housing stock.

\subsection{Demographics and Social Profile}

Calculation of population in housing estates in Athens is necessarily based on approximations, since there are no official records for the estates and the dwellings they comprise. Moreover, there are multiple agencies responsible for part of the estates and some of these have been recently abolished, leaving no responsible authority that could provide such data. This is partly explicable, since most housing estates by now are simple condominiums, absolutely independent from the public agencies that produced them.

The most reliable available source is the national census. However, even the most detailed geographical level of the census tract (CT) does not usually coincide with the limits of the estates, due to their rather small surface. Estates often constitute only part of a census tract, while in some cases even small estates are split into different census tracts. Under these conditions, and after identifying on the map, the 106 census tracts containing publicly funded housing estates (in a total of 3,185 census tracts in the metropolitan area of Athens), ${ }^{3}$ we estimated the share of the local population in each census tract that lives in the estates, using the estates' surface and the number of floors. ${ }^{4}$ We thus estimated a population of about 61,000 persons in 49 housing estates in 2011. Similar results were obtained for 2001 and 1991 (58,000 and 54,000 individuals, respectively). These figures mean that the

\footnotetext{
${ }^{3}$ The spatial unit we use in this chapter is a derivative of the official census tracts, with a minimum population of 1,000 and an average population of 1,200 individuals.

${ }^{4}$ Satellite images from Google Maps were used in order to visually identify the proportion of the estates' surface in the total built surface of their census tracts. The estimated shares vary between $0.08 \%$ and $100 \%$. All census tracts with any proportion of publicly constructed residential buildings are included in the housing estates statistics that follow.
} 
share of people living in housing estates in the Athens metropolitan area was about $1.6 \%$ in 2011, almost identical to that in 1991 and $2001(1.5 \%){ }^{5}$

In terms of basic demographic characteristics, the population of census tracts with housing estates does not differ significantly from the total population of the metropolitan area. The average age of residents in census tracts containing housing estates was 41.5 years in 2011 compared to 41.1 years for the whole metropolitan area; and $17.6 \%$ of this population was over 65 years compared to $17.3 \%$ for the metropolitan area; and $15.8 \%$ of housing estates' residents lived in households with no family nucleus, compared to $15.5 \%$ in the whole metropolitan area. The proportion of single-parent families was $14.1 \%$, slightly higher than that for the metropolitan area $(12.2 \%)$.

The share of immigrants from less developed countries in census tracts containing housing estates was $10.8 \%$ in 2011 , slightly higher than their share in the metropolitan area $(9.5 \%)$. However, there are noticeable exceptions in some cases of older (refugee) estates in central Athens, where the presence of immigrants is much higher (21\% in Dourgouti and $25 \%$ in Alexandras Avenue). Immigrants are more present in the estates where the filtering-down process has been long-lasting and more pronounced (Fig. 4.6).

Figure 4.7 summarises certain differences between areas containing housing estates and the rest of the city. The unemployment rate is considerably higher in housing estate areas and especially in areas with higher concentration of housing estates (of more than $50 \%$ of the respective surface). The socio-professional distinctiveness of the estates is indicated by the relative absence of professionals (major group 2 of ISCO-08). These occupations almost disappear in higher concentrations of estates. Professionals were not eligible for the estates in the beginning and their meagre presence should be attributed to intergenerational mobility rather than to some form of gentrification process for which there is no other corroborating evidence. On the other hand, the relatively stronger presence of routine occupations (major group 9 of ISCO-08) is evidence of a filtering-down process in the estates. Furthermore, the presence of the broader category of manual workers (major groups 7, 8 and 9 of ISCO-08) - comprising the traditional skilled working-class and the unskilled routine occupations - is higher in the broad areas containing estates and considerably lower, even than the city's average, in areas where housing estates prevail. This might mean that the filtering-down process attained the better-off part of the salaried workers who probably moved away from the estates but not from the surrounding traditional working-class areas.

The social differentiation of the estates is also reflected in the educational level of their inhabitants. Among residents aged over 25 in census tracts with estates, 17.8\% were university graduates in 2011, in comparison with $28.3 \%$ in the metropolitan area. However, there is a much lower difference in regard to current participation in

\footnotetext{
${ }^{5}$ These figures may represent a minor underestimation, since some dispersed houses of the pre-war refugee settlements that have not been demolished are not identifiable amidst the newer residential buildings. In any case, their identification would not alter significantly the whole picture.
} 


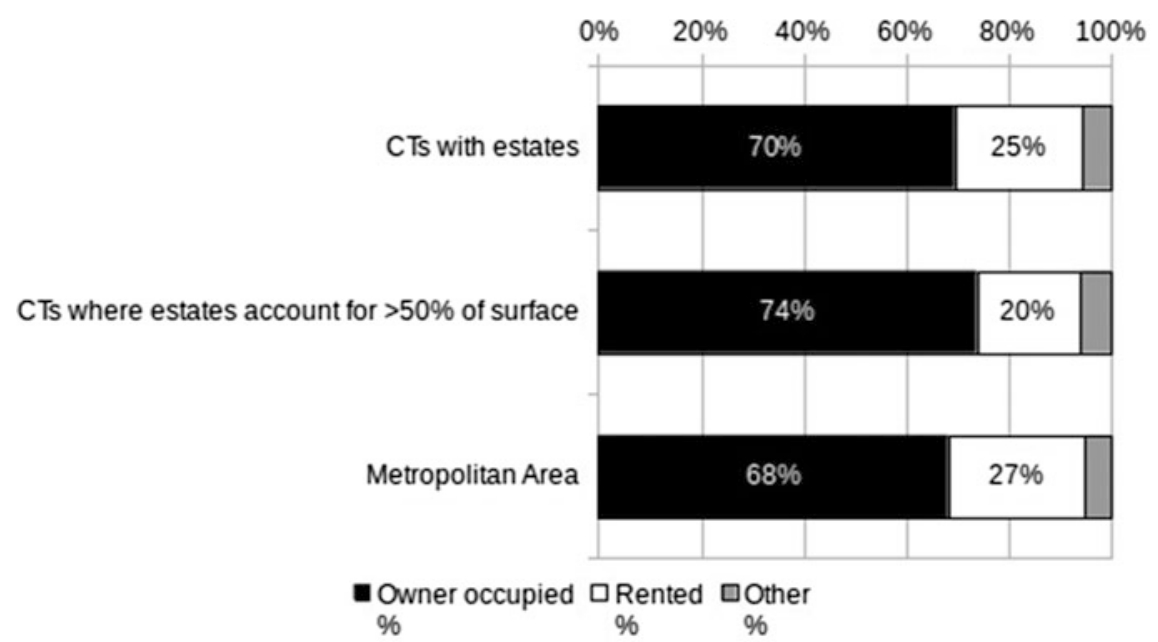

Fig. 4.6 Tenure structure in housing estate areas and Athens Metropolitan Area, 2011. Data Source Panorama of Greek Census Data

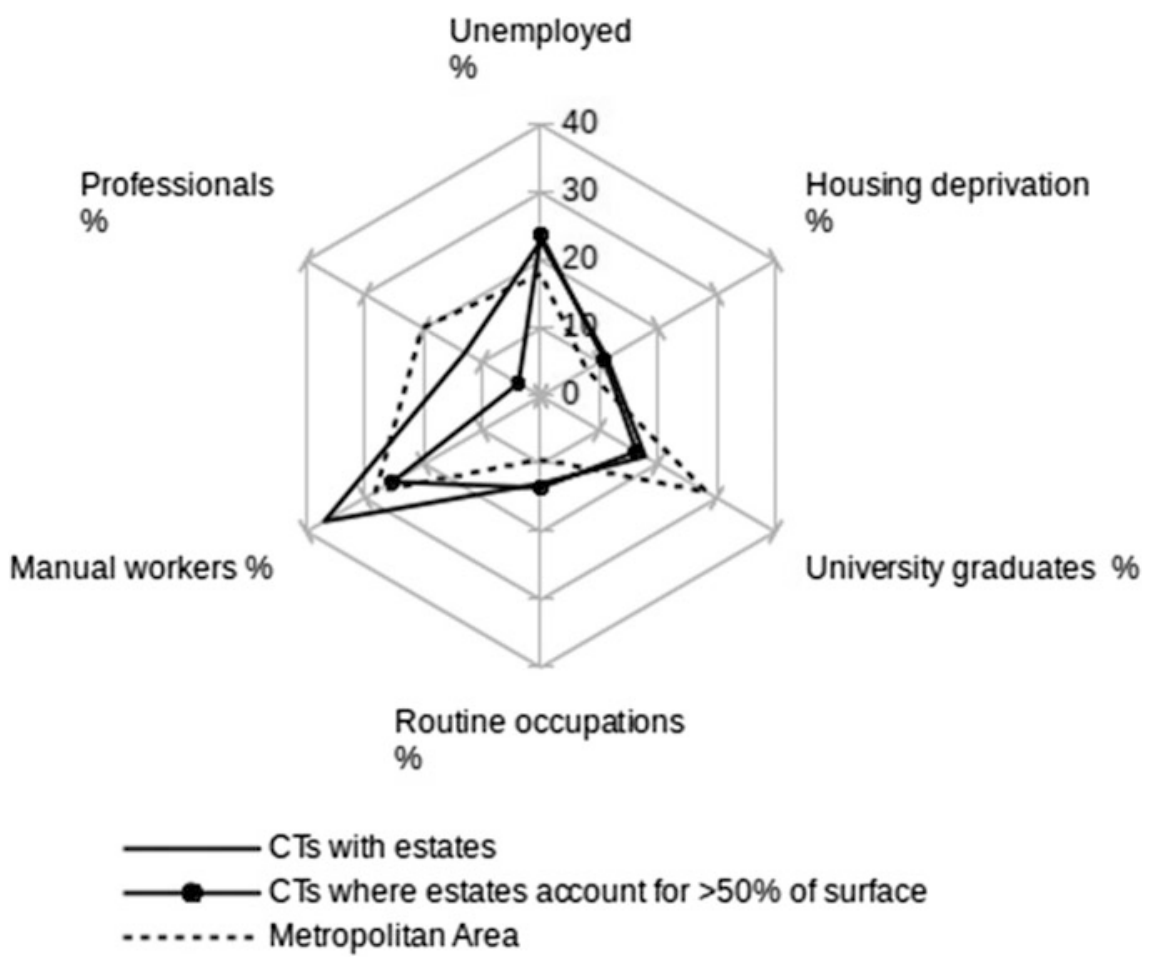

Fig. 4.7 Sociodemographic characteristics in areas containing housing estates, Athens Metropolitan Area, 2011. Data Source Panorama of Greek Census Data 
tertiary education: the proportion of adults in tertiary education was $4.2 \%$ in census tracts with estates and $4.7 \%$ in the whole metropolitan area, an indication that the older education disparity is not reproduced in recent times.

Another variable which expresses living conditions in a direct way is available housing space per capita. Residents in census tracts with estates live in dwellings with an average surface of 29.1 square metres per person, while the metropolitan average is somewhat higher at 32.4 square metres per person. Census tracts with estates also show higher rates of housing deprivation, defined as living in dwellings with less than 15 square metres per person: $11.3 \%$ of estates' residents live in such dwellings, while the respective proportion for the entire metropolitan area is $7.8 \%$. Since the average household size in census tracts with estates and in the entire metropolitan area is almost identical (2.53 members per household), these figures indicate slightly disadvantaged housing conditions in the former.

Interestingly enough, this landscape of differences seems to be quite stable over time. Figure 4.8 presents the comparative dynamics of some of the above sociodemographic variables. In general, census tracts with estates seem to follow the general trends of the metropolitan area between 1991 and 2011. As a consequence, both relative disparities, as in the cases of manual workers (ISCO-08 major groups 7-8-9), university graduates and housing deprivation, as well as similarities, as in the case of immigrants, tend to persist. The only exception is the unemployment rate, which increased slightly faster in census tracts with estates than in the metropolitan area between 2001 and 2011.

The comparison of census tracts comprising housing estates with their immediate surrounding residential areas (i.e. in adjacent census tracts not containing estates) generates a more complex picture at the microscale of the Athenian neighbourhood (Table 4.1). The unemployment rate and the proportion of routine occupations are generally higher, while the proportion of tertiary education graduates is lower in the estates than in their surrounding areas, even when the differences are quite small. In regard to immigration, except in older central city estates where some concentration is observed, the proportion of immigrants is generally very close or even lower in the estates in comparison to the surrounding areas. In some cases, this might indicate the existence of native working-class enclaves in the estates and in other cases the rather recent production of the estatee.g. the Olympiako Chorio settlement that was transferred to beneficiaries in the mid-2000s - which precludes high rates of mobility.

Moreover, this comparison illustrates the importance of the social profile of the broader areas in which estates are located. In the traditional working-class suburbs of western Athens and Piraeus, most housing estates present sociodemographic characteristics almost identical with those of their neighbouring areas. On the contrary, estates located in middle-class areas in the northern suburbs are socially much more distant from their surroundings, especially concerning occupational composition, the proportion of tertiary education and to a lesser extent unemployment rate. Older estates in the city centre also differ substantially from their surroundings, especially regarding access to tertiary education and the proportion of immigrants from less developed countries. 

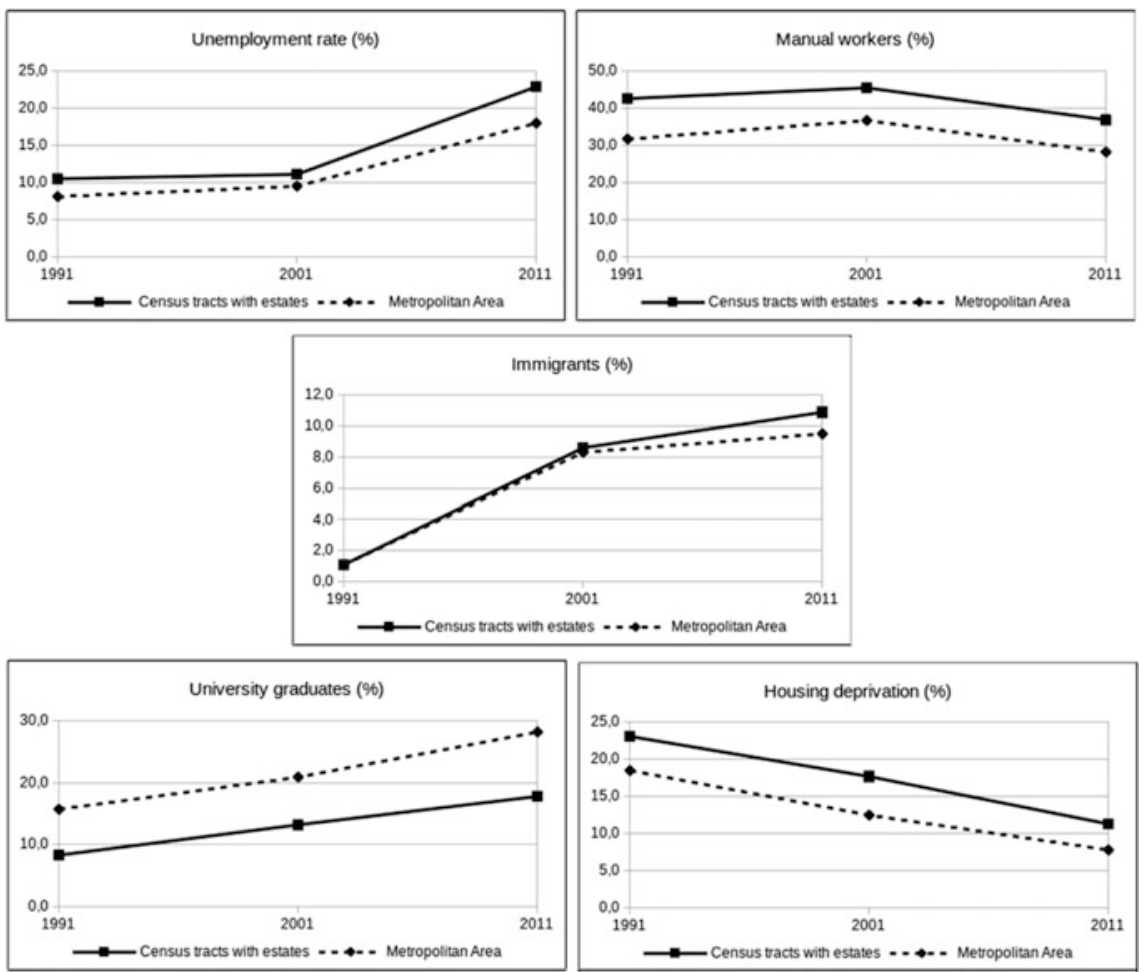

Fig. 4.8 Comparative evolution of census tracts with housing estates and the Athens Metropolitan Area. Data Source Panorama of Greek Census Data

\subsection{Ongoing Degradation and New Planning Initiatives}

There are two main parameters which affected the evolution of the socioeconomic and demographic profile of the housing estates of Athens. The first is that all the estates-regardless of the period they were produced-were destined for owner occupation and, thus, did not make much difference in the city's housing market and the social profile of the particular neighbourhoods where they were located since they followed the dominant housing mode. The second parameter is that the responsible public agencies were only involved during the production, allocation and repayment period. Taking into account that beneficiaries comprised exclusively low-means households, it was inevitable that housing estates started to deteriorate from day one due to the perpetual lack of resources for maintenance and upgrading. Moreover, housing estates were produced during an era of impressive population growth and of rapidly improving housing conditions. Therefore, living in housing estates seemed as a kind of entrapment to increasingly lower housing standards, especially for estates not adjacent to working-class areas. 


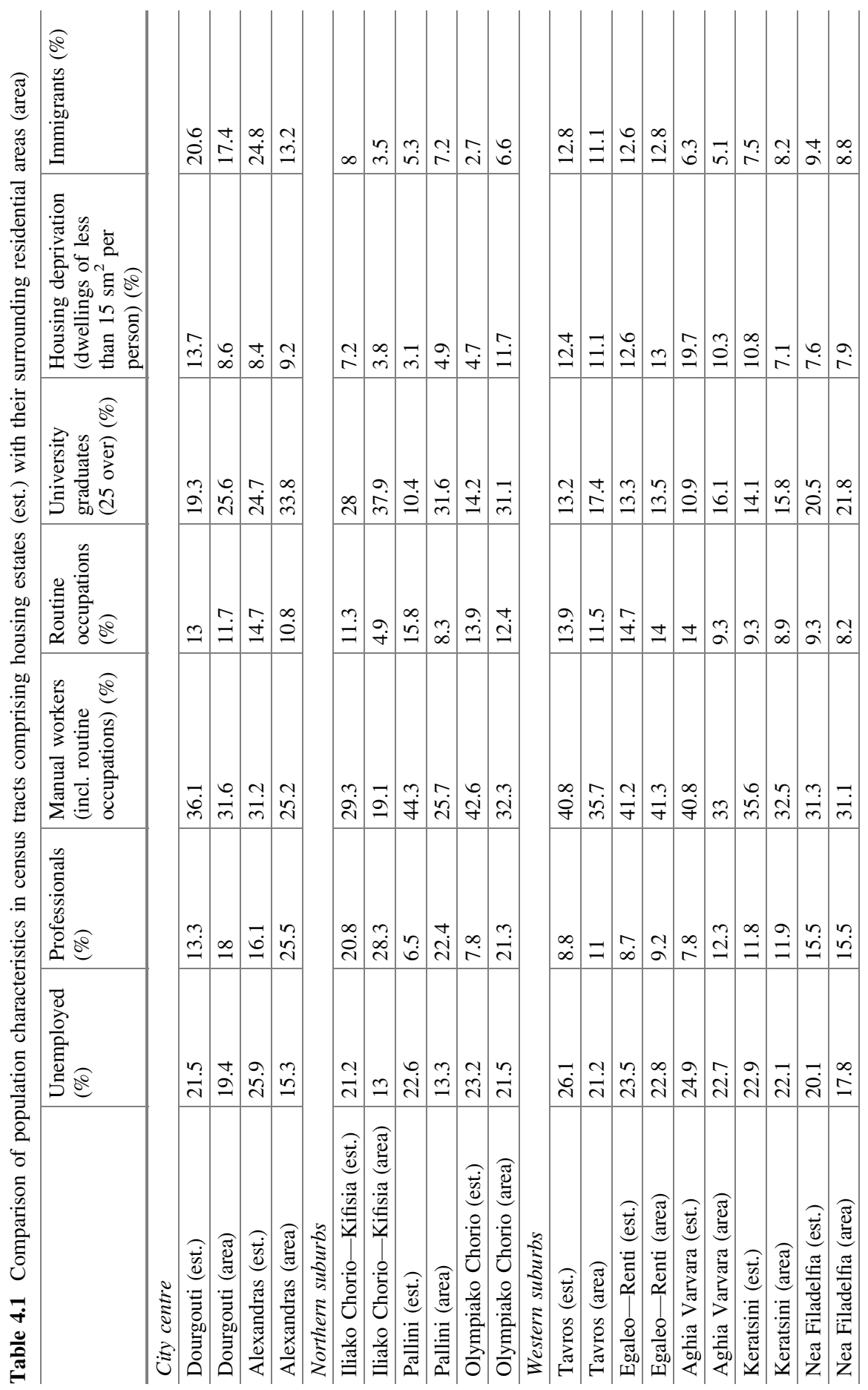


Properties in housing estates eventually followed the fate of the rest of the housing stock, since after they were repaid they became ordinary apartments. Shifting and sorting of the housing market relegated most estate properties to lower positions of this market's hierarchy, and processes of filtering-down deprived estates from a considerable part of the skilled working-class and salaried employees who were the main beneficiaries at the time they were produced.

New policies about old housing estates were rather scarce, since they constitute private properties where the state or local authorities have no greater vested interest than anywhere else. The link with the public sector is, therefore, mainly historical and symbolic, but it is true that residents of housing estates feel much more entitled to public assistance than others (Myofa forthcoming). Such new policies were mostly driven by cultural rather than social considerations-i.e. preserving the city's architectural patrimony - as were most of the planning interventions since the 1980s, including the regeneration of the old neighbourhood of Plaka and other areas near the city centre, like Gazi and Metaxourgheio (Alexandri 2013). Interventions related to housing estates were often ineffective, as in the case of the renewal project for the centrally located estate on Alexandras avenue (dating back to the 1930s), which never materialised (Fig. 4.2). Various regeneration plans were proposed, including the demolition of part of the estate that was opposed by the residents (Tzirtzilaki 2014). In 2009, the responsible state agency decided that the estate should be preserved because of its historical and architectural significance.

A completely different outcome resulted from the much more active and efficient intervention in Tavros. The estate was radically renovated by DEPOS - the planning and housing agency under the Ministry of Public Works - with the contribution of the Municipality of Tavros following the active agreement of current residents and former residents who left due to degradation. This estate comprised several groups of buildings from the 1930s and the 1950s, the first produced by the Ministry of Social Care for Asia Minor refugees and the second by the Ministry of Reconstruction, with a total of 140 dwellings (Papadopoulou and Sarigiannis 2006). The majority of them were about $25-30 \mathrm{~m}^{2}$, reflecting housing standards at the time they were built, and a smaller number of dwellings were bigger $\left(30-50 \mathrm{~m}^{2}\right)$, but the real situation was much worse according to Kostas Varelidis, former manager of the consortium DEPOS-Municipality of Tavros:

there was a kind of ghetto area (...) too degraded, a tragic situation. There were apartments of 50 sq.m. in which lived 10 people. (...) And the social status (of residents) was too low. Because those who had made money (...) had left and had gone elsewhere. (...) (interviewed by Myofa, 06/10/2015; Myofa forthcoming).

Over the years, initial owners were replaced by new residents (internal migrants mostly) who settled in as tenants or as new owners. New poor residents were generally unable to renovate their apartments. Moreover, several apartments remained closed or abandoned because their owners were unable to rent or sell them. According to Aristidis Romanos, former director of the design and research department of DEPOS, the regeneration 
was an initiative of a group of apartment owners (...) who, through the Mayor of the Municipality, came to DEPOS and said, "here is an issue, what can you do since you are the public agency of planning and housing?" (...) The Mayor became the intermediate between the public agency and the citizens (interviewed by Myofa, 21/10/2015; Myofa forthcoming).

These managing practitioners of DEPOS were wholeheartedly involved in the project. Varelidis discusses 'complete participatory planning' and Romanos believes that the contribution of DEPOS was much less architectural than social. Moreover, a great effort was deployed in order to provide housing space according to effective needs in the new estate, even if the supplementary space in many cases had to be provided below the construction cost (Myofa forthcoming).

However, this was an exceptional case. Most estates have never been renovated since they were first built, in spite of the effort of DEPOS to use the positive experience from Tavros in other cases. In Dourgouti, for example, the old stock of public estate building consisting of eight condominiums was constructed during the 1930s for Asia Minor refugees. These buildings followed a similar degradation process and their population increasingly comprised new poorer households as the position of the estate in the city's residential hierarchy deteriorated. However, there are still many descendants of Asia Minor refugees - sometimes fourth generationwho reside in the old building stock for practical (proximity to the city centre), as well as sentimental reasons. It is mainly these old residents who resist regeneration projects for the old estates. They believe that due to the country's financial situation and the lack of social policy, the compensation they could get from expropriation would be very small, while they would lose the economic security that homeownership provides. Eventually, DEPOS was abolished in 2010, 2 years before the Workers' Housing Organization was also terminated.

\subsection{Conclusion: Current Challenges for Housing Estates}

The first thing about housing estates in Athens is that they no longer represent a particular challenge for public policies at the metropolitan level, if they ever did. They are a small part of the city's broader housing stock to which they were integrated a long time ago in terms of property relations, while the agencies that produced them have either been abolished or are no longer responsible for their fate. However, estates experience a number of particular problems that should be addressed by public policies, since they appear to follow a trajectory of perpetual decline. The main problem leading to this decline is the inability of their residentsusually owner-occupiers - to maintain and upgrade the private and collective spaces of the estates.

At the same time, there is a much broader challenge than existing housing estates: it is the absence of housing solutions for social groups most in need, to which the currently existing housing estates and the policy that produced them were never an adequate response both in quantitative and qualitative terms. In terms of 
quantity, housing estates have a capacity of about 60,000 inhabitants in a city with a population of 4 million. In terms of quality, the production of housing estates in Athens has primarily been related to facing exceptional situations and events - from the refugee crisis of the 1920s to the Olympic Games of 2004-rather than to cater in a systematic way for the housing needs of the part of society which persistently does not have access to decent housing. Moreover, this production aimed exclusively at promoting homeownership and, therefore, targeted households with a level and security of income that made them reliable for repaying the subsidised loan they obtained to become apartment owners in the housing estates.

It may sound paradoxical that with such a small and ill-targeted provision of public housing in a rather poor European country, there was no major housing crisis since the end of World War II. This is even more paradoxical for Athens, whose population almost tripled since that date and housing needs escalated at least until the 1980s with the settlement of internal migrants, and again in the 1990s and 2000s with the important inflow of immigrants from poorer countries. The absence of housing crisis, as well as of social movements related to housing (Siatitsa 2014), can only be understood in the South European context of residual welfare states, where public assistance in terms of various social services was different from their form in the classic West or North European welfare states, while other institutions - and primarily the family_-worked as a substitute for their organization and provision (Allen et al. 2004). The state has not been absent in the social reproduction process in this region. Regarding housing, in particular, it has not been particularly involved in direct housing provision but followed policies that indirectly lowered substantially the cost of access to homeownership and made it effectively more affordable to much broader social strata than in the rest of Europe (Arbaci 2018).

The real challenge is that the ineffectiveness of the South European residual welfare model has become more pronounced in Greece in a period of severe economic austerity, recession, mass unemployment and precaritisation. The traditional ways for lower status social groups to access homeownership-i.e. self-promotion and self-construction - are no longer an option and working-class as well as lower middle-class groups are limited to defensive strategies for managing the properties they already have. New property-less groups have been increasingly present with increased difficulty to emulate the local dominant housing model in a period when access to homeownership becomes increasingly unequal in terms of class. Homelessness - which was marginal during the post-war period-has been rising (Arapoglou and Gounis 2018) and the most deprived groups-usually combining the lowest category in the occupational hierarchy (routine occupations) with an ethnic identity related to subaltern social positions - have been relegated to the worst part of the private rented sector. As a result, the latter have been experiencing acute housing issues — enhanced by the effect of the sovereign debt crisis which increased unemployment and poverty and by the new refugee crisis from Syria, Afghanistan and Pakistan - and are increasingly concentrated in particular neighbourhoods in the city centre and part of the periphery, creating potentially new spaces of segregation. 
On the other hand, important resources remain untapped, especially the very large number of vacant houses which, partly at least, are situated in areas where needs are the most pressing (Maloutas and Spyrellis 2016). For the time being, these broader housing issues are not tackled by the relevant central or local administrations, which have no know-how and tradition in housing and area-based policies. On the contrary, regressive steps were taken with the abolition of the few available institutional resources following the imposed reduction of resources for social services. Under these circumstances, the problems of existing housing estates may appear as a small glitch on the screen. However, new policy tools that would allow for the improvement of the deteriorating housing stock and the expansion of housing opportunities for those facing risks of housing deprivation seem to be matters of urgent priority in the immediate future.

\section{References}

Acharnes (2017). http://www.acharnes.gr/ContentFiles/54/Images/olymhor1.jpg

Alexandri G (2013) Spatial and social transformations in the city centre of Athens: the case of Metaksourgheio. Harokopio University of Athens, Athens

Allen J, Barlow J, Leal J, Maloutas T, Padovani L (2004) Housing and welfare in Southern Europe. Blackwell, Oxford

Antonopoulou S (1990) The post-war transformation of the greek economy and the residential phenomenon. Papazisis, Athens

Arapoglou V, Gounis K (2018) Contested landscapes of poverty and homelessness in Southern Europe: reflexions from Athens. Palgrave-Macmillan, London

Arbaci S (2018) Paradoxes of segregation: urban migration in Europe. Blackwell, Oxford

Doxiadis K (1947) Sacrifices of Greece, claims and reimbursements in WWII. Ministry of Reconstruction, Athens

Filippidis D (1984) New Greek architecture. Melissa, Athens

Gouvousi SI (2011) Organized housing compounds in Greece: possibilities and regeneration prospects for the settlements of OEK. Aristotle University of Thessaloniki, Athens

Guizeli V (1980) Transformations sociales et origines du logement social en Grèce 1920-1930. Thèse de Doctorat en Sciences Sociales, École des Hautes Études en Sciences Sociales

Katsikas E (2000) Social content and economic consequences of antiparochi. Greek Rev Soc Res 103:3-26

Kyriazi-Alisson E (1998) Internal migration in Greece in the 1990s: Trends, challenges, prospects. Greek Rev Soc Res 96-97:279-309

Leontidou L (1989) Cities of silence. ETBA Cult Foundat, Athens

Leontidou L (1990) The mediterranean city in transition: social change and urban development. Cambridge University Press, Cambridge

Leontidou L (2017) Slums of hope. In: Maloutas T, Spyrellis S (eds) Athens Social Atlas. Digital compendium of texts and visual material. Athens

Maloutas T, Spyrellis S (2016) Vacant houses. In: Maloutas T, Spyrellis S (eds) Athens social atlas. Digital compendium of texts and visual material

Myofa N (forthcoming) Social housing in Athens. Study of the refugee set-tlements in Dourgouti and Tavros since 1922. Harokopio University of Athens, Athens

Panorama of Greek census data. https://panorama.statistics.gr/en/

Papadopoulou E, Sarigiannis Y (2006) Summary report about refugee areas in the basin of Athens Papaioannou I, Vasilikioti E (1975) Housing in Greece. Technical Chamber of Greece, Athens 
Saliveros D (1961) Social investigation report on the neighbourhood of asyrmatos. Confidential report, Athens

Siatitsa D (2014) Claims for the 'right to housing' in the cities of Southern Europe: the discourse and the role of social movements. National Technical University of Athens, Athens

Stavridis S, Koutrolikou P, Vatavali F, Kopanari M, Marathou C, Cizeli V (2009) Transformations of the relationship between public and private space in the public housing compounds in the Greek cities. Report for the Basic Research Subsidization Program. National Technical University of Athens

Tzirtzilaki E (2014) Refugee tenement houses in Alexandras: a lively squat in emergency

Vasiliou I (1944) Popular housing. Athens

Open Access This chapter is licensed under the terms of the Creative Commons Attribution 4.0 International License (http://creativecommons.org/licenses/by/4.0/), which permits use, sharing, adaptation, distribution and reproduction in any medium or format, as long as you give appropriate credit to the original author(s) and the source, provide a link to the Creative Commons license and indicate if changes were made.

The images or other third party material in this chapter are included in the chapter's Creative Commons license, unless indicated otherwise in a credit line to the material. If material is not included in the chapter's Creative Commons license and your intended use is not permitted by statutory regulation or exceeds the permitted use, you will need to obtain permission directly from the copyright holder. 


\title{
Chapter 5 \\ Large Housing Estates of Berlin, Germany
}

\author{
Florian Urban
}

\begin{abstract}
Large estates of towers and slabs can be found all over the German capital, and the differences between those which, before 1990, were situated on different sides of the Berlin Wall are often hard to tell for the layperson. They stand witness to the dream of modern living and acceptable housing conditions for the whole population, which in the decades after World War II inspired the socialist regime in the East in the same way as the welfare state in the West. In terms of political background and social significance, however, the Plattenbauten (slab buildings) in the East were rather distinct from the Wohnblöcke (dwelling blocks) in the West. Not only were those in the East far more frequent - in 1990 about one-third of East Berliners called a large housing estate their home, compared to about only $5 \%$ of West Berliners - they also constituted an environment that was closely aligned to the East German regime's sociopolitical goals. This chapter summarises the history of large housing estates in both East and West Berlin, pointing out commonalities and differences that determine significance and perception of these buildings to date.
\end{abstract}

Keywords Berlin urban design - Tower blocks • Modern architecture Mass housing

Berlin's large housing estates, like those all over Europe, were the outcome of a great hope. Along with rapid modernisation in the mid-twentieth century, there was a widespread conviction that the dreadful housing conditions of the early industrial era could be overcome, and the divide between the life standards of the rich and the poor narrowed. A strong state was believed to be capable of carrying out this epochal task: providing modern amenities for everybody and ending substandard living and overcrowding.

In this respect, estates built under socialism in East Berlin and under capitalism in West Berlin share many commonalities, despite the political differences of their

F. Urban ( ()

Glasgow School of Art, Glasgow, UK

e-mail: f.urban@gsa.ac.uk

(C) The Author(s) 2018

D. B. Hess et al. (eds.), Housing Estates in Europe, The Urban Book Series, https://doi.org/10.1007/978-3-319-92813-5_5 
respective regimes during the division (1949-1990) and particularly during the times of the Berlin Wall (1961-1989). Both were the outcome of planning efforts since the late 1950s. The largest estates in West Berlin were the Märkisches Viertel (1963-1975, planned by Hans Müller, Georg Heinrichs and others, c. 40,000 inhabitants in 2016) on the northern periphery, Gropiusstadt (1962-1975, designed by Walter Gropius, Wils Ebert and others, c. 35,000 inhabitants in 2016) on the southern and Falkenhagener Feld (begun 1962, planned by Hans Stefan, c. 37,000 inhabitants in 2016) on the western fringe were mostly built in the 1960s. Also, in the East the first large estates were built in the 1960s; for example, the Hans-Loch-Viertel in the Treptow district (begun 1961, designed by Werner Dutschke). The largest estates, however, went up in the 1970s and 1980s: Marzahn (started in 1977), Hellersdorf (started in 1981) and Hohenschönhausen (started in 1984). The three districts together had approximately 350,000 inhabitants in 2001 when the district borders were redrawn.

The time lapse can be explained by shifting political priorities. Walter Ulbricht, East Germany's top leader from 1949 to 1971, mostly focused on representative construction in the city centre. In contrast, his successor Erich Honecker, who ruled from 1971 to 1989, poured significant resources into housing. In both East and West Berlin, large housing estates came under criticism starting in the late 1960s. But while the socialist leaders in the East were less responsive and carried out only small corrections in their construction policy, the West Berlin government, following increasingly negative media coverage, largely discontinued construction of large estates in the mid-1970s. Dwelling in large estates thus became far more frequent in the East. While in 1989 only about $5 \%$ of the 2.2 million West Berliners were residents of a large estate, the aforementioned three large schemes in the East housed close to one-third of East Berlin's 1.2 million inhabitants (Gudermann 1999, p. 162).

The difference between East and West Berliners' experiences is also reflected in the terminology. While the West German Großsiedlung (large estate) is a more or less neutral description, the East German die Platte ('the slab') is a loaded term that merges several meanings. It can denote a constructive element from which the blocks were built (the prefabricated concrete slab), the building (the slab block), as well as by extension the entire estate. To date, die Platte evokes memories of the socialist lifestyle connected with bleakness, shoddy workmanship and forced collectivism, but also with modernisation and social equity. On both sides of the Berlin Wall the large housing estates were pragmatically accepted rather than loved, but in the East, there was a strong narrative that connected them to what many East Berliners would sorely miss after the German reunification: low rents, the absence of unemployment and a narrow gap between rich and poor.

Both East and West Berlin's large estates started out as legitimate heirs of the much-celebrated Siedlungen (housing estates) of the 1920s with their innovative design and technology. These include the Horseshoe Development (1925-1931, designed by Martin Wagner and Bruno Taut), Siedlung Schillerpark (1924-1930, designed by Bruno Taut) and the White City (1929-1931, designed by Martin Wagner and Otto Salvisberg), which are composed of high-quality 3-4 storey 
walk-ups, and which in 2009 were declared UNESCO world heritage sites. Being comparatively few, the interwar housing estates only improved the quality of life for a small minority, but set the stage for a new architecture of standardised design. Berliners were also lured towards modernist dwelling through the showcase buildings of the early post-war period. Most famously was the 'building exhibit' Interbau in the West Berlin Hansaviertel (1954-1957). Generously subsidised by the West Berlin government, internationally renowned architects such as Alvar Aalto, Arne Jacobsen and Walter Gropius were invited to design their visions for multistorey buildings in a park-like landscape. Few later estates lived up to their precedents in terms of design and technological quality. However, most of them initially were widely celebrated.

The following sections provide an overview of this new architecture. They lay out the historical and sociopolitical background of Berlin's large housing estates and introduce the main debates connected with these buildings, as evidenced in the case of the Märkisches Viertel and Marzahn. Evidence of changes in the population composition will be given. The chapter concludes with an assessment of the significance of large housing estates in the post-reunification era in Berlin, characterised by relatively high population stability, on the one hand, but signs of social polarisation on the other hand.

\subsection{The Formation of Large Housing Estates in Berlin}

During the post-war decades, both German states built on pre-war experiences to tackle the housing crisis. In the West, most multifamily buildings - both small and large estates - were built by state-sponsored institutions. Builders and operators of these estates were so-called gemeinnützige Wohnungsbaugesellschaften (roughly translating to 'non-profit housing associations'). They were owned by municipalities or sometimes other public bodies such as trade unions, and they were favoured by subsidies and tax breaks and had a legal remit to provide affordable housing. Best known were GEHAG, which built the Horseshoe Development in the 1920s and portions of Falkenhagener Feld in the 1960s, GESOBAU, which built the Märkisches Viertel, and DEGEWO, which contributed to the construction of Gropiusstadt and which is still the largest single owner of rental housing in Berlin.

Non-profit housing associations were set up in the early twentieth century and engaged in the construction of different forms of housing - not only large estates. In the decades after World War II, they were tightly connected to West Berlin's governing Social Democratic Party. Nonetheless, they were not departments of the local authority (as, for example, Vienna's communal house builders), and they also did not merely act as trustees for the local authority (as they did in other West German cities or in the Netherlands). Their close ties with the politicians who were also their clients were much criticised from the late 1960s onwards, as was the fact that they profited from large commissions and mostly carried out schemes based on nineteenth-century tenement demolition and forced relocation (Bodenschatz 1987, pp. 174-177). 
West Germany's and West Berlin's interventionist housing policy, which funnelled large amounts of public funding into housing, was set up in the early 1950s, and at the time approved by both conservatives and Social Democrats. When World War II ended, most large cities were heavily damaged or destroyed. At the time Germany was a country of refugees: approximately 12 million ethnic Germans had fled from the eastern provinces of Silesia, Pomerania and East Prussia, which Germany had to cede to Poland and the Soviet Union, as well as from Czechoslovakia, Hungary and Yugoslavia. More than 8 million ended up in West Germany, a country of 50 million at the time. Here, they were soon joined by another wave of refugees from East Germany. Camps or emergency shelters became home to millions throughout the 1950s and 1960s.

Against this background, all political parties perceived the housing shortage as the most pressing problem of the time and supported state investment into housing and strong regulation of the market. After all, suffering from the scarcity of housing was not class-specific. Members of all social groups had lost their homes in the bombings, and also the fate of becoming a refugee was shared by the East Prussian aristocracy as much as by the Silesian peasants and coal miners.

Accordingly, social housing did not necessarily mean working class accommodation. In the early post-war years, the group eligible for social housing was approximately $70 \%$ of the population. This reflected the desolate state of the war-ravaged country, but at the same time meant that the receipt of state benefits was no embarrassment for anyone. Although the economic situation improved over the course of the 1950s, the institutional culture of social housing had been firmly established and was to remain for decades to come (Wagner 1995, pp. 2, 8-12). To date, living in social housing is not a stigma in Germany to the extent that it is in Britain or the United States.

In fact, in the whole of Germany, a free housing market had been non-existent since World War I. During the unstable Weimar Republic the authorities imposed numerous restrictions in favour of tenants. The Nazi regime after 1933 upheld and partially reinforced these regulations, effectively replacing the free rental market with a system of apartment distribution through municipal institutions (Führer 1995, pp. 77-108). Hence, in the early post-war years not only in the socialist East but also in the capitalist West there was no free housing market. Only by 1951, when West Germany passed its Wohnraumbewirtschaftungsgesetz. (Law on the Management of Dwelling Space), did houses and apartments cease to be distributed exclusively by state authorities. Numerous regulations nonetheless remained in place, and only in 1988, when West Berlin was the last city in West Germany to abolish comprehensive rent regulation, one could more or less speak of a free housing market. In East Berlin, a similar introduction of market principles would happen after the German reunification in 1990.

Somewhat in contrast to this apparent interventionism, the status of social housing in West Germany and West Berlin was less stable than for example in Austria, since it was always temporary rather than permanent. 'Social housing', which meant rent control and restricted tenant allocation, was a status assigned to particular units, and it expired after a certain time, usually 20-40 years until the 
subsidies were amortised. After that, the units could be sold or rented out at market rate. This arrangement has led to a substantial decrease in social housing units since the 1980s, as most support programmes have been discontinued. However, given Germany's comparatively tenant-friendly legislation, some units for which the official status has expired have retained some of the characteristics of social housing: they are affordable and tenants are protected against eviction.

West Berlin's large estates reflected the new urban planning paradigm Urbanität durch Dichte (urbanity-through-density), which around 1960 was promoted by the planner Edgar Salin and the sociologist Hans Paul Bahrdt (Salin 1960; Bahrdt 1961). It replaced the 1950s model of small and low-rise schemes that were referred to as the 'structured and dispersed city' (Göderitz et al. 1957).

Märkisches Viertel, Gropiusstadt and Falkenhagener Feld all aimed at urbanity in this sense, containing densely built 6-20 storey blocks for several tens of thousands of inhabitants. They were modelled after the principles of the Athens Charter such as functional separation, separation of traffic flows and predominance of light and air. They were situated on the periphery, fitted with ample car infrastructure, but reasonably well connected to the city centre through public transit. They were generally planned in conjunction with communal facilities such as schools, kindergartens, shops and sports centres.

These estates were built using prefab technologies and serial construction. However, given the greater variety of clients and builders, the degree of standardisation was never as comprehensive as in the East. Planning and construction also did not become centralised. In the West traditional methods of construction were never completely abandoned, and industrialised construction remained one among many ways of building.

\subsection{The Formation of Large Housing Estates in East Berlin}

In East Germany, the paradigm change towards large estates was far more comprehensive. Following the model promoted by Nikita Khrushchev in the Soviet Union, the 'industrialisation of the construction industry' was decided at the first Building Conference in East Berlin in 1955 and carried out between 1963 and 1968 (Flierl 1998 pp. 56, 62). During that time, small firms were gradually replaced by Kombinate - integrated state-owned companies. They stood under tight control of the central government. Being the designers and builders of nearly all East German housing, they focused on standardisation through the use of prefabricated concrete slabs, and increasingly engaged in the construction of large estates.

The first developments started by these firms were built in cities other than East Berlin, such as Hoyerswerda (begun 1957 for 50,000 inhabitants) or Halle-Neustadt, the largest slab estate in East Germany (begun 1964 for 100,000 inhabitants). Particularly the latter corresponded to the 'urbanity-through-density' principle, which also in the German Democratic Republic would soon replace the 
loosely scattered low-rise estates of the 1950s, and which would provide the matrix for urbanisation of East Berlin's eastern periphery.

East Berlin's housing estates went up in the 1970s under Erich Honecker, who had become Head of State in 1971. In 1973, he launched his famous Housing Program, which promised the construction of approximately three million new dwelling units in a country of just 17 million inhabitants (Junker 1973). Approximately, two million were actually built (Schröder 1998, p. 283; Palutzki 2000, pp. 113-120). The programme had a massive impact. It made 'the slab' the standard dwelling experience for the majority of the urban population, and prefab construction the next-to-exclusive way of building. During that time, the large estate became the most conspicuous urban form in East Germany, and particularly in East Berlin with the construction of Marzahn, Hellersdorf and Hohenschönhausen.

\subsection{A Nation of Tenants}

Both East and West Berlin's large estates were based on an ideology of state-driven modernisation, which at the time was shared by many countries in both the Eastern and Western blocs. West Berlin, in this context, was probably the most socialist city in the western hemisphere with regard to strong regulation and the virtual absence of powerful private players.

The general acceptance of state intervention over matters of housing was also related to the fact that Germany had developed a strong tenant culture (Urban 2015a). Homeownership was restricted by the fact that between 1900 and 1951 (in East Germany until 1990) German legislation outlawed ownership of individual apartments - a measure that was originally meant to diminish lawsuits between neighbours (Bürgerliches Gesetzbuch 1903, pp. 93-94; Bundesgesetzblatt 1951, p. 175). During a period when individually owned urban abodes became rapidly popular in the Anglo-Saxon world, German city dwellers could rarely own their flats. With the exception of the very wealthy, who possessed entire buildings, urbanites tended to be tenants. This included large portions of the middle and upper middle classes. In West Germany and West Berlin, over the course of the post-war decades, the number of flat owners increased, but never reached the level of countries such as Britain. In East Germany and East Berlin, all units in multifamily buildings were rentals by default, administered by municipal institutions. A move towards owner-occupation, which was, for example, promoted in the Soviet Union in the 1980s, never happened in East Germany.

In the early twenty-first century, $85 \%$ of Berlin households still rent their apartments - in London, the rate is less than 50\% (Infas Geodaten 2011; National Housing Foundation Homeownership data for Britain 2014). For the whole country, the homeownership rate is only $45 \%$ of households. This is one of the lowest rates in Europe, compared, for example, to approximately $70 \%$ in the UK (2007 data in Norris and Winston 2011). Since powerful middle-class groups have been tenants 
for generations, they not only advanced the acceptance of tenancy as a way of life but also contribute to the promotion of tenant-friendly legislation. Despite some erosion from the 1980s onwards, these laws are still largely in place. Tenants frequently stay for decades in the same flat. Unless the owner needs the flat for him or herself, it is next to impossible for them to evict their tenant against their will. This has far-reaching consequences on the housing market, which is generally more stable than, for example, in Britain or the US. Compared to these countries, both tenants and owners in Germany move far less frequently. Processes of gentrification or residualisation of entire neighbourhoods are therefore significantly slower (Urban 2015a, pp. 91-94).

\subsection{The Märkisches Viertel Estate in West Berlin}

West Berlin's largest housing estate, the Märkisches Viertel, was typical for modernist compounds erected in the 1960s. It was planned as a self-sufficient neighbourhood unit, based on the principles promoted by pre-war theorists such as Clarence Perry, Moisei Ginzburg, or Le Corbusier. It was planned by 'experts' imbued with a belief in progress and modernisation, and aimed to meet the 'scientifically' calculated needs of a defined population. These included facilities for all basic features of life, including shops, kindergartens, schools, playgrounds, youth clubs, football pitches, ice rinks, post offices and nursing homes. The Märkisches Viertel was thus designed to be part and parcel of a paternalistic welfare state that provided for its citizens and offered housing in the context of public services. This approach made it rather similar to the estates east of the Berlin Wall.

The Märkisches Viertel was built 1963-1974 on West Berlin's northern periphery. It comprised more than 17,000 apartments in tower blocks with ten to fourteen stories. Originally, it was planned for 50,000 inhabitants. In the early twenty-first century, it housed about 38,000. The architects, Georg Heinrichs, Werner Düttmann, Oswald Mathias Ungers, René Gagès and others, belonged to the architectural elite of the time, and there is no evidence that they were not satisfied with their design. One of them, the Chinese architect Chen-Kuen Lee (1915-2003), even spent his old age in one of the tower block flats he designed (Strauss 2003). Born in Shanghai, he moved to Germany as a teenager in 1931, later worked for Hans Scharoun, and in the 1950s designed his famous 'organic' single-family houses (Kählert 2012). The Frenchman Gagès (1921-2008) established his fame with the tower blocks in Lyon-Bron-Parilly, which he built in the late 1950s (Allix 2008). Ungers (1926-2007), one of Germany's most famous twentieth-century architects, at the time was the dean of the Faculty of Architecture at Berlin Technical University, and well known beyond the German borders.

The architectural ambitions were thus high. Ironically, the architects had consciously attempted to avoid some of the key features they were later blamed for, in particular the bleakness and monotony that was characteristic of so many functionalist estates. They rejected continuous rows of houses and repetitive building 
types. They separated car and pedestrian traffic, but unlike other planned neighbourhoods at the time they put a strong focus on public transit. They planned different forms of greenery to avoid the appearance of an asphalt jungle. And they took great pains in designing youth clubs, playgrounds and public squares to foster community life.

The planners dedicated large spaces to parks and artificial bodies of water, such as the lake Segelluchbecken, which were easy to build in the flat and boggy Berlin region. Spaces enclosed by buildings were designed as gardens - examples include blocks by Shadrach Wood, Oswald Mathias Ungers and Georg Heinrichs. The 'extended backyards', where the inhabitants were unaffected by traffic, were aimed to provide leisure spaces for both children and adults.

Colourful façades designs and unusual plans aimed to be a contrast to the 'monotony' of Berlin's late-nineteenth-century tenements, where most inhabitants had lived before. Conspicuous examples include Karl Fleig's multicoloured Papageiensiedlung (Parrot Scheme), or the semicircular or jagged plans of Karl Schudnagies' blocks.

The modernist desire for increased light and air was met not only by scattered blocks and greenery but also by many balconies. Building plans showed a high degree of awareness of the location. René Gagès' large block-later nicknamed Der lange Jammer (The Long Lament) for its alleged monotony-took advantage of a strict north-south division to afford the inhabitants cool, north-facing kitchens and sunny, south-facing living rooms with balconies. Ungers' point blocks, unspectacular with regard to appearance, were nonetheless built on well-thought-out plans that gave all rooms sufficient daylight while at the same time sheltering balconies from neighbour's views. If any of the criticism at an architectural level was justified, it was about shabby workmanship related to the aim of building cheap and fast.

The fact that the designers attempted to improve functionalist planning was not lost on the contemporaneous reviewers. A journalist celebrated the 'rejection of the modernist dormitory town' while another one commended the use of 'felicitous stylistic devices from pre-war architecture', such as rounded corners and corner windows, which 'mitigate the dictatorship of the right angle, one of the characteristic evils of postwar architecture' (Presse und Informationsamt des Landes Berlin 1971, p. 53). Observers also commended a meaningful overall composition in which different architectural volumes are combined to form a harmonic built landscape. Descriptions such as 'plastic strength' (Schulz 1968) echo the numerous studies of city image and city perception that followed the publication of Kevin Lynch's classic 'The Image of the City' (Lynch 1960). The book was translated into German in 1968 and reflected growing concerns with the idea of the city as a meaningful and readable environment.

Widespread acceptance of state intervention and tenant culture, as well as the architects' efforts, did not spare West Berlin's large estates from a rapidly declining reputation in the late 1960s (Urban 2015b). The fact, however, that the Märkisches Viertel became a scapegoat for the shortcomings of the German construction industry, was largely coincidental. The other two large West Berlin estates, Falkenhagener Feld and Gropiusstadt, suffered from an equally bad image, but 
received far less media attention. The same applied to many similar developments all over West Germany.

Few people would have anticipated a sudden fall from grace. In the first years after construction began, the Märkisches Viertel appeared to be a straightforward success. A journalist in 1966 praised the towers and slabs as forming an 'expressive composition' that embodies a 'will to art' and a 'sensible and not only mechanistic spatial order'; she even went as far as comparing the 'post-office overpass' that stretched across the main road Wilhelmsruher Damm to the 'great urban design tradition' of the Brandenburg Gate (Teut 1966, p. 13). Another writer called the new neighbourhood 'a hope for designers in many European countries' (BZ 1967). Only a few years later, things looked very different. Now, the same neighbourhood was censured as 'monotonous', 'sterile', a 'depressing mass of monotonous slabs' and a 'realisation of a dismal science-fiction movie' (Wilde 1989, p. 127).

The abrupt swing in public opinion started with a celebration. On the fifth Bauwochen (Building Fair) in 1968, the West Berlin government was determined to show the successes of its urban renewal programme, which had started 5 years before. The organisers decided to complement the official programme with an exhibit by architecture students titled 'Diagnosis on the construction in West Berlin', which was subsidised with the considerable amount of 18,000 deutschmarks (equalling approximately 15 years of rent payments for a two-bedroom tenement flat at the time). In return, the local establishment of architects, planners and politicians received caustic criticism (Aktion 507 1968; Schröder 1998). The rebellious students tainted the Märkisches Viertel as a textbook example of modernist hubris that entailed both ugly architecture and bad planning, and accused the local government, in alliance with housing associations and architects, of exerting totalitarian rule over the built environment.

In an atmosphere stirred by student protests across the globe, the polemic spread like wildfire. West Germany's most eminent news magazine Der Spiegel took up the cue and a few weeks later published a six-page article, in which it condemned the Märkisches Viertel as 'the bleakest product of concrete architecture' and a 'grey hell' (Der Spiegel 1968). Five months later Der Spiegel followed up with a cover story that included quotes of frustrated inhabitants: 'I feel like I'm in a prison camp', 'I will die in this monotony' and 'Every night when I come home I curse the day we moved into these barracks' (Der Spiegel 1969). Other papers and magazines followed suit. Within a few months, the Märkisches Viertel became infamous throughout West Germany as the place where, according to the reports, 'already four-year olds are condemned to spend their future lives as unskilled labourers' and 'housewives, apparently for no reason, become alcoholics' (Wilde 1989, p. 127).

The frontlines of the debate were particularly noteworthy. The battle, to a large extent, took place between different factions of the left and not between leftists and conservatives. The students, who in the name of the working classes demanded citizen participation and the end of expert planning, first and foremost opposed the Social Democratic local authority and their allies in architecture and construction. That is, they fought precisely those societal forces that had set off to improve the housing situation of the most disadvantaged. They were supported by leftist 
housing activists as well as by bourgeois traditionalists. A prominent representative of the latter was publisher Wolf Jobst Siedler (1926-2013), who vociferously decried West Berlin's urban renewal programme as 'murdering the city'-not only promoting what he deemed bad modernist design but at the same time sponsoring the demolition of beautiful nineteenth-century residences (Siedler and Niggemeyer 1964). Calls for market liberalisation and a retreat of the welfare state, which would dominate the debate a generation later, were conspicuously absent. All factions involved in the polemic took it for granted that state intervention as such was beneficial and should be reorganised rather than abolished.

With several decades of historical distance, it is clear that the 'architectural debate' over the Märkisches Viertel, and by extension over other large estates, was about anything but architecture. It certainly was not about the design of this particular estate, which, as most observers agreed, was significantly better designed than, for example, Gropiusstadt (Funke 1970, p. 233).

Rather, catchwords such as 'monotonous blocks' and 'grey hell' were ciphers for different strands of criticism. They were directed against rationalist planning, in particular functional separation and car-orientation, and against modernist governance - top-down decision-making that entailed large-scale tenement demolitions, forced relocation and the disruption of old neighbourhood structures. They sometimes merely pointed to the fact that many basic aspects of the new neighbourhoodshops, services and green spaces-remained under construction for years after the first tenants had moved in, which was annoying for those affected, but not per se a weakness of the plan.

Accordingly, the inhabitants remained ambiguous vis-à-vis the debate in the media. They were unhappy about the infrastructural shortcomings and lamented the remote location away from their workplaces. But they were similarly shocked about the press reports depicting their neighbourhood as a ghetto and themselves as criminals or, at best, helpless victims of the local housing bureaucracy (Wilde 1989, p. 130). They generally deemed the Märkisches Viertel an improvement to the substandard tenements where most of them had lived before. Their biggest challenge, it seemed, was neither bad architecture nor deficient planning, but rather the rent level, which despite rent control and subsidies was usually more than twice as high as in a substandard inner-city flat (Wilde 1989, pp. 112-115; Bodenschatz 1987, p. 246). From a scholarly point of view, this is particularly disconcerting, since it points to the limitations of almost any measure, which in a market economy tries to improve the housing situation of the poorest.

Over the following years, the storm slowly waned. Once the parks, shops and communal facilities were completed in the 1970s, and once the owner carried out improvements on leaking roofs and deficient insulation in the early 1980s, resident satisfaction was on the rise. Press reports were increasingly positive, commending the parks and playgrounds, the amount of street life and the community spiritwhich, ironically, was to a large extent a result of the common fight against architects and bureaucrats (Gethke 1979; Schardt 1986; Wilde 1989, p. 130). Statistics from the 1980 s reveal that $69 \%$ of residents were 'pleased' or 'very pleased' with their environment, and $85 \%$ expressed that they would like to remain 


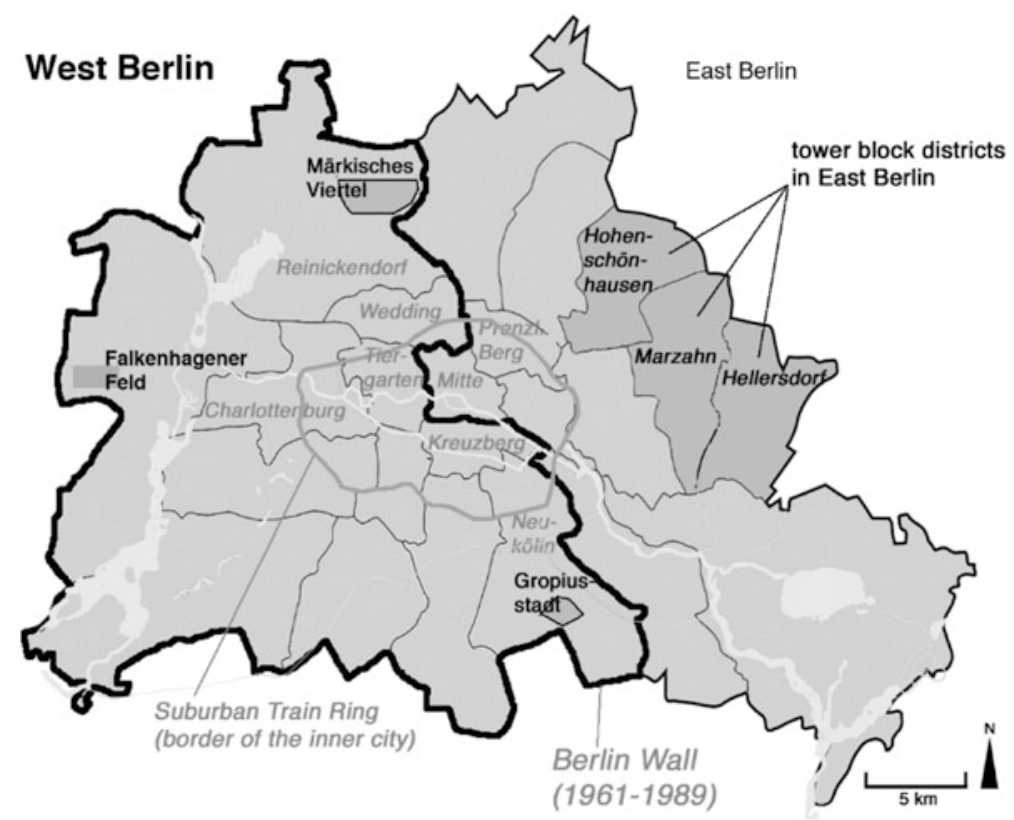

Fig. 5.1 Berlin's large estates. Source Florian Urban

(Institut für Markt und Medienforschung 1986). At the time, the Märkisches Viertel was a modest neighbourhood with social challenges, but by no means the 'grey hell' as which it had been depicted 20 years earlier (Figs. 5.1 and 5.2).

\subsection{The Marzahn, Hellersdorf and Hohenschönhausen Estates in East Berlin}

East Berlin's large estates fared slightly different than those in the West. Nevertheless, they were also first widely accepted and then became subject to increasing criticism. Textbook examples were the aforementioned schemes in Marzahn, Hellersdorf and Hohenschönhausen. They resulted from a master plan worked out in 1969, and went up from the late 1970s onwards. The plan was rather general and specified use and not design, but nonetheless aimed at density and renounced both suburban single-family homes and loosely scattered low-rise buildings. Specification came in the context of the 1973 Housing Programme. The first large estate Marzahn, begun in 1977, was built of regular, identical apartment blocks of the P2 series. They had ten stories, four entrances and contained approximately 180 dwelling units each.

The underlying planning principle was called Komplexer Wohnungsbau (complex residential construction) and, like West Berlin's estates at the time, was 


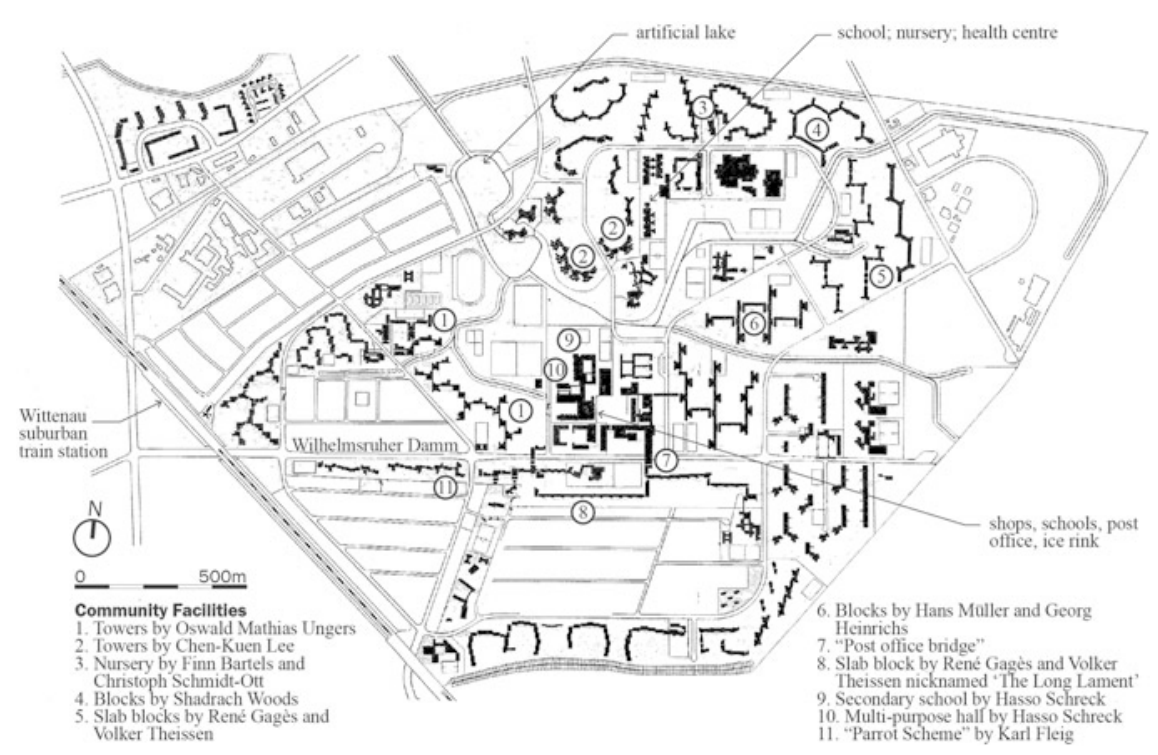

Fig. 5.2 Plan of the Märkisches Viertel, built 1963-1975. Source Florian Urban

indebted to early twentieth-century theories such as Clarence Perry's neighbourhood unit, Le Corbusier's Radiant City, and early Soviet functionalism. 'Complex residential construction' yielded the East German equivalent to the Soviet mikrorayon (micro-district). Residential buildings were built next to 'communal' buildings such as shops, schools, kindergartens, playgrounds and sports facilities. These neighbourhoods were thus not that different from the projects of West Berlin's welfare state institutions such as the Märkisches Viertel, but promoted as reflecting the principles of a socialist society: equal living conditions and modern amenities for everyone, state authorities that care for basic human needs, and education as the basis of the socialist collective.

Criticism of these standardised schemes was noticeable at an early stage, which is remarkable given the restrictions on free speech in East Germany. In a surprisingly blunt way, already in the 1960s they were criticised as being 'monotonous', 'uniform' and 'carelessly designed' (Henselmann 1966; Staufenbiel 1966). A 1975 report to top leader Gerhard Trölitzsch's office pointed out that the situation was serious and suggested that the low aesthetic quality of the housing blocks seriously endangered the citizens' identification with the socialist state (Abteilung Bauwesen 1975).

The leaders were nonetheless eager to brush away such warnings. Since the housing shortage in East Berlin continued to be harsh, they were convinced that standardised flats in large estates were the only way to provide sufficient modern flats. In addition, there was an important aspect of path dependency. With the 'industrialisation of the construction industry' in the 1950s East Germany had embarked on a course that within the rigid corset of centralised state planning was 
impossible to revise. There were simply no firms left that were able to carry out different forms of construction. Hence, the only concessions that the leaders were able to make were slight variations in design and use of concrete slabs, most notably through the promotion of small-scale slab buildings in the city centre from 1982 onwards (Urban 2009, pp. 85-91). The large estates on the periphery, however, had already largely been laid out and were subjected to only small modifications. For example, in contrast to Marzahn, the later estates of Hellersdorf and Hohenschönhausen contained a mix of higher and lower blocks and a greater variation in arrangements, including large courtyards.

It is fair to say that in the last two decades all construction debates in East Germany in one way or another centred around 'the slab'-whether to support, modify, or stop industrialised construction. By the 1980s, even many leading construction officials, and certainly the majority of the population, would have supported a different approach to housing than standardised prefab construction (Urban 2009, pp. 85-91). However, the regime proved to be too inflexible to admit substantial modifications, and slabs were built until the East German regime collapsed in 1989.

\subsection{Large Estates and Market Liberalisation}

Since the German reunification in 1990, municipal policy towards Berlin's large housing estates was somewhat contradictory. In the early 1990s, both the local authority and the national government poured generous subsidies into the housing stock. Housing associations in both halves of Berlin received ample funds to renovate buildings that frequently had started to deteriorate less than two decades after their completion. At the time, most large estates were renovated. Particularly, the crumbling 'slabs' in the East received additional insulation, updated plumbing and often added balconies. Underused green spaces between the buildings were refurbished and often built up with shops and service buildings. Particularly noteworthy was a retro-1970s style with bright colours and geometrical forms that was applied to many façades. The massive investment certainly helped to reduce residualisation. In terms of architectural features, there were nonetheless limitations in making these buildings attractive. Featuring low ceilings and small rooms, they could not compete with stately nineteenth-century buildings, single-family homes or new build blocks of flats.

At the same time, the tide was turning against social housing, and thus against the very institution from which these estates derived. Along with increasing international popularity of market-centred ideas, Germany gradually reduced its social housing programmes. In 1988, the 80 -year-old legal privileges were abolished and West Berlin's non-profit housing associations, as those in the whole of West Germany, had to operate on market principles (Bundesgesetzblatt 1988, p. 1093). When the German Democratic Republic collapsed a year later, the state-owned homes in East Berlin attained a similar legal status. They were 
transferred to newly created companies owned by the city of Berlin, but privately managed as limited liability corporations.

The most noticeable changes took place from the late 1990s onwards, when Berlin's local authority began to regard its municipal housing stock as a means to relieve its financial misery-debts that were unrelated to housing in the first place. Between 2000 and 2006, Berlin sold 100,000 dwelling units to international investors, thus sacrificing a system working with long-term success for short-term profit (Focus 2006; Berliner Mieterverein 2006). For tenants, this meant a sharp rise in rent levels, as the new owners tended to exploit all options for profit offered by the law.

The sales first and foremost affected the most attractive flats- that is, in most cases not the large estates. But it contributed to a polarisation of the housing market. With the total number of housing-association-owned flats rapidly dwindling, there was fewer affordable dwelling space available. Large estates on the periphery thus gradually turned into a refuge for those who could no longer afford to live in attractive inner-city neighbourhoods.

In Marzahn and the Märkisches Viertel, most flats are still owned and operated by housing associations, and rents have stayed comparatively low. They rose significantly from the levels under socialism, but remained moderate compared to other flats. In 2017, a small two-bedroom flat of 65 square metres in a renovated Marzahn slab would cost about 430 euros rent per month; in a similar tower block flat in the Märkisches Viertel the rent would be about 70 euros higher (SenStadt 2017). ${ }^{1}$ These numbers relate rather favourably, for example, to the local minimum wage of $€ 8.84$ per hour - that is approximately $€ 1,400$ per month before tax) (Handwerkskammer Leipzig 2017). But they have to be put in context, as they refer to the average of all rental contracts, many of which have been in place for decades. Someone signing a new contract is likely pay significantly more. The security of low rents for existing contracts, however, is a significant incentive for long-term residents to stay and to a certain extent staves off the equivalent of 'white flight'.

\subsection{Residential Change in Berlin's Housing Estates}

Compared with cities such as London or Paris, Berlin has had low levels of social segregation for a long time. This was also related to the economic slump of the 1990s and early 2000s and the comparatively relaxed housing market at the time. To a certain extent, this is still reflected in the comparatively high level of social

\footnotetext{
${ }^{1}$ The Berlin government's rent index is at $€ 5.07$ per square metre for a slab in the street Allee der Kosmonauten 181 in Marzahn. This amounts to $€ 330$ monthly, plus an estimated $€ 100$ for heating and utilities. For the street Senftenberger Ring in the Märkisches Viertel and a 65 square metre flat completed in the 1970s the rent index is at $€ 6.12$ per square metre, which would bring the sample flat up to €398 plus heating and utilities (2017 figures in SenStadt 2017).
} 
integration in the large housing estates, although the times of abundant flats are long gone and since the 2010s Berlin is ravaged by an exacerbating housing shortage.

Berlin's large estates are modest neighbourhoods inhabited by society's poorer strata, but whether or not they are considered problematic depends on the standpoint. In the eyes of city officials, some estates, such as the Märkisches Viertel, Marzahn, Hellersdorf and Hohenschönhausen, contain a 'high concentration of problems' related to unemployment and poverty (SenStadt 2004, p. 10) and required 'particular attention' (SenStadt 2015, p. 13). Similarly, high indicators of deprivation, however, can also be found in some nineteenth-century tenement neighbourhoods in the inner city, and thus do not correlate to flats in modernist blocks. In addition, in contrast to Britain or France, the differences between 'good' and 'bad' neighbourhoods are still comparatively small.

In 2002, $10 \%$ of the Märkisches Viertel inhabitants were on social welfare, higher than the Berlin average of $6.2 \%$, but not overwhelmingly different, and the unemployment rate stood at $15.6 \%$, compared to the Berlin average of $14.2 \%$ (the rate refers to inhabitants with a German passport, as statistics at the time were different for non-German inhabitants) (SenStadt 2004, data for neighbourhood 'Märkisches Viertel'). A decade later the unemployment rate declined in absolute numbers, but rose in comparison to the general level. In 2014, it stood at $12.1 \%$, compared to the Berlin average of $7.5 \%$ (now calculated jointly for both Germans and foreigners).

A striking level of disadvantage could only be found at the level of benefits (which now, in contrast to the earlier statistics, lumped together social welfare payments and housing benefits): it stood at $28.9 \%$, compared to the Berlin average of $12.1 \%$ (SenStadt 2015, data for district region 'MV1'). These numbers have to be taken with a grain of salt, as the 2014 statistic was set for a slightly smaller area than that of 2002. Also, like all statistics mentioned in this article, the figures refer to areas that approximately match the large estates, but to a small extent also include adjacent low-rise and single-family houses (Fig. 5.3).

Immigrant presence is still not as strong as in the tenement neighbourhoods in the inner city. In 2002, the Märkisches Viertel had only $9.1 \%$ residents with a non-German passport (2.5\% Turks), well below the Berlin average of $13.3 \%(3.7 \%$ Turks), and markedly different from the ratio of $41.4 \%$ in the portion of the central Kreuzberg district nicknamed 'Little Istanbul' (29.1\% Turks) (SenStadt 2004, data for neighbourhoods 'Märkisches Viertel' and 'Mariannenplatz'). In 2014 the number rose to 20.1 compared to the Berlin average of $14.4 \%$ and compared to 32.1 in 'Little Istanbul' although the figures, again, refer to slightly different areas (SenStadt 2015data for district regions 'MV1' and 'Nördliche Luisenstadt'). The numbers of course do not include nationalised foreigners, Germans nationals with foreign parents, or Russlanddeutsche, immigrants from the former Soviet Union with ethnic German ancestry (Figs. 5.4 and 5.5).

The share of foreigners in the Märkisches Viertel is similar to that in other large West Berlin estates such as Gropiusstadt (13.7\% foreigners/5.4\% Turks compared to the Berlin average of 13.3/3.7\%) in 2002 (SenStadt 2004, data for neighbourhoods 'Lipschitzallee') and $17.5 \%$ foreigners in 2014, compared to the Berlin 


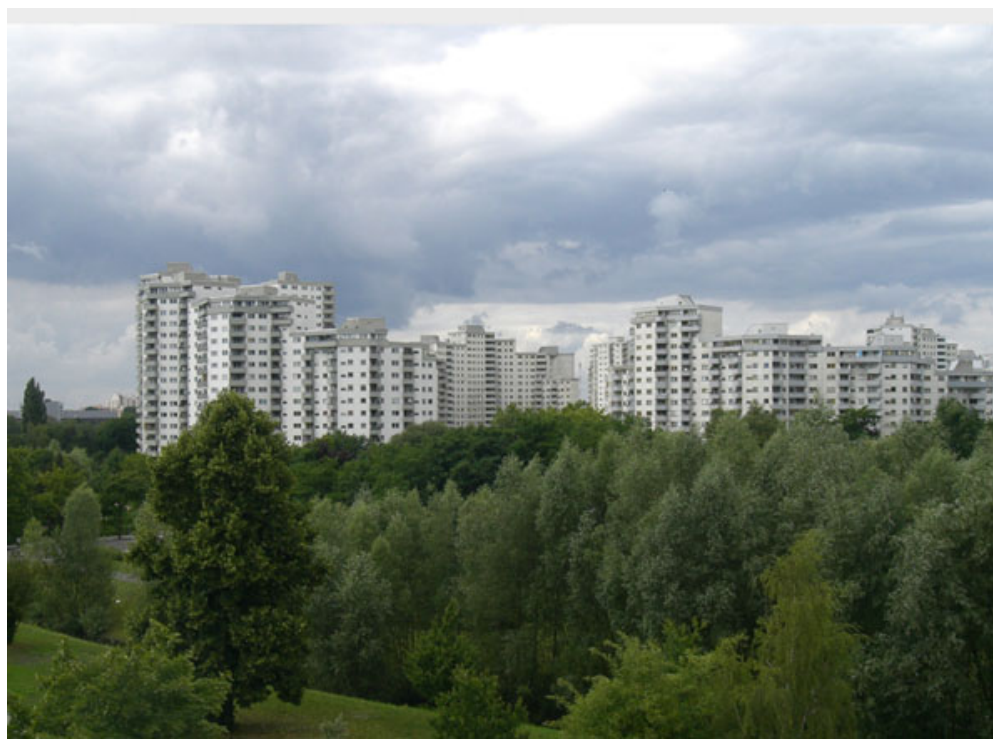

Fig. 5.3 Märkisches Viertel: residential towers on Senftenberger Ring by Chen-Kuen Lee (left and right in foreground) and by Heinz Schudnagies (middle in the background), built 1964 . Source Florian Urban 2009

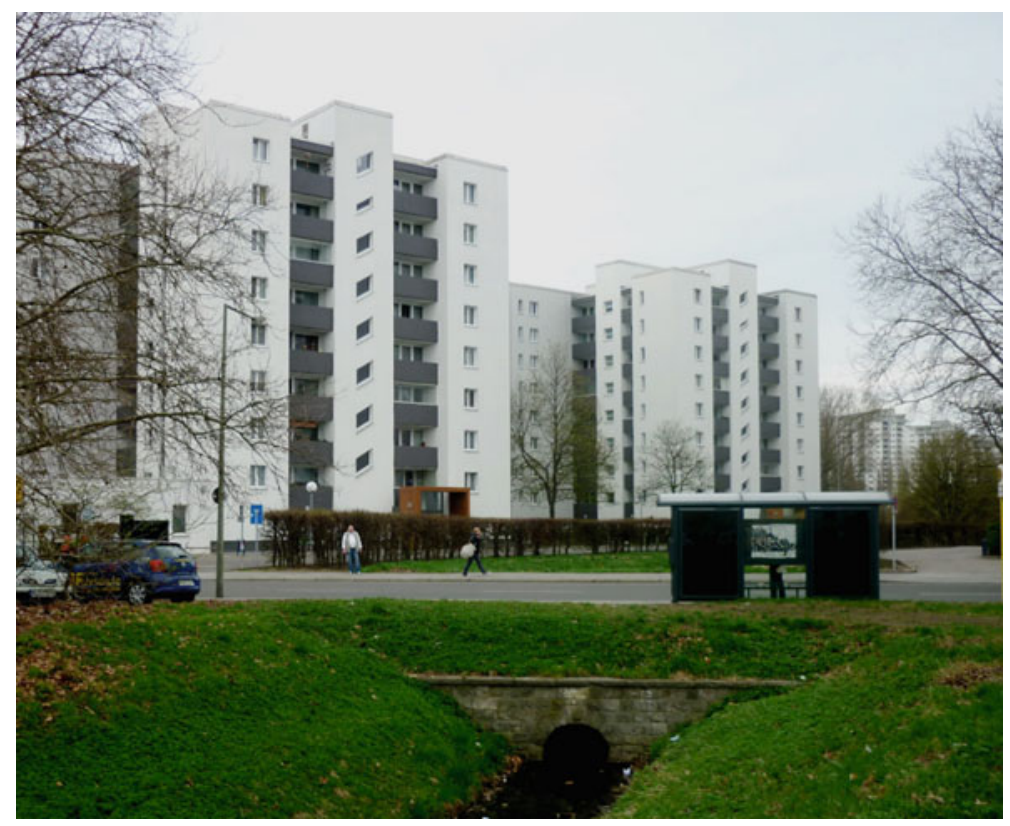

Fig. 5.4 Buildings by Oswald Mathias Ungers, built 1964. Source Florian Urban (2009) 


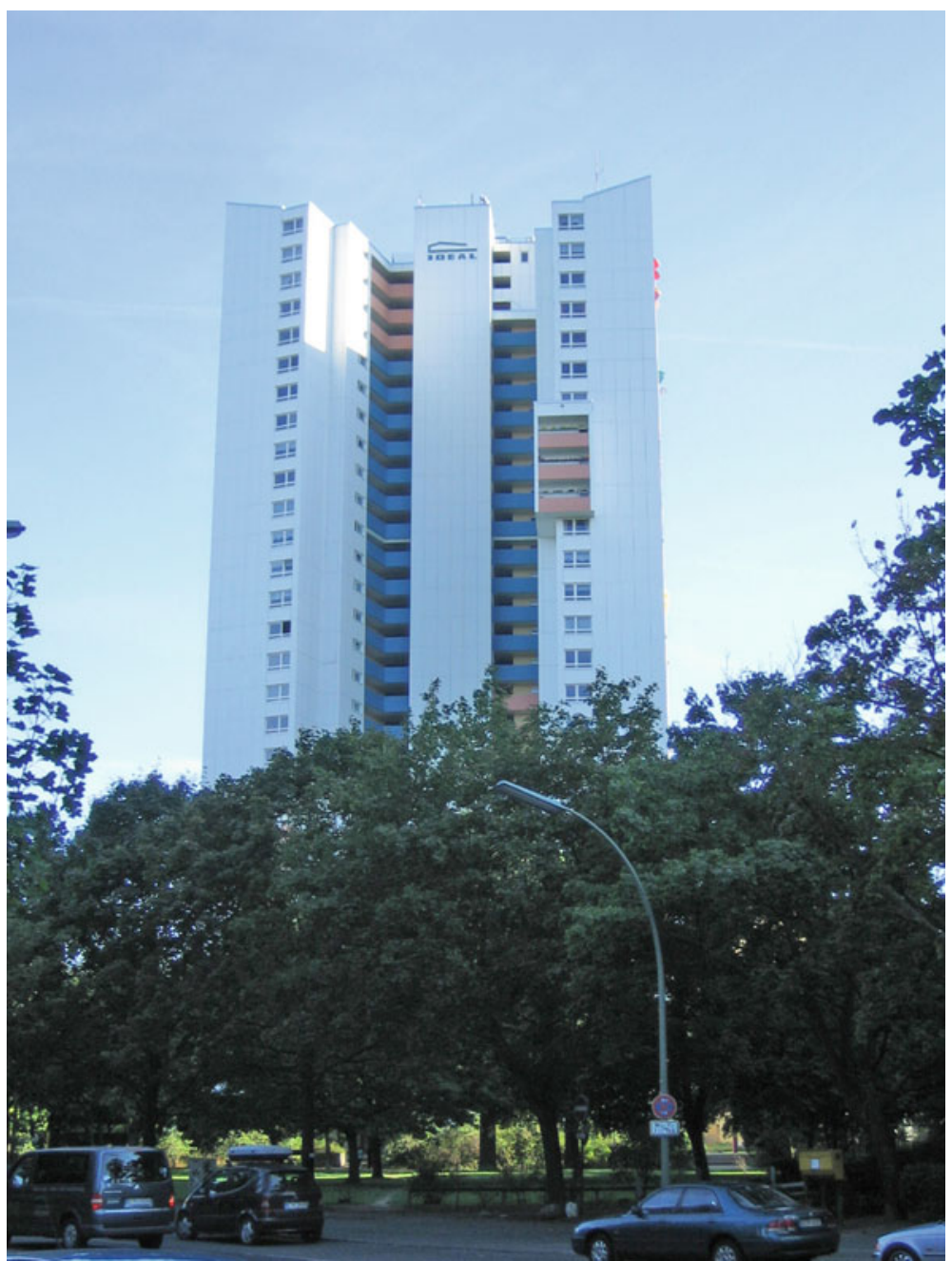

Fig. 5.5 The 'Ideal Tower' (1966-1969, Walter Gropius/Alexander Svianovic), commissioned by the Ideal Construction Cooperative in the Gropiusstadt estate in West Berlin. Source Wikimedia Commons/Magnus Manske, 2008

average of $14.4 \%$ - again, referring to slightly different areas (SenStadt 2015, data for district region 'Gropiusstadt').

East Berlin's housing estates show similar levels of integration, but have changed significantly since the end of the socialist regime. The slabs in Marzahn or Hellersdorf, once desired for providing running warm water and central heating, have now turned from a comparably privileged to a comparably underprivileged environment given the general rise in living standards. The days in which the doctor lived wall to wall with the labourer are gone. Those who have stayed are mostly 


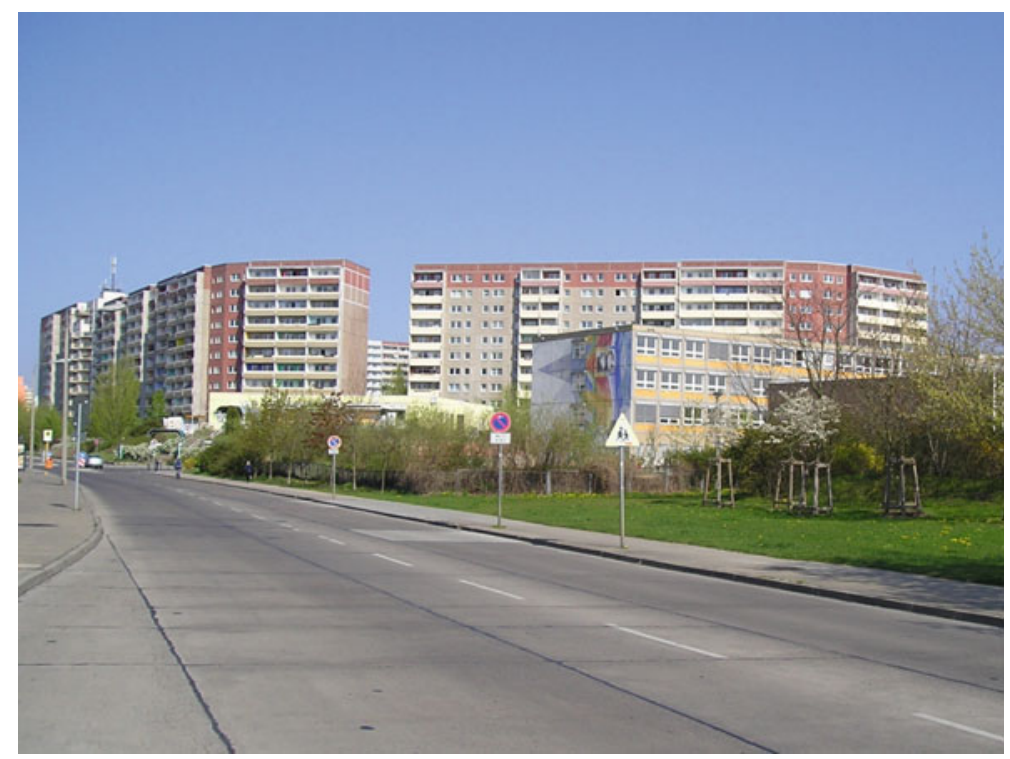

Fig. 5.6 Buildings in Marzahn, built late-1970s. Source Florian Urban, 2005

elderly, and those who come increasingly belong to the lower classes. The areas are nevertheless not exclusively inhabited by the marginalised. In 2002, the unemployment rate (of Germans) reached $17.1 \%$ in Marzahn and 15.4 in Hellersdorf; certainly very high, but not so far above the Berlin average of $14.2 \%$ (SenStadt 2004).

Historically, the share of non-Germans in East Berlin has always been small, as the share of foreign nationals in the German Democratic Republic was less than $1 \%$. This has not changed significantly since the German reunification. In contrast to large estates in the West, those in the East are largely ethnically German. The rate of foreigners in the Marzahn-Hellersdorf district in 2001 was about a third of that in the Märkisches Viertel and stood only at 3.4\%, compared to the Berlin average of 13\% (Statistisches Landesamt Berlin 2002, p. 29).

A decade later, also in the large estates in the East, there was a decrease in unemployment rates and a slight increase in social welfare status and share of foreign nationals. In 2014, the district of Marzahn-Hellersdorf had an unemployment rate of $9.0 \%$ (Berlin average: $7.9 \%$ ) and a share of housing benefit and social welfare receivers of $15.8 \%$ (Berlin average: 13.3\%) (SenStadt 2015, data for district 'Marzahn-Hellersdorf'). The share of foreigners rose slightly, but was still small at 5\% (Berlin average: 14.3\%) (Statistisches Landesamt Berlin 2015, p. 57).

If one, somewhat coarsely, equals immigrants with migrant workers and leaves aside the much smaller number of students and immigrants from privileged backgrounds these numbers suggest that the popular estimation that 'historic tenements are attractive and tower blocks are not' (mainstream at least since the 1990s) has not yet fully translated into settlement patterns. Berlin's large estates are certainly no 


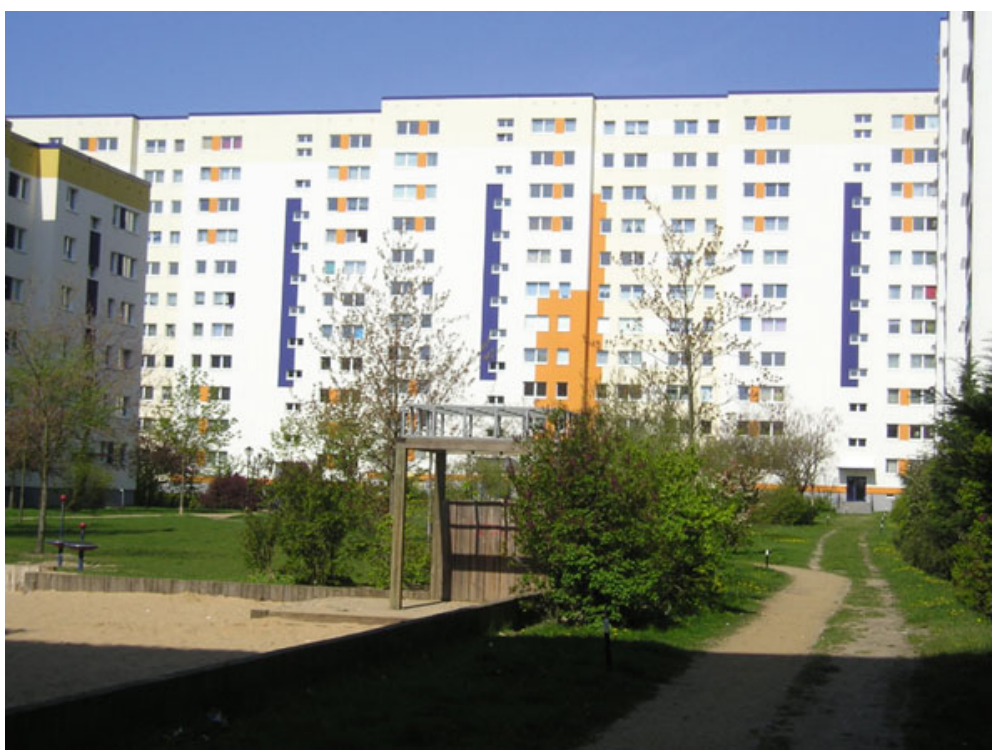

Fig. 5.7 A large courtyard in Marzahn built in the 1970s; renovated and fitted with insulation and colourful façades in the 1990s. Source Florian Urban, 2005

immigrant ghettos, and immigrant presence still concentrates on the inner-city neighbourhoods that were considered unattractive in the 1960s when the first wave of immigrants arrived.

The figures also suggest that in the early twenty-first century large estates in both East and West Berlin have witnessed a slight increase in the share of disadvantaged groups, which aligns with an increasing housing shortage and the increasing desire for privileged groups to live in the city centre. Compared to similar estates in Britain or France, however, Berlin's tower block developments nonetheless still appear to be well integrated (Figs. 5.6 and 5.7).

\subsection{Conclusion}

In both East and West Berlin, large housing estates cannot be equated with crumbling tower blocks, where the marginalised eke out a miserable living. This does not mean that the German capital does not face problems of poverty and marginalisation, but they are distributed among different housing types, including some late-nineteenth-century neighbourhoods in the inner city. Modernist estates tend to be inhabited by the working and lower middle classes, but they are generally well maintained. While Berlin's privileged groups increasingly return to the inner city, the numbers of ethnic minorities and unemployed on the periphery are on the 
rise, but their share in large housing estates is (still) only slightly higher than in other neighbourhoods.

The comparative integration is an outcome of several factors. First, in contrast to Britain or the US, there is no stigma attached to being a tenant or living in a multistorey building. Early twentieth-century legislation made Germany a society of tenants, a condition that for a long time has been supported by the middle classes and guarded by a high degree of rent protection. Particularly in East Berlin's 'slabs' there is still a living memory that these buildings had originally been erected for the whole society, and until 1990 housed families from all social classes. Second, urban changes in Germany are slow because of rent protection and a cultural habit that does not favour frequent moves. This has so far prevented the growth of 'ethnic neighbourhoods' in the American or British sense of an area where an overwhelming majority belongs to the same group. In none of Berlin's large estates is the share of foreign nationals higher than $20 \%$. Even if the percentage of inhabitants 'with a migrant background' (thus the official term) is higher, one can hardly speak of ethnic ghettos.

Large housing estates, as part of both East and West Germany's welfare state policy, were highly successful in achieving their original goals. Overcrowding and deep deprivation have largely disappeared since the post-war period, and the overwhelming majority of Berliners enjoys acceptable living conditions and modern amenities. At the same time, these estates, like the institution of social housing in general, to some extent have fallen victim to their own success. The significant improvement in dwelling conditions for the majority has led to diminishing political support for the minority of marginalised citizens, as those who improved their personal situation no longer regard housing as the most pressing problem. The fact that from the early 2000s onwards large estates were among the few areas that were not affected by the privatisation of municipally owned flats is likely to increase social polarisation and contribute to a rising gap between better and worse housing conditions. In light of an increasingly unequal society, skyrocketing rents and eroding tenant protection, large estates now are a refuge for the most vulnerable in the housing market, but at the same time also concentrate those who are unable to profit from the economic upswing of the post-industrial era.

\section{References}

Abteilung Bauwesen (1975) Architekturanalyse im Bezirk Leipzig. Paper presented at the 7th National Convention of the Architects Association of the German Democratic Republic on 13-14 November, Federal Archive Berlin, call number DY 30/18088

Aktion 507 (1968) Manifest, Rump, West Berlin [manifesto authored by architecture students at Berlin Technical University]. http://issuu.com/textraum/docs/aktion_507-manifest?e=7005999/ 2871121. Accessed June 2017

Allix G (2008) René Gagès [obituary] Le monde, 17 Feb

Bahrdt HP (1961) Die moderne Großstadt. Wegner, Hamburg

Bodenschatz H (1987) Platz frei für das neue Berlin. Transit, West Berlin 
Bundesgesetzblatt (1951) Gesetz über das Wohneigentum und das Dauerwohnrecht Bundesgesetzblatt 10 Mar, p 175

Bundesgesetzblatt (1988) Gesetz zur Überführung der Wohnungsgemeinnützigkeit in den allgemeinen Wohnungsmarkt. Bundesgesetzblatt 25 July, p 1093

Bürgerliches Gesetzbuch (1903) Berlin, Guttentag

BZ (1967) Hoffnungsschimmer für die Städtebauer in halb Europa, West Berlin, 19 Oct

Der Spiegel (1968) Slums verschoben. Der Spiegel 22(37):134-138

Der Spiegel (1969) Es bröckelt. Der Spiegel 23(6):38-63

Flierl B (1998) Berlin baut um-Wessen Stadt wird die Stadt? Kritische Reflexionen 1990-1997. Verlag für Bauwesen, Berlin

Focus (2006) Ausverkauf an Großinvestoren. Focus 20 Oct, Munich

Funke H (1970) Da hilft nur noch Dynamit. Der Spiegel 24, 2 Nov

Führer KC (1995) Mieter. Hausbesitzer, Staat und Wohnungsmarkt Steiner, Stuttgart

Geodaten Infas (2011) Quoted in Berlin bleibt die Mieter-Hauptstadt. BZ, 4 July, Berlin

Gethke G (1979) Früher verschrien, heute begehrt: Wohnungen im MV. Der Nord-Berliner 6 July, West Berlin

Gudermann R (1999) Wohnungsbaupolitik und-finanzierung in Ost-Berlin 1949-1989. In: Arbeitsgemeinschaft der Berliner Wohnungsbaugesellschaften ed. Wohnen in Berlin. Edition StadtBauKunst, Berlin

Göderitz J, Rainer R, Hoffmann H (1957) Die gegliederte und aufgelockerte Stadt Wasmuth, Tübingen

Handwerkskammer Leipzig (2017) Minimum Wage. https://www.hwk-leipzig.de/artikel/ mindestlohn-2017-3,0,7602.html. Accessed June 2017

Henselmann H (1966) Der Einfluss der sozialistischen Lebensweise auf den Städtebau und die Architektur in der DDR. Deutsche Architektur 5:264-265

Institut für Markt und Medienforschung (1986) Märkisches Viertel. West Berlin

Junker W (1973) Das Wohnungsbauprogramm der DDR für die Jahre 1976-1990. Deutsche Architektur 12:708-712

Kählert G (2012) Organische Architektur von Chen Kuen Lee. Architektur und Wohnen 5

Lynch K (1960) The Image of the City. MIT Press, Cambridge, Massachusetts

Mieterverein Berliner (2006) Schwarzbuch Privatisierung. Berliner Mieterverein, Berlin

National Housing Foundation (2014) Homeownership data for Britain. http://www.housing.org. uk/news/housing_market_crisis_as_home/full_press_release_on_housing.aspx. Accessed June 2017

Norris M, Winston N (2011) Does Home Ownership Reinforce or Coun-terbalance Inequality?. University College Dublin, Dublin

Palutzki J (2000) Architektur in der DDR. Reimer, Berlin

Presse und Informationsamt des Landes Berlin (1971) Das Märkische Viertel, Presse- und Informationsamt des Landes Berlin, West Berlin [reprints of press articles on the Märkisches Viertel on pp 53-55]

Salin E (1960) Urbanität, in Deutscher Städtetag, ed., Vorträge, Aussprachen und Ergebnisse der 11. Hauptversammlung des Deutschen Städtetages. Kohlhammer, Augsburg

Schardt T (1986) Hochhausstadt besser als ihr Ruf. Berliner Morgenpost 31 Jan

Schröder K (1998) Der SED-Staat. Geschichte und Strukturen der DDR, Bayerische Landeszentrale für politische Bildungsarbeit, Munich

Schulz E (1968) Das Märkische Viertel Frankfurter Allgemeine Zeitung, 13 January 1968, reprinted in Presse und Informationsamt des Landes Berlin Presse- und Informationsamt des Landes Berlin. Das Märkische Viertel, Berlin

SenStadt (2004) Senatsverwaltung für Stadtentwicklung, Monitoring Soziale Stadtentwicklung 2004. Senatsverwaltung für Stadtentwicklung - Bericht 2004, Berlin

SenStadt (2015) Senatsverwaltung für Stadtentwicklung, Monitoring Soziale Stadtentwicklung 2015. Senatsverwaltung für Stadtentwicklung-Bericht 2015, Berlin

SenStadt (2017) Senatsverwaltung für Stadtentwicklung, Monitoring Soziale Stadtentwicklung 2017. Senatsverwaltung für Stadtentwicklung, Berlin 
Siedler W, Niggemeyer E (1964) Die gemordete Stadt. Herbig, West Berlin

Statistisches Landesamt Berlin (2002) Die Kleine Berlin-Statistik. Statistisches Landesamt, Berlin Statistisches Landesamt Berlin (2015) Die Kleine Berlin-Statistik. Statistisches Landesamt, Berlin Staufenbiel F (1966) Kultursoziologie und Städtebau. Deutsche Architektur 6:326-327

Strauss S (2003) Zwei Zimmer im 14. Stock, Berliner Zeitung 22 January

Teut A (1966) Huldigung an die städtebauliche Tradition. Die Welt 8 November, p 13

Urban F (2009) Neo-historical East Berlin: Architecture and Urban Design in the German Democratic Republic 1970-1990. Routledge, London

Urban F (2015a) Germany. Country of Tenants. Built Environment 41(2):183-195

Urban F (2015b) The Märkisches Viertel in West Berlin. In: Swenarton M, Avermaete T, van den

Heuvel D (eds) Architecture and the Welfare State. Taylor and Francis, Abingdon Wagner G (1995) Sozialstaat gegen Wohnungsnot. Schöningh, Paderborn

Wilde A (1989) Das Märkische Viertel. Nicolai, West Berlin

Open Access This chapter is licensed under the terms of the Creative Commons Attribution 4.0 International License (http://creativecommons.org/licenses/by/4.0/), which permits use, sharing, adaptation, distribution and reproduction in any medium or format, as long as you give appropriate credit to the original author(s) and the source, provide a link to the Creative Commons license and indicate if changes were made.

The images or other third party material in this chapter are included in the chapter's Creative Commons license, unless indicated otherwise in a credit line to the material. If material is not included in the chapter's Creative Commons license and your intended use is not permitted by statutory regulation or exceeds the permitted use, you will need to obtain permission directly from the copyright holder.

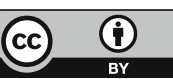




\title{
Chapter 6 \\ Decline and Response? Lifecycle Change and Housing Estates in Birmingham, England
}

\begin{abstract}
Alan Murie
Abstract This chapter discusses mass public housing estates in England and uses Birmingham to illustrate how estates have changed. In British cities, large housing estates built between the 1950s and 1970s are particularly associated with flats and tower blocks. They formed an important part of public housing, but failures in design, construction, management and maintenance meant that they often also damaged its status and reputation. Estates have changed over time and this Chapter, highlights internal and external influences and demolition, privatisation and regeneration. These influences have been layered on each other and interacted to generate different outcomes in different places. Some estates and properties from this era have proved popular and successful, but in other cases questions have arisen about their construction, suitability for disadvantaged communities and continuing role. The failures of some estates and of their regeneration are likely to continue to generate demands for demolition and substantial funding for their redesign.
\end{abstract}

Keywords Birmingham • England - Council housing · Privatisation Regeneration $\cdot$ Residualisation

\subsection{Mass Housing in England}

British public housing, built between the 1950s and 1970s, mainly by local authorities, was heavily influenced by modernist architecture and industrialised building systems. It introduced new divisions, related to dwelling form, type, location and estate layout, within an already substantial council housing sector. Public housing built before this phase was high quality, high status and popular. It provided for households with housing need: demand was high and rents and processes determining access often excluded the lowest income groups and recent

\footnotetext{
A. Murie $(\bowtie)$

The Centre for Urban and Regional Studies, University of Birmingham, Birmingham, UK e-mail: a.s.murie@bham.ac.uk

D. B. Hess et al. (eds.), Housing Estates in Europe, The Urban Book Series, https://doi.org/10.1007/978-3-319-92813-5_6
} 
migrants. Both these estates and the later mass estates were built as single tenure council estates. This determined how access was negotiated and this, distinctive layouts and property types, established them as coherent neighbourhoods. Estates built from the mid-1950s onwards proved less resilient. Their popularity was often undermined and attempts to halt decline were not always effective.

Government subsidies had enabled councils to build over 1 million dwellings in England and Wales between 1919 and 1939 with the highest level of completions $(104,000)$ achieved in 1927/28. When the outbreak of war in 1939 halted housebuilding, councils already provided over $10 \%$ of housing. Public sector housebuilding recommenced rapidly after 1945 and increased government subsidies reflected its importance in post-war economic reconstruction and the welfare state. Between 1945 and 1951 public sector housebuilding accounted for over 80\% of houses built: completions in England and Wales reached 92,000 in 1946 and 186,000 in 1948. They peaked at 221,000 in 1954 (Holmans 1987). By 1953, 2,400,000 dwellings were rented from councils or new towns in England and Wales $-19 \%$ of dwellings. Almost all were traditionally built, family houses (mainly three-bedroom houses in suburban areas) with few flats. The key planning and architectural influences were garden cities rather than modernism. Council housing was superior to most private sector dwellings and attractive to affluent white- and blue-collar workers, but largely inaccessible to poorer households. Housing costs were lower in poorer quality, private rented housing, mostly subject to rent control.

Following success in reducing post-war housing shortages, the focus of policy shifted, from the mid-1950s, to clearing and replacing slum housing, without increasing urban sprawl. This meant rehousing people from private sector slum housing-lower income households, older people and households without children. Councils changed what they built. Government, the construction industry and building professionals promoted modernist designs and industrialised building techniques as a 'technological short cut' (Dunleavy 1981) to enable more to be done quickly, and government subsidies offset the higher costs of building high. This helped to persuade local authorities to set aside views that flats were costly and unpopular. Various types of mass housing, using unfamiliar building systems, with different layouts and environments, were built on inner-city and peripheral sites. By the mid-1960s, councils increased their use of industrialised building and off-site prefabrication, even though the basis for their promotion was sometimes superficial and misleading (Cantle 1986). By 1965, flats comprised 52\% of public sector housebuilding and continued to account for over 50\% until 1973 (Cooney 1974).

In sum, government and its partners supported an experiment to facilitate council house building that altered the balance of dwelling sizes, introduced unfamiliar designs and types of housing and estate layouts in different locations, for different populations. Most of this modern housing was initially welcomed as a dramatic improvement on the slum housing it replaced, but its reputation was soon damaged. The catalyst is generally regarded as the 1968 gas explosion at Ronan Point, a tower block in the London Borough of Newham. Design faults meant that this explosion caused a partial collapse and six people were killed. But criticisms of high costs that achieved negligible increases in densities, of physical and mental health problems 
and about safety, social, aesthetic and other issues meant that government had already planned to reduce subsidies, and local authorities reduced their investment in high flats after 1967.

Accounts of what happened to estates over their lifecycle identify various influences (Hall et al. 2005a). Mass estates had some different dynamics from traditional housing estates. Smaller dwellings, housing smaller (younger and older) households, tended to have higher turnover. Other 'internal' lifecycle factors (demographic changes and the need to replace materials when they fail) applied as in other estates. But some mass estates had significant design and construction faults: the need for remediation emerged more quickly and required more challenging and expensive solutions. In addition, 'external' factors that affected estates included how residualisation of social renting (linked both with economic and housing changes) narrowed the social base of the tenant population and contributed to a spiral of decline.

In England, both internal and external factors affected mass estates. Although generally popular at the outset, many estates were becoming unpopular by the 1980s. Residents were critical of the appearance and environment on estates and of management and maintenance: communal parts of buildings were often poorly designed and easily damaged; open space was unused and poorly maintained. Some system-building techniques had defects that contributed to water penetration, condensation, infestation and inadequate and expensive heating; a long list of physical problems emerged (Cantle 1986). There were concerns about unfavourable effects on families with children, isolation affecting older and other residents, and higher levels of crime and anti-social behaviour. Unpopularity and high turnover were likely where there was poor access to employment; people in employment often preferred other estates and tenants who obtained employment sometimes moved away. High levels of vandalism, vacancy and turnover reflected the pattern of decline, physical defects and unpopular environments. Initial problems and emerging unpopularity generated a second wave of instability, making estates even more difficult to live in and manage.

Mass housing estates slipped towards the bottom of the hierarchy of value and choice within council housing. The status of public housing also declined generally as economic changes and higher unemployment after the 1970s left more households with no alternative other than renting and, as the private rented sector continued to shrink, were more dependent on public housing. Bargaining power and capacity to wait determined who was offered attractive public housing: those with least bargaining power were steered towards the least popular dwellings and estates. Mass public housing estates were among the least desirable, residual parts of an increasingly residual tenure. Poorer people became concentrated in unpopular estates and this partly explained failures to improve estates.

By this stage, the post-war consensus over expanding council housing had been overtaken by political competition to promote homeownership, and later, agendas to reduce the public sector and public expenditure. Council housing had played a steadily increasing role between 1919 and 1981. It provided $25 \%$ of all dwellings in England in 1961 and $28 \%$ in 1971 and 1981. But funding for council house building had dried up by the mid-1980s, there was an increasing backlog of 
disrepair and better quality council housing was a target for privatisation that was popular and generated capital receipts to fund general government expenditure (Forrest and Murie 1990). Public housing stock declined in size and this meant reduced staffing. It also meant there were fewer older properties with low outstanding debt that could cross subsidise properties needing higher expenditure on management, maintenance and repair. Some council housing was also transferred to housing associations, which, along with councils, formed a social rented sector increasingly providing welfare housing for people in crisis rather than high-quality housing for a mixed population. In 1981, this social rented sector provided $31 \%$ of dwellings in England. Its share fell to 23\% in 1991, 20\% in 1992 and 17\% in 2011 and 2016.

Estates spiralling downwards often required major, disruptive and costly investment, but government was unwilling to commit to this. As resources were not forthcoming, low-cost alternatives were favoured-including local lettings schemes under which low demand properties were made available to a wider population, not otherwise eligible for them. This could signal failure and exacerbate high turnover. Although restrictions on management and maintenance expenditure limited capacity to address problems, decentralisation and other local strategies to improve management were adopted. Other approaches included the sale of whole blocks and estates to private developers and housing trusts for refurbishment, involving different levels of demolition.

Until the mid-1980s, government concern about deprived neighbourhoods and inadequate housing largely focussed on inner-city private housing. But difficulties in public housing estates attracted attention and additional funding for selected estates through the Priority Estates Project (1979-1987), the Urban Housing Renewal Unit and its successor Estate Action (1985-1994), Housing Action Trusts (1988-2007), the Estate Renewal Challenge Fund (1995-2000) and Housing Market Renewal (2002-2011). These programmes largely funded investment in dwellings and the physical environment but later programmes and the Single Regeneration Budget (1994-2008) and New Deal for Communities (1998-2010) placed greater emphasis on employment and community. Policies to encourage transfers of council housing to housing associations were also actively pursued from the mid-1980s onwards - partly because transfers enabled access to private finance and, through this, to increased investment in new and existing social housing. These various initiatives helped to make some estates more attractive. Difficulties in letting properties were also relieved by population growth and new demand from refugees, asylum seekers and other migrants. As housing shortages increased it became easier to let less attractive housing - albeit often to households with the most problems and least choice.

Undeniably, government's privatisation policies affected strategies to improve mass estates. When the Right to Buy (2016) introduced higher discounts to encourage sales of flats, government had not fully anticipated the consequences (Murie 2016). Sales and subsequent resales left blocks of flats with mixed ownership: a mix of public and private owners, including absentee private landlords. The leasehold system in England appeared to cope with this but there were 
continuing concerns over levels of service charges; privatisation complicated the process and increased costs where demolition or major refurbishment was planned, and questions arose about where responsibilities related to health and safety rested.

Between 2001 and 2010, government adopted a Decent Homes Policy to raise standards and improve energy efficiency across tenures, but additional funding to enable council housing to reach this higher standard was only available where councils transferred their stock to housing associations or adopted new organisational arrangements such as Arms Length Management Organisations (ALMOs) and Tenant Management Organisations (TMOs). Although councils responded to this agenda in different ways, the social rented sector outperformed other tenures in improving its stock to the Decent Homes Standard.

\subsection{Birmingham}

The city of Birmingham, the largest UK local authority, with a population fluctuating around one million, built 30,000 council dwellings by 1930 and 50,000 by 1939 - almost all single-family, suburban houses. The city was reluctant to build flats that were associated with saving costs and lowering standards: the few flats it built were unpopular (Sutcliffe 1974; Sutcliffe and Smith 1974). The outbreak of war in 1939 halted housing construction, but when Birmingham restarted building after 1945, council completions on land that was already owned, using existing plans, increased rapidly: 18,000 council dwellings were completed between 1945 and 1953, rising from 413 in 1946 to a peak of 4,774 in 1952 (Sutcliffe and Smith 1974; 226-8). This reduced the council's reserves of building land and, by 1949, in spite of continuing reservations about their suitability, more flats were planned. The switch to slum clearance and higher government subsidies to offset the higher costs of building flats persuaded the council to build different dwelling types and designs in different locations. Municipal building increased (over 4,000 dwellings completed within the city boundary in both 1965 and 1966) and the proportion of flats and maisonettes in buildings of three or more storeys also increased (from 4\% in 1951 , to $75 \%$ in 1957) and remained high (85\% in 1961; 77\% in 1965) although with fewer high blocks.

Birmingham constructed 417 high-rise blocks and 60,897 municipal dwellings between 1953 and 1973. Table 6.1 refers to nine Housing Market Areas identified by the city council (Fig. 6.1). Most dwellings built in this period were in peripheral and suburban areas: almost a third in the South West (Northfield, Longbridge and Kings Norton) but almost 1-in-10 built on slum clearance sites around the city centre. Flats and maisonettes accounted for two out of every three dwellings completed. Over $50 \%$ of dwellings had fewer than three bedrooms. Most flats had one or two bedrooms, while most existing and new houses had three bedrooms (Table 6.2). The new estates in this period were usually extensions of existing estates or new areas of fewer than 2,000 dwellings, although there were some larger new estates including Castle Vale. 
Table 6.1 New council dwellings built in Birmingham, 1953-1973: location. Source City of Birmingham

\begin{tabular}{l|l|r}
\hline & \multicolumn{2}{l}{ Total stock } \\
\cline { 2 - 3 } & Number & $\%$ \\
\hline City Centre & 5989 & 9.8 \\
\hline East & 3886 & 6.4 \\
\hline Eastern Periphery & 7510 & 12.3 \\
\hline North West & 6221 & 10.2 \\
\hline Northern Periphery & 1006 & 1.7 \\
\hline Northern Suburbs & 2292 & 3.8 \\
\hline South West & 19388 & 31.8 \\
\hline Suburban Ring North & 7463 & 12.3 \\
\hline Suburban Ring South & 5802 & 9.5 \\
\hline Total & 60897 & 100 \\
\hline & &
\end{tabular}

\subsection{Estates at the Outset}

The first tenants of mass housing estates included households which differed from traditional 'affluent working-class' council tenants. There were more low-income and non-family households, including both older and younger single-person and two-adult households. Although precise statistics are not available, research provides an authoritative account of access to housing (Rex and Moore 1967). In the 1960s, Birmingham was the most prosperous part of Britain after the South East, and attracted immigrants from Britain and beyond. There was excessive demand for council housing, which comprised the best quality, affordable housing in the city, yet priority for council housing went to households displaced by the massive slum clearance programme. While some 'immigrant' households were rehoused from slum clearance areas, minority ethnic groups generally lived outside areas scheduled for redevelopment (Henderson and Karn 1987; 6). A wider section of the population could access council housing but the poorest households-black and minority ethnic groups and recent immigrants-were often excluded, were systematically disadvantaged by the management of slum clearance and allocation processes, and remained in private, inner-city housing.

\subsection{Decline and Fall?}

After the 1960s, changing demography, higher unemployment, the decline of manufacturing and greater income inequalities affected competition for housing in Birmingham. There were changes in housing allocation policy and practice and wider housing policy. Changes in tenure structure and differentiation within tenures further affected patterns of access and the roles of different neighbourhoods. The era following mass public housing construction was marked by promotion of mass 


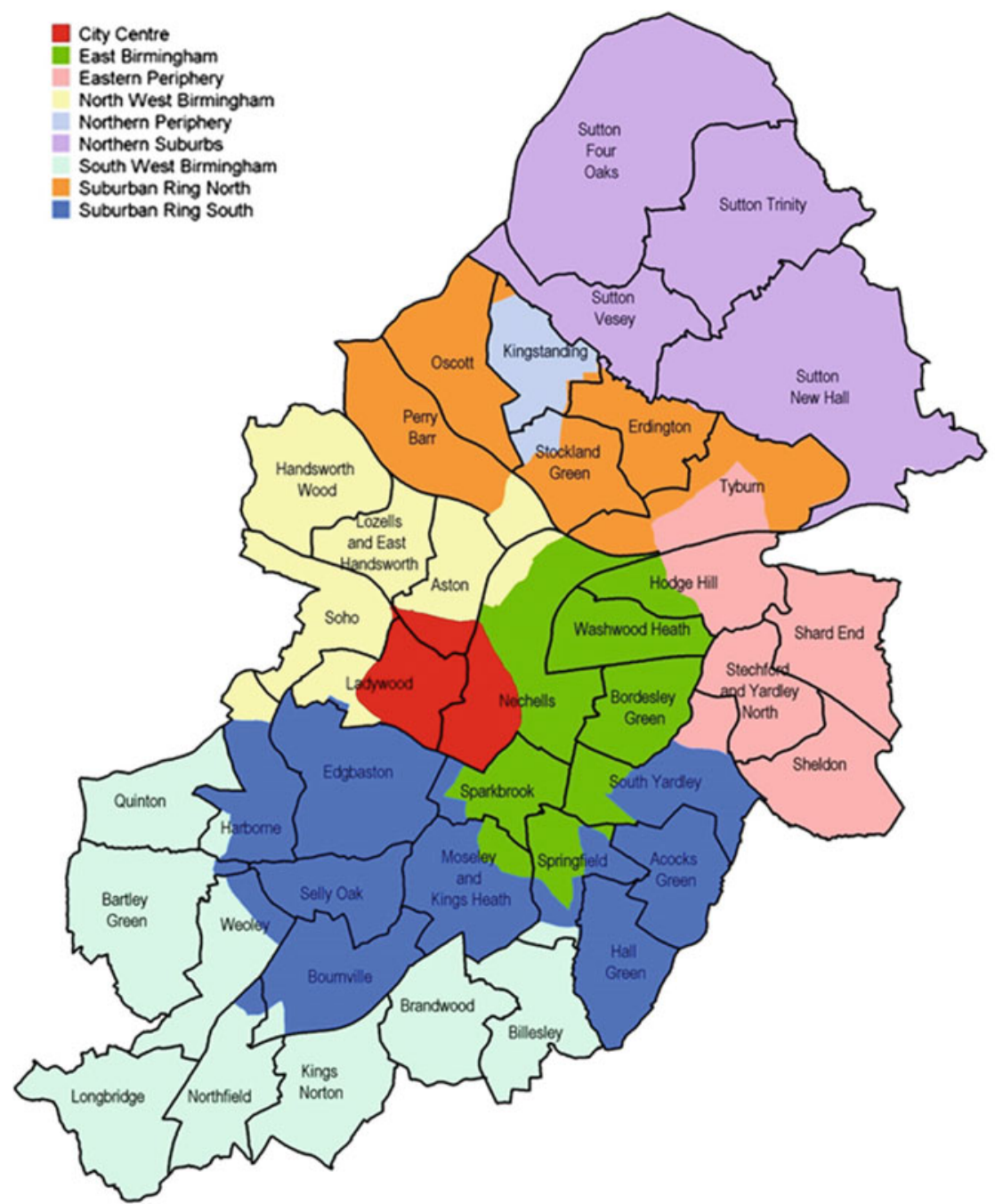

This map is reproduced from Ordnance Survey material with the permission of Ordnance Survey on behalf of the Controller of Her Majesty's Stationery Office $\odot$ Crown copyright. Birmingham City Council, 100021326, 2004

Fig. 6.1 Wards and housing market area boundaries, June 2004, Source City of Birmingham

home ownership. The reputation, quality and resources for council housing declined and being excluded from council housing no longer had the same connotations.

New council house building declined from the mid-1970s and almost ceased within a decade. At the same time, sales of council houses to sitting tenants increased. In 1966, 41\% of dwellings in Birmingham were council owned but this 
Table 6.2 New council dwellings built in Birmingham, 1953 to 1973: size and type

\begin{tabular}{|c|c|c|c|c|c|c|c|}
\hline \multicolumn{7}{|c|}{ Number of bedrooms } & \multirow[t]{2}{*}{ Total } \\
\hline & bedsit & 1 & 2 & 3 & $4+$ & Unknown & \\
\hline Bungalow & 41 & 1988 & 107 & 24 & & & 2160 \\
\hline Flat & 833 & 12360 & 15390 & 4518 & 6 & 19 & 33126 \\
\hline House & & & 1747 & 13967 & 2082 & 265 & 18061 \\
\hline Maisonette & & 16 & 1287 & 6178 & 56 & & 7537 \\
\hline Other & & 1 & 10 & & 1 & 1 & 13 \\
\hline Total & 874 & 14365 & 18541 & 24687 & 2122 & 285 & 60897 \\
\hline
\end{tabular}

Source City of Birmingham

declined to $38 \%$ in $1977,35 \%$ in $1981,27 \%$ in $1991,19 \%$ in 2001 and $15 \%$ in 2011. Although the housing association stock had grown from $4 \%$ in 1981 to $9 \%$ in 2011, the combined social rented stock had declined enormously. The council housing stock was smaller and older and higher rents and restrictions on expenditure reduced its attractiveness.

The 1970 s to 1990 s saw slum clearance superseded by urban renewal: older private housing was improved and repaired rather than demolished and replaced. Changes to council housing allocation rules also meant that black and immigrant households were no longer excluded. The number of black households in council housing increased from 1,500 in 1969 to over 6,000 in 1977 (Henderson and Karn 1987). In $1975,10 \%$ of the population of the city were 'immigrants' but they still formed but only $3 \%$ of council tenants. Although not excluded from council housing, it remained more difficult for households of Asian and West Indian heritage to access council housing; and where they became council tenants, it was more likely to be in inner-city areas irrespective of stated preferences. The combination of bureaucratic processes and household preferences $(90 \%$ of immigrants preferred inner-city locations) left ethnic minorities (especially Asian households) concentrated in inner-city areas. Peripheral estates were less attractive to ethnic minority groups than inner-city estates where they were over-represented (Rex and Tomlinson 1981). This divergence in the ethnic mix between inner and outer city estates affected bureaucratic allocation decisions and household choices and consolidated, segregation between estates. The debate shifted to questions about concentration (segregation) and unequal access to different estates in the city.

Explanations for patterns of choice and residence were complicated as homeownership became more accessible. New community-based urban renewal policy channelled public expenditure towards inner-city neighbourhoods and private housing and this, as well as policies affecting access to council housing, affected competition for housing. Some households - including those from minority ethnic groups-preferred inner-city areas where they had family and social networks. These were no longer areas of last resort, neglected by public expenditure. Urban renewal improved opportunities for inner-city residents including a growing population of working-class owner-occupiers. 
Subsequent analysis of Birmingham shows a complex pattern of cross-tenure deprivation replacing the 1960s pattern of exclusion from council housing. In 1991, ethnic minority households were less likely to be in council housing than white households but there was variation between minority groups. Black African households $(0.3 \%$ of the population) were more than twice as likely to be council tenants than their population share would suggest (and four times more likely to be in council flats). The ratios for other groups were Black Caribbean, $4.7 \%$ of the population with a probability of being council tenants of 1.4; Bangladeshi, 1.3\% and 0.7; Pakistani, 6.9\% and 0.4; and Indian, 5.3\% and 0.2. Birmingham did not have the polarised pattern associated with some British cities with social renting for marginalised groups and homeownership for affluent households. Less affluent households lived in both private and council housing, in inner-city and peripheral locations: ethnic minority households were concentrated in inner-city private housing with low-income white households in peripheral council estates (Lee and Murie 1997; 27, 48; 2002).

Access to council housing was also affected by privatisation. Birmingham pioneered sales of council houses to sitting tenants, at discounted prices but flats were not sold until after legislation providing a Right to Buy (1980). Both before and after 1980, Birmingham disproportionately sold attractive traditional houses in low-density suburban areas, to affluent, long-standing, middle-aged tenants (Forrest and Murie 1990). The lowest rates of sale were among properties built between 1954 and 1963 and between 1964 and 1973: the highest rates among pre-war properties (Jones and Murie 1999). Mass housing was further residualised. Fewer relets of better council houses meant new applicants were steered towards flats and maisonettes in less popular estates.

By the mid-1980s, it had become evident that Birmingham had to address problems associated with mass housing estates and especially flats with spalling concrete and loose mosaic. In view of the failures elsewhere, the approach that Birmingham adopted to refurbishment is important. The city established and kept under regular review, its standard for refurbishment: repairing concrete, removing loose mosaic, covering with mineral fibre insulation secured by wire mesh that held everything in place and providing the key for a render overcoat. The system could cope with variable thickness to mask any undulations and imperfections. It ensured that insulation was dry and allowed different colours and designs - enabling residents to influence the final appearance. The city considered panel systems, but the structural problems encountered, fire safety and cost considerations and the first blocks considered being 'out of square', favoured the render-based solution.

Alongside this standard for refurbishment, the council increased local management and maximised funding from government programmes. The council was reluctant to follow central government's encouragement of stock transfers. It transferred stock, with tenants' agreement, in Castle Vale and the Central Estates in order to access additional funding. But a proposal by the Labour-controlled council for a city-wide stock transfer was rejected by tenants in 2002. Subsequently, both Conservative and Labour-controlled councils rejected further significant stock transfers and sought to reach the Decent Home Standard through asset 
management. This involved evaluation of the costs of refurbishing properties to achieve the standard. Where modelling indicated that rental income over 30 years would be less than the investment needed plus the costs of management and maintenance, consideration was given to alternative strategies, including demolition. The council worked with housing associations (including new community-based associations) and private sector partners to modify or demolish unsustainable estates. The strategy took account of capacity to provide for homeless and larger households and of poverty traps. By 2009, the council had established its own delivery vehicle for new homes for rent and sale (Birmingham Municipal Housing Trust). This contributed by building new homes - within limits presented by subsidy arrangements and grants from the Homes and Communities Agency.

By 2016 , over $20 \%$ of all properties built by Birmingham city council between 1953 and 1973 and over $40 \%$ of maisonettes and over $25 \%$ of flats had been demolished (excluding stock transferred before demolition). Demolitions were proportionately highest in the North West, Northern Periphery and South West. Some $30 \%$ of council housing from this period had also been sold. All estates developed some tenure mix but sales were uneven: about $68 \%$ of houses from this period had been sold but only $21 \%$ of maisonettes and $9 \%$ of flats. Privatisation meant that a higher proportion of the remnant council sector comprised flats. Demolitions and sales together had dramatically changed mass estates. By 2016, less than half the mass housing built in the Eastern periphery, North West and South West areas was still there and still council owned (Table 6.3). The stock was least reduced in the City Centre and the East, North and South suburban rings.

Table 6.3 New council housing built in Birmingham, 1953 to 1973: demolished or sold by area.

\begin{tabular}{|c|c|c|c|c|c|}
\hline \multirow{2}{*}{$\begin{array}{l}\text { Housing } \\
\text { market areas }\end{array}$} & \multirow{2}{*}{$\begin{array}{l}\text { Total public } \\
\text { housing built }\end{array}$} & \multirow{2}{*}{$\begin{array}{l}\text { Public housing } \\
\text { demolished by } 1.4 .16\end{array}$} & \multicolumn{3}{|c|}{ Remaining Dwelling Stock } \\
\hline & & & Total & $\begin{array}{l}\text { Privately owned } \\
\text { (sold by } 31.12 .15 \text { ) }\end{array}$ & $\begin{array}{l}\text { Council } \\
\text { rented }\end{array}$ \\
\hline City Centre & 5989 & 494 & 5495 & 814 & 4581 \\
\hline East & 3886 & 458 & 3428 & 786 & 2642 \\
\hline $\begin{array}{l}\text { Eastern } \\
\text { Periphery }\end{array}$ & 7510 & 1589 & 5921 & 2398 & 3523 \\
\hline North West & 6221 & 1949 & 4272 & 1243 & 3029 \\
\hline $\begin{array}{l}\text { Northern } \\
\text { Periphery }\end{array}$ & 1006 & 269 & 737 & 206 & 531 \\
\hline $\begin{array}{l}\text { Northern } \\
\text { Suburbs }\end{array}$ & 2292 & 339 & 1953 & 764 & 1189 \\
\hline South West & 19388 & 4919 & 14469 & 4805 & 9664 \\
\hline $\begin{array}{l}\text { Suburban } \\
\text { Ring North }\end{array}$ & 7463 & 1032 & 6431 & 1943 & 4668 \\
\hline $\begin{array}{l}\text { Suburban } \\
\text { Ring South }\end{array}$ & 5802 & 653 & 5149 & 1332 & 3817 \\
\hline Total & 60897 & 12350 & 48547 & 14882 & 33665 \\
\hline
\end{tabular}

Source City of Birmingham 


\subsection{The Central Estates}

A case study of five adjacent estates in central Birmingham informs the rest of this chapter. It draws on research and observation over more than 10 years (Hall et al. 2003, 2005b; Rowlands and Murie 2009). The Central Estates were built in the 1950s and 1960s, on land cleared following demolition of high-density housing built without modern amenities and often with outside toilets and washing facilities. Figures 6.2,6.3a, b present images typical of housing in the area, scheduled for slum clearance. By the 1950 s, these predominantly private rented dwellings were affected by poor maintenance and in some places by wartime bomb damage. Their original design and physical deterioration meant they failed to reach minimum fitness standards for healthy housing.

The new estates that replaced slum housing reflected the political and professional enthusiasm for towers in the park, one- and two-bedroom flats, maisonettes and high-rise blocks. The estate layout was a compromise: previous roads were retained with limited new landscaping for tower blocks in green spaces. There were new community facilities although budgetary constraints and services nearby restricted these. Figures 6.4 and 6.5 present positive images of the new estate-a new shopping precinct and a children's paddling pool. Many of the first residents of the Central Estates had previously lived in the neighbourhood and new dwellings were initially popular. By the mid-1990s, however, the management and maintenance of properties and green spaces had largely failed. The paddling pool in Fig. 6.4 no longer existed, and the shops in Fig. 6.5 were mostly empty. The Central Estates were among the most deprived in the city, with high turnover and vacancy rates and poor local facilities, including schools and shops. Estate Action and other funding had enabled some refurbishment but residents felt they were repeatedly overlooked and demanded investment in the neighbourhood. Residents protested about 'The Slum Quarter of Birmingham', outside the city council offices, on a major road route into the city adjacent to the estates (Fig. 6.6a, 6.3b) and elsewhere.

Faced with protests, the city council, with residents' support, bid for Government funding for regeneration under the Estates Renewal Challenge Fund (ERCF). Once this bid was approved and there was a promise of funds, an offer to residents was prepared setting out what was proposed for each part of the estate including demolition, details of refurbishment, proposals for new housing, other property development and new parks. The bid and offer emphasised local priorities and tenant demands rather than conforming to bidding guidelines. It would have been less costly and more comfortable for government if more refurbishment had been proposed with less demolition and new build. The offer was subject to a ballot and residents voted to accept it, having also secured an undertaking from the council to reinvest any receipts from sales of land and property within the area, back in the area. Following the ballot, approval was given to the payment of grant and to the transfer of the council housing that was a condition for payment. Residents decided against working with an existing housing association and Optima Community Association was established with an unprecedented level of tenant 


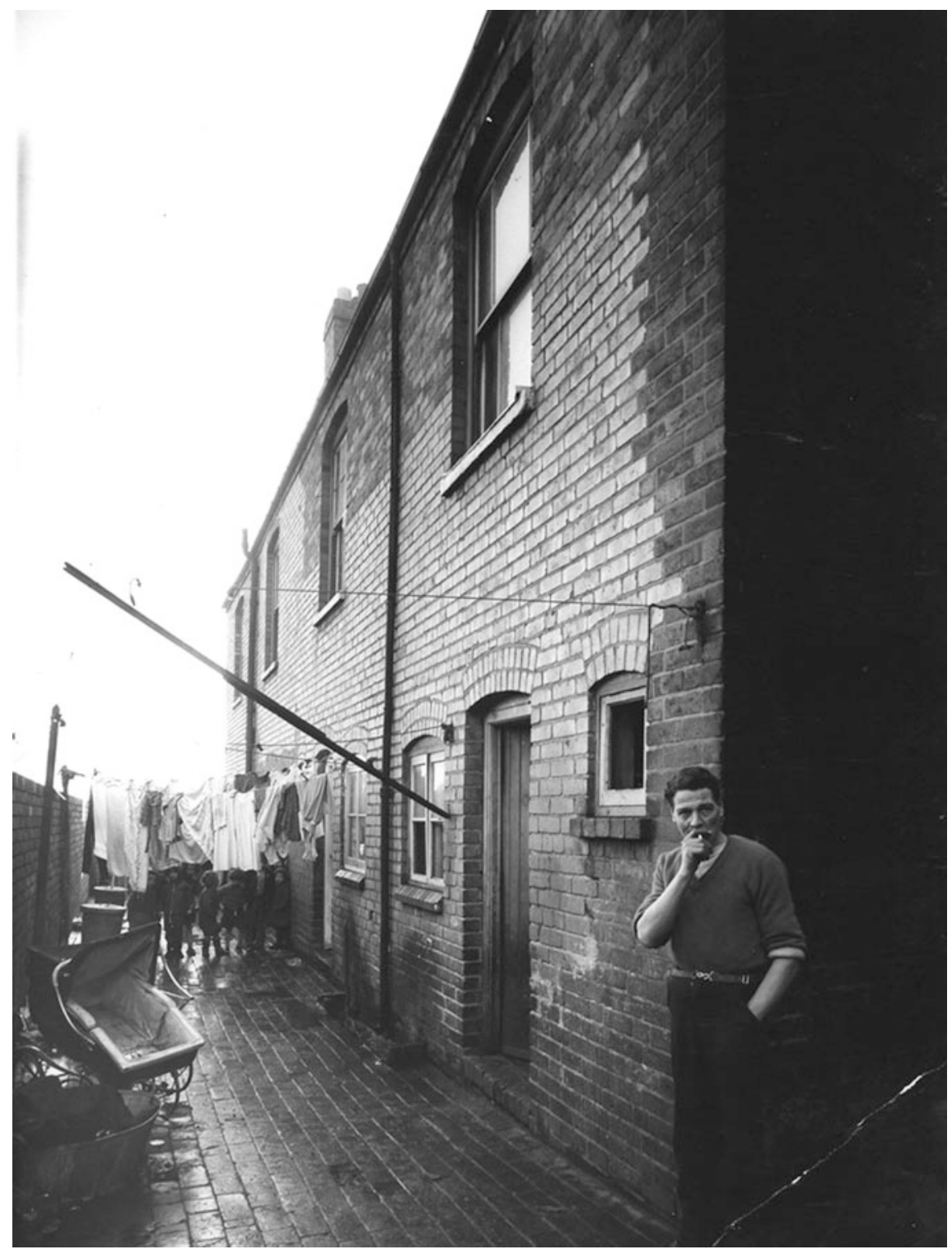

Fig. 6.2 Rear entries to Victorian terraced housing, 1950s, Birmingham. Source Birmingham Library Archives and Optima Community Association, used with permission

participation - seven tenant Board members elected by tenants, three council nominees and five 'independents'.

The Central Estates had some 2,900 council dwellings with 5\% sold under the Right to Buy. The regeneration programme envisaged 1,400 properties being 
(a)

(b)

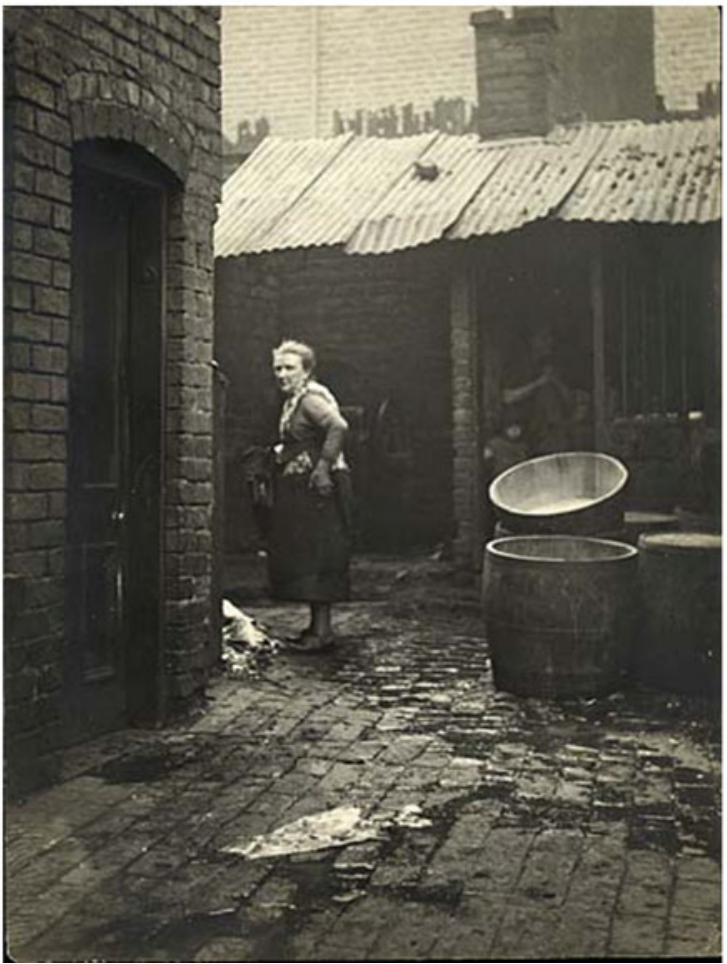

Fig. 6.3 a Streetscape of typical slum properties before clearance, Birmingham $\mathbf{b}$ Rear yard of slum property before clearance, Birmingham. Source Birmingham Library Archives and Optima Community Association, used with permission 


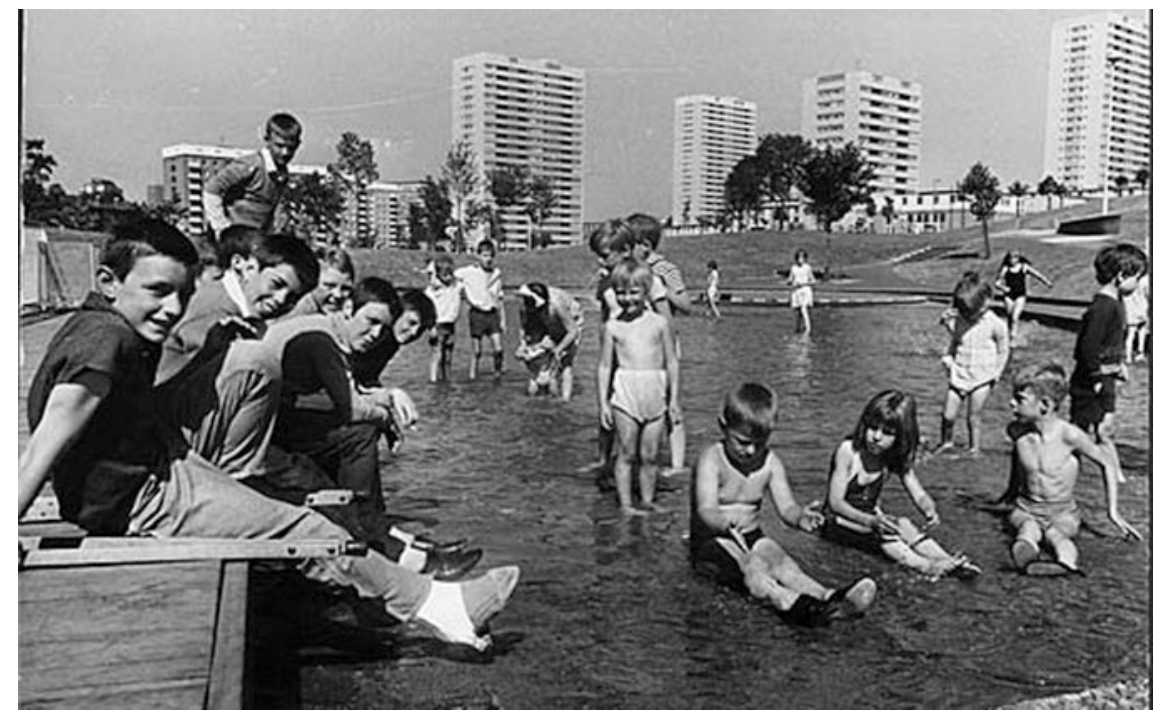

Fig. 6.4 A short-lived paddling pool among towers in the park, 1960s, Lee Bank, Birmingham. Source Birmingham Library Archives and Optima Community Association, used with permission

demolished, 1,400 refurbished and over 2,500 new homes in different tenures (including 550 affordable, predominantly social rented, housing). Refurbishments involved modernisation of kitchens and bathrooms, updating of heating systems, replacement of windows, external cladding and insulation-all improving energy efficiency and meeting the Decent Home standard. Regeneration involved redesigning the estate with changes to levels and road layouts, two new, linked parks replacing the unused green space that had existed around tower blocks, two further small parks, new community facilities (including a health centre, school and community centre) and commercial premises (offices, shops and hotels). What was proposed transformed the look and feel of the estates. Major landmark tower blocks were demolished (including Haddon Tower in Fig. 6.7), while others were refurbished to a high standard. These included the highest two blocks (the 32-storey Sentinels) where new windows and exterior cladding, rewiring, new bathrooms and kitchens and new lifts and entry arrangements to improve security were involved (Fig. 6.8). At the heart of the estates, Fig. 6.9 shows remaining refurbished towers alongside a large area where demolitions facilitated significant work shifting earth to change levels for new mixed-tenure housing built around new parks.

The investment in these estates was substantial: in Birmingham, only the Housing Action Trust funding for Castle Vale was comparable. Funding for 


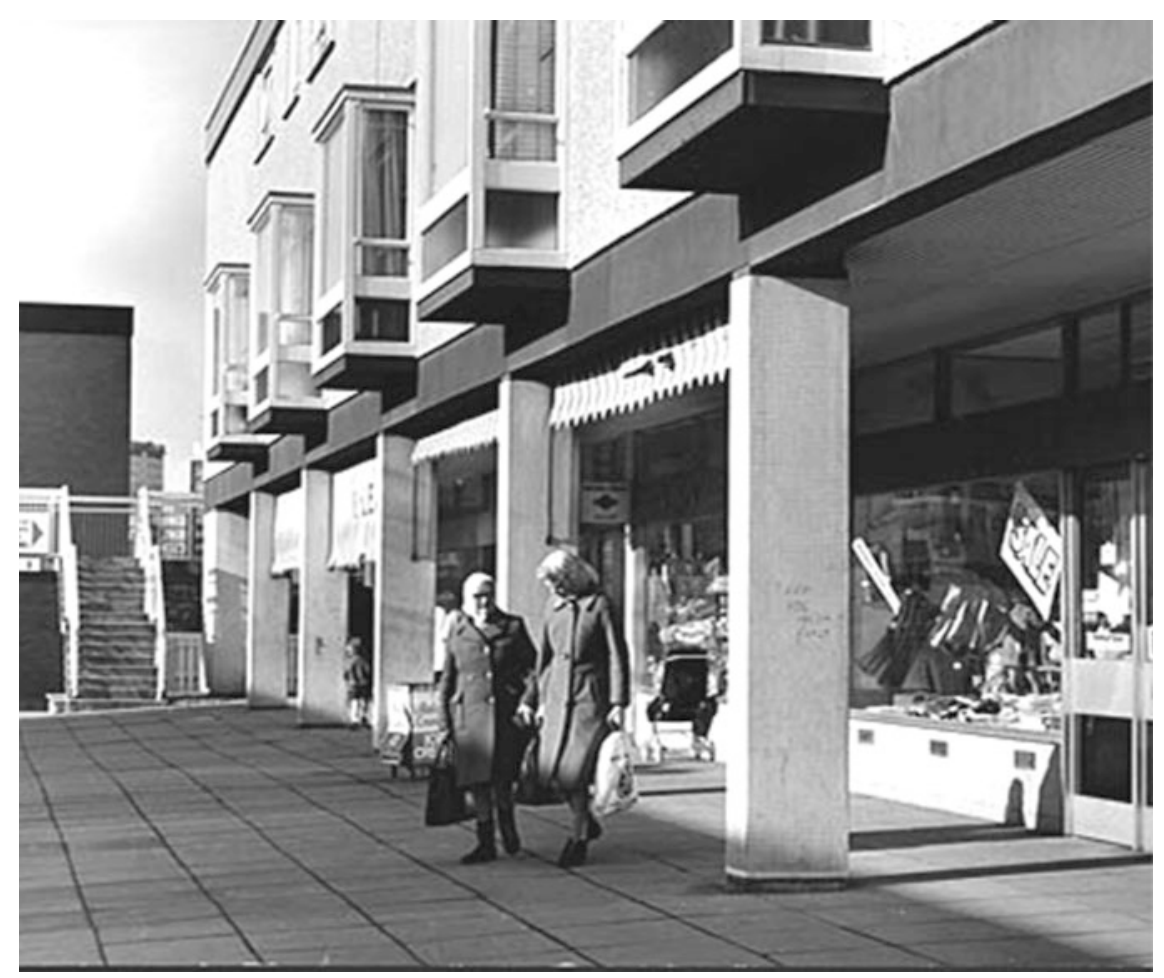

Fig. 6.5 Shopping opportunities in the housing estate, Lee Bank, Birmingham. Source Birmingham Library Archives and Optima Community Association, used with permission

clearance and demolition on the Central Estates exceeded $£ 12$ million: $£ 50$ million for refurbishment of social housing and $£ 83$ million for new social housing. The initial ERCF grant exceeded $£ 46$ million and included over $£ 4$ million for social and economic regeneration. Sales of land and property generated a further $£ 20$ million for reinvestment in the area. These figures exclude investment to build some 700 private dwellings in the first 10 years and a further 1,000 subsequently. A development agreement for the most ambitious and transformative part of the regeneration involved a lead private developer building under licence with the council and Optima as partners. After 10 years, 275 houses and 402 flats had been completed for social rent and a further 25 houses and 45 flats for shared ownership. Continuity in external designs made it hard to identify the tenure of properties: most new houses were rented from Optima, and most new private dwellings were flats. The clearance and demolition programme had been completed along with substantial new building when the credit crunch affected private sales: the developer stopped building for sale in 2008 and it was 2 years before construction restarted. Two blocks of apartments, held at shell construction stage pending sales, were sold to Optima as additional social housing, at below 50\% of 
(a)

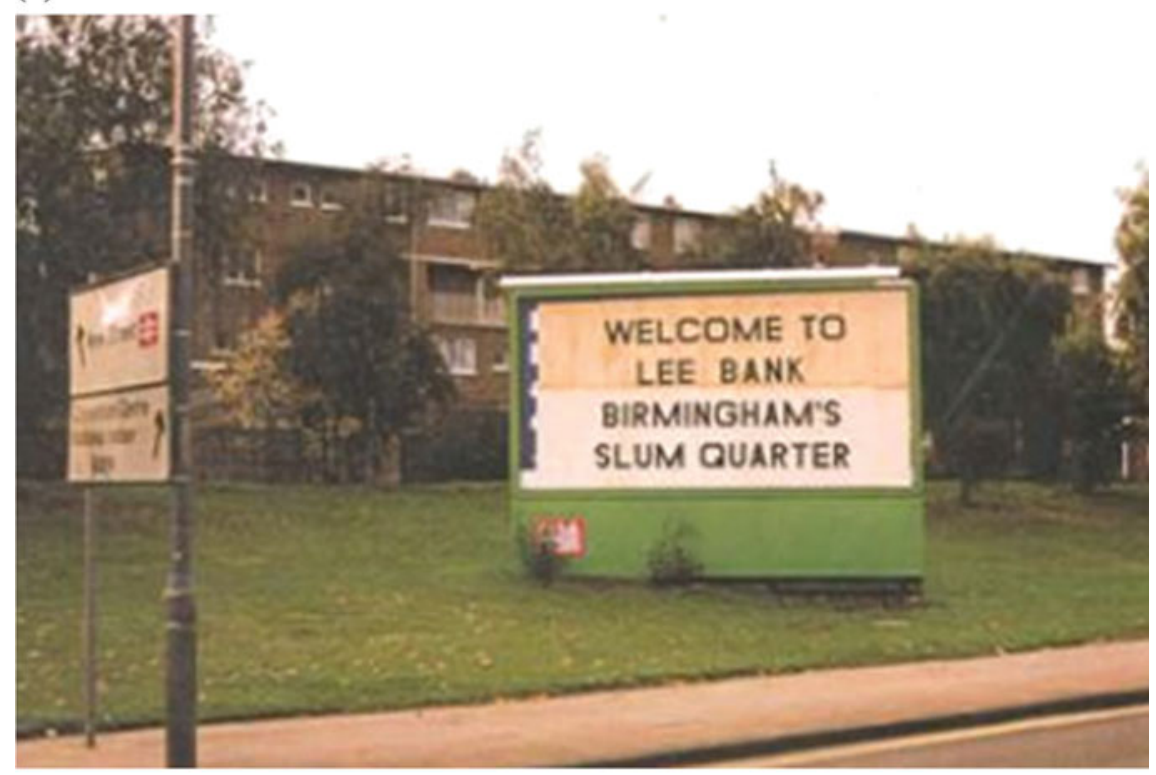

(b)

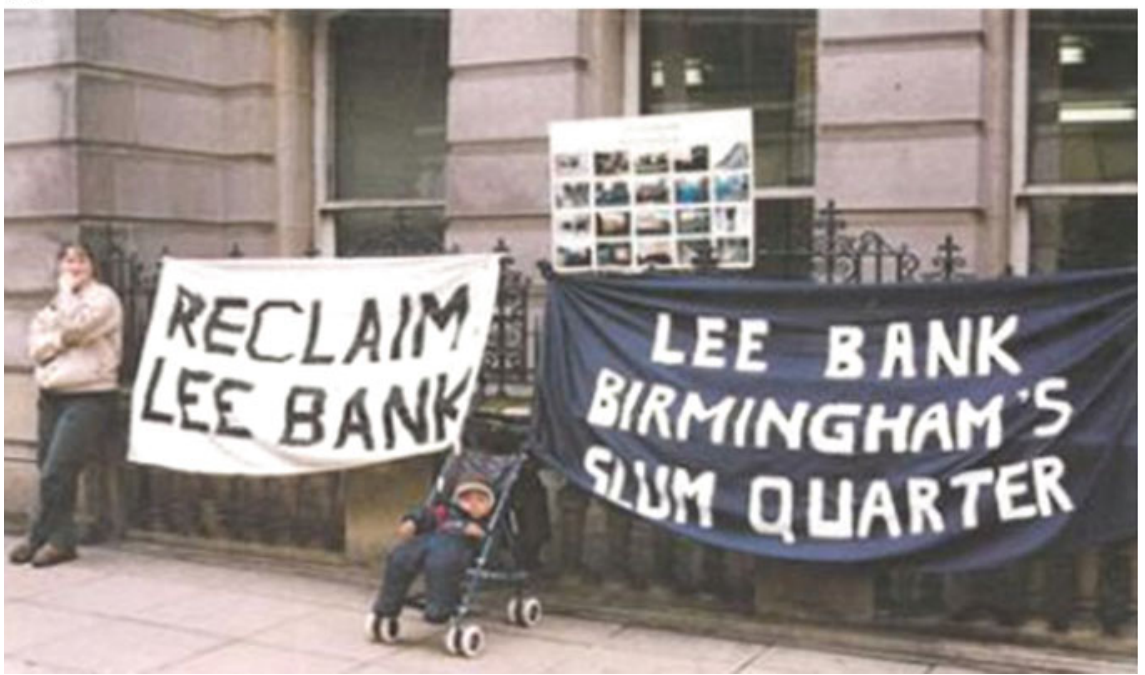

Fig. 6.6 a Residents' protests on Bristol Street, late 1990s, Lee Bank, Birmingham b Residents' protests outside the Council Offices, late 1990s, Lee Bank, Birmingham.

Source Birmingham Library Archives and Optima Community Association, used with permission 


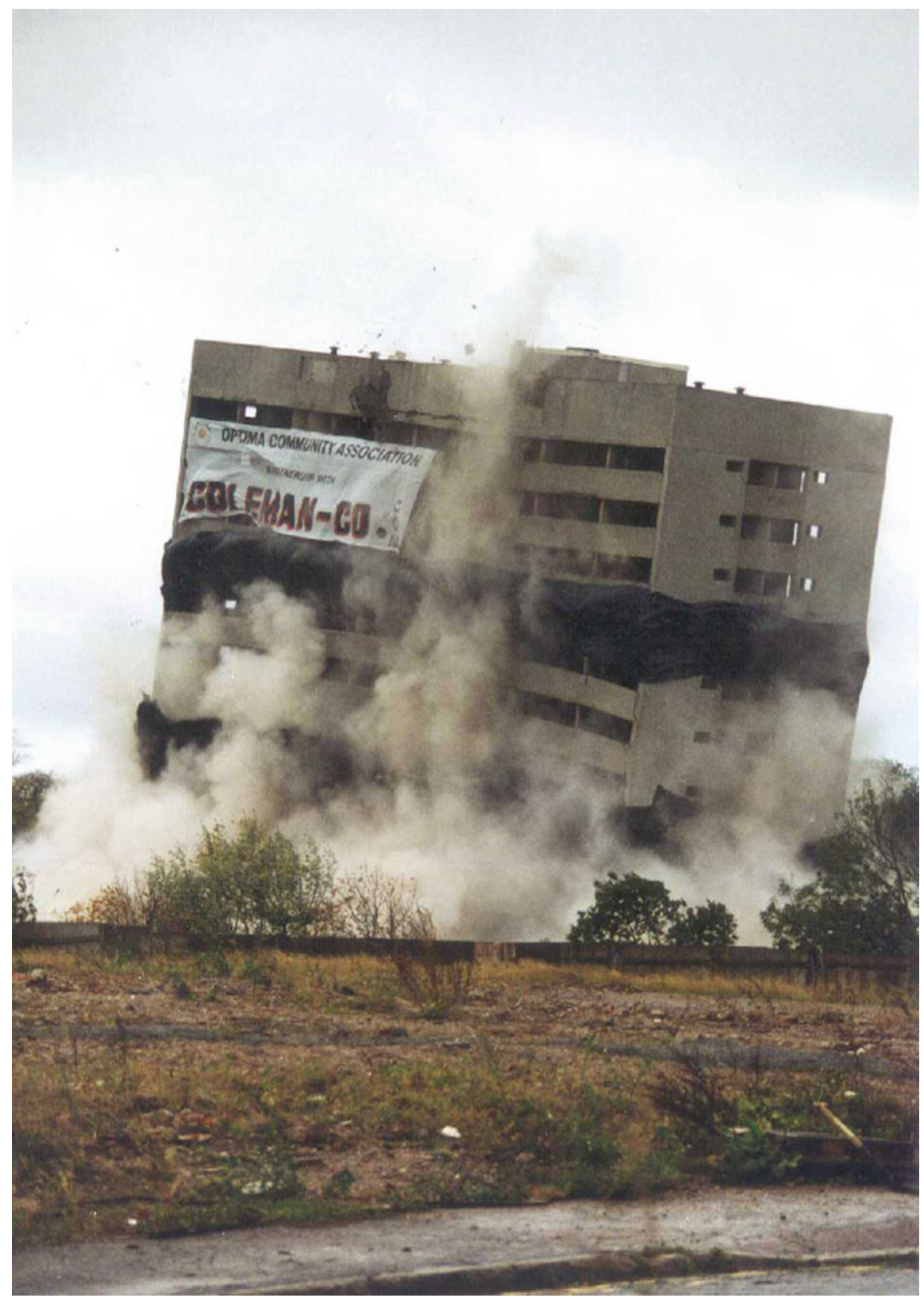

Fig. 6.7 Explosive demolition of Haddon Tower, Lee Bank, Birmingham. Source Birmingham Library Archives and Optima Community Association, used with permission 


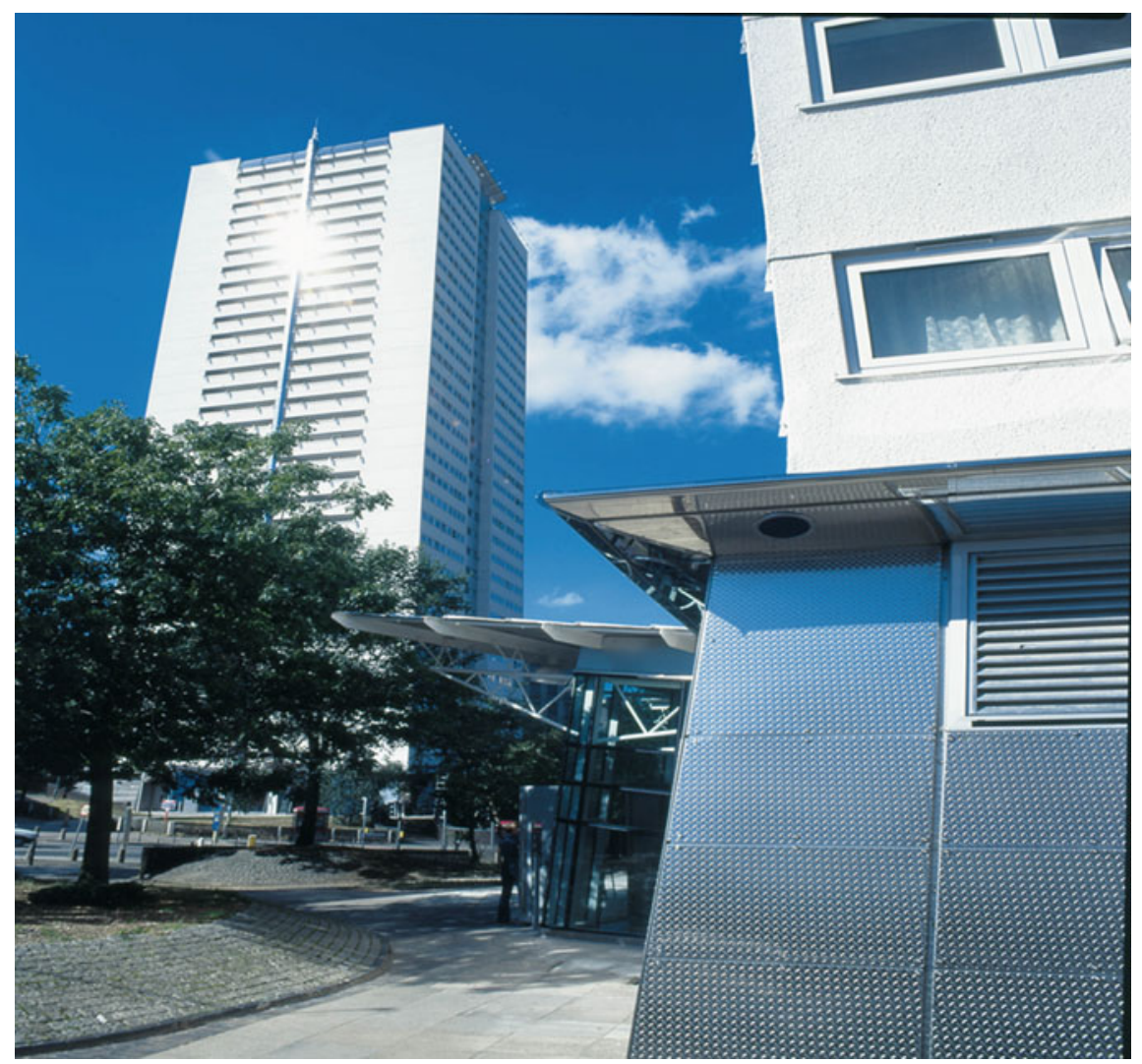

Fig. 6.8 The Sentinels (32-storey blocks) following refurbishment. Source Birmingham Library Archives and Optima Community Association, used with permission

the intended private sale price and with grant funding as government sought to deal with problems arising from the credit crunch. Importantly, the developer did not cease trading and continuity of their personnel (and Optima and city council personnel) sustained the underlying strategy.

By 2017, regeneration of the Central Estates was almost complete. It had taken longer than planned, but the ambitions in terms of quality of housing, tenure mix, new parks, shops, community, school and health facilities and commercial office accommodation were largely achieved. Modernised social rented housing included houses and a greater mix of flats. Building properties for sale completed the transformation from a residential council estate to a mixed-use, mixed-tenure estate. The transformation was achieved through joint action by the state and private sectors, and legitimate questions arise about winners and losers, and whether regeneration was simply planned gentrification and whether improvements were sustainable. 


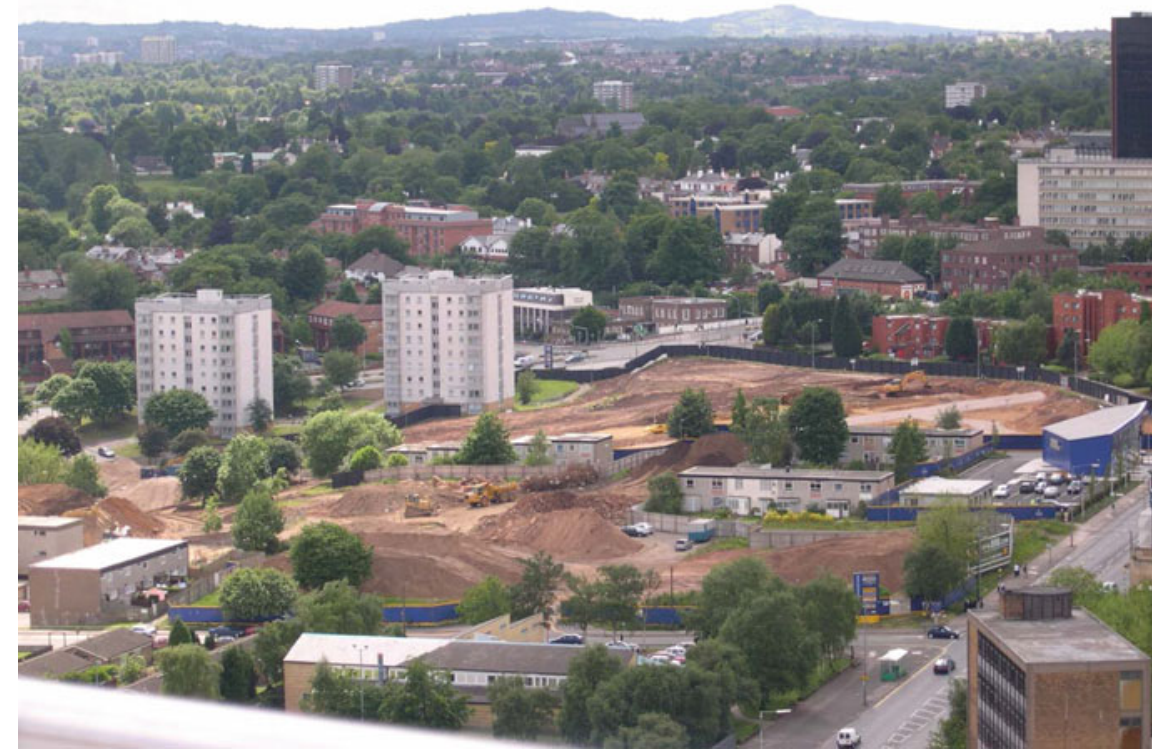

Fig. 6.9 Refurbished tower blocks alongside cleared sites being prepared for new parks and new mixed-tenure housing. Source Birmingham Library Archives and Optima Community Association, used with permission

Lees (2008) suggested that regeneration initiatives fail to improve the quality of life for neighbourhood residents and involve gentrification with 'overwhelmingly negative effects', particularly through displacing low-income groups. This does not hold for the Central Estates. They were in progressive decline and regeneration involving demolition and major capital investment represented an expensive change in approach. Continuing neglect would have further damaged the neighbourhood and prepared the ground for wholesale redevelopment or privatisation. Doing nothing would not have defended residents or public sector housing or prevented eventual gentrification. In the Central Estates, residents' opposition to doing nothing was the catalyst for regeneration, demolition and tenure diversification. These were each regarded positively as changing neighbourhood dynamics: building private housing also generated funds for social housing renewal.

A critical test is whether existing residents benefitted or were displaced. Refurbishment did not require tenants to move out but demolitions involved 1400 properties. Their tenants received Home Loss and Disturbance Payments and gained priority in social housing allocations on the estate and across the city. Where residents in properties being demolished wanted to stay in the area, but could not stay because no suitable properties were available, they could register their wish to return. Households on this 'returners' list had priority for subsequent social housing 
vacancies in the area, including new properties. By mid-2006, all registered 'returners' had returned: everybody forced to move but wanting to move back had done so. In some cases, where the opportunity to move back was not exercised, clearance had enabled households to move and find satisfactory housing elsewhere. The conclusion that there was little or no direct displacement reflects a managed and regulated regeneration process with strong resident scrutiny. The state and private sectors were involved in regeneration to pursue their own interests but there were real material gains for existing residents rather than wholly negative outcomes. Regeneration delivered benefits to local and lower income people. Before the regeneration commenced, there were high levels of vacant homes and tenancy turnover-both indicating the unattractiveness of the estate and failures of management. In 1998 , over $20 \%$ of properties were vacant and in $2000 / 01,17 \%$. The annual tenancy turnover rate was also over $20 \%$.

Were improvements sustained or did problems re-emerge? By 2017, some of the earliest investments had been completed 15 years earlier-but construction was still underway on the last development site. Assessing the sustainability of improvements remains difficult but reduced levels of abandonment, turnover and empty properties had been sustained. There were 46 abandonments in 2001/02, 29 in $2002 / 03$, and four, nine and four in the following 3 years, and they remained low with only one property abandoned in 2016. High demand was also sustained beyond the regeneration phase and turnover of properties declined from over $11 \%$ in $2001 / 02$ to $6 \%$ in $2015 / 16$. Transfer to a housing association headed off the risk that property problems would emerge without resources to remedy them: by 2017 , an asset management strategy was working and funding for a 20-year kitchen and bathroom replacement programme and the expensive and complicated replacement of soil and vent pipes in tower blocks.

The Central Estates were selected for regeneration partly because of high levels of deprivation, and funds were explicitly used to improve social and economic circumstances. Success in this area is difficult to evaluate and complicated by population change. Rent arrears' levels had improved but remained above those in some parts of Birmingham because of the large numbers of tenants in and out of work, or in low-paid jobs. There was a slowly rising trend in the proportion of new tenants that were from black and minority ethnic groups. In the financial year 2015/ $16,72 \%$ of new tenants were black and minority ethnic households compared with $52 \%$ in $2003 / 04$, and $62 \%$ in $2005 / 06$. As in the past, the vast majority of lettings were made to residents under the age of 45 .

Regeneration of the Central Estates was facilitated by continuities in personnel and policy. But, however well planned and intentioned the regeneration was and however effectively it represented residents' demands, unanticipated changes put it at risk. Implementation of the regeneration strategy was interrupted by planning disputes and problems over commercial premises but, more importantly, by the credit crunch in 2007 and by changes in government's approach to benefits. The Welfare Act 2012 was designed to reduce the welfare budget nationally. In the central estates, reductions in housing benefits (including cases where tenants were deemed to have spare rooms) undoubtedly affected working age tenants: some 
accepted transfers to smaller properties to reduce housing costs but the majority coped in other ways. The pressure on household budgets affected the sustainability of regeneration with changes that could force some residents to move and some tenancies to fail. Reduced benefits for people under 35 years old also affected the affordability and lettability of one-bedroom flats in tower blocks and the successful policy to not house families in tower blocks was, consequently, changed.

The regeneration programme for the Central Estates supported higher staffing levels and closer engagement with residents. Optima as a regeneration vehicle with its own staff developed its own culture, reflected in the participation of residents and attention to strategy and detail over major investments and routine management. However, once demolition, refurbishment and new building were completed, existing levels of staffing could not be supported by the residual budget. With government and the regulator convinced about economies of scale and maintaining a patronising disposition, rather than valuing accountability to tenants, there was pressure for Optima to become part of a larger group of housing associations. Whatever its other merits, acceding to this pressure diluted local resident involvement and accountability.

\subsection{Conclusion}

Estates built in the mass housing era have not stood the tests of time as well as traditionally built council estates. What happened to them was not, however, simply a consequence of design and construction or even of life cycle processes of obsolescence and population ageing. Estates were also affected by economic and social changes, the residualisation of council housing and the promotion of private housing. Mass estates became among the least attractive parts of what increasingly became a residual council tenure - a double residualisation. Many estates, including the Central Estates, were in decline. In the Central Estates, action by residents and the city council accessed funds and enabled regeneration that benefitted existing and new residents. The modernised estate had more social and tenure mix and more middle-class households, but because of the amount of additional housing rather than displacement. It also improved the quality and variety of social housing and improved energy efficiency, in new and refurbished social housing, benefitted tenants. The estate continued to house tenants from black and minority ethnic groups and low-income households, but in better housing than previously. Regeneration did not involve displacement, improved residents' living conditions and favourably changed the estate's trajectory. It was a better response to decline than doing nothing and leaving the way open for privatisation and regeneration driven by different interests, with less concern for avoiding displacement, improving social housing and changing neighbourhood facilities and dynamics.

Contextual changes, demolition, privatisation and regeneration initiatives have variously and unevenly transformed mass public estates. Some 50 years after construction, estates are very different than at the outset. Their transformation 
results from factors, layered upon each other, that were more or less important in different places. For example, some estates were severely damaged by local factory closures; others were affected by design and construction failures and associated high turnover. Different starting points (location, design and construction), life cycle changes (the deterioration of physical fabric and changing population), economic and social developments, management and maintenance practices and regeneration and renewal responses interacted with each other. While the first two of these suggest some intrinsic characteristics affecting how estates evolved, the latter two emphasise social and political action. Distinctive characteristics of mass estates generated different risks and contingencies than traditional estates, but did not determine their history.

A life cycle account highlights changes over time rather than physical characteristics. Estates that were generally popular at the outset lost popularity and reputation through obsolescence, failures of management and maintenance and changing contexts. Mass housing proved less sustainable than single-family dwellings and many estates soon needed costly, estate level, regeneration. When and how regeneration was conducted affected who benefitted and reset the starting position for the next phase of their life cycle. But whatever the potential, following regeneration, what actually happens depends upon policies, political action and social and economic changes.

The role of mass public housing estates has changed dramatically. When they were built they formed part of a privileged, high demand, high standard tenure. While not all mass housing became unpopular and not all traditional council housing remained popular, by 2017 mass estates were often stereotypically portrayed as dysfunctional areas for homeless and vulnerable households, new migrants and ethnic minorities. Their residents risked being denigrated and demonised because of their incomes, immigrant status, ethnicity or status as social tenants. The politics of race and migration and neo-liberal attitudes to poverty and welfare formed a further layer affecting estates. The estates did not, however, provide the only housing for marginal groups. Other social housing as well as home ownership housed lower income households and, for many of the most vulnerable, new migrants and younger single people, poor quality privately renting was most accessible.

A layered and life cycle approach highlights changes over time and differences between estates. It suggests three different ideal types among estates:

- Estates that were 'built to fail' - so flawed by their scale, design, construction and layout that they were bound to fail.

- Estates that were 'failed by management' - where neglect, management and maintenance failures and restrictions on expenditure prevented appropriate responses to initial problems and challenges associated with economic and social change.

- Estates that were potentially 'resilient'-where locational and other factors sustained demand. 
Each of these ideal types has been exposed to decline with the passage of time but they map on to two strategic responses: renewal and redesign, and better management. In practice, both better management and new capital expenditure have been necessary but not always sufficient for sustainability. Where estates have not been demolished, major refurbishment has been critical. The discussion of the Central Estates highlighted factors making refurbishment work-including residents' involvement, the organisations and partnerships involved, significant government funding and continuity and commitment of professional staff working locally. Some elements are less visible-locational advantage and regulatory control. Other elements potentially put refurbishment at risk - privatisation, deregulation, wider economic fluctuations, organisational change, loss of local control and disrespectful treatment of marginal groups.

Responses to the decline of mass estates have variously involved minimal action (unmodernised estates continuing to adversely affect residents' health and well-being), renewal and refurbishment, and demolition. Whether regeneration involved displacement and gentrification or improved liveability and opportunities for existing residents is an empirical question, but reflects financial arrangements, political processes and social action. In some cases, refurbishments have failed other tests. The deaths of 71 people at Grenfell Tower in the London Borough of Kensington and Chelsea following a fire in June 2017 highlighted health and safety problems in refurbished tower blocks. Public and media debate about this catastrophe focussed on failures associated with funding, technical solutions, regulation, contracting, inspection and implementation of refurbishment. But underlying these failures was underfunding and neglect of social housing over decades and the treatment of marginal groups and ethnic minorities by some public and private sector agencies. Layered explanations for continuing failure must include these and other elements. Doing nothing, privatisation and regeneration that serves developers' interests (and involves displacement) and refurbishment all pose risks for residents. It is unclear whether increased awareness of failure will further damage the reputation of high-rise blocks, mass estates and public housing or will lead to increased funding, regulatory supervision and resident engagement that will improve estate futures.

Acknowledgements The author acknowledges assistance from the Birmingham Library Archives, the City of Birmingham and Optima Community Association

\section{References}

Cantle T (1986) The deterioration of public sector housing. In: Malpass P (ed) The housing crisis. Croom Helm, London, pp 57-85

Cooney EW (1974) High flats in local authority housing in England and Wales since 1945. Multi-Storey Living, Croom Helm, London

Dunleavy P (1981) The politics of mass housing in Britain, 1947-1975. Clarendon Press, Oxford Forrest R, Murie A (1990) Selling the welfare state, 2nd edn. Routledge, London 
Hall S, Lee P, Murie A, Rowlands R, Sankey S (2003) Large housing estates in united kingdom overview of developments and problems in London and Birmingham. Restate Report $2 \mathrm{~J}$. University of Utrecht, Utrecht

Hall S, Murie A, Knorr-Siedow T (2005a) Large housing estates in their historical context. In: van Kempen R, Dekker K, Hall S, Tosics I (eds) Restructuring large housing estates in Europe. Policy Press, Bristol, pp 63-84

Hall S, Murie A, Rowlands R, Sankey S (2005b) Large housing estates in London and Birmingham, United Kingdom, Opinions of Residents on recent developments. Restate Report 4j. University of Utrecht, Utrecht

Henderson J, Karn V (1987) Race class and state housing. Gower, London

Holmans AE (1987) Housing policy in Britain. Croom Helm, London

Jones CA, Murie A (1999) Stability and change in council estates: the right to buy. Hous Plann Rev 54(2):11-12

Lee P, Murie A (1997) Poverty, housing tenure and social exclusion. The Policy Press, Bristol

Lee P, Murie A (2002) The poor city: national and local perspectives on changes in residential patterns in the British City. In: Marcuse P, van Kempen R (eds) Of states and cities: a partitioning of urban space. Oxford University Press, Oxford

Lees L (2008) Gentrification and social mixing: towards an inclusive urban renaissance? Urban Studies 45(12):2449-2470

Murie A (2016) The right to buy?. Policy Press, Bristol

Rex J, Moore R (1967) Race, community and conflict. Oxford University Press, Oxford, Community and Conflict

Rex J, Tomlinson S (1981) Black immigrants and the housing system in Birmingham. In: Cochrane A, Hamnett C, McDowell M (eds) City economy and society: a comparative reader. Harper and Row, London

Rowlands R, Murie A (2009) Whose regeneration? The spectre of revanchist regeneration Palgrave. In: Rowlands R, Musterd S, van Kempen R (eds) Mass housing in Europe. Macmillan, Basingstoke, pp 235-264

Sutcliffe A (1974) A century of flats in Birmingham, 1875-1973. In: Sutcliffe A (ed) Multi-storey living. Croom Helm, London, pp 181-206

Sutcliffe A, Smith R (1974) Birmingham 1939-1970, History of Birmingham, vol 3. Oxford University Press, London

Open Access This chapter is licensed under the terms of the Creative Commons Attribution 4.0 International License (http://creativecommons.org/licenses/by/4.0/), which permits use, sharing, adaptation, distribution and reproduction in any medium or format, as long as you give appropriate credit to the original author(s) and the source, provide a link to the Creative Commons license and indicate if changes were made.

The images or other third party material in this chapter are included in the chapter's Creative Commons license, unless indicated otherwise in a credit line to the material. If material is not included in the chapter's Creative Commons license and your intended use is not permitted by statutory regulation or exceeds the permitted use, you will need to obtain permission directly from the copyright holder. 


\title{
Chapter 7 \\ Sprouted All Around: The Emergence and Evolution of Housing Estates in Brussels, Belgium
}

\author{
Rafael Costa and Helga de Valk
}

\begin{abstract}
The purpose of this study is to investigate the socioeconomic evolution of large housing estates in Brussels, Belgium, in particular their role in shaping residential segregation in the city. As in many European countries, modernist and functionalist ideas of the mid-twentieth century led to the raising of large housing estates in Brussels, in an attempt to offer middle-class households affordable yet modern and comfortable dwellings. However, contrary to other countries, the development in Belgium was marked by general housing policies that promoted homeownership, with limited investment in social housing, and a lack of laws and political vision related to spatial planning Whereas some public ensembles were conceived by modernist architects, most of Brussels' large housing estates were built by private contractors in peripheral neighbourhoods and were aimed at homeownership of the lower middle class. In this chapter, we first present a brief historical perspective of the policies, ideologies and territorial processes that made it possible for housing estates to develop and spread in Brussels. Next, we analyse how large housing estates evolved since the 1990s in terms of socioeconomic composition and the role they play in segregation. We finally discuss the challenges, current perspectives and political awareness with respect to large housing estate. Our findings point out that Brussels' housing estates are spatially scattered and have only a limited impact on the concentration of deprivation and foreign nationals. However, the trends identified in our study indicate that housing estates can become important socioeconomic fractures at the local level.
\end{abstract}

Keywords Brussels • Belgium • Housing estates • Public housing Housing policies $\cdot$ Residential segregation

\footnotetext{
R. Costa $(\bowtie)$

Interface Demography, Vrije Universiteit Brussel, Brussels, Belgium

e-mail: rafael.costa@vub.be

H. de Valk

Netherlands Interdisciplinary Demographic Institute, Academy of Science, University of Groningen, The Hague, Netherlands

e-mail: valk@nidi.nl

(C) The Author(s) 2018

D. B. Hess et al. (eds.), Housing Estates in Europe, The Urban Book Series, https://doi.org/10.1007/978-3-319-92813-5_7
} 


\subsection{Introduction}

As in many European countries, modernist and functionalist ideas of the mid-twentieth century led to the raising of large housing estates in Brussels, in an attempt to offer middle-class households affordable yet modern and comfortable dwellings. However, contrary to other countries, the development in Belgium was marked by general housing policies that promote homeownership, with limited investment in social housing, and a lack of laws and political vision related to spatial planning (De Decker 2008). Whereas some public ensembles were conceived by modernist architects, most of Brussels' large housing estates were built by private developers in peripheral, green neighbourhoods and were aimed at homeownership of the lower middle class (Broes and Dehaene 2016).

The purpose of this study is to investigate the socioeconomic evolution of large housing estates in Brussels, in particular their role in shaping residential segregation and social mix in the city.

These housing estates house large numbers of people in extensive areas and as such they can have a considerable effect in shaping ethnic and socioeconomic segregation in the city. If they are deteriorating over time in terms of living standards and housing quality, they might increasingly concentrate deprived households, including newly arrived migrants. In addition, inasmuch as people are socialised in large and deprived apartment complexes, large housing estates may also produce cumulative disadvantages over their residents' life courses (Andersen 2002; Phillips 2007). So far there is limited knowledge on the situation of large housing estates in Brussels, and despite their potential negative effects, no systematic study to date has investigated the impact of housing estates on socioeconomic and ethnic disparities in this city.

In this chapter, we first present a brief historical perspective of the policies, ideologies and territorial processes that made it possible for large housing estates to develop and spread in Brussels (Sect. 7.2). In the third section, we make an inventory of housing estates in Brussels and discuss their location and physical layout. The fourth section analyses how estates evolved in Brussels since the 1990s in terms of socioeconomic composition and the role they play in segregation patterns. Section 7.5 discusses the challenges, current perspectives and political awareness in Brussels with respect to large housing estates.

\subsection{Public Policies and Large Housing Estates: The Belgian Particularity}

In many European cities, housing production in the mid-twentieth century was marked by the construction of vast ensembles of mid- and high-rise apartment buildings. These 'large housing estates', inspired by modernist and functionalist ideas, were often conceived to meet the housing shortage after World War II and to 
accommodate an increasing urban population (Musterd and van Kempen 2005; Wassenberg et al. 2004). Moreover, they were designed in many cases as an affordable social housing alternative provided by the welfare state (Tammaru et al. 2016).

This general pattern observed across Europe was, however, not applicable to Belgian cities. Large housing estates emerged in cities such as Brussels, Antwerp and Liege in a context of population decline, urban sprawl, lack of spatial planning and heavy state promotion of homeownership.

Throughout the twentieth century, Belgian housing policy was based on the promotion of homeownership (De Decker 2008). This was consolidated in the post-war period by the De Taeye act, passed in 1948 (Theunis 2006). With this act, low- and high-income households could profit from grants, tax benefits and loans to buy or to build their own house (Grosjean 2010). In the absence of spatial planning restrictions, households were able to buy land in the city fringes and rural areas and build their own detached house (De Decker 2008; Kesteloot and Cortie 1998). The production of single-family houses became an important instrument of the Fordist economy: the increasing demand for new housing, financed by the state's homeownership policies, nourished economic growth via the building industry (Kesteloot and Van der Haegen 1997).

Homeownership policies resulted in massive urban sprawl in Brussels (De Decker 2008). The emerging middle class progressively left old dwellings in nineteenth-century neighbourhoods and moved to the green outskirts. This process coincided with the arrival of international labour migrants from southern Europe, Turkey and Morocco from the late 1960s onwards. These migrants established themselves in the working-class neighbourhoods left behind by Belgians (Kesteloot and Van der Haegen 1997). The same neighbourhoods have clustered, until today, high shares of non-western migrants, most living in low-quality dwellings from the private rental market (De Winter and Musterd 1998).

Most of the public investment during this time was put into the tools to support homeownership and into infrastructure to accompany urban sprawl (Kesteloot and Cortie 1998). At the same time, investments in public housing remained limited.

The Brunfaut act, passed in 1949, was intended to address the lack of social public housing (Grosjean 2010; Kesteloot and Cortie 1998). Despite this act, public housing production remained marginal compared to private production (Broes and Dehaene 2016). Still, the act allowed the construction of some large public housing estates from the late 1950s through the 1970s (Grosjean 2010; Sterken 2013). These estates were inspired by modernist ideas, and a number of them were conceived by prominent Belgian modernist architects such as Renaat Braem and Willy Van Der Meeren. These estates were built in vast (and cheap) lands on the fringes of Brussels, while the public authorities laid down the infrastructure to connect them to the city centre (Sterken 2013). Following the modernist precepts, these estates were designed to function as independent and autonomous neighbourhoods - an ideal that was never achieved (Sterken 2013). Public estates were intended to be occupied by vulnerable households. As is the case of the public sector as a whole, these estates have functioned as a 'safety net' in the Belgian housing system (De Decker 2008; Winters and Elsinga 2008). 
Parallel to this, private contractors had taken an important role in the economic landscape. As early as the 1950s, contractors began to organise and lobby housing legislation (Broes and Dehaene 2016). One example is the 1953 act for slum clearance. By this act, private firms benefited from a flexible legislation that allowed them to expropriate slums, demolish insalubrious dwellings and buy the land at cheap prices, without specifying the purpose of their investments in the area (Grosjean 2010). The liberal legislation led to what became known as 'brusselisation': a chaotic urban development driven by the speculation of private contractors. Much of the new constructions carried out in this context were related to transport infrastructure and the raising of office towers, but a number of projects were intended for housing (Grosjean 2010).

In particular, two contractors played a major role in the construction of housing estates: Etrimo S.A. and Ammelinckx S.A. These two companies specialised in the mass production of high-rise apartment slabs; together they built approximately 65,000 apartment units in Belgium through the 1960s and the 1970s (Broes and Dehaene 2016). These apartments were intended for homeownership by the lower social classes. They offered standardised, affordable dwelling in apartment slabs, but still equipped with all the 'modern' amenities.

These apartment slabs were replicated in Brussels over the years (Broes and Dehaene 2016, p. 103). In order to keep costs down, contractors preferred to integrate them inside existing transport and service facilities rather than invest in new infrastructure (Broes and Dehaene 2016). Therefore, we find isolated slabs inside the city, as well as agglomerations of slabs in vaster areas in the fringes. In this last case, they are often located next to existing public estates, where infrastructure had recently been laid. Production of private estates was much greater in scope than that of social housing. However, their functionalist, cost-efficient architecture is the subject of much criticism, especially in view of the high architectural quality of modernist estates (Broes and Dehaene 2016).

In sum, large housing estates in Brussels arose as a result of two parallel processes. On the one hand, public modernist estates - some with great architectural appeal-were conceived for social housing following the Brunfaut Act (1949). On the other hand, a greater number of private estates were produced by developers that benefited from liberal laws and were aimed at the homeownership by the lower middle-class.

\subsection{Large Housing Estates in Brussels}

\subsubsection{Definition and Selection of Large Housing Estates}

In this study, we defined a large housing estate as an architecturally coherent ensemble of mid- and/or high-rise buildings, constructed after World War II up until the 1980s, and containing at least 500 housing units. This threshold of 500 housing units was preferred to larger ones (1,000 in other chapters of this book) 
because it better reflects the reality of Brussels' housing estates where those of 1,000 units are extremely rare. Large housing estates are scattered around the city and its fringes, rather than clustered together as is the case in other European cities. In fact, only a few housing estates in Brussels contain more than 1,000 housing units, making it not a very useful level of analyses.

In order to identify the large housing estates in Brussels, we used the most recent available data from the 2011 Census at the statistical sector level. This is the finest geographic level for which spatialised exhaustive data are available in recent years and that are comparable over time with older censuses. The 2011 Census is the first administrative census in Belgium: it combines data from the national population register, the land register (Cadastre/Kadaster) and other databanks at the individual and household levels. For this reason, data on population and dwellings are considered to be rather complete and of high quality.

The process of identifying large housing estates followed quantitative and visual steps. First, we selected all statistical sectors containing more than 250 housing units built in one single decade between 1946 and 1990. The choice of a lower number of housing units - 250 — was to capture large housing estates extending over adjoining sectors or built over different decades. Second, we proceeded to a visual inspection of the pre-selected sectors using an overlay of Google Maps and statistical sectors mapping as well as Google Earth's 3D tool (as depicted in Fig. 7.1). This allowed us to inspect whether the housing units selected with the census data were located in coherent ensembles of mid- and high-rise buildings, to identify the cases in which adjoining sectors made up for coherent estates of 500 housing units, and to check if any housing estate had been left out in the first quantitative selection. We excluded all sectors containing estates with more than 250 units which accounted for less than $50 \%$ of the sectors' population and with no coherent buildings in adjoining sectors. In the end of this process, we kept 59 statistical sectors (Fig. 7.2), corresponding to 30 ensembles that we denote as 'large housing estates'. Among these estates, 16 are composed of private housing only, whereas 11 are composed of public housing and three are mixed.

The main limitation of our selection process is that some statistical sectors are not entirely composed of large housing estates: they may also include other older houses. Still, only 13 of the selected sectors have more than $10 \%$ of their housing units built before 1945, and this share never exceeds 50\%. We therefore assume that the presence of other types of dwellings does not influence the quantitative analysis of large housing estates.

\subsubsection{The Configuration and Physical Aspects of Brussels' Large Housing Estates}

Even though we can find isolated apartment towers inserted in the Brussels urban fabric, most large housing estates are located in the fringes of the city (Fig. 7.2). In the case of private estate projects, the peripheral location is explained by cheaper 


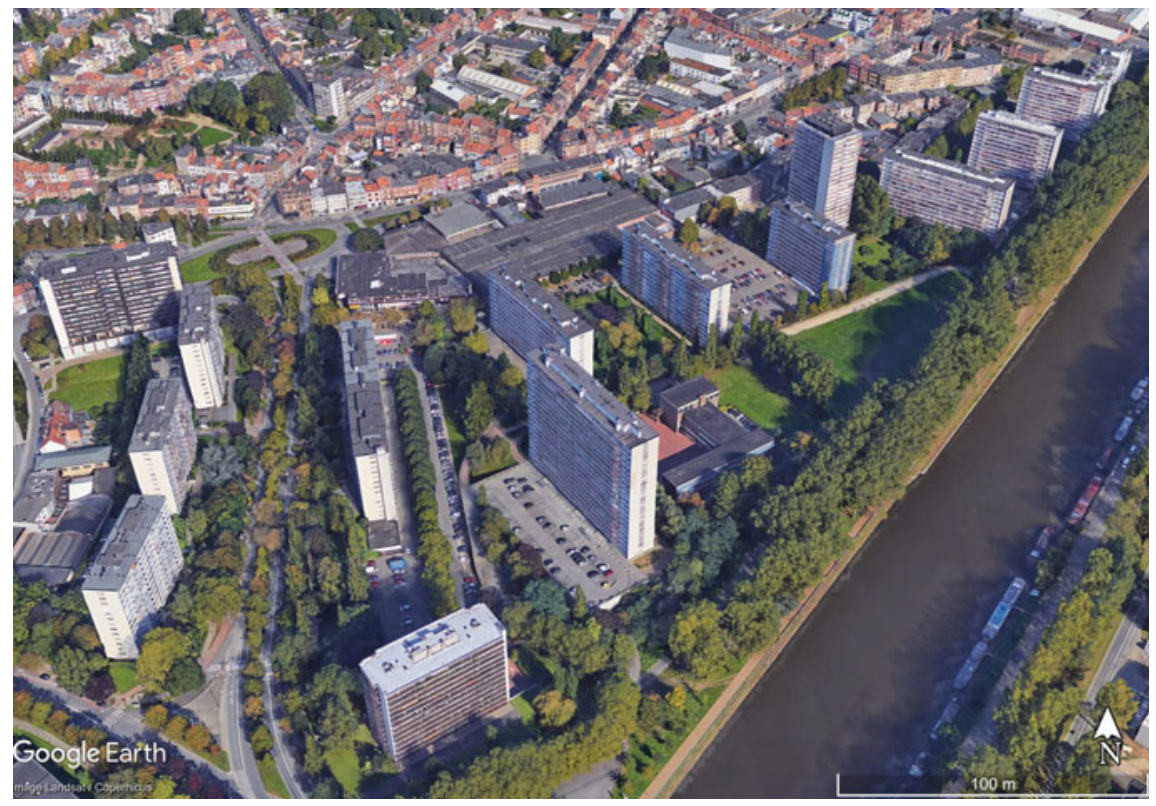

Fig. 7.1 A private large housing estate in Brussels depicted in Google Earth's 3D tool, showing typical configuration of private large housing estates, with similar slabs inserted in a shared greenspace. Source Google Earth

land, but also by the appealing prospect for the lower middle class at the time of an affordable suburban property easily connected to the city centre (Broes and Dehaene 2016). As for some notable social housing estates (e.g. Cité Modèle/ Modelwijk and Ieder Zijn Huis), the peripheral location also benefited from cheaper land but was part of the modernist project of creating independent and autonomous neighbourhoods, combining commerce, services, leisure and housing. Large housing estates in Brussels are typically composed of ensembles of high-rise apartment buildings separated by shared green areas.

Public housing estates are very diverse in terms of style and size. As mentioned above, some public estates were conceived as modernist projects and have a true architectural importance. This is the case of the Cité Modèle/Modelwijk conceived by prominent Belgian modernist architects led by Renaat Braem. The project of this complex (Fig. 7.3) was presented during the Brussels World's Fair in 1958 as a groundbreaking model of social housing embodying the principles of Modernism: industrial-style apartment towers, vast parks and common facilities (Sterken 2013).

Private housing estates, in contrast, were marked by functionalism rather than by modernism: the main concern in their conception was to minimise construction costs and keep the housing units at affordable prices. The few contractors in the large-scale property business made use of standardised blueprints and prefabricated construction elements to produce quasi-identical slabs (Fig. 7.4). The typical slab 


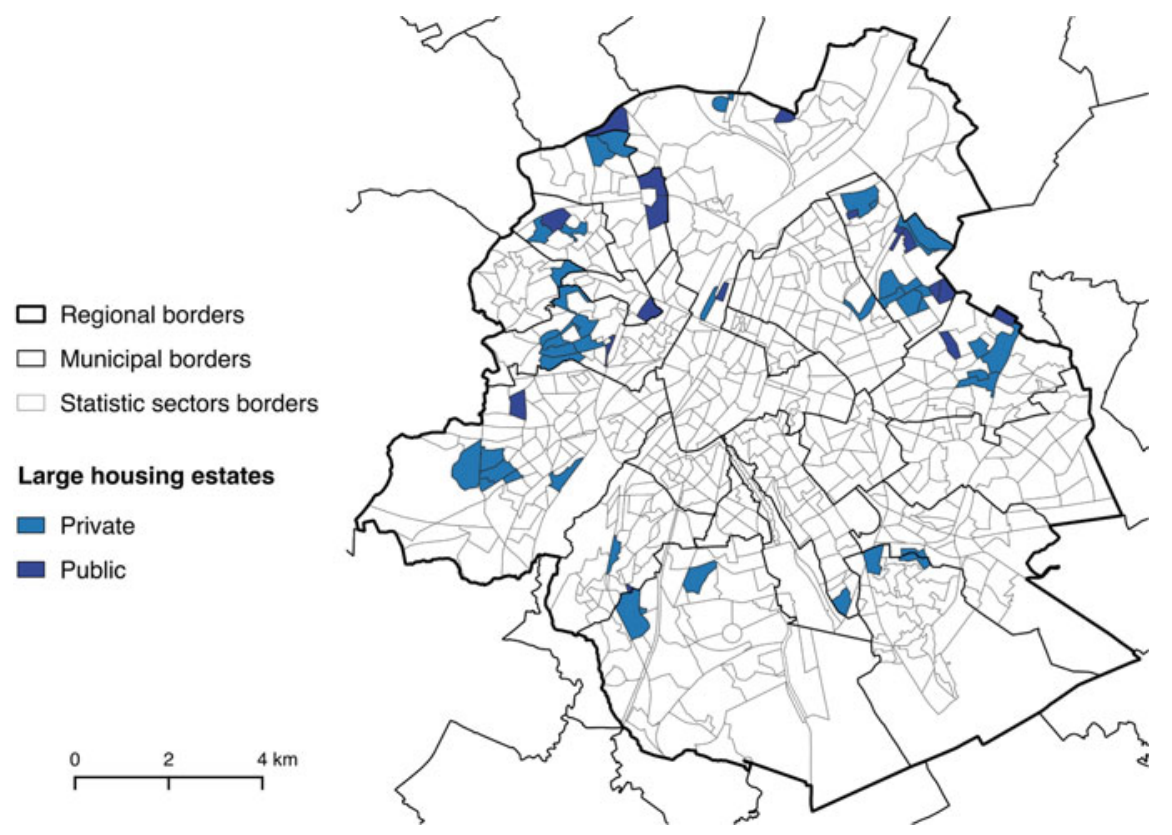

Fig. 7.2 Statistical sectors containing or composing large housing estates in Brussels. Data Source Census 2011 (Statistics Belgium)

contains approximately 150 apartments: they are composed of three columns side by side, with 12 to 13 floors and four apartments per floor. Several slabs scattered over green areas made up for vast private estates (Fig. 7.1).

\subsection{Brussels' Large Housing Estates: Structures of Segregation?}

\subsubsection{Demographic and Socioeconomic Evolution of Large Housing Estates (1991-2011)}

The share of the Brussels' population living in large housing estates is not considerably high. Our data - at the level of the statistical sectors - do not allow us to obtain an exact number of housing estate inhabitants (see Sect. 7.3). Still, a rough estimation can be obtained by examining the number of people in the statistical sectors of the selected estates who lived in housing units built between 1946 and 1990 (Table 7.1). In 2011, this number added up to 84,099, which is no more than $7.4 \%$ of the total Brussels population. Only $2.0 \%$ of Bruxellois live in public estates. If we consider the population in the large housing estates' statistical sectors (including the marginal older buildings that are encompassed), we notice that the 


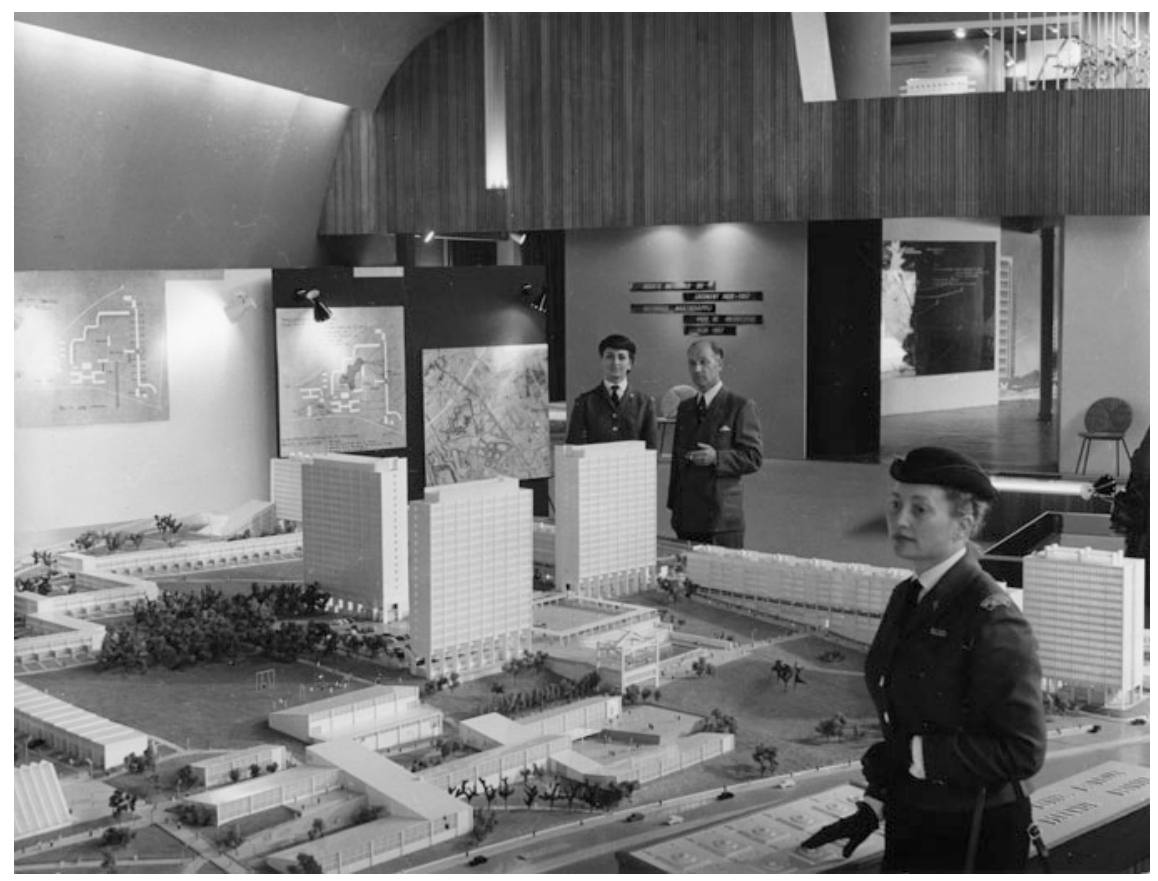

Fig. 7.3 La Cité Moderne: maquette presented at the Brussels Expo 1958 as a model of modern housing. Source $\mathbb{C}$ AAM/Foundation CIVA Stitching, Brussels

estates' population increased in absolute numbers, but remained stable relative to the city. At the same time over the whole period, it is also clear that more people live in private housing estates than in public ones. This is in line with the limited public investments in public housing and the dominance of the private housing market.

Concerning the tenure structure, public estates are logically dominated by rented apartments managed by public housing companies. In private estates, on the other hand, $57 \%$ of the housing units were owner-occupied in 2011. This is considerably high compared to the overall Brussels' level (38\%). What is more, the high ownership rates seem to be a peculiarity of private housing estates that is not linked to the tenure structure of their location in the city: in sectors surrounding these estates, the rate is much lower $(40 \%)$.

We analysed in a second step the socioeconomic composition of those living in large housing estates. To this end, we used data from the censuses of 1991, 2001 and 2011. As definitions and data quality vary from one census to the other (see Deboosere et al. 2003; Deboosere and Willaert 2004; The Eurostat Census Hub Metadata eu/eurostat/web/population-and-housing-census/census-data/2011), we selected indicators that are fairly comparable over the three census rounds. Despite their rather basic level, they offer a good overview of large housing estates' socioeconomic and demographic profiles: 


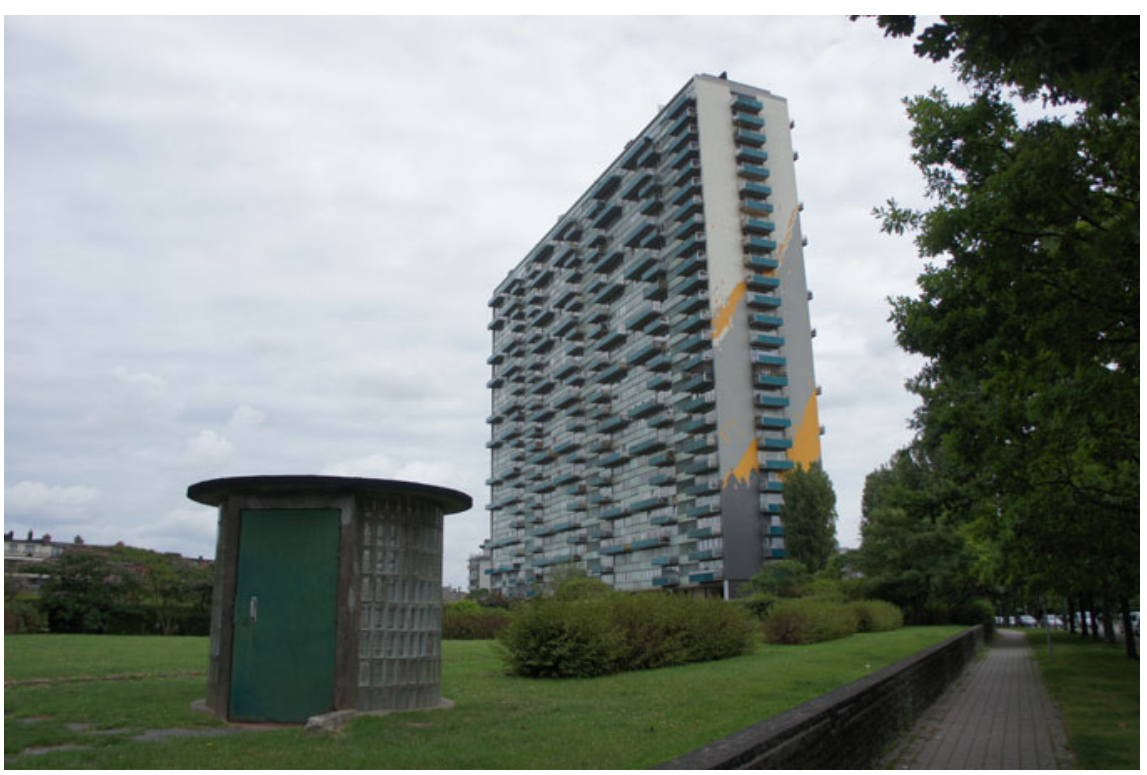

Fig. 7.4 One tower of the Mettewie buildings, an example of a private apartment slab. Source R. Costa and H. de Valk

- age structure: share of the total population aged 0 to 15 and 65 and older;

- share of households composed of a single parent living with children;

- share of people with foreign nationality;

- employment rate: share of people in employment among the population aged $15-65^{1}$;

- education level: share of the not-studying population aged 18 and older with maximum lower;

- secondary diploma (low education) and minimum tertiary diploma (high education).

Table 7.2 shows these indicators calculated for private, public and mixed housing estates. For contextual comparison, these indicators are also presented for the entire city, as well as for the statistical sectors surrounding large housing estates (in parentheses).

The age structure in large housing estates did not change considerably in the last decades. It is noteworthy, nevertheless, that both younger and older populations

\footnotetext{
${ }^{1}$ The censuses of 1991 and 2001 relied on self-reported questionnaires, while the Census 2011 was based on administrative sources. In the former, categories of unemployment and inactivity could be interpreted by respondents in different ways. As a consequence, unemployment in the census data does not necessarily correspond to the official definition (working-age persons out of employment looking for a job). Employment, on the other hand, is more accurately comparable over different census rounds. We therefore chose employment over unemployment.
} 
Table 7.1 Population in Brussels' large housing estates, 1991-2011: absolute numbers (share of the Brussels population in parentheses)

\begin{tabular}{l|l|l|l|l}
\hline $\begin{array}{l}\text { Large } \\
\text { housing } \\
\text { estate type }\end{array}$ & \multicolumn{2}{|l|}{$\begin{array}{l}\text { Population of statistical sectors assigned as large } \\
\text { housing estates }\end{array}$} & $\begin{array}{l}\text { Living in units built } \\
\text { from 1946 to 1990 } \\
\text { in 2011 }\end{array}$ \\
\cline { 2 - 5 } & 1991 & 2001 & 2011 & $22,287(2.0 \%)$ \\
\hline Public & $28,825(3.0 \%)$ & $28,677(2.9 \%)$ & $31,270(2.8 \%)$ & $50,577(4.5 \%)$ \\
\hline Private & $56,154(5.9 \%)$ & $57,000(5.8 \%)$ & $65,140(5.7 \%)$ & 5010 \\
\hline Mixed & $12,322(1.3 \%)$ & $12,008(1.2 \%)$ & $12,996(1.1 \%)$ & $11,235(1.0 \%)$ \\
\hline $\begin{array}{l}\text { Total large } \\
\text { housing } \\
\text { estates }\end{array}$ & $97,301(10.2 \%)$ & $97,685(9.9 \%)$ & $109,406(9.6 \%)$ & $84,099(7.4 \%)$ \\
\hline
\end{tabular}

Data sources Censuses 1991, 2001 and 2011 (Statistics Belgium)

(aged 0-15 and over 65) are overrepresented in public housing estates: each of these two age categories accounted for $23 \%$ of their inhabitants in 2011 (against 19\% and $18 \%$ in Brussels, respectively). In contrast, private estates house a much older population: one-third of their inhabitants are older than 65. This is considerably high compared to the overall Brussels level, but also compared to the areas surrounding these estates $(21 \%)$. The older population in private estates may be in fact the original owners of the apartments, who bought their units during the construction of the estate and did not move throughout their lives: this would explain the high levels of owner occupation in private housing estates.

Concerning household composition, public housing estates have a particularly high share of single-parent families. These account for $34 \%$ of the households of public estates (compared to $24 \%$ in Brussels), which reflects the socioeconomic vulnerability of their tenants.

It is difficult to produce comparative measures of the proportion of foreigners over time with the census data. The share of foreign nationals fell between 1991 and 2001 due to naturalisation waves that took place in the 1990s (see Renauld et al. 2016). The 2001 figures are not strictly comparable with those of 2011, as the Census 2011 also includes asylum seekers in the waiting list. Moreover, the indicator used here does not include descendants of migrants (second and third generation). It only reflects those who have a foreign nationality and moved to the country themselves.

Despite these limitations in definitions and comparability, we nevertheless start with analysing the share of foreigners in large housing estates compared to the overall Brussels levels for each of the three time points. Foreigners remained underrepresented in public estates: they account for only $17 \%$ of public housing tenants in 2011, and this proportion has even decreased somewhat since 1991. At the same time, whereas foreigners were underrepresented in private estates in 1991 $(10 \%)$, their proportion doubled since then. This is not to say that public estates host fewer people from foreign origin: many migrants may have acquired Belgian nationality and thus not appear in our indicator. But this does suggest that new migrants may face more barriers in accessing public housing in large housing estates - probably due to the long waiting lists (Dessouroux et al. 2016) — while 


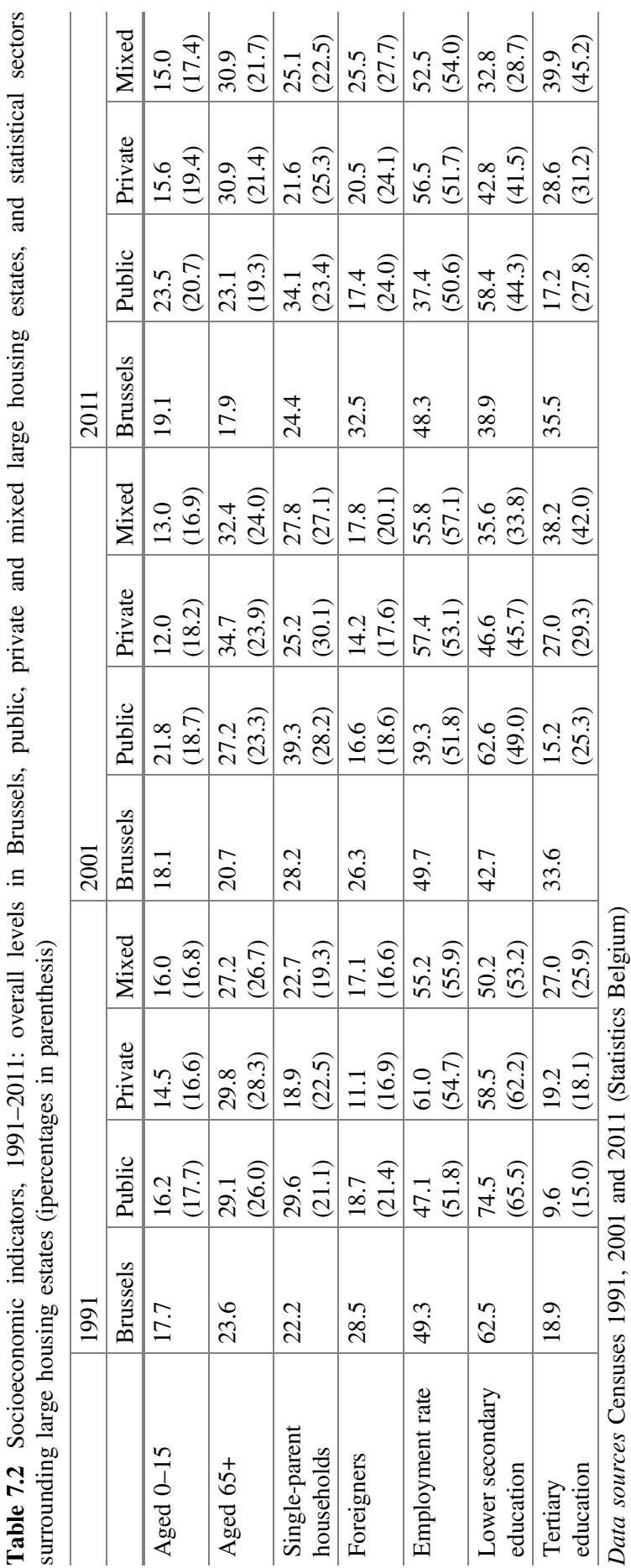


private estates seem to accommodate part of the recent international migration to Brussels.

Socioeconomic conditions, measured here by employment and education, also differ between public and private estates. While employment rates remained stable in Brussels around $49 \%$ since the 1990s, they fell considerably in public estates. In 2011, the employment rate in public estates was $27 \%$. This is half the level in the areas surrounding public estates.

In terms of education, Brussels experienced, since the 1990s, a rapid change in educational composition: the share of inhabitants with lower education fell from 62 to $39 \%$, while the proportion holding a university degree rose from 19 to $35 \%$. Public housing estates did not follow these trends: educational levels increased at much slower rates and remained considerably low (lower education only fell from $75 \%$ in 1990 to $58 \%$ in 2011). Yet, it is noteworthy that education levels in public housing estates did increase (albeit slowly) at the same time that employment rates were falling. This could indicate that it is increasingly difficult for the lower classes to convert education into employment.

Moreover, one explanation of the socioeconomic deterioration of public housing estates is the fact that public housing stock did not increase significantly in Brussels during this period; therefore, the existing public estates increasingly fulfil the role of 'safety net' for an increasing number of deprived households (De Decker 2008). In contrast, the socioeconomic profile in private estates followed Brussels' overall trends: stable employment and increasing education levels. Nonetheless, the share of inhabitants with a tertiary diploma increased much slower. This is certainly due to the permanence of an older population in these estates.

It is important to note that the indicators calculated here for Brussels' public and private estates hide important differences within large housing estates of the same category. To illustrate this diversity, the 30 large housing estates are plotted in Figs. 7.5 and 7.6, respectively, by the share of foreigners and the employment rate in 2011 and the corresponding rate of change since 1991. These can be compared to Brussels' levels represented by the dashed lines.

The share of foreign nationals in 2011 ranges between 8 and $25 \%$ in public estates, and between $8 \%$ and $35 \%$ in private estates. But the rates of changes reveal a clear pattern in which the shares of foreigners are progressing much slower in public, and rapidly in private housing estates. With respect to employment rates, all public housing estates experienced negative rates of changes since 2011 - in most cases much lower than the Brussels level. In the case of private housing estates, only one case has significantly deteriorated since 1991 .

In sum, generally speaking, public and private large housing estates experienced different evolutions in the last decades. Private housing estates house an older population, many of them of apartment owners. The share of foreigners in private estates is low compared to the city average, but it is increasing rapidly. In contrast, the proportion of foreigners decreased somewhat in most public estates; and while the educational level of the inhabitants is increasing, employment levels at the same time have decreased considerably. It is not surprising that public housing estates in Brussels host a more vulnerable population-this is their function within the 
Fig. 7.5 Share of foreigners in large housing estates: share in 2001 and percentage change since 1991 compared to Brussels' overall levels (dashed lines). Data Source Census 1991 and 2011 (Statistics Belgium)

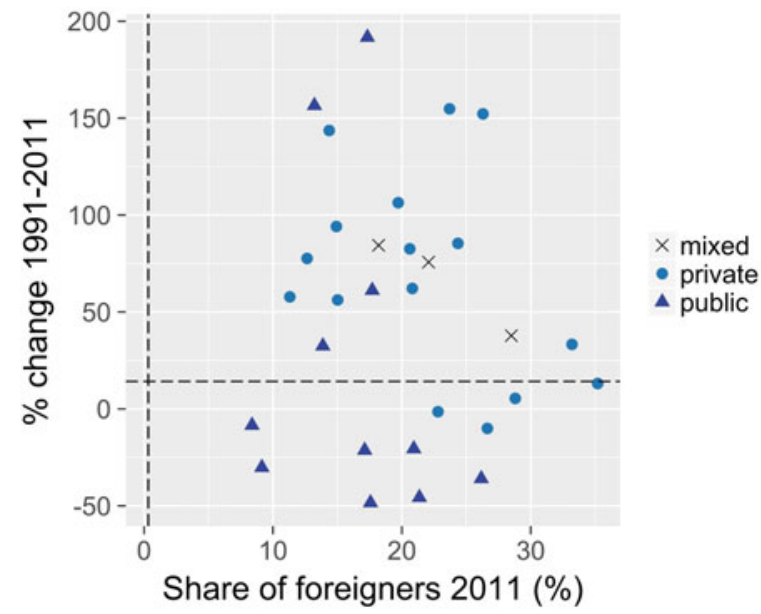

Fig. 7.6 Share of employed people aged 15-65 living in large housing estates:

employment rate in 2011 and percentage change since 1991 compared to Brussels' overall levels (dashed lines). Data Source Census 1991 and 2011 (Statistics Belgium)

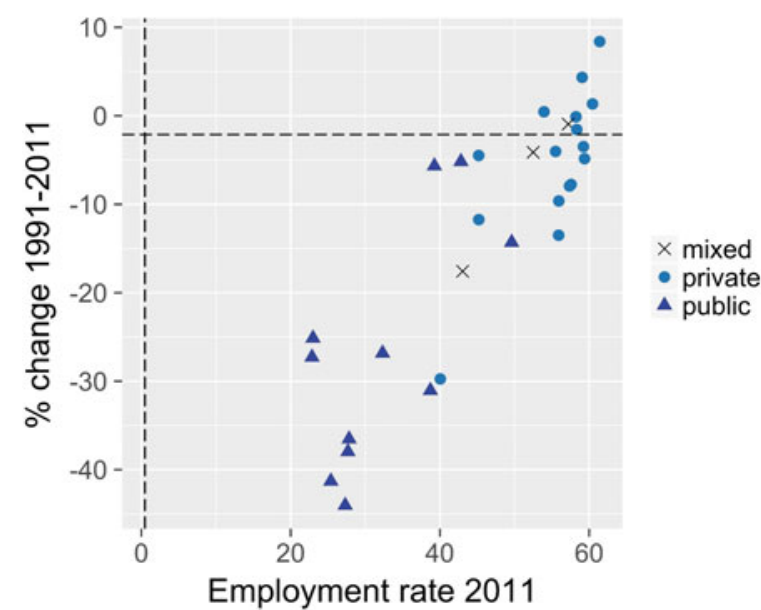

Belgian housing policy. However, the deterioration of socioeconomic conditions in these estates indicates that they are being more and more often allocated to more vulnerable households.

\subsubsection{Large Housing Estates' Impact on Ethnic and Socioeconomic Segregation in Brussels}

Because of their large scope and their particular evolution, large housing estates can potentially shape concentration patterns and influence segregation levels in the city. Figures 7.7 and 7.8 show the concentration patterns of foreigners and employment 


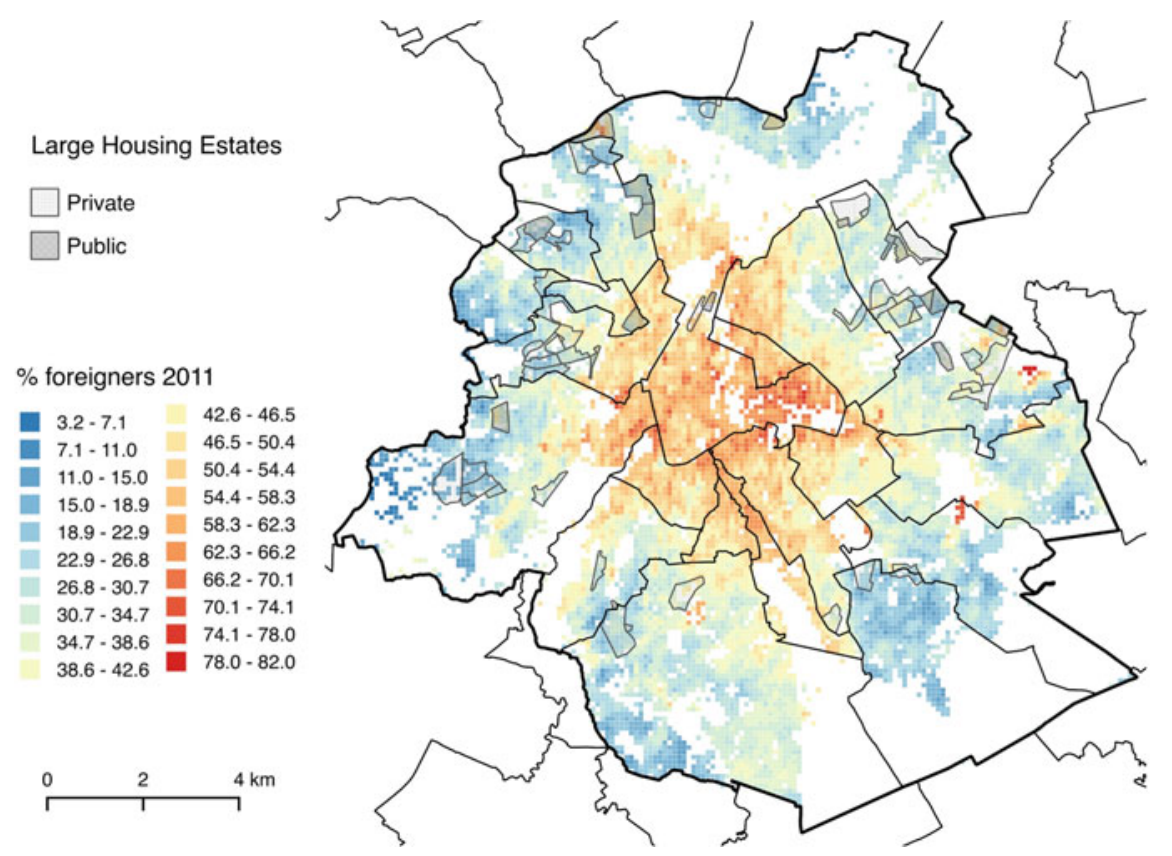

Fig. 7.7 Share of foreign-born people in 2011 among the 400 nearest neighbours (gridded data). Data Source Census 2011 (Statistics Belgium)

in Brussels. The maps were made at the level of $100 \mathrm{~m} \times 100 \mathrm{~m}$ grids with geo-coded data using a nearest-neighbour approach ${ }^{2}$ : they depict the proportion among the 400 nearest neighbours that are foreign-born (Fig. 7.7) and employed (Fig. 7.8). This allows us to attain a geographic level that is finer than the statistical sectors.

It is in the central neighbourhoods of Brussels that ethnic and socioeconomic segregations overlap. In particular, the nineteenth-century neighbourhoods west from the city core concentrate high shares of foreigners (often surpassing $50 \%$ of the nearest neighbours) and very low employment rates (lower than $30 \%$ of the neighbours of working age). As mentioned in Sect. 7.2, these areas are dominated by the lowest-quality dwellings and have long hosted labour migrants (De Winter and Musterd 1998; Kesteloot and Van der Haegen 1997).

Large housing estates, in contrast, are located in the fringes of the city. As the gridded data in Fig. 7.7 show, large housing estates do not concentrate high shares of migrants compared to their surroundings and certainly not compared to the

\footnotetext{
${ }^{2}$ The maps were elaborated within the research project 'Residential segregation in five European countries' (ResSegr), financed by JPI Urban Europe, and in collaboration with Statistics Belgium. They were developed based on the geo-located data from the Census 2011 and using the EquiPop software (Östh et al. 2015)
} 


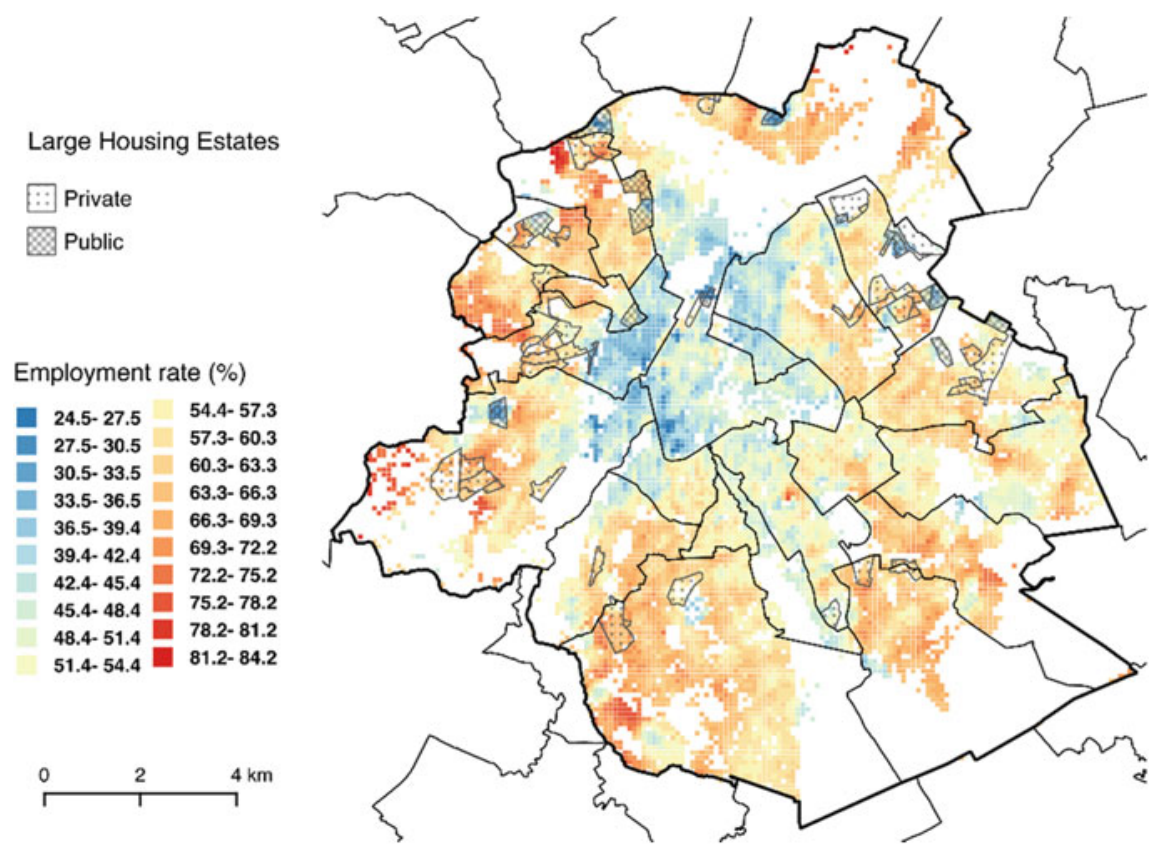

Fig. 7.8 Share of people aged 25-64 in employment in 2011 (employment rate 2011) among the 400 nearest neighbours (gridded data). Data Source Census 2011 (Statistics Belgium)

central neighbourhoods. In the case of employment, public estates do have lower rates compared to their surroundings, as one could expect. However, for private estates, employment levels tend to be close to that of their surrounding areas. In sum, the maps suggest that large housing estates do not play a major role in the segregation patterns of Brussels as a whole. Only public housing estates seem to play a role in the socioeconomic disparities at the local level. Most of the ethnic and socioeconomic segregation happens in the old working-class neighbourhoods west of the inner city.

In order to assess large housing estates' impact on segregation levels, we calculated the dissimilarity index (DI) for foreigners and persons not in employment, with and without large housing estates (Table 7.3) ${ }^{3}$. The dissimilarity index is a traditional way to measure segregation levels. In our case, it compares the distribution of foreign nationals and persons aged 24-65 not in employment in a statistical sector to the overall distributions in Brussels. What interests us here is the relative change in the index value as we take public and private estates out of the

\footnotetext{
${ }^{3}$ As aforementioned, data on unemployment are not accurately comparable over different census rounds. Therefore, in the calculation of the dissimilarity indices we use 'persons not in employment' instead of 'unemployed': it refers to all working-age persons who do not have a job (either because they are unemployed or because they are inactive and not looking for a job).
} 
Table 7.3 Dissimilarity indices for foreigners and persons not in employment, 1991-2001: overall levels in Brussels and percentage change in the index value as large housing estates are taken out of the calculation

\begin{tabular}{|c|c|c|c|}
\hline & 1991 & 2001 & 2011 \\
\hline \multicolumn{4}{|l|}{ Foreign persons (with respect to Belgians) } \\
\hline Brussels & 0.4002 & 0.2617 & 0.2289 \\
\hline without all large housing estates & $-1.16 \%$ & $-4.42 \%$ & $-4.86 \%$ \\
\hline without public large housing estates & $+0.13 \%$ & $-0.59 \%$ & $-2.18 \%$ \\
\hline without private large housing estates & $-1.41 \%$ & $-3.23 \%$ & $-2.53 \%$ \\
\hline \multicolumn{4}{|c|}{ Working-age persons not in employment (with respect to employed persons) } \\
\hline Brussels & 0.1709 & 0.1724 & 0.1537 \\
\hline without all large housing estates & $-0.67 \%$ & $-0.35 \%$ & $-2.05 \%$ \\
\hline without public large housing estates & $+0.17 \%$ & $-1.49 \%$ & $-1.89 \%$ \\
\hline without private large housing estates & $-1.19 \%$ & $+1.02 \%$ & $0.00 \%$ \\
\hline
\end{tabular}

Data source Census 2011 (Statistics Belgium)

calculation. This change is a measure of housing estates' weight on ethnic and socioeconomic segregation. For example, if the relative change in the DI without large housing estates is $-10 \%$, this means that the absence of large housing estates decreases the segregation index by one-tenth; in other words, the presence of estates has a positive contribution to the overall segregation level.

DI values for foreigners are not comparable over time because of data issues; however, we can still observe the large housing estates' weight in segregation for each year. In 2001 and 2011, if all large housing estates are left out of the calculation, the DI decreases slightly: by $4.42 \%$ and $4.86 \%$, respectively. This means that large housing estates do concentrate foreigners and account for some of the segregation in Brussels, although their weight is only limited. Interestingly, whereas the impact in 2001 came mostly from private housing estates $(-3.23 \%)$, it was balanced in 2011 between private and public estates $(-2.53$ and $-2.18 \%)$. In other words, public estates have had an increasing role in segregation levels.

Large housing estates have a smaller effect on segregation on the basis of employment (maximum $-2 \%$ of the DI in 2011). It is noteworthy that the contribution of public estates to the overall employment segregation increased over time: it went from null in 1990 to $-1.8 \%$ in 2011 . This reflects the fact that public housing estates host an increasing proportion of unemployed.

In sum, large housing estates have a small influence on the overall levels of segregation in Brussels, most probably because they represent a small share of the housing stock. Public estates have some impact on segregation patterns at the local level and their importance in the segregation level on the basis of employment is increasing. 


\subsection{Challenges, Political Awareness and Public Intervention}

Alongside the challenges related to socioeconomic aspects and social mix, large housing estates also face important challenges associated with their physical estate and their internal design.

The current physical state of Brussels' housing estates varies from case to case. As a general rule, the materials used in their constructions went through significant deterioration. Run-down façades have presented permeability issues leading to infiltration. Another problem is the instability of balcony guardrails, which do not comply with today's safety regulations. The primary motivations for renovation, when the means are available, are therefore to make façades watertight and to improve balcony security. When these interventions are undertaken, works often involve enhancing energy efficiency.

Another common problem in large housing estates is the lack of safety in the shared areas, which is a direct result of their urbanistic conception. The circulation of cars was kept away from housing estate neighbourhoods to provide shared greenspaces for leisure; as a consequence, there is little social control preventing criminality, especially at night.

As a general rule, spatial planning and housing policies in Brussels have not been specifically concerned with the situation of large housing estates. No large-scale programme to date has been targeted to renovation of large housing estates, safety problems or socioeconomic aspects. Instead, regional public policies ${ }^{4}$ have given priority to the 'revitalisation' of deprived neighbourhoods in the nineteenth-century belt (Dessouroux et al. 2016), which are densely populated and are often in a worse state (Kesteloot and Van der Haegen 1997).

In the lack of an integrated policy directed to large housing estates, their trajectories and their present conditions vary from case to case. Below we discuss the specific trajectories of public and private estates and the means through which regional policies affect their physical and socioeconomic state.

\subsubsection{Public Large Housing Estates}

As aforementioned, some public housing estates were conceived under modernist principles; however, the ideal of prosperous autonomous neighbourhoods was never achieved (Sterken 2013). Since the 1980s, policymakers seem to have become somewhat aware of this fact and concerned with the isolation of social

\footnotetext{
${ }^{4}$ Since the 1980s, spatial planning and housing policies in Belgium fall in the jurisdiction of regions (Winters \& Elsinga 2008). The Brussels Capital Region possesses autonomy in the matters of public housing, urbanism and infrastructure, among others. Only private rent legislation is still regulated at the federal level, and it remains largely liberal.
} 
tenants who had little interaction with other social profiles. Indeed, public authorities have since integrated new social housing units inside the urban fabric: new investments focused on renovation of existing houses and construction of small units inside neighbourhoods promote social mix. However, existing housing estates were not the object of large-scale programmes: they are dealt with case by case.

Public housing stock in Brussels is managed by 19 local housing companies (Sociétés Immobilières de Service Public_-SISP) functioning under the umbrella of the regional social housing authority (Société du Logement de la Région de Bruxelles-Capitale - SLRB). The latter sets the rules in public housing, determines the criteria for their attribution and funds the renewal and construction of public units. In the case of the renewal of public estates, it is the local housing companies that apply for the SLRB funding. They set the priorities for renovation according to the needs in the dwellings they manage. As they operate at the local level, they are expected to have good knowledge of these priorities and the citizens' needs.

Although large housing estates were not specifically targeted by the SLRB nor the SIPS, many of them went through important renovation works in the last decades alongside other types of public housing. The SLRB directed most of its budget in the last decade for the renewal of the existing stock. It invested 500 million Euros between 2000 and 2017, from which many social large housing estates benefited. The works range from complete renovation of housing estates to targeted improvements (see Leroy 2012, 2014).

One example is the emblematic Cite Modèle/Modelwijk. By the initiative of the responsible SISP, Le Foyer Laekenois, this public estate has gone through an important transformation since 2004, with a budget of more than 10 million Euros (see Le Foyer Laekenois 2014). The project was based on in-depth studies of the physical and social conditions and with attention to the evolution of tenants' needs since its construction in the 1960s. The works involved the thorough renovation of the existing buildings, the construction of new housing units with an architectural design complementary with the modernist ensemble and the reorganisation of the common area by a landscapist. Also, shared space was improved with the creation of a new common restaurant, a nursery and sport facilities at the disposal of the residents.

Whereas the physical state of public estates improved in the last years, their socioeconomic conditions have been deteriorating (as shown in Sect. 7.3). Public housing units are allocated according to a priority system: the more vulnerable the household, the higher the priority. For example, a single parent with a disabled child cumulates more 'priority points' than a household with a dependent elderly person. Whereas the demand for social housing is on the rise, the supply has not followed (Romainville 2010): today, only $8 \%$ of the total housing stock in the city is public; there are as many households on the waiting list for social housing as there are public housing units - around 40,000 (Dessouroux et al. 2016). In this context, public housing units are more and more often attributed to the priority (most vulnerable) households. At the same time, access to the private rental market becomes more difficult for impoverished households as the rental prices increase (Dessouroux et al. 2016). Rental prices are significantly higher in the private 
market: $604 €$ on average for a two-bedroom apartment, against $234 €$ in public housing units (see Brussels Institute for Statistics and Analysis https://monitoringdesquartiers.brussels).

In sum, despite the investments in the physical state of public estates, public housing in Brussels increasingly has the role of social safety net. If demand continues to rise faster than available offerings, one can expect that units in public housing estates will be attributed to an increasingly deprived population, making social mix less probable in these estates.

\subsubsection{Private Large Housing Estates}

Although the construction of private large housing estates had ceased by the 1980s, there has never been a will to reject the existing ones. Today, these apartments still do well in the real estate market. Their physical state and socioeconomic conditions are variable and depend on the neighbourhoods in which they are located.

Because the private sector is liberal, the physical condition of large buildings has depended on the way they were managed by their owners (or co-property), rather than on public initiatives. Their renovation depends on the owners' financial conditions and on their capacity to find consensus among the large number of residents for the execution of works. Some private estates went through important renovations and maintained good physical condition, especially in affluent neighbourhoods; others are in a visibly worse state.

Apartment owners in large housing estates can apply for public grants for renovation, insulation or embellishment. However, they do not benefit from special grants or large-scale renovation programmes. This is because a high share of public investment in the physical state of private housing is directed to the deprived central neighbourhoods within the Area for Reinforced Development of Housing and Renewal (Espace de Développement Renforcé du Logement et de la Rénovation, EDRLR) (Romainville 2010; Dessouroux et al. 2016). Inhabitants of the EDRLR benefit from higher renewal grants and from area-based programmes conceived through citizen participation (neighbourhood contracts) (see Romainville 2010; Romańczyk 2015). As large housing estates fall outside the EDRLR area (except for one), they do not benefit from any special rule for public intervention. Furthermore, the applicable grants represent only a partial support of the works' costs: their realisation still lies on the large housing estates' owners' capacity to mobilise and finance them.

Regional policies have even less reach in the socioeconomic conditions of private housing estates. Because the private rental market falls into federal jurisdiction and is largely deregulated, the region has little or no way to promote social mix inside the private-owned apartment buildings. 


\subsection{Conclusion}

Large housing estates in Brussels emerged under a particular context of national housing policies, marked by homeownership support, lack of spatial planning, very liberal legislation in the construction business and low investments in public housing. These conditions allowed the construction of a limited number of public estates and a large number of private estates composed of standardised buildings.

In Brussels, we can find many examples of mid- and high-rise apartment buildings built after World War II. In this study, we focused on the large ensembles with more than 500 housing units. As these ensembles concentrate an important number of households, they potentially have an impact on segregation patterns in the city as well as on the residents' lives.

The 30 large housing estates identified in this study account for a relatively low proportion of the Brussels population: around $7 \%$ in 2011 , of which only $2 \%$ are in public estates. Moreover, large housing estates are not clustered together, but scattered around the fringes of the city. These two features seem to limit housing estates' role in overall segregation levels and patterns.

In fact, our analyses show that Brussels' large housing estates have a modest impact on segregation on the basis of nationality and employment. Most of the ethnic and socioeconomic segregation in Brussels happens in dense central neighbourhoods located in the nineteenth-century belt. These neighbourhoods have traditionally hosted migrants in vulnerable conditions and they continue to do so. The reason why new migrants end up in these neighbourhoods rather than large housing estates may be attributed to the housing market in these areas, which offers cheap prices in the private rental market (albeit in the lowest-quality dwellings). In addition, long-established networks may play a role in migrants' trajectories.

Nevertheless, public estates seem to contribute to local disparities. Our analyses suggest that public housing estates have concentrated an increasingly deprived population, considerably different from their surrounding areas. As the supply of public housing has not accompanied the increasing demand, public housing units are more and more often filled by the most vulnerable households. This situation is not likely to change in the next years.

Private large housing estates were originally intended for ownership by the lower middle class. Today, these estates still have a majority of apartment owners, and one-third of their inhabitants is older than 65 . It is thus reasonable to assume that a considerable share of units in private estates is still occupied by the original owners. If this is the case, we can expect that these apartments will progressively fall into the real estate market in the next decades. Private housing estates can therefore change quickly in the near future. In fact, our study shows that the share of migrants in these estates has already increased rapidly since the 1990s. If this trend continues, private large housing estates will perhaps have more significant weight in segregation. 
In sum, Brussels' large housing estates are spatially scattered and have only a limited impact on the concentration of deprivation and foreign nationals. However, the trends identified in our study indicate that large housing estates can become important socioeconomic fractures at the local level. Although policymakers have seemingly acknowledged the potential problems of social housing estates since the 1980 s, the policy strategy was to direct new investments in social housing to small housing units in mixed areas. The existing large housing estates have not been part of an integrated agenda in the regional housing policies. Although this is not likely to change in the near future, policies encouraging a social mix in large housing estates could anticipate their potential role in spatial inequalities and social cohesion of neighbourhoods.

Acknowledgements The authors thank Cécile Dubois, historian of the architectural heritage of Brussels, for her insights on how the perception of housing estates evolved among policymakers and the general public. They also thank Guillaume Sokal, architect at Brussels regional social housing authority (SLRB), for his clarifications on the complex structure of public housing in Brussels and on the system of public funds and grants. Gregory Hye, architect with experience in renovation of private housing, provided technical and practical information on renovation of private housing estates.

This work is part of and financed by the JPI Urban Europe project 'Residential segregation in five European countries: a comparative study using individualised scalable neighbourhoods' (ResSegr). More information is available at www.residentialsegregation.org.

\section{References}

Andersen HS (2002) Excluded places: the interaction between segregation, urban decay and deprived neighbourhoods. Hous Theor Soc 19(3-4):153-169

Broes T, Dehaene M (2016) Real estate pioneers on the metropolitan frontier. In: The works of Jean-Florian Collin and François Amelinckx in Antwerp. Cidades, Comunidades e Territórios vol 33, pp 89-112

Brussels institude for statistics and analysis. https://monitoringdesquartiers.brussels

De Decker P (2008) Facets of housing and housing policies in Belgium. J Hous Built Environ 23:155-171

De Winter M, Musterd S (1998) Towards undivided cities in western Europe: new challenges for urban policy: part 4 Brussels. Delft University Press, Delft

Deboosere P, Stoop R, Willaert D (2003) Codeboek Volkstelling 1-3-1991. Working Paper 2003-1. Steunpunt Demography, Vrije Universiteit Brussel

Deboosere P, Willaert D (2004) Codeboek Algemene Socioeconomische Enquête 2001. Working Paper 2004-1. Steunpunt Demography, Vrije Universiteit Brussel

Dessouroux C, Bensliman R, Bernard N, De Laet S, Demonty F, Marissal P, Surkyn J (2016) Housing in Brussels: diagnosis and challenges. BSI Synop Brussels Stud 99

Grosjean (2010) Urbanisation sans urbanisme. Une histoire de la ville diffuse. Margada, Wavre

Kesteloot C, Cortie C (1998) Housing turks and moroccans in brussels and amsterdam: the difference between private and public markets. Urban Stud 35(10):1835-1853

Kesteloot C, Van der Haegen H (1997) Foreigners in Brussels 1981-1991: spatial continuity and social change. Tijdschrift voor Economische en Sociale Geografie 88(2):105-119

Le Foyer Laekenois (2014) La Cité Modèle à Bruxelles: un chantier qui vit. Dossier de présentation technique. http://www.lakensehaard.be/srcpresse/pdf/fr/Avril2014_DossierTechnique.pdf 
Leroy X (2012) Programme quadriennal 2014-2017 rénovation et de construction de logements sociaux en photos. SLRB-INFO 65

Leroy X (2014) Programme quadriennal 2014-2017 rénovation et de construction de logements sociaux en photos. SLRB-INFO 70

Musterd S, van Kempen R (2005) Large housing estates in European cities. Utrecht University, Faculty of Geosciences, Opinions of residents on recent development

Phillips D (2007) Ethnic and racial segregation: a critical perspective. Geogr Comp 1(5):1138-1159

Renauld B, Caestecker F, Perrin N, Eggerickx T (2016) Devenir Belge. Histoire de l'acquisition de la nationalité belge depuis 1830 . Wolters Kluwer, Mechelen

Romainville A (2010) Who benefits from home ownership support policies in Brussels? Brussels Stud 34

Romańczyk KM (2015) Towards urban governance: Twenty years of neighbourhood contracts in the Brussels - capital region. Cities 44:1-8

Sterken S (2013) Bruxelles, une capitale en mouvement? 50 ans d'architecture et urbanisme. Bruxelles Patrimoines

Tammaru T, Musterd S, van Ham M, Marcińczak S (2016) A multi-factor approach to understanding socio-economic segregation in European capital cities. In: Tammaru T, Marcińczak S, van Ham M, Musterd S (eds) Socio-Economic segregation in European Capital cities: East Meets West. Routledge, London and New York, pp 1-29

The Eurostat Census Hub Metadata. http://ec.europa.eu/eurostat/web/population-and-housingcensus/census-data/2011-census

Theunis K (2006) De Wet De Taeye. Individuele woning als bouwsteen van de welvaartstaat. In: Aermaet T, Van Herck K (eds) Wonen in Welvaart. Antwerp, De Singel/Centrum Vlaamse Architectuur archieven, pp 67-77

Wassenberg R, Turkington R, van Kempen R (2004) High-rise housing estates in Europe. In: Turkington R, van Kempen R, Wassenberg F (eds) High-rise housing in Europe: current trends and future prospects. University Press, Delft, pp 1-14

Winters S, Elsinga M (2008) The future of Flemish social housing. J Hous Built Environ 23:215-230

Östh J, Clark WAV, Malmberg B (2015) Measuring the scale of segregation using k-nearest neighbor aggregates. Geogr Anal 47(1):34-49

Open Access This chapter is licensed under the terms of the Creative Commons Attribution 4.0 International License (http://creativecommons.org/licenses/by/4.0/), which permits use, sharing, adaptation, distribution and reproduction in any medium or format, as long as you give appropriate credit to the original author(s) and the source, provide a link to the Creative Commons license and indicate if changes were made.

The images or other third party material in this chapter are included in the chapter's Creative Commons license, unless indicated otherwise in a credit line to the material. If material is not included in the chapter's Creative Commons license and your intended use is not permitted by statutory regulation or exceeds the permitted use, you will need to obtain permission directly from the copyright holder. 


\title{
Chapter 8 \\ The Many (Still) Functional Housing Estates of Bucharest, Romania: A Viable Housing Provider in Europe's Densest Capital City
}

\author{
Vera Marin and Liviu Chelcea
}

\begin{abstract}
Housing estates built during the post-World War II decades in many countries have followed diverging trajectories. These include maintenance and repair, demolition, 'doing nothing,' and demolition with mixed-usage replacements. Drawing on empirical and historical material from Bucharest, Romania, a city in which $80 \%$ of the housing stock consists of socialist era housing estates, we argue that such housing continues to be viable and is even enjoying a minor renaissance, mainly through the financial efforts of residents and, occasionally, through the allocation of a certain amount of public funds. The empirical analysis illustrates that it is neither the mass character of such housing, nor its high-rise nature that creates the problems and negative image often associated with housing estates elsewhere in the world. Rather, we outline seven challenges faced by such estates: ageing of their structure and resident population, networked connectivity, energy efficiency, densification, urban planning that favours real estate agents, neglect of housing policies and housing rights, and condominium governance. The housing estates and their problems are so much a part of everyday normality in Bucharest that the local administration tends to take them for granted and has not placed them on the public agenda despite the inevitability of their structural decay at some time in the future. More than anything else, the state and the owners need to gather data in order to preempt future emergencies or continuing physical decay of this valuable housing stock.
\end{abstract}

Keywords Housing estates - Housing policy - Mass housing - Material culture Eastern Europe · Bucharest

\footnotetext{
V. Marin · L. Chelcea $(\square)$

Bucharest, Romania

e-mail: liviu.chelcea@sas.unibuc.ro

V. Marin

e-mail: vera.atu@gmail.com

(C) The Author(s) 2018

D. B. Hess et al. (eds.), Housing Estates in Europe, The Urban Book Series,

https://doi.org/10.1007/978-3-319-92813-5_8
} 


\subsection{Introduction: A City With Many Housing Estates}

In the early 1970s, at the time when the Pruitt-Igoe housing estate was being demolished with explosives in St. Louis (Fishman 2004; Freidrichs 2011) and housing estate construction in France was losing momentum (Cupers 2014a, b), a 300.000-inhabitant housing estate (Balta Albă) was being completed in Bucharest. This large neighborhood and a number of smaller (but still with more than 100,000 inhabitants) housing estates constructed in the 1960s, 1970s and 1980s account for a staggering 80 to $82 \%$ of all buildings in Bucharest and some $83 \%$ of the city's population, according to the 2011 census (INS 2011). By comparison, the share of housing estates in the total housing stock is 40 to $50 \%$ in other large cities of Central and Eastern Europe, and less than $10 \%$ in the countries of Western Europe (van Kempen et al. 2005).

Prefabricated housing estates constructed in cities all over the world after the conclusion of World War II have followed divergent trajectories. In Great Britain, the US, the former German Democratic Republic (Bernt 2009), as well as in Moscow, Russia (Luhn 2017) a number of housing estates have been demolished. In other parts of the world, they have been demolished and replaced with new apartment buildings, usually for wealthier families (Lees et al. 2008, p. 112). A 'do nothing' policy on the part of authorities and gradual deterioration has often been the fate of housing estates. In France, however, the state has continued to invest in maintenance and repair and housing estates remain viable (Wacquant 1993). In Romania, a 99\% privatisation rate in the early 1990s (INS 2011) led to dwellings in apartment buildings becoming the responsibility of the households who own them but who do not always possess the culture, knowledge or financial resources for property management (but who, nonetheless, cherish their apartments). Far from entering a downward spiral, as some scholars rightly feared in the early 1990s (Andrusz 1996), the collective housing estates in Bucharest are highly functional. Despite their problems, and despite class-based criticism of collective housing by upwardly mobile individuals and the cultural bourgeoisie, housing estates are neither pockets of poverty, ghettos, sites of social uniformity, or crime-ridden slums, nor do they carry 'territorial stigma' (Wacquant 1993). An appreciation of living in a large socialist-era housing estate even shows up in TV series, music, blogs, and visual arts projects (Dumitru 2016). Accommodating a large majority of Bucharest inhabitants in privately owned apartments, they are a good illustration of a combination of a public (mostly) 'do nothing' approach while private (but occasionally public) maintenance and repair are also important.

Although housing estates have problems (which we later describe in detail), most real estate transactions in Bucharest involve housing estates. Banks have not redlined them. Moreover, they are socially mixed, containing low- and medium-income households. They are liked by their residents, their population tends to be stable, and demolishing them is not even close to appearing on the 
public agenda. ${ }^{1}$ On the contrary, having lately attracted modest public funding, housing estates are enjoying something of a renaissance. Although some of their residents dream of higher quality housing, housing estates have kept their value, and this situation ought to be judged not against a 'growth' assumption (i.e. 'an expectation of moving up the housing ladder') but against several realities: the virtual absence of construction of new public housing; evictions from nationalised housing; the fact that almost 50\% of the country's population live below the poverty line; and, the tragic condition that approximately $5 \%$ of Romania's population live in squats, shanties, and other makeshift housing (Berescu et al. 2006). Moreover, the new residential ensembles are not necessarily better (although they are certainly flashier), since they have been built fast, construction legislation is weakly enforced, and the provision of urban services is sometimes deficient.

The data that we use come from a variety of sources. For her doctoral research (Marin 2009), Vera Marin interviewed approximately 30 architects, policy makers, representatives of condominium associations, and advocacy groups. A mapping instrument was assembled to analyse the state of the housing estates in Bucharest. We also reviewed plans, legislation, and strategic documents. Additional data come from capacity building activities organised for representatives of condominium associations, as well as for applied research carried out in the development of a new edition of the Master Plan of Bucharest (2014). We have also used 2002 and 2011 aggregate census data, which, as we explain in the last section of the article, are unfortunately a weak descriptor of housing estate residents, as census tracts do not overlap with apartment building groupings. This reflects the lack of interest in housing in the post-socialist period, when housing stopped being a right and became a merit-based good. We also mention that Bucharest's administration does not own or provide much data, as housing is, compared to private transportation for instance, at the bottom of the priorities list in many ex-socialist countries (Tuvikene 2018; Chelcea and Druță 2016).

\subsection{Growth of Bucharest's Housing Estates in Four Periods}

Buildings providing collective housing first appeared in Bucharest at the end of the nineteenth century on the Hausmannian boulevards that opened up the city (e.g. B-dul Elisabeta, B-dul Carol). Prior to World War II, these were low-rise detached buildings with gardens. Both the central government and various major economic actors (e.g. Romanian Railway Companies) developed affordable social housing programs, but these were very low-density (one or two storeys high) and very few in number compared with what was to come.

\footnotetext{
${ }^{1}$ There are rumours that the administration of District 5 plans to demolish Zăbrăuți, one of the poorest, if not the poorest, mikrorayons in Bucharest (see Florea 2017).
} 
The population of Bucharest grew from around 1,025,000 inhabitants in 1950 to around 1,366,000 in 1960 and around 1,800,000 in 1975 (Marin 2009). In 1990, the population reached 2 million. With the exception of the 1950s, when the old, centrally located housing stock absorbed a migration wave through housing nationalisation (Chelcea 2012), most of this population growth was housed in newly built housing estates (see Figs. 8.1 and 8.2). It was a period of continued industrialisation, carried out following very centralised decision-making processes in city planning and placing a large emphasis on efficiency in producing large numbers of standard housing units made with prefabricated elements.

It is possible to identify four fairly distinct periods in the production of mass housing in Bucharest. Each of these stages will be briefly discussed in this section, and we explain shifts in related political and economic conditions. The short-lived but intense changes that took place during the period 1950-1955 correspond with

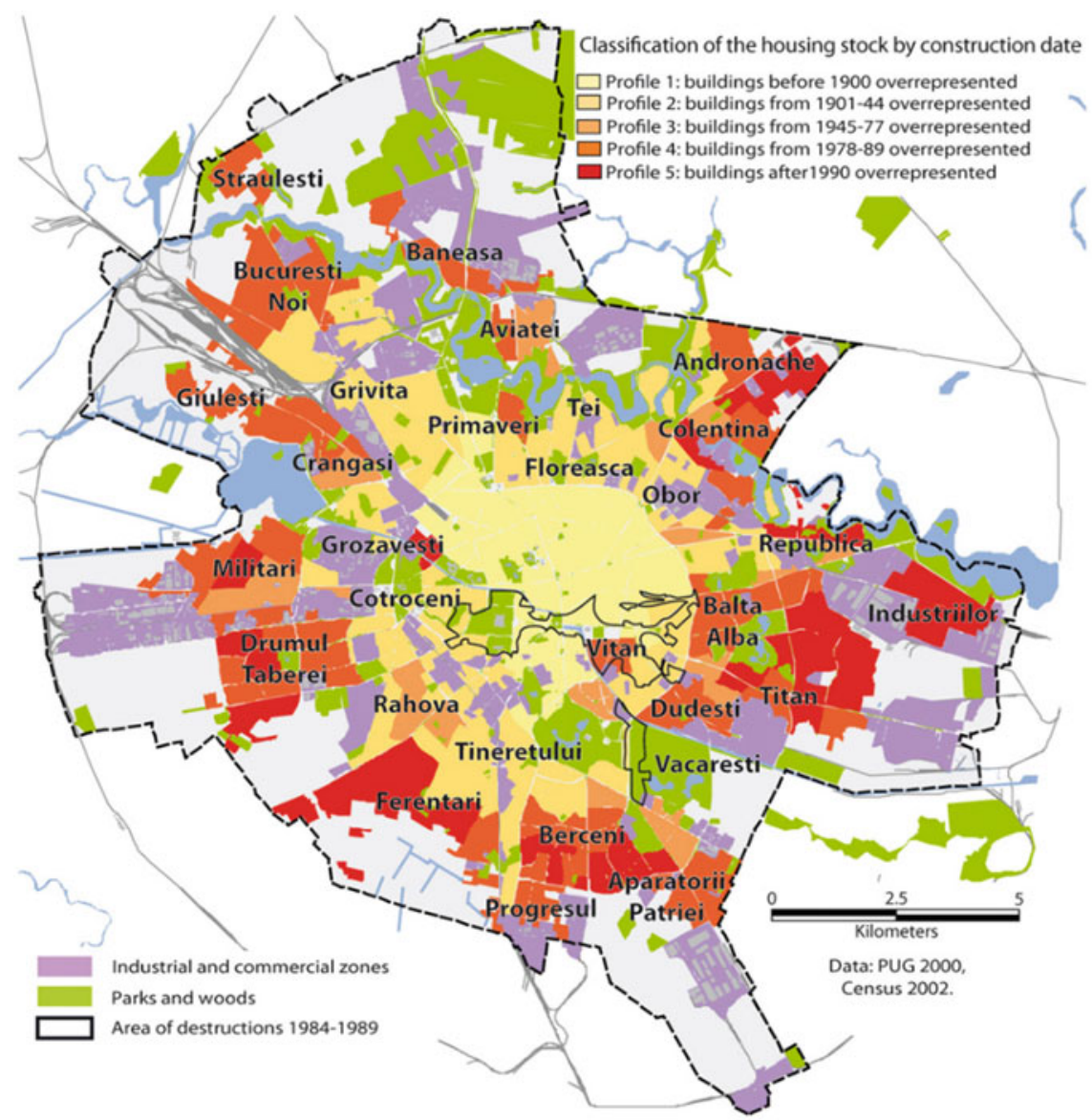

Fig. 8.1 Land use and building age in Bucharest. Source Direcţia Urbanism şi Amenajarea Teritoriului 2000; INS 2002, Marcińczak et al. 2014 


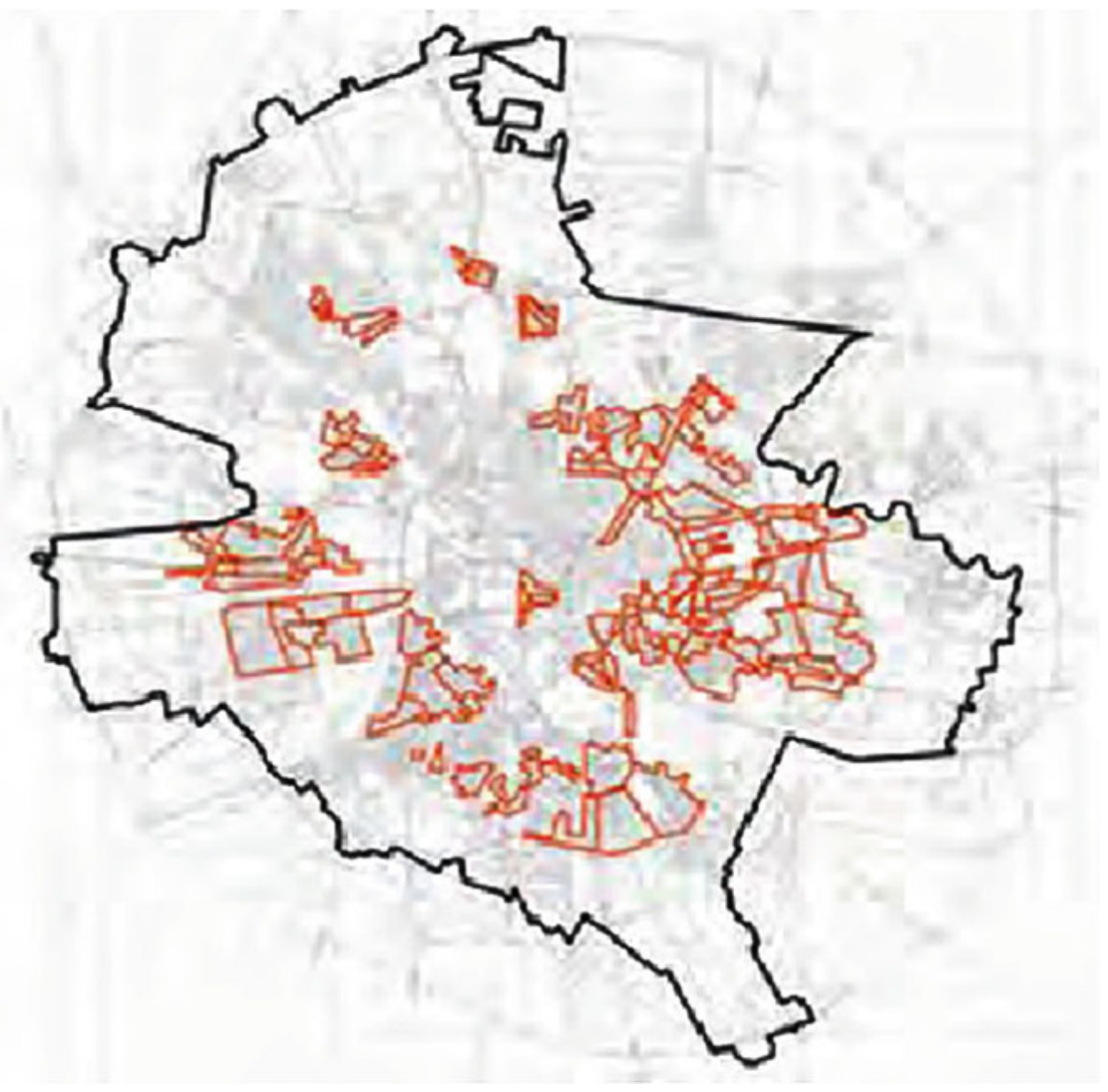

Fig. 8.2 Location of pre-1990 housing estates. Source Personal analysis Vera Marin, based on https://cadastral.github.io/

the appropriation of Soviet housing policy. From 1956 to 1977, there was a certain opening toward the principles of the functionalist city. From 1977 to 1990, housing policy reflected significant austerity measures (see also Fig. 8.1). The construction of housing estates ceased after 1990. It was only after economic growth and the development of the securitised market in mortgages that former industrial sites in large cities were transformed into new privately developed residential ensembles.

\subsubsection{5-1955: Introduction of High-Quality Small-Scale Housing Estates}

Immediately after World War II, the socialist state began to pay more attention to large-scale collective buildings, using the cvartal model as developed in the Former Soviet Union. These were massive buildings for their location (of 3-5 storeys, see Fig. 8.3), 


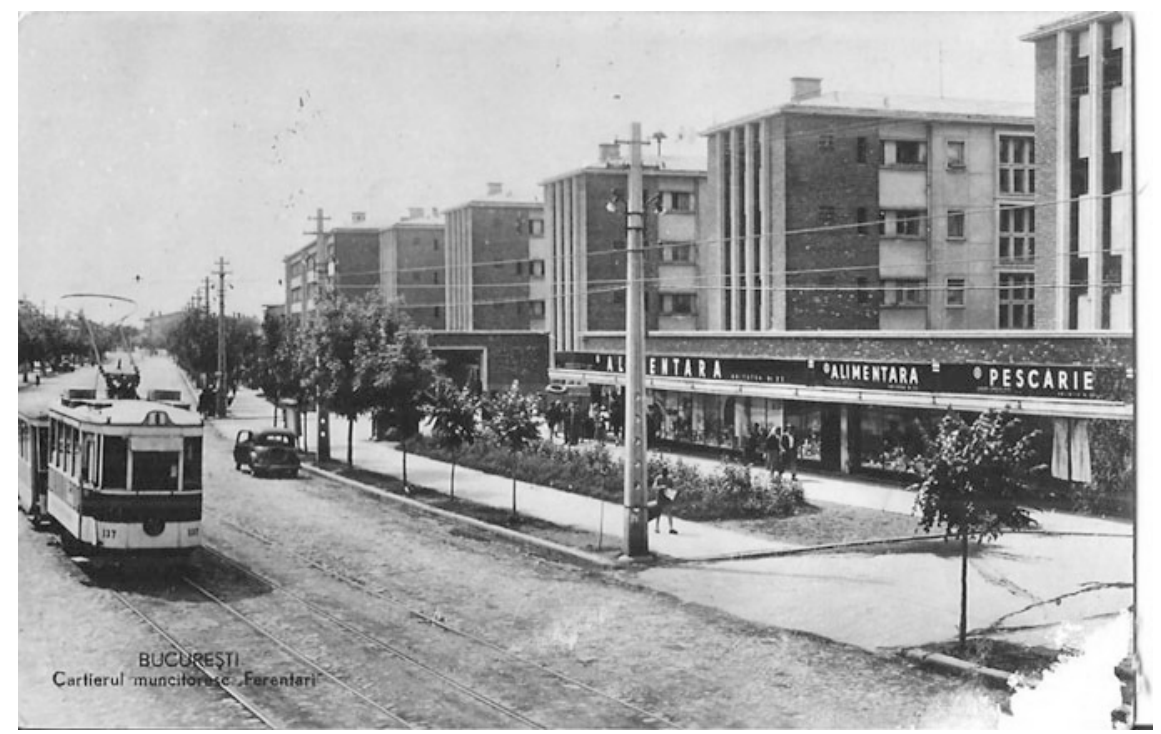

Fig. 8.3 A Cvartal in a poor working-class neighbourhood (Ferentari), 1950s. Source https:// www.okazii.ro/cpi-b4447-bucuresti-cartierul-muncitoresc-ferentari-circulata-stampila-1960-tramvaia166487002, public domain

which were sporadically inserted into low-rise working-class and middle-class areas in Bucharest. They were imagined as 'Palaces for workers,' so they were designed with grandiose entrances, arches and columns, multiple staircases, and an inner courtyard with a generous garden (see Fig. 8.4). They were high-quality buildings; to this day they are highly sought after, even if the apartments are small (Tudora 2003). Housing construction attracted increased attention during that period. In 1950, the local administrations were permitted to establish construction companies, and, in the following years, plans aimed to intensify housing construction. The scope of these interventions was, however, modest, compared with what was to come. In 1954, for instance, only 1,000 apartments were produced (Marin 2009).

\subsubsection{6-1977: Quality in Mass Housing}

Beginning in the late 1950s, and then in full force during the 1960s and 1970s, the socialist state substantially financed urban renewal plans based on functionalist principles. 'Systematisation,' as urban renewal was called, was meant, according to Gheorghe Gheorghi-Dej, the head of the ruling party at the time, to deliver 'constructions that are cheap, good and beautiful, which contribute to the embellishment of the cities. For the towns and cities which do not have yet the systematisation plan, a detailed systematisation plan will be made for the pieces of land that will be 


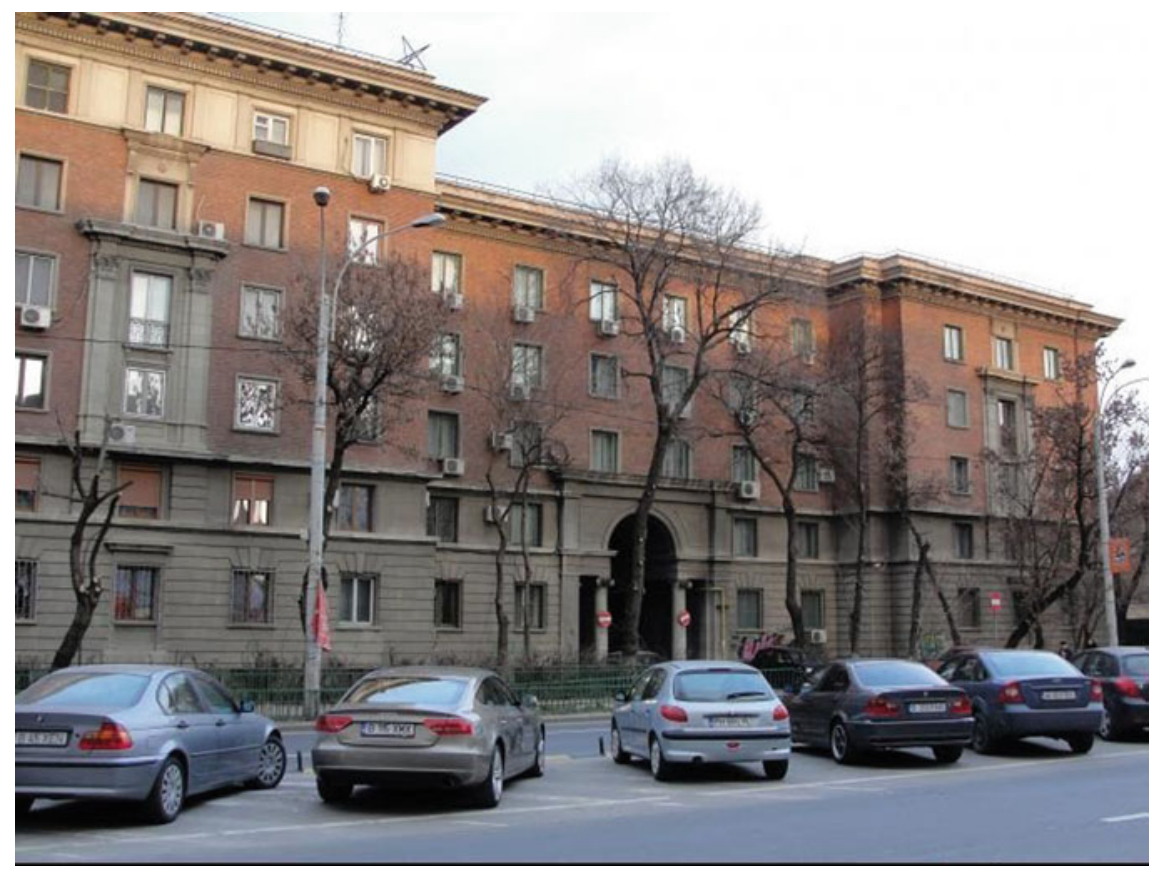

Fig. 8.4 A 1950s-era Cvartal building near a pre-war middle-class neighbourhood (Cotroceni). Source http://wikimapia.org/17751797/ro/Corpul-BC, public domain

used.' These plans aimed to deliver 300,000 units between 1960 and 1965 and subsequently 100,000 per year (Locuința urbană 1962). These ambitious plans followed developments throughout Eastern Europe and even beyond, where the 'socialist modern' style of mass housing production-echoing 'international modernism'-became the norm (Fehérváry 2013, p. 82). As Krisztina Féherváry (2013, p. 83) notes, 'this style of architecture was not unique to socialism. In the 1960s, governments from London, Copenhagen, and New York City to Moscow and Bombay looked to new, prefabricated housing technologies to solve urban housing shortages.' On a more general level, they were inspired by the 5th Congress of the International Union of Architects; the decision makers and professionals were looking for a rational system inspired by Clarence Perry's neighbourhood units. If, in the late 1950s, housing construction policies focused on producing more units, from 1958 onward, as can be seen in Fig. 8.5, collective consumption functions and utilities also began to receive more attention (Gusti 1962; see Stroe 2015 for an analysis of housing policy at that historical juncture).

In the late 1960s and early 1970s, enormous housing estates were built in Bucharest. These included Titan, Drumul Taberei, Pantelimon and Colentina, with populations ranging from 150,000 to 300,000 inhabitants. They followed a nested hierarchy of density and concentration of functions. Playgrounds, kindergartens and primary schools were built for concentrations of buildings housing up to 1,500 


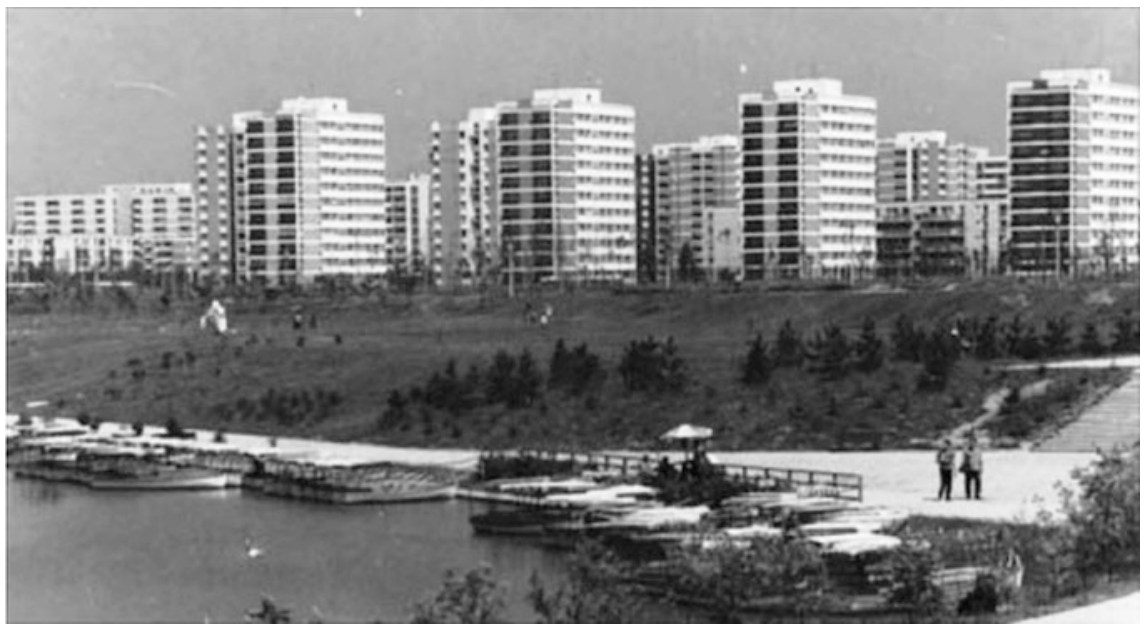

Fig. 8.5 A large housing estate (Balta Alba/Titan) built in the early 1970s providing accommodation for approximately 300,000 inhabitants. Source http://turismistoric.ro/wp-content/uploads/ 2015/08/61453699.jpg, public domain
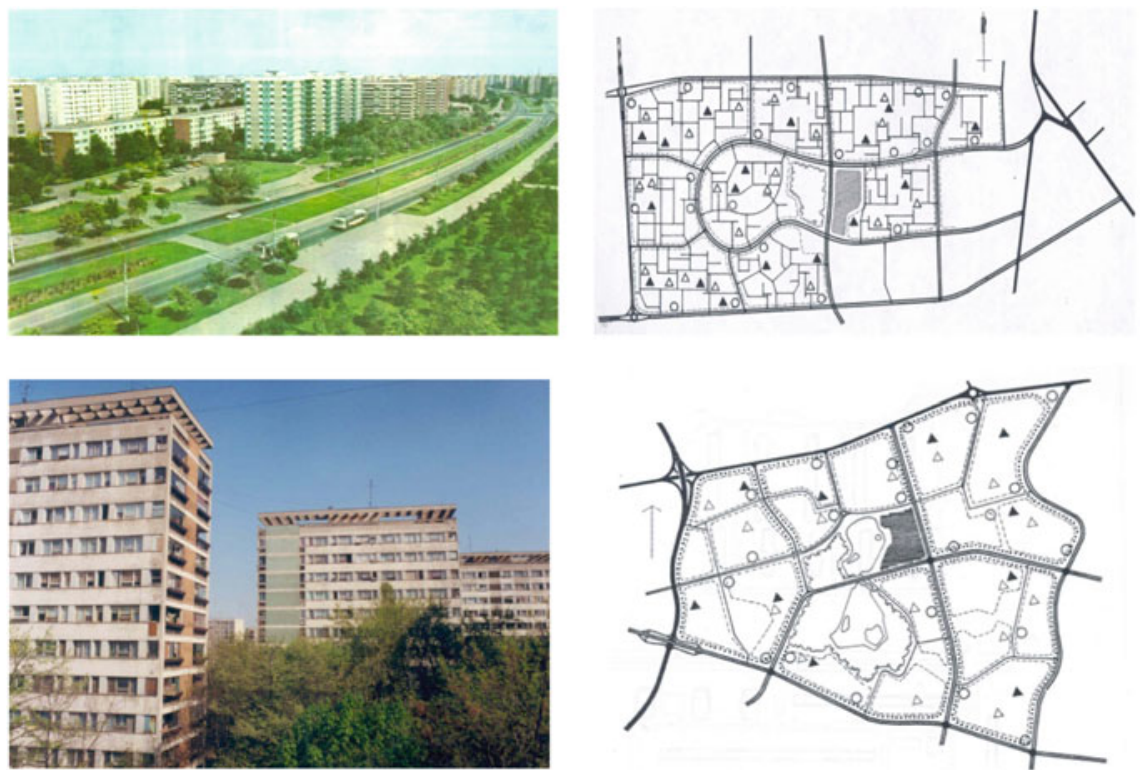

Fig. 8.6 Images and plans of two huge housing estates of the early 1970s, Drumul Taberei (upper images) and Balta Albă (lower images). Source "Locuinţa urbană,"1962, public domain 

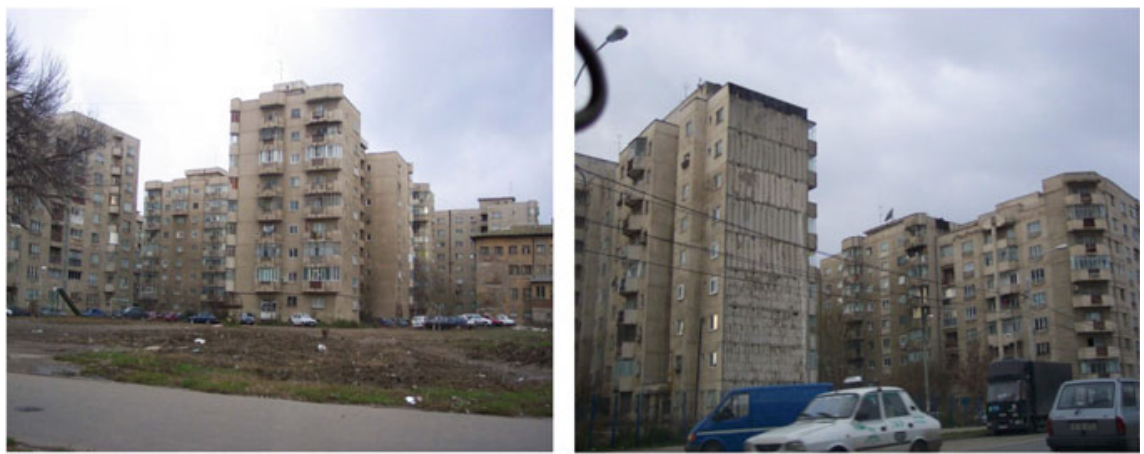

Fig. 8.7 Apartment buildings (in poor condition) from the 1980s on Calea 13 Septembrie. Source Author's images

people. Several such units, jointly accommodating 4,000 to 12,000 residents, formed a mikrorayon, and were outfitted with food, clothing, and shoe shops, restaurants, libraries, cultural centres, sports facilities and medical centres. A cluster of mikrorayons housing up to 40,000 inhabitants made up a rayon, which required secondary schools, sporting facilities, cinemas, post offices and hospitals. Finally, an agglomeration with over 40.000 inhabitants needed a theatre, a concert hall, a university, parks, hospitals and offices for state institutions. The buildings were simple, with large windows that opened onto large green spaces (see Figs. 8.6, 8.7, 8.8 and 8.9), with natural ventilation for bathrooms and with balconies and pantries.

As Krisztina Féherváry (2013, p. 86) reports for Hungary (though similar dynamics apply for Romania) 'compared with crowded living arrangements in village houses, which usually had no indoor plumbing and often still had packed-earth floors, a new apartment with an indoor toilet, running water, and heating seemed an undreamed-of luxury.' One gets a glimpse of that in the 1976 movie Serendă pentru etajul 12 (Serenade for the 12th floor) (see Boboc 2016, p. 94). On the other hand, not all planned collective consumption facilities were actually built, leading to serious frustrations for the population in the austerity decade of the 1980s. These ensembles are, nevertheless, still appreciated and various surveys indicate that people who grew up in these areas want to remain in them, not only because of family ties but also because of childhood nostalgia. Hipster bookstores in central Bucharest sell magnets with 1970s images of such districts to their youthful clientele. The way people inhabit apartments in housing estates is a good illustration of the saying 'My home is my castle' (Soaita 2012; Druṭă and Ronald 2017). As Krisztina Féherváry (2013, p. 16) explains, 'people strove to transform the interiors of apartments into heterotopic private spaces utterly distinct from the buildings that surrounded them,' in stark opposition to the 'perception that these public spaces ... belonged to an impersonal, unitary state.' Apartments were inhabited as spaces of 'normality,' clearly delineated materially, aesthetically, and politically from the abnormal politics present in the public space during the socialist and post-socialist periods (Fehérváry 2013, pp. 19, 29, 37). 
There is evidence for this in the attention paid to material and symbolic borders and thresholds, e.g. investment in massive apartment entrance doors, investments in double-glazed windows (Iancu 2011), or the separation ritual of taking off one's shoes as one enters the apartment (Fig. 8.6).

Usually, these high-rise estates were built in areas that were weakly or 'under'urbanised. Drumul Taberei, for instance, was built on former military space in the western part of the city. In 1974, however, the new urban planning legislation (Law 59/1974) stipulated more intensive use of land, so, especially after 1977 when an earthquake killed 1,000 residents of the central and semi-central areas, urban renewal plans began to address the older, semi-central, already urbanised core. Many buildings with long-expired lifespans were targeted for demolition and plans were made to rebuild from scratch. An old, centrally located radial, retail street (Calea Mosilor, though the same goes for Stefan cel Mare) was razed to the ground, enlarged and flanked by 10 -storey buildings.

\subsubsection{7-1990: Austerity, Poorer Quality and Densification}

The 1980s, a decade of IMF debt repayment austerity, import substitution, and the neo-Stalinist dictatorship of Nicolae Ceaușescu witnessed the densification of existing housing estates through inserts, generating poorer quality apartments. Compared to previous decades, the major differences of the late 1970s and 1980s are, in addition to densification, the shrinking of collective consumption facilities and a reduction in the level of attention paid to the quality and aesthetics of both urban composition and buildings themselves. That meant that balconies became smaller or disappeared altogether, the sizes of windows and green areas were reduced, and more exposed concrete was on view due to a lack of exterior plaster or paint. All of this materialised in poorer quality new housing, echoing, and probably exceeding, similar developments elsewhere in the region (in the former GDR and

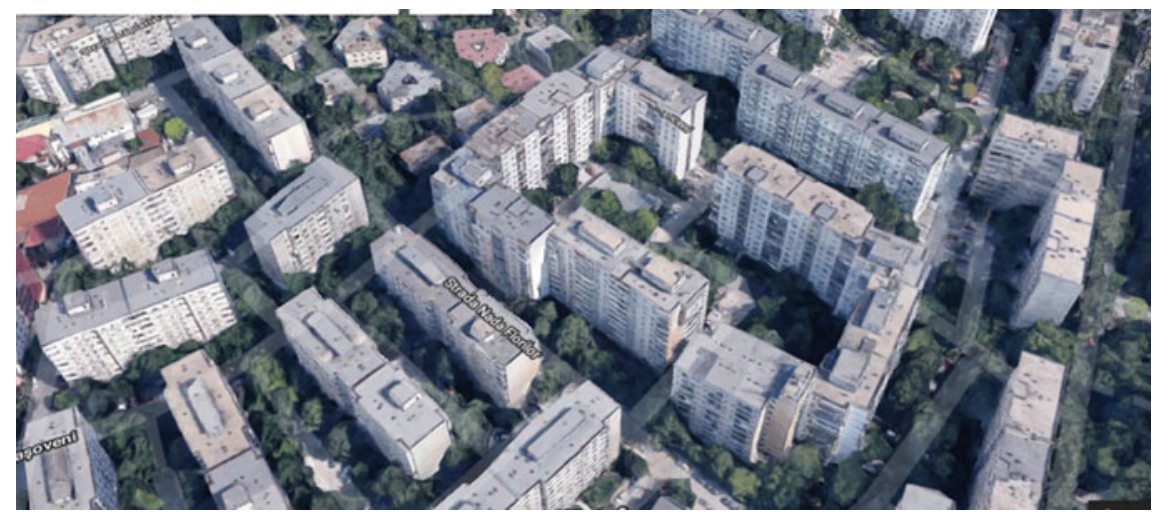

Fig. 8.8 Dense development, characteristic of the 1980. Source Google Maps 

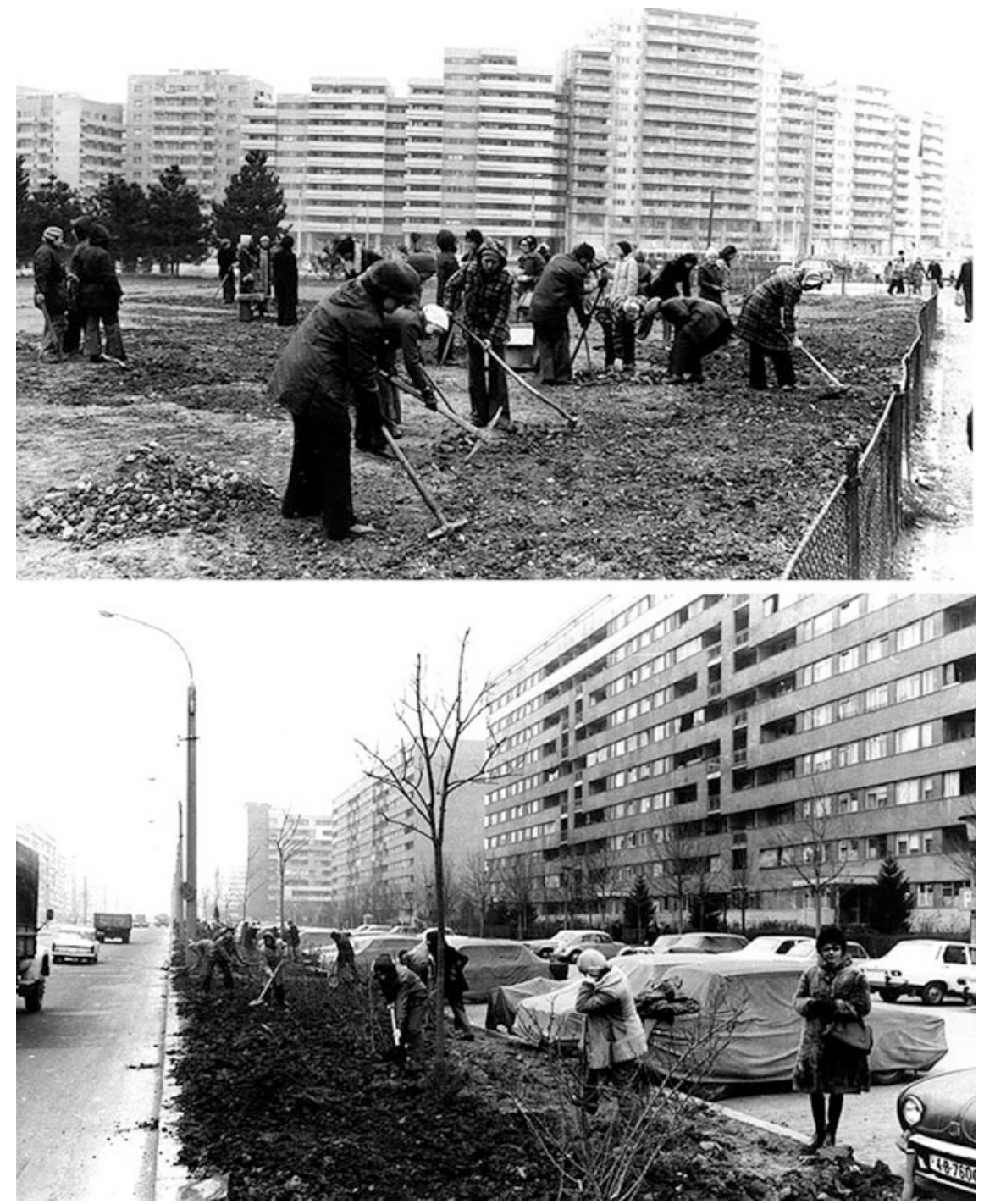

Fig. 8.9 "Voluntary" work by residents of a large housing estate (Lujerului), 1980s. Source Vera Marin, personal archive

Hungary, for instance (see Fehérváry 2013, p. 100). Buildings became twisted around small spaces, aggregated around a heating unit in the middle, or rather simple objects surrounded by barren land (see Fig. 8.7). The poor quality of public spaces was a contentious area in the politics of late socialism. Currently, the beautification of such spaces tops the list of ways in which local politicians go about accumulating political capital. Putting in grass playgrounds and painting buildings are very popular interventions with residents. 
Between 1960 and 1976 an average rayon or administrative district housed 10,000 inhabitants at a density of about 200-500 persons per hectare. In 1961, the average height of a building was 4.8 storeys. That rose to 6.8 storeys and was accompanied not only by a reduction in the space between buildings from twice the height to as little as the height but also by an increase between 1964 and 1975 in the maximum footprint from $10 \times 32 \mathrm{~m}$ to $18 \times 104.4 \mathrm{~m}$. The intensified construction of new apartment buildings among those constructed in the previous two decades meant a further distancing from the principles advocated by the functionalist movement. Berceni, a district in southern Bucharest, is a good example of this. Some parts of it were decent in the 1970s, but it is now the epitome of 1980s densification. These buildings conformed to more reliable seismic norms as far as their reinforced concrete structure was concerned. Rooms here were larger, however the poorer quality of their public spaces is reflected in their place in the housing market nowadays (see Fig. 8.8).

During the 1980s, schools and the municipal administration required inhabitants to engage in 'voluntary' work, usually to clean up green public spaces and parks. Article 8 of the decree 216/1981 imposed an obligation on citizens committees and building associations to clean public spaces and maintain and repair buildings and streets. Basically, this law forced everyone to become involved in the embellishment of the cities (see Fig. 8.9).

Also during the same period, some boulevards became simple 'canyons' with long rows of high-rise buildings on both sides, sometimes with very limited sidewalks (see Fig. 8.10). An exception not only in terms of quality but also in terms of design is the late 1980s 'civic center,' an aggressive urban renewal project that razed about a quarter of central and semi-central Bucharest.

\subsubsection{After 1990: The End of Mass Housing, Further Densification and Gated Communities}

At the beginning of the 1990s, the World Bank advised the former communist countries to privatise their housing units. Romanian municipalities sold these apartments very quickly to private parties. This is how private ownership skyrocketed to almost $100 \%$, practically overnight. After the 1990s, the massive allocation of state funds for housing, which, in previous decades had been around 8\% of GDP, ceased abruptly. In 1990, the ratio of privately financed to state-financed housing construction was 1:7; by 2008, that ratio had changed to 10:1 (Soaita 2012, p. 1014). Apart from the completion of structures already begun, there was very little construction of new mass housing. In the 1990s, there was timid real estate development and many urban dwellers returned to rural settlements (back to the regions where they were born). Others who preferred a house with a garden over mass housing ensembles moved to the sprawling suburbs if they could afford to do so.

It was only after 2005 that banks began to offer long-term mortgage loans. Apartments built then promised to change the image of the home from a refuge 


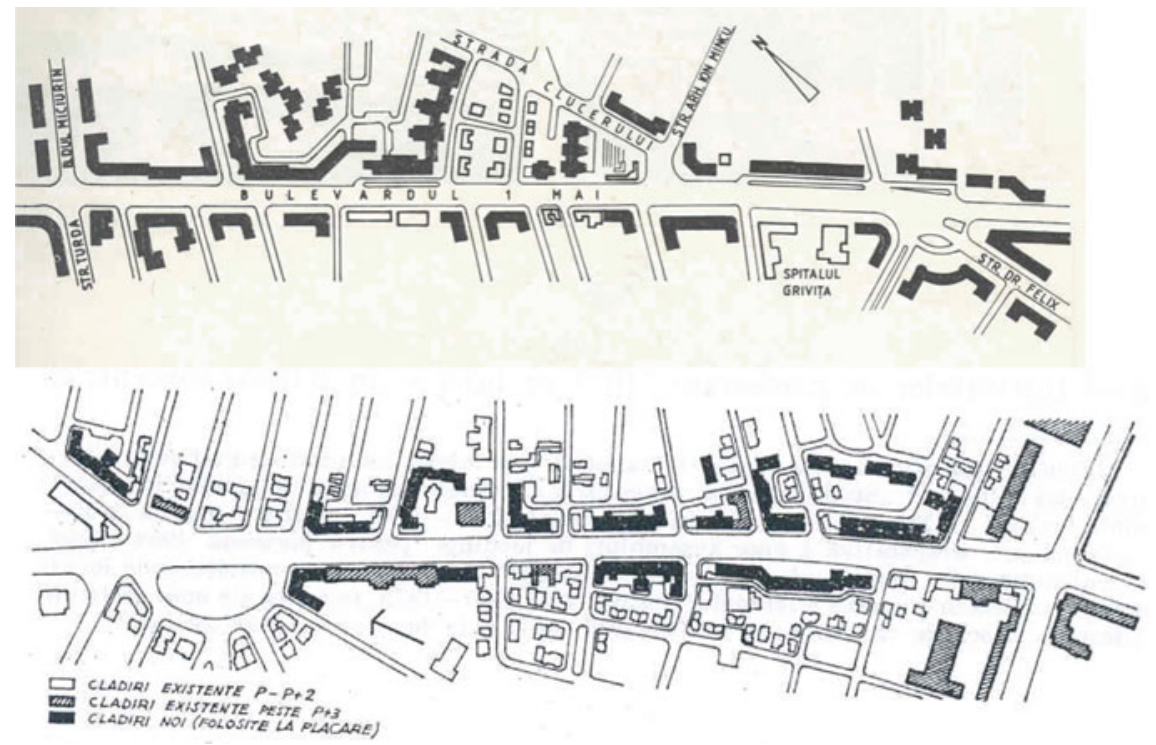

Fig. 8.10 Various 'canyon'-style configurations of apartment buildings along radial boulevards in old, low-rise, central areas of Bucharest (Bulevardul 1 Mai and Calea Mosilor). Source Marin 2009

from public space to a 'symbol of social success' (Boboc 2016, pp. 93-94). Less spatially concentrated and usually inserted into the older central and semi-central areas (Chelcea 2008), these new high-rises, designed as gated communities, replicated some of the negative planning and construction problems of the socialist housing estates. These included speed of construction, lack of integration with the surrounding space and lack of collective consumption facilities. If these new ensembles are built on brownfield sites, they rely on the already existing infrastructure (including utilities) of socialist-era housing estates. In the 1980s, it had been the (socialist) state that put pressure on urban planners to construct cost-efficiently; currently it is the developers who press for maximum profit (see Fig. 8.11). The layout of these new apartment blocks is sometimes less functional than those projected by the socialist-era state planning offices.

\subsection{Characteristics of Physical Layouts of Housing Estates: 'Surround,' 'Points,' 'Blades,' and 'Canyon'}

Despite the immense size of housing estates, their nested structure allows enough scope for variability. The mikrorayon sections of housing estates do not necessarily occupy a significant surface area. Rather, what sets these housing estates apart is their lack of integration with surrounding urban tissues and their dense occupation 


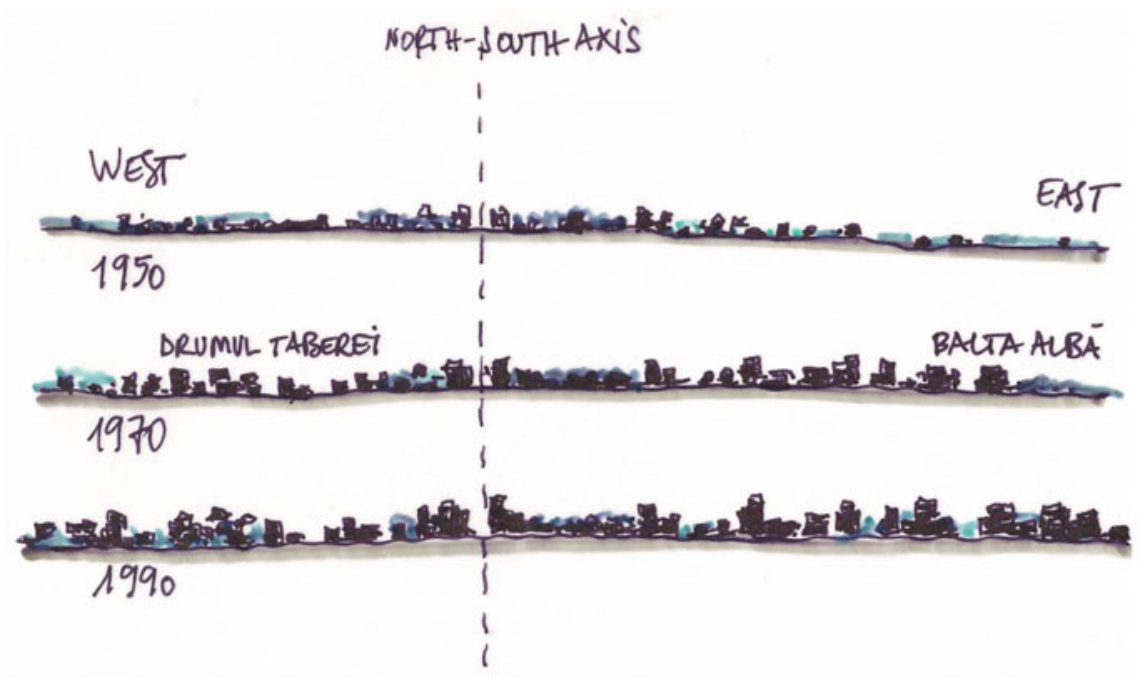

Fig. 8.11 Section profile of Bucharest at the inception and end of the high-rise era. Source Vera Marin, 2018

of urban land. At their inception, and throughout their gradual densification, housing estates came to have several kinds of physical layout. Based on Marin (2009), we distinguish four dominant types: (1) surround; (2) points and blades; (3) parallel blades; (4) canyon. Figure 8.12 illustrates the physical layouts that are commonly visible in the housing estates of Bucharest.

This bird's eye view of such housing estates suggests that the modernist ideology that underwrote them was fading away due to the pressures of densification. The public spaces - especially the green areas - are less generous than they were envisioned. Moreover, by the 1980s, the idea of building new collective housing areas with prefabricated panels had, by and large, been abandoned in much of Europe, though in Romania and other socialist countries, it was reaffirmed and remained the dominant housing policy (and even spilled over into some villages).

\subsection{Social Composition and Challenges Faced by Housing Estates}

At present - and it was probably even moreso at the time of their constructionhousing estates enjoy a high level of social mixing between professional ranks and middle-class positions (Marcińczak et al. 2014). Middle-income families often live next door to low-income families. Given the low level of residential mobility, some of the initial occupants still live in these apartments (Suditu et al. 2014). Historically, many of the apartments were acquired through a bank savings system, 

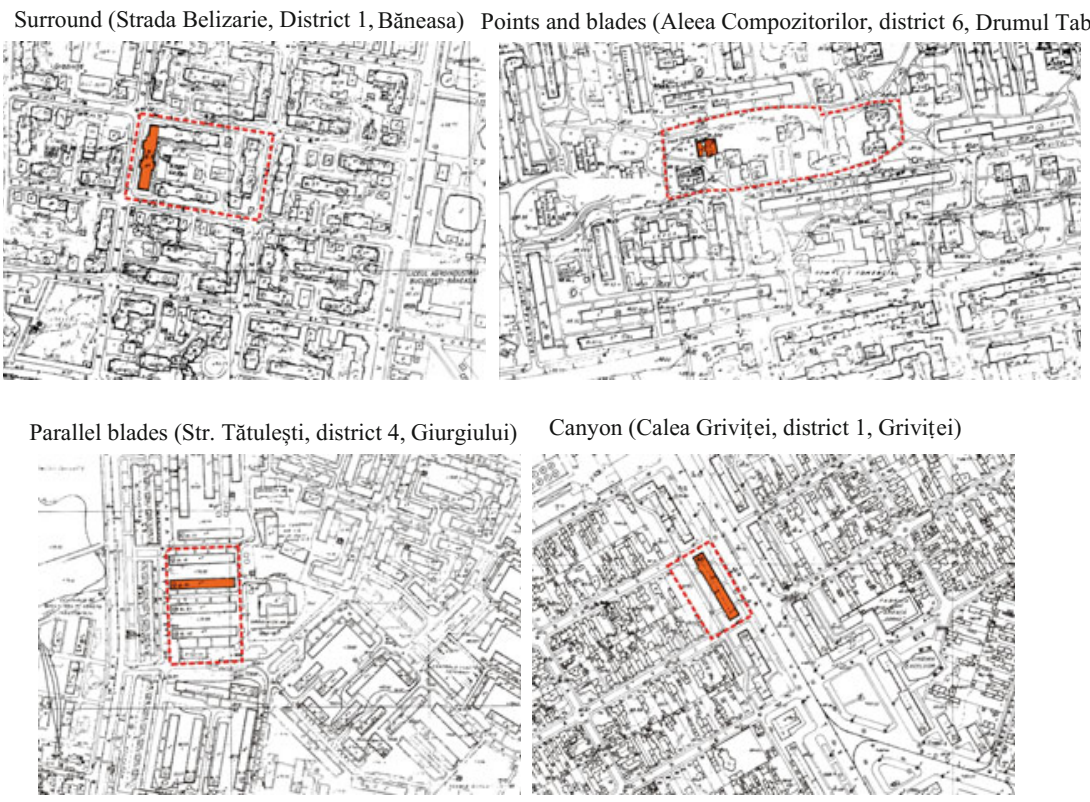

Fig. 8.12 Common physical layouts of buildings in Bucharest's housing estates. Source Marin, 2009

with mortgages usually lasting 30 years. Others were allocated as social housing to young workers, to newlyweds, and to those who had been relocated with their jobs to Bucharest. Retired people, as well as those earning less than a certain threshold, were allowed to rent apartments; those who earned more money were encouraged to start saving and then purchase apartments. Sizeable families were given priority. Some ministries developed their own housing programs in certain parts of Bucharest, as was the case with a number of mikrorayons in Drumul Taberei after 1963.

A lack of fit between census tracts and the boundaries of housing estate makes it difficult to provide a precise assessment of the exact number of residents, the share of minorities, and their economic status. Several conclusions can be drawn, however. First, tenure structure in housing estates is, of course, dominated by private ownership: units are mostly owner-occupied. Second, geographic distribution by education and profession, according to the 2011 census, suggests that the number of college-educated individuals is higher in central areas than in housing estates. Conversely, vocationally trained people occupy around $12.5 \%$ of the areas within housing estates, compared to $8.31 \%$ for the entire city and $2.22 \%$ for the central areas (INS 2011; in Chelcea et al. 2015).

The challenges faced by housing estates are obvious, as are the problems faced by the condominium associations, and local and central government. Seven such problems - the ageing of structures and the population; urban infrastructures and 
connectivity; energy efficiency; high densities; weak and pro-business planning; post-privatisation condominium administration and aesthetic challenges - are outlined below. Some of these issues may be relatively easily addressed (e.g. aesthetic problems), while some (e.g. high densities) require housing to be taken seriously as a right and an urban planning matter, rather than as a 'for-profit' domain outside the reach and scope of public policies. Here, we offer a brief account of each such challenge, as well as the programs and measures that it has attracted.

Ageing. The ageing problem in the housing estates is double-fold: it covers both the physical structures and the resident population. The original lifespan of the buildings has expired. When they were planned and erected, they were designed to last 50 years. This means that many of their functional systems (roofs, pipes, joints, etc.) need replacement. Second, 1992, 2002 and 2011 census data suggest that Bucharest's population is ageing. When the estates were built, $60 \%$ of the incoming residents were aged between 15 and 29 years old (Marin 2009). Although there has been generational replacement, some of the original population have now retired. This creates a host of planning challenges. For instance, many building are four storeys high and, as a rule, they do not have elevators. As a result, one may expect increasing mobility challenges for their occupants.

Urban infrastructure and connectivity. When first built, the apartments were fully integrated into networked infrastructures for water, gas, electricity and centralised heating, although the austerity decade of the 1980s created substantial service problems (see Chelcea and Pulay 2015). Owing to privatisation and deficient condominium management, some connectivity and building efficiency problems persist. For instance, the water company (Apa Nova Bucuresti, part of the multinational Veolia) is responsible for the upkeep of street water mains; water pipes inside the buildings, however, should be repaired and replaced by the condominium associations. Some associations are more proactive and replace them, while others lack either the resources or the trust required for the upkeep of the internal pipework (see Soaita 2012). The water company is currently trying to create a coalition of actors (condominium associations, Ministry of Development, and local government) for resource allocation for the replacement of pipes. As yet, these efforts remain a 'corporate social responsibility' of the water company, limited to the replacement of the pipes in 300 buildings in Bucharest. Some forms of 'splintering urbanism' (Graham and Simon 2001) have occurred. All apartments were scheduled for water metre installation (Bouzarovski 2009; Poputoaia and Bouzarovski 2010). Many households, especially in the late 1990s and the 2010s, rushed to disconnect from the centralised provision of heat and hot water. With the substantial increase in the price of natural gas, some have come to pay more for these services than they used to when they were connected to centralised networks, especially since the Bucharest municipality allocates more substantial subsidies for these services than other cities in Romania.

Energy efficiency. With $72 \%$ of its urban housing stock concentrated in housing estates, Romania had to address the issue of poor thermal insulation as part of its EU accession deal. Newly constructed buildings, most often in the form of detached housing, incorporate thermal insulation requirements from the moment of their 
construction. A more difficult challenge has been the retrofitting of existing buildings. One challenge has to do with the size of the buildings to be retrofitted. Although the average heated surface in apartments in housing estates is smaller than the heated surface in urban and suburban detached houses (48 sq. m compared to 73 sq. m), on average, apartment buildings in Romania contain 40 apartments each. Another challenge is regulatory. There are several central government agencies with overlapping authority over construction policy. They do not always cooperate and integrate their actions. There is, for example, no common nation-wide policy on what technologies and approaches should be used.

In addition to the size of the buildings and regulatory problems, another challenge is financial. Funds have not always been available, due either to the global financial crisis, or to there being other priorities. The apartment owners - the actual beneficiaries of this policy - have been unwilling to share even a small fraction of the costs of refurbishing their buildings. The shares of central government, local administration, and household contributions have varied. ${ }^{2}$ As a rule, household contributions have been minimal or not required. In some cases, the central government share was overwhelming, in others, the local government paid $100 \%$. In addition, quality issues have emerged. As thermal insulation is a recent addition to the activities of the construction industry in Romania, its financing has been sporadic, and the labour force is unfamiliar with recent technologies, companies that refurbish these apartment buildings have been charging substantial prices and have often placed substantial burdens on state budgets (for work of dubious quality). Finally, administrative knowledge (or lack of it) has been a further obstacle to progress with these buildings, although, starting from 2005, local authorities should have conducted an inventory of high-rise buildings in order to set criteria and establish priorities.

In Bucharest, as of $2011,21 \%$ of the housing stock had been retrofitted, which means 180,132 buildings out of a total of 844,586 (INS 2011). The poorest local government (District 5) had retrofitted only $16 \%$ of its buildings, while the richest (District 1) had retrofitted $28 \%$. Yet, there is hardly a linear correlation between the wealth of a district and the percentage of retrofitted buildings. A more fine-grained analysis is difficult, and this reflects not only scholarly difficulties, but administrative practices. Fieldwork evidence suggests that the choice of buildings for thermal insulation has been ruled by considerations of visibility (with buildings on main arteries attracting most investment), random criteria, or the persistence of the elected presidents of condominium associations. The criteria for prioritisation became looser and looser between 2002 and 2009, thus making a key dimension of targeted urban policies - slowing or reversing the downward spiral of certain struggling areas-impossible.

\footnotetext{
${ }^{2}$ Bucharest has two levels of governance: the general municipality and six district administrations. Their functions are sometimes distinct (e.g. the administration of some boulevards may lie with the general municipality; likewise waste collection) while at other times, they overlap (large-scale infrastructure projects).
} 
Density. A problem transcending political regimes and historical periods has been the high density of the population in housing estates of Bucharest (see Figs. 21 and 22 for bird's eye views of Drumul Taberei housing estate between 1966 and 2002). Bucharest is the most densely populated capital city in Europe with about 8,000 inhabitants per sq. km (Chelcea and Iancu 2015) and with particular areas inside the housing estates reaching a density of 13,000 inhabitants per sq. km (e.g. the Tineretului area and Lujerului area). Compared to housing estates in cities elsewhere in Europe, they feel rather cramped (see Fig. 8.13 for the evolution of Drumul Taberei). Even at their inception in the 1960s, when functionalist urban planning in Bucharest had some coherence, there was less green space and fewer collective consumption facilities than in cities such as Prague, Budapest and Kiev. The initial vision was to have 'cities within the city,' independent of the city centre and gravitating around large industrial areas. The above-mentioned Balta Albă neighbourhood - with its 300.000 inhabitants, many of whom worked in the nearby 23 August industrial area - was comparable in population size to Romania's second, third and fourth largest cities (Cluj, Timişoara and Iași, respectively). Despite that, it only had one movie theatre (Gloria) and one major department store (Magazinul Titan). Similar under-provision was evident in education. The cohorts that went to primary and secondary school in the 1980s remember that schools functioned in three shifts (early morning, afternoon and evening).

Densification continued in full swing even after the implosion of mass housing programs after 1989. After the rigid top-down approach that operated during Soviet times, urban planning in the 1990s changed to the opposite extreme. As in many places in Central and Eastern Europe, there was little or no urban planning at all in the 1990s. That meant that urban land could be speculated with in order to produce maximum profit. With no large housing estates being built inside or near Bucharest, two types of urban land became the major location for new buildings. First, due to de-industrialisation, industrial brownfields, which occupied about $15 \%$ of all urban land in Bucharest, were speculated for new condominium construction, most often in the form of gated communities (even if they were situated in central areas of Bucharest) (Chelcea 2008; Simion 2016). Not only did this increase the overall concentration of housing in socialist-era estates, but the densities inside such small-scale gated estates became similar to the areas they hoped to isolate themselves from, both physically and symbolically. Second, an unfortunate interpretation of restitution legislation allowed the construction of new buildings on green spaces populated with benches, playgrounds and gazebos lying between existing buildings (Hirt and Stanilov 2007). As Hirt and Stanilov explain (2007, p 228), 'as long as there were no buildings on the ground, the land was eligible for restitution. Since the laws allowed the restitution of almost any chunk of land, as long as there were no buildings upon it, neighborhood open spaces became legally eligible for private development.' Both brownfield conversion and restitution led the construction of new buildings. They tend to reproduce the shortcomings of the previous decades, adding more pressure on collective consumption (schools, kindergartens, 

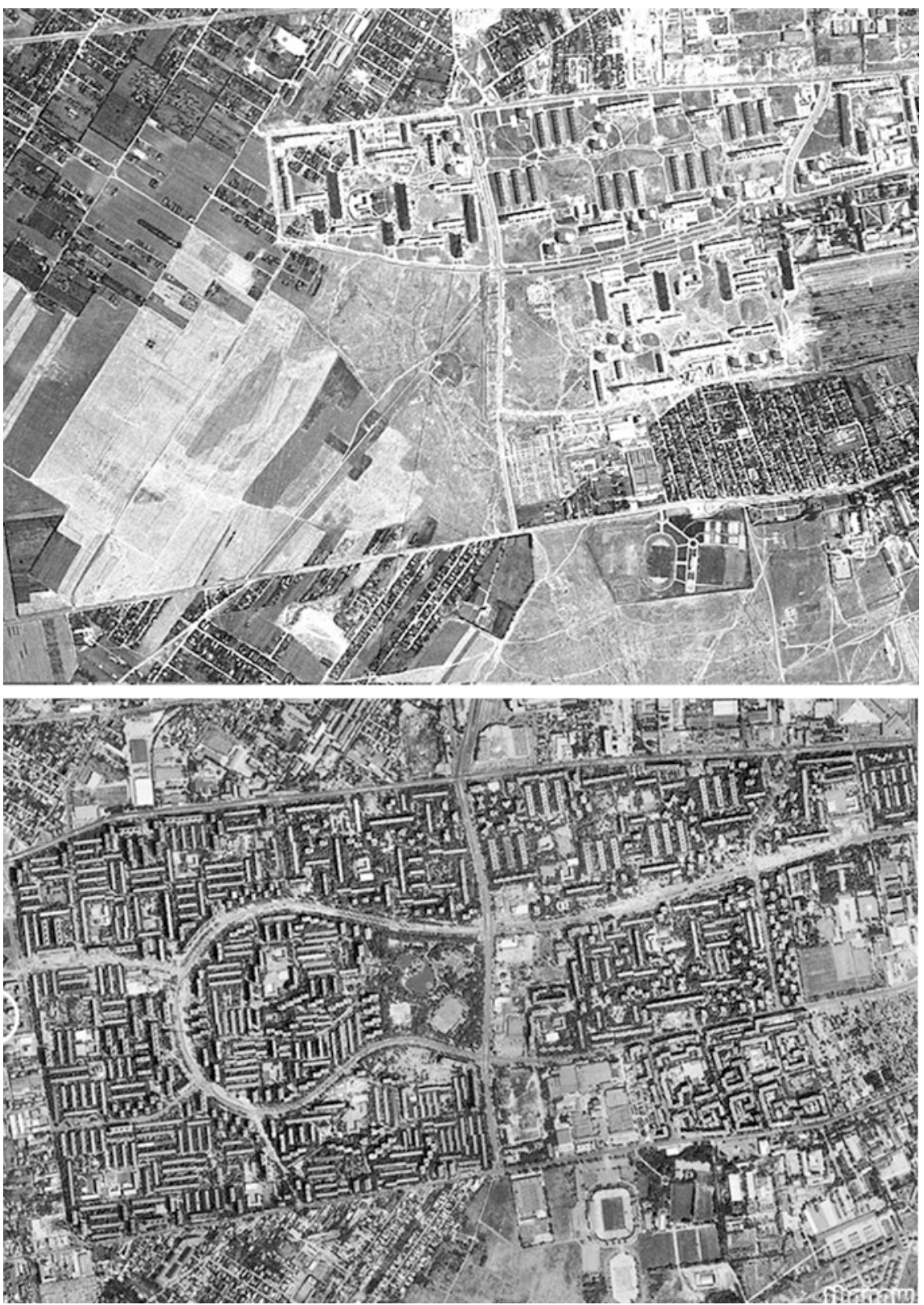

Fig. 8.13 Densification of Drumul Taberei Microraions between 1966 and 2012. Source http:// www.costingheorghe.ro/thenow/cartiere-dormitor-din-bucuresti/ 
and utilities) and intensifying automobile traffic and parking problems. One might imagine that density would eliminate inhabitants' reliance on their cars; however very often sidewalks are hijacked as parking lots, rendering them inaccessible to pedestrians. Since apartments in such buildings sell at higher prices than those in the 'old' socialist-era housing estates, they also increase urban segregation, often actively 'selling' segregation as a desirable trait.

Weak planning biased toward real estate developers. The further densification of housing estates after 1989 is also a symptom of weak urban planning, generally catering to the interests of real estate developers. A failure to find a balance between principles of urban planning and the private real estate business is due to insufficient community consultation, the softness of sanctions and weak municipal control of building activity. One example of such planning is the construction of large hypermarkets and shopping malls within already dense housing estates. In a truly dialectical manner, the under-provision of retail space during socialism has been used (and is still being used) as an argument for granting permits for large commercial investments, usually using industrial brownfield sites. Planning decisions of this kind have drastically intensified the heavy traffic in the already dense housing estates, as cars are parked, most often, directly on sidewalks.

Bolstering the importance of urban planning could follow two directions. First, public spaces might be easily improved. Local administrations have invested funds for such purposes, although public space has been shrinking constantly, both as a result of planning and spontaneously due to large pressure for car parking. Second, local administrations should invest more in collective consumption and urban functions. Education (especially nurseries and kindergartens), health, and sports facilities have been undersized from the inception of housing estates, and late-socialist and especially post-socialist densification has made the situation worse. To the extent that they have been created in the last two decades, such services and facilities are exclusively private, thus attracting only those who can afford them.

Housing is a low public agenda priority. Housing privatisation and the creation of a super-homeownership society were accompanied by the shifting of moral and financial responsibility from central government to the local authorities and then to the owners themselves. For some years after privatisation, this meant the withdrawal of any public subsidy for housing. From being a right, housing became an economic merit. Thus, a number of poor households became, as James Fearn (2004) argues, 'too poor to move, too poor to stay.' This is reflected, among other things, in the shape of census tracts. Many tracts include both housing estates and low-rise housing areas. Although often lumped together in uniform administrative categories, there are significant differences among structures in housing estates in terms of structural safety, energy efficiency, aesthetics, the financial power of owners and the efficiency of condominium associations. As they are privately owned, the administration places them outside its area of concern. This makes it difficult, for instance, to establish criteria and priorities for intervention and encourages ad hoc 
decisions that emphasise visibility. Some timid subsidies were reintroduced in the late 2000s, such as the subsidy for heating (since energy poverty is an important problem in Romania) (Buzar 2007).

Post-privatisation condominium governance. The mass privatisation of state-owned housing apartments in housing estates eliminated some problems and created others. For occupants of housing estates, it created protection against displacement and financial relief during the 1990s, a period of economic turmoil in Romania. Through housing privatisation, the cost of housing (at least) was written off for families struggling with shrinking social rights. As Stephens and Lux (2015, p. 1220) argue, 'giveaway privatisation thus created secure, debt-free home-owners, and played a crucial role in offsetting declining living standards arising from economic restructuring.' But it also meant a challenge to the administration of owner-occupied condominiums, including administrative efforts on behalf of new owners. Initially, all condominium associations were run by apartment owners, as they are legally non-profit organisations. Their scale may range from those apartments tied to a particular entrance in a building, to several neighbouring buildings linked by infrastructural nodes (such as a district heating system), proximity, or some other functional principle. One common problem has been the difficulty of actively prevailing upon their members to join in the election meetings, which has sometimes led to weak decision-making. Some residents could not afford to pay for utilities and had their apartments auctioned, others moved to the countryside, while yet others lived cramped together with their children in their apartments in order to make ends meet. Lack of trust between residents and the leadership of the association was also a problem (Soaita 2012, see also The Block, a documentary about condominium life in Romania, by Maria Sălaru). In the last 10 years, management companies began to emerge, assuming responsibility for accounting.

\subsection{Conclusion}

One may wonder what the appropriate course of action is for dealing with a large stock of apartments in vast housing estates. Should all apartment buildings in housing estates be maintained and repaired? Should they be left as they are? Should some perhaps be demolished completely or demolished and replaced with something else? Ironically, one cannot even speculate about this; first one needs to gather data in order to imagine solutions and perform administrative planning. Even if the state and the municipality allocated funds for thermal rehabilitation and built environment improvements (like the addition of playgrounds), prefabricated buildings were not built to last forever and even the most conscientious apartment owners will be overwhelmed at some point. The gloom and doom scenario outline by Andrusz (1996) may eventually come true in some areas. 
Our vision is that housing estates should be allocated public funds for maintenance and repair, but not to every owner. Public funds should be especially used to help low-income families, a strategy which will help maintain a social mix in Bucharest. If, however, there are solid arguments for demolition, under no circumstances should apartments buildings be demolished for the dispersal of poverty, unless better accommodation is offered to displaced lower class families.

Any properly grounded discussion about any policy will first need data gathering and data analysis, something that no public body is preoccupied with at the moment. In order to establish criteria, typologies and eligibilities, one needs to understand the broader vision for housing estates. Both the public authorities and the apartment owners are completely unprepared to ask uncomfortable questions and to allocate resources to seek answers.

Acknowledgements The authors would like to thank Daniel Hess, Tiit Tammaru, and Marteen van Ham for their help and suggestions.

\section{References}

Andrusz G (1996) Structural change and boundary instability. In: Andrusz G, Harloe M, Szelenyi I (eds) Cities after socialism. Blackwell, Cambridge, MA

Berescu C, Celac M, Ciobanu O, Manolache C (2006) Housing and extreme poverty: The case of Roma communities. Editura Universitara Ioan Mincu, Bucharest

Bernt M (2009) Partners for demolition: The governance of urban renewal in East Germany's shrinking cities. Int J Urban Reg Res 33(3):754-769

Boboc C (2016) Mare, curat și frumos. De la blocul comunist la ansamblul residential. In: Negru N (ed) Bucharest Housing Stories. Editura Pro Universitaria, Bucharest, pp 91-110

Bouzarovski S (2009) East-Central Europe's changing energy landscapes: a place for geography. Area 41(2):452-463

Buzar S (2007) Energy poverty in Eastern Europe: Hidden geographies of deprivation. Routledge, London

Chelcea L (2008) Bucureștiul postindustrial: Deindustrialiare, memorie și regenerare urbană. Polirom Iași

Chelcea L (2012) The housing question and the socialist answer: city, class and state remaking in 1950s Bucharest. Int J Urban Reg Res 36(2):281-296

Chelcea L, Druță O (2016) Zombie socialism and the rise of neoliberalism in Central and Eastern Europe. Eurasian Geogr Econ 57(4-5):521-544

Chelcea L, Iancu I (2015) An anthropology of parking: Infrastructures of automobility, work and circulation. Anthropol Work Rev 36(2):62-73

Chelcea L, Popescu R, Cristea D (2015) Who are the gentrifiers and how do they change the inner city neighborhoods: privatization, commodification and gentrification in Bucharest. Geografie 120(2):113-133

Chelcea L, Pulay G (2015) Networked infrastructures and the "local": Flows and connectivity in a postsocialist city. City 19(2-3):344-355

Cupers K (2014a) The social project. Places. https://doi.org/10.22269/140402 
Cupers K (2014b) The social project: housing in postwar France. University of Minnesota Press, Minneapolis, MN

Direcția Urbanism și Amenajarea Teritoriului (2000) Planul urbanistic general al municipiului Bucuresti

Druță O, Ronald R (2017) Young adults' pathways into homeownership and the negotiation of intra-family support: a home, the ideal gift. Sociology 51(4):783-799

Dumitru AM (2016) Apartamentul de bloc între spațiu de locuit și ,acasă’ The block flat as a living space and 'home'. In: Negru N (ed) Bucharest Hous-ing Stories. Pro Universitaria Bucharest

Fearn J (2004) Too poor to move, too poor to stay: A report on housing in the Czech Republic. Open Society Institute, Budapest, Hungary and Serbia

Fehérváry K (2013) Politics in color and concrete: socialist materialities and the middle class in Hungary. Indiana University Press, Bloomington

Fishman R (2004) Rethinking public housing. Places 16(2):16-33

Florea I (2017) To name or not to name: Contradictions in naming process in one district of Bucharest. In: Harris R, Vorms C (eds) What's in a name? Talking about urban peripheries. University of Toronto Press, Toronto

Freidrichs C (2011) The Pruitt-Igoe myth: an urban history

Graham S, Simon M (2001) Splintering urbanism: networked infrastructures, technological mobilities, and the urban condition. Routledge, London

Gusti G (1962) The influence of the new collective forms of living on the features of the socialist city, Bucharest. Arhitect Mag 2:2-5

Hirt S, Stanilov K (2007) The perils of post-socialist transformation: Residential development in Sofia. In: Stanilov K (ed) The post-socialist city: urban form and space transformations in Central and Eastern Europe after socialism. Springer, Dordrecht, pp 215-244

Iancu B (2011) The golden age of termopane. The social life of post-socialist windows. Martor 16:19-33

Institutul Naţional de Statistică. Recensămîntul populației și lo-cuințelor (2011) http://www. recensamantromania.ro/rezultate-2/

Lees L, Slater T, Wyly E (2008) Gentrification. Routledge, London

Locuinţa urbană (1962) Locuinţa urbană. Realizări din capitală 1959-1961. ed. Tehnică București

Luhn A (2017) Moscow's big move: Is this the biggest urban demolition project ever? The Guardian: Cities

Marcińczak S, Gentile M, Rufat S, Chelcea L (2014) Urban geographies of hesitant transition: Tracing socioeconomic segregation in post-ceaușescu Bucharest. Int J Urban Reg Res 38 (4):1133-1150

Marin V (2009) Politicile de locuire și planificiarea urbană: Ameliorarea lo-cuirii colective la București. Universitatea de Arhitectură and Urbanism Ioan Mincu, Bucharest, Romania

Poputoaia D, Bouzarovski S (2010) Regulating district heating in Roma-nia: legislative challenges and energy efficiency barriers. Energy Policy 38(7):3820-3829

Simion G (2016) Effects of postsocialist deindustrialization in Central and Eastern Europe: Results of an industrial site survey and GIS mapping in Bucharest city Romania. Human Geogr 10 (1):79-93

Soaita A (2012) Strategies for in-situ home improvement in Romanian large housing estates. Hous Stud 27(7):1008-1030

Stephens M, Lux M, P S (2015) Post-socialist housing systems in Europe: Housing welfare regimes by default? Hous Stud 30 (8):1210-1234

Stroe M (2015) Locuirea între proiect și decizie politică. România 1954-1966. Simetria, București

Suditu B, Dumitrache L, Vîrdol D, D.-G V (2014) New trajectories of post-socialist residential mobility in Bucharest. Human Geogr 8(1):75-82

Tudora I (2003) Le bloc, l'escalier et la communauté rêvée. Arches Mag (6) 
Tuvikene T (2018) Post-socialist (auto)mobilities: Modernity, freedom and citizenship. Geogr Comp 12(3). https://doi.org/10.1111/gec3.12362

Wacquant L (1993) Urban outcasts: Stigma and division in the Black American ghetto and the French urban periphery. Int J Urban Reg Res 17(3):366-383

van Kempen R, Dekker K, Hall S, Tosics I (2005) Restructuring large housing estates in Europerestructuring and resistance inside the welfare industry. Policy Press, University of Bristol, Bristol

Open Access This chapter is licensed under the terms of the Creative Commons Attribution 4.0 International License (http://creativecommons.org/licenses/by/4.0/), which permits use, sharing, adaptation, distribution and reproduction in any medium or format, as long as you give appropriate credit to the original author(s) and the source, provide a link to the Creative Commons license and indicate if changes were made.

The images or other third party material in this chapter are included in the chapter's Creative Commons license, unless indicated otherwise in a credit line to the material. If material is not included in the chapter's Creative Commons license and your intended use is not permitted by statutory regulation or exceeds the permitted use, you will need to obtain permission directly from the copyright holder. 


\title{
Chapter 9 \\ Persistence or Change: Divergent Trajectories of Large Housing Estates in Budapest, Hungary
}

\author{
Zoltán Kovács, Tamás Egedy and Balázs Szabó
}

\begin{abstract}
In post-socialist cities of Central and Eastern Europe, large housing estates became dominant features of post-war housing development. Unlike in Western Europe, these neighbourhoods were not developed for immigrants and the poorest segment of society. Instead, they provided homes for lower middle class and working class families with stable incomes. After the change of regime, however, these neighbourhoods experienced different development trajectories not only on the international but also on national and city levels. With regard to contemporary developments of housing estates, Budapest provides a typical post-socialist case where housing estates are continuously re-evaluated by the people and the market, while socialist legacies leave their imprints on the actual socio-economic developments. This chapter focuses on the development of large housing estates in Budapest and in Hungary before and after the transition. Today, one-fifth of the Hungarian population and one-third of Budapest's residents live in housing estate neighbourhoods. The main objectives of the study are to display the spatial distribution of different generations of housing estates at the national and city level with special emphasis on their physical and social characteristics. The chapter also sheds light on the consequences of the post-socialist transition on the recent developments of housing estates in Budapest. After almost three decades of transition, debates about housing estates and their future possibilities are still relevant in Hungary and Budapest, because some of these neighbourhoods are experiencing a renaissance in the housing market, attracting younger and better off strata, whereas others show symptoms of socio-economic decline.
\end{abstract}

Z. Kovács $(\varangle)$

Department of Human Geography, University of Szeged, Szeged, Hungary

e-mail: zkovacs@iif.hu

Z. Kovács · T. Egedy · B. Szabó

Hungarian Academy of Sciences, Budapest, Hungary

e-mail: egedy@gmx.net

B. Szabó

e-mail: szbazs@gmail.com

(C) The Author(s) 2018

D. B. Hess et al. (eds.), Housing Estates in Europe, The Urban Book Series,

https://doi.org/10.1007/978-3-319-92813-5_9 
Keywords Housing estates - Post-war housing development • Housing policy Urban regeneration - Budapest, Hungary

\subsection{Introduction}

Similar to other post-socialist cities of Central and Eastern Europe, housing estates became dominant features of the urban structure in Budapest after World War II (Sýkora 2009). Providing shelter for about one-third of the city's population, housing estates represent a significant part of the local housing stock and they satisfy the needs of a great variety of socio-economic groups, but mainly the less affluent segments of society. After the demise of state-socialism, liberalisation of the housing market as well as changing residential preferences of people created new opportunities for housing markets. Dwellings located in housing estates became re-evaluated and they generally tended to lose their previous prestige (Kovács and Herfert 2012). The global financial crisis and the subsequent shrinkage on the demand side of the housing market further exacerbated the downward process. However, housing estates are not at all homogeneous. We can identify substantial differences among them, according to age, size, building technology, accessibility and the quality of the built environment (Kovács and Douglas 2004).

The main aim of this chapter is to shed light on the main socio-economic changes of large housing estates that have taken place in Budapest since the change of regime. Our analysis builds on data from three previous censuses (1990, 2001 and 2011) and relevant media and policy documents referring to recent developments of large housing estates. The main research questions are as follows: How has the post-socialist transformation affected the housing estates of Budapest and whether the socialist heritage still persists or not? To what extent is physical and social decline typical for housing estates? How have the different generations of housing estates been affected by decline or upgrading? Focusing on these questions, we outline the overall development trends of housing estates in Budapest and discuss the socio-economic, structural and environmental challenges that have affected them in the last three decades. We also try to conceptualise our findings and place them in the wider context of urban development in Budapest dominated by urban sprawl (i.e. suburbanisation) and most recently urban regeneration (i.e. gentrification).

\subsection{The Evolution of Housing Estates in Hungary with Special Attention to Budapest}

In Hungary, the first housing-estate-like neighbourhoods appeared before World War I. These early estates were garden-city type compounds with primarily small dwellings built for the working class. They were built by state companies (e.g. 


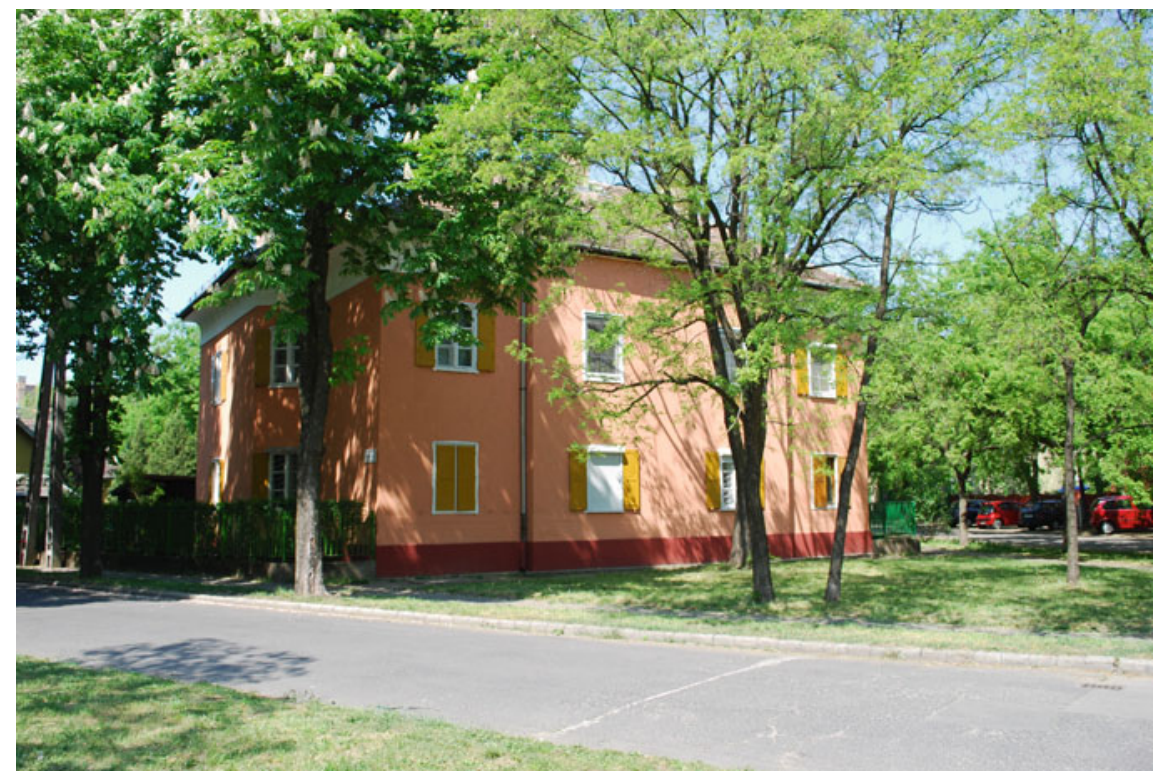

Fig. 9.1 Wekerle garden city, built at the beginning of the 20th century at the then urban fringe of Budapest. Source Kovács, Egedy and Szabó

national railway) or large municipalities like Budapest, which, for instance, erected the Wekerle-estate at the fringe of the city after 1908 (Fig. 9.1).

In the interwar period, housing shortages and overcrowding of dwellings became serious challenges in Budapest. In the 1920s, several low-quality barrack estates were built in order to ease the housing shortage and provide shelter for Hungarian refugees expelled from territories acquired by Romania, Yugoslavia and Czechoslovakia. By 1932, there were 18 barrack estates in Budapest containing nearly 6,400 homes and housing about 40,000 people, mainly in low-quality one-room flats without running water and sanitation (Gyáni 1992; Györi 1996). Housing estates meeting modern criteria appeared in Hungary only after World War II. The first project was launched in 1948 and it was the continuation of a smaller scale housing estate (Fiastyúk utca) planned and partly constructed before WWII. The general notion of housing estates applied in Hungary followed very much the concept of Clarence Perry's neighbourhood scheme, though without size limits. Housing estates had to form coherent neighbourhoods with strict internal organisation, separated from the surrounding neighbourhoods by arterial streets with distinct names. Taking into account their construction period, size, physical layout and the building materials used, we can define four generations of housing estates in Hungary and Budapest. 


\subsubsection{Housing Estates of the 1950s}

In the late 1940s and early 1950s, there were few housing estates built in Hungary since the communist regime designated the majority of state revenues for post-war reconstruction and forced industrialisation, including the development of socialist new towns (e.g. Dunaújváros, Várpalota, Komló, Kazincbarcika). At the same time, housing received low priority in the economic plans of the late 1940s and 1950s; thus, housing construction fell below the level of the interwar period and the population grew faster than the housing stock. These conditions raised serious tensions within Hungarian society. In urban areas, especially in Budapest and other major cities, the mismatch between supply and demand in the housing market was even more severe due to high immigration from rural areas. In 1949, the estimated national housing shortage was around 265,000 dwellings (and 63,000 dwellings or $23.7 \%$ in Budapest) (Sillince 1985). Public money spent on housing construction started to rise significantly after 1953 when the orthodox communist leader of the country, Mátyás Rákosi, was replaced by Imre Nagy. By the end of the decade, the proportion of dwellings built in housing estates in Budapest rose from the previous 20 to $40 \%$ (Preisich 1998).

Housing estates in the 1950s were most often developed on sites close to the inner-city, which had already been provided with public utilities or were easily accessible. These housing estates could be characterised by their 'human scale' physical form and a relatively small size comprising between 300 and 800 dwellings. Buildings were made of bricks arranged in a frame structure surrounding courtyards and squares. The height of houses did not exceed 3-4 levels. These estates became tangible symbols of the new system and the architectural style (sometimes popularly referred to as 'Stalin baroque') left distinct traces on the cityscape (Fig. 9.2).

Housing estates built in the 1950s undoubtedly improved the quality of urban life. Although the share of one-room apartments was extremely high (52\%), the comfort level of the apartments was significantly better than average as most of the dwellings were equipped with running water, bathroom and toilet (Fóti 1988). Residents of housing estates of the 1950s could be characterised by a strong working class profile and were loyalists to the communist system.

\subsubsection{Housing Estates of the 1960s}

In the 1960s, the principles of modernist architecture spread all over Hungary and standardisation in housing construction became commonplace. The construction of large housing estates at the urban edge was adopted as a major strategy for urban growth. Thanks to the block construction technology, apartment buildings in housing estates started to 'rise'. In addition to the 3- to 4-storey buildings typical of the 1950s, 9- to 10-storey blocks appeared in the second half of the decade. It was 


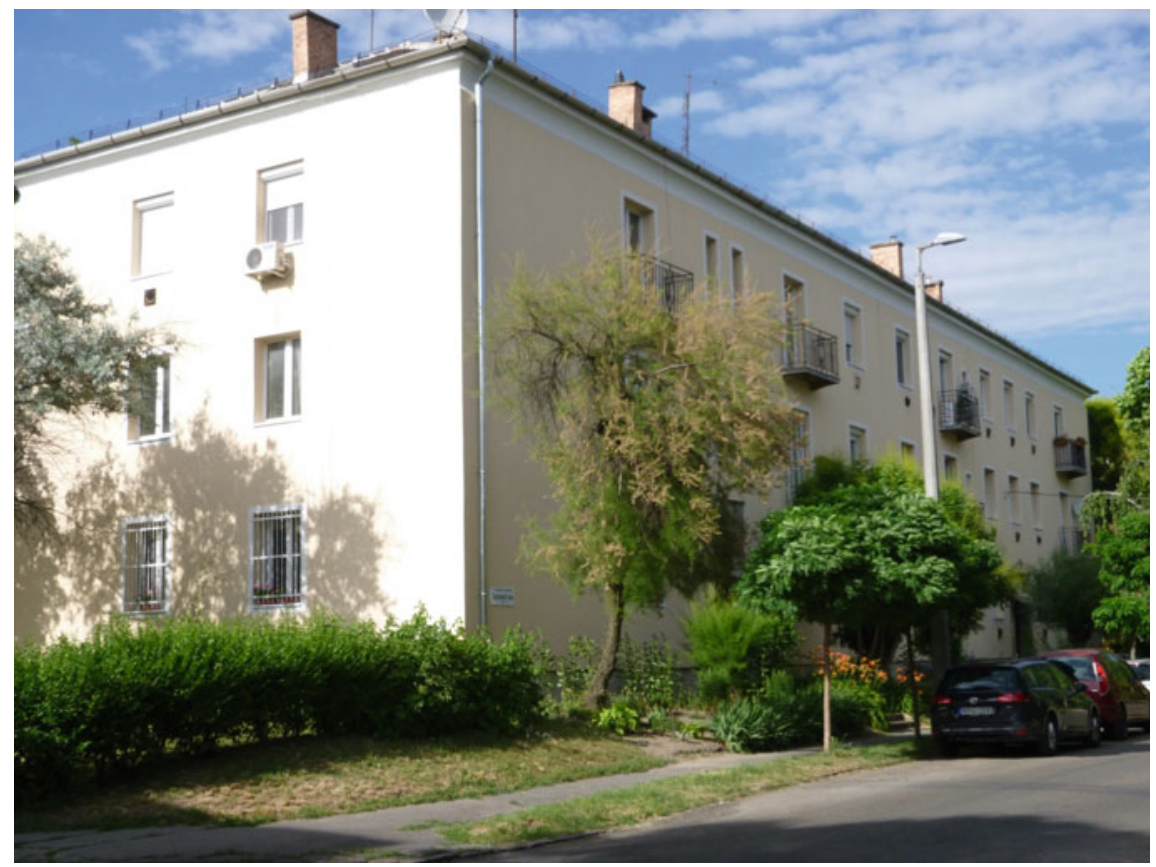

Fig. 9.2 Gubacsi housing estate in the 20th district of Budapest, built in the 1950s. Source Kovács, Egedy and Szabó

no surprise that the first pioneering reports on the sociological problems of large housing estates were published in the late 1960s (Szelényi and Konrád 1969) though without much resonance.

State housing policy changed in 1960, when the so-called ' 15 -year housing development programme' was launched in Hungary, which aimed at building one million new dwellings in Hungary (with a population of 10 million), out of which 250 thousand was foreseen for Budapest. The succeeding years saw a rapid increase in state housing expenditure and construction. Eventually, the plan was fulfilled, primarily thanks to a substantial overshot in private construction. Within the framework of the programme, a total of 187,000 apartments were built in Budapest, of which about 106,000 were built in the 1960s (Preisich 1998). However, the overall housing situation did not improve since the number of households grew faster than the number of dwellings.

In the 1950s, the share of public and private sectors in new housing construction was more or less balanced, but in the 1960s, $68 \%$ of new dwellings in Budapest were built by the state. Compared to the previous decade, the composition of dwellings was more favourable since the share of two-room apartments with bathroom and central heating considerably increased. At the same time, the average size of housing estates also increased, requiring more urban space. Consequently, the majority of housing estates in the 1960 s were built further from the city centre in 
the so-called transition zone, and housing estate construction gradually shifted towards the periphery (Pieniążek 2010).

Throughout the 1960s, block construction was gradually replaced by point and line houses, inner courtyards disappeared and large amounts of undeveloped space dominated the layout (Fig. 9.3). The average size of housing estates also increased to 1,000-2,000 dwellings. The prestige of these housing estates was considerably higher than the existing housing stock, thus, they became very much favoured by young middle-class families with children who often moved away from the outdated inner-city dwellings to new housing estates (Csanádi and Ladányi 1992; Szelényi and Konrád 1969).

By the mid-1960s, it became obvious that the ambitious objectives of the 15-year housing development programme could not be fulfilled by conventional construction technologies. Therefore, the decision was made to adopt the technology of the Soviet housing factories (the first were produced in Budapest in 1965). Housing factories made housing construction faster and more economical and permitted buildings of various sizes and heights (Benkő 2015).

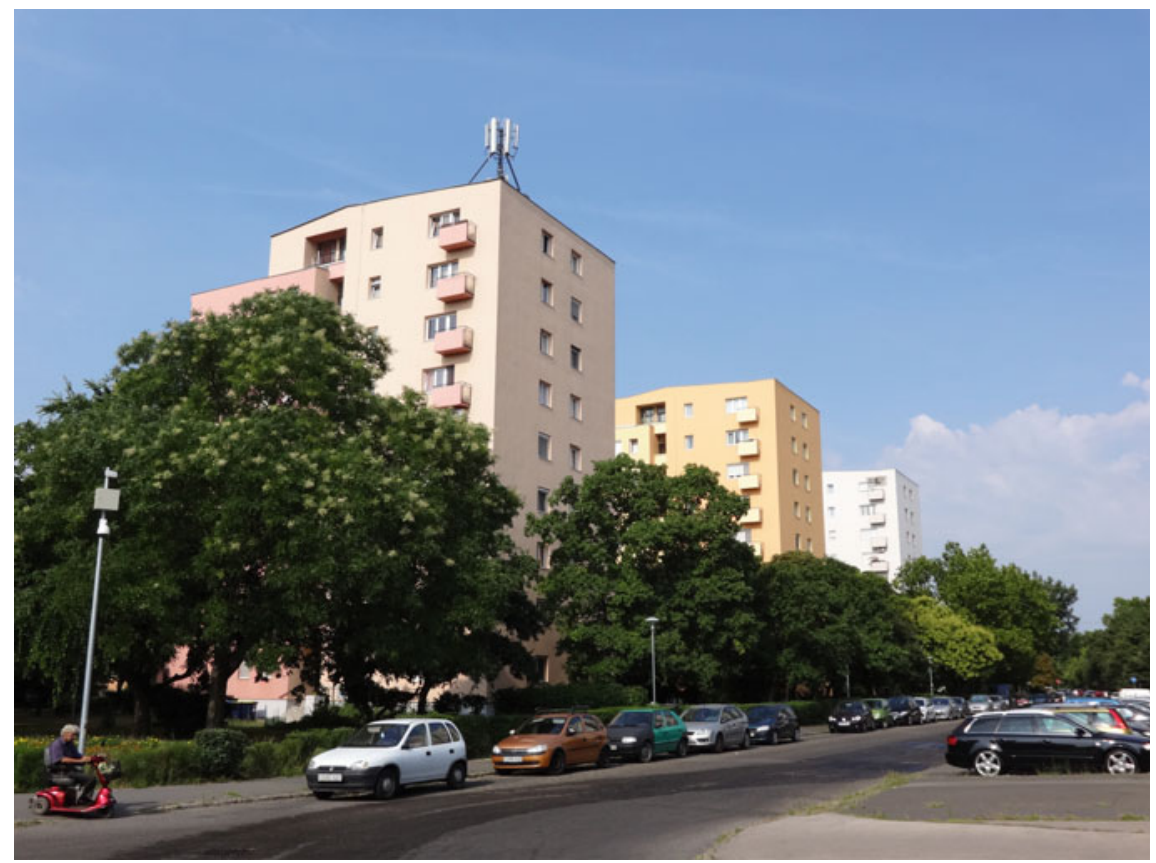

Fig. 9.3 József Attila housing estate, built in the 9th district of Budapest using mixed building technology in the 1960s. Source Kovács, Egedy and Szabó 


\subsubsection{Housing Estates of the 1970s}

The 1970s marked the peak of housing construction in Hungary during state-socialism, due to the proliferation of pre-fabricated technology. By 1976, 10 housing factories and 6 panel plants were in operation, producing 35,000 dwellings per year in the country. With this technology, a large number of dwellings could be built quickly and at reasonable cost, mainly in the form of large housing estates. It became an important aspect of the state-socialist welfare system that the urban population could expect sooner or later to obtain access to public dwelling if they wished. This never applied to the rural population, however, which was expected to solve its housing problems through private and 'self-help' channels.

Housing estate development concentrated mainly in Budapest and other larger regional centres (e.g. Miskolc, Debrecen, Szeged, Pécs). In Budapest, the number of newly constructed dwellings reached its apex in 1975 with close to 20,000 new units (Fig. 9.4). More than $70 \%$ of the new dwellings were built by the state with pre-fabricated panel technology. Huge housing estates were established, often in 5-year-run periods, with 5000-15,000 flats housing 30,000-40,000 people.

The layout and architectural character of the 1970s housing estates was increasingly determined by the Soviet type large-panel technology. Ten-storey high strip houses became dominant, mostly with five (and sometimes 10) staircases (Iván 1996). A permanent tension arose between architects and the representatives of the state investors, as cost considerations influenced all aspects of planning. There was very little opportunity for variation in the building composition, the interior

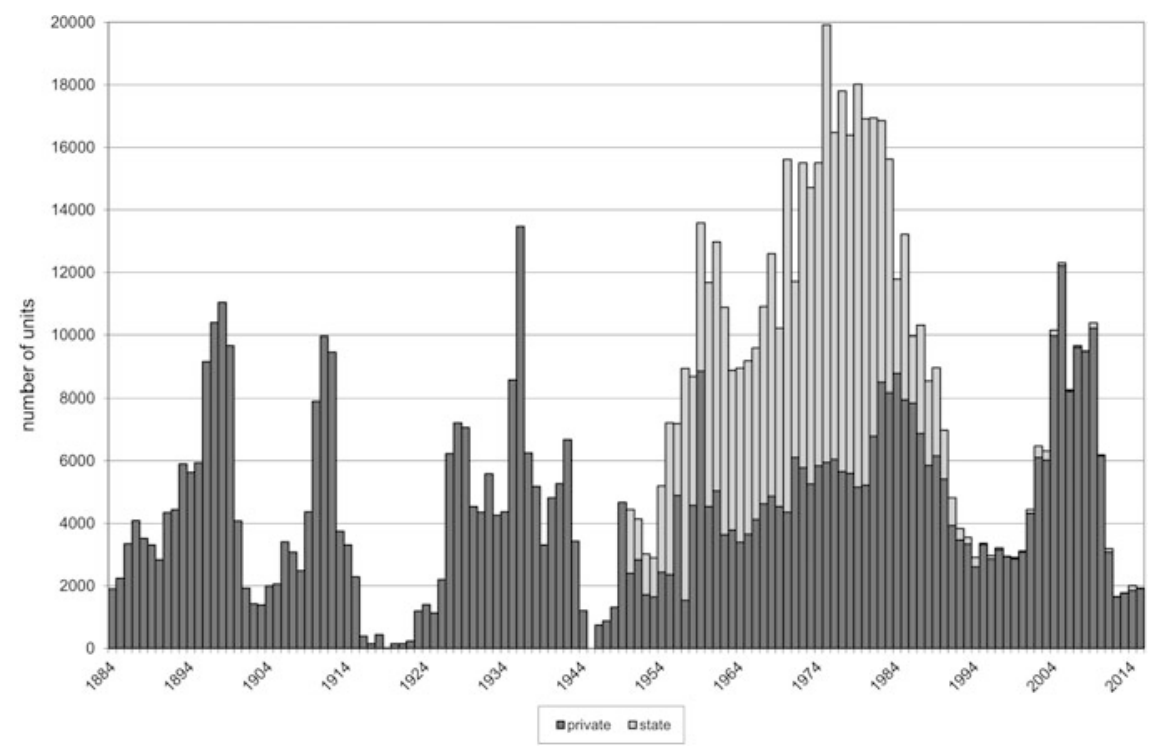

Fig. 9.4 New dwellings constructed in Budapest, 1884-2015 


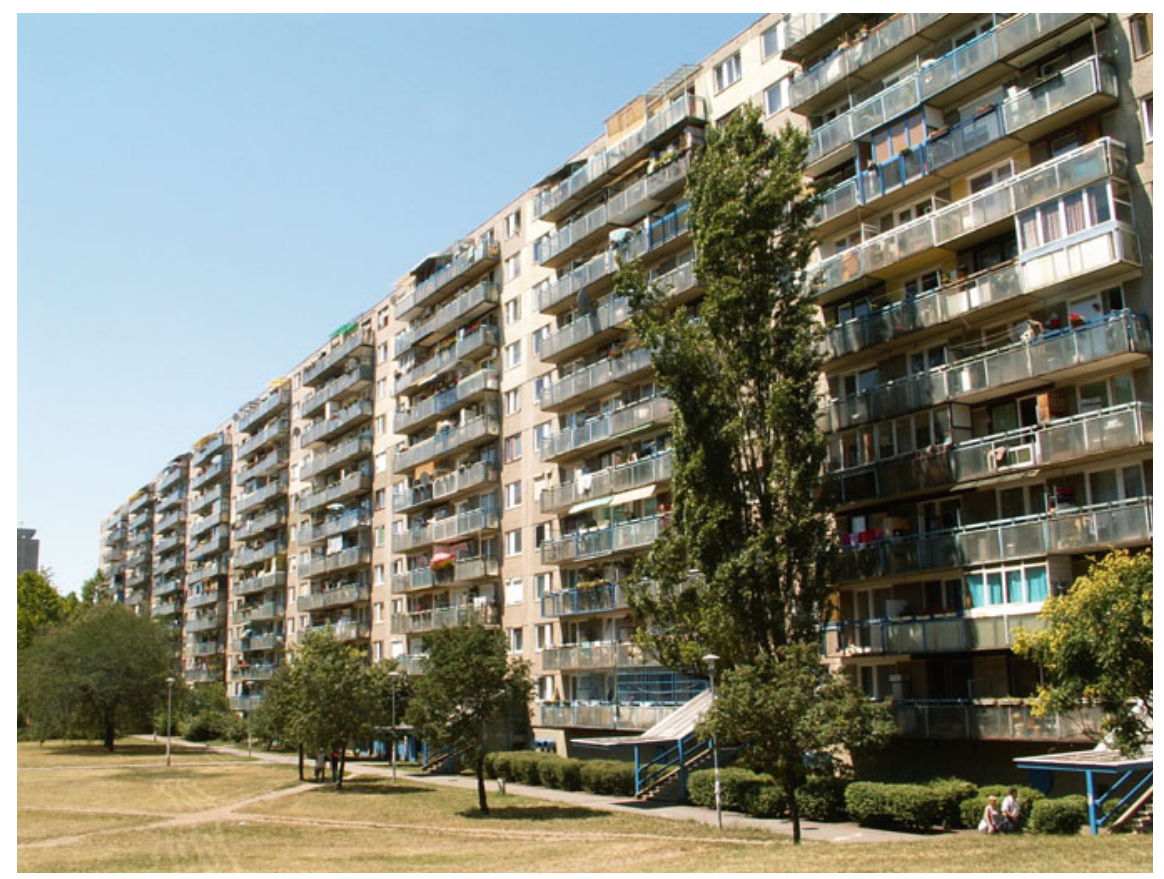

Fig. 9.5 Havanna housing estate in the 18th district of Budapest, built using pre-fab technology in the late 1970s. Source Kovács, Egedy and Szabó

organisation of flats, and other details. Reducing costs alone was possible with the abandonment of the construction of public institutions, which became one of the most serious deficiencies in these housing estates. The large pre-fabricated housing estates ensured housing quantity, but the quality of living conditions for the population at large became an enduring topic of discussion (Hall et al. 2005; Benkő 2015). Simultaneously, new housing estates increasingly shifted to the periphery of the city, where excessive un-urbanised areas offered cheap construction opportunities (Fig. 9.5).

Compared to the previous decade, the share of one-room flats significantly decreased in housing estates, while the proportion of two- and three-room apartments increased. The level of comfort also rose; central and district heating became widespread and full comfort remained, for a long time thereafter, the most important quality feature of these apartments. The 1970s also brought about changes in the social composition of housing estates. The Housing Act of 1971 made the state-led delivery of dwellings dependent on income level and social conditions, primarily on the number of children. Thus, poorer and less educated people could have better access to public housing, and the average social status of new housing estates decreased accordingly (Rietdorf et al. 1994; Farkas and Szabó 1995; Rietdorf 1997). 


\subsubsection{Housing Estates of the 1980s}

Economic difficulties in the late 1970s drove the government to revise and modify its welfare policy, which soon meant vigorous changes in housing policy too. New measures, introduced in 1983, effectively set out to abolish the previous extensive subsidies for housing. The number of dwellings built by the state gradually decreased and the dominant form of new housing became privately owned single-family homes.

In the 1980s, thanks to efforts to 'humanise' the environment of housing estates, planners managed to break through the schematism characterising the estates in the previous decades. Housing factories gradually produced more varied types of buildings. Lower buildings of 4- to 5-storeys appeared again in housing estates, and tentatively even 1- to 2-storey row houses were built. The size of housing estates rarely exceeded 2,000-3,000 dwellings. The quality requirements for panel technology also changed. As new technological standards came into being, the efficiency of thermal insulation had to be increased. In the 1980s, the construction spread of more attractive panel buildings with pitched roof (Fig. 9.6).

The share of dwellings built by the contribution of private capital steadily grew, either as cooperative housing or as condominiums with the support of OTP (state bank of Hungary before the change of regime). This had positive effects on the

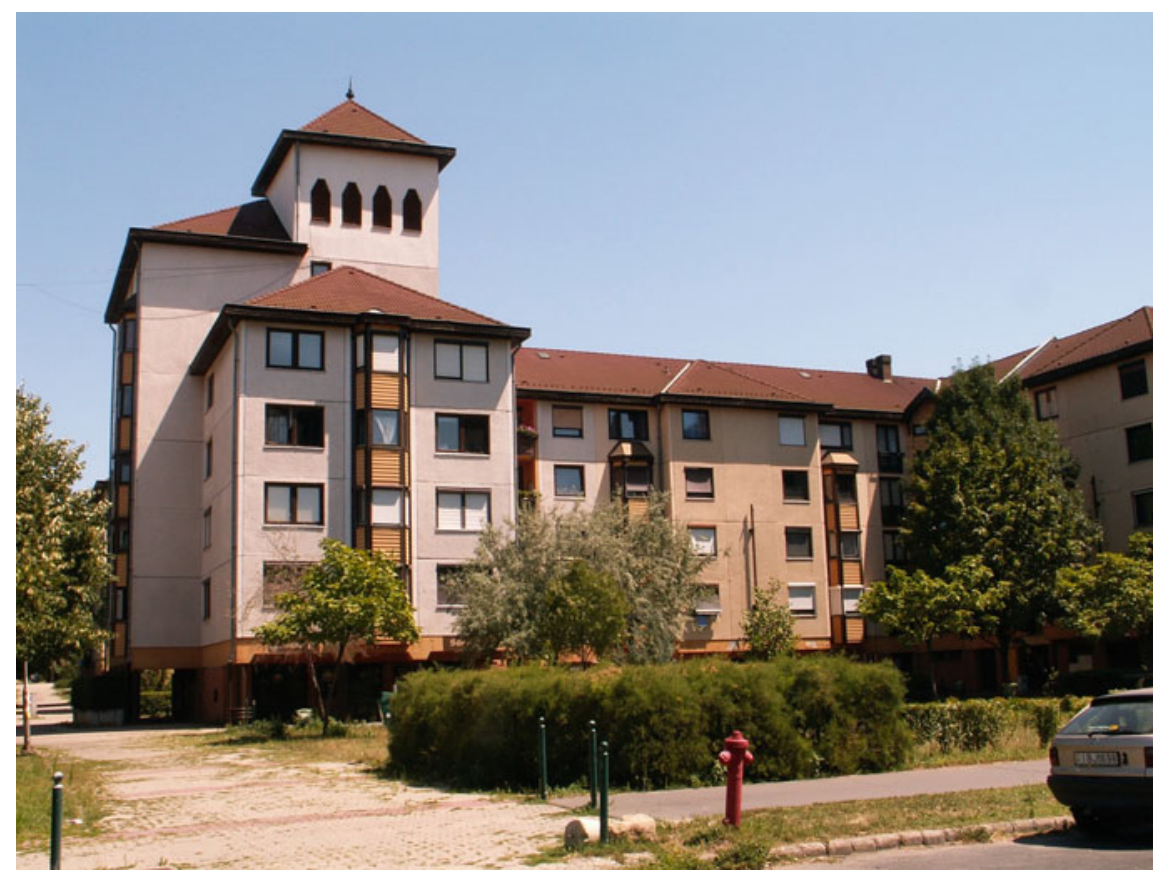

Fig. 9.6 Gloriette housing estate built in the late 1980s in the 18th district of Budapest. Source Kovács, Egedy and Szabó 
composition of dwellings: the size of flats generally increased and their internal division became more varied. As a consequence, these housing estates were much more popular than their counterparts from the 1970s; their prestige clearly exceeded those built in the previous decade.

In the early 1990s, the construction of housing estates ceased in Hungary and a new era of development began in the housing market with the mushrooming of residential parks and other upmarket residential compounds (Kovács and Hegedüs 2014). These homogeneous residential enclaves are perceived by some scholars as the newest generation of housing estates, symbolising the advent of global capitalism and its dominant lifestyle (Csizmady and Csanádi 2009).

We can conclude that housing construction between 1950 and 1990 was characterised by the increasing predominance of housing estates. Especially in the 1970s, the proportion of dwellings built in housing estates was extremely high. Towards the end of the period, the construction of housing estates gradually declined and abruptly ceased. While housing estates of the 1950s still embodied considerable social expectations, their prestige declined in the following decades and only the elite housing estates in the late 1980s restored a positive image.

\subsection{Housing Estates in Hungary and Budapest}

\subsubsection{Distribution of Housing Estates at the National Level}

Official statistics about housing estates were first published by the Hungarian Central Statistical Office after the 1980 census. At that time, $15.2 \%$ of the Hungarian housing stock was located in housing estates. The definition of housing estates applied was: 'a group of mid-rise and high-rise blocks and rows of houses built mostly by pre-fabricated technology in the last decades.' Since the construction of new dwellings in housing estates ceased by the early 1990s, the micro-census carried out by the Central Statistical Office in 1996 provides compelling information about their overall significance. In 1996, approximately 786,000 (or 20\%) of the Hungarian housing stock was situated in housing estates (Table 9.1).

The average size of housing estates in Hungary is relatively small compared to other East Central European (especially post-Soviet) countries, and $71 \%$ of Hungarian housing estates have fewer than 1,000 dwellings. Giant housing estates, having more than 10,000 apartments, are very rare; only 9 such giant estates were recorded and only two of them are located outside Budapest (in Miskolc and Pécs).

Figure 9.7 shows the spatial distribution of larger housing estates with over 1,000 dwellings in Hungary. There were 173 such estates in 1996, and the overwhelming majority of them were located in: (i) Budapest, (ii) the county seats and (iii) the so-called 'socialist new-towns' (Dunaújváros, Ajka, Komló, Ózd etc.). The geographic distribution of housing estates in Fig. 9.7 is uneven in Hungary; cities of the more industrialised northern and western regions are well supplied with this 
Table 9.1 Size distribution of housing estates in Hungary. Source HCSO Micro-census 1996 and author-conducted survey

\begin{tabular}{l|l|l|r|r|r}
\hline $\begin{array}{l}\text { Size (number of } \\
\text { dwellings) }\end{array}$ & $\begin{array}{l}\text { Number of } \\
\text { housing estates }\end{array}$ & $\begin{array}{l}\text { Total number of } \\
\text { dwellings }\end{array}$ & $\begin{array}{l}\text { Ratio } \\
(\%)\end{array}$ & $\begin{array}{l}\text { Total } \\
\text { population }\end{array}$ & $\begin{array}{l}\text { Ratio } \\
(\%)\end{array}$ \\
\hline $10.000<$ & 9 & 121,900 & 15.5 & 342,900 & 15.2 \\
\hline $7.500-10.000$ & 7 & 61,400 & 7.8 & 164,300 & 7.3 \\
\hline $5.000-7.500$ & 21 & 131,800 & 16.8 & 388,800 & 17.2 \\
\hline $2.500-5.000$ & 41 & 137,900 & 17.6 & 375,900 & 16.6 \\
\hline $1.000-2.500$ & 95 & 149,100 & 19.0 & 440,600 & 19.4 \\
\hline $1.000>$ & $\sim 430^{\mathrm{a}}$ & 183,400 & 23.3 & $549,700^{\mathrm{a}}$ & 24.3 \\
\hline Total & $\sim 600^{\mathrm{a}}$ & 785,500 & 100.0 & $2,262,100^{\mathrm{a}}$ & 100.0 \\
\hline
\end{tabular}

${ }^{\mathrm{a} E s t i m a t e s}$

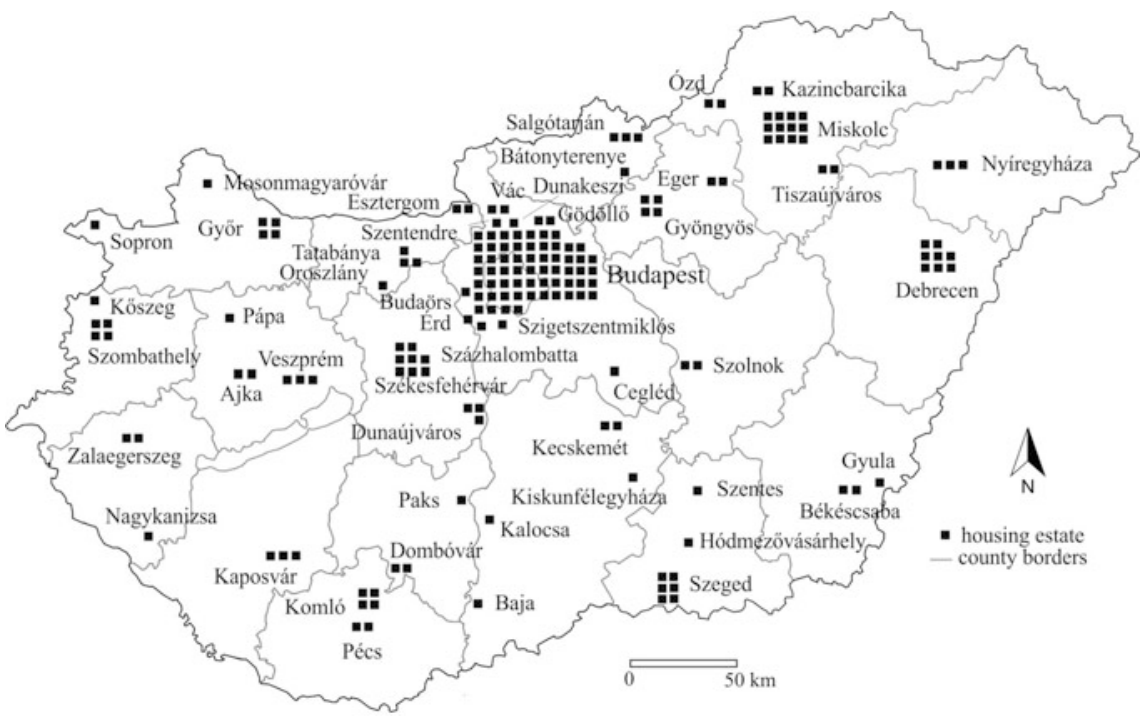

Fig. 9.7 Spatial distribution of large housing estates (1,000 or more dwellings), 1996, Hungary. Source HCSO Micro-census 1996 and author-conducted survey

form of housing, whereas in the predominantly agricultural south-eastern regions, only the major administrative centres (e.g. Szeged, Debrecen) have large housing estates.

Hungarian housing estates are dominated by two-room flats with $50-59 \mathrm{~m}^{2}$ (44\%), while apartments larger than $80 \mathrm{~m}^{2}$ are rare (1.8\%). A trend emerges: the younger the housing estate, the larger the average floor space. The average level of comfort of the housing estates has always been higher than the rest of the housing stock. This has been the main factor that attracted younger and better educated people to housing estates in the state-socialist period. However, housing estates 
built in the 1970s and 1980s with central heating became very costly by the 1990 s due to dramatic energy price increases. Not surprisingly, younger and more mobile residents departed housing estates and moved to the suburbs in the first years of the transition (Kovács and Tosics 2014).

\subsubsection{Characteristics of Housing Estates in Budapest}

In Budapest, there are 121 officially recognised housing estates (Micro-census 1996). For the sake of the present study, we identify a housing estate as group of 1,000 or more dwellings in mid-rise or high-rise buildings, developed as a coherent and compact planning unit. Altogether 62 estates, ca. half of the 121 officially recognised housing estates, meet these criteria. According to the 2011 national census, there were 239,750 dwellings located in these housing estates in Budapest, i.e. $30.5 \%$ of the total housing stock, providing home for $29.5 \%$ of the population.

In terms of the time of construction, $63.1 \%$ of the dwellings in housing estates were constructed in the 1970s. This is the most dominant group of housing estates with uniform style buildings erected by pre-fabricated systems. Housing estates of the 1980 s comprise $16.2 \%$, while housing estates of the 1960 s encompass $13.6 \%$ of the housing stock. The smallest group is made up of small-scale housing estates built in the $1950 \mathrm{~s}$, where only $7.1 \%$ of the housing estates dwellings are concentrated. This categorisation of age will reappear later in our analysis on the trajectories of the various generations of housing estates in Budapest (Fig. 9.8).

In terms of size, housing estate dwellings are generally below the city's average. While the share of smaller dwellings (i.e. below $40 \mathrm{~m}^{2}$ ) is about the same (ca. 17\%) as in other parts of Budapest, larger apartments are nearly completely missing. Apartments above $80 \mathrm{~m}^{2}$ comprise only $1.6 \%$ of the dwelling stock in housing estates while it is $28 \%$ in the rest of the city. As opposed to size parameters, the level of comfort is very favourable in housing estates. $89 \%$ of flats have full comfort (central heating and full sanitation) while in the rest of the city, only $64 \%$ of dwellings fall into this category.

As far as tenure is concerned, in $20114.1 \%$ of the dwellings in housing estates were owned by local governments (i.e. district governments) and used as public rentals. This figure is below the city's average (5.1\%). In 1990, the share of public rental dwellings in housing estates was higher (48.4\%), but due to large-scale privatisation programmes, their number radically decreased. After 1990, in the transformation of the housing market, privatisation of public dwellings played an important role. Privatisation of state housing in Budapest meant a pure 'give away' type of privatisation to sitting tenants, at remarkable low prices (Hegedüs 2013). The 1993 Housing Law made privatisation of public housing compulsory with the 


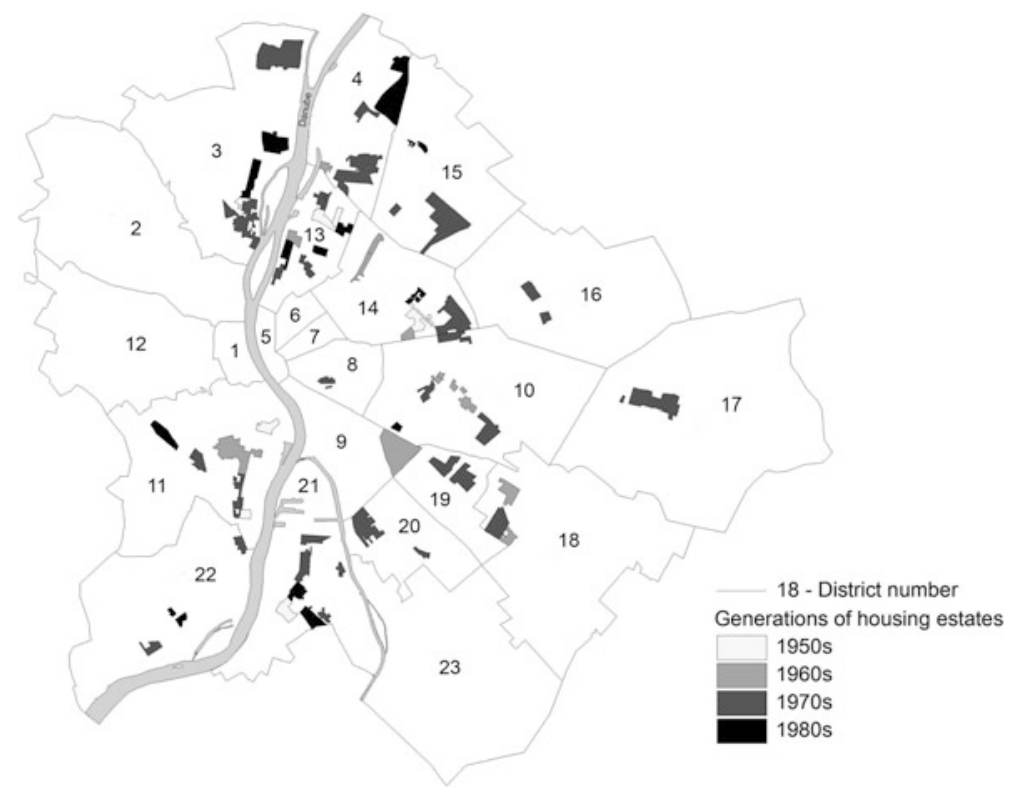

Fig. 9.8 Spatial distribution of four generations of large housing estates (1,000 or more dwellings), 2011, Budapest. Source HCSO Census 2011

introduction of the Right to Buy. As a consequence, the share of public housing in Budapest decreased from $51 \%$ to a mere $5.1 \%$ by 2011 .

Regarding the age structure of residents, housing estates have a fairly similar profile to the city's average, however, younger age groups (below age 20) are slightly underrepresented, and older cohorts (above age 60) are slightly over-represented. Differences in the demographic profile of residents are more pronounced among the various generations of housing estates. In terms of educational attainment, residents of housing estates are generally less educated, the share of those having a university diploma in the adult (20+) population was $24.1 \%$ in 2011, whereas it was $36.2 \%$ in the rest of the city.

The spatial distribution of housing estates is very much determined by the physical geography of the city. East of the Danube, on the plain Pest side of Budapest, there are favourable opportunities for housing estate construction, while on the hilly Buda side, only limited areas near the river could accommodate housing estates. Consequently, the share of housing estates within the housing stock is somewhat higher on the Pest side (32\%), than on the Buda side (27\%). In terms of the socio-economic status of residents, it is also important to emphasise that housing estates located on the environmentally more attractive Buda side have always had higher prestige. 


\subsection{Socio-economic Changes in Housing Estates in Budapest After 1990}

In this section, we focus on the position of housing estates in the housing market, with special emphasis on how the demographic and socio-economic profile of housing estates changed after 1990. Our findings are based on comparative analysis of data from the three most recent censuses (1990, 2001 and 2011). We also provide an overview of how the different generations of housing estates developed during the post-socialist transition.

The share of population living in large housing estates has decreased in Budapest since 1990 (Table 9.2). On the eve of the political changes, 33.9\% of the city's population lived in housing estates, which decreased to $29.5 \%$ by 2011 . After 1990 , Budapest experienced substantial population loss due to suburbanisation and natural decline, however, the loss in housing estates was more in relative terms than in the rest of the city.

In terms of the demographic structure of the population, like other post-socialist cities, Budapest has been strongly affected by ageing. This is also true for housing estates, but the pace of ageing in housing estates was faster than the city's average. In 1990, the share of younger age groups (i.e. below 20) was much higher, and the proportion of older age groups (above 60 years) was significantly lower in housing estates than elsewhere (Fig. 9.9). These differences practically disappeared by 2011, and even the share of older generations (above 40 years) became somewhat higher in housing estates than in Budapest.

Demographic change and most notably ageing affected the various generations of housing estates differently. Census data suggest that the generations of the 1970s and 1980s are most affected by ageing, whereas the share of elderly (above 60 years) decreased in the 1950 s estates from 35.1 to $29.7 \%$ between 1990 and 2011. Although previous research from the 1990s determines a linear correlation between the age of housing estate and ageing of the local population (Egedy 2000; Csizmady 2003), this trend seems to have changed since the turn of the millennium. We suggest a reason for this change: the mobility of people. Even though housing estates have below average mobility rates, $30.5 \%$ of the residents had moved to the

Table 9.2 Share of housing estates in Budapest, 1990-2011. Source HCSO Census 1990, 2001, 2011

\begin{tabular}{l|l|l|l|l|r|l}
\hline & 1990 & 2000 & \multicolumn{2}{l}{2011} & \multicolumn{1}{l}{} \\
\cline { 2 - 7 } & $\mathrm{N}$ & $\%$ & $\mathrm{~N}$ & $\%$ & $\mathrm{~N}$ & $\%$ \\
\hline Number of people & 683,556 & 33.89 & 580,046 & 32.73 & 509,461 & 29.49 \\
\hline Number of dwellings & 250,199 & 31.51 & 240,347 & 32.69 & 239,718 & 30.45 \\
\hline Public rental dwellings & 121,171 & 30.61 & 12,400 & 19.50 & 9,831 & 24.40 \\
\hline ISCO7-8-9 & 122,658 & 36.69 & 66,239 & 37.98 & 57,256 & 35.62 \\
\hline Unemployed & 25,427 & 30.93 & 17,105 & 34.57 & 28,077 & 31.26 \\
\hline Large households (5-) & 16,011 & 38.86 & 10,589 & 28.57 & 7,119 & 23.36 \\
\hline
\end{tabular}




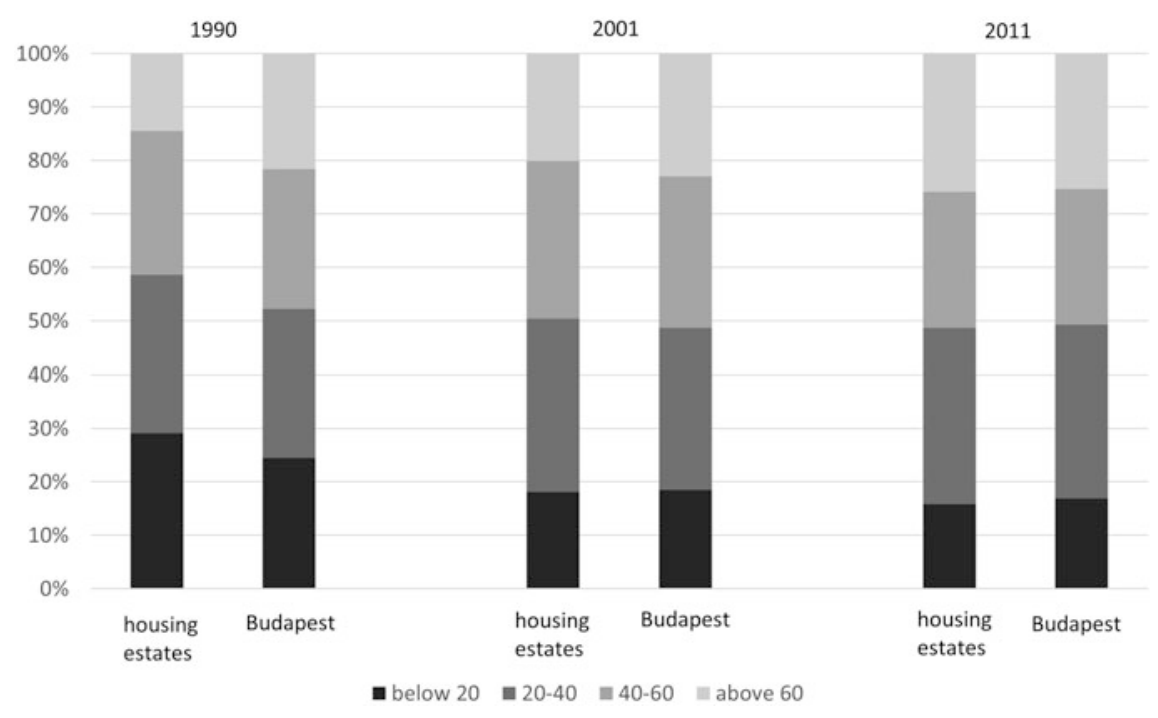

Fig. 9.9 Demographic structure of population, 1990-2011. Source HCSO Census 1990, 2001, 2011

present dwelling before 1990 , whereas it is only $22.8 \%$ for the rest of the city. Residential mobility induced robust population change. The most remarkable population change took place in the housing estates of the 1950s where the proportion of newcomers significantly increased after 1990. This finding is also confirmed by changes in household structure. The share of single-person households grew in each generation of housing estates after 1990, however, higher growth rates were clearly evident in the housing estates of the 1950s and 1960s. A decreasing share of elderly and a growing share of single-person households suggest the arrival of younger, single people to the oldest generations of housing estates and a possible socio-economic upgrading.

To measure the socio-economic status of local residents and the level of segregation, we use data for education and occupation. But beforehand, we must note two important features which make the situation of housing estates in Budapest different from Western cities. First, as opposed to the West, housing estates in Hungary were not constructed for the lowest socio-economic strata (as in social housing programmes). In fact, the exact opposite is true: in the 1960s and early 1970s, housing estates had a clear middle-class profile (Szelényi and Konrád 1969). Second, Hungary (and other post-socialist countries) was not affected by large-scale immigration from former colonies or other less developed countries after World War II. Thus, ethnically and culturally, Hungarian society remained fairly homogeneous. Indicators for ethnicity used in other (predominantly Western) cities are inappropriate in measuring segregation in Budapest. Census data indicate a growing gap between housing estates and the rest of Budapest as far as educational attainment is concerned (Fig. 9.10). 


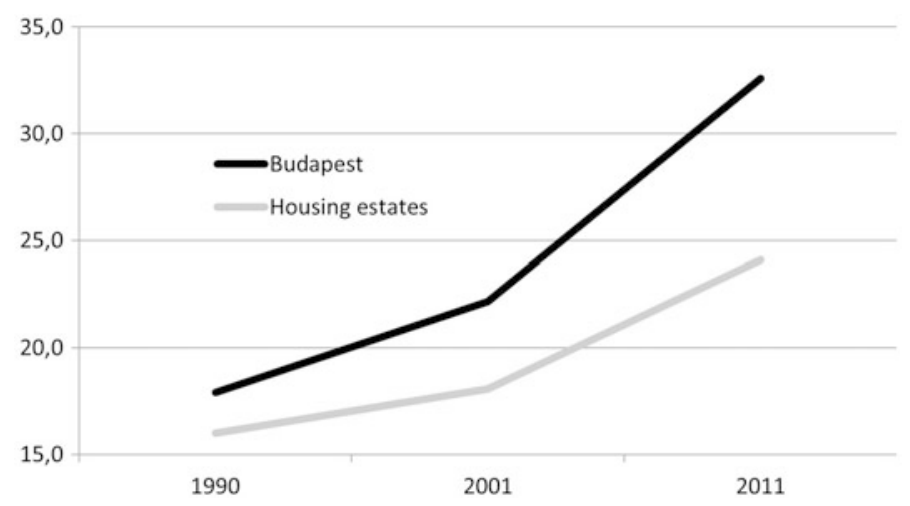

Fig. 9.10 Share of residents with a university or college degree, 1990-2011. Source HCSO Census 1990, 2001, 2011

Figure 9.10 depicts that the share (in 1990) of those with a university or college degree among people 20 years or older was fairly similar in housing estates and in the rest of Budapest; by 2011, however, a gap arose. On the eve of the last census, $32.6 \%$ of Budapest residents (older than 20 years) had earned a degree, but it was only $24.1 \%$ in the housing estates. Thus, the global trend of professionalisation of the labour force was slower in housing estates than in the city. Different generations of housing estates followed very different pathways. In 1990, the share of graduates was the lowest in the housing estates built in the 1950s. However, by 2011, the situation in these housing estates had improved considerably due to population change, and the proportion of people with the highest qualifications nearly reached the level of the 1980s generation, which otherwise was very much favoured by young intellectuals in the time of construction. On the other hand, the share of graduates is lowest in housing estates dating from the 1970s, and the gap compared to other generations has clearly grown since 1990 .

To detect changes in the socio-economic status of housing estates and the level of social segregation, we use occupational data for the economically active population, according to the occupational categories of ISCO (International Standard Classification of Occupations). In order to simplify the analysis, we aggregated the top two (managers, professionals) and bottom three (industrial workers, machine operators, unskilled workers) categories, and refer to them hereinafter as 'intellectuals' and 'workers'.

The general trends are clear: in 1990, the share of intellectuals was somewhat lower and the share of workers was slightly higher in housing estates than the city's average. The professionalisation of the labour force progressed in housing estates resulting in higher shares of intellectuals and lower shares of workers, however the pace of changes was less dynamic than in the rest of the city. As a consequence, occupational differences between housing estates and the rest of the city increased, and the working class character of housing estates strengthened. In 2011, the share of workers was $24.6 \%$ in housing estates, whereas only $19.2 \%$ in the rest of the city. 
Among the different generations of housing estates, the share of workers was highest in the housing estates of the 1970s. Housing estates of the 1950s managed to change their working class profile after 1990, since the proportion of intellectuals increased more rapidly than in other generations. Consequently, the prestige of these housing estates has continuously grown.

We conclude that housing estates in Budapest have been affected considerably by ageing and lowering socio-economic status in relative terms since 1990 . Nevertheless, different generations of housing estates followed very different trajectories. Housing estates of the 1950s had a disadvantageous position in 1990 with ageing population, and a less educated, predominantly lower class population. However, after the change of regime, these housing estates were considerably re-evaluated by the city's inhabitants; they attracted younger and better educated residents and their prestige started to grow. As a consequence, the working class profile of these estates gradually changed and their population became demographically more balanced. Housing estates of the 1960s started the post-socialist transition from a better position than the 1950s generation, and their prestige and social status was generally higher. Since the turn of the millennium, this generation has been characterised by similar trends in social transformation like the 1950s, and these two older generations seem to be attractive options on the housing market. The biggest losers of the transformation were housing estates of the 1970s, built by pre-fabricated technology. These estates have been hit by a downward spiral where younger, more educated people gradually moved out; at the same time, the elderly, lower class profile of these estates strengthened. However, this group is not homogeneous either: the largest, more monotonous housing estates built in working class neighbourhoods with poor image are in the worst position. Housing estates of the 1980s were in the most favourable position in 1990 as far as their prestige and social composition were concerned. They were highly appreciated by younger, middle-class families, and consequently, their status was higher compared to other generations. However, between 1990 and 2011, social transformation processes were not as favourable as previously (Kovács and Douglas 2004). Higher social status of this generation is still detectable, but its favourable position is diminishing.

\subsection{Post-socialist Transition and the Challenges of Large Housing Estates}

During the post-socialist transition, various phases of development could be distinguished in housing estates. In the first period (early 1990s), the most important factor affecting the development of housing estates was privatisation (Sailer-Fliege 1997; Hegedüs 2013). By the late 1990s, only 5-6\% of the housing stock in housing estates remained in the hands of local governments. Increasing private home ownership paved the way for market-led property development and residential mobility. A high level of comfort was one of the main advantages of 
pre-fabricated housing estates before 1990. That very same feature became the main disadvantage after 1990, due to rapidly rising housing costs, especially energy costs (Egedy 2000). After privatisation, the new owners living in pre-fabricated housing estates had to face a difficult situation: the relative value of apartments in pre-fabricated buildings declined while running costs drastically increased. As a consequence, lower status residents in housing estates often became trapped: they could not sell their flats or buy another one of similar quality; thus, their housing career ended (Hegedüs and Tosics 1998). Rapidly rising housing costs were connected with inefficient central heating systems and the insufficient insulation of houses, therefore, rehabilitation interventions were needed urgently.

The second development period started with the rehabilitation of housing estates in 1997. In 1996, the Ministry of Economy, the Hungarian Development Bank and the German Creditanstalt für Wiederaufbau created a 30-million deutsche mark (ca. 3 billion HUF at the current exchange rate) credit facility in order to support energy saving renewal (Government Decree 105/1996). It was the first important intervention in the history of pre-fabricated buildings organised by the state. Under the scheme, $75 \%$ of the renovation costs in panel buildings could be financed by the credit construction. The loan programme was extended several times until 2001, yet only about one-third (950 million HUF) of the budget was drawn, because of the strict conditions. Also in 1997, the Energy Saving Loan Program was launched, whereby municipalities could get a loan totalling of 800 million HUF. The programme continued with an additional one billion HUF credit facility in 1998. These early regeneration programmes paved the way for a large-scale, nationwide intervention called 'Panel Programme' where the European Union took a lion's share.

The Panel Programme, signalling the third development phase of housing estates, was launched in 2001. The EU-funded renovation programme targeted the improvement of energy efficiency in pre-fabricated buildings. It has been renamed and restructured several times since its start, but it is still the most prominent and largest state-financed residential rehabilitation programme in Hungary (Panel I, 2001-2008; Panel II, 2009-2013; Panel III, 2014-2020). Unfortunately, it is extremely difficult to obtain accurate and tangible data on the number of renewed apartments and the amount of public subsidies used in the programme, as there are different numbers in government (national and local) and other professional documents. According to the latest data, a total of 320,000 pre-fabricated dwellings have been renovated in Hungary in the Panel Programme between 2000 and 2014. Within the framework of Panel Program III, which has been underway since 2014, a total of 380,000 flats are planned to be included in the energy efficiency renovation (lasting until 2020), or 75\% of the total housing stock.

In 2017, the development of large pre-fabricated housing estates once again rose high on the agenda of national politics in Hungary. In 2017, the government began to elaborate a new 20- to 25-year panel regeneration strategy aimed at improving the quality of life of people living in panel housing estates by improving the residential environment. The programme is currently in the preparatory phase, but it is certain that the government will not rule out the partial demolition of pre-fabricated buildings either. 
Concerning demolition, it is important to know the opinion of local residents living in large housing estates. In 2014, a questionnaire survey was carried out in Budapest with the aim to measure the satisfaction of residents living in downgrading neighbourhoods. The survey covered four neighbourhoods including Hungary's second largest housing estate, Újpalota (15th District of Budapest), erected using pre-fabricated technology in the early 1970s. Other neighbourhoods were selected in the densely built inner-part and the low-rise outer fringe of the city. Respondents were randomly surveyed from renovated and non-renovated buildings of housing estates. Survey data show that local residents of housing estates have more negative opinion about their neighbourhood than people living in other run-down quarters (Table 9.3).

The negative internal image highly correlates with residential mobility chances. Almost one-third of the residents in Ujpalota feel that they are stuck in the housing estate (unable to move due to financial or other reasons), while this share is less than one-fifth in other downgrading areas. The renewal process started in the quarter only in the late 2000s and remained limited until now. However, the very few respondents living in renovated houses already expressed their higher satisfaction with the neighbourhood compared to those living in non-renovated buildings.

Although satisfaction with housing estates as a form of living varies greatly by country, city and neighbourhoods, the physical rehabilitation of pre-fabricated buildings (e.g. better insulation, lower level of noise, lower costs of heating, aesthetic aspects) improves the satisfaction of inhabitants (Kovács and Herpai 2011). Yet, the need for regeneration shows significant differences among the various types and generations of housing estates, and often within the same generation. For instance, regarding the pre-fabricated panel buildings, there is a much higher demand for renewal in housing estates of the 1970s showing infrastructural and architectural problems than those of the 1980s, but there are also significant differences between housing estates built in the first and the second half of the 1980s (van Kempen et al. 2005). In the first half of this decade, mainly large, 'traditional' housing estates were built, while during the second half, smaller scale elite housing estates became dominant. In the latter group, there is less need for full renovation.

Table 9.3 Perception of declining neighbourhoods by residents in Budapest, 2014

\begin{tabular}{l|l|l|l}
\hline Statement & \multicolumn{3}{|l}{$\begin{array}{l}\text { Percentage of those residents who totally or } \\
\text { partly agree with the statement }\end{array}$} \\
\cline { 2 - 4 } & $\begin{array}{l}\text { Újpalota, } \\
\text { non-renovated } \\
\text { buildings }\end{array}$ & $\begin{array}{l}\text { Újpalota, } \\
\text { renovated } \\
\text { buildings }\end{array}$ & $\begin{array}{l}\text { Other } \\
\text { declining areas } \\
\text { of Budapest }\end{array}$ \\
\hline $\begin{array}{l}\text { 'The value of dwellings is continuously } \\
\text { decreasing in this neighbourhood' }\end{array}$ & 92.4 & 81.3 & 66.1 \\
\hline $\begin{array}{l}\text { 'Mainly those people move into this } \\
\text { neighbourhood who cannot afford to buy a } \\
\text { flat somewhere else' }\end{array}$ & 83.0 & 45.5 & 37.7 \\
\hline
\end{tabular}


In this respect, other important factors - besides age and technology — are the size and location of housing estates. Generally, we can conclude that housing estates which are embedded in low-rise environments tend to be more commonly renovated. They are not elite housing estates, but typically smaller units (less than 1,000 dwellings) with low-rise buildings, and most of them differ little from their surroundings.

Another important factor about the perception of housing estates is the quality of environment and local services. Originally, great emphasis was placed on the proper provision of infrastructure and services in housing estates of the 1950s and 1960s; in the 1970s, however, due to a lack of financing and the acceleration of construction works, little attention was paid to this aspect. Thus, infrastructure and basic services were often lacking. After the change of regime, especially in the 1990s, small retail and service units (e.g. shops, pubs, hairdresser etc.) providing predominantly daily consumer goods and services appeared in the ground floor of panel buildings. With the renovation of housing estates and the construction of shopping centres at the urban fringe, and due to growing motorisation and the transformation of consumer culture, the role of these small service units has significantly diminished since the early 2000 s.

The evaluation of housing estate dwellings by the market has shown twists and turns since 1990. After the general relative decline of dwelling prices throughout the 1990s, there was growing appreciation on the market (after the turn of the millennium) accompanied by relative price increase. This was halted by the global financial crisis in 2008, followed by a frozen housing market with falling prices until 2013. Housing prices have rapidly risen in Budapest since 2014, and in recent years, housing estates became one of the most popular segments in the housing market. The reasons for growing popularity are manifold. Running costs of housing estate dwellings have not increased since 2013, and the average selling time of housing estate apartments is much shorter and prices are 20-30\% lower compared to apartments in brick buildings. Consequently, buyers of housing estate flats can enter the housing market more easily.

As far as the local self-governance of housing estates is concerned, we can conclude that housing estates are not the focus of political interest. There are only four districts in Budapest (out of the 23) that locally have a sub-municipality (a part of an upper tier municipal government), two of which are located in housing estates (4th district, Káposztásmegyer; 9th district, József Attila housing estate). This highlights a lack of self-governance and management in large housing estates. On the one hand, housing estates in Hungary and Budapest do not appear as independent administrative or urban planning entities, and they are therefore not targeted objects of municipal policies. The two aforementioned housing estates with partial local governments are not giant housing estates, suggesting the successful establishment of local sub-municipality cannot be linked with overall size (i.e. number of inhabitants). Rather, it is related to the local power relations and the activities of key persons and actors in the local community. After 2000, several attempts were made in other districts to establish sub-municipalities $(2008,11$ th district; 2009, 10th district), but these efforts failed; after 2010, due to the 
centralisation efforts of the conservative government, the issue of partial governance was removed from the agenda. Due to the lack of targeted policies for housing estates, there is no special attention given to housing estates in development tenders issued by the city or district governments. Thus, proposals are free to apply for housing estates and other residential areas (i.e. in general, there are no development tenders on local levels targeting exclusively at housing estates). For example, the Tér-Köz (Public-Space) programme in Budapest is aimed to draw attention to community building activities (e.g. innovative design of public areas, community programmes) and complex regeneration of public spaces. Although the call is not targeted specifically for housing estates, there is always a significant share of housing estate projects among the winners (for example, there were four housing estates subsidised in 2013 and 2016 by the programme).

Regarding the local civil society and civic life, the gradual strengthening of local communities and civic self-organisations could be witnessed in housing estates both in Budapest and the countryside. The process accelerated in two fundamental forms: first, local associations appeared in order to bring together active local residents (e.g. Association for the Centenarium Housing Estate in the 16th district founded in 2007, or Agora Local Patriot Association in the Lakatos Street housing estate in the 18th district founded in 2014) and, second, foundations have been established to finance local developments and institutions (e.g. Fund for the József Attila Housing Estate provided by the Ferencváros Community Association in the 9th district or Békásmegyer Church Foundation in the 3rd district).

\subsection{Conclusion}

Considering the number and size of its housing estates, Hungary has an intermediate position among European countries. The share of the population living in housing estates is approximately $20 \%$ in Hungary, and approximately $30 \%$ in Budapest. There are seven giant housing estates with more than 10,000 dwellings, but both Hungary and Budapest can be characterised by predominately small and medium-size housing estates. In 2011, the average size of housing estates (with more than 1,000 apartments) was 3,870 dwellings in Budapest, housing 8,200 people on average.

In Hungary, housing estates built after WWII can be readily categorised by the time of their construction. These housing estate generations show different features with regard to their physical layout and socio-economic characteristics. Socio-economic changes that took place after the change of regime (1989) are widely affected by the physical parameters of the housing and the dwelling stock (e.g. time and type of construction, age and size of housing estates).

Our results show that various generations of housing estates have followed distinct trajectories. In addition, their social composition remained relatively heterogeneous until now and became even more diversified due to the influx of new residents. 
Considering the composition of population by age and type of households, we can conclude that the technology applied (pre-fabricated systems or brick) strongly affected population changes that have taken place in the various generations. In older generations (especially in the housing estates of the 1950s), an influx of younger, better educated strata can be detected, while in younger generations (in housing estates of the 1970s and 1980) an ageing process and a relative socio-economic decline has taken place. Although the share of residents with tertiary education is growing in all housing estate generations, its dynamics lags behind the Budapest average; consequently, our results confirm, in relative terms, a gradual downgrading process in the social status of housing estates. The composition of population by occupation groups clearly demonstrates the social downgrading process of high-rise pre-fabricated housing estates built in the 1970s.

Housing estates in Hungary and Budapest generally provide home for lower middle class strata. Processes of social exclusion and an influx of immigrants (occurring in certain Western European housing estates) are not typical in Hungary or Budapest. Thus, problems regarding ethnicity, poverty, marginalisation and discrimination appear only in a very limited form compared to other European countries and cities.

Since housing estates do not appear as independent administrative or planning units, there are no targeted policies for housing estates per se either on the national or local level. However, the future of housing estates is permanently on the agenda in public debates. As a consequence of the long-term attention to the destiny of housing estates, the first attempts to improve the physical environment of housing estates date back to the late 1990s. Large-scale regeneration of pre-fabricated housing estates began in Hungary in 2001, and by the end of the 2010s, large share of pre-fabricated buildings will be modernised (with new insulation and heating systems). Rehabilitation seems to be an efficient instrument to prevent socio-economic decline and strengthen the position of large housing estates on the housing market. Despite the negative socio-economic tendencies, current market trends give rise to optimism about the future development of large housing estates. A large wave of urban sprawl terminated in Budapest by 2010, and since then the city has a moderate surplus of migration and population growth. The regeneration of inner-city neighbourhoods commenced since the turn of the new millennium, and the central city has been discovered again by younger and more affluent strata. In these dynamically changing housing market conditions, housing estates have a specific role to provide basic housing for newcomers (i.e. students), less affluent and elderly people. Sustainable demand is justified by housing market data and steadily growing dwelling prices since 2014 .

Acknowledgements Funding for the research leading to this publication was received from the Hungarian Scientific Research Fund (OTKA) Grant Agreement No. K119710. 


\section{References}

Benkő M (2015) The lifespan of large prefabricated housing estates in post-communist cities: an international comparison. Architektura \& Urbanizmus 49(3-4):180-197

Csanádi G, Ladányi J (1992) Budapest térbeni-társadalmi szerkezetének vál-tozásai. Akadémiai Kiadó, Budapest

Csizmady A (2003) A lakótelep. Gondolat Kiadó, Budapest

Csizmady A, Csanádi G (2009) From housing estates to gated communities. In: Smigiel C (ed) Gated and guarded housing in Eastern Europe. Forum Leibniz-Institut für Landerkunde, pp 9-20

Egedy T (2000) The situation of high-rise housing estates in Hungary. In: Kovács Z (ed) Hungary towards the 21st century, the human geography of transition. Geographical Research Institute, Hungarian Academy of Sciences, Budapest, pp 169-185

Farkas EJ, Szabó M (1995) Privatizáció és szociálislakás-gazdálkodás. Statisztikai szemle 73(12): 999-1014

Fóti P (1988) Röpirat a lakáshelyzetről Magvető Kiadó, Budapest

Gyáni G (1992) Bérkaszárnya és nyomortelep. Magvető Kiadó, Budapest

Győri P (1996) A várospolitika és a lakásépítés szerepe egyes szegregációs minták kialakulásában. In: Győri P (ed) A város, a város társadalma, életformacsoportok. Wesley János Lelkészképző Föiskola (szöveggyüjtemény), Budapest, pp 77-112

Hall S, Murie A, Knorr-Siedow T (2005) Large housing estates in their historical context. In: van Kempen R, Dekker K, Hall S, Tosics I (eds) Restructuring large housing estates in Europe. Policy Press, Bristol, pp 63-84

Hegedüs J (2013) Housing privatization and restitution in post-socialist countries. In: Hegedüs J, Lux G, Teller N (eds) Social housing in transition countries. Routledge, pp 33-49

Hegedüs J, Tosics I (1998) Towards new models of the housing system. In: Enyedi G (ed) Social change and urban restructuring in Central Europe. Akadémiai Kiadó, Budapest, pp 137-168

Iván L (1996) Mégegyszer a budapesti lakótelepekről. In: Dövényi Z (ed) Tér-GazdaságTársadalom-Huszonkét tanulmány Berényi Istvánnak. MTA Földrajztudományi Kutatóintézet, Budapest, pp 49-80

Kovács Z, Douglas M (2004) Hungary-from socialist ideology to market reality. In: Turkington R, van Kempen R, Wassenberg F (eds) High-rise housing in Europe: current trends and future prospects, housing and urban policy studies 28. University Press, Delft, pp 231-248

Kovács Z, Hegedüs G (2014) Gated communities as new forms of segregation in post-socialist Budapest. Cities 36:200-209. https://doi.org/10.1016/j.cities.2013.08.004

Kovács Z, Herfert G (2012) Development pathways of large housing estates in post-socialist cities: an international comparison. Housing Stud 27(3):324-342. https://doi.org/10.1080/02673037. 2012.651105

Kovács Z, Herpai T (2011) A panelprogram társadalmi és környezeti hatásai Szegeden. In: Szabó V, Fazekas I (eds) Környezettudatos energiatermelés és -felhasználás. MTA DAB Megújuló Energetikai Munka-bizottsága, Debrecen, pp 322-328

Kovács Z, Tosics I (2014) Urban Sprawl on the Danube. Confronting suburbanization. Wiley Ltd. https://doi.org/10.1002/9781118295861.ch2

Pieniążek M (2010) The peripheral housing estate as a form of urban spatial development: the status quo and perspectives. Miscellanea Geographica 14:273-281

Preisich G (1998) Budapest városépítésének története 1945-1990. Müszaki Könyvkiadó, Budapest

Rietdorf W (1997) Weiter wohnen in der Platte: Probleme der Weiterentwicklung großer Neubaugebiete in den neuen Bundesländern. Institut für Regionalentwicklung und Strukturplanung. Ed. Sigma, Berlin

Rietdorf W, Liebmann H, Knorr-Siedow T (1994) Großsiedlungen in Mittel- und Osteuropa. Regio, Beiträge des IRS 4, Berlin 
Sailer-Fliege U (1997) Transformation of housing markets in East Central Europe. In: Kovács Z, Wiessner R (eds) Prozesse und Perspektiven der Stadtentwicklung in Ostmitteleuropa. Münchener Geographische Hefte 76 Geographisches Institut der Technischen Universität München, L.I.S. Verlag. Passau, pp 33-47

Sillince J (1985) The housing market of the Budapest urban region 1949-1983. Urban Stud 22(2): 141-149

Szelényi I, Konrád G (1969) Az új lakótelepek szociológiai problémái. Akadémiai Kiadó, Budapest

Sýkora L (2009) Post-socialist cities. In: Kitchin R, Thrift N (eds) International encyclopedia of human geography. Elsevier, Oxford

van Kempen R, Dekker K, Hall S, Tosics I (2005) Restructuring large housing estates in Europerestructuring and resistance inside the welfare industry. Policy Press, University of Bristol, Bristol

Open Access This chapter is licensed under the terms of the Creative Commons Attribution 4.0 International License (http://creativecommons.org/licenses/by/4.0/), which permits use, sharing, adaptation, distribution and reproduction in any medium or format, as long as you give appropriate credit to the original author(s) and the source, provide a link to the Creative Commons license and indicate if changes were made.

The images or other third party material in this chapter are included in the chapter's Creative Commons license, unless indicated otherwise in a credit line to the material. If material is not included in the chapter's Creative Commons license and your intended use is not permitted by statutory regulation or exceeds the permitted use, you will need to obtain permission directly from the copyright holder. 


\title{
Chapter 10 \\ Experience of a Preventive Experiment: \\ Spatial Social Mixing in Post-World \\ War II Housing Estates in Helsinki, \\ Finland
}

\author{
Mari Vaattovaara, Anssi Joutsiniemi, Matti Kortteinen, \\ Mats Stjernberg and Teemu Kemppainen
}

\begin{abstract}
The contingent of large housing estates built in the 1960s and 1970s accounts for almost a half of all high-rises in Finland. The primary ideology in their genesis was to combine industrially prefabricated urban housing development with the surrounding forest landscape - together with a policy of spatial social mixingto prevent social disorder and segregation. These policies seemed to work as intended until the early 1990s, but have since proved to be insufficient. With Western integration and new information and communication-based economic growth, new trends of population differentiation have emerged. As new wealth has moved out to the fringes of cities, the large housing estates have declined socio-economically - and have been enriched ethnically. This differentiation is structurally produced, works through the regional housing market and, as such, is beyond the scope of the preventive policies pursued. Recent attempts at controlling the regional markets and new forms of spatial social mixing have so far proved difficult.
\end{abstract}

M. Vaattovaara $(\bowtie) \cdot$ M. Kortteinen · T. Kemppainen

Department of Geosciences and Geography, University of Helsinki,

P.O. Box 64, 00014 Helsinki, Finland

e-mail: mari.vaattovaara@helsinki.fi

M. Kortteinen

e-mail: matti.kortteinen@helsinki.fi

T. Kemppainen

e-mail: teemu.t.kemppainen@helsinki.fi
A. Joutsiniemi
Aalto University, Helsinki, Finland
e-mail: anssi.joutsiniemi@aalto.fi
M. Stjernberg
Nordregio, Stockholm, Sweden
e-mail: mats.stjernberg@ helsinki.fi
(C) The Author(s) 2018
D. B. Hess et al. (eds.), Housing Estates in Europe, The Urban Book Series,
https://doi.org/10.1007/978-3-319-92813-5_10 
Keywords Differentiation - Helsinki, Finland - Large housing estates Local social life $\cdot$ Nordic regime $\cdot$ Preventive policies $\cdot$ Segregation Spatial disintegration $\cdot$ Spatial social mixing

\subsection{Introduction}

The birth of large housing estates in Finland is intrinsically linked to the late and sudden urbanisation of the country. In as late as 1948 , over $50 \%$ of the workforce earned their living from the agriculture and forestry industry, but by 1975, this group had decreased by over 700,000, to about 1,000,000 individuals. Hundreds of thousands migrated - from rural areas in Northern and Eastern Finland - to urban centres in the south, and many also migrated to Sweden. Between 1955 and 1975, about 900,000 new apartments were built, mainly in large high-rises constructed on the outskirts of cities (Hankonen 1994).

Compared to the situation in the rest of Europe, the shift in Finland to urban economic and regional structures emerged particularly late and was both exceptionally sudden and extensive. The national urban and social policies related to this change had several distinctive characteristics, as do the public structures through which the changes were managed, factors which are clearly reflected in their resultant urban structures.

\subsection{Planning and Construction}

Compared to many other countries, municipalities in Finland enjoy an exceptionally large degree of autonomy. The reasons for this are largely historical: the strong and independent peasantry was the main social and political agent in the early twentieth century, and municipal self-determination was inserted into the constitution for this reason. As a result, municipalities in Finland have an autonomous right to levy taxes (i.e. they have their own revenue base) and significant legal obligations to provide social, healthcare and educational services for their residents. The decision-makers are chosen in local elections. Residential planning, too, is controlled by the municipalities and since 1932 they have had a monopoly over all aspects of planning, giving them the sole right to dictate all land use, including privately owned land (Puustinen 2006).

In the post-war Finland of the 1950s architect-led discourse dominated in community planning, and since 1999 there has even been a national register of qualified planners (Puustinen 2006). Architects following this national tradition see themselves as pursuing a 'common good', fighting against the private interests that prevail in the market. This concept has varied somewhat over time, and in the 1960s 
and 1970s, planning discourse was dominated by a particular sociopolitical perspective: 'Common good was now about "equal good for everyone" (Puustinen 2006, p. 168). Also, the new goal of planning was to reduce social inequality. Through this, the urban policies pursued were a part of a larger political project that ended in the construction of the Finnish version of a Nordic Welfare State.

Ever since the first national Planning Act (Asemakaavalaki) of 1931, all planning activity in Finland has been considered municipal activity, with the exclusion of private planning. Initially, this pertained only to urban agglomerations but was later extended to cover all land use. This has also given Finnish planning a specific focus on the 'common good' and the public sector as a whole.

The Building Act of 1959 obligated municipalities to build infrastructure. The massive migration and related growth had created an immense financial burden on municipalities, in a country that was still, by European standards, rather poor. The structure of the public sector together with the national legislation presented above created a situation that had a profound influence on the urban structures thus ensuing.

Municipalities could only meet the challenge they faced through allying with private construction companies in a quite peculiar way. The solution was called 'neighbourhood construction procedure' The municipality agreed to allocate a specific piece of land for the construction of a certain amount of floor space, and the property developer agreed to pay for the right to build and sell houses on it. At the same time, the developer also agreed to construct and pay for the municipal infrastructure needed for the area.

The financial logic from the perspective of the municipality was simple: the more floor space the municipality designated to be constructed on a given piece of land, the more money it could ask for it from the developer. The cheaper the land originally, the greater was the increase in its value. This gave the municipalities a chance to profit from planning, thanks to the monopoly they enjoyed; the most cost-effective projects were achieved by having a lot of floor space built on inexpensive and remote land in order to maximise the increase in its value. On the private side, the appeal of the deal lay obviously in the allocated floor space that could be sold. It was therefore easy to reach a compromise: the greater the floor space the municipality designated for a given site, the higher the price asked for it, as the construction company would have more floor space to sell.

This resulted in a peculiar urban structure, typical in the Helsinki Region but also in other major cities in Finland: The proportion of large housing estates built in the 1960s and 1970s is notably high (Fig. 10.1), compared to any other housing type. Furthermore, the large high-rise suburbs tend to be scattered here and there - in the middle of forests and fields that isolate them from the existing urban fabric (Fig. 10.5). 


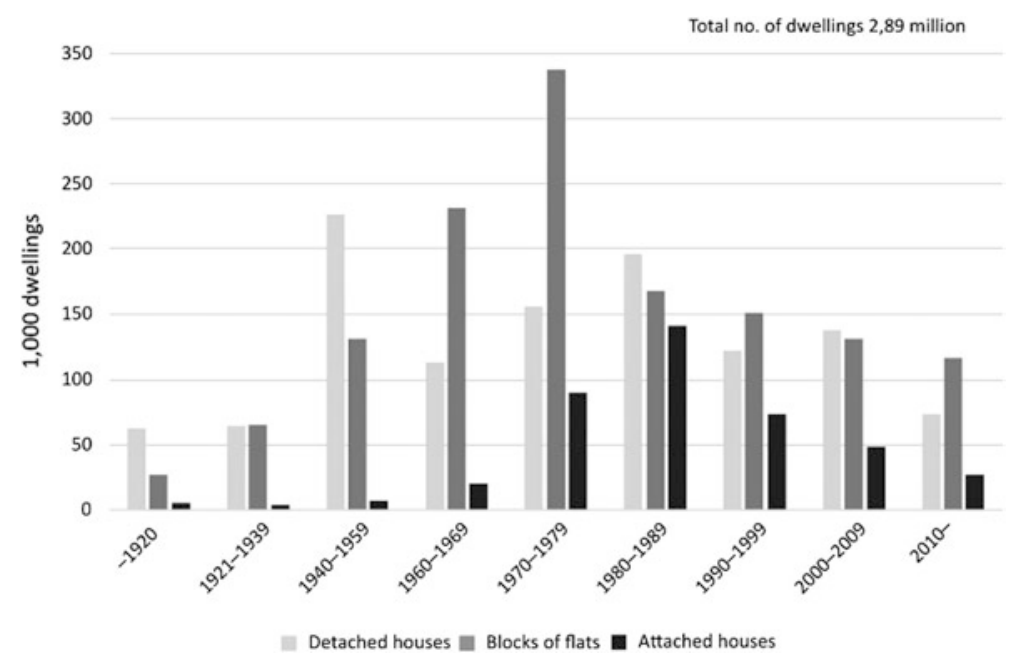

Fig. 10.1 Number and type of dwellings constructed by decade in Finland. Source Statistics Finland 2017

\subsection{National Interpretations of Planning Ideologies}

Tapiola Garden City, established in 1951, served as the model for Finnish new town development. The central ideology was to combine industrially prefabricated urban housing development with the surrounding forest landscape, a concept that quickly acquired international reputation and still serves as an iconic example of Finnish urban planning. The concept became somewhat more streamlined and brutal during the main construction period of suburban fringe in the 1960s and 1970s, although the social ideology survived for a surprisingly long time (the idea of a public library in every suburb, for example) (Fig. 10.2).

It is common in Finnish textbooks to claim that this national style of decentralisation was carried out in accordance with the so-called 'neighbourhood scheme', usually attributed to Clarence Perry and Clarence Stein (Perry 1929; Stein 1942). The original neighbourhood ideology of Perry and Stein was, however, adopted in a very piecemeal manner and was merged with national policies concerning main roads and arterial roads. This dominant model of road building was taken from the parkway typology of the USA, where the road was surrounded by unbuilt nature (Meurman 1947). Although the roadside landscape hardly meets the criteria of what we traditionally mean by a park, it became a success as it also provided a means to reduce the number of road intersections, thus supporting the two grand ideals of traffic planning - traffic separation and free traffic flow.

This amalgamation is best seen in the iconic 'Neighbourhood Unit Plan' (below on the left) and the 'Plan of a Decentralised Town' (below on the right) by Prof. Olli Kivinen in his Hämeenlinna town plan (Kivinen 1959, pp. 19-20) (Fig. 10.3). 


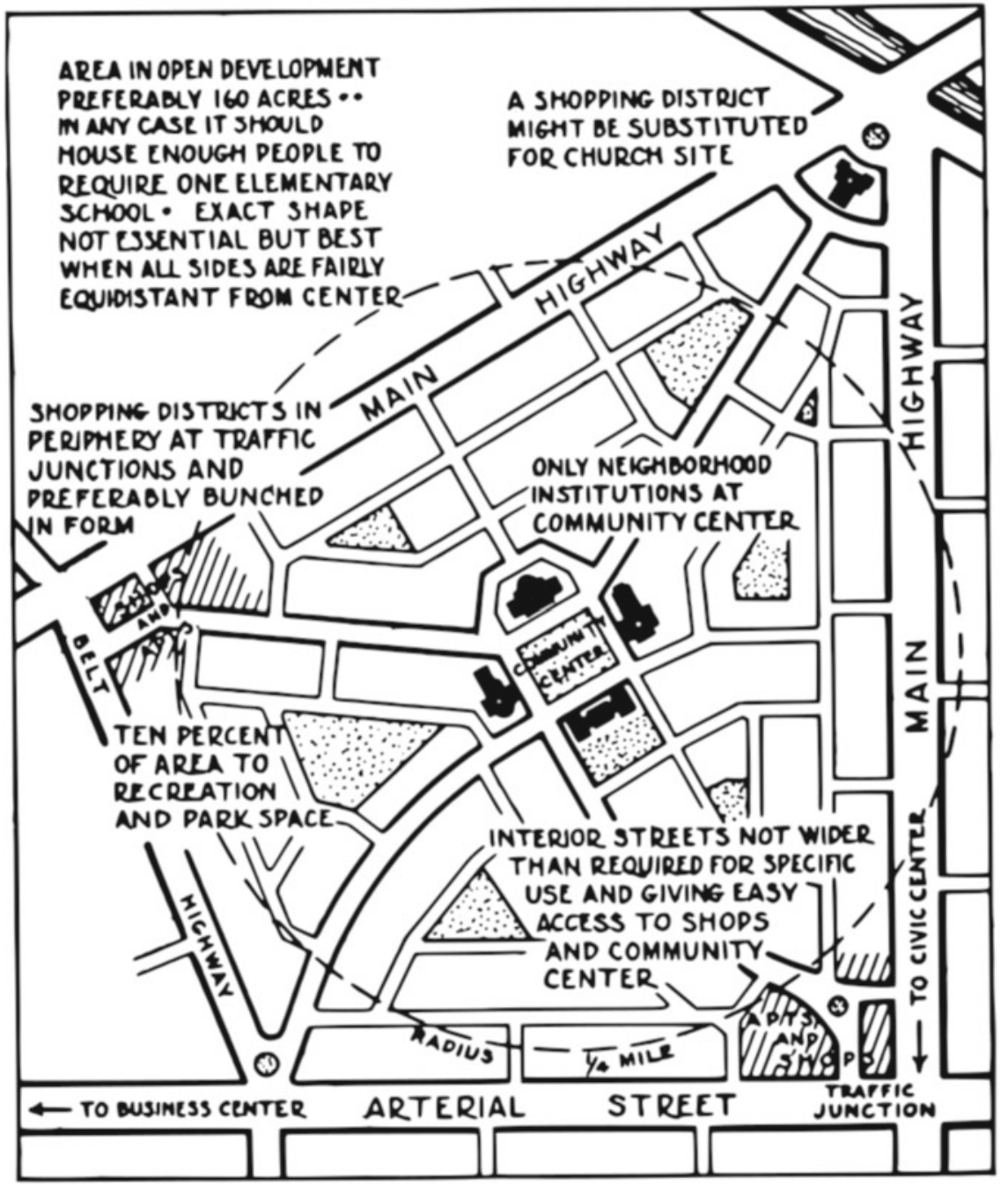

Fig. 10.2 Concept for a planned neighbourhood (after Perry 1929)

It is not difficult, however, to see differences between the original sources and the Finnish 'lung model', as it was later called. The transportation network was created following a strict hierarchical tree pattern, which divided activities into separate fixed-sized units with minimal interaction outside the neighbourhood units. In Perry's scheme, the shopping facilities are located along the main arteries for optimal accessibility. The schematic representation by Perry is misleading and led to oversimplified solutions - a mistake that became obvious later when new layers of commercial activities appeared from the 1990s onwards. Closer analysis shows that Perry's scheme and its further derivation by Stein are based in built-up areas 

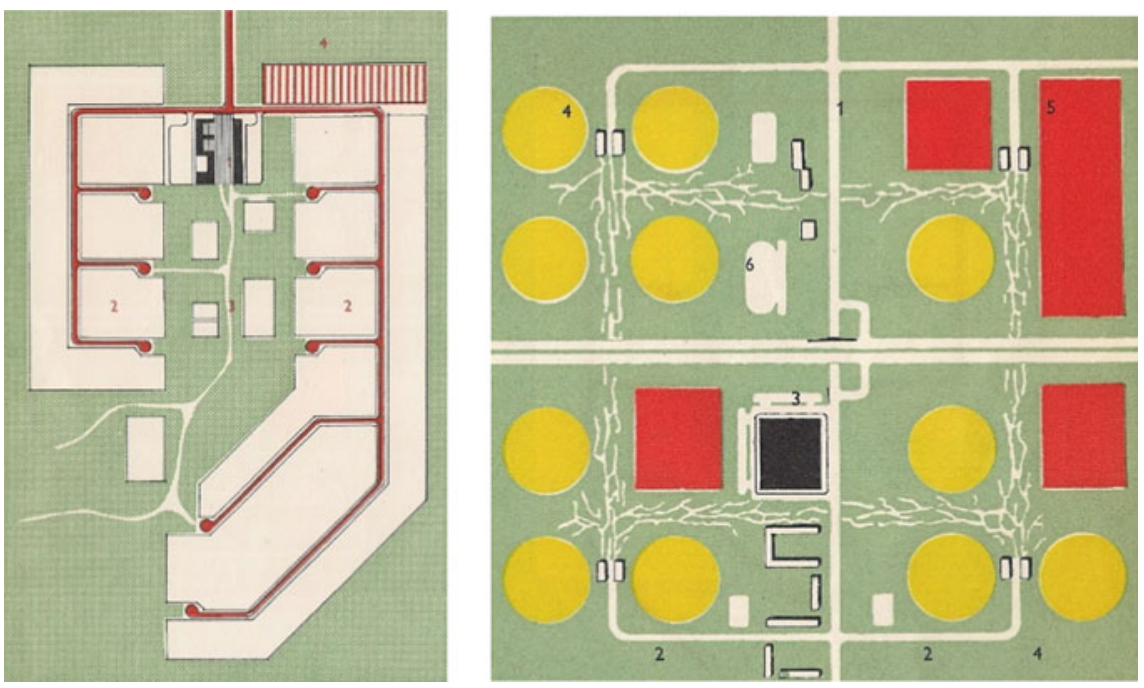

Fig. 10.3 Neighbourhood unit plan (left) and plan of decentralised town (right) by Olli Kivinen

where neighbourhoods seamlessly continue over arterial roads, making the model flexible for the increase and overlap of multiple centrality needs - hardly the case in the Finnish implementation. Perry's model was a part of the continuous urban fabric of New York, while the Finnish model deliberately separates the housing units from the large urban whole.

A new layer of commercial activities also came into being on the suburban fringe from the 1980s onwards. This new logic of large-scale shopping centres and municipal level sub-centre development did not follow the logic of earlier suburban neighbourhoods but built new indoor shopping centres in-between the existing scattered suburban fabric. In the following images, it is easy to recognise how smaller suburban sub-centres were reconnected with new larger shopping centres. The new locations are mainly those with excellent access for private cars and a concentration of public transport routes. This also led to the decline of the original commercial centres of older suburbs, now mainly hosting local pubs, small shops and occasional one-person companies (Figs. 10.4 and 10.5).

Nevertheless, it must be appreciated that the housing policy in Helsinki also had a socio-political dimension, at the core of which was the idea of spatial social mixing. Its historical starting point was the Siilitie riot of 1961, in which young people from a large area of rented housing started to riot and to fight with police (see Schulman 2000). The incident resulted in an emergency meeting of the Helsinki city administration. The solution was to scatter municipal rental housing amongst other types of housing, thereby preventing the formation of large areas with primarily rented flats. With one exception, the policy has been consistently pursued since then. 

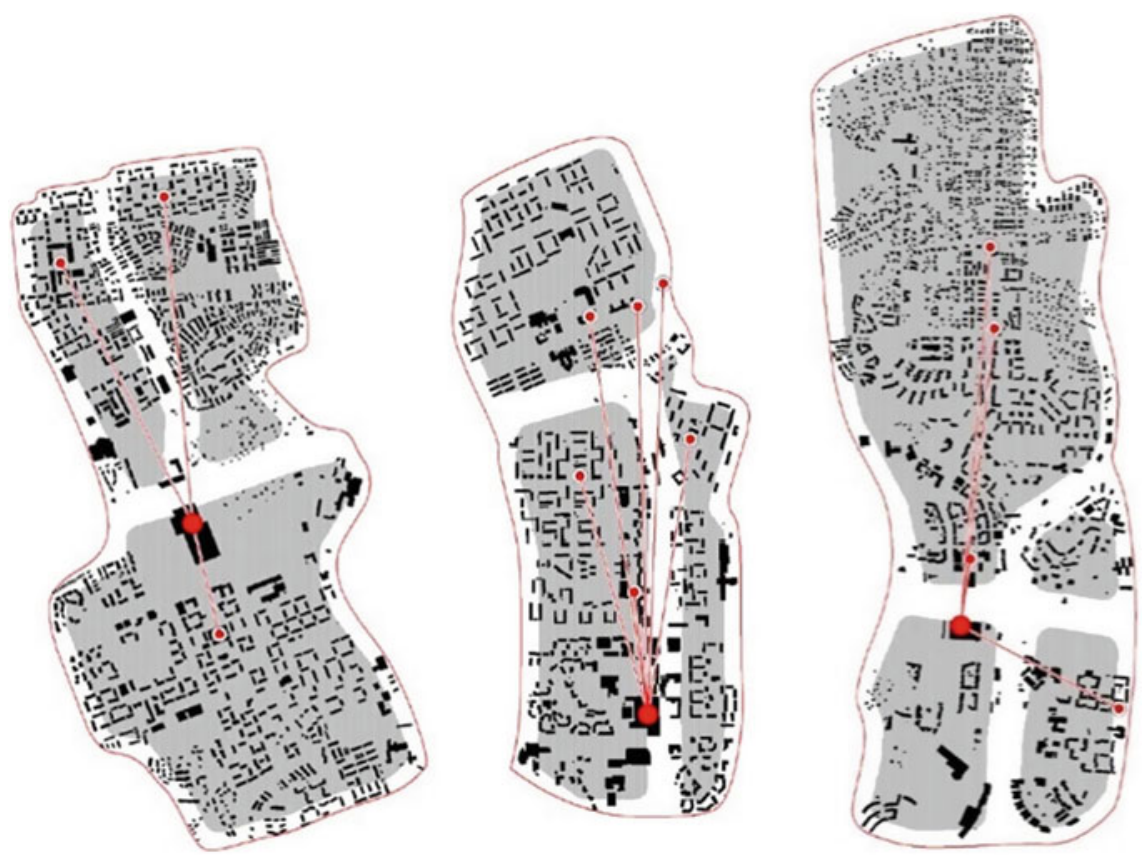

Fig. 10.4 Reconfiguration of neighbourhood-level shopping activity in Matinkylä, Myyrmäki and Leppävaara sub-centres in greater Helsinki region. (Joutsiniemi 2006, p. 45)

Spatial social mixing was initially practised at the residential block level, i.e. using blocks as the units to be mixed. This led large rented housing units, the size of relatively massive blocks, to clearly separate from the rest of the neighbourhood and with hundreds of residents. The policy was revised in the mid-1970s when the decision was made to use buildings instead of blocks as the units for mixing. Since the 1970s, the policy has been to construct blocks with architecturally identical buildings but with many types of tenure. In one particular case (Ruoholahti in the 1990s), tenure mixing was extended inside the buildings. The political argumentation changed, too: since the 1960s, there has been no more talk of social order (cf. the case of Siilitie), but rather of equality - the aim being to produce an urban structure in which everyone lives together in the same reality.

This policy of mixing was implemented strictly and consistently in projects in Helsinki and, in the 1970s, it spread to the adjacent towns of Espoo and Vantaa, covering the whole of the metropolitan area.

This caused the Helsinki Region to become quite exceptional by international standards, not only spatially but also socio-economically. As late as in the late 1980s and early 1990s, differences in income between sub-districts were small (the relationship of incomes in the richest and the poorest sub-districts was the same in 1994 as it had been in 1980). This was also the case with regard to unemployment 


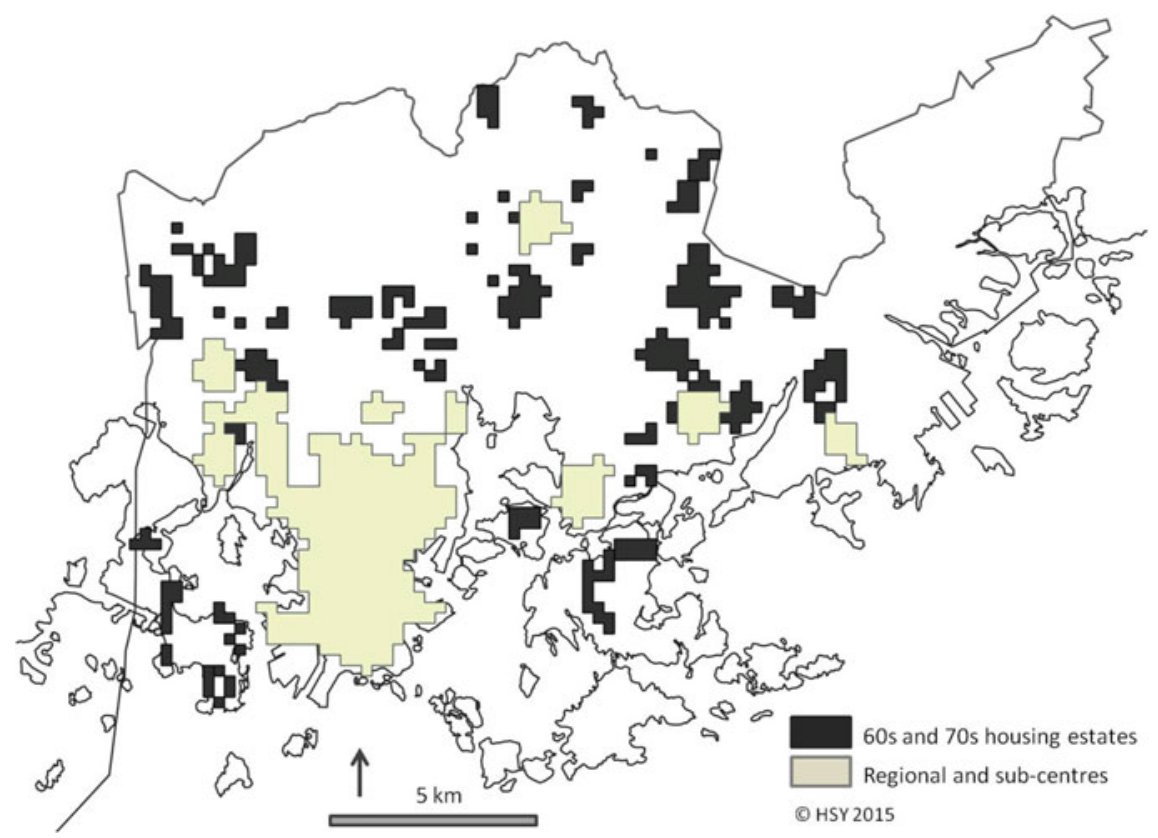

Fig. 10.5 Locations of 1960s and 1970s housing estates in Helsinki

(in 1989, the lowest unemployment rate was $0.1 \%$ and the highest $2.1 \%$ ) (Vaattovaara and Kortteinen 2003). In addition, the areas built after 1960 are each internally heterogeneous, i.e. each has its own so-called 'social apartment base', at the level of either blocks or buildings, scattered inside the area. The outcome of these factors was an urban structure that is, to the best of our knowledge, unlike any other in the world, with deprivation spread across the region in a mosaic-like pattern (Vaattovaara 1998).

As Finland opened up more towards the West in the early 1990s, and the USSR collapsed, the country was hit by the deepest depression among the OECD countries. This quickly had a profound effect on urban development: unemployment quickly reached exceptionally high levels (with about one-third of the workforce being unemployed in some sub-districts of Helsinki). The depression was followed by a strong information and communication-based upswing, based around Nokia, which started in 1994. Through this, the demand for labour moved towards professions requiring a high level of education, while the demand for unskilled labour diminished drastically (see Vaattovaara and Kortteinen 2003). This gives an opportunity to study how spatial social mixing, designed to be preemptive, works under conditions of rapid socio-economic and also ethnic differentiation. 


\subsection{Socio-Economic and Demographic Change Since the Early 1990s}

The information and communication-based economic growth that had begun in 1994 gave rise to a growing multi-municipal metropolis in the Helsinki Region. The commuting area grew fast to extend first to the neighbouring communities of Espoo and Vantaa and later also the so-called 'ring municipalities': 14 municipalities surrounding the metropolitan area consisting of the three major cities. The result was a single metropolitan district consisting of nearly 20 different municipalities.

All municipalities independently control the planning and construction within their region. However, in a multi-municipal commuting area inter-municipal competition emerges, not only of firms but also of residents. This is based on the structure of public governance in Finland, in which a municipal economy is based on municipal tax revenue, the majority of which comes from the salaries of wage-earners. As the municipalities are responsible for the provision of public services to their residents, and the subsequent expenses are largely towards services in social welfare and health, this setting creates the basis of municipal competition for the working, tax-paying population that produces more public revenue than it spends. The rapid ageing of the population adds specific intensity to this competition.

Helsinki has predominantly produced dense, high-rise and mixed urban constructions, mainly large housing estates, along the main railway lines. Both social and ecological considerations have are at play in this - it is a way to combine affordable housing and sustainable development. As the neighbouring, traditionally rural, municipalities have relied more on the production of detached housing, the quality of housing supply varies across municipalities.

The new information and communication-based growth of the 1990s led to significant growth of wealth in the region. This, together with an overall downward trend in the real price of housing relative to real wages (see Lönnqvist and Vaattovaara 2004), resulted in a situation in which people (especially the wealthier ones) could afford bigger and/or better housing. All surveys regarding housing demand show that this results in the growth of demand for detached housing, preferably in peaceful settings close to nature (Vaattovaara and Kortteinen 2003).

As a result, new spatial differentiation has emerged, with two distinct facets: new wealth moves out to the growing belt of detached housing surrounding the previously built large estates, and these, at the same time, start to decline socio-economically, and their ethnic diversity starts to grow.

As a starting point, there is the dispersed, mosaic-like structure based on the policies of mixing. A spatial description based on small GIS units, the size of a block ( 250 by $250 \mathrm{~m}$ ) is the most suitable basis to describe the spatial structure (see Fig. 10.6). The attached maps (Figs. 10.6, 10.7 and 10.8) show the GIS squares that are in the lowest quintile in education, employment and income in 1990, 2000 and 2010. Both the number and size of these pockets of poverty have grown, and new ones have emerged in the immediate vicinity of the old ones. As development has 
continued over the last 20 years, larger spatial units have formed, predominantly in the eastern part of Helsinki.

The development has affected the relative position of the large housing estates in the region, especially that of housing estates built in the 1960s and 1970s (see Table 10.1). In 1990, most suburban housing estates were largely similar to their wider subregion in terms of unemployment and level of income, in Finland as a whole and within the Helsinki Region. In terms of education, however, housing estates, already had a lower proportion of people with tertiary education. As the demand for labour turned towards professions requiring tertiary education, a clear downward socio-economic trend appeared. In 2010, housing estates were also in a weaker socio-economic position in terms of unemployment rate and income. In other words, the large housing estates in the region started their socio-economic decline in the early 1990s, and not before.

The median unemployment rate among the 48 housing estates increased from 1.8 to $12.5 \%$ between 1990 and 2013, while unemployment in the whole of Helsinki grew from 2.0 to $10.0 \%$. The most significant changes in unemployment occurred during the 1990s in the aftermath of the recession, but unemployment peaked again between 2010 and 2013 during a new economic downturn. The same trend applied to levels of income and education, and to the ageing of the population: all these features have developed unfavourably, especially on the large housing estates.

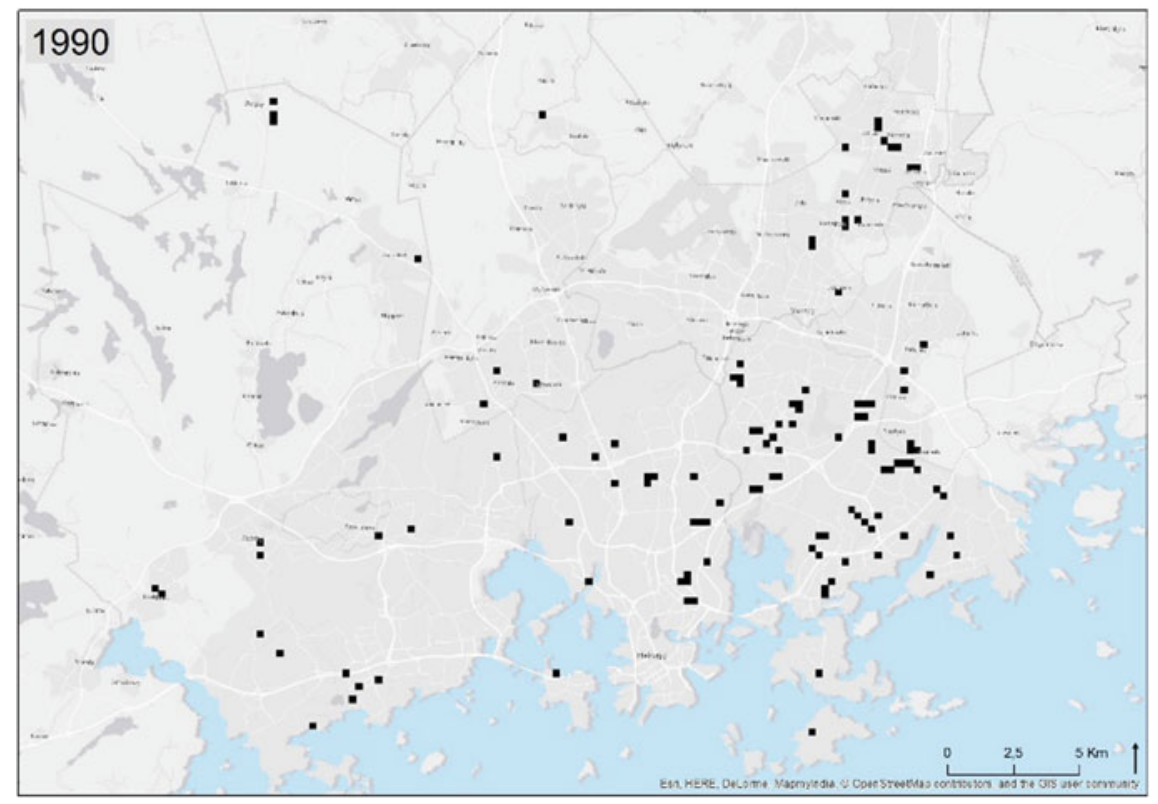

Fig. 10.6 Distribution of the lowest spatial quintile units (measuring education, employment and income), 1990 


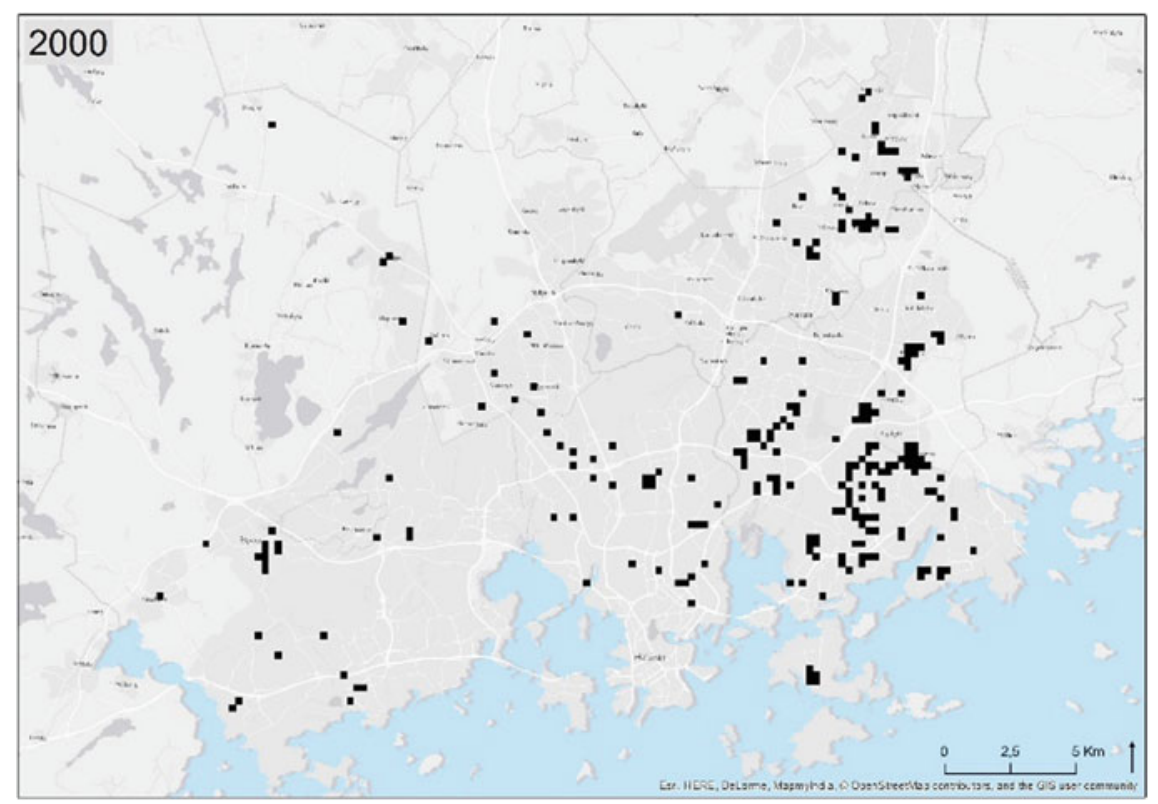

Fig. 10.7 Distribution of the lowest spatial quintile units (measuring education, employment and income), 2000

These 48 estates had a total population of 115,090 in 2014 , meaning that approximately $19 \%$ of the total population in Helsinki lived in these specific estates (Table 10.2). In 1990, 124,823 people lived in these housing estates that formed around $25 \%$ of the city's population. These housing estates are quite heterogeneous in terms of their internal characteristics. Figure 10.2 shows that there are noticeable differences in their overall size, illustrated by substantial variation in population size and the number of dwellings. For instance, whereas the median population size in these estates in 2014 was 1,306, eight estates had populations greater than 5,000, and 11 estates had populations lower than 500. There are also clear differences in terms of housing tenure, which is exemplified by the fact that some estates were clearly dominated by renter-occupied housing (over $80 \%$ in three estates), whereas others had substantial proportions of owner-occupied housing (over 60\% in nine estates) (Figs. 10.9 and 10.10).

It further seems that the unfavourable development of the large housing estates is closely related to housing tenure - despite the continuation of policies of spatial social mixing. In Table 10.2, housing estates have been divided into quartiles according to the proportion of socially rented housing on each estate. Housing estates with above-average numbers of socially rented housing are socio-economically the most disadvantaged. The same correlation is also true with the level of immigrant population. Generally speaking, estates with high proportions of socially rented housing have substantially higher numbers of residents with 


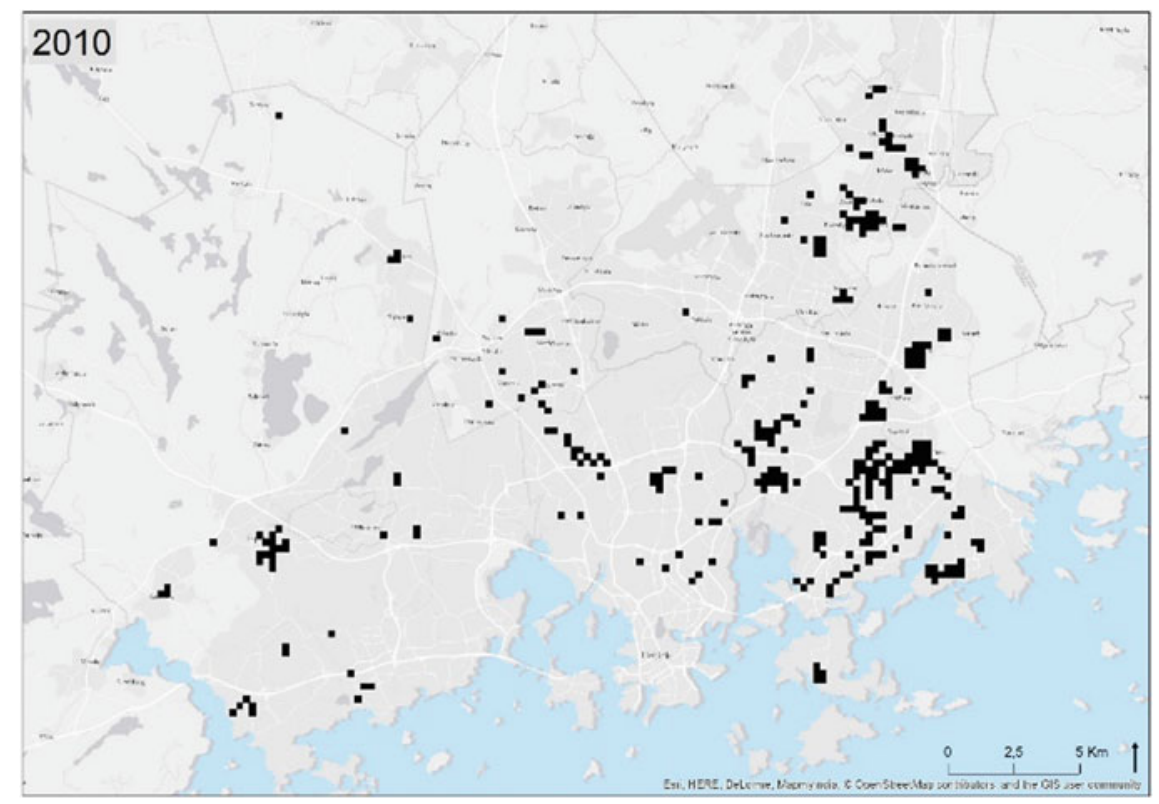

Fig. 10.8 Distribution of the lowest spatial quintile units (measuring education, employment and income), 2010

a language other than Finnish or Swedish as their first language, indicating that people with immigrant backgrounds have often settled where social housing is common (Table 10.3).

A separate analysis on the development of the estates illustrates significant changes both in unemployment and in the proportion of ethnic minorities between 1990 and 2013. Initially, both unemployment and immigrant population were virtually non-existent, but in both cases, the differentiation amongst the estates has become increased substantially. The development has concentrated on the estates with larger than average proportions of social rental housing, especially on the eastern parts of Helsinki and along the main railway line to the north-in other words, into the areas that originally had lower than average levels of education and income.

In summation, it seems that the major shift in the demand for labour has produced a socio-economic decline in populations with lower than average levels of education and that this decline has spatially affected the large housing estates in which these populations originally settled. These are the estates farthest from the centre, in the northeast and east of Helsinki. The immigrant population tends to concentrate specifically in these areas. 

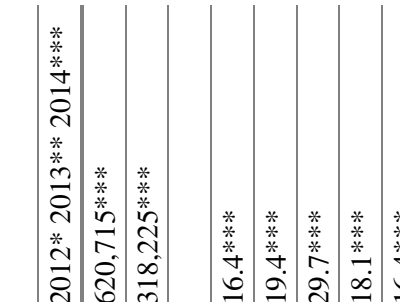

$\mid$

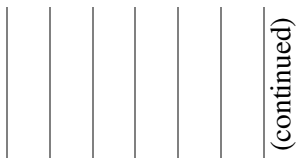

ז̂

ナ. $\neg-\forall$

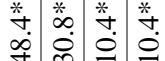

苟

$-2 \therefore 0$

-

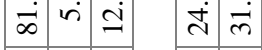

趈

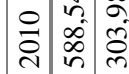

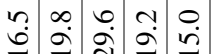

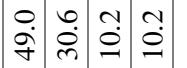

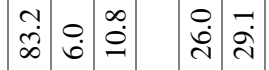

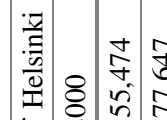

น

Iุ

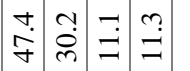

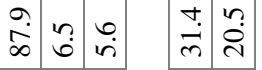

高

8 으

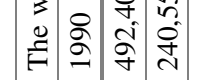

I.

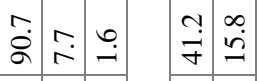

究

*

$\stackrel{*}{*}$

호

蒡

호 *

$\cong$

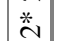

글

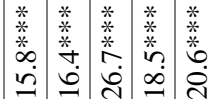

草

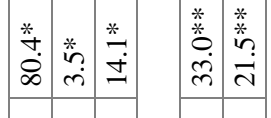

$\begin{array}{cccc}\stackrel{\infty}{+} & 0 & \vec{n} & n \\ \text { II } & \stackrel{n}{n} & n & n\end{array}$

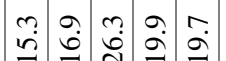

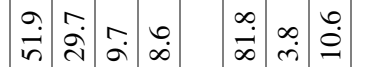

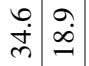

营 $\exists$

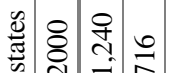

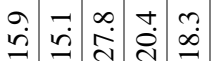

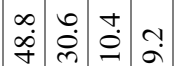

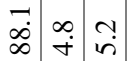

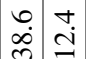

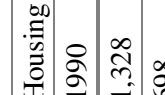

$\ln \frac{\pi}{2}$

๓ฺ

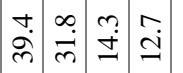

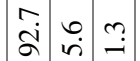

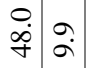

可

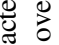

突 공

ธี ํㅗ

홀 옹

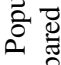

홍 छे

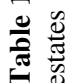

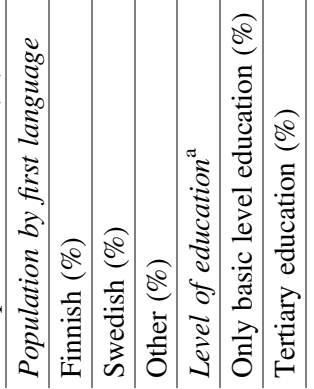




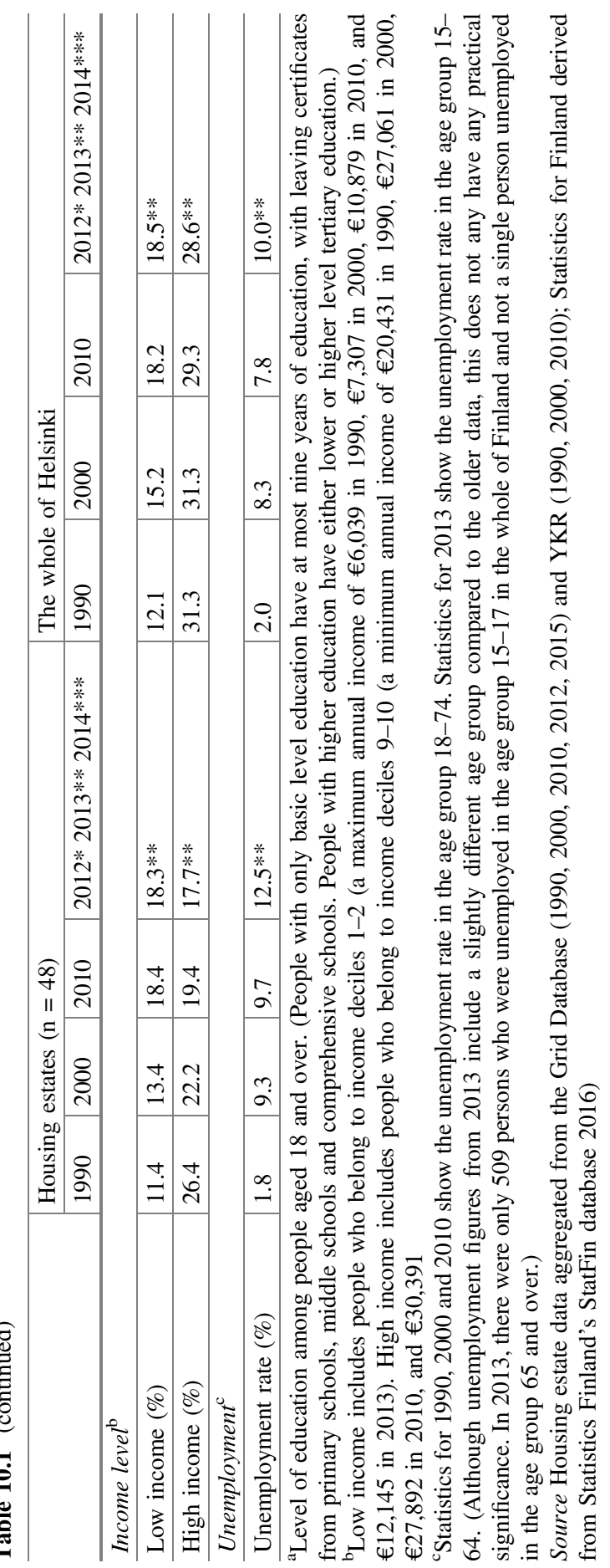


Table 10.2 Total population and share of population in Helsinki's 1960s and 1970s housing estates in 1990, 2000, 2010 and 2014

\begin{tabular}{l|l|l|l}
\hline & Housing estates $(\mathrm{n}=48)$ & Helsinki & $\begin{array}{l}\text { Share of Helsinki's } \\
\text { population in housing } \\
\text { estates }(\%)\end{array}$ \\
\hline Total population 1990 & 124,823 & 492,400 & 25 \\
\hline Total population 2000 & 114,944 & 555,474 & 21 \\
\hline Total population 2010 & 112,494 & 588,549 & 19 \\
\hline Total population 2014 & 115,090 & 620,715 & 19 \\
\hline
\end{tabular}

Number of inhabitants

in housing estates (2014)

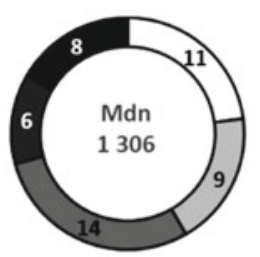

-499

口500-999

Share of owner-occupied dwellings

in housing estates (2010)

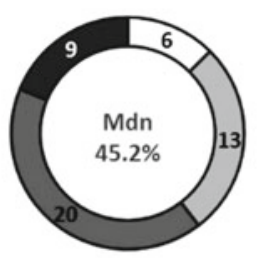

口0-19\% 口20-39\% व $40-59 \%$

\section{Number of dwellings}

in housing estates (2014)

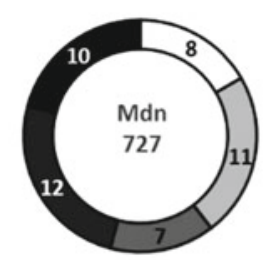

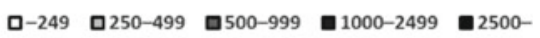

Share of renter-occupied dwellings in housing estates (2010)

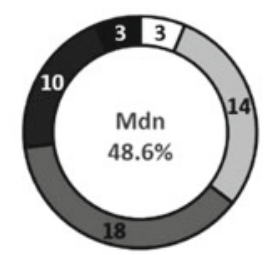

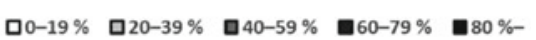

Fig. 10.9 Number of inhabitants and dwellings, as well as tenure structure of housing estates in Helsinki $(n=48)$ (Numbers inside the graphs show number of housing estates that belong to each category and median share among all estates)

\subsection{Local Social Life in Helsinki Housing Estates}

It is worth noting that the decline of the eastern part of the Helsinki metropolitan area has been gradual and mainly relative in nature. In the conditions caused by the upswing of the 1990s, unemployment diminished, and incomes still grew in the 
Share of foreign-language speakers

in housing estates (2012)

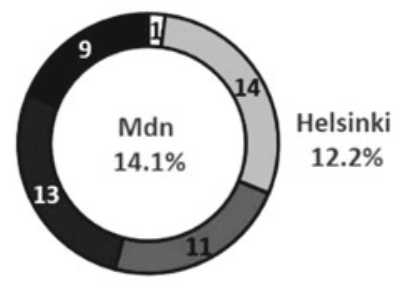

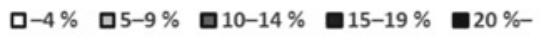

Share of low-income earners

in housing estates (2013)

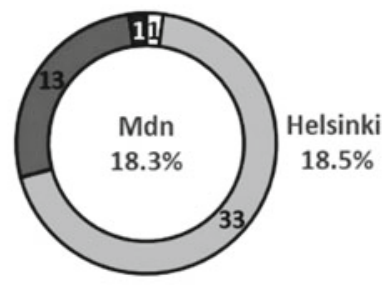

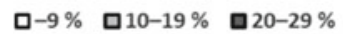

$30-39 \%$

$40 \%-$

\section{Share with only basic level education} in housing estates (2013)

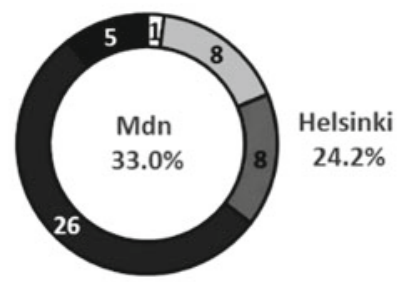

\section{Unemployment rate}

in housing estates (2013)

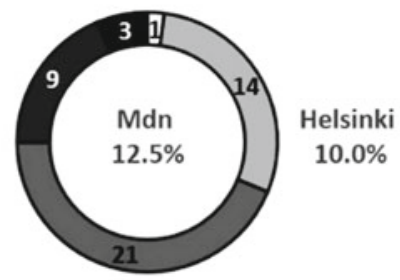

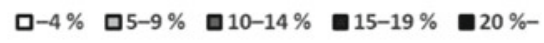

Share of high-income earners
in housing estates (2013)

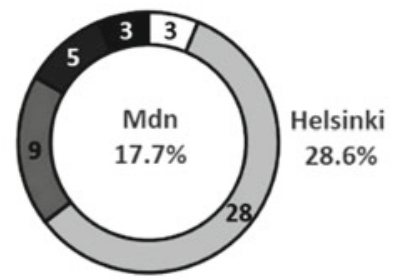

口10-19\% ㅁ20-29\%

$40 \%-$

\section{Share with tertiary education \\ in housing estates (2013)}

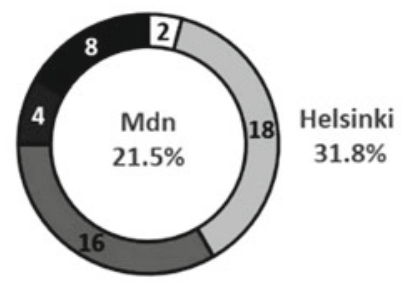

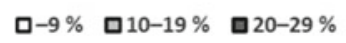

$30-39 \%$

$40 \%-$

口-9\%

口10-19\% प $20-29 \%$

$30-39 \%$

$40 \%-$

Fig. 10.10 Ethnic and socio-economic structure of housing estates in Helsinki $(n=48)$ (Values inside the figures show number of housing estates that belong to each category and median shares among all estates as well as the respective share for the whole city)

east, only the pace of the upswing was somewhat slower than elsewhere. Undeniable impoverishment, however, has also emerged. As a spatial phenomenon, long-term unemployment did not exist in housing estates before the 1990s. The number of long-term unemployed in the research area was 1,400 , comprising $0.2 \%$ 


\begin{tabular}{|c|c|c|c|c|c|c|c|c|c|c|c|c|c|}
\hline 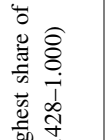 & 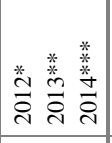 & : & 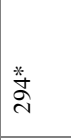 & & 䔲 & 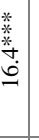 & 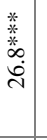 & & & $\begin{array}{l}\text { 䖭 } \\
\text { 字 }\end{array}$ & 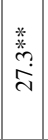 & $\stackrel{\text { * }}{\text { : }}$ & $\begin{array}{l}* \\
* \\
2 \\
0 \\
0\end{array}$ \\
\hline 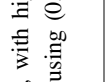 & 음 & : & 令 & & $\hat{\dot{i}}$ & $\stackrel{9}{\Xi}$ & चूं & $\overrightarrow{\mathrm{i}}$ & $\dot{I}$ & $\hat{b}$ & $\begin{array}{c}\dot{a} \\
\dot{d} \\
i\end{array}$ & $\stackrel{ \pm}{\mathrm{I}}$ & $\overline{\mathrm{I}}$ \\
\hline 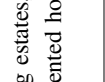 & ¿্ণ & $\vec{G}$ & $\begin{array}{l}\infty \\
\infty \\
i \\
i\end{array}$ & & 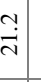 & $\stackrel{\infty}{\dot{ \pm}}$ & $\stackrel{\vec{\lambda}}{\vec{\lambda}}$ & $\stackrel{9}{2}$ & $\stackrel{n}{0}$ & $\exists$ & 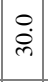 & $\stackrel{\circ}{\stackrel{+}{ \pm}}$ & $\stackrel{+}{\stackrel{D}{~}}$ \\
\hline 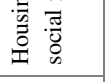 & ఏ & $\mathscr{\infty}$ & ¿্ల & & $\begin{array}{l}\mathbf{Z} \\
\mathbf{Z}\end{array}$ & $\begin{array}{l}m \\
\stackrel{n}{2}\end{array}$ & $\frac{m}{m}$ & $\stackrel{?}{\simeq}$ & 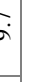 & 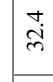 & $\begin{array}{l}0 \\
0 \\
\dot{0} \\
i\end{array}$ & $\stackrel{m}{\infty}$ & $\stackrel{\circ}{\stackrel{5}{\leftrightarrows}}$ \\
\hline 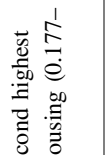 & 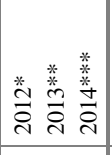 & 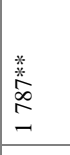 & $\stackrel{*}{\sigma}$ & & 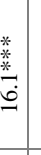 & בֶ. & 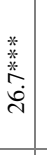 & & S. & $\stackrel{*}{m}$ & $\mid \begin{array}{l}* \\
* \\
\cdots \\
\vdots \\
\vdots \\
\vdots\end{array}$ & 落 & 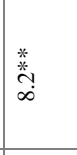 \\
\hline 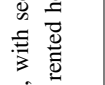 & $\stackrel{0}{\circ}$ & $\underset{\infty}{ \pm}$ & م & & $\begin{array}{l}\mathfrak{n} \\
\\
\end{array}$ & $\vec{a}$ & $\begin{array}{l}n \\
\stackrel{n}{2} \\
\end{array}$ & $\stackrel{m}{2}$ & $\stackrel{?}{\mathrm{v}}$ & $\stackrel{\infty}{:}$ & $\begin{array}{l}0 \\
\dot{\rho} \\
\end{array}$ & $\partial$ & $\begin{array}{l}0 \\
\infty\end{array}$ \\
\hline 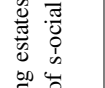 & \&્ત & $\underset{\infty}{\infty}$ & ล & & $\begin{array}{l}\dot{t} \\
\dot{\bullet}\end{array}$ & $\begin{array}{l}\infty \\
\dot{n} \\
\end{array}$ & $\vec{i}$ & $\stackrel{+}{\overrightarrow{0}}$ & $\stackrel{?}{\mathrm{v}}$ & $\begin{array}{l}\stackrel{0}{\circ} \\
\dot{q}\end{array}$ & $\begin{array}{c}\vec{j} \\
\stackrel{m}{~}\end{array}$ & $\stackrel{\infty}{=}$ & $\ddot{a}$ \\
\hline 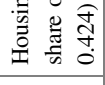 & ๖ & $\begin{array}{l}\infty \\
2 \\
2 \\
-\end{array}$ & $\hat{\sigma}$ & & $\begin{array}{l}+ \\
\dot{\sigma}\end{array}$ & $\begin{array}{l}n \\
\infty \\
\infty\end{array}$ & $\begin{array}{l}m \\
\dot{\infty} \\
\dot{\sim}\end{array}$ & $\begin{array}{c}\infty \\
\varrho \\
\varrho\end{array}$ & $\dot{a}$ & $\frac{n}{m}$ & $\begin{array}{l}n \\
m \\
m\end{array}$ & $\stackrel{n}{n}$ & $\stackrel{\circ}{\mathrm{I}}$ \\
\hline 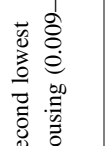 & 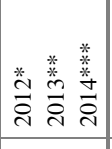 & 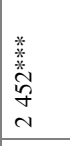 & 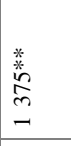 & & . & 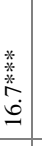 & 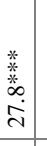 & 䊪 & 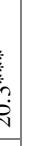 & $\begin{array}{l}\text { * } \\
\text { 絭 } \\
\dot{f}\end{array}$ & $\begin{array}{l}* \\
* \\
* \\
\stackrel{*}{*} \\
\end{array}$ & $\begin{array}{l}* \\
\cdots \\
\infty \\
\infty \\
\infty\end{array}$ & 菼 \\
\hline 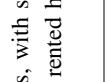 & $\stackrel{\circ}{\circ}$ & $\frac{a}{9}$ & 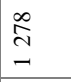 & & ذి & $\overrightarrow{0}$ & 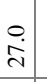 & \begin{tabular}{l|l}
0 \\
i
\end{tabular} & D. & in & $\vec{a}$ & $\underset{\infty}{+}$ & $\stackrel{2}{\sim}$ \\
\hline 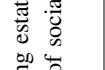 & \&্ণ & $-\infty$ & $\begin{array}{r}0 \\
-5 \\
\end{array}$ & & $\stackrel{m}{ \pm}$ & ?ִ & $\begin{array}{l}a \\
\dot{i} \\
i\end{array}$ & $\begin{array}{l}0 \\
\dot{\vec{\lambda}}\end{array}$ & 巳. & $\stackrel{0}{i}$ & $\begin{array}{l}0 \\
\dot{m}\end{array}$ & $\infty$ & $\infty$ \\
\hline $\begin{array}{l}0 \\
0 \\
0 \\
0\end{array}$ & ڤ & त है & $-\stackrel{f}{\delta}$ & & $\begin{array}{l}n \\
\varrho \\
\end{array}$ & $\stackrel{+}{\circ}$ & 芦 & $\vec{\square}$ & : & $\stackrel{ナ}{\dot{f}}$ & m. & $\hat{\check{2}}$ & $\vec{I}$ \\
\hline 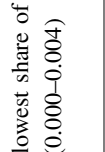 & 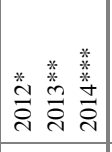 & $\stackrel{\text { F }}{*}$ & 策。 & & 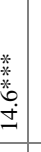 & 总 & 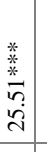 & 赵 & $\begin{array}{l}1 \\
\vdots \\
\vdots \\
\dot{b} \\
\end{array}$ & 畨 & 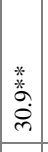 & $\begin{array}{l}\text { *. } \\
\text { 范 } \\
\infty\end{array}$ & $\begin{array}{l}* \\
* \\
\infty \\
\infty \\
\infty \\
\end{array}$ \\
\hline 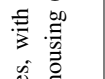 & 움 & - & I & & $\begin{array}{l}0 \\
\text { in }\end{array}$ & $\begin{array}{l}\infty \\
\stackrel{-}{-}\end{array}$ & 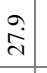 & 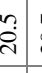 & s. & in & $\overrightarrow{\dot{m}}$ & $\vec{a}$ & $\stackrel{0}{\circ}$ \\
\hline 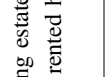 & ষ্ণ & $-\stackrel{\infty}{\infty}$ & $\vec{\sim}$ & & $\begin{array}{l}\text { 过 } \\
\end{array}$ & $\stackrel{\dot{\leftrightarrow}}{\grave{m}}$ & $\begin{array}{l}0 \\
\dot{i} \\
i\end{array}$ & $\begin{array}{l}\infty \\
\dot{i} \\
\end{array}$ & 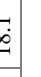 & $\vec{\sigma}$ & $\begin{array}{l}0 \\
\dot{m} \\
\end{array}$ & $\stackrel{\infty}{\sigma}$ & $\stackrel{\circ}{\circ}$ \\
\hline 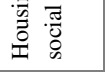 & ஃ & $\_\stackrel{\mathscr{\infty}}{+}$ & 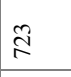 & & $\stackrel{\infty}{\leftrightharpoons}$ & $\begin{array}{l}\stackrel{\leftrightarrow}{\infty} \\
\stackrel{\infty}{*}\end{array}$ & ले & $\stackrel{\circ}{\stackrel{\infty}{\infty}}$ & 2 & $\stackrel{\circ}{\dot{m}}$ & $\begin{array}{l}\mathrm{m} \\
\mathrm{m}\end{array}$ & $\grave{\mathrm{I}}$ & $\stackrel{0}{\dot{2}}$ \\
\hline & & 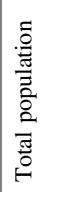 & 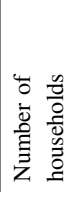 & 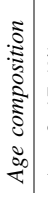 & 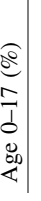 & 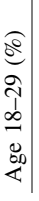 & 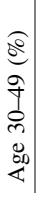 & 每 & $\begin{array}{l}0 \\
6 \\
6 \\
8 \\
0 \\
x\end{array}$ & 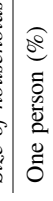 & 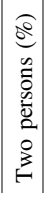 & 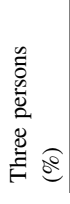 & 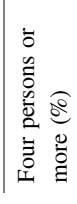 \\
\hline
\end{tabular}




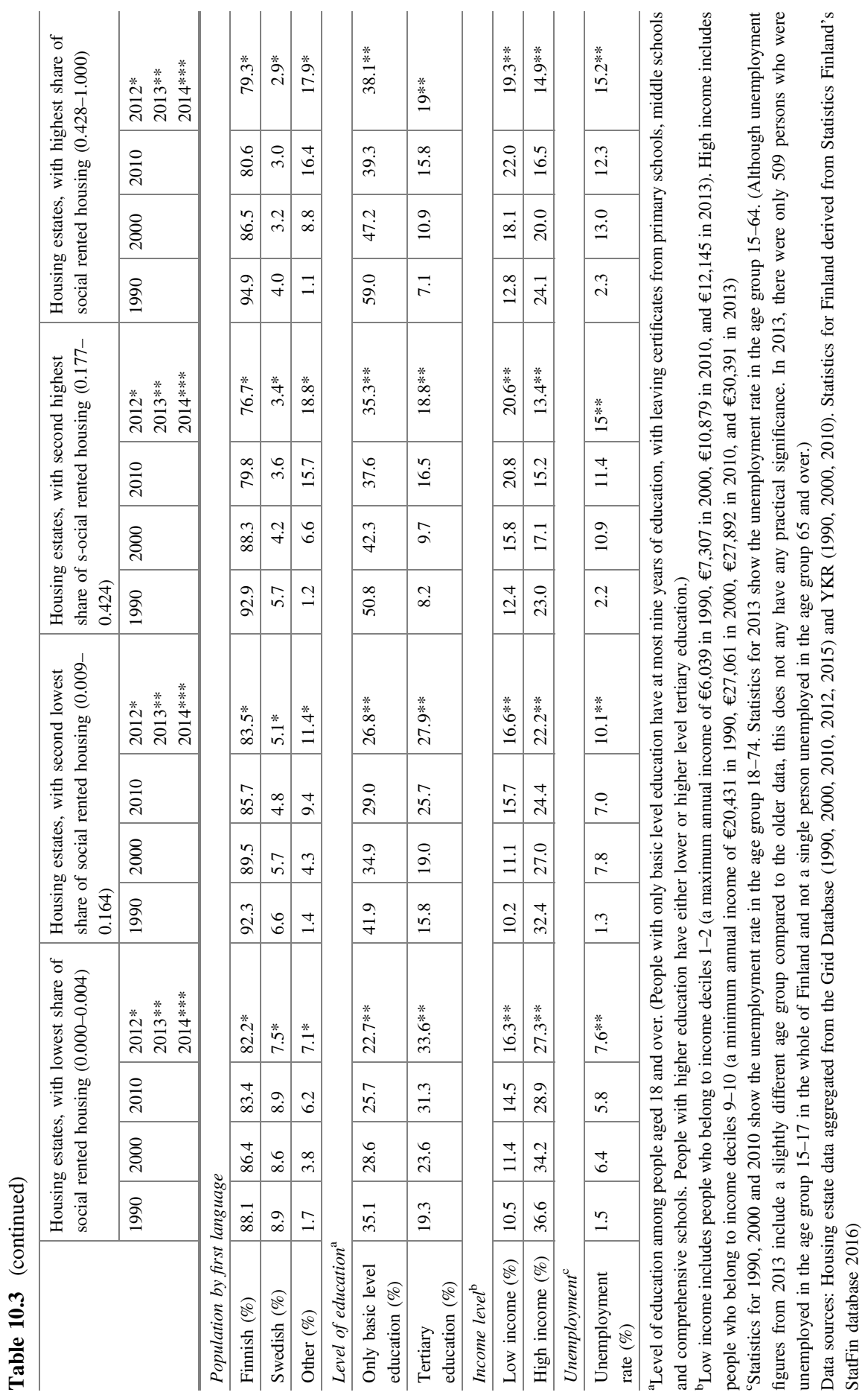


of the population of housing estates. In August 2010, the unemployment rate in Helsinki was $8.6 \%$, 26,983 people, of whom 5,149 were long-term unemployed. More striking, however, is the growing differentiation of this phenomenon within the city.

A statistical study on developments within social rental housing in Helsinki shows that during the economic upswing in the late 1990s and early 2000s, the employment rate rose until 2002, after which it has plateaued at around 52-55\%. Therefore, in a significant part of social rental housing in Helsinki, the majority of people of working age - excluding students - do not work but live on social benefits of some kind. A separate study was conducted on a high-rise suburb with a preponderance of rented housing, on the outer fringes of the metropolitan region (the suburb of Peltosaari, in the town of Riihimäki, about $100 \mathrm{~km}$ north of Helsinki). It showed that about $50 \%$ of the population of working age was either long-term unemployed or living on disability pensions of some kind.

Taking the proportion of residents over $65(15-25 \%$ on average, depending on the socio-economic level of the estate) into further account, going to work is, at present, not the default way of life in major sections of large high-rise estates in Helsinki. This makes local social life on the estates particularly significant, and the composition and community life of the different groups within the daytime population gains in importance.

A survey of the housing satisfaction of residents in the Helsinki region (Kortteinen et al. 2001, 2005) shows how feelings of insecurity and unrest have grown within the dense high-rise areas, and how these feelings co-vary with a wish to move away. A survey of those who prefer the detached suburban belt showed that the people who opt out of mixed high-rise surroundings do so in search of greater social and material homogeneity.

In 2012 a study was conducted which - for the first time in the history of the region-seemed to show that a part of the middle class was moving out of the large housing estates (Vilkama et al. 2013). The foremost local reasons for this exodus were the social conditions of life, regarded as unsafe and/or not suitable for children. In another study, we likewise found that the major causal factor producing a willingness to move away was local social disorder and feelings of insecurity (Kortteinen et al. 2001).

In 2012, we conducted a large-scale survey in the Helsinki Region, with a gross sample size of 27,000 and a response rate of $36 \%$. As the data include items on perceived social disorder, we can use it to infer the role of social housing as a determinant of local social life (see also Kemppainen 2017; Kemppainen and Kortteinen forthcoming).

Perceived social disorder was measured using six items to gauge how much the respondent had observed antisocial behaviours in the residential area; the items measured were littering or vandalism, public drunkenness, disruptive neighbours, drug abuse or trafficking, trouble-making or threatening behaviour and thefts or malicious damage. The response options ranged from never to very often. Figure 10.11 presents the unadjusted levels of a factor score variable on perceived social disorder according to the share of social housing (in quartiles). In the first 
Fig. 10.11 Perceived social disorder by share of social housing (quartiles); means of factor score variable with cluster-robust $95 \%$ confidence intervals

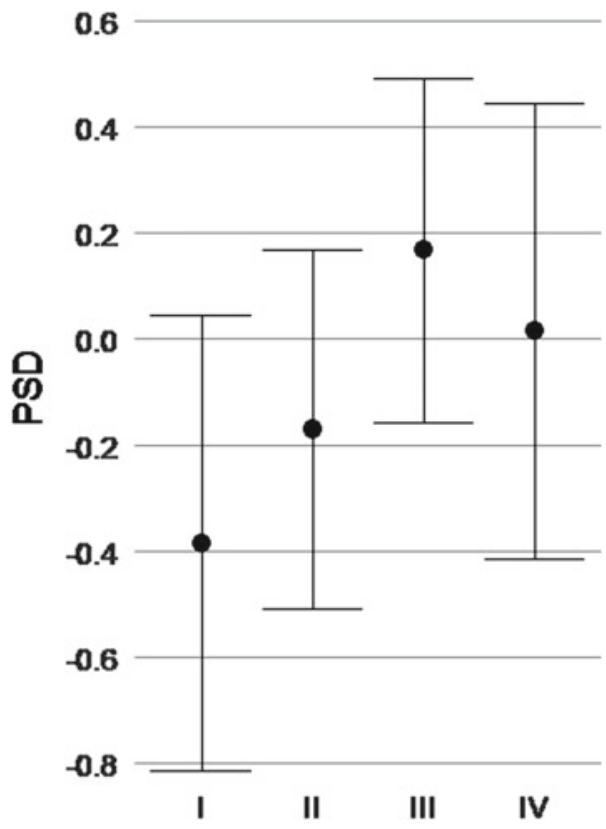

quartile - with practically no social housing - the extent of social disorder is lowest and increases linearly with increasing social housing.

Next, we ran a multilevel model of perceived social disorder with standard controls at both levels. We had to combine the variable on social housing with socio-economic and ethnic indicators due to their high correlations. The predictive power of this latent disadvantage variable — also including social housing - remains significant in the fully adjusted model. Thus, we can say that the multidimensional disadvantage of the estate - covering not only education, income and unemployment, but also ethnic heterogeneity and social housing - strongly differentiates those estates that are socially peaceful from those which are not. There is also a suggestion that this structural dimension matters in terms of local social interaction, but this topic needs more attention in the future.

Another interpretation also emerges: the small housing companies (a single house or block of houses, on average) are institutions through which the owners try to preserve and uphold the value of their greatest single asset, their dwelling. There are strong and straightforward interests that unite owners in a joint effort to achieve local social control in their houses and housing surroundings.

A separate study was conducted on the Facebook groups of the different housing areas in Helsinki. It found that the discussions among the residents of the more prosperous areas were dominated by issues having to do with social disorder and maintaining order. In the poorer housing areas (in which the problems of social disorder are most common) discussions were, surprisingly enough, linked more with swapping, sharing, recycling and cohesion (Autio 2017). Taken together, 
we propose the general hypothesis of a qualitative difference in community life in different housing types, also in the large housing estates, but this is a question that clearly demands further elaboration and research.

\subsection{Conclusion}

We started from the notion that, from an international perspective, Helsinki (and the cities of Espoo and Vantaa) has been an interesting exception in urban policy, especially concerning the development of large housing estates. An attempt has been made to use spatial social mixing (through the mixing of different tenure types) as a universal preventive policy against social disorder and segregation. Our empirical analysis seems to show that the results are mixed, or rather, that it yielded two outcomes: preventive policies seem to work as intended but, despite this, they have not been able to prevent the emergence of segregation.

Analysis of the structural development of the region gives a clear indication as to the inadequacy of the policy; attempts have been made to prevent the social drivers of segregation but, at the same time, the structural drivers have been ignored. As the structure of the public sector is based on the exceptionally strong position of the separate municipalities, problems emerge during a period of marked regional growth, as municipalities have an interest in competing for the working, tax-paying population. The municipalities on the fringes have had an advantage in this competition because of their capability to plan the predominantly detached, non-mixed housing stock, valued by the new middle classes (Vaattovaara and Kortteinen 2003). As the new wealth has moved away to the fringes, the large housing estates have declined socio-economically, and have been enriched ethnically. This differentiation is structurally produced and, as such, beyond the scope of the preventive policies pursued.

The results seem dire: although from the socio-economic perspective the spatial structure of the region is characterised by its mosaic-like pattern (based on social mixing), spatial development of deprivation is characterised by spatial concentrations, i.e. the forming of larger spatial clusters and their spatial expansion. The core areas of deprivation in the region seem to be concentrated in Helsinki and, more specifically, in and around the large housing estates in the eastern districts of Helsinki. This urban macrostructure was born during the 1990s and has prevailed and slowly intensified ever since. It would, therefore, seem that the effectiveness of the policy of spatial social mixing in the region has progressively fallen.

Two phases can be distinguished in this development. Urban differentiation in Helsinki started with a drastic structural change: with a major economic depression and the subsequent upswing, the demand for labour changed and the spatial result was seen in the socio-economic decline of the eastern sub-district of Helsinki. If the interpretation of the second phase in the development holds true, it has socio-political significance. While, given the Finnish system of governance, the housing market supply can be guided by public administration, drivers of demand 
are more difficult to control. The more heavily housing demand is guided culturally, the stronger the argument is for new political initiatives.

A plethora of research has added to the picture of the social changes taking place (Vaattovaara 1998; Vaattovaara and Kortteinen 2003; Rasinkangas 2013) as well as its ethnic dimension (Vilkama 2011), impact on students' learning outcomes and school choices (Bernelius 2013), feelings of insecurity (Kemppainen et al. 2014), prices of flats (Harjunen et al. 2014) and selective migration (Vilkama et al. 2013). In all these studies, the large housing estates in decline stand out as specific problems, starting in the early 1990s.

In Finland, poverty and social exclusion have traditionally been problems of the declining, sparsely populated rural areas. This has changed since the early 1990s, with the new challenges inherent in the rise of new urban poverty, and the growing ethnic heterogeneity. With our tradition of universal, national strategies in social policies we end up with a problem: as a nation, we have virtually no ready-made policies for the new situation. We do not have any tradition of urban or of metropolitan policies (Vartiainen 1998), and-compared to continental western Europe - we have very little experience of neighbourhood-specific initiatives.

Various debates have emerged, and these are reflected in the political initiatives and policy efforts seen in new urban development. Taken together, the emphasis of these efforts has shifted from (1) social initiatives linked to local communities, to (2) attempts at public control of the regional housing markets, to (3) physical reconstruction of the fringes of the large housing estates (new, low-rise construction in the green areas surrounding the old high-rise areas).

In the Helsinki Region - and in Finland as a whole - there is a long tradition of people-oriented initiatives targeting rootlessness, loneliness, alcoholism, antisocial behaviour and illegal drugs, all based on an assumption of improving local community life as being the basic remedy.

The Finnish Ministry of the Environment has launched specific suburban policy programmes for the development of the high-rise suburbs built in the 1960s and 1970s. These programmes began in the 1990s. Big cities and urban regions all have their own suburban developmental programmes, focused strongly on the large housing estates. In addition to Helsinki, the Finnish cities of Tampere, Turku, Jyväskylä and Oulu are involved. The work builds on partnership networks, but - in accordance with its strategy - there is a continuous search for new ideas and initiatives with the aim of also meeting social needs and problems related to low employment rates and population ageing. In addition to the above policy programmes, Finland has participated in the EU's Urban Programme (2000-2006) and with URBACT - in several social, partly neighbourhood-specific policy programmes. These programmes have functioned as an umbrella for many smaller projects, which have often been created in a decidedly local fashion.

Compared to continental Europe, however, we seem to be latecomers in these initiatives and prefer to try to find and adopt the best practices developed elsewhere. In addition, it seems that a fundamental part of these initiatives is essentially oriented towards developing local community life, seeing this as a potential 
remedy. Empirical evidence on the validity of this assumption is yet to be seen, but work continues.

Every 4 years in Finland the most important aspects of policy are concretised in the Government Programme of the Prime Minister. This also concerns housing and metropolitan policies. The attitude of the state towards the growth of the Helsinki metropolitan area has so far been somewhat negative, trying to contain the growth rather than to further encourage it. The current government has, however, launched a Metropolitan Policy Programme to identify solutions to the problems associated with land use, housing and traffic, social exclusion and to promote business and internationalisation. Multiculturalism and bilingualism are also promoted. The current letter-of-intent procedure between central government and the Greater Helsinki Area, and cooperations based on partnerships with the individual administrative sectors, will be reinforced and extended: housing production in the Helsinki region will increase from 12,000 to 13,000 apartments per year.

A characteristic feature in these new partnerships is the ethos and aim of intervening in the functioning of regional housing markets. This ethos is intertwined with the so-called 'municipal reform' by the previous government (which failed) and the attempt at a regional reform the present government (in dire difficulties). One of the aims of these initiatives is to build up bigger, more financially sustainable public units that could better manage regional development. Political tensions and contradictions abound, both nationally and regionally, and both the results and forms of implementation are yet to be seen. The main reason for the continous dispute is the increasing discrepancy with the national ideology of equality and spatial differentiation of resources combined with municipal sovereignty. The sovereignty of the municipalities enshrined in the constitution is a difficult threshold to pass and, in addition, the big cities oppose the idea of a regional administration ruling over them (Alanen 2004; Vaattovaara and Kortteinen 2003). The battle continues in an ongoing crisis where the position of the exisiting Government is seriously challenged.

The urban problems of the large housing estates have, consequently, fallen into the laps of their respective municipalities, which have tried to cope with them as best they can. The city of Helsinki, for instance, has modestly adjusted its housing policy: in 1991 the city administration still stated that 'culturally and ethnically segregated communities must be avoided' (Helsinki Immigrant Policy Proposal 1991, p. 50), but in 1999 , the aim was being reformulated to housing immigrants 'as equally as possible' (Helsinki Integration Policy, 1999, 23, in Vilkama 2006).

No demolitions have so far taken place in the Helsinki Region, excluding one rental high-rise in 2017 in the most stigmatised large housing estate of the region. Nationally, however, this is about to emerge as a major future problem. A significant share of the large housing estates built in the 1960s and 1970s has, at present, a market value that is clearly below the costs of reasonable repair, and, as a result, the small local housing companies have difficulties in procuring loans for these repairs. No solutions have been presented, except demolition.

The overall situation of the large housing estates in the Helsinki Region is better, Helsinki being the main area of growth in Finland. Attempts to counteract the 
decline have during the last ten years centred upon the idea of 'complementary construction'. Densification, support for local services and support for the socio-economic level of a housing area are all among the objectives of the policy, the predominant result of which is building low-rise and dense townhouse-type of housing into the green belt surrounding the old large housing estates. The policy aims at integrating the previously disintegrated urban fabric and, in social characteristics, resembles the mixing policies pursued in continental western Europetrying to redevelop a housing area in decline with new constructions for the middle classes. This is currently the predominant strategy in the Helsinki Region.

In a study focusing on the effects of this policy (Vilkama et al. 2013), we compared three different sites of complementary constructions, all adjacent to large housing estates and all in eastern Helsinki. The results were generally positive but contained a decidedly negative component. International discussions of the theme (Uitermark 2003; Van Beckhoven and Van Kempen 2003; Kruythoff 2003; Kleinhans 2004) seem to attach importance to the assumed social networks that are to emerge between the new and the old residents-which tend unfortunately to exhibit rather depressing outcomes. This perspective, however, overlooks the positive effect of complementary construction on the local services. In this respect, the results of the complementary construction projects were, according to our data, quite positive. The differences in the composition of the old and the new residents were, in our study, not big enough to cause the newcomers to avoid using the local services, which, as a result, gained new strength. The newcomers did, however, concentrate their living in their own micro-area within the wider neighbourhood, with very few links farther afield. To them, however, this was not a problem, but the solution: this was how they could create their own specific neighbourhood which they could safely control, in which they could settle down and feel well. On the other hand, this easily leads to the emergence of sharply demarcated, micro-geographic structures of segregation within the confines of the neighbourhood, with old and new residents both inhabiting their own areas. When this happens, one of the main aims of the legacy of the time when housing estates were built remains unfulfilled: in such a setting people do not mix, but live different realities, with very few links between them. As long as some links remain, and the local middle classes remain strong, the original objective of social order might, however, be furthered, even without local social bridging.

Taken as a whole, and compared to western Europe, the Helsinki Region seems to be a latecomer both to the decline of the large housing estates and in the remedial policies. There is a strong legacy of urban policies based on spatial social mixing. However, according to the analysis presented above, the recent decline in the large housing estates is due to reasons beyond the control of policy: structural changes in the demand for labour, socio-economic decline and migration have created a platform for the emergence local social drivers of segregation. In other words, the policy has proved inefficient and insufficient.

In addition, public discussion around this is quite difficult, partly due to the strength of the legacy of the time when housing estates were built. Questioning the traditional definitions of the common good (such as how, where and for whom the 
policy should be pursued to achieve its objectives), the discussion inevitably turns into either public moral outrage (to defend the egalitarian ethos) or professional silence-producing very little or nothing. The monopoly in the planning apparatus together with the legacy defining the public taboos are obstacles in the search for new initiatives.

Acknowledgements The authors express thanks to the Academy of Finland, Helsinki Metropolitan Region Urban Research Program.

\section{References}

Alanen JP (2004) Ihmisten arki ei tunne hallinnon rajoja-yhteistyöllä Helsingin seutu menestykseen. Sisäasiainministeriön julkaisuja, vol 13. Sisäasiainministeriö, Helsinki

Autio M (2017) Koheesio ja kontrolli. Helsingin kaupunginosat Facebookissa. University of Helsinki, Helsinki

Bernelius V (2013) Eriytyvät kaupunkikoulut. Helsingin peruskoulujen oppilaspohjan erot, perheiden kouluvalinnat ja oppimistuloksiin liittyvät aluevaikutukset osana kaupungin eri-ytymiskehitystä. Tutkimuksia, vol 1. Helsingin kaupungin tietokeskus, Helsinki

Hankonen J (1994) Lähiöt ja tehokkuuden yhteiskunta. Otatieto Oy \& Gaude-amus, Tampere

Harjunen O, Kortelainen M, Saarimaa T (2014) Best education money can buy? capitalization of school quality in Finland. Valtion taloudellinen tutki-muskeskus. Edita Prima Oy, Helsinki

Joutsiniemi A (2006) Ei-kenenkään Helsinki-Raportti esikaupungista 2005. Tampereen teknillinen yliopisto, Yhdyskuntasuunnittelun laitos, Tampere

Kemppainen T (2017) Disorder and insecurity in a residential context: a study focusing on Finnish suburban housing estates built in the 1960s and 1970s. Helsingin kaupunki, Helsinki

Kemppainen T, Kortteinen M (forthcoming) Tenure structure and local social life. In: A multi-level study on threshold effects

Kemppainen T, Lönnqvist H, Tuominen M (2014) Turvattomuus ei jakaudu tasan. Mitkä asuinalueen piirteet selittävät helsinkiläisten kokemaa tur-vattomuutta? Yhteiskuntapolitiikka Y79 (1):5-20

Kivinen O (1959) Hämeenlinnan Yleiskaava 1957. Suomalaisen kirjallisuuden kirjapaino, Helsinki

Kleinhans R (2004) Social implications of housing diversification in urban renewal: a review of recent literature. J Housing Built Environ 19:367-390

Kortteinen M, Tuominen M, Vaattovaara M (2001) Helsingin sosiaalimaantieteellinen rakenne ja pahoinpitelyrikollisuus. Yhteiskuntapolitiikka 66(4):318-328

Kruythoff H (2003) Dutch urban restructuring policy in action against socio-spatial segregation: sense or nonsense? Eur J Housing Policy 3(2):193-215

Lönnqvist H, Vaattovaara M (2004) Asuntojen hintojen kehitys pääkau-punkiseudulla: Mitä asuntojen hinnat kertovat kaupungin ajallisesta ja alueellis-esta kehityksestä. Helsingin kaupungin tietokeskus, Helsinki

Meurman OI (1947) Asemakaavaoppi. Otava, Helsinki

Perry C (1929) The neighborhood unit, a scheme of arrangement for the family-life community. Regional survey of New York and its environs, vol 7. Committee on the Regional Plan of New York and Its Environs, New York, pp 2-140

Puustinen S (2006) Suomalainen kaavoittajaprofessio ja suunnittelun kommu-nikatiivinen käänne. Vuorovaikutukseen liittyvät ongelmat ja mahdollisuudet suurten kaupunkien kaavoittajien näkökulmasta. Yhdyskuntasuunnittelun tutki-mus- ja koulutuskeskuksen julkaisuja A 34. Helsinki University of Technology, Espoo 
Rasinkangas J (2013) Sosiaalinen eriytyminen Turun kaupunkiseudulla. Tutkimus asumisen alueellisista muutoksista ja asumispreferensseistä. In, vol Tutkimuksia A 43. Siirtolaisuusinstituutti, Turku,

Schulman H (2000) Helsingin suunnittelu ja rakentuminen. In: Schulman H, Pulma P, Aalto S (eds) Helsingin historia vuodesta 1945. Edita, Helsinki, pp 13-107

Stein CS (1942) City patterns - past and future. New Pencil Points 23:52-56

Uitermark J (2003) 'Social mixing' and the management of disadvantaged neighbourhoods: the Dutch policy of urban restructuring revisited. Urban Stud 40(3):531-549

Vaattovaara M (1998) Pääkaupunkiseudun sosiaalinen erilaistuminen. Tutkimuksia, Helsingin kaupungin tietokeskus, Helsinki, p 7

Vaattovaara M, Kortteinen M (2003) Beyond polarisation versus professional-isation? a case study of the development of the Helsinki region, Finland. Urban Stud 40(11):2127-2145

Van Beckhoven E, Van Kempen R (2003) Social effects of urban re-structuring: a case study in Amsterdam and Utrecht, The Netherlands. Housing Studies 18(6):853-875

Vartiainen P (1998) Suomalaisen aluepolitiikan kehitysvaiheita. Aluekehit-ysosaston julkaisu 6/ 1998. Sisäasiainministeriö, Helsinki

Vilkama K (2006) Asuntopolitiikka ja vieraskielisen väestön alueellinen keskittyminen Helsingissä vuosina 1992-2005. Helsingin yliopiston maantieteen laitos, Helsinki

Vilkama K (2011) Yhteinen kaupunki, eriytyvät kaupunginosat? Kantaväestön ja maahanmuuttajataustastaisten asukkaiden alueellinen eriytyminen ja muut-toliike pääkaupunkiseudulla. Helsingin kaupungin tietokeskus, Helsinki

Vilkama K, Vaattovaara M, Dhalmann H (2013) Kantaväestön pakoa? Miksi maahanmuuttajakeskittymistä muutetaan pois? Yhteiskuntapolitiikka 78(5):485-497

Open Access This chapter is licensed under the terms of the Creative Commons Attribution 4.0 International License (http://creativecommons.org/licenses/by/4.0/), which permits use, sharing, adaptation, distribution and reproduction in any medium or format, as long as you give appropriate credit to the original author(s) and the source, provide a link to the Creative Commons license and indicate if changes were made.

The images or other third party material in this chapter are included in the chapter's Creative Commons license, unless indicated otherwise in a credit line to the material. If material is not included in the chapter's Creative Commons license and your intended use is not permitted by statutory regulation or exceeds the permitted use, you will need to obtain permission directly from the copyright holder. 


\title{
Chapter 11 \\ The Diversity of Trajectories of Large Housing Estates in Madrid, Spain
}

\author{
Pedro Uceda, Daniel Sorando and Jesús Leal
}

\begin{abstract}
Public and private housing developments between 1940 and 1990 shaped the City of Madrid by differentiating urban area types according to social composition, location and development type. Spanish housing policies over these decades fostered public housing stock that, unlike in European cities, ended up being transformed into owned rather than rented homes; closely linking certain disadvantaged groups to the most vulnerable areas of the city. In this chapter, current processes of physical and social vulnerability are analysed using data from the 2001 and 2011 Population and Housing Censuses using a multivariate analysis. Our analysis differentiates between two stages of social housing estates in Madrid (under Francoism and in the democratic period) and private housing developments. These analyses show significant differences both in the trajectories of each of the types analysed in relation to contemporary vulnerability processes, as well as in the composition of the population that resides in them. Lastly, we examine challenges and proposals for the future of these urban areas, considering their social composition and the urban policies that seek to rebalance Madrid's neighbourhoods and paying attention to the insertion of the immigrant population into the most vulnerable neighbourhoods of the city.
\end{abstract}

Keywords Social housing - Large housing estates - Urban vulnerability Madrid • Urban policy

\footnotetext{
P. Uceda $\cdot$ D. Sorando $(\bowtie) \cdot$ J. Leal

Universidad Complutense de Madrid, Madrid, Spain

e-mail: dsorando@ucm.es

P. Uceda

e-mail: puceda@ucm.es

J. Leal

e-mail: jleal@cps.ucm.es

D. B. Hess et al. (eds.), Housing Estates in Europe, The Urban Book Series, https://doi.org/10.1007/978-3-319-92813-5_11
} 


\subsection{Introduction}

Large housing estates built after WWII come from diverse origins and have developed through different trajectories, and this contradicts their representation as spaces that have always been disadvantaged. Half a century after their construction, many of these developments pose no relevant problems and are integrated into residential markets as viable options for all types of residents. However, many others have become stigmatised urban spaces, which are discursively linked to the accumulation of a whole series of social, economic and physical problems (Hall et al. 2005). The reasons these large housing estates have followed divergent trajectories have long been the focal point of important debates in contemporary urban studies, giving rise to complementary theories about their recent evolution (van Kempen et al. 2005b; Rowlands and Murie 2009).

In this debate, the Spanish case presents characteristic specificities that necessitate the systematic study of the evolution of its large housing estates. Particularly important among these specificities is the institutional context in which this type of housing was produced: a totalitarian regime (1939-1978) followed by a transition to the current democracy. In this context, the City of Madrid constitutes a paradigmatic case for the production and transformation of these large housing estates, because of the large volume of housing developments initiated there after the civil war. These developments were a reaction to the demand for housing by a growing work force who were looking for new opportunities in the capital and that, in its first settlement, were often crammed into squatter settlements on the city's periphery (Tatjer 2005).

Madrid is a relevant case study to research the trajectories of its large housing estates within a context of increasing urban and social vulnerability (fueled by its huge socioeconomic crisis and impressive international immigration). With this aim, we will focus on how these large housing estates have been diversely affected by these processes depending on three factors: their initial characteristics (private or public development), the existence (or not) of the neighbourhoods' processes of social mobilisation and the institutional context (totalitarian or democratic) in which they were developed. Previous research, such as the RESTATE project, focuses on the study of urban policies in the case of two neighbourhoods in Madrid. Following this line of research, this chapter expands the number of neighbourhoods analysed and proposes a quantitative analysis to know its evolution between 1991 and 2011. First, to this end, the production of public and private large housing estates built in the city of Madrid between 1940s and 1990s is contextualised within the framework of the evolution of housing policies in Spain. Next, we present the data and methods used to analyse the different social and residential trajectories of these large housing estates from 1991 to 2011 . We introduce the Urban Vulnerability Index to measure the socio-residential deterioration of these large housing estates. Third, connections are drawn between the trajectories of these large housing estates and the large housing estates characteristics that might explain their diverse types of evolution. In the last section, we reflect on the challenges faced by these large housing estates in 
contemporary Madrid society which is characterised by social polarisation, cultural heterogeneity, and the mutation of public policies that significantly differentiate it from the context in which these large housing estates were produced.

\subsection{0-1990: Fifty Years Evolution in Urban Policy and Resident Populations in Madrid}

When it comes to understanding the processes involved in both public and private housing development, a differentiation must be made between the two periods which so significantly shaped transformations in the built environment of Madrid: the Francoist period (1939-1978) and the current democracy.

In the 1940s, in the wake of a devastating civil war, people began to think about the restoration of urban space in Madrid. A General Urban Development Plan was created in 1944, the main objective of which was to regulate land use in Madrid and the surrounding cities. Private investment in multiple privatised public plots was often the means through which an increase in the housing production was achieved, alongside land expropriation where the land subdivision process was to be blocked by land owners (Lopez de Lucio et al. 2016). These measures meant that land was reserved to produce accessible public housing as well as to promote private investment, which benefitted from central locations and higher quality residences in terms of size and construction materials than public developments (Lopez de Lucio et al. 2016).

Throughout the 1950s and 1960s, urban policy developments were influenced by certain noteworthy socioeconomic processes taking place in Madrid. Madrid's slowly evolving industrialisation attracted rural populations from around the country and led to the growth of suburbs surrounding Madrid, based among squatter settlements built by the newly arrived population. These suburban places evolved from rural nuclei to becoming new districts of the city of Madrid, and thus increased the area and population of the municipality (see Fig. 11.1).

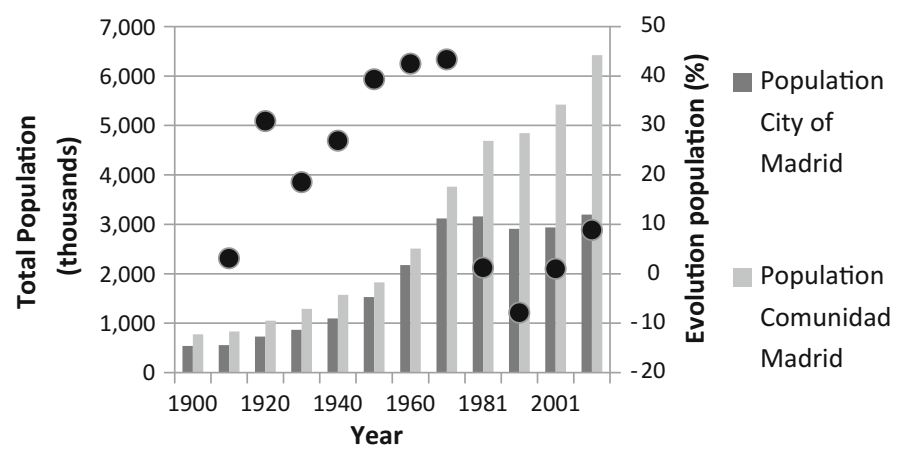

Fig. 11.1 Transformations in the population of the city of Madrid and the Comunidad de Madrid 1900-2011. Source INE (National Statistics Institute), Municipal alterations in Population Censuses from 1842 
To solve problems like the housing scarcity and housing shortages of the post-war period, in 1957 the Social Urgency Plan was implemented, which aimed to put an end to the problem created by these new settlements. Towards this end, various public policy intervention categories were created: poblados de absorción (absorption settlements), poblados mínimos (minimal settlements), poblados dirigidos (guided settlements), poblados de gestión social (social urbanistic management settlements), new urban planning zones and absorption neighbourhood units. Overall, this involved a total of 66 interventions and around 100,000 homes whose purpose was to put a stop to the informal growth of the city and increase police control over internal migration from the rest of Spain into Madrid and its informal settlements (Sambricio 1999; López Díaz 2002).

Figure 11.2 demonstrates residential behaviour patterns in the decades of extreme growth in the city of Madrid, with increases of over $300 \%$ in peripheral areas over a period of only 15 years. This growth is largely made up of unskilled populations, in contrast to the populations which appear in the analysis of the city centre and expansion districts. These areas also grew rapidly at this time, but the population contingent was different: the new middle classes and goods and service industry workers were concentrated in expansion districts; while the working population resided in central areas alongside more skilled households.

Over the years of development, 1960s to 1970s, an explosion in land rezoning beyond the Master Plans occurred. This was in response to pressure from landowners and the large construction and real estate companies of the Francoist oligarchy. This drive was based on the struggle for capital gains and concessions in what can be considered the first wave of reckless town planning in Spain. This period saw an intensification of real estate development along Spanish coasts and a boom of migration from the countryside to the city (Naredo 2010). In this context, the scope of the 1963 General Urban Development Plan went beyond the limits of the municipality to incorporate the metropolitan area. According to Caprarella and Hernández (2008), the province of Madrid grew by more than one and a half million inhabitants between 1962 and 1975. Of this growth, nearly one million people were immigrants from rural Spain constituting an actual annual growth rate

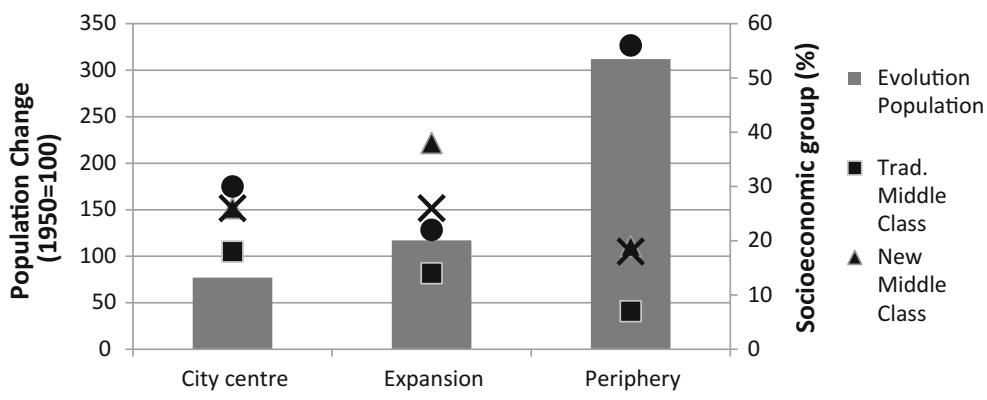

Fig. 11.2 Population change according to socioeconomic condition and urban area of residence, 1950-1965. Data source 1967 FOESSA report 
of $4 \%$, rather than the $2.5 \%$ that had been estimated in the 1963 General Plan (Molinero and Ysas 1998 in Caprarella and Hernández 2008).

This urban development process can be summarised in the words of the very first minister of the Francoist Ministry of Housing, José Luis Arrese, who laid out the real estate model not only of that time but also for its future designs, when he said: 'We do not want a Spain of proletarians but of property owners.' Effectively, the relative importance held by renters in public housing developments shifted towards deferred access to property (involving periods of 20-50 years and based on very favourable monthly payments for aspiring owners). Similarly, the few rental houses built by public agencies and other entities were sold to tenants over the 1960s, with the support of the 1960 Horizontal Property Act (Tatjer 2005). From then on, a formative period in Spanish housing policy began, the purpose of which turned out to be paving the way for private investment in Spanish cities (Vinuesa et al. 2009).

From the end of the 1970s onwards, this urban development process became the cornerstone of local policy in the first stage of democracy (1978-1990). This is due to concerns raised in political and social settings about the urban problems inherited from the previous era: infrastructure, services and equipment deficits, as well as excess population density and the environmental deterioration linked to the mismanaged internal migration process (Ortiz 2006; Terán and Sánchez de Madariaga 1999). The arrival of democratic councils also prompted changes in decision-making processes for urban policies, where a key role was played by the different neighbourhood associations that had ended up integrating themselves into political life based on their militancy in leftist parties like the Communist Party of Spain, thanks to the tremendously effective social mobilisation of that time.

In short, with the arrival of the democratic city councils after the 1979 local elections, three main public policies were created in terms of housing and urban development: (1) the protection of heritage, (2) the eradication of chabolas (large squatter settlements) in the city and (3) the remodelling of neighbourhoods built under public policies in the 1950s and 1960s, which, due to their low quality, had very serious shortfalls (Ortiz 2006). In Madrid (1975-1990) 29 interventions to eradicate chabolas and remodel neighbourhoods took place, which led to the creation of 38,000 housing units, largely in the city's most disadvantaged peripheries in which the role of neighbourhood movements was key for the realisation of these works (Villasante et al. 1989).

The Neighbourhood Remodeling Plan was the Ministry of Public Works' response to loud and persistent demands from residents which, in the mid-1970s, with the assistance of left-wing political parties, lead to demonstrations, gatherings and people's assemblies. This response came when the central government was very weak politically, due to an economic crisis, and the aim of the plan was twofold: to avoid the political cost that the continuous neighbourhood demonstrations entailed and to boost a construction sector in crisis (Vinuesa 2002; Morán and Aja 2006). The most important aspects of this plan were the requirements for the population to be rehoused in the neighbourhood of origin, for the property regime of the homes affected to remain the same and for special models for housing finance 
and compensation updates. In this way, the original population composition of these neighbourhoods was respected.

Today, these large housing estates have followed diverse trajectories within a wider context of increasing urban vulnerability. This is due to the differing exposure of these large housing estates to both the ongoing socioeconomic crisis and the inflow of many impoverished international immigrants into the city of Madrid. Through this lens, we systematically analyse how these large housing estates have been diversely affected by these processes since the 1990s, when the Neighbourhood Remodeling Plan came to an end.

\subsection{Data and Methods}

The first criterion under which large housing estates were selected for analysis relates to their classification into the three most prominent housing development models adopted in Madrid over the period of study: the first public interventions of the Francoist period undertaken from 1940 to 1975, private housing developments from 1945 to 1985 and the Neighbourhood Remodeling Plan from 1975 to 1990. These three initiatives accounted for a total of 246 interventions and 323,000 homes in the city of Madrid between 1940 and 1990 (Lopez de Lucio et al. 2016).

The selection of large housing estates from each of these three housing development types was restricted to those developments that included at least 1,000 homes. We attempted to cover diverse types of public housing development from the Francoist period with regard to construction, size and designs available and selected those developments of larger scope from the Neighbourhood Remodeling Plan. Among private housing developments, 11 large housing estates were selected, and include both social housing and non-social housing and constructions from the four decades studied in diverse type and form of buildings as defined in the Urbanism and Urban Design Guide by López de Lucio et al. (2016). Table 11.1 shows the relative importance and distribution of the 29 chosen large housing estates in each of the three types of development, which cover about half the homes built in this period $(44.8 \%)$.

The typical large housing estates consist of a series of free standing buildings with at least four storeys of apartments, superblocks and free access open spaces between buildings. These large housing estates are located in dense neighbourhoods with an important fabric of local commerce as well as sufficient public facilities. Also, they are close to large green spaces, which are often poorly maintained. These large housing estates are next to the main ring roads of the city and also have access to the system of public buses, although they are unevenly connected to the subway system (Figs. 11.3 and 11.4). Finally, and unlike most of the previous large housing estates, in the Neighbourhood Remodeling Plan, there was a clear interest to configure streets or avenues that produce recognisable urban spaces (Fig. 11.5).

The characterisation of the selected large housing estates recent trajectories was established using two complementary approaches. First, we have used an index 
Table 11.1 Distribution of interventions and housing by type of housing development

\begin{tabular}{|c|c|c|c|c|c|}
\hline \multirow[t]{2}{*}{$\begin{array}{l}\text { Type of } \\
\text { development }\end{array}$} & \multicolumn{2}{|c|}{$\begin{array}{l}\text { Total large housing } \\
\text { estates }\end{array}$} & \multicolumn{3}{|c|}{ Analysed large housing estates } \\
\hline & $\begin{array}{l}\text { Large } \\
\text { housing } \\
\text { estates }\end{array}$ & Dwellings & $\begin{array}{l}\text { Large } \\
\text { housing } \\
\text { estates }\end{array}$ & Dwellings & $\begin{array}{l}\% \text { of type } \\
\text { development }\end{array}$ \\
\hline \multirow{2}{*}{$\begin{array}{l}\text { Public development } \\
\text { 1940-1975 }\end{array}$} & \multirow[t]{2}{*}{110} & 106,000 & \multirow[t]{2}{*}{11} & 36,486 & \multirow[t]{2}{*}{34.4} \\
\hline & & $(32.8 \%)$ & & $(25.2 \%)$ & \\
\hline \multirow{2}{*}{$\begin{array}{l}\text { Private development } \\
1945-1985\end{array}$} & \multirow[t]{2}{*}{107} & 179,000 & \multirow[t]{2}{*}{11} & 77,066 & \multirow[t]{2}{*}{43} \\
\hline & & $(55.4 \%)$ & & $(53.2 \%)$ & \\
\hline \multirow{2}{*}{$\begin{array}{l}\text { Neighbourhood } \\
\text { remodelling plan } \\
1975-1990\end{array}$} & \multirow[t]{2}{*}{29} & 38,000 & \multirow[t]{2}{*}{7} & 31,274 & \multirow[t]{2}{*}{82.3} \\
\hline & & $(11.8 \%)$ & & $(21.6 \%)$ & \\
\hline \multirow[t]{2}{*}{ Total } & \multirow[t]{2}{*}{246} & 323,000 & \multirow[t]{2}{*}{29} & 144,826 & \multirow[t]{2}{*}{44.8} \\
\hline & & $(100 \%)$ & & $(100 \%)$ & \\
\hline
\end{tabular}

Source López de Lucio et al. 2016

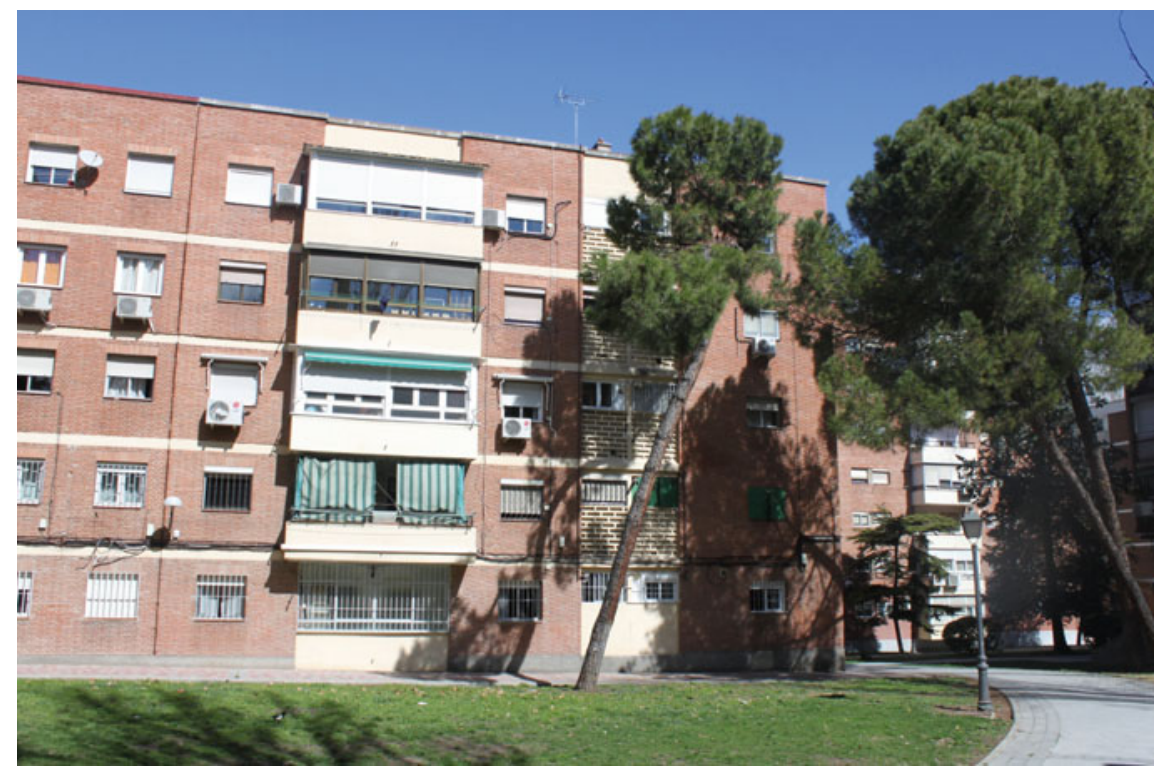

Fig. 11.3 Grupo Marcelo Usera, a large public housing estate. Source Daniel Sorando, March, 2018

establishing an urban vulnerability value for each neighbourhood in which the analysed large housing estates are located. Specifically, we have used the Urban Vulnerability Index (Uceda 2016). This index has been applied as the main dependent variable to understand the current degree of socio-residential 


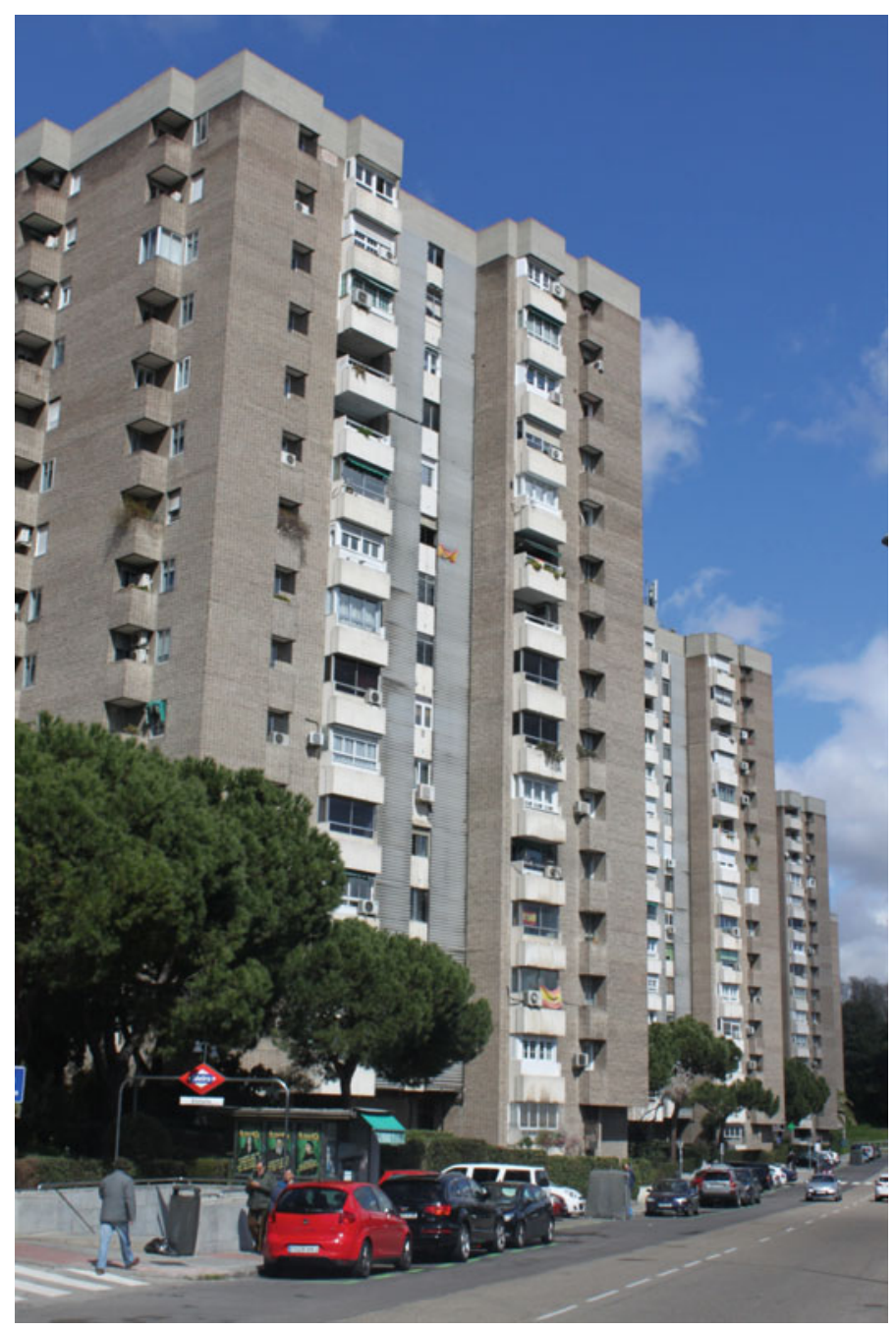

Fig. 11.4 Barrio de la Estrella, a private large housing estate. Source Daniel Sorando, March, 2018

deterioration for this type of large housing estate. This index is based on factorial principal components analysis (PCA), which synthesises the information contained among five variables related to urban vulnerability; the percentage of economic immigrants, the unemployment rate, the population lacking education, the number of houses in poor states and dwellings without heating, into a single factor that represents the latent dimension of said phenomenon. Second, to classify the resident population within the large housing estates under study, socio-demographic variables are included, like the percentage born abroad (in the absence of statistical 


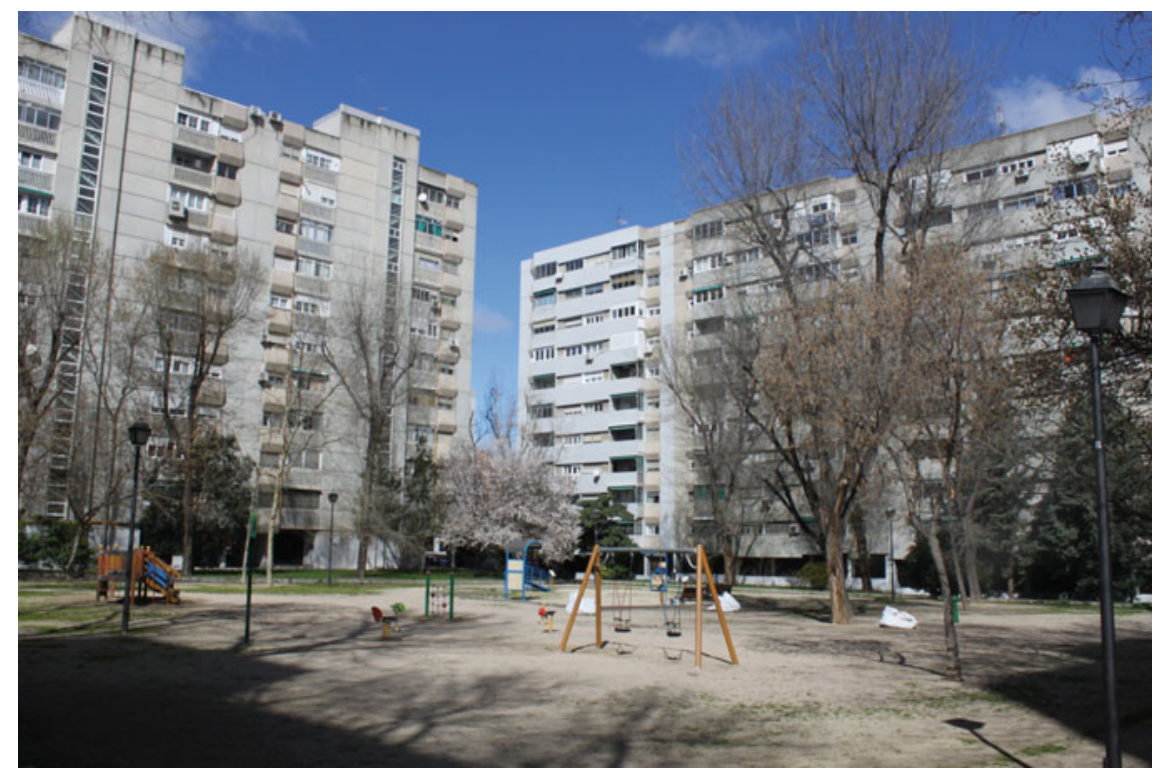

Fig. 11.5 Poblado Dirigido de Orcasitas, a remodelled large housing estate. Source Daniel Sorando, March, 2018

information on the most stigmatised ethnic minority in Spanish cities, which is the Roma population), the rate of unemployment and the percentage of the diverse types of housing tenure system (property, rent, assignment, etc.) This information was obtained from the large housing estates under studies census tracts from 1991, 2001 and 2011, and the aim in obtaining it was to discern the evolution of their trajectories over recent decades.

The independent variables included were those relating to the type of housing development (public from the Francoist phase, private, and from the neighbourhood remodelling phase), the decade of construction and the central or peripheral location of each large housing estates. Location is extremely important in the case of the city of Madrid, given the great inequality between central districts and the inner metropolitan ring (Leal and Sorando 2016; Uceda 2016).

\subsection{Types of Social Change in Large Housing Estates in Madrid (1991-2001)}

Regarding social composition, the large housing estates analysed follow four different trajectories from 1991 to 2001. Table 11.2 shows the average value for the complexes included in each of these trajectories for each of the main components shaping their evolution, the percentage of the population born abroad and the 
unemployment rate and the main housing tenure arrangement. Each large housing estate is classified based on the values held by said components, according to the importance given to them in the literature on this neighbourhood type (Hall et al. 2005)

Table 11.3 classifies the large housing estates into trajectory type and shows the evolution of its Urban Vulnerability Index. The first type of trajectory is composed of large housing estates whose Urban Vulnerability Index values remain below average in 2001 and 2011 (meaning that these large housing estates are privileged). These large housing estates were built from the 1940s and 1950s onward, largely in private housing developments located in the city centre (including the only two public developments classified within this type.) These are the social spaces of a native population with high socioeconomic status, and despite being the place of

Table 11.2 Characteristics of large housing estates by trajectory type

\begin{tabular}{|c|c|c|c|c|c|c|}
\hline \multirow[t]{2}{*}{ Variables } & \multicolumn{5}{|c|}{ Trajectory Type } & \multirow[t]{2}{*}{ Madrid } \\
\hline & 1 & 2 & 3 & 4 & Total & \\
\hline \multirow{2}{*}{$\begin{array}{l}\text { Number of dwellings } \\
(2011)\end{array}$} & 31,150 & 31,496 & 73,860 & 8,320 & 144,826 & $1,320.530$ \\
\hline & $21.5 \%$ & $21.7 \%$ & $51.0 \%$ & $5.7 \%$ & $100.0 \%$ & \\
\hline \multicolumn{6}{|l|}{ Development type: } & \\
\hline - Private & 8 & 1 & 2 & 0 & 11 & \\
\hline - Public & 2 & 7 & 5 & 4 & 18 & \\
\hline \multicolumn{6}{|l|}{ Location: } & \\
\hline - Central & 9 & 0 & 1 & 0 & 10 & \\
\hline - Peripheral & 1 & 8 & 6 & 4 & 19 & \\
\hline \multicolumn{6}{|l|}{ Decade of origin: } & \\
\hline • 1940 & 4 & 0 & 0 & 1 & 5 & \\
\hline - 1950 & 4 & 1 & 4 & 3 & 12 & \\
\hline - 1960 & 1 & 1 & 2 & 0 & 4 & \\
\hline • 1970 & 1 & 5 & 1 & 0 & 7 & \\
\hline • 1980 & 0 & 1 & 0 & 0 & 1 & \\
\hline \multicolumn{7}{|l|}{ \% born abroad $(\%)$ : } \\
\hline • 1991 & 3.1 & 1.1 & 1.9 & 1.3 & 2.0 & 2.8 \\
\hline • 2001 & 6.2 & 3.6 & 7.6 & 9.6 & 6.4 & 9.7 \\
\hline • 2011 & 9.0 & 11.0 & 17.1 & 28.5 & 14.6 & 16.5 \\
\hline \multicolumn{7}{|c|}{ Unemployment rate (\%): } \\
\hline • 1991 & 11.9 & 14.9 & 14.8 & 16.2 & 14.1 & 14.3 \\
\hline • 2001 & 10.8 & 16.7 & 13.6 & 13.1 & 13.7 & 12.4 \\
\hline • 2011 & 16.7 & 29.9 & 25.4 & 33.4 & 25.0 & 21.5 \\
\hline \multicolumn{7}{|l|}{ \& of rental units $(\%)$ : } \\
\hline • 1991 & 17.6 & 8.1 & 10.4 & 5.0 & 11.3 & 19.2 \\
\hline • 2001 & 12.2 & 7.6 & 10.9 & 7.8 & 10.2 & 16.5 \\
\hline • 2011 & 12.7 & 8.8 & 16.2 & 17.1 & 13.9 & 20.0 \\
\hline
\end{tabular}

Source Compiled by the authors based on the Population Censuses of 1991, 2001, and 2011 (INE) 
Table 11.3 Urban vulnerability index for large housing estates by trajectory type

\begin{tabular}{|c|c|c|c|c|c|c|c|}
\hline \multirow[t]{2}{*}{ Type } & \multirow{2}{*}{$\begin{array}{l}\text { Large } \\
\text { housing } \\
\text { estate }\end{array}$} & \multirow[t]{2}{*}{ Development } & \multirow[t]{2}{*}{ Origin } & \multirow{2}{*}{$\begin{array}{l}\text { Large housing estate } \\
\text { name }\end{array}$} & \multicolumn{3}{|l|}{ IVU } \\
\hline & & & & & 2001 & 2011 & Change \\
\hline \multirow[t]{10}{*}{1} & 1 & Private & $1947-75$ & $\begin{array}{l}\text { Colonia de la } \\
\text { Comisaría }\end{array}$ & -1.2 & -1.1 & 0.1 \\
\hline & 2 & Private & $1947-59$ & Barrio del Niño Jesús & -1.4 & -1.5 & -0.2 \\
\hline & 3 & Private & $1953-79$ & Sector Santamarca & -1.2 & -1.5 & -0.3 \\
\hline & 4 & Private & $1951-69$ & Barrio de la Estrella & -1.4 & -1.5 & -0.1 \\
\hline & 5 & Private & $1956-70$ & $\begin{array}{l}\text { Parque de las } \\
\text { Avenidas }\end{array}$ & -1.6 & -1.3 & 0.4 \\
\hline & 6 & Private & 1973-80 & $\begin{array}{l}\text { Grupo Parque de } \\
\text { Roma }\end{array}$ & -1.4 & -1.4 & 0.0 \\
\hline & 7 & Private & $1948-58$ & $\begin{array}{l}\text { Barrio de la } \\
\text { Concepción }\end{array}$ & -0.7 & -0.5 & 0.2 \\
\hline & 8 & Private & $1964-87$ & Ciudad de los Poetas & -0.8 & -0.5 & 0.3 \\
\hline & 9 & Public & $1942-56$ & $\begin{array}{l}\text { Colonia Virgen del } \\
\text { Pilar }\end{array}$ & -0.6 & -0.8 & -0.2 \\
\hline & 10 & Public & $1955-65$ & $\begin{array}{l}\text { San Antonio de la } \\
\text { Florida }\end{array}$ & -1.0 & -1.2 & -0.2 \\
\hline \multirow[t]{8}{*}{2} & 11 & Private & $1968-81$ & CR Santa Eugenia & -1.1 & -0.9 & 0.1 \\
\hline & 12 & Public & $1956-63$ & Barrio de Entrevías & 1.7 & 1.2 & -0.5 \\
\hline & 13 & Public & $1976-85$ & $\begin{array}{l}\text { Remodelación PD } \\
\text { Orcasitas }\end{array}$ & -0.1 & -0.4 & -0.3 \\
\hline & 14 & Public & 1973-83 & Meseta de Orcasitas & 0.1 & -0.1 & -0.2 \\
\hline & 15 & Public & $1976-85$ & Barrio de Orcasur & 1.3 & 0.7 & -0.7 \\
\hline & 16 & Public & 1979-82 & Cornisa de Orcasitas & 1.3 & 0.8 & -0.4 \\
\hline & 17 & Public & $1976-86$ & \begin{tabular}{|l|} 
Pozo del Tío \\
Raimundo
\end{tabular} & 1.4 & 0.6 & -0.8 \\
\hline & 18 & Public & $1981-88$ & Palomeras Norte & 1.8 & 0.6 & -1.2 \\
\hline \multirow[t]{7}{*}{3} & 19 & Private & 1960-79 & Ciudad Parque Aluche & -0.1 & 0.1 & 0.2 \\
\hline & 20 & Private & $1960-78$ & Barrio del Pilar & 0.6 & 0.4 & -0.1 \\
\hline & 21 & Public & $1957-60$ & $\begin{array}{l}\text { Poblado Dirigido de } \\
\text { Fuencarral }\end{array}$ & 0.4 & -0.1 & -0.5 \\
\hline & 22 & Public & $1951-59$ & Gran San Blas & 1.8 & 2.1 & 0.2 \\
\hline & 23 & Public & $1957-69$ & $\begin{array}{l}\text { Poblado Dirigido de } \\
\text { Caño Roto }\end{array}$ & 1.5 & 1.8 & 0.3 \\
\hline & 24 & Public & $1958-62$ & $\begin{array}{l}\text { Grupo Virgen de } \\
\text { Loyola }\end{array}$ & 0.2 & 0.2 & 0.1 \\
\hline & 25 & Public & 1970-93 & Palomeras Sureste & 0.4 & 0.4 & 0.0 \\
\hline \multirow[t]{4}{*}{4} & 26 & Public & $1955-60$ & Grupo Marcelo Usera & 0.4 & 1.5 & 1.0 \\
\hline & 27 & Public & $1957-67$ & \begin{tabular}{|l} 
Pob. Absorción \\
Virgen Begoña
\end{tabular} & -0.3 & 0.7 & 0.9 \\
\hline & 28 & Public & $1958-73$ & $\begin{array}{l}\text { Poblado Dirigido de } \\
\text { Almendrales }\end{array}$ & 0.9 & 0.0 & -0.9 \\
\hline & 29 & Public & 1949-67 & $\begin{array}{l}\text { Colonia San Vicente } \\
\text { Paúl }\end{array}$ & 0.1 & 0.7 & 0.6 \\
\hline
\end{tabular}

Source Compiled by the authors based on the Population Censuses of 2001 and 2011 (INE) 
settlement for some of the first foreign immigrants (both in 2001 and again in 2011), the foreign immigrant population is shown to be remarkably underrepresented. Similarly, the unemployment rate was systematically lower than that of the rest of Madrid for the duration of the period studied (1991-2011). Thus, the social composition of these neighbourhoods stems from the maintenance of their privileged position in the residential market at the time of their construction, as well as from the rather restrictive criteria imposed on free market access that have facilitated the maintenance of socially privileged and homogeneous neighbourhoods. Essentially, these are privately developed large housing estates which retain a privileged position in terms of urban vulnerability.

The second type of trajectory is formed of large housing estates, which, starting from an elevated situation of urban vulnerability in 2001, improve relative position due to the good conditions of the homes, although their urban vulnerability values are still above the city average. The large housing estates included in this trajectory are the result of the Neighbourhood Remodeling Plan and are in the urban periphery. They replaced the old chabolas and are appalling public housing developments built in the first decades of the Francoist period. The ethnic homogeneity of the resident populations of these large housing estates is striking as the foreign immigrant population is significantly underrepresented throughout the period studied (1991-2011). The low percentage of rental housing throughout the period explains the absence of the immigrant population, given that this is their main way of accessing housing in Madrid (of people born abroad $60.1 \%$ resided in rented homes in 2011 while for the population born in Spain the figure is at 12.9\%). Overall, the native resident population in these neighbourhoods can be said to remain due to a combination of two key factors: the quality of their homes, and the fact that they own them. Lastly, the unemployment rate is systematically higher than the average both in Madrid and in the large housing estates studied. To summarise, these are frozen neighbourhoods that are characterised by housing units in good residential conditions and an ageing native population that is vulnerable in the labour market.

The remaining trajectory types are both characterised by the settlement of a significant foreign immigrant population from 2001 to 2011, albeit to differentiated degrees. The third type is formed by large housing estates for which vulnerability values remain within the municipality's average from 2001 to 2011, except in the cases of two public housing development areas where the values are extremely elevated (Poblado Dirigido of Caño Roto and Gran San Blas). These large housing estates housed elderly working-class native populations in 2001 and incorporated a new foreign population over the following decade. These are spaces which went from having below average representations of foreign immigrant populations at the start of the migratory cycle (1991-2001) to slightly above average representations in 2011. These new residents mainly settled in rental housing according to the openings available that were either caused by vacancies left by the native population who took advantage of the real estate bubble to move to other neighbourhoods or due to the availability of empty housing that was mobilised for the rental market. In this regard, an increase in the relative importance of rental housing 
accounts for most of the increase in the absolute number of main dwellings. However, the changes in demographic composition did not alter the tendency for the rate of unemployment to be systematically higher than the Madrid average (though this rate is average for the large housing estates studied). Four of the seven large housing estates that make up this type were built by public housing developments during the 1950s and 1960s, when a maximalist criterion prevailed (based on the construction of the maximum number of houses using the lowest possible budget) resulting in inferior quality buildings. Furthermore, a neighbourhood that was remodelled in democracy and two privately developed neighbourhoods (Ciudad Parque Aluche and Barrio del Pilar) also form part of this type, and their peripheral development process meant that they were built in stages with varying architecture and planning quality.

Finally, the fourth type of trajectory is made up of large housing estates whose Urban Vulnerability Index grew remarkably between 2001 and 2011. These are neighbourhoods with a native working-class presence and a significant foreign population that settled there from 2001 to 2011, in which time the unemployment rate also increased significantly. All large housing estates included in this type correspond to public housing developments located in the city's peripheries that were started in the $1950 \mathrm{~s}$ and followed the maximalist criteria. In these large housing estates, the high percentage of agreements for grants of use and property in 1991 and 2001 was very notably reduced in 2011, as the percentage of rented properties increased with the increase in the stock of main dwellings throughout the entire period.

In short, the divergent trajectories of the large housing estates analysed in the city of Madrid reveal the relevance of certain key factors. In the first place, the initial characteristics of these large housing estates (in terms of type of promotion, building quality and social composition) significantly condition the structure and transformation of their social and demographic composition. Regarding initial social composition, the original criterion through which each housing development could be accessed is key. As observed above, in the case of public housing developments from the Francoist period, these were responses to the scarce supply of private housing for the period's large low-income populations. In the case of private housing development, $42 \%$ of developments of more than 500 homes built between 1940 and 1985 did not have any public subsidies or restrictions, so they were aimed at an economically solvent population (Lopez de Lucio et al. 2016). Public subsidies for the remaining developments were managed using different regulations, among which the variety of different low-income versions stood out. Lastly, homes included in the Neighbourhood Remodeling Plan were intended for those residents in substandard dwellings (making up approximately 35,000 dwellings), as well as for rehousing those already living in mediocre quality subsidised housing in homes with better conditions from the first decades of the Francoist period.

Thus, private housing developments are characterised by the permanence of homogenous native populations in high social positions. In contrast, public housing developments with appalling conditions built under Francoism are characterised by 
ethnically heterogeneous working-class populations. Between both development types, the evolution of neighbourhood remodelling developed by the first democratic governments is revealing. In this case, the better conditions of these public housing developments, as well as the accessibility to homeownership for their traditional occupants, led to the permanence of native working classes in buildings in good condition. In this regard, the fact that some public housing developments were remodelled, and others were not closely related to neighbourhoods' capacities to mobilise during the transition to democracy. The availability of facilities and public housing that met minimum standards of habitability blocked some neighbourhoods protests while favouring others, resulting in diverse processes of social change over the following decades. In this context, institutional factors were also key, given that the political conditions that enabled neighbourhood groups to exert influence at the start of democracy (in a context of governmental weakness) made processes that were banned during the Franco regime possible.

Lastly, the location of the large housing estates is another decisive factor for subsequent transformations (see Fig. 11.6). In this regard, the density of private housing developments is higher when they are located on limited land in the city centre. In contrast, the few examples of private housing developments on the peripheries of the city have more land available to them, which is, however, offset by lower quality urban facilities. These large housing estates have therefore been built in various stages, with improvements to facilities at every stage, bringing about social mixing that is the result, rather than the intention of real estate speculation strategies. On the other hand, public housing developments are located on non-privatised public land, which is mostly located on the periphery. This condition is key in a social space that is as segregated as Madrid, given that it limits the chances that these large housing estates have to be revalued. In conclusion, in the large housing estates analysed, social group permanence, and succession can be observed, and these processes are powerfully conditioned by a series of factors that differentiate them: the large housing estates development type, their geographical position, the quality of their original construction, (as well as its urban insertion in terms of facilities and transport links), their initial social composition, the social mobilisation of their neighbourhoods and the institutional context.

\subsection{Challenges and Political Response}

Three underlying processes determine the recent trajectory and near future of the large housing estates analysed, and each of them significantly affects its social and built environments: social polarisation of Madrid's urban society; its increasing ethnic heterogeneity; and the volatility of its institutional context. 


\subsection{Social Polarisation and Ethnic Diversity}

In relation to the first process, the large housing estates analysed occupy various positions in the residential market of Madrid in an increasingly polarised social space (Leal and Sorando 2016). As a consequence, the less attractive large housing estates (public housing developments which have not been remodelled and located in the southeast periphery) are located where filtering processes caused by these large housing estates loss in market value took place. As a result, some of the higher income households migrated to new housing developments that were more competitive, taking advantage of the wealth effect of the real estate bubble (López and Rodríguez 2010; Naredo 2010). In Spain, the children of the first generations that settled in these large housing estates from rural areas are the main players in the processes of ascending social mobility, thanks (in part) to the democratisation of the educational system. Often, it is this population who abandoned these large housing estates for more attractive housing developments (Pareja-Eastaway et al. 2003). This process is both a cause and a consequence of the arrival of new households with fewer resources (mainly foreign immigrants employed in the lowest paid jobs) who occupied these complexes because of the relatively lower prices of these homes, honouring classic patterns of invasion/succession (Grigsby et al. 1987).

In contrast, large housing estates with better residential conditions (due to either their original private development or their remodelling in the early years of democracy) that still retain homeownership as the main form of tenure, retain their original population to a much greater extent. In these neighbourhoods, no increase in the foreign immigrant population is observed, and the original residents continue to live in them, and either have high social status (in private housing developments) or vulnerable positions in the labour market (in remodelled housing developments). This process confirms Prak and Priemus' model (1986) in that the fact of physical decline is not bound to the spiral of social decline in these neighbourhoods, but presupposes maintenance at privileged levels or improvement from disadvantaged levels on the Urban Vulnerability Index. Events in Madrid certainly seem to confirm the importance of neighbourhood struggles for the fate of large housing estates. In this vein, Temkin and Rohe (1996) point out that the neighbourhoods receive both internal (demographic ageing, physical deterioration) and external (international immigration, unemployment, disinvestment) pressures to which residents and institutions respond in different ways according to the composition of each neighbourhood in terms of capital and its social cohesion (whether collective organisation is weak or strong and whether this leads to the abandonment of the neighbourhood or its defence and pressure on the institutions.)

In Spain, the collective political power of the residents of some housing complexes managed to influence the institutions to make improvements to them (Pareja-Eastaway et al. 2004), as shown by the success of neighbourhoods that managed to obtain improvements to the conditions of their homes (Neighbourhood Remodeling Plan) and neighbourhoods (new urban facilities.) The Madrid experience is telling in one respect, private development large housing estates located on 


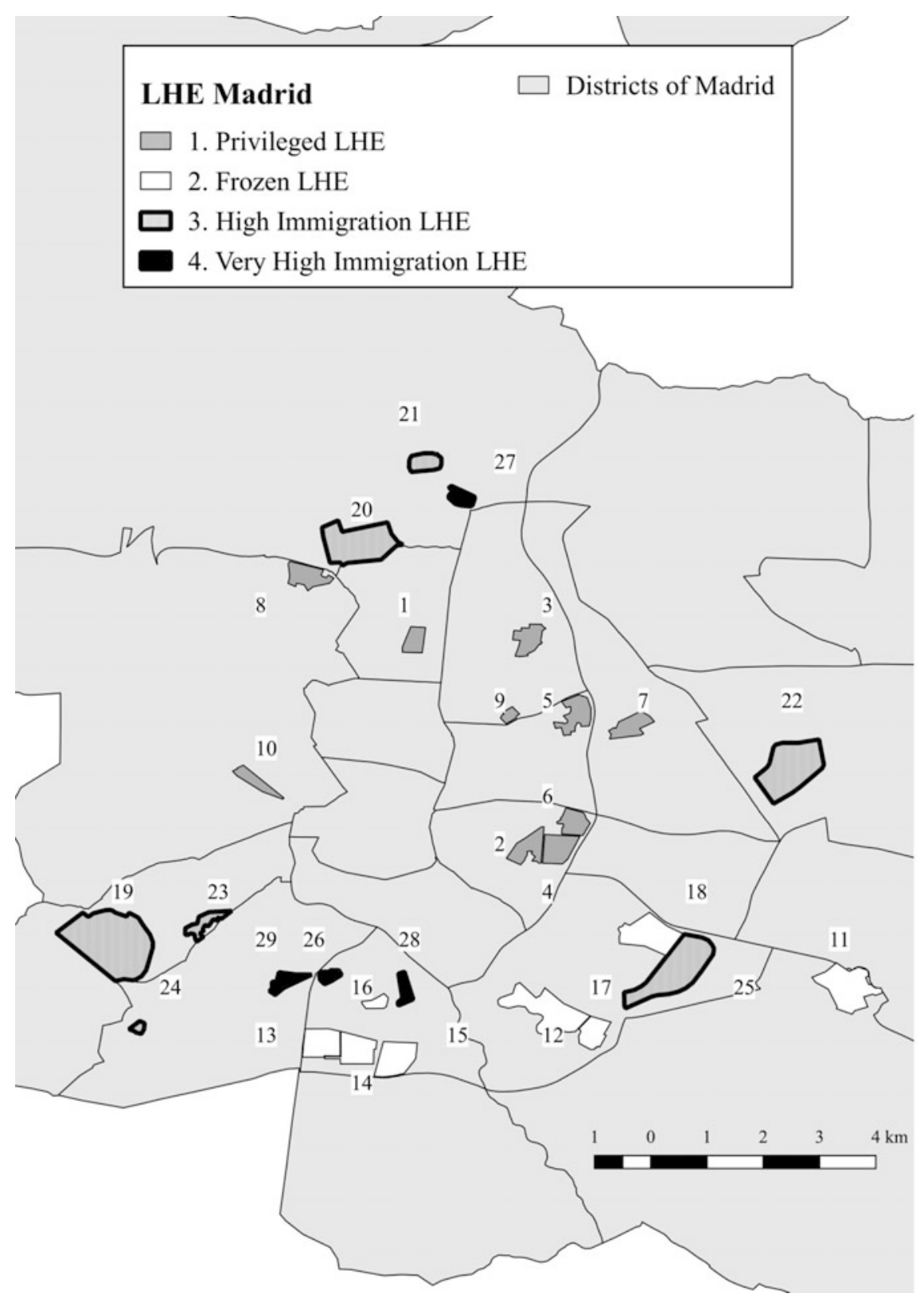

Fig. 11.6 Location and trajectory of large housing estates. Source Compiled by the authors based on the Population Censuses of 1991, 2001 and 2011 (INE)

the periphery had notable successes in their demand for urban inclusion thanks to the combination of the militancy of the working-class residents in these large housing estates earliest phases and the bourgeois organisation of the residents in 
later phases (Castells 1983). In the same way, residents in very deteriorated public housing developments that achieved the inclusion of their neighbourhoods in the Remodeling Plan lived in neighbourhoods that were united around strong leadership, as revealed in the Orcasitas case (Cervero and Agustín 2015). At present, the increase in heterogeneity in some of the large housing estates of greatest urban vulnerability raises questions about the future of these neighbourhoods. Much of the literature suggests that the residential settlement of foreign immigrants in these large housing estates supposes tensions between ethnic groups that hinder social cohesion and urban revitalisation (Skifter Andersen 2003). However, Martín Criado (Criado 2012) argues that the cause of the decrease in community trust in ethnically heterogeneous neighbourhoods is not the presence of immigrants, but the ethnic stratification of Western societies, whose corollary is distrust and alienation among ethnically differentiated agents.

Conversely, the institutional framework appears to be a central variable in each of the stages in which these large housing estates were built. In this regard, the social influence secured in the early years of democracy pertains to a completely different sociopolitical context from that which characterised the production of the first large housing estates at the height of the Francoist regime. The importance of considering this dimension raises questions about the effects of the volatility of urban policy in the case of Madrid. In general terms, in Madrid, as in Spain, the volume of public housing is negligible, and so too are the measures aimed at promoting social mixing, unlike in northern European countries (Andersson and Musterd 2005). Hence, the filtering processes are deployed in a favourable political context, which has peaked in recent years with the sale of a good part of the scarce public housing and land to investment funds, reducing the housing possibilities of the most vulnerable populations. Nevertheless, even in this context, there are examples of public policies co-designed by some of the large housing estates neighbourhoods analysed, whereas the change in municipal government in the 2015 local elections made possible a change in the urban policy of the city.

\subsection{Urban Policies}

The objective of different urban policies in the City of Madrid has prioritised the regeneration of various parts of the city. From the 1990s onward, Integrated Rehabilitation Areas involved the physical rehabilitation of certain neighbourhoods, through joint action of all levels of government, but did not include measures relating to economic and social needs. These interventions involved varying degrees of citizen participation across different neighbourhoods: in some neighbourhood demands were incorporated while in others intense social conflict occurred (Díaz-Orueta 2007). These interventions were mostly carried out in the historic centre of Madrid; very few occurred among the peripheries (Leal and Sorando 2013; Hernández Aja et al. 2015). 
Of all the municipal urban policies carried out over the last two decades, three types of interventions stand out: Special Plans of Investment and Intervention (known by its Spanish acronym, PEIA) the Planes de Barrio (Neighbourhood Plans) and the Madrid Recovers Plan (known by its Spanish acronym, MAD-RE). All these initiatives ultimately aim to promote socio-economic rebalancing and counter the existing inequalities in the city of Madrid.

The PEIA are territorial intervention programs that, based on the active participation of citizens in their design and management, articulate diverse types of policies and interventions aimed at correcting socio-economic, urban and non-residential imbalances of different districts in relation to the rest of the city (Ayuntamiento de Madrid 2008). Such interventions focus on the construction of facilities in disadvantaged districts. The districts where PEIA have been implemented include those of the large housing estates analysed. These programs involved a total investment of more than 650 million euros from 2004 to 2013 in the city of Madrid.

The Neighbourhood Plans consist of more localised actions, and the selection of urban spaces eligible to receive aid is carried out by the City Council and the Regional Federation of Neighbourhood Associations of Madrid (known by its Spanish acronym, FRAVM) in a consensual manner. In this regard, many of the public housing developments of the Francoist period and the large housing estates that were the object of the Neighbourhood Remodeling Plans have been the objects of these Neighbourhood Plans.

The objective of these plans is to empower the resident population in these types of disadvantaged neighbourhoods, so they do not include investment in infrastructure or facilities (which are reserved for the PEIA and the MAD-RE plans.) In this way, the budget is devoted entirely to the promotion of social, economic and labour interventions. Once the neighbourhoods are determined, the process of identifying problems and solutions is initiated by District Boards and local associations (not only neighbourhood associations). After this, they are subject to technical and budgetary evaluation by the local government departments involved, who consider other action plans for territorial rebalancing coming from Madrid City Council. The budget from 2009 to 2014 was of more than 40 million euros (Ayuntamiento de Madrid 2014). During the process, the proceedings are monitored by a citizen commission, made up of agents from District Boards and departments of the City Council itself and from public entities, that negotiates between the administration and residents.

Lastly, the MAD-RE Plan consists in generating economic grants designed to encourage and promote construction and/or interventions to improve the accessibility, conservation and energy efficiency of existing residential buildings. These grants target buildings located in the 120 Preferential Areas for Urban Regeneration approved by Madrid City Council in 2017 (Ayuntamiento de Madrid 2016). The parameters that determine the inclusion of the areas to be regenerated include aspects such as the age of the buildings and their quality, the percentage of elderly residents and the percentage lacking education. For the 2017-2019 grants, the Madrid City Council has allocated 49.2 million euros. 


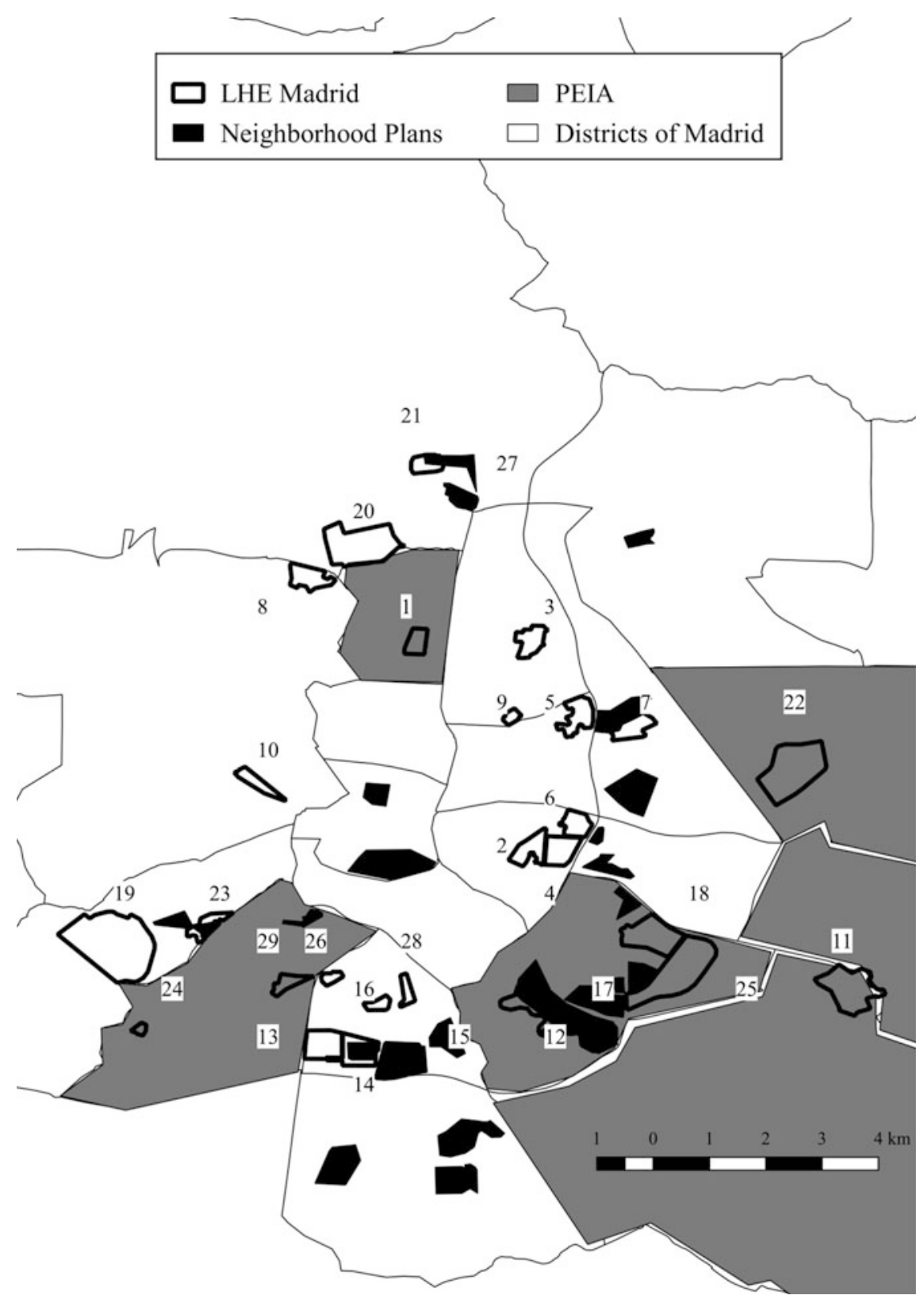

Fig. 11.7 Location of large housing estates, PEIA and neighbourhood plans. Source compiled by the authors based on Ayuntamiento de Madrid (2008, 2014) 
Overall, policies aimed at the socio-economic rebalancing of the city of Madrid have focused on historically disadvantaged areas. The programs directed towards the improvement of housing stock (PEIA and MAD-RE) as well as those destined to improve the socioeconomic conditions of the population that reside in these vulnerable areas (Neighbourhood Programs) share spatial locations of intervention; many of them were carried out in 1940-1975 public development neighbourhoods and the large housing estates with trajectories that show increases in urban vulnerability from the 1975-1990 Neighbourhood Remodeling Plan (see Fig. 11.7).

\subsection{Conclusion}

The trajectories of large housing estates built in Madrid from 1940 to 1990 were conditioned by the combination of their initial characteristics, their neighbourhoods' processes of mobilisation and the institutional context in which they were developed. Thus, the Francoist regime restricted all social mobilisation promoting a right to the city that contradicted its own segregated housing policy, a policy which was driven by the interests of the regime's oligarchy that was not inclined toward promoting social mixing. This was the panorama in which neighbourhood associations became the only channel for the expression of political and social unrest during the final years of Francoism. Associations assumed a leading role in mobilisations for the first years of democracy, when organised neighbourhoods with the worst urban and residential conditions found a favourable context in which to get their demands met. As a result, some of the publicly developed large housing estates obtained a level of residential stability thanks to remodelling, although they retained a high degree of social vulnerability that contrasted to the privileged position of the privately developed large housing estates. Conversely, the remainder of the publicly developed large housing estates built under Francoism have deteriorated over recent decades and are subject to a process of succession, whereby the most vulnerable groups (particularly the most impoverished foreign migrants) settle in this type of neighbourhood due to their weak position in the housing market. The result is a process of stigmatisation by which the most stigmatised social groups reside in housing complexes with equally stigmatised positions in the city, and the taint of space is added to those of ethnicity and poverty (Wacquant 2008). This is a novelty within the context of South European cities. The RESTATE project concluded that large housing estates located in cities like Madrid and Milan have used to be characterised by a large percentage of native elderly people who owned their homes (van Kempen et al. 2005a). This seems to be still the case of both the privately developed large housing estates and public large housing estates which were remodelled in democracy. However, there is another development trajectory of the large housing estates in Madrid that shows a new and socially relevant pattern: a process of succession by which many native neighbors left the most dilapidated large urbanizations, leaving empty spaces occupied by foreign immigrants who did not live in these areas before. This new socio-spatial 
configuration poses great challenges to the future of these large housing estates. In this scenario, the plans implemented to compensate for these imbalances have not managed to repair the dynamics of an urban and social model that is increasingly dual. In a new, more favourable institutional setting, these large housing estates are characterised by increasing ethnic diversity and social vulnerability, a combination that poses a challenge for neighbourhood organisation, the only strategy from the recent history of these large housing estates to improve social environments and residential living.

Acknowledgements This chapter is the result of the research developed along the program of activities 'Vulnerability, participation and citizenship: keys to sustainable urban development' (S2015/HUM-3413), financed by the Comunidad de Madrid and the European Social Fund.

\section{References}

Andersson R, Musterd S (2005) Social mix and social perspectives in post-war housing estates. In: Van Kempen R, Dekker K, Hall S, Tosics I (eds) Restructuring large housing estates in Europe. Policy Press, Bristol, pp 127-147

Ayuntamiento de Madrid (2008) Mapa de Áreas Preferentes de Regeneración urbana (APIRU). Resource document

Ayuntamiento de Madrid (2014) Planes de barrio para el reequilibrio social y territorial. Resource document

Ayuntamiento de Madrid (2016) Mapa de Áreas Preferentes de Regeneración urbana (APIRU)

Caprarella M, Hernández F (2008) La lucha por la ciudad: vecinos-trabajadores en la ciudad de Madrid 1968-1982. In: Pérez V, Sánchez P (eds) Memoria ciudadana y movimiento vecinal: Madrid, 1968-2008. Los Libros de la Catarata, Madrid, pp 33-53

Castells M (1983) The city and the grassroots: a cross-cultural theory of urban social movements. University of California Press, Berkeley

Cervero N, Agustín L (2015) Remodelación, Transformación y Rehabilitación. Tres formas de intervenir en la Vivienda Social del siglo XX. Informes de la Construcción 67(1). https://doi. org/10.3989/ic. 14.049

Criado EM (2012) El fraude del capital social. Consideraciones críticas en torno a 'E Pluribus Unum'. Revista Española de Sociología 17:109-118

Díaz-Orueta F (2007) Madrid: urban regeneration projects and social mobilization. Cities 24 (3):183-193

Grigsby W, Baratz M, Glaster G, Maclennan D (1987) The dynamics of neighborhood change and decline. Progress Plan 28:1-76

Hall S, Murie A, Knorr-Siedow T (2005) Large housing estates in their historical context. In: Restructuring large housing estates in Europe restructuring and resistance inside the welfare industry. Policy Press. https://doi.org/10.1332/policypress/9781861347756.003.0004

Hernández Aja A, Matesanz Parellada Á, Rodríguez-Suarez I, García Madruga C (2015) Evolución de las políticas de rehabilitación en Áreas de Rehabilitación Integrada en España (1978-2012). Informes de la Construcción 67(1):m024

Leal J, Sorando D (2013) Rehabilitación urbana y cambio social en las grandes ciudades españolas. Monografías de Revista Aragonesa de Administración Pública 15:205-236

Leal J, Sorando D (2016) Economic crisis, social change and segregation processes in Madrid. In: Tammaru T, Marcinczak S, van Ham M, Musterd S (eds) Socioeconomic segregation in European capital cities: east meets west. Routledge, London/New York, pp 214-237 
Lopez de Lucio R, Ardura A, Bataller JJ, Tejera J (2016) Madrid 1900-2010: urbanism and urban design guide. Ayuntamiento de Madrid, Madrid

López Díaz J (2002) La vivienda social en Madrid, 1939-1959. Espacio, tiempo y forma. Serie VII, Historia del arte 15:297-338

López I, Rodríguez E (2010) Fin de ciclo: financiarización, territorio y sociedad de propietarios en la onda larga del capitalismo hispano (1959-2010). Traficantes de Sueños, Madrid

Morán N, Aja AH (2006) La participación ciudadana en la intervención urbana. Boletín CF + S 34

Naredo JM (2010) El modelo inmobiliario español y sus consecuencias. Boletín CF + S 44:13-27

Ortiz S (2006) Actuaciones urbanísticas en el área metropolitana de Madrid durante la democracia: planeamiento y vivienda social. Revista M 3(1):6-17

Pareja-Eastaway M, Tapada-Berteli T, Van Boxmeer B, Garcia-Ferrando L (2003) Large housing estates in Spain: overview of developments and problems in Madrid and Barcelona. Utrecht University, Utrecht

Pareja-Eastaway M, Tapada-Berteli T, Van Boxmeer B, Garcia-Ferrando M (2004) Large housing estates in Spain. Utrecht University, Utrecht, Policies and Practices

Prak NL, Priemus H (1986) A model for the analysis of the decline of post-war housing. Int J Urban Reg Res 10(1):1-17

Rowlands R, Murie A (2009) Whose regeneration? The spectre of revanchist regeneration Palgrave. In: Rowlands R, Musterd S, van Kempen R (eds) Mass housing in Europe. Macmillan, Basingstoke, pp 235-264

Sambricio C (1999) La vivienda en Madrid, de 1939 al Plan de Vivienda Social, en 1959. Recurso electrónico en línea 01

Skifter Andersen H (2003) Urban sores: on the interaction between segregation, urban decay and deprived neighborhoods. Ashgate, Aldershot, UK

Tatjer M (2005) La vivienda obrera en España de los siglos XIX y XX: de la promoción privada a la promoción pública (1853-1975). Scripta Nova: revista electrónica de geografía y ciencias sociales 9

Temkin K, Rohe WM (1996) Neighbourhood change and urban policy. J Plan Edu Res 15(159170)

Terán FD, Sánchez de Madariaga I (1999) Madrid: ciudad-región 2, En-tre la ciudad y el territorio en la segunda mitad de siglo XX. Dirección General de Urbanismo y Planificación Regional, Madrid, Madrid

Uceda P (2016) La ciudad desequilibrada. El derecho a la ciudad en los barrios vulnerables de Madrid, Resource Document

Wacquant L (2008) Urban outcasts: a comparative sociology of advanced marginality. Polity Press, Cambridge

van Kempen R, Dekker K, Hall S, Tosics I (2005a) Restructuring large housing estates in Europe -restructuring and resistance inside the welfare industry. Policy Press, University of Bristol, Bristol

van Kempen R, Dekker K, Hall S, Tosics I (2005b) Restructuring large housing estates in Europe: restructuring and resistance inside the welfare industry. Policy Press, University of Bristol

Villasante TR, Alguacil J, Denche C, Aja AH, León C, Velázquez I (1989) Retrato de un chabolista con piso. Alfoz-IVIMA-SGV, Madrid

Vinuesa J (2002) La operación de remodelación de barrios de Madrid. In: Sambricio C, Vinuesa J (eds) Madrid, siglo XX Ayuntamiento de Madrid, Madrid, pp 261-262

Vinuesa J, De La Riva JM, Palacios J (2009) Política de vivienda y urbanismo. Ciudad y territorio estudios territoriales. Ciudad y territorio estudios territoriales 41(161-162):505-520 
Open Access This chapter is licensed under the terms of the Creative Commons Attribution 4.0 International License (http://creativecommons.org/licenses/by/4.0/), which permits use, sharing, adaptation, distribution and reproduction in any medium or format, as long as you give appropriate credit to the original author(s) and the source, provide a link to the Creative Commons license and indicate if changes were made.

The images or other third party material in this chapter are included in the chapter's Creative Commons license, unless indicated otherwise in a credit line to the material. If material is not included in the chapter's Creative Commons license and your intended use is not permitted by statutory regulation or exceeds the permitted use, you will need to obtain permission directly from the copyright holder.

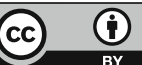




\title{
Chapter 12 \\ Social and Ethnic Transformation \\ of Large Social Housing Estates \\ in Milan, Italy: From Modernity \\ to Marginalisation
}

\author{
Petros Petsimeris
}

\begin{abstract}
This chapter examines the case of large estates of social housing in Italy's economic capital, Milan. Production of this housing occurred in the period of intensive industrialisation and associated urbanisation from the late 1940s to the mid-1970s. Development of these schemes occurred mainly in the periphery of the city, and led to land speculation and changed the social geography of the city. These estates initially housed Italian economic migrants attracted to Milan during the 'economic miracle', and since the 1990s have been the residence of a growing number of international migrants. Housing estates ceased to be developed after the 1980s, and a large part of the stock has been privatised since the 1990s. Today housing estates are more heterogeneous in terms of tenancy regimes and the social and ethnic groups who live there. The majority of the stock shows signs of (often serious) physical deterioration. The resident population has aged in situ, with ethnic segregation occurring in some residual parts of the stock. This chapter studies the evolution of these large social housing estates in spatial and social terms, using published and unpublished data from 1951 to 2017, pointing out their critical points and their potential.
\end{abstract}

Keywords Milan $\cdot$ Periphery $\cdot$ Large housing estates $\cdot$ Migration Social housing $\cdot$ Italy

\subsection{Introduction}

Milan's metropolitan region is the most important urban area of Italy in terms of economic base and centrality. Its area of influence goes beyond regional and national boundaries. This is mainly due to the important processes of industrialisation and urbanisation that Milan experienced following World War II, which had as a consequence the quantitative and qualitative transformation of its structure

P. Petsimeris $(\triangle)$

University of Paris, Paris, France

e-mail: petros.petsimeris@wanadoo.fr

(C) The Author(s) 2018

D. B. Hess et al. (eds.), Housing Estates in Europe, The Urban Book Series,

https://doi.org/10.1007/978-3-319-92813-5_12 
from city to international metropolis. During the period of growth (1950-1973), Milan consolidated its position as Italy's capital of industrial and housing production. Milan's urban landscape was transformed by the development of large industrial sites and housing estates that respectively employed and housed thousands of Italian immigrants.

After this period of growth, decline set in characterised by processes of de-urbanisation and deindustrialisation (Petsimeris 1998). In the late 1970s, the production of large housing estates drastically ended. Since the 1990s, the internationalisation of Milan's demographic structure due to global economic migration flows has become an established trend. The city has experienced a transition from domestic migration to international migration and a change of its economic base from an industrial to service economy (Bolocan Goldstein and Botti 2006). Other processes are the ageing of both housing estates and their tenants (Mugnano and Zajczyk 2008).

Our analysis will focus on the evolution of large housing estates and their populations using census data from 1991 to 2011, special data produced by the Piano Intercomunale Milanese (PIM) and interviews with the inhabitants and actors in the city of Milan. Distribution of housing estates of the public sector (ALER former IACP and council housing) in intra-urban space will be examined in terms of their temporality, and their qualitative and qualitative characteristics by taking into account the social and ethnic division of the city (Petsimeris and Rimoldi 2016).

Large housing estates constitute an important factor that quantitatively and qualitatively conditions the urban landscape of the city and its social geography. Despite their overwhelming appearance, they are not homogeneous but different entities in terms of housing density, planning standards, architectural aesthetics, degree of maintenance and social and ethnic composition of their populations. This chapter explores how these estates transitioned from Fordism to post-Fordism, the relation between location and socio-ethnic segregation, and the outlook for these estates as an integral part of a north Italian metropolis.

\subsection{Genesis and Evolution of Large Housing Estates in Milan}

In order to outline who was responsible for the development of large housing estates in Italy, one has to start with the question of what is 'social housing' in the Italian context. An official definition was provided as recently as 2008 (D.M. 22/04/ 2008), which defines social housing as 'mainly dwellings rented on a permanent basis; also to be considered as social housing are dwellings built or rehabilitated through public and private contributions or with the use of public funding, rented for at least eight years and also sold at affordable price, with the goal of achieving a social mix' (Caruso 2017, p. 23). As Caruso goes on to make clear, social housing, therefore, includes a mix of tenancy categories (rentals and owner occupation), and at the national level does not set out criteria by which housing should be allocated. The underlying principle for social housing in Italy is to promote social cohesion by 
means of reducing housing stress through the provision of housing to low-income households (Caruso 2017, p. 23).

In contrast to those countries that have received the most attention in literature on social housing, Italy had a national policy on social housing for a relatively brief period (Padovani 1996; Priemus and Dieleman 2002), and is currently at the bottom of the European league table in terms of number of social housing units by country (Tosi and Cremaschi 2001). Commenting on Italian housing policy in general, Tosi and Cremaschi note:

'The traditional model of housing policy that has characterised the Italian system is one in which public intervention in housing has been conceived mainly as a side by side intervention with respect to the market, in order to satisfy the demand which is not able to access the market, rather than having the objective of regulating the market' (Tosi and Cremaschi 2001, p. 14).

Private actors include: individuals, building societies, insurance companies and state pension funds. Not only has the relative importance of these actors changed over time, so has the line between the public sector and insurance companies and state pension funds been blurred due to government intervention aimed at using the housing stocks of these two private actors in order to try to control rental levels. Despite the subsidiary role of social housing, Italy is home to some of the largest social housing projects developed in Europe, including a development of close to 4,000 apartments called Gratosoglio in Milan (developed between 1962 and 1965), which helps to account for the relatively large share of housing accounted for by the public sector in the city. Responsibilities for housing are regional, which in the case of Milan means the region of Lombardy. Below the region, a high (and increasing) degree of discretionary power is afforded to the municipalities.

Social housing has a long history in Milan. In 1909, the City of Milan developed a large housing project on a $32,000 \mathrm{~m}^{2}$ site to the north of the city. The development, named Mac Mahon, included five large four-storey buildings, a small number of rows of housing and independent cottages, in an experimental fashion combining housing and community facilities typical of housing projects elsewhere in Europe at the time. The IACP (Istituto Autonomo Case Popolari, the Institute for Public Housing) was established soon after and started the production of quartieri of working class affordable housing with good standards in line with the hygienist ideology of the time. These experimental schemes acted as ways of innovating the building process in terms of housing, and would progressively lead to the provision of internal services, tidy layouts and self-sufficiency. As was to be the case throughout Milan's history of social housing provision, the private sector was active alongside the public sector, with the Società Umanitaria building two large complexes in the city in 1904 and 1909.

In the 1930s, the economic crisis had an impact on the production of social housing, and their size was reduced. After World War II IACP played a leading role in the process of housing production in order to satisfy the growing demand for dwellings, which was the result of the historically accumulated shortage combined with the massive destruction during the war and the pressing demand of domestic 
immigrants attracted to the city during the post-war economic boom (Castronovo 1970). After World War II, the IACP produced housing for soldiers and for people who were displaced. Housing was produced for white-collar households, the lower middle class and the working class.

After the late 1940s, two national programmes for the provision of social housing began: INA Casa (Istituto Nazionale Assicurazioni Casa, Institute for Social Housing) and, from 1963, Gescal (Gestione Case per Lavoratori, Institute for the Administration of Worker' Houses) (Di Biagi 2001). Essentially, these were means of raising finances for the development of quartieri autonomi (selfsufficient neighbourhoods) such as Harrar, Lorenteggio and Comasina. These autonomous neighbourhoods were financed in part by 'forced' contributions (deductions from wages) from the workers (private sector or state employees), and in part from contributions by employers and the state (Ferracuti and Marceloni 1982). These contributions were centralised by the CER (Comitato per l'Edilizia Residenziale, Committee for Residential Building) before being distributed to the regions. The aim was to reduce the housing shortage but also to create employment in the building industry (segmented in small units with a low-qualified, mainly manual workforce). The ideology behind the programme was to provide a means of access to home ownership by means of riscatto (i.e. after a number of years the tenant would become the owner). Both the ideology and spatial practices of these programmes have been criticised by a number of scholars — such as Tafuri (1986) and Secchi (1972) and Indovina (1972) - while others have criticised the social segregation generated by these schemes (Carozzi and Mioni 1970). This source of capital was important for housing production although insufficient to cover all housing needs.

Even if Milan has played an important economic, social, and political role throughout the history of Italy, its urban fabric came to be most dramatically transformed during the period of the so-called 'economic miracle' from the end of World War II to the late 1960s. The development of large social housing estates was a key element of this urban transformation. Main characteristics of this brief period were the processes of industrialisation and urbanisation, and the modernisation of Italian society and economy. Milan was not only the protagonist and main generator of these processes in terms of decision-making and investment, but also the territory in the so-called 'industrial triangle' (Milan, Turin, Genoa) that experienced the most dramatic quantitative and qualitative changes passing from the status of a city to a metropolis with significant transformation in its urban landscape and housing stock.

Milan has a concentric form that still characterises the city's spatial structure and social geography. The core is composed of the historic centre of the city delimited by the Spanish walls. Many prestigious institutions and firms, and the residences of the elite are located in this area. The core accounts for $4.5 \%$ of the total area of the city. The second ring is the extension of the city at the end of the 19th century (Corpi Santi, Greco Milanese, and Turro Milanese) (36\%), and the outer part of the city $(60 \%$ of the total area) is a heterogeneous area formed by the annexation of 12 contiguous rural municipalities (Baggio, Trenno, Musocco, Affori, Niguarda, Greco, Gorla, Precotto, Crescenzago, Lambrate, Chiaravale, and Vigentino) completed in the 1920s. It was mainly the municipalities of the outer rings that absorbed 
the rapid processes of urbanisation and industrialisation, and which were transformed from agricultural and rural areas into zones with high concentrations of large housing estates that gave shelter to large numbers of migrants in collective housing (see below). In these areas, there were contradictory processes of production and appropriation of space with the coexistence of small historic nuclei, large housing estates, industrial plants, self-promoted housing developments by the migrants of the 1950s and 1960s (coree), and shrinking green and agricultural areas.

In the 1950s and 1960s, Milan attracted many hundreds of thousands of Italian economic migrants originating from a range of places: from the city's more proximate rural areas to Italy's most remote regions, particularly in the South. Between 1951 and 1971 Milan gained just under half a million inhabitants (Table 12.1). The processes by which these migrant workers and their families were housed occurred rapidly and largely in the absence of land use planning, resulting in the development of virtually every free space towards the periphery by large housing estates located on greenfield sites. Many of the sites had poor accessibility; some were located between industrial estates or along (but without direct access to) highways or railway infrastructure, while others were in the middle of historic centres and farming areas of contiguous rural municipalities (Gambi 1973; Dalmasso 1972). At the same time, there was another process of major renewal and intensive development in the centre of the city, consolidating its historical role as the elected space for residences of the upper middle classes, and the location of financial and high tertiary institutions (although it still included enclaves of derelict housing, 'cheap' bedsits, and short-term rentals). Production of these peripheral housing estates was-at the time considered to be a miraculous solution, giving shelter to new urbanites. Nevertheless, it consolidated the territoriality of social polarisation between the centre and the periphery (ILSES 1964; Cerasi and Ferraresi 1974).

From Table 12.1, it appears that during the six decades, there has been a continuous improvement in terms of overcrowding: from 1.21 persons per room in 1951 to 0.58 in 2011.

Also impressive is the improvement in the provision of dwellings with basic facilities: from $30 \%$ in 1951 to $99.88 \%$ in 2001 . But the most important change that has occurred is in tenure regime. Homeownership tripled its share, jumping from

Table 12.1 Key housing characteristics in Milan, 1951-2011

\begin{tabular}{l|l|l|l|l|l}
\hline Year & $\begin{array}{l}\text { Population } \\
\text { (thousands) }\end{array}$ & $\begin{array}{l}\text { Inhabitants/ } \\
\text { room }\end{array}$ & $\begin{array}{l}\text { Share of housing units } \\
\text { possessing basic facilities } \\
(\%)\end{array}$ & $\begin{array}{l}\text { Share of owned } \\
\text { housing units (\%) }\end{array}$ & $\begin{array}{l}\text { Family } \\
\text { size }\end{array}$ \\
\hline 1951 & 1,274 & 1.21 & 30.7 & 26.3 & 3.6 \\
\hline 1961 & 1,582 & 1.07 & 53.8 & 35.4 & 3.4 \\
\hline 1971 & 1,732 & 0.93 & 84.5 & 41.9 & 3.1 \\
\hline 1981 & 1,605 & 0.75 & 92.9 & 52.9 & 2.9 \\
\hline 1991 & 1,369 & 0.65 & 96.8 & 65.0 & 2.7 \\
\hline 2001 & 1,256 & 0.61 & 99.8 & 71.0 & 2.5 \\
\hline 2011 & 1,242 & 0.58 & 99.8 & 74.3 & 2.3 \\
\hline
\end{tabular}

Source ISTAT Census data, 1951-2011 
$26.3 \%$ in 1951 to $74.3 \%$ in 2011 . The picture, however, is far from euphoric. Even if housing densities have declined and housing conditions have improved, these have occurred in a context of economic crisis characterised by deterioration in employment opportunities. Associated with this are threats to continuity of employment and income from employment for the less skilled, the continuous decline of the welfare state and reduced availability of social housing. As a consequence, the most vulnerable households find it increasingly difficult to solve their condition of housing stress.

A comparative analysis by IAURIF showed that the intensity of production of housing in Milan was greater than in metropolises such as Chicago, Amsterdam, Los Angeles and London (Dalmasso 1972). As a consequence, the power of the real estate sector grew enormously both in Milan and nationally, with the group of developers, contractors, landowners and real estate companies coming to be known as the blocco eldilizio (the real estate block) (Indovina 1972). This sector has been able to exert significant influence on national policy and city finances, and is widely acknowledged to be linked to mafia interests. The greatly increased pace of housing production was nevertheless unable to redress both the historical shortage of decent quality housing and to provide shelter for all of the new arrivals (ILSES 1964; Garzena and Petsimeris 1984). Unsatisfied demand for housing was expressed towards the end of the 1960s and in the 1970s by protest movements, which occasionally erupted into violent tensions as protests over housing issues were incorporated into protests over working conditions.

Since the housing reform introduced in 1971 (Law 865), responsibility for social housing has progressively passed from central to regional and local governments, with regional government being responsible for setting the objectives of social housing, and establishing regulations for management and funding. This trend reflects the general process of liberalisation, which in this case involves the privatisation of the institutions responsible for public housing and the redefinition of the public sector's role relative to the market in terms of welfare provision. Such processes have, of course, not been confined to Italy. At the same time, levels of construction have continuously declined. This has occurred within the context of reduced central government finance to regions, which makes regions more reliant on their own resources and places them in the position whereby the sale of social housing presents one means by which to balance their budgets.

\subsection{Location and Diffusion of Large Housing Estates in Milan}

Large housing estates are cause and consequence of the transition of Milan from regional centre to Italy's largest metropolitan area and economic capital. They reshaped the city's skyline and its social geography. Figure 12.1 represents the location of large housing estates in Milan by period of construction and gives an indication of their size, form, typology and spatiality of their diffusion. Large housing estates are many, scattered, different in size and form, and adhere to 


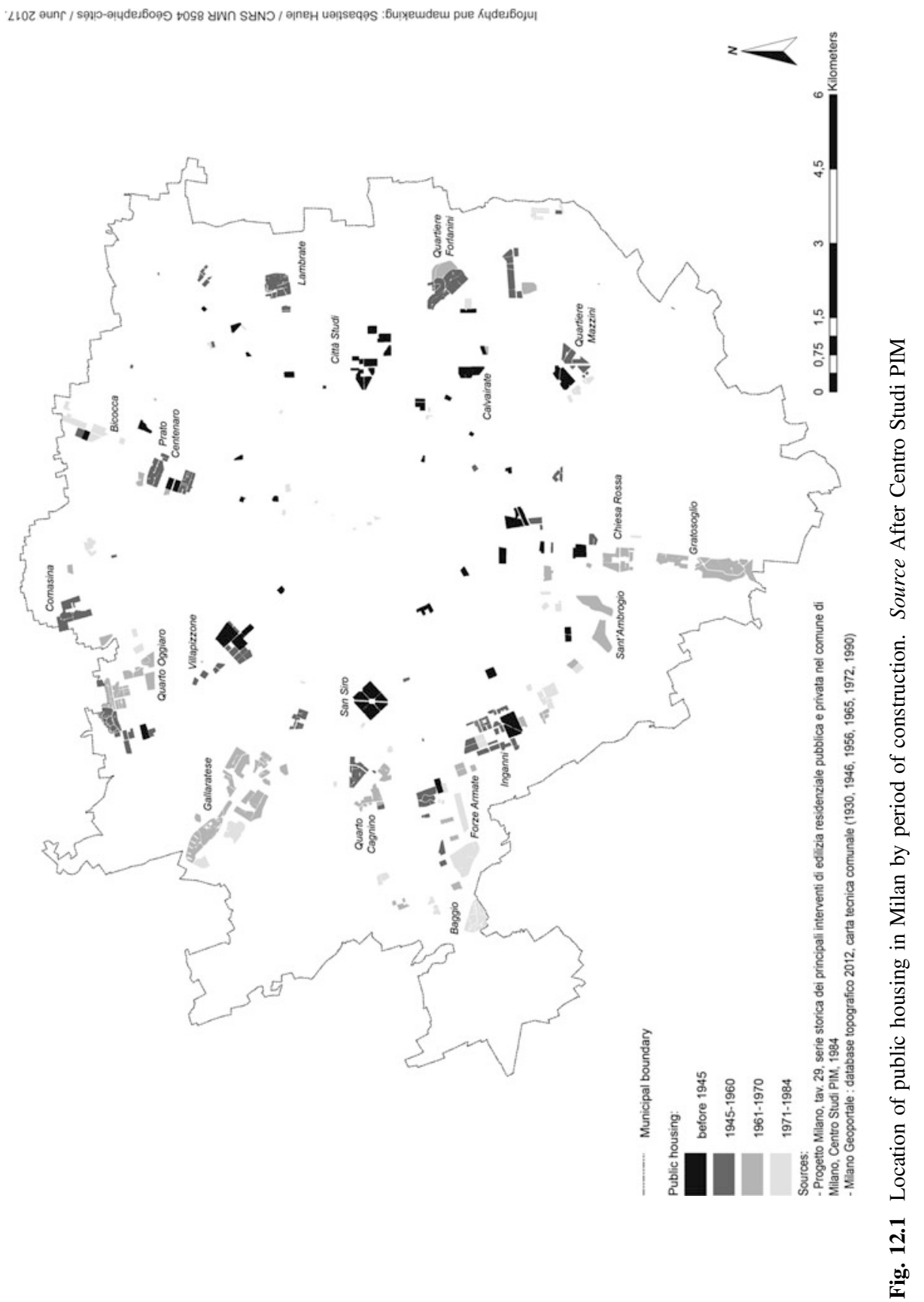


different visions, architectural fashions, and planning practices. Milanese architects produced rationalist schemes (Belgiojoso in Grattosoglio), modernist (Aymonino) or postmodernist (Aldo Rossi) in Gallaratese (Belgiojoso 1972; Tafuri 1986; Grandi and Pracchi 1980). These estates are now at different stages in terms of ageing, decay and maintenance, and continue to occupy a significant amount of space mainly towards the periphery of the city.

These large housing estates are scattered across the urban fabric but not in a haphazard manner because they are located more towards the periphery-where land was available - and their concentration is stronger in the west - the more industrialised part of the city - than the east. The height of the buildings has increased over time. Large estates developed before World War II were four storeys high, those developed in the post-war period were six storeys high, and later developments in the 1960s and 1970s reached 12-16 storeys in height. These taller developments were constructed using industrialised methods of heavy prefabrication 'à la française'. Establishment of Gescal and the introduction of a national 10-year plan for housing provided a context for experimentation by public housing authorities, and Milan led the way. An agreement was signed with five providers of prefabricated housing for a construction programme of 21,000 houses within 1968, including the Olmi neighbourhood at Baggio. The impact of these high-rise estates on the cityscape has been considerable, not least because in most cases, the engineers, planners and architects failed to integrate them with the rest of the city.

There is a positive relationship between the size of the estates and their distance from the city centre: the larger the floor-print of an estate, the more peripheral its location. Part of the explanation for this pattern is afforded by decreasing land values along a centre-periphery gradient. However, this has to be qualified by the fact that these developments contributed to fuelling increases in land values through speculation on free spaces located between the periphery and the centre (Graziosi and Vigano 1970).

Large housing estates were distant from any sort of centrality, symbolic values, public and cultural services and institutions (Gambi 1973). Generally, they were located in the middle-of-nowhere, forming ghettos without infrastructure, with poor accessibility to the city centre and to the work places of their inhabitants. There was a severe shortage of shops, public and private services, cultural activities and public space. Justification for their marginal and inaccessible location put forward at the time had to do with lower land values toward the periphery, which would be the means by which rents could be made affordable for households with low incomes. But this was part of a speculative mechanism invented by the landowners and tolerated by the state. Landowners frequently sold less valuable land holdings on the administrative boundaries of the city to ICAP and the city authority at prices close to nothing. These landowners gifted these peripheral sites so that they could subsequently benefit from the betterment of their land holdings located between these sites and the centre, a betterment which was provided by the infrastructure and social services that the state financed in order to dis-enclave the peripheral housing estates (Ferracuti and Marceloni 1982). This process was dislocated from city planning. The drawing board designs of internationally acclaimed architects went on to become mega containers for the segregation and dislocation of lower income groups. 
The last developments of IACP (1961-1985) are located in the peripheral parts of the city (such as Gallaratese, Quarto Oggiaro, Sant'Abrogio and Gratosoglio) and are much larger than previous ones. Development was undertaken by IACP in association with the municipality of Milan. As the pressure of urbanisation continued, overspill increased in the form of large housing estates in the contiguous municipality of Rozzano. These are characterised by a high concentration of housing by IACP, which accounts for more than $50 \%$ of the housing stock of the municipality. There has been a process of diffusion of the housing estates from the centre to the periphery and from the ground to the sky, which has brought about the rapid transformation of agricultural land to built-up areas, and the further diffusion of Milan to the first, second, and third rings.

Gratosoglio is a massive housing estate built in the southern part of the city in 1962 and designed by the famous architecture studio BBPR. It consists of 21,000 prefabricated units, arranged in 52 buildings on 9 floors. In 1972, an extension to this development was added in the form of eight white towers of 16 floors each (Fig. 12.2).

The spatial arrangement of apartment towers is depicted in Fig. 12.2. A rectilinear configuration along a main axis route, via dei Missaglia, connects the development to the southern periphery - and eventually - the centre of Milan. In the context of their immediate and not so immediate surroundings, these 16-storey buildings are imposing. Furthermore, the juxtaposition of these buildings with a business park and commercial units trading in luxury brands on the other side of

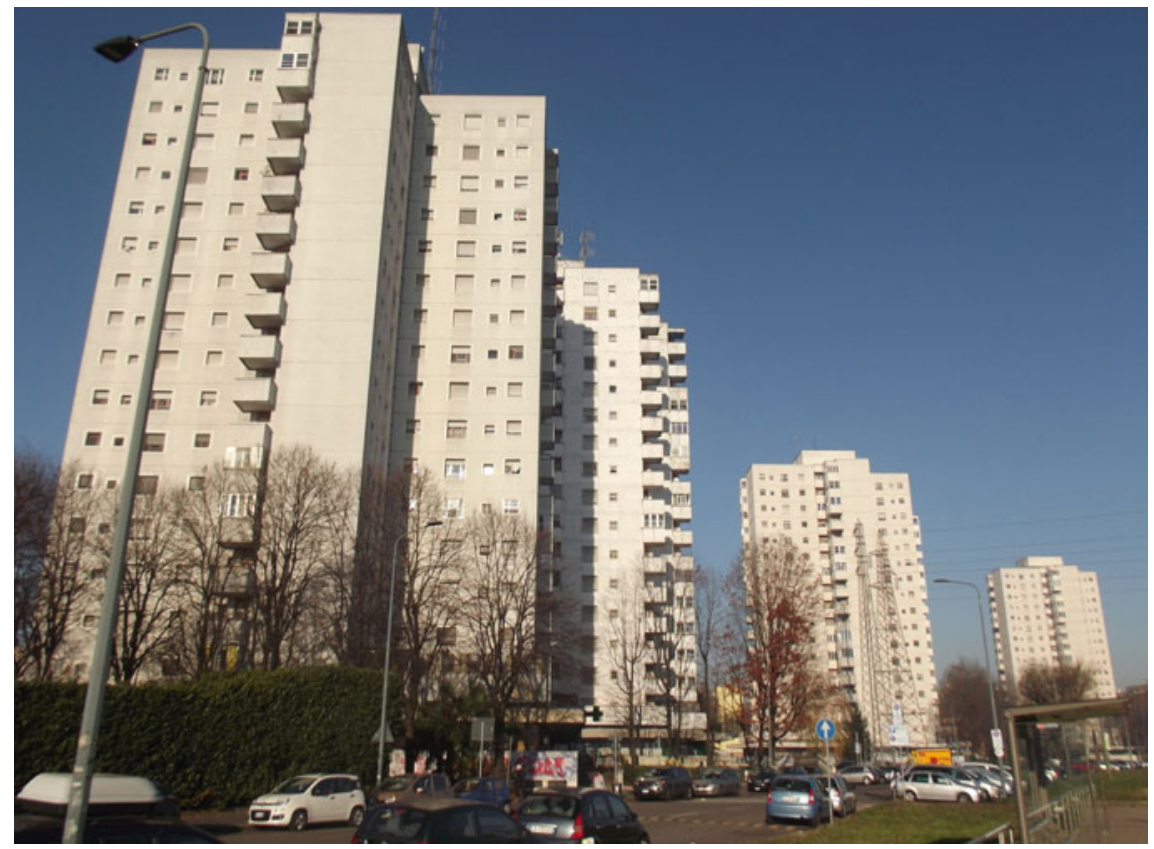

Fig. 12.2 Grattosoglio, tower apartments designed by BBPR. Source Petros Petsimeris 
Via dei Missaglia is accentuated by this axis route, which has now become a new frontier.

Many of the problems that have occurred since the 1970s in this development were foreseen by the architect Belgiojoso (1972): rigidity in terms of prefabricated structural elements, poor accessibility, segregation due to the isolation of the working class, and failure to provide services concurrent with families taking up residence in the development. There were also a number of positive aspects: orientation favouring good luminosity, hygiene, conception, spatial integration of services, and the provision of green areas. It will be interesting to see how the current attempts at regeneration will draw on the positive aspects of the original architectural design and help move towards the amelioration of the more negative aspects.

The following observations were made during fieldwork conducted at Grattosoglio in February and December 2017. Most of the public space at ground floor level is currently empty (Fig. 12.3), the most notable exception being the queue of people outside the ALER offices.

While the laundry and pharmacy continue to function, all of the other shop units originally provided in the development are now vacant and boarded up. A covered market, together with a small supermarket, serves the needs of the local population. Both of these opened 20 years after the housing development was completed. The people who use the public open space are mainly elderly and Italian. When questioned about their living conditions they stated that they were generally content. However, as the conversation developed many of the older residents agreed that the problem of the development's isolation during the 1970s had come to be replaced by an increasing sense of insecurity among its residents. This they

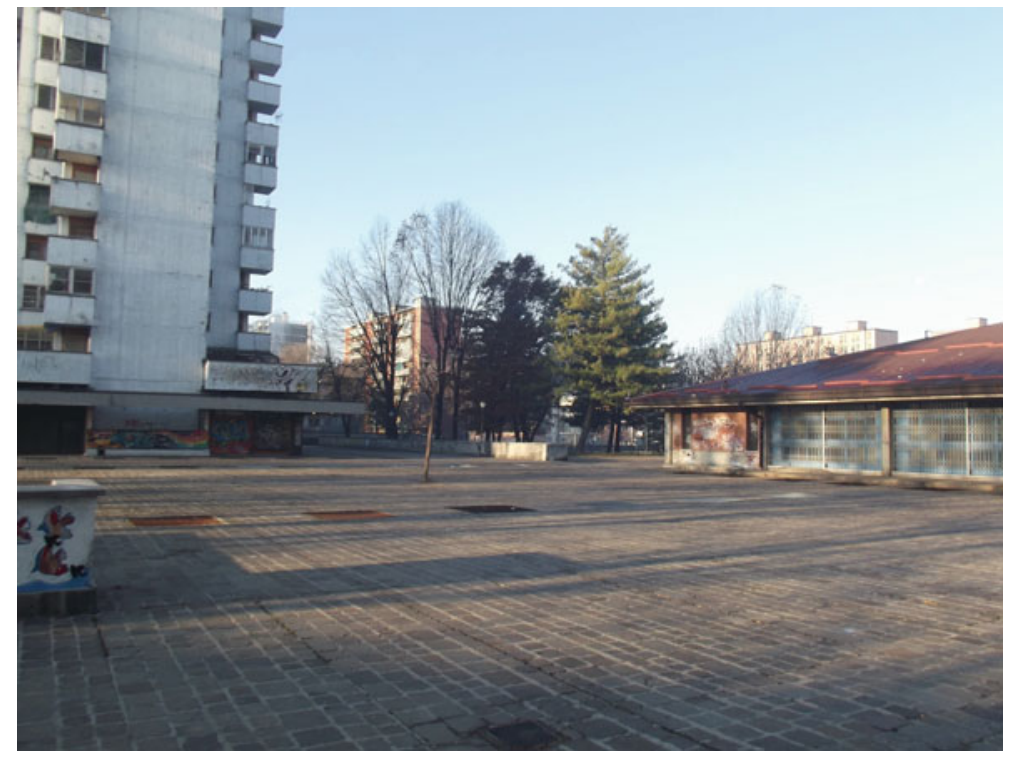

Fig. 12.3 Vacant shop units and public open space at Grattosoglio. Source Petros Petsimeris 


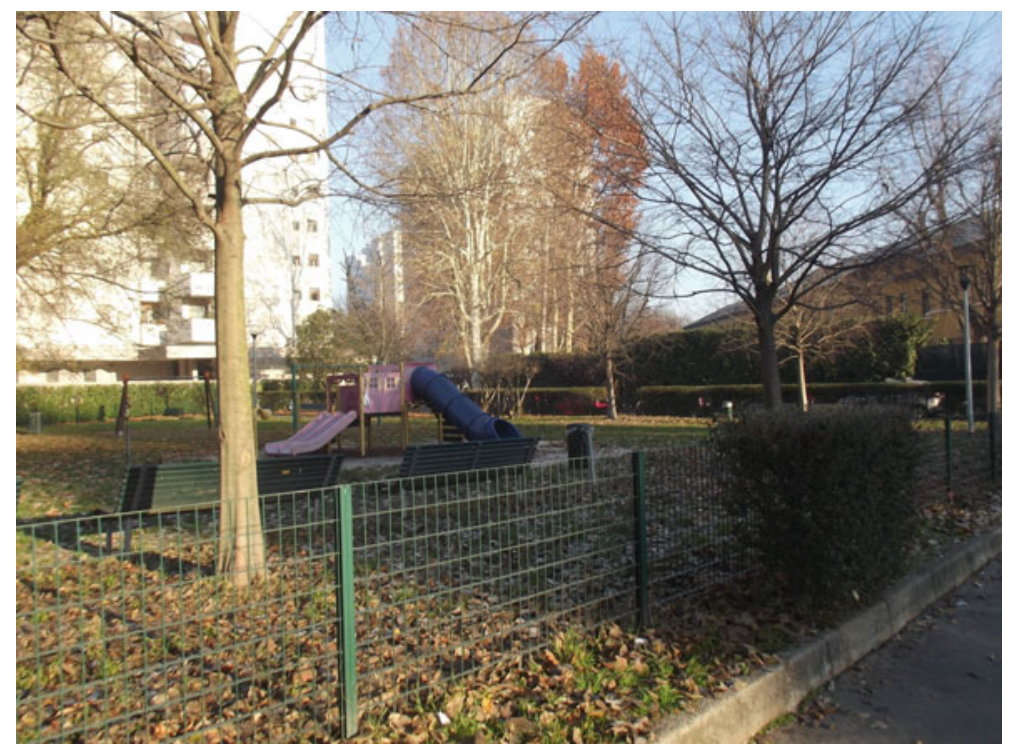

Fig. 12.4 Children's park facilities at Grattosoglio. Source Petros Petsimeris

attributed to a number of factors, including: the recent location of a centre for immigrants in the place of the former elementary school; maintenance, cleaning and waste disposal problems; and the abusiveness of squatters.

The green areas are large and generally well maintained although — at least at the time of my fieldwork - the children's play facilities were under-used (Fig. 12.4). The road and tram connections with Milan are good, and have played an important role in reducing the perceived and practical isolation of the development. There is evidence of upgrading of a number of individual apartments and the renewal of the façades of some blocks of housing in via Baroni.

In the 1990s, a process of denationalisation of social housing occurred (Cremaschi 1994), with the devolution of the housing question to the local authorities. This is not only a question of change of name from IACP to ALER (Azienda Lombarda Edilizia Residenziale) in 1996 but also marks a period that corresponds to a decrease in resources for social housing. This has occurred alongside an increase in the size of the more marginal population due to international migration and a decrease in welfare provision by the state.

Since 1992 the public housing stock in Italy has been progressively eroded. In Milan, 60,000 units out of 100,000 have been privatised (Marini 2007; Granata and Lanzani 2008). The public housing stock managed by the ex-IACP is now subdivided into two parts: one owned and managed by ALER and the other owned by the city and managed by MM. 
Both entities focus their priorities more on the maintenance of the existing housing rather than on new production (Osservatorio Metropolitan sui Bisogni Abitativi 2006)

\subsection{Social and Ethnic Succession in Public Housing Estates}

In the beginning, large housing estates provided residences for domestic workers in skilled manual labour and white-collar employment related to the manufacturing industry. Skilled labourers were predominantly from the north-east of Italy, while unskilled labour was drawn from the south. After the 1980s, processes of deindustrialisation and migration from the Global South and Eastern Europe had an impact on the social structure of the city. These are reflected in processes of 'succession' of residential location in derelict and overcrowded areas in the inner city and in substandard large housing estates.

Are housing estates containers of social and ethnic segregation, or are housing estates going through a shift from a social divide to an ethnic divide? Data are not available at the appropriate scales and periods to carry out detailed analysis of the changes in the micro-social geography of large housing estates. However, with data available from the PIM (Piano Intercomunale di Milano, Inter-municipal plan of Milan) and the council, the relationship between container and content will be outlined.

According to the Observatory for Public Housing, in 2006 Milan had 39,923 dwellings, of which 14,333 (36\%) were owned by ALER and 25,580 (64\%) by others (mainly the city of Milan). It is noteworthy to underline that amongst them there were 2,631 dwellings occupied illegally and 1,741 non-attributed. This means that there is a problematic situation in terms of governance and turnover.

As is seen in Table 12.2, more than half of social housing has an age that ranges from 70 to 100 years and more recent housing has an age between 30 and 50 years. This means that there is a process of natural decay that is very important and big investments are needed for areas that are oldest. The same table also indicates that more recent housing estates and extensions are larger. This is very important in

Table 12.2 Characteristics of social housing in Milan by period of production, 1908-2005

\begin{tabular}{l|l|l|l|l}
\hline Period & Number of dwellings & Share $(\%)$ & Total area & Share $(\%)$ \\
\hline $1908-1945$ & 19,845 & 50.8 & 844,197 & 41.1 \\
\hline $1946-1960$ & 3,479 & 8.9 & 176,039 & 8.6 \\
\hline $1961-1970$ & 7,642 & 19.6 & 476,473 & 23.2 \\
\hline $1971-1990$ & 7,875 & 20.2 & 545,837 & 26.5 \\
\hline $1991-2005$ & 206 & 0.5 & 13,548 & 0.7 \\
\hline Total & 39,047 & 100 & $2,056,094$ & 100.0 \\
\hline
\end{tabular}

Source Centro Studi PIM, 2006 
terms of the quality of standards both for domestic space and the areas assigned to green spaces and social and private services.

One can observe the impact of ageing housing on the quality of housing conditions of the public stock that can also have serious consequences on the social geography of the neighbourhood.

Large public estates are heterogeneous in terms of quality of housing conditions (Table 12.2). Decay is greater in the central city rather than in the rest of the metropolitan area, and it concerns mainly small dwellings of two rooms $(58.2 \%)$ and three rooms $(31.2 \%)$ in Milan, and dwellings of two and three rooms in the suburbs (54.6\% and $25.4 \%$, respectively). These dwellings belong to older estates in Milan and to the most recent in the periphery that are also relatively larger (Table 12.3).

Previous data concern the stock owned by ALER and the city council. More recent data are only available from the city council that owns 27,945 dwellings occupied by 24,648 households for a total of 50,500 inhabitants.

There is an over-representation of the elderly (Table 12.4), particularly that of the oldest age group (over 65 years old). These big housing estates were designed for young families with children, and services like schools, playgrounds and sport fields - even if often insufficient-were addressed to this type of household. Today the services are inadequate for a population which has aged in situ.

Images diffused by the media give the impression that large housing estates are mainly occupied by different groups of 'others': immigrants from southern Italy in the 1960s and from the Global South since the 1990s. But as seen in Table 12.5, public council housing in Milan is mainly occupied by Italians $(83.17 \%)$ while non-Italians represent only $16.13 \%$. Amongst non-Italians, the highest shares are recorded by nationalities from outside the European Union, such as Morocco (2.9\%), the Philippines (2.3\%), Sri Lanka (1.6\%), and Peru and Ecuador (1.1\% each).

Table 12.3 Share of social housing by number of rooms and by housing condition in Milan and the metropolitan area, 2006

\begin{tabular}{l|l|l|l|l|l|l}
\hline \multirow{2}{*}{ Number of rooms } & \multicolumn{4}{|l}{ Milan } & \multicolumn{3}{l}{ Rest of the metropolitan area } \\
\cline { 2 - 7 } & Good & Mediocre & Decaying & Good & Mediocre & Decaying \\
\hline 1 & 1.7 & 0.0 & 8.8 & 0.0 & 0.0 & 4.9 \\
\hline 2 & 17.4 & 0.5 & 58.2 & 1.2 & 0.0 & 54.6 \\
\hline 3 & 20.5 & 15.2 & 31.1 & 13.1 & 11.1 & 25.4 \\
\hline 4 & 20.7 & 32.3 & 1.7 & 24.9 & 66.7 & 13.6 \\
\hline 5 & 30.3 & 43.5 & 0.1 & 41.3 & 0.0 & 1.3 \\
\hline 6 & 8.2 & 8.6 & 0.0 & 18.4 & 22.2 & 0.3 \\
\hline 7 & 1.1 & 0.0 & 0.0 & 1.1 & 0.0 & 0.0 \\
\hline Total & 100 & 100 & 100 & 100 & 100 & 100 \\
\hline
\end{tabular}

Source Centro Studi PIM 2006 
Table 12.4 Council housing in Milan by age of inhabitants, 2017

\begin{tabular}{l|l}
\hline Age groups & Share $(\%)$ \\
\hline $0-14$ & 8.36 \\
\hline $15-18$ & 4.69 \\
\hline $19-45$ & 23.50 \\
\hline $46-65$ & 30.54 \\
\hline Over 65 & 32.90 \\
\hline
\end{tabular}

Source City of Milan unpublished data

Table 12.5 Council housing by ethnicity of tenants,

\begin{tabular}{l|c}
\hline National origin & Share $(\%)$ \\
\hline Italy & 83.2 \\
\hline Morocco & 2.9 \\
\hline Philippines & 2.3 \\
\hline Sri Lanka & 1.6 \\
\hline Peru & 1.1 \\
\hline Ecuador & 1.1 \\
\hline Other & 7.8 \\
\hline Total & 100
\end{tabular}

Source City of Milan unpublished data

A comparison of this data with data on the occupation of housing stock in Milan shows that the Italian population is two percentage points lower, and that migrant groups record correspondingly larger shares: Philippines (2.6\%), followed by Egypt and China (1.6\% each), and Peru (1.4\%). Each of these groups records a higher concentration in the city than in the large housing estates. Only immigrants from Sri Lanka and Ecuador ( $0.9 \%$ each at the city level) have higher concentrations in the housing estates. Therefore, Italians record higher concentrations in the large housing estates relative to the rest of the city, and the majority of larger ethnic minority groups have the tendency to live outside public housing estates. This pattern is due to the availability of the housing stock, and the history of migration to Milan of each ethnic group. Limited knowledge of more recent migrants on how to access social housing, and the eligibility and selection mechanisms used by the public housing institutions help to account for the differences. Other factors include the limited number of dwellings available to newcomers. These dwellings are mainly residual parts of the stock with high levels of decay, and very frequently are those that have previously been turned down by Italian households.

Another important issue concerns the size of households that occupy large housing estates (Table 12.6). The smallest households constituted by one or two members count for three-quarters of the total stock while larger households (five and more persons) represent less than $5 \%$. This is a reversal of the situation during the Fordist period, when medium and large-sized households represented the vast majority in large housing estates. A comparison of small households in public housing with those in the rest of the city shows that single-dweller households are 
Table 12.6 Council household size, Milan, 2017

\begin{tabular}{l|l}
\hline Size of households & Share $(\%)$ \\
\hline 1 & 41.9 \\
\hline 2 & 31.3 \\
\hline 3 & 13.7 \\
\hline 4 & 8.2 \\
\hline More than 5 & 3.3 \\
\hline
\end{tabular}

Source City of Milan unpublished data

less concentrated within public housing (41.9\%) than in the rest of Milan (45\%). This suggests that in public housing there is a dissymmetry between size of the dwelling and the size of the household. This is most probably the case for most recent estates where dwelling sizes are larger.

This issue is important to address in the context of rehabilitation that is urgently needed for the majority of public stock. Through a process of subdivision, a better correspondence between size of household and dwelling size could be achieved, which would also help to address the issue of overall housing shortage. Such a solution, however, would require a considerable increase in the level of funds available for the refurbishment of a rapidly decaying housing stock.

\subsection{Physical Decay, Ageing and Social Segregation}

According to the last census in 2011, a number of large housing estates show high levels of social deprivation on the ACE scale (Table 12.7). The estates of Gallaratese, Barona, and Quarto Oggiaro face a number of severe problems in terms of ageing structures (50 years old on average), unemployment, and youth unemployment. The most deprived areas are Quarto Oggiaro and Selinunte. The former has the highest rates of unemployment $(12.5 \%)$ and young people out of work and out of study (27\%), and also records the second highest rate of rental accommodation $(53.5 \%)$. Selinunte has the second highest population $(22,210)$, a concentration of ethnic minority groups (30\%), and rented accommodation (55.4\%). Gallaratese too is very deprived in terms of youth unemployment and ageing, but is the area with the lowest number of migrants (4\%) and the highest level of home ownership (82\%).

But there are also housing estates such as San Siro, Comasina and Baggio with relatively low indices of deprivation in terms of unemployment, youth unemployment, and very low shares of rental accommodation $(20 \%, 18 \%$, and $32 \%$ respectively). This picture shows heterogeneity of socio-economic characteristics of large housing estates, despite their frequent amalgamation and homogenisation in images projected by the media. It is important to underline that the concentration of 


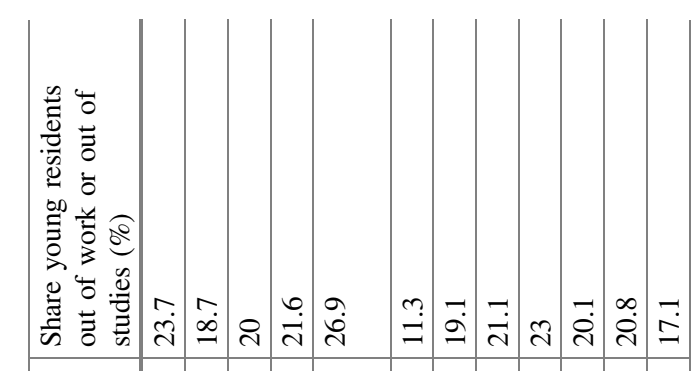

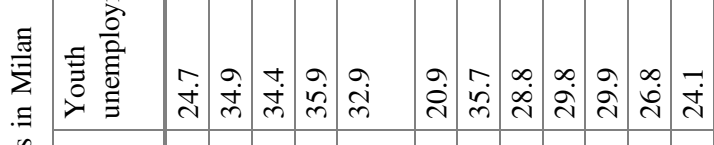

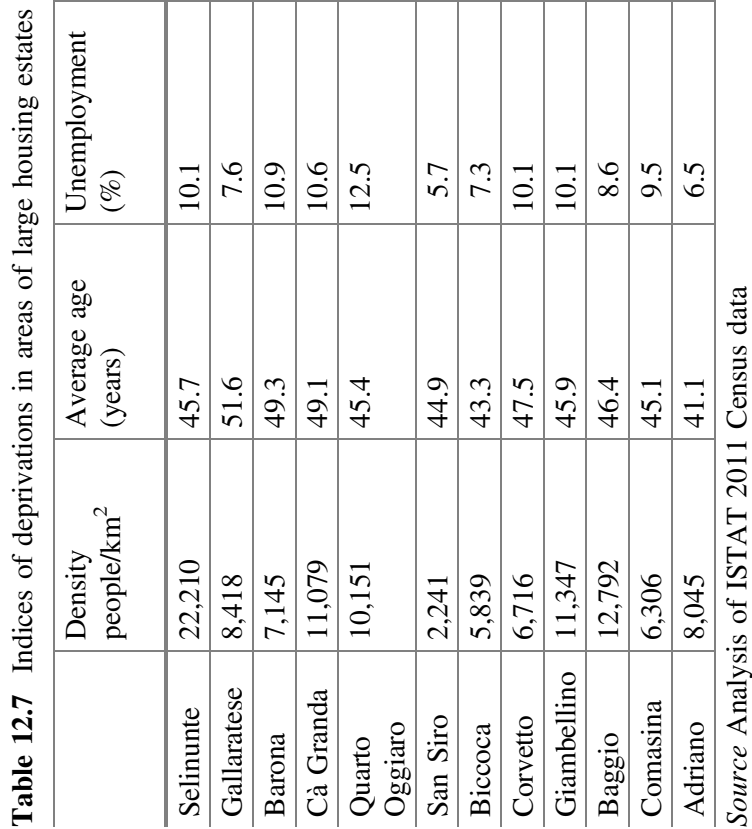




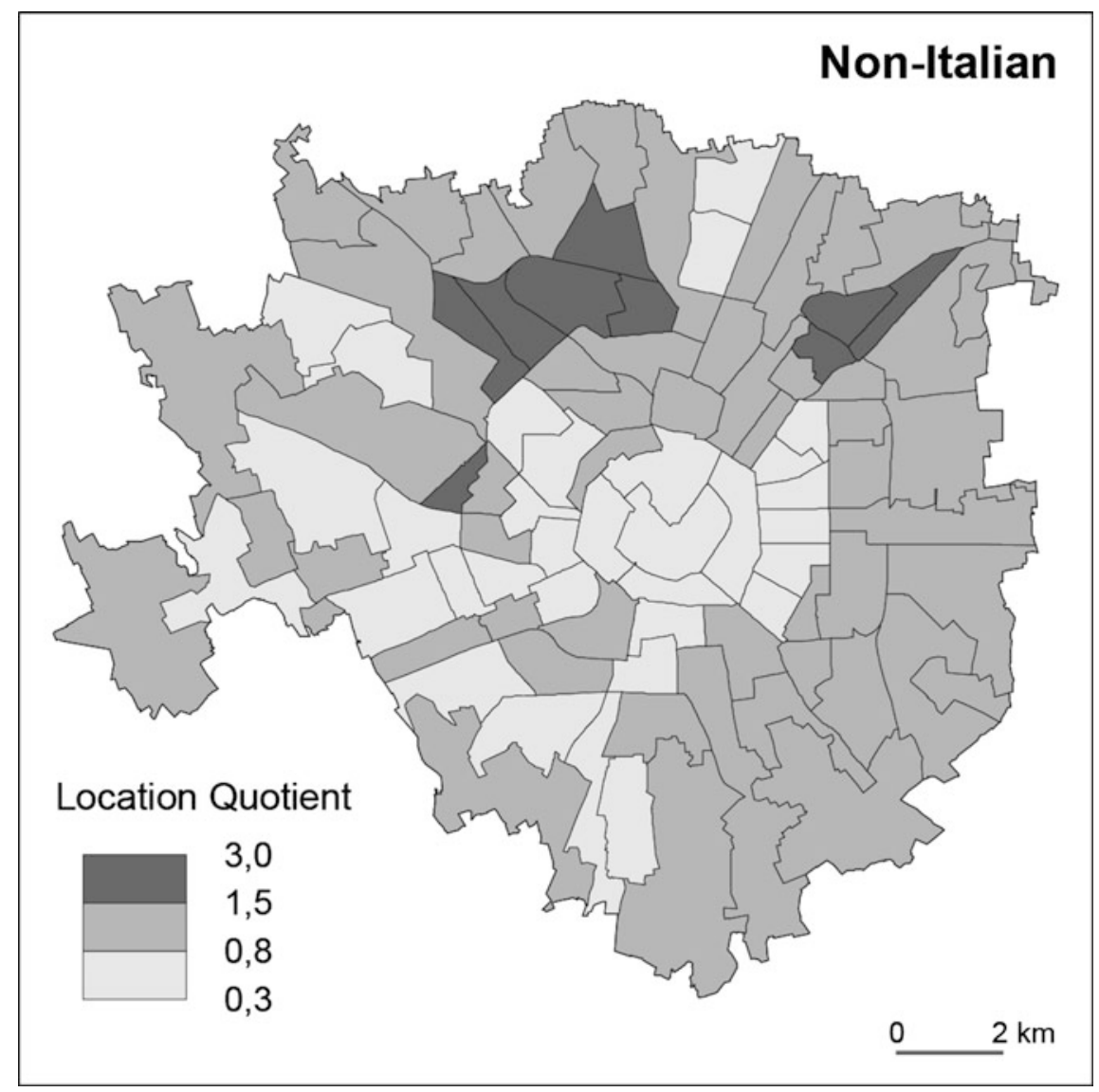

Fig. 12.5 Location quotients of non-Italians, Milan, 2011. Source Analysis of Istat 2011 Census data

social problems is also due to long-term decay and the absence of work opportunities.

Figures 12.5 and 12.6 at the ACE scale based on 2011 census data give indirect supplementary information on the relationship between ethnic segregation and the location of large housing estates.

Non-Italian residents are mainly located in the north of the city and in particular between the edges of the nineteenth-century city and the most distant intra-urban ring, with location quotients up to three times the city average (Fig. 12.5). The highest concentrations are recorded in Selinunte, a zone in north-west (Accursio, Villapizzone, Dergano and Affori) and a sector in the north-east around via Padova (Turro Crescenzago). This representation hides a more complex ethnic division of space due to specific patterns of each ethnic group. 

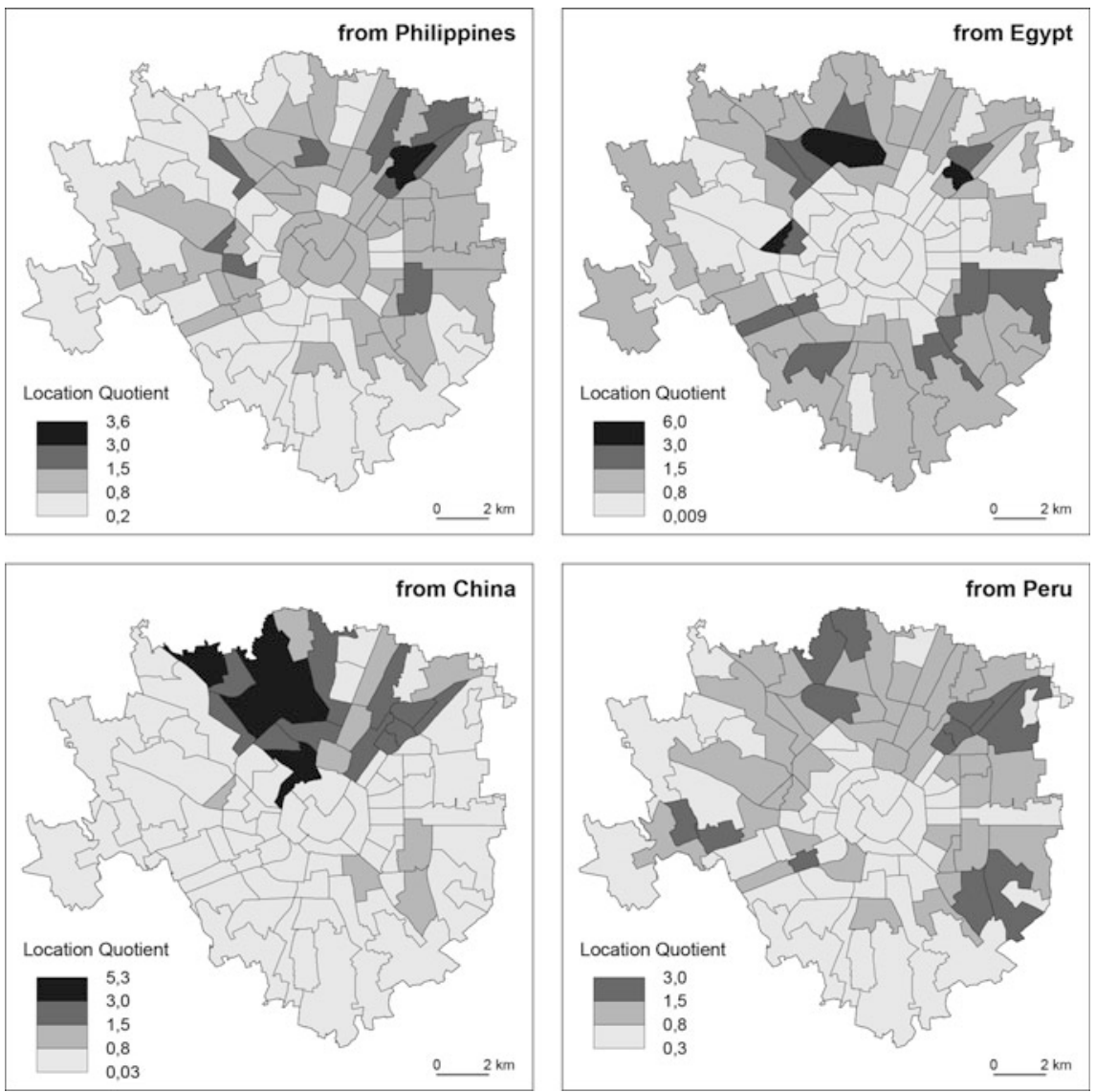

Fig. 12.6 Location quotients of selected ethnic groups, Milan, 2011. Source Analysis of Istat 2011 Census data

Groups with high levels of relative concentration are: Pilipino residents located in Turro and Padova with concentrations 3.6 times greater than the city average; Egyptians in Selinunte (6.0), who are also highly concentrated in Bovisa; and Dergano and Turro (five times the city average) (Fig. 12.6). Chinese residents have a more complex pattern, forming two clusters with high location indices: their central original settlement around via Sarpi (5.3) and more peripheral relative concentrations including Villapizzone, Bovisa, Dergano, Affori and Comasina-Bovisasca with concentrations four times the city average. The category 'other African' are relatively concentrated in Selinunte, Giambellino and Corvetto, with concentrations up to 5.1. Egyptians and 'other Africans' present their highest concentrations in two big housing estates: Selinunte and Giambellino.

Groups with lower levels of segregation are: Romanians, who exhibit a relatively scattered pattern in the most peripheral areas, with relatively low concentrations 
inferior to 2.3; Ecuadorians are dispersed in the city, having their highest concentrations in zones of peripheral estates such as Giambellino, Selinunte, and Viale Umbria (2.5), which are characterised by social deprivation; 'EU (Italian excluded)' are mainly located in the residential areas of the centre (3.2), with concentrations decreasing towards the periphery (with an exception of Musocco); and Peruvians (up to 3.0) are mainly dispersed in the city with two important concentrations in Bisceglie and Baggio.

As we observed earlier in Table 12.1, there is a substantial improvement of the housing conditions in Italy and Milan in particular from the situation described at the end of the 1970s by Garzena and Petsimeris (1984). But this relief represents an average density that hides severe housing problems for many fragile groups of the population (Padovani 1996) in a context of a shrinking welfare state and the end of the production of housing by the public sector for low-income groups (Tosi 1994; CARITAS 2008; Federcasa 2015). This is also due to the change of tenure regimes. In Milan, in the 1950 s, only $23.6 \%$ of the population were owner-occupiers while in the last census their share tripled (74.3). This caused a dramatic decrease of rental accommodations offered for groups of population that are excluded from the market of home ownership. The situation has become more critical since the 1990s with an accentuation of privatisation of social housing and a decline in new production (Table 12.8).

Between 1991 and 2011, there was a 30,000-unit increase in the number of dwellings in Milan. This was not equally distributed to various of housing actors (owners). Private individuals increased by 90,000 their part, the state by 1,000 , and cooperatives decreased by 5,000 . The most dramatic decline was recorded by the public housing sector, which lost 27,000 units in two decades, thereby reducing its share of the total housing stock in Milan from 11 to $6 \%$. The biggest loss occurred in the 1990s due to the national act promoting the privatisation of $50 \%$ of social housing.

From this section, it emerges that even in a context of urban demographic decline, the absence of new public housing production and the erosion of public housing through privatisation, it becomes more difficult for the most fragile social groups to have access to affordable housing.

\subsection{Critical Points and New Challenges}

From this empirical analysis of large housing estates in Milan, a number of points emerge. It is clear that the number of households is increasing faster than the number of dwellings. At the same time, smaller household size indicates the need for an increase in the number of smaller dwellings. The need for housing by economic groups who are excluded from the market (ownership and rent) persists and is increasing. Other groups in acute need of housing are: the elderly, single-parent families, the disabled, and people with special needs. While many 


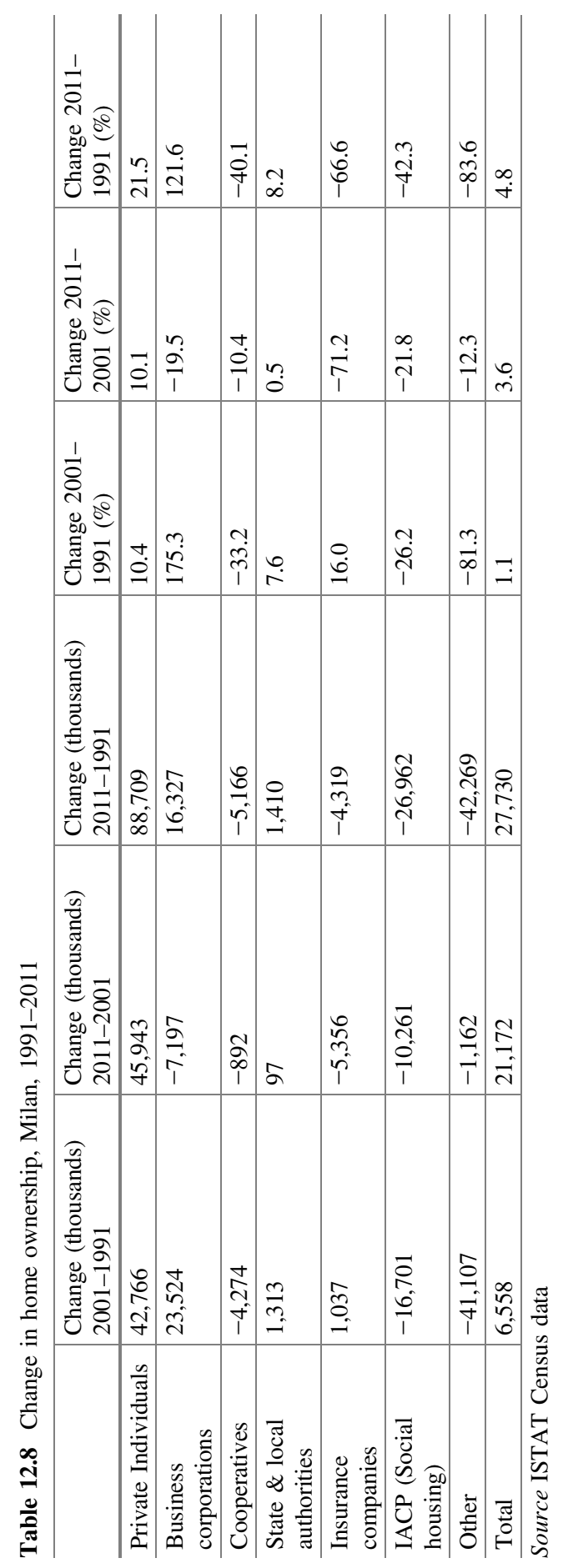


members of these groups are already technically housed, their housing conditions are inadequate.

The fact that many tenants are not paying their rent and charges for electricity, water and/or gas has resulted in physical decay and social conflicts within buildings. Non-payment of charges by illegal occupants adds to the economic problems of ALER or the local authority, further compromising the financing of management and maintenance functions. In interviews in San Siro conducted by the author with older residents, they described their frustration with the continuous worsening of their living conditions, and their growing sense of vulnerability and isolation. One resident stated:

"In these buildings we also experience vertical segregation particularly when the lift is broken for days or weeks. Particularly the old have no access to 'earth' in order to shop or walk or to see friends. My daughter comes from the city to bring me food one or two times per week, walking up all these stairs".

Despite the variety of social housing in terms of size, conception, typologies and the social and economic characteristics of inhabitants, the media produce stereotypes of 'othering'. Although activists on estates have been able to harness parts of the media in order to make their case, their use of social media faces the problem of representation of large, diverse groups of people. The wider context of denationalisation of social housing policies and the erosion - through privatisation - of public housing also needs to be acknowledged. In the case of Milan, the main actors are the city council and ALER (former IACP). These two actors have different budgets. ALER has a more problematic economic situation, such that the two sets of tenants have different opportunities in terms of management and maintenance of their buildings and public space. Future work on these issues will have to overcome the fact that data on large estates is incomplete. While it remains difficult to source data on housing conditions and the characteristics of the inhabitants of large estates, the PIM study and the San Siro Mapping Project offers avenues worthy of exploration.

Another issue relates to the ageing of the housing stock. Most of the housing is between 50 and 100 years old. Some estates - like Selinunte (known also as the Quadrilatero) in San Siro - are experiencing physical decay, and have problems with utility provision (water, electricity). Rehabilitation options must be explored in more detail from a range of perspectives: social, economic and physical. In order to do this, more data is required. There are also problems of ghettoization, particularly in areas characterised by high rates of vacancy and decay, such as Selinunte, Grattosoglio and Giambellino. This has occurred due to the dramatic decrease in resources for investment in social housing. Current levels of finance for renewal are little more than drops in the ocean of Milan's decaying stock of large housing estates.

These physical, data availability and financial problems occur in the context of the latest round of migration. This has been mainly of low-income groups originating from the Global South. The majority of these migrants have no access to social housing and those who have access are directed to the less desired areas or 
ones with quotas. Networks that operate illegal routes to occupation operate in a context of desperate housing need for a large number of migrants. The incidence of illegal occupation has grown since the 1990s and affects Milan more than other Italian cities. Illegal occupation of the ALER housing stock became a frequent phenomenon affecting the most vulnerable segments of the stock: empty dwellings for reasons of turnover or delays in refurbishment (due to the lack of resources and/ or serious structural problems of the buildings). The gravity of the problem varies from estate to estate. In some areas, it spreads very rapidly from the ground floor to the upper floors. One measure of the severity of this problem is the space that it takes on the front page of ALER's website, warning - in Italian, English, French, Spanish and Arabic - that occupation is a crime. A further measure is the fact that eligibility for social housing in Lombardy is denied if the applicant has a record of illegal occupation. Concerning the stock of social housing in Milan, the highest level of occupation occurred in 2014 (1,720 dwellings). In 2016, the new city government announced that the level had been brought down to 2010 levels (i.e. 1,000 dwellings).

There is a very low rate of residential mobility in the large housing estates of Milan's periphery in comparison with the rest of the city (Petsimeris et al. 2015). This is due to the small number of units available. In contrast to the period when a significant proportion of the population vacated the estates - in part as a function of social mobility through education - during the period of austerity, social and residential mobility through employment has declined. Coupled with increases in rents and reduced availability of units for rent relative to the 1960s and 1970s, for a growing proportion of the population, it is currently almost impossible to live in Milan. New migrants cannot move in and the old migrants are caught in place.

A vicious circle linking fragmentation, lack of investment, deterioration, and illegal occupation distresses a high proportion of Milan's large housing estates. The economic crisis increased the problems of both the major actors in public housing and the most vulnerable part of the population. Further privatisation of the housing stock as a means of raising capital for renovation and management is not the best solution, particularly in a period of increasing housing shortage that also affects the middle classes. The non-profit sector can be a solution and some developments within the areas of housing estates such as Barona Village can improve the balance in terms of housing, services and social mix. However, due to the increasing difficulty of attracting private investment, these are likely to be exceptions. In the wider context of neoliberal policies attempting to transfer from the state to the private sector the role of welfare state provisions, social housing in Italy has arrived at this current impasse. Reforms in a number of policy areas, some directly and others indirectly related to housing, will be required in order for progress to be made. 


\section{References}

Belgiojoso L (1972) L'esperienza di un quartiere. Casabella 363:19-26

Bolocan Goldstein M, Botti S (2006) Milano oltre Milano. Racconti della città che cambia 19902005. Skira, Milano

CARITAS (2008) VII Rapporto Caritas/Migrantes sull'immigrazione. IDOS, Roma

Carozzi C, Mioni A (1970) L'italia in formazine; ricerche e saggi sullo sviluppo urbanistico del territorio nazionale. De Donato Editore, Bari

Caruso N (2017) Policies and practices in italian welfare housing. Springer Briefs in Geography. https://doi.org/10.1007/978-3-319-41890-2_2

Castronovo V (1970) L'Istituto autonomo case popolari di Milano dal 1908 al 1970 in Edilizia Popolare. Case Popolari Urbanistica e Leggislazione Milano 1900-1970:13-96

Cerasi M, Ferraresi G (1974) La residenza operaia a Milano. Officina, Roma

Cremaschi M (1994) La denazionalizzazione del problema abitativo. Urbanistica 102:23-28

Dalmasso E (1972) Milano capitale economica d'Italia. Franco Angeli, Milano

Di Biagi P (2001) La grande ricostruzione: il piano Ina-Casa e l'Italia degli anni Cinquanta. Donzelli Editore, Roma

Federcasa L (2015) L'edilizia residenziale pubblica. Elemento centrale della risposta al disagio abitativo e all'abitazione sociale, Federcasa, Roma

Ferracuti G, Marceloni M (1982) La casa; mercato e programazione. Einaudi, Torino

Gambi L (1973) Da città ad area metropolitana. Storia d'Italia 1

Garzena B, Petsimeris P (1984) Estimating future housing needs at the national and regional scales. Ekistics 307(4):309-316

Granata E, Lanzani A (2008) La fabbrica delle periferie. Produzione col-lettive della scarsità, disagio e conflitti latenti a Milano. In: Fregolent L (ed) Periferia e periferie. Roma, Aracne editrice, pp 273-309

Grandi M, Pracchi A (1980) Milano. Guida all'architettura moderna, Zanichelli, Bologna

Graziosi S, Vigano A (1970) Milano vendesi. Relazioni sociali

ILSES (1964) Indagine sul valore delle aree fabbricabili a Milano e nel suo territorio metropolitano dal 1956 al 1963. ILSES, Milano

Indovina F (1972) Lo spreco edilizio. Marsilio Editori, Padova

Marini E (2007) La città pubblica Milanese, in Multiplicity. Lab Milano cronache dell'abitare, Bruno Mondatori, Milano

Mugnano S, Zajczyk F (2008) Ripensando Milano guardando l'Europa: Pratiche di riqualificazione urbana. Edizioni libreria Cortina, Milano

Padovani L (1996) Italy. In: Baltchin P (ed) Housing policy in Europe. Routlege, London, pp 188-209

Petsimeris P (1998) Urban decline and the new social and ethnic divisions in the core cities of the Italian industrial triangle. Urban Stud 35(3):449-465

Petsimeris P, Rimoldi S (2016) Socio-economic segregation in Milan in the post-fordist era. In: Tammaru T, Marcinczak S, van Ham M, Musterd S (eds) Socio-economic segregation in European capital cities/east-meets west. Routledge, London and New York, pp 186-213

Petsimeris P, Rimoldi S, Sanchez-Aguilera D (2015) Changing places and places changing: housing mobility, gentrification and social polarization. In: Moore-Cherry $\mathrm{N}$ (ed) Urban challenges in a complex world: resilience, governance and changing urban systems. Geographical Society of Ireland, Dublin

Priemus H, Dieleman F (2002) Social housing policy in the European union: past, present and perspectives. Urban Stud 39(2):191-200 
Secchi B (1972) Il settore edilizio e fondiario in un processo di sviluppo economico. In: Indovina F (ed) Lo spreco edilizio. Marsilio Editori, Padova, pp 3-46

Tafuri M (1986) Storia dell'architettura italiana 1944-1985. Einaudi, Torino

Tosi A (1994) Abitanti. Le nuove strategie dell'azione abitativa, Il Mulino, Bologna

Tosi A, Cremaschi M (2001) Housing policies in Italy. Interdis-ciplinary Centre for Comparative Research in Social Sciences, Vienna

Open Access This chapter is licensed under the terms of the Creative Commons Attribution 4.0 International License (http://creativecommons.org/licenses/by/4.0/), which permits use, sharing, adaptation, distribution and reproduction in any medium or format, as long as you give appropriate credit to the original author(s) and the source, provide a link to the Creative Commons license and indicate if changes were made.

The images or other third party material in this chapter are included in the chapter's Creative Commons license, unless indicated otherwise in a credit line to the material. If material is not included in the chapter's Creative Commons license and your intended use is not permitted by statutory regulation or exceeds the permitted use, you will need to obtain permission directly from the copyright holder.

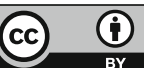




\title{
Chapter 13 \\ Path-Dependent Development of Mass Housing in Moscow, Russia
}

\author{
Maria Gunko, Polina Bogacheva, Andrey Medvedev \\ and Ilya Kashnitsky
}

\begin{abstract}
Since the 1950s, Moscow's housing development has been underlined by modernist planning schemes. From the 20th to 21 st centuries, the quality and appearance of apartment buildings changed, but housing estates designed as coherent neighbourhoods not only remain the principal type of housing organization but are still being constructed in Moscow and its suburbs. Though the concept itself has not been challenged by policy-makers and planners, by the end of the 20th century it became apparent that early housing estates have become a problem due to poor quality of construction. In 2017, the Moscow Government announced a highly controversial program suggesting the demolition of housing estates built between the 1950s and 1960s. Our contribution analyzes the history of housing estates development in Moscow aiming to understand what has led to the adoption of the 2017 "renovation" program. If this program ends up being fully implemented, along with planned renovation of former industrial areas, the cityscape of Russia's capital will be completely redefined.
\end{abstract}

Keywords Mass housing $\cdot$ Housing estates $\cdot$ Moscow, Russia Post-socialist city

M. Gunko $(\bowtie) \cdot$ A. Medvedev

Institute of Geography, Russian Academy of Sciences, Moscow, Russia

e-mail: msgunko@igras.ru
A. Medvedev
e-mail: medvedev@igras.ru
P. Bogacheva
Glorax Development, Moscow, Russia
e-mail: pb-gann@yandex.ru
I. Kashnitsky
National Research University Higher School of Economics, Moscow, Russia
e-mail: ikashnitsky@hse.ru
(C) The Author(s) 2018
D. B. Hess et al. (eds.), Housing Estates in Europe, The Urban Book Series, https://doi.org/10.1007/978-3-319-92813-5_13 


\subsection{Introduction}

A housing supply deficit was a persistent problem in Moscow throughout the 20th century caused by the accelerated rate of city's development. Between 1900s and 1910s the municipal government put much efforts into solving the issue, but lack of planning made the efforts insufficient (Brumfield 2002). The Russian Revolution of 1917 changed all aspects of social life in the country. In August 1918, the decree "On the abolition of private ownership of urban real estate" launched nationalization of housing stock. The first phases of Soviet housing policy, which were mostly about violent redistribution of nationalized properties and "squeezing" (the forced addition of residents to apartments), did not improve average residential conditions. The shortage of housing was further aggravated by a massive and intensified in-migration linked to industrialization (Denissenko and Stepanova 2013). Therefore, there was a strong necessity for cheap and extensive construction of new residential quarters. Meeting the above necessity, large housing estates (zhylye massivy) - uniformly developed housing areas consisting of mid-rise or high-rise apartment building (Metspalu and Hess 2018) and evenly distributed public services and facilities - i.e. outpatient clinics, kindergartens, schools, culture centers - have been constructed in Moscow since the end of 1950s. In Moscow, they are not interventions to the cityscape, rather they form the cityscape outside the historical city center. Moscow's housing estates, especially those constructed in the late Soviet period, tend to be massive in scale. In appearance, they resemble social housing in the countries of the Global North, which was intended for lower social status groups requiring assistance from the state. The difference lies in the Soviet ideology, which extended those principles to the entire population (Vysokovsky 2002).

Even today, new housing estates of various sizes are still being constructed in Moscow and its suburbs. Accounting for a greater part of housing stock in the city, they are not contested as a concept by policy-makers and planners, nor stigmatized in public discourses. However, early housing estates, consisting of so-called khrushchëvki apartment buildings (named after Nikita Khrushchëv during whose reign they were developed), are negatively perceived by many Muscovites. Since the end of the 1990s there have been both large-scale programs aimed at demolition of khrushchëvki neighborhoods, as well as individual reconstructions of apartment buildings based on private investments (Pogorelsky 2017). A highly controversial program announced in the beginning of 2017 suggested the entire demolition of khrushchëvki, replacing them with new housing estates which are to consist of high-rise apartment buildings (Moslenta 2017). In June 2017, Moscow city government approved the demolition of more than 4,000 apartment buildings in various location across the city. This hasty decision and the lack of clarity on implementation mechanisms brought thousands of Moscow residents into the streets in protest (Korzhova 2017). Our contribution analyzes the development of housing estates in Moscow aiming to understand what led to the adoption of the 2017 "renovation" program. If this program ends up being fully implemented along with 
a plan to renovate former industrial areas (Moscow City Hall 2017a), the cityscape of Russia's capital will be completely redefined.

A general limitation of our research is the scarceness of data on population characteristics which is a widely acknowledged problem (Vishnevsky and Zakharov 2010). However, the abundance of large housing estates in Moscow makes the city an interesting case for research; although the dominant nature of this type of housing makes it difficult to judge if some of the urban processes are affected by housing estates per se.

The chapter is structured as follows. First, we provide an overview of mass housing evolution in Moscow during the 20th-21st centuries; second, drawing on available data, we describe the main processes of social change within the city's districts; third, we discuss programs and individual interventions aimed at the alteration of khrushchëvki housing estates; in conclusion, we present an overview of the issues at hand.

\subsection{Evolution of Mass Housing in Moscow During the 20th and 21st Centuries}

During the 20th and 21st centuries, Moscow in its official boundaries increased from $176 \mathrm{~km}^{2}$ in 1915 to $2,519 \mathrm{~km}^{2}$ in 2015 (Fig. 13.1). The population size has correspondingly increased from 1.8 million people to 12 million (Denissenko and Stepanova 2013). Such an expansion has led to a substantial transformation of its built environment and housing development.

There were several waves of mass housing construction in Moscow, different in volume and type of constructed housing, as well as ideology, underlying architecture and urban planning.

The first wave of Soviet housing construction (1920s to mid 1930s) was the era of avant-garde style in architecture, when projects revolutionary in construction and design were proposed and widely implemented. Residential construction was mainly conducted through standalone projects: communal houses and residential complexes of a transitional type, where partial or complete collectivization of everyday life would be possible. Apart from the ideology, it was believed that communal houses helped to save on the cost of living due to collective use of an auxiliary area (Bliznakova 2002). Those houses were built mainly as a comfortable accommodation for non-families, students, and the like (Khan-Magomedov 2007).

The second wave of Soviet construction (mid 1930s to mid 1950) is known as the Stalinist period, which saw a shift towards a distinctly retrospectivist architecture (Paperny 2016). The new style emerged in 1932 with a design contest for the Palace of Soviety, which was never constructed in the end. After this contest, all major projects were proposed in the new Stalinist style, while projects in avant-garde style were no longer approved for construction (Khmelnitsky 2006). The new housing, so-called stalinki, were massive four- to nine-storied apartment 


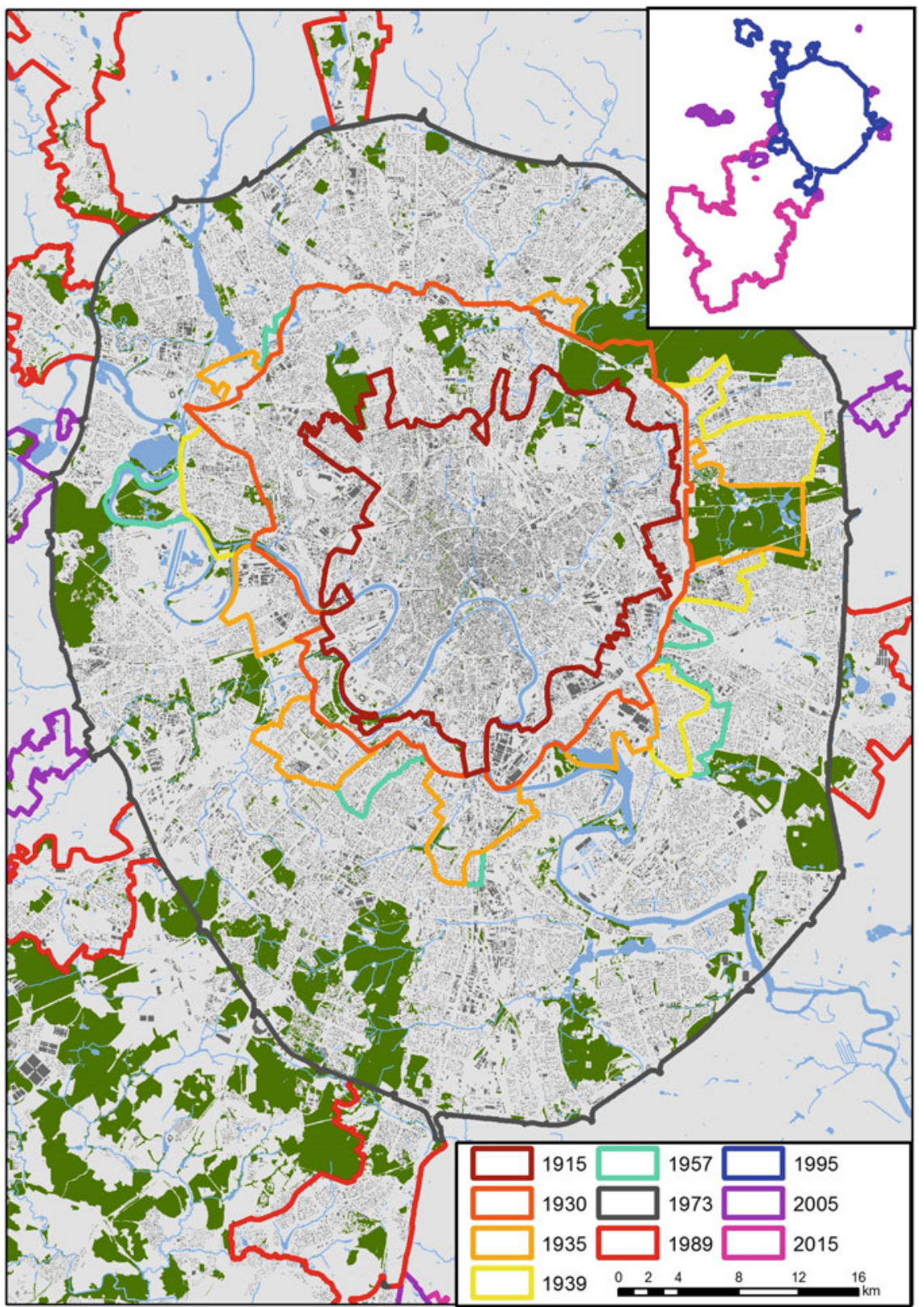

Fig. 13.1 Moscow's official boundaries in the 20th-21st centuries. Figure prepared by: Andrey Medvedev. Source Alferov 1939; Central Intelligence Agency 1957; Katalog geodannikh 2005; Khorkov 1935; Mesheryakov 1930; Portal otkritikh dannykh 2015; Sultanova 1973; Suvorin 1915; Ustav goroda Moskvi 1995; Zaytseva 1989 
buildings with spacious apartments, high ceilings, and rich personal facilities. To build them, some of the old city quarters were demolished in 1932-1934. Stalinki were mainly constructed as individual projects for the upper strata of the Soviet society and were located in prestigious locations of the city. Apart from elite apartment buildings, nine simplified types of stalinki were developed, most of which can be found in Moscow. They consisted of less comfortable housing intended for working class people. Built in small numbers, they were usually located near factories or at the city's outskirts and other neighborhoods with underdeveloped infrastructure. Those simple stalinki formed the first, small- scale housing estates in the city, though it was just the beginning of the housing estates era in Moscow.

The third wave of Soviet construction (mid 1950s to late 1960s). The reign of Nikita Khrushchëv started with a partial reflection on the faults of Stalin's epoch. The resolution "On the elimination of excesses in designing and construction" in 1955 was a notable part of de-Stalinization. Urban planning principles, which had been utilized for a quarter of a century, did not anticipate the development of a city as a system of large residential areas with appropriate infrastructure. Therefore, the basic principles of new, modernist, urban planning were adopted from the West (Khmelnitsky 2017). During the following five to seven years, professional guidelines in urban planning and architecture in the Soviet Union changed significantly, including the norms of providing citizens with housing and social care, the scale of funding for civil construction, principles of organization of the urban environment, typology of housing and residential infrastructure, and official architectural style. The organization of new residential areas closely followed the core principles of Clarence Perry's Neighbourhood Unite Scheme (Perry 1929): main streets with shops were placed along the perimeter of residential areas, with schools and kindergartens in their center surrounded by apartment buildings and green spaces with playgrounds and sports fields.

The khrushchëv period saw a complete transition to housing estates as the main type of mass housing organization in Moscow (and other cities of the Soviet Union), intended for all citizens. This differed fundamentally from Stalin's Moscow, which consisted of a ceremonial center with elite housing for privileged populations and quarters of barrack-like buildings where working class people lived. Newly built housing estates consisted of mid-rise (four- or five-storied) apartment buildings, constructed from panels of large blocks, designed for 80-100 apartments (about 300 inhabitants). Over ten type series of khrushchëvki apartment buildings were developed between the 1950s and 1960s (Fig. 13.2).

Construction of khrushchëvki was aimed to solve the housing shortage problem as quickly as possible, which manifested itself in the low quality of the buildings. The comfort of apartments was traded for speed of construction (Proekty domov 2017). They had low ceilings, extremely small rooms, thin walls, and poor soundproofing. On the other hand, even these low-quality apartments were a huge step forward compared to the previous housing of their new inhabitants.

The first and canonical khrushchëvki housing estates - the Ninth quarter of Novie Cheremushki district in the south-west of Moscow_was planned in 1955- 


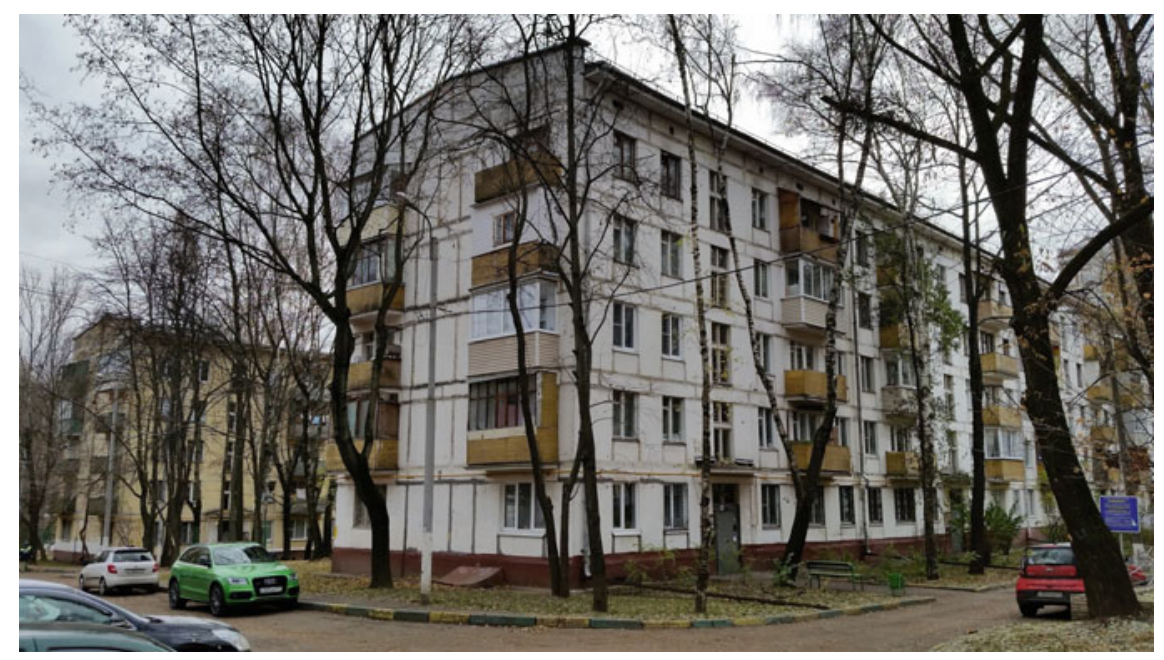

Fig. 13.2 Khrushchëvki apartment building in Nagorny district, southern administrative okrug of Moscow. Source Igor Sokolov

1956 (chief architect Natan Ostermann). The project was already implemented in 1958. This first housing estate became the prototype of all residential areas built in the Soviet Union in coming decades. The name Cheremushki itself became a metaphor signifying a generalized standard of a housing estate with a developed system of public services and monotonous five-storied large-block or large-panel apartment buildings (Ikonnikov 1984).

The fourth wave of Soviet construction (late 1960s to late 1980s). Housing estates consisting of khrushchëvki had for the most part solved the problem of housing shortage in Moscow, although, demand for better quality housing together with nonstop in-migration required continuous territorial expansion of the city. Starting from the late 1960s, housing estates consisted of eight- or nine-storied apartment buildings; later the average number of storeys increased to 12 and to 17 (Fig. 13.3).

Moreover, some of those housing estates constructed in the late 1950s were supplemented by high-rise apartment buildings which somewhat contributed to a revival of those areas, mitigating their monotony. Since this construction started during the reign of Leonid Brezhnev, these high-rise apartment buildings were called brezhnevki, although this term is not widely used because there are at least 40 main housing type series (Proekty domov 2017). Apartments in brezhnevki were more spacious and comfortable compared to those in khrushchëvki. Depending on the type series, each apartment building consists of over 400 apartments (circa 1000 inhabitants). The most common among them are $\Pi-44$ buildings (Fig. 13.4). Around 1200 such apartment buildings were constructed in Moscow's peripheral districts between the 1980s and beginning of 2000 s. 


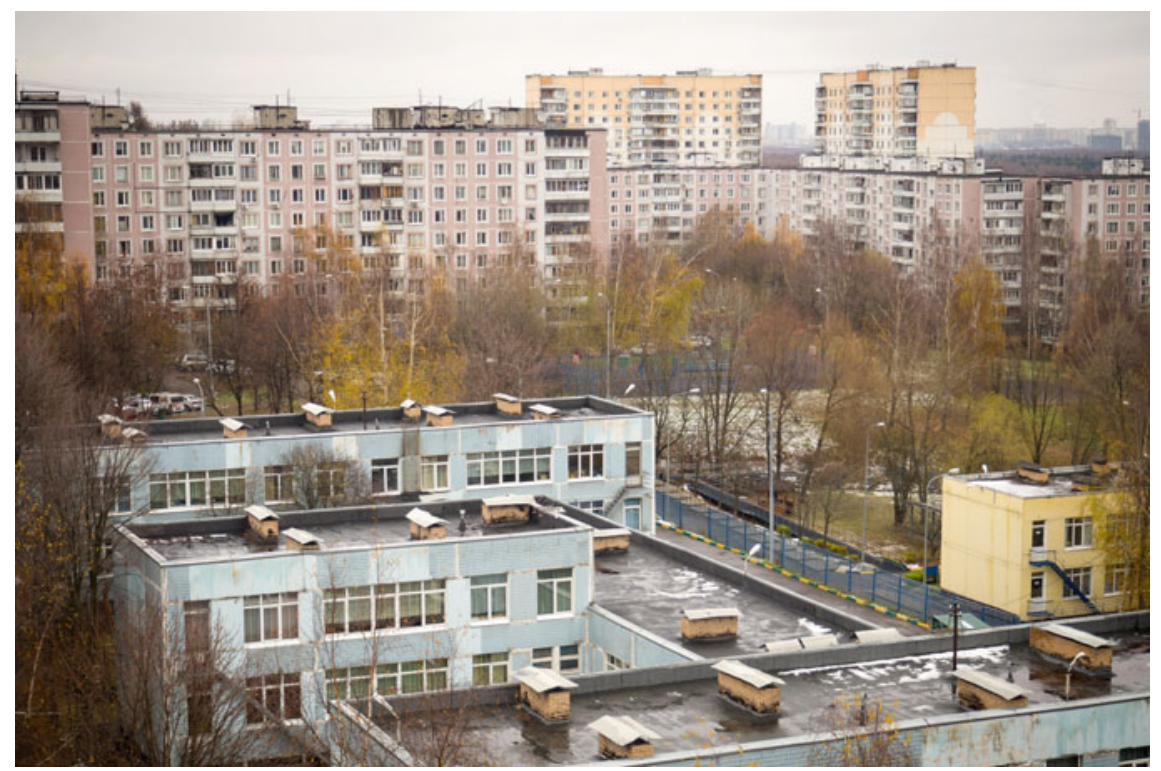

Fig. 13.3 Typical configuration of Soviet neighborhood constructed in 1970s, including a playground, sports field (blue structure behind trees), school (yellow two-storey building) and kindergarten (blue two-storey building) in Yasenevo district, southern administrative okrug of Moscow. Source Inna Zyuganova

Generally, there were two ways to obtain housing in a newly built apartment building in Moscow, and the Soviet Union in general: to lease it from the state (or employer) or to buy a cooperative apartment. However, cooperative apartments, which were distributed among members only, accounted for no more than $8 \%$ of newly constructed housing in Moscow (Kommersant 2010). Public housing was constructed by and belonged to institutions and municipalities. Institutional housing was allocated to workers of enterprises and organizations, as well as some categories of people defined in legislation (e.g. Heroes of the Soviet Union, women with the medal "Mother-heroine", distinguished workers of arts and sciences). The regulations to receive housing from institutions and municipalities were almost identical, except that queues for municipal housing were longer.

The Soviet housing program in Moscow appeared to be successful if you looked at the enormous volume of construction that met an unprecedented housing demand. On the down side, the quality of apartment buildings and the infrastructure in newly constructed quarters were low. For the communist party, the success of the housing program was measured by one key indicator - the number of new square meters constructed. All other important matters like the comfort of the apartments or the aesthetics of living environment were ignored (Ruble 2002; Vysokovsky 2002). Such a quantitative focus resulted in a dull monotony of housing and urban environment in general. Moreover, the choice of accommodation was extremely 


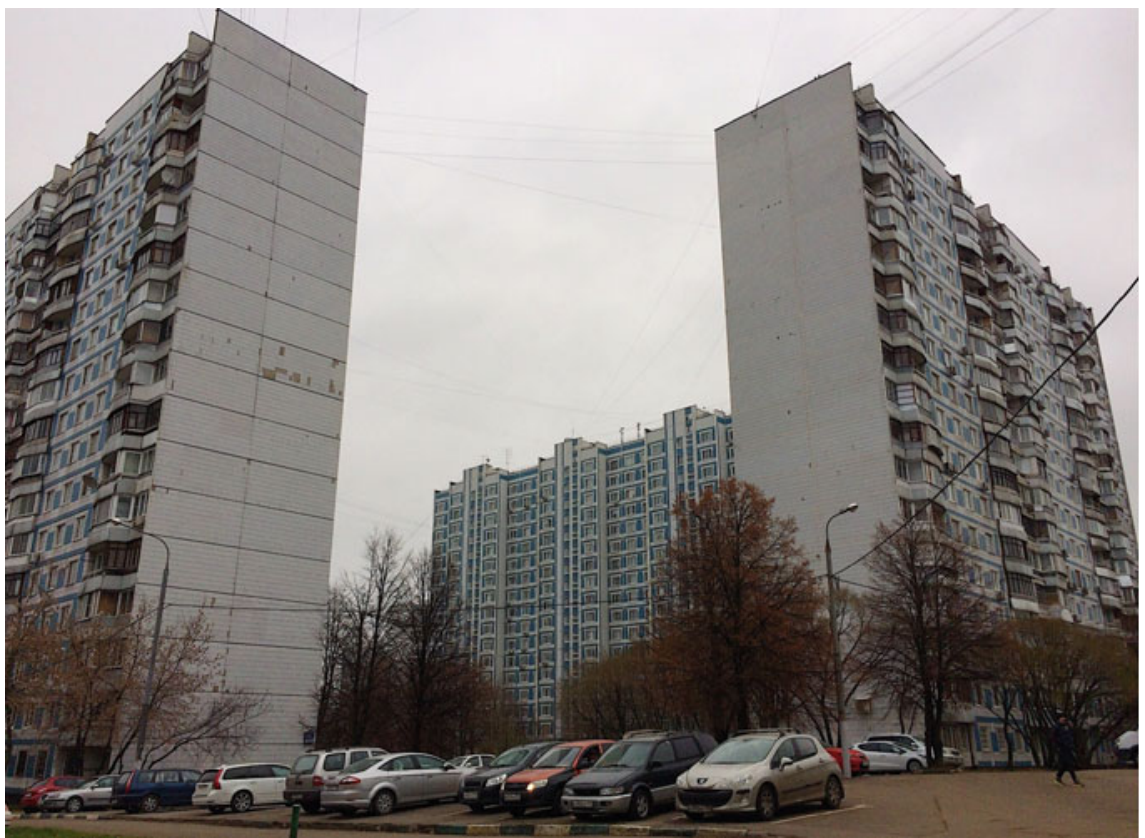

Fig. 13.4 Late Soviet housing estate (constructed in mid-1980s) with П-44 apartment buildings, Orekhovo-Borisovo Uzhnoe district, southern administrative okrug of Moscow. Source Maria Gunko

limited. Housing, just like any other product distributed in the form of rations, was typical, average, and mostly low quality (Khmelnitsky 2017).

Post-Soviet period of construction. One of the main changes in the post-Soviet era was the recognition of private property rights, giving birth to a housing market which resulted in new massive interventions to Moscow's built environment. Mass privatization of housing was officially allowed in Russia on 4 July 1991 when the law "On privatization of housing fund in the Russian Federation" (Russian Government 1991) was adopted. According to the document, housing could be privatized free of charge if there was consent of all residents, timely payment of housing and communal services, and fulfillment of several other conditions depending on the type of housing. No associations were formed to manage apartment buildings. Privatization was individual and voluntary and, if desired, residents could continue living in their apartments without privatizing them on terms of social hiring. At the present time, there are still around $10 \%$ of apartments in Moscow which are not privatized (TASS 2016).

In the early stages of the real estate market, the main property buyers were new businessmen. They preferred elite housing constructed in prestigious locations that usually had big apartments, private parking, and security. Even though this new type of construction was very prominent, the actual share of such buildings in the overall structure of post-Soviet housing stock remains quite moderate. 
Most new housing in the 1990s was panel housing estate built by order of Moscow's city government, which had enormous social responsibilities. New districts were located outside the MKAD, Moscow's Ring Road which circles the city and delineates the "traditional" territory of Moscow, or in previously industrial peripheral areas. More than half of new apartments were allocated to citizens eligible for social housing improvement programs, the remaining were sold freely by the city government itself. By the end of the 2000s, social and commercial housing resembling housing estates in greenfields was finally being squeezed out of the Moscow Ring Road to territory further afield. An exception was the district Kurkino, which is a rare case of a carefully designed neighborhood for 10 thousand inhabitants built of high-quality low-rise houses resembling those in European cities. The apartments here were sold to middle class people, and none of them were allocated via social programs (Postanovlenie Pravitelstva Moskvy 1994).

The global financial crisis of 2008-2009 coupled with a change in the management team of Moscow Government in 2010 naturally affected the development of the city. The issuance of new permits for construction was suspended, while most previously agreed contracts were terminated. As a result, the pace of mass housing construction reduced trifold by 2012; initiation of new projects became very rare. Among other, to boost the stagnating housing market, in 2012, the territory of Moscow was expanded 2.5 times. But even five years later, the New Moscow remains an underdeveloped peripheral area where relatively cheap panel housing estates prevail (Fig. 13.5).

Figure 13.6 illustrates the spatial distribution of housing estates in Moscow. Their construction started at the boundaries of the historical city center, and gradually captured new areas. Currently, the first established mid-rise housing estates are located in the areas of "middle belt", while more recent high-rise housing estates dominate in semi-peripheral and peripheral districts.

\subsection{Socio-spatial Stratification of Moscow}

To better understand socio-spatial stratification of Moscow, one needs to consider long-lasting spatial patterns of housing prestige, which were formed in the 19th century and are still pronounced in the cityscape. There are two major gradients of housing prestige in Moscow: center-peripheral and sectoral (or West-East) (Popov 2014). Today, housing prestige is manifested in the symbolic advantage of the city center where historical and cultural institutions are located. The sectoral differentiation is almost as pronounced as center-peripheral; outside the city center it becomes the prime determinant. Further, we use the term "prestige vector" to designate the more prestigious districts that are located along the major radial highways. There are three such vectors: north-western, south-western and western.

Nationalization of housing in the Soviet Union and the following centralized distribution resulted in a deep social and residential interfusion, when people of different cultural, social, and financial levels began to live in the same apartment 


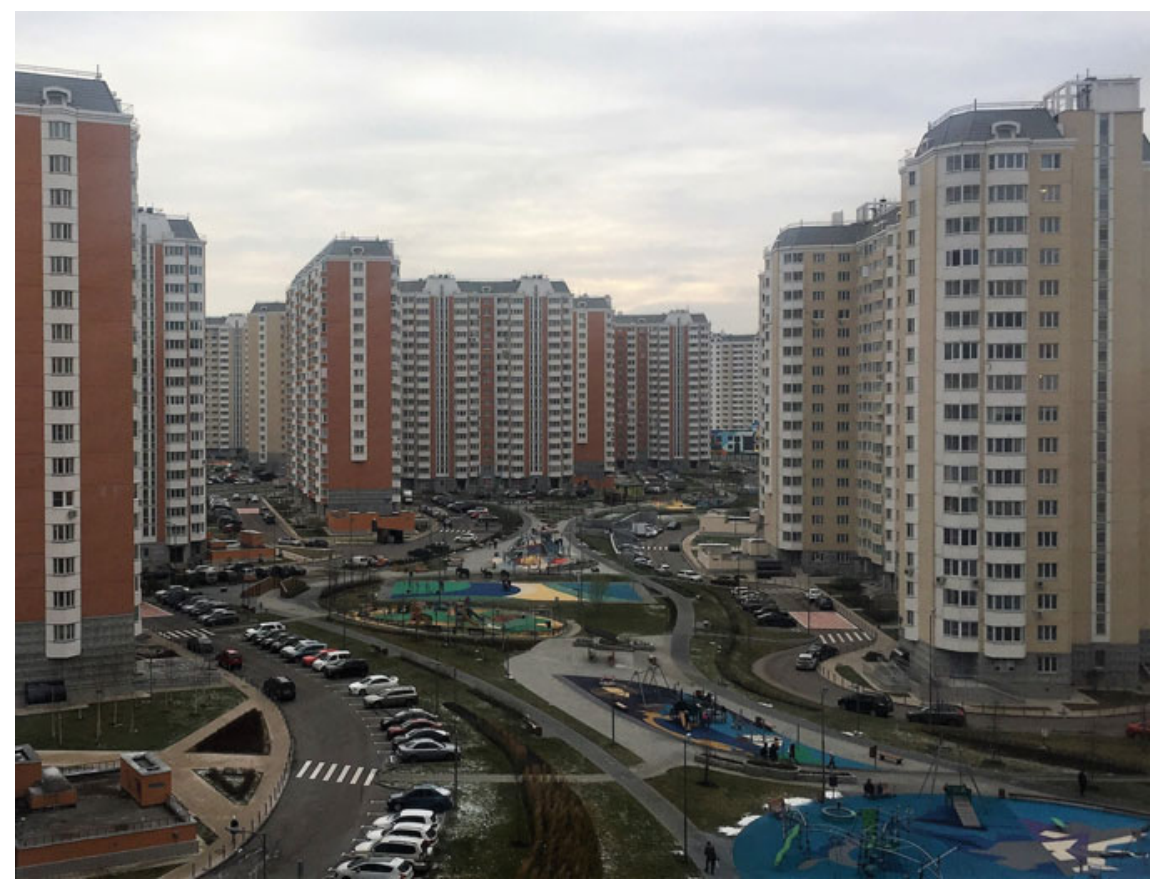

Fig. 13.5 Post-Soviet large housing estate in Vnukovskoe settlement, New Moscow. Source Maria Lazareva

buildings or neighborhoods. Nevertheless, even the new mixed reality was not uniform across the city. Social composition of housing estates was determined largely by the institution that received the property for its employees. People of working class lived mostly in the eastern, south-eastern and southern parts of the city in khrushchëvki and brezhnevki housing estates. Elites resided in the city center and the areas along the prestige vectors where unique elite apartment buildings and housing estates were constructed, forming the so called "golden ghettos". Social stratification existed but was based on occupation rather than income (Vendina 1997). In the post-Soviet period, the emergence of a free housing market, new commercial development, reorganization of industrial enterprises, and finally, increased in-migration and intra-urban mobility of the population were the factors that determined the evolution of socio-spatial stratification in Moscow (Popov 2007). As was noted in the introduction, a significant challenge for our research is the absence of official data on main population characteristics. Therefore, we use proxies based on available data to broadly describe the current patterns of Moscow's socio-spatial stratification at the level of city districts.

Stratification via property is studied using data on housing ownership because rental arrangements are largely undocumented. Furthermore, up to $85 \%$ of Moscow's residents are owners of their properties (Popov 2007). The evolution of property stratification is approximated via transactions in both primary and 


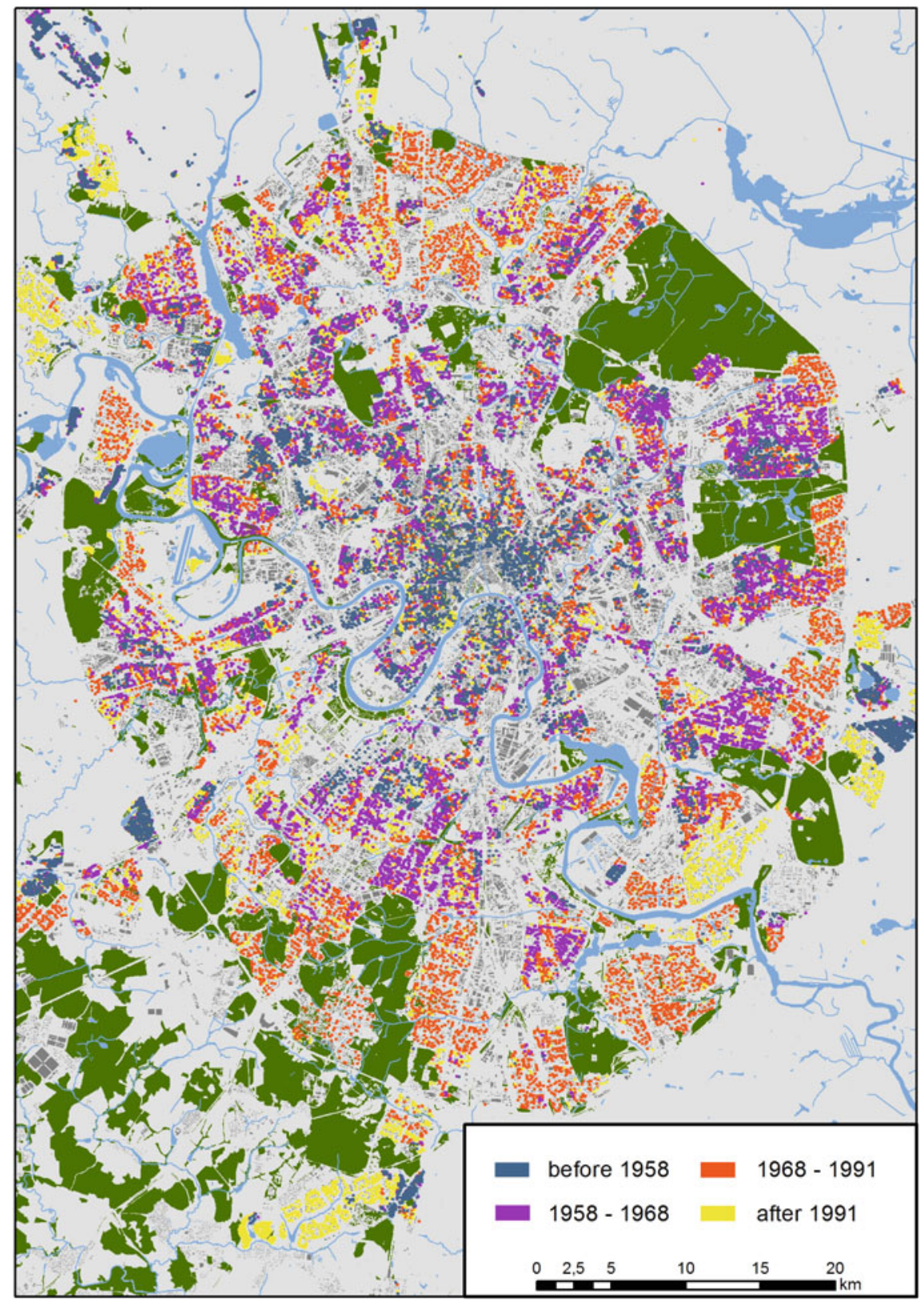

Fig. 13.6 Age of housing in Moscow; locations of housing estates can be delimited with a certain probability based on the dates of housing construction: 1958-1968 are khrushchëvki housing estates, 1969-1990 are brezhnevki housing estates, and after 1990 new housing estates are constructed in peripheral and semi-peripheral districts. Figure prepared by: Andrey Medvedev. Source BTI 2017 
secondary housing markets. At the level of city districts, the average prices for housing clearly show the south-western and north-western prestige vectors. Interestingly, the new elite of the 2000s have been choosing the same locations that were considered prestigious in the era of a planned economy. These areas have some objective advantages like transport infrastructure, amenities, and aesthetic living environment, i.e. proximity to the floodplain of the Moskva River. The property stratification derived from the housing transaction data shows much less stratification in the eastern districts compared with the western locations. Thus, this major spatial pattern indicates that even if there is gentrification (understood widely as "upgrading" of depressed areas) in peripheral and semi-peripheral districts, its pace is slow.

Car ownership per 1000 people in 2010 was highest in the areas of freshly built top-level housing. Thus, the level of motorization is mostly useful for identifying the new most prestigious residential areas.

Educational stratification. A lack of opportunity to freely change the place of residence in the Soviet era created a tendency of settlement near the places of employment, which formed clear boundaries between the zones with population of different educational level. The modern spatial pattern of educational stratification largely inherits patterns of the Soviet era. Higher levels of education were typical not only for the population of the city center, but also the districts located on the south-western and north-western vectors of prestige, where the scientific elite of Moscow State University and the institutes of the Academy of Sciences of the Soviet Union received housing. The belt of housing estates along the north-western vector of prestige was populated by scientific personnel of the aviation and space industries, as well as representatives of creative intelligentsia. The least educated population resided in the industrial east and south, as well as in the northern periphery. The emergence of the housing market launched a somewhat disruption in the spatial distribution of highly educated people. The areas of intensive commercial housing construction in the most recent decades usually attracted new residents of higher educational level, as buyers are mostly middle-class people (Popov, personal communication, 2017; Kuricheva, personal communication, 2017).

To delineate the areas of old and new prestige, we use data on spatial distribution of scientific staff. From the Soviet time, the popularity of a neighborhood among the scientific elite was closely associated with the overall prestige of a district. Even today only areas located along the south-western and north-western prestige vectors have relatively high proportions of residents with scientific degrees. One of the reasons why academic degrees give such a clear distinction lies in the fact that, while the acquisition of higher education in general became more widespread, getting an academic degree is still almost exclusively an endeavor for people of higher social strata.

Electoral pattern of stratification. Electoral geography of Moscow is well-covered in research (Kolosov and Borodulina 2004; Zhidkin 2002). We only focus on the most evident patterns in the way Moscow's population votes, since electoral preferences of the population indicate the dynamics of social movements within the city. For the purposes of interpretation, we divide the political spectrum 
into four broad types (communist, democratic, pro-Government, remainder), and conduct analysis for two periods: 1996-2005 and 2011-2013. There is a clear negative correlation $(-0.96)$ between the support of democrats and pro-Government politics. The support of democrats is higher in the areas of rapid social replacement, where younger and more educated people settle. The support of communists is concentrated in the old prestigious locations, where the academic elites and former nomenklatura reside. However, the areas of voting for democrats and communists intersect; the main distinction between them lies in the speed of social renewal.

Given the fairly stable electoral preferences of the main social groups, the dynamics of voting results can be used to assess changes in the social structure of districts. Central districts, where the process of gentrification is going on, are notorious for their support of democrats, while the leader of democratic voting is the new middle-class district Kurkino. Territories with mass housing construction in the first wave of post-Soviet development, as well as renovated districts, show tendencies towards democratization.

Findings. Various types of social stratification show quite similar spatial patterns giving the opportunity of using a composite index to map them (Fig. 13.7). The composite indicator is the average of five normalized indictors: average price of an apartment bought in the district, number of cars per 1000 people, number of inhabitants with tertiary education per 1000 people, number of inhabitants with an academic degree per 1000 people, share of votes for democrats.

Some transformations of social structures happen uniformly, while others contribute to polarization of the social cityscape. The key role in the process of stratification is played by re-distribution and replacement of population via intra-urban mobility and in-migration. In such an attractive city for migrants as Moscow, it is logical to assume that characteristics of migrants determine the dynamics of the neighborhoods' social structure. The contribution of migration in shaping social structure at the level of city districts was researched in detail previously (Kashnitsky and Gunko 2016) based on migration data for 2012, and no update of this data was published since. Generally, the level of ethnic and social segregation of migrants in Moscow is quite low (Demintseva 2017; Kashnitsky and Gunko 2016). Migrants are able to settle in virtually any districts of the city due to the rich variation of their residential strategies (Demintseva 2017).

The rate of social structure renewal is approximated in the current research by activity in the real estate market. We evaluated the activity of the primary market through the volume and qualitative characteristics of the newly constructed housing stock, and the secondary housing market, through the number of registered housing purchase transactions. The coefficient of social renewal is the arithmetic mean of the normalized renewal ratio of the housing stock and housing transactions. We interpret this composite index as the rate of physical change in the composition of population.

We observe higher levels of the composite index in the following groups of districts (Fig. 13.8). First, central districts, where the share of new housing stock is quite moderate, but the quality of the older apartment buildings is often high. Usually these districts experience top levels of activity at the secondary real estate 


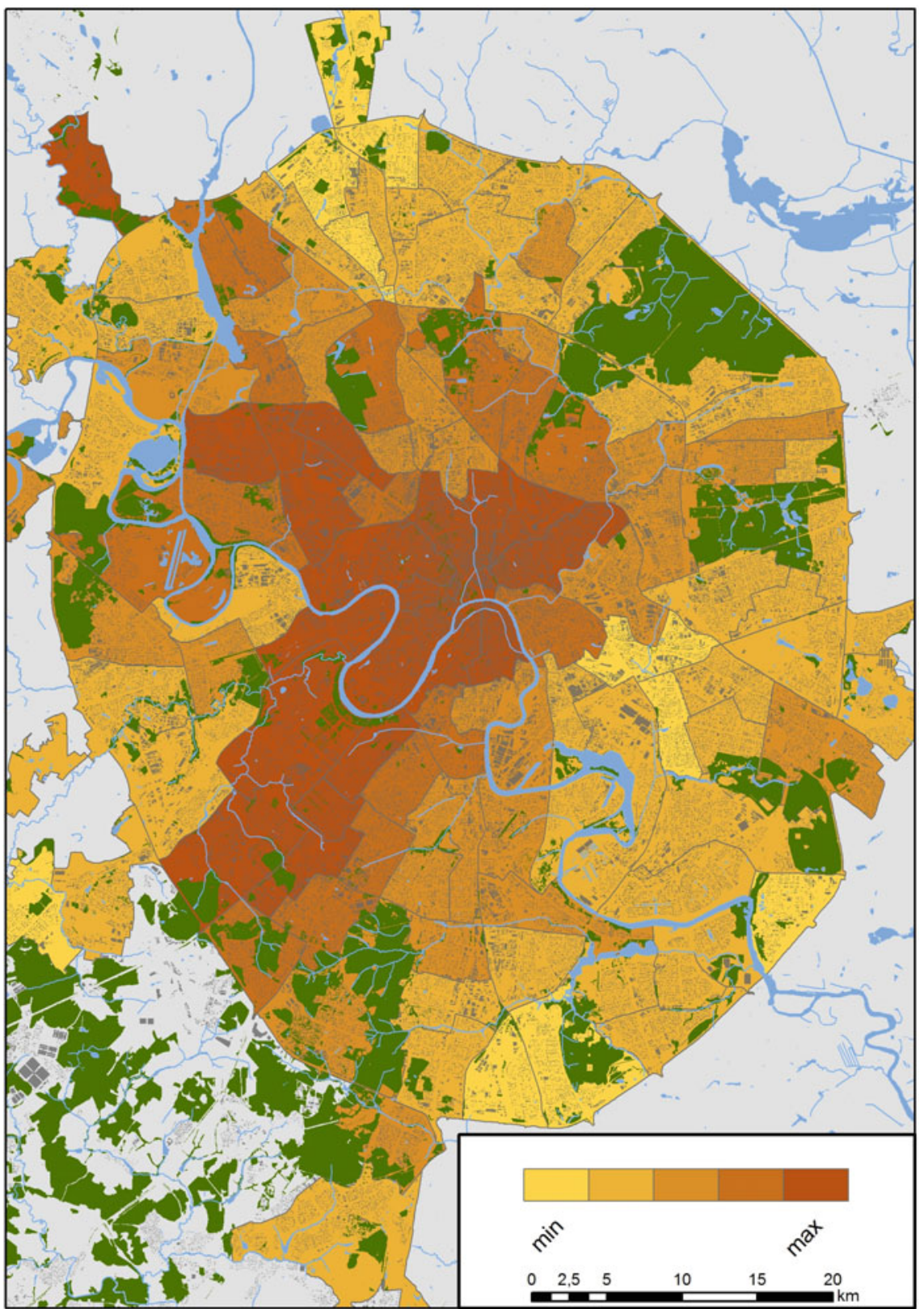

Fig. 13.7 Composite of Moscow's socio-spatial stratification; higher values indicate higher average social status of residents. Figure prepared by: Andrey Medvedev. Source BTI 2017; Department of Territorial Agencies of Executive Power 2012; Rosreestr 2014; Rosstat 2010; TsiK 2014 


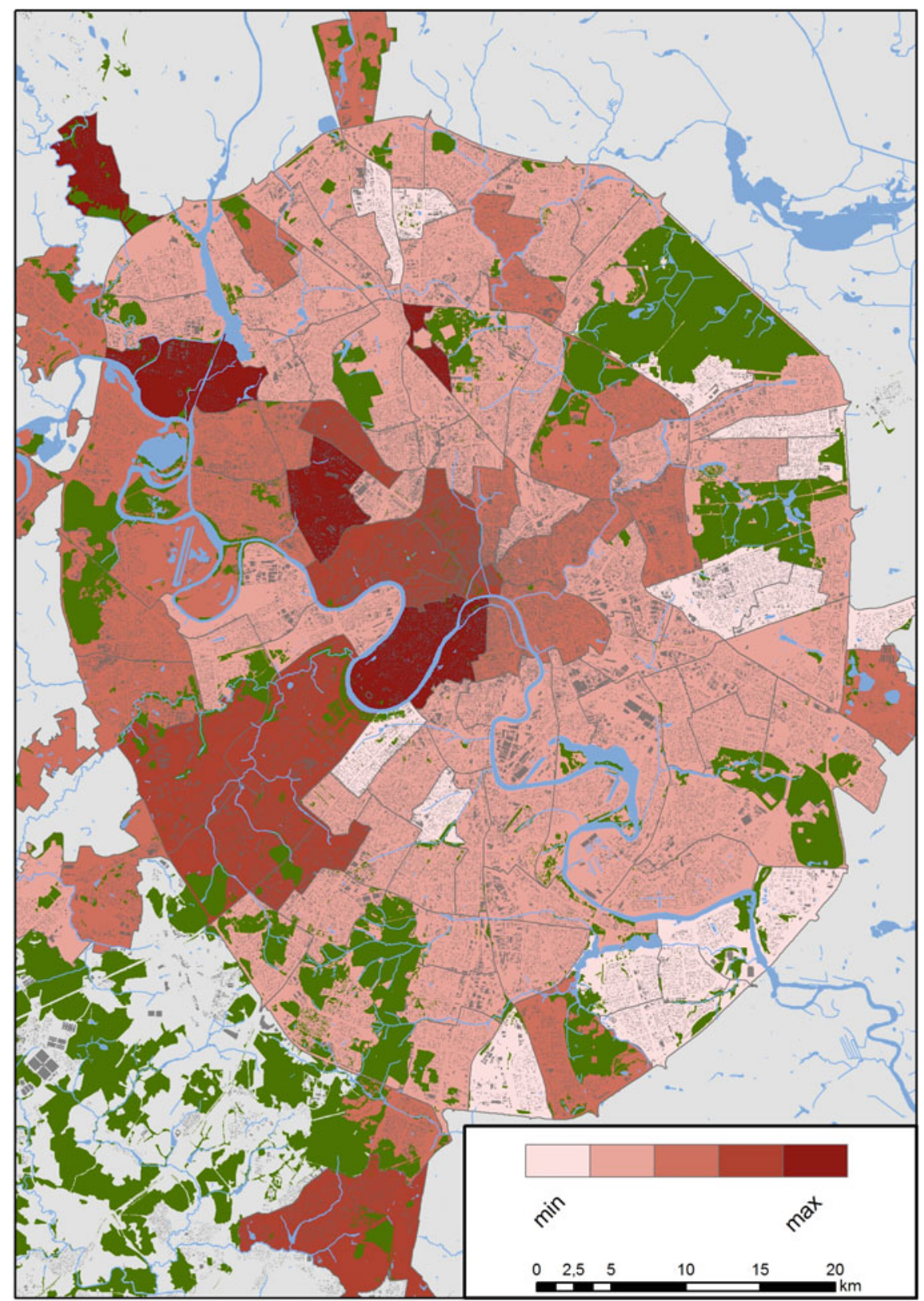

Fig. 13.8 Spatial patterns of the social renewal coefficient. Figure prepared by: Andrey Medvedev. Source BTI 2017; Rosreestr 2014 
market, suggesting an ongoing gentrification. Second, districts along the vectors of prestige with stalinki as the main housing, supplemented by post-Soviet individual elite apartment buildings and housing estates. Third, significantly renovated districts. Two subtypes can be distinguished here: reorganized industrial areas and districts along the vectors of prestige where the first program of khrushchëvki estates demolition was implemented. Fourth, peripheral areas that were developed in the 1990s and early 2000s.

In contrast, low rate of social renewal is characteristic of almost the whole periphery of non-prestigious sectors built up in the late Soviet period with large panel housing estates, particularly southern and south-eastern districts.

Overall, by the beginning of the 2010 s, the social structure of the city was self-reproducing preserving most of the Soviet patterns of socio-spatial stratification. Interestingly, new construction of cheap mass housing does not lead to deterioration of the social structure, but rather improves it. The reason is the general inflated cost of housing in Moscow. As a result, buyers of commercial new buildings, even in the most inexpensive segment, are young, civically-active, educated people with relatively high and stable income (Popov, personal communication, 2017). Furthermore, new housing now is designed to include room at the ground floor for shops, cafes, and other services that are in high demand by local business, which, in turn, positively affects the quality of life in such areas. Therefore, newly developed areas, even those being built up with relatively low-budget housing estates are, in many respects, the centers of positive change on the periphery.

\subsection{Demolition, Reconstruction and "Renovation" of Khrushchëvki Housing Estates}

Built in the1950s and 1960s, khrushchëvki apartment buildings were subject to a complete overhaul 50 years later. However, by the end of the 1980s many buildings were already in derelict condition (Department of Urban Development Policy 2017). In 1988, four apartment buildings were dismantled in Novie Cheremushki district, although demolition did not become widespread. The first organized resettlement took place in 1993 after mass complaints of Fili-Davydkovo district residents who pointed to the unbearable living conditions in khrushchëvki apartment buildings. The cost of neighborhood reconstruction was not included in the city budget so a private investor became involved in the project. After technical examination showed reconstruction to be impossible, a seventeen-storied apartment building was constructed for the resettlement of khrushchëvki residents (Department of Urban Development Policy 2017). 
In 1999, Moscow Government started a program "Comprehensive reconstruction of the areas of five-storied apartment buildings ${ }^{1}$ built during the first period of industrial housing construction" (Moscow Government 1999) which was aimed at demolishing old apartment buildings and replacing them with new ones simultaneously enhancing the built environment, e.g. constructing new playgrounds and recreational spaces. It was intended to demolish apartment buildings according to the type series, thus covering entire housing estates; however, the approach was to evaluate buildings on an individual basis. The program contained strict criteria and reasons for demolition. In order for each particular building to be subjected to demolition, it had to undergo a thorough technical examination to determine its condition and inhabitability. In total 12 million $\mathrm{m}^{2}$ (out of 20 million) of housing have been demolished in the course of the program (Pertsova 2017). The majority of demolished khrushchëvki housing estates were located in the Central, Southern, South-Eastern and Northern administrative Okrugs of Moscow. By the beginning of 2017, around seventy apartment buildings entitled to demolition within the framework of this first phase remained in Moscow (Department of Urban Development Policy 2017).

To relocate residents, new housing was built in the same district by private investors, who had signed a contract with Moscow Government. The excess of apartments was sold freely on the market. Owners of apartments in the apartment buildings entitled to demolition could refuse relocation options proposed by the Moscow Government and require alternatives. Also, there was an opportunity to move into a larger apartment (including one located in another district) by paying for the extra square meters at a market price. Generally, in districts along prestige vectors, elite housing was constructed in place of demolished khrushchëvki. In other districts, replacement housing comprised typical post-Soviet panel housing estates.

Alongside mass demolition, there were individual projects of khrushchëvki renovation and reconstruction based on private initiative and investments. Apartment buildings were not only overhauled, including improvement of water and electrical supply systems, energy efficiency, and soundproofing, but often increased by two or three floors. Residents of such reconstructed buildings did not pay the investors. Investors made their profit from the sales of new apartments located at the overbuilt floors (Pogorelsky 2017).

Today, the remained khrushchëvki are colloquially sometimes called khrushchëby, a combination of words khrushchëvki and trushcheby (slums in Russian) although, with the mixed social landscape within residential neighborhoods and separate apartment buildings remaining from the Soviet times, none of

\footnotetext{
${ }^{1}$ The program was primarily focused at khrushchevki, i.e. mass demolition have undergone khrushchevki type series K-7, II-32, II-35, 1МГ-300, 1605-AM and their modifications; however, other five-storied apartment buildings could have been demolished as well, if they fit the criteria for demolition.
} 
the city districts have become places of true ethnic segregation or socio-economic disparity (Demintseva 2017; Vendina 2004). In February 2017, the question of five-storied housing stock renovation was raised again by the current mayor, Sergey Sobyanin (Moscow City Hall 2017a). Although, there are a number of successful examples of reconstruction of five-storied apartment buildings in other post-socialist cities, as well as in Moscow itself, Moscow Government is campaigning in favor of mass demolition (Pogorelsky 2017; Russian Agency for Legal and Judicial Information 2017). A fundamental difference of the new "renovation" program from the one launched in 1999 is that now it is not only apartment buildings in dire condition that are subject to demolition and resettlement (Pertsova 2017). The initially named volume of the project was 7934 apartment buildings which would result in the resettlement of around 1.6 million people (Bekbulatova et al. 2017). Later, the list of buildings to be included in the program was reviewed. In early May 2017, Moscow Government published a preliminary list of 4566 apartment buildings located in 85 districts. Formal criteria were: date of construction between 1957 and 1968, use of standard construction material and techniques, and maximum height of 5 storeys. In addition to krushchëvki, the list included about 100 buildings which were late stalinki, avant-garde apartment buildings, and pre-revolutionary housing. During one month from 15 May until 15 June 2017, a vote was taken among apartment owners and tenants (if the apartment was not privatized) for the inclusion of apartment buildings from the preliminary list into the program. They could cast their vote through online applications or at meetings of property owners. For the building to be included in the program, two thirds of apartment owners and tenants had to vote for the inclusion. After voting the program included 4087 apartment buildings (Moscow City Hall 2017b). The preliminary list did not include nine-storied panel housing; however, Sergey Sobyanin noted that the city government will consider the possibility of their demolition with the consent of residents, if those apartment buildings are in poor condition and fall within the quarters chosen for the demolitions (Stulov 2017). By August 2017, the renovation program included 5144 apartment buildings (Moscow City Hall 2017c).

So far, it is not immediately clear what will be constructed instead of the demolished housing. Moscow Government announced plans to hold an international architectural contest for the development of new neighborhoods which will be erected at five experimental sites in the city (Vedomosti 2017). According to Sergey Sobyanin, the number of storeys in new apartment buildings will be up to twenty, individually determined for each neighborhood (Moslenta 2017). The new program has been criticized by many experts and civic activists (e.g. Zubarevich 2017), and its proposal led to mass street protests at the end of spring 2017. There is a widespread perception that Moscow Government lacks money and resources to implement the program (Liyauv and Gruzinova 2017). 


\subsection{Conclusion}

The post-Soviet period saw a major but not yet uniform shift towards a better quality of living environment in Moscow. The majority of derelict apartment buildings were demolished, as well as estates of obsolete housing built in the 1950s and 1960s. Traditional panel construction was reviewed in 2015 when new standards of construction quality were adopted (Department of Urban Development Policy 2017). Implementation of "My Street", a project of the Moscow Government aimed at improving the aesthetics of the urban landscape, began in 2016. Within its framework, streets are being repaired and landscaped, while the facades of buildings are restored and lighted (Moscow City Hall 2017a). But despite all innovations and improvements, housing estates remain the principal type of housing organization. First constructed in the $1950 \mathrm{~s}$ to address the unprecedented housing need, they have undergone changes in appearance, but the original modernist planning scheme is still reproduced in newly developed residential quarters. The number of new housing estates within the traditional geographical territory of Moscow, delineated by the Moscow Ring Road, decreased, but apartment buildings within it grew in height. Developers prefer to construct multistoried complexes to maximize revenues as the usual area for construction is barely 5-7 hectares (Popov, personal communication 2017). In the New Moscow where available lands are still abundant, new housing comprises massive panel housing estates built in "green fields", while individual projects like the low-rise complex Kurkino are rather an exception.

Since the collapse of the Soviet Union, interventions to Moscow's housing estates from the city's Government and property owners have been primarily driven by the poor condition of apartment buildings. In 2017, the mass demolition of khrushchëvki housing estates proposed by the Moscow Government has become the main topic on the agenda of architects, planners, and civic society. The need to do something with the remaining khrushchëvki housing stock is recognized by most experts (Zaytseva and Kosareva 2017), but there is still no consensus on how to reconstruct the quarters (Butuzova 2017). Meanwhile, no interventions are being suggested to alter housing estates constructed in the late Soviet times where the quality of the apartment buildings is relatively high, compared to that of khrushchëvki. Those neigbourhoods, however, face other problems, among them poor quality of public spaces, lack of both high- and low-end commercial services and amenities, low aesthetic qualities of the living environment (Novikov, personal communication, 2017; Kuricheva, personal communication, 2017). Not being the object of a deliberate policy, positive changes in those neighborhoods, if any, are usually the result of coincidence rather than planned actions of the city Government (Popov, personal communication, 2017).

At the moment, it is difficult to say how the areas where mass demolition of khrushchëvki has been proposed will change, since the prospect of their redevelopment has not yet been presented to the public and discussed. One thing is certain - the concurrent demolition of khrushchëvki quarters and the gentrification of 
Moscow's old industrial zones may potentially bring long-awaited changes to the stagnated Moscow cityscape.

Acknowledgements The authors express deep gratitude to all experts who participated in interviews and to colleagues who helped with illustrative material. The research was supported by the Basic Research Program of the National Research University Higher School of Economics and Basic Research Program of the Institute of Geography, Russian Academy of Sciences (No. 01201352495 and No. 01201352481).

\section{List of interviewees}

Ekaterina DEMINTSEVA - director of the Centre for Qualitative Social Policy Research at the National Research University Higher School of Economics, Moscow. Interview held on 11 April 2017.

Yury KOCHETKOV - head of analytics and marketing department at the engineering and construction company IFK "Fort", Moscow. Interview held on 23 June 2017.

Ekaterina KURICHEVA - senior analyst at design bureau KB Strelka, Moscow. Interview held on 24 April 2017.

Alexey NOVIKOV - dean of the Vysokovsky Graduate School of Urbanism at the National Research University "Higher School of Economics", Moscow; president of Habidatum International, Inc., New York. Interview held on 19 May 2017.

Alexey POPOV - head of the Centre for Real Estate Data and Analytics (CIAN), Moscow. Interview held on 17 May 2017.

\section{References}

Alferov NV (1939) Plan Moskvi [General layout of Moscow]. Moscow

Bekbulatova T, Voronov A, Ivanov M (2017) Renovatsiya na marshe [Renovation on the march]. Kommersant. https://www.kommersant.ru/doc/3237430

Bliznakova M (2002) Sovetskoy zhilishnoe stroitelstvo v godi eksperimenta 1918-1933 [The Soviet housing construction in the years of experiment 1918-1933]. In: Brumfield WC, Ruble B (eds) Zhylitshe v Rossii XX vek. Tri kvadrata, Moscow, pp 53-89

Brumfield WC (2002) Stroitelstvo: komfort i pribil [Construction comfort and profit]. In: Brumfield WC, Ruble B (eds) Zhylitshe v Rossii XX vek. Tri kvadrata, Moscow, pp 35-52

BTI (2017) Database of Moscow housing. Moscow Bureau of Technical Inventory. http://www. mosgorbti.ru

Butuzova L (2017) Arkhitektor Krotov—o renovatsii: "Moskvichi rastvorytsya kak sakhar v chae" [Architect Krotov - about the renovation: "Muscovites will dissolve like sugar in tea"]. Novie Izvestiya. https://newizv.ru/interview/14-04-2017/arhitektor-krotov-o-renovatsii-moskvichirastvoryatsya-kak-sahar-v-chae

Central Intelligence Agency (1957) Guide to streets and locations in Moscow

Demintseva E (2017) Labour migrants in post-Soviet Moscow: patterns of settlement. J Ethnic Migrat Stud 43(15):2556-2572. https://doi.org/10.1080/1369183X.2017.1294053 
Denissenko MB, Stepanova AV (2013) Dinamika chislennosti naseleniya Moskvi za 140 let [Dynamics of Moscow population over 140 years]. Vestnik MSU. Economics 3:88-97.

Department of Territorial Agencies of Executive Power (2012) Programs of integrated development of Moscow's administrative districts 2012-2016. Moscow Government, Moscow. http://dtoiv.mos.ru/legislation/projectsotchets/detail/851969.html

Department of Urban Development Policy (2017) Kompleks gradostroitelnoy politiki [Housing policy roadmap]. Moscow Government. https://stroi.mos.ru/snos-piatietazhiek

Ikonnikov AV (1984) Arkhitektura Moskvi: XX vek [The architecture of Moscow: 20 century]. Moskovsky rabochy, Moscow

Kashnitsky I, Gunko M (2016) Spatial variation of in-migration to Moscow: testing the effect of housing market. Cities 59:30-39. https://doi.org/10.1016/j.cities.2016.05.025

Katalog geodannikh (2005) Catalogue of Moscow city geodata. Moscow committee on urban planning and architecture. http://egip.mka.mos.ru/egip/egip.nsf/va_GeoDataCatalogByCat? OpenView

Khan-Magomedov SO (2007) Ilya Golosov. Arkhitektura-S, Moscow

Khmelnitsky DS (2006) Arkhitektura Stalina: Psikhologiya i stil [Stalin's architecture: Psyhology and style]. Progress-Traditsiya, Moscow

Khmelnitsky DS (2017) Reformy Hrushheva. Chto sluchilos' s sovetskoj arhitekturoj v pjatidesjatye gody? [The reforms of Khruschëv. What happened to the Soviet architecture in the 1950s?]. Gefter. http://gefter.ru/archive/21563

Khorkov BF (1935) Skhema planirovki Moskvi [A planning scheme of Moscow]. Moskovsky rabochy, Moscow

Kolosov VA, Borodulina NA (2004) Elektoralnie predpochteniya izbirateley krupnikh gorodov Rossii: tipy i ustoychivost (1995-2003) [The electoral preferences of voters in large Russian cities: types and stability (1995-2003)]. Polis (Politicheskie Issledovaniya) 4:70-79

Kommersant (2010) Zhylyschnye kooperativy v SSSR [Housing cooperatives in the USSR]. https://www.kommersant.ru/doc/1495585

Korzhova D (2017) Protestujushhie protiv snosa pjatijetazhek v Moskve prinjali rezoljuciju [Protesters against the demolition of five-story buildings in Moscow adopted a resolution]. Vedomosti. https://www.vedomosti.ru/realty/articles/2017/05/14/689732-protestuyuschie-protivsnosa-pyatietazhek

Liyauv B, Gruzinova I (2017) Snos pyatietazhek kak predvybornaya programma Sobyanina. Snos pyatietazhek kak predvybornaya programma Sobyanina [Demolition of five-story buildings as a pre-election program Sobyanin]. Vedomosti. https://www.vedomosti.ru/politics/articles/ 2017/03/06/680010-snos-pyatietazhek-kak-predvibornaya-programma

Mesheryakov NL (1930) Moskva. Skhematichesky plan [Moscow. A schematic general layout], Sovetskaya entsiklopediya, Moscow

Metspalu, Hess DB (2018) Revisiting the role of architects in planning large-scale housing in the USSR: the birth of three large housing estates in Tallinn, Estonia. Plan Perspect 33(3):335-361. https://doi.org/10.1080/02665433.2017.1348974

Moscow City Hall (2017a) City's projects. https://www.mos.ru/city/projects/

Moscow City Hall (2017b) Itogi golosovaniya po proektu renovatsii [The voting results on the renovation project]. https://www.mos.ru/news/item/25633073/

Moscow City Hall (2017c) A map has been published showing houses that entered the renovation program of the house. https://www.mos.ru/news/item/27345073

Moscow Government (1999) Resolution of the Moscow Government. http://docs.cntd.ru/ document/901738444

Moslenta (2017) Renovatsionnyy opyt [Renovation experience]. https://moslenta.ru/govoryat/ francuzskiiopyt.htm

Paperny VZ (2016) Kultura dva [The second culture], 4th edn. Novoe literaturnoe obozrenie, Moscow

Perry C (1929) The neighborhood unit, a scheme of arrangement for the family-life community. Regional survey of New York and its environs, vol 7. Committee on the Regional Plan of New York and Its Environs, New York, pp 2-140 
Pertsova V (2017) Sobyanin i Luzhkov: kak razlichajutsya programmy ren-ovacii dvuh moskovskih mjerov [Sobyanin and Luzhkov: how different are the programs for the renovation of two Moscow mayors]. Forbes. http://www.forbes.ru/biznes/344649-sobyanin-iluzhkov-chem-otlichayutsya-programmy-renovacii-dvuh-moskovskih-merov

Pogorelsky A (2017) Nadstrojka 2.0. Kak zhiteli pjatijetazhek Moskvy ras-shirjajut svoi kvartiry [Add-on 2.0. How the inhabitants of 5-storeyed buildings enlarge their apartments]. RBK. https://realty.rbc.ru/news/598478429a79473d6b86ebbe

Popov AA (2007) Territorialnaya differentsiatsia kachestva gorodskoy sredy v Moskve [Spatial differentiation of urban environment quality in Moscow].Vestnik MSU. Geography 4:29-36

Popov AA (2014) Prostranstvenno-vremennoj analiz faktorov tsenoobra-zovaniya na rinke zhiloj nedvizhimosti [Spatiotemporal analysis of key factors for residential real estate estimates in Moscow]. Regionalnie issledavaniya 46(4):70-80

Portal otkritikh dannykh (2015) The open data portal of the Moscow Government. Moscow Government. https://data.mos.ru/

Postanovlenie Pravitelstva Moskvy (1994) Postanovlenie Pravitelstva Moskvi \# 471-ПП ot 7.06.1994 "O zastroyke zhilogo rayona Kurkino" [The Resolution of the Moscow Government № 471-ПП from 7.06.1994 "About the development of residential district "Kurkino"].

Proekty domov (2017) Proekty domov po periodam industrialnogo domodtroeniya [Specifications of houses by periods of industrial housing construction]. http://www.apb1.ru/proekty-domovpo-periodam-industrialnogo-domostroeniya.html

Rosreestr (2014) Database of Moscow's real estate. Russian Federal service for state registration, cadastre, and cartography in Moscow. https://portal.rosreestr.ru/wps/portal/p/is/cc_informSections/ ais_mrn

Rosstat (2010) Russian Census 2010. Population structure by municipalities. Federal State Statistics Service. http://www.gks.ru/free_doc/new_site/perepis2010/croc/perepis_itogi1612.htm

Ruble B (2002) Ot "khrosheb" k korobkam [From "khroshebi" to boxes]. In: Brumfield WC, Ruble B (eds) Zhylitshe v Rossii XX vek. Tri kvadrata, Moscow, pp 139-161

Russian Agency for Legal and Judicial Information (2017) Snos khrushchevok v Moskve: al'ternativnyye stsenarii [Demolition of Khrushchev in Moscow: alternative scenarios]. http:// www.rapsinews.ru/incident_publication/20170411/278158355.html

Russian Government (1991) Federalniy zakon ot 4.07.1991 \# 1541-1 "O privatizatsii zhilogo fonda v Rossii" [Federal law from 4.07.1991 \# 1541-1 "On the privatization of housing in Russia"]. http://www.consultant.ru/document/cons_doc_LAW_100/

Stulov M (2017). Pod snos v Moske mogut popast ne tolko khruchevki, no i devytaetazhki [Not only khruchevki may be demolished in Moscow, but also nine storey houses]. Vedomosti. https://www.vedomosti.ru/economics/articles/2017/03/06/680008-snos-moskve-hruschevkidevyatietazhki

Sultanova N (1973) Skhematichesky plan [Moscow. A schematic general layout]. Moskovsky rabochy, Moscow

Suvorin AS (1915) Plan goroda Moskvy s prigorodami [General layout of Moscow city with suburbs]. Novoe vremiya, Moscow

TASS (2016) Privatizatsiya zhil'ya v Rossii [Privatization of housing in Russia]. http://tass.ru/ info/3426534

TsiK (2014) Database of the Russian central election commission. Russian central election commission. http://www.vybory.izbirkom.ru/region/izbirkom

Ustav goroda Moskvi (1995) Zakon goroda Moskvi ot 28.06.1995 [Law of Moscow city from 28.06.1995]

Vedomosti (2017) Vlasti Moskvy provedut arkhitekturnyy konkurs po programme renovatsii zhil'ya [The Moscow authorities will hold an architectural competition for the program of housing renovation]. https://www.vedomosti.ru/realty/news/2017/04/25/687305-arhitekturniikonkurs-programme-renovatsii

Vendina OI (1997) Transformation processes in Moscow and intra-urban stratification of population. GeoJournal 42(4):349-363. https://doi.org/10.1023/A:1006890108182 
Vendina OI (2004) Moskva etnicheskaya: grozit li gorodu getoizaciya? [Ethnic Moscow: will the city turn into a ghetto?]. Demoscope Weekly 177-178. http://demoscope.ru/weekly/2004/ 0177/tema01.php

Vishnevsky AG, Zakharov SV (2010) Chto znaet i chego ne znaet ros-siyskaya demograficheskaya statistika [What Russian demographic statistics does and does not know]. Voprosi Statistiki $2: 7-17$

Vysokovsky AA (2002) Ujut-ne-geroy [Comfort is not a hero]. In: Brumfield WC, Ruble B (eds) Zhylitshe v Rossii XX vek. Tri kvadrata, Moscow

Zaytseva ME (1989) Moskva. Plan goroda [Moscow. General layout]. GUGK, Moscow

Zaytseva O, Kosareva NB (2017) Vorkug "khrusheb" [Around "khrushevki"]. Polit.ru. http://polit. ru/article/2017/04/27/khrushchevki

Zhidkin AP (2002) Territorialnie razlichiya v structure i dinamike elektoralnikh predpochteniy naseleniya Rossii [Territorial differences in the structure and dynamics of Russian population's electoral preferences] (Unpublished thesis). Lomonosov Moscow State University, Moscow

Zubarevich NV (2017) Stolichnie "vershki" i "koreshki" [Capital's "winners" and "losers"]. Vedomosti. https://www.vedomosti.ru/newspaper/articles/2017/04/26/687706-vershki-koreshki

Open Access This chapter is licensed under the terms of the Creative Commons Attribution 4.0 International License (http://creativecommons.org/licenses/by/4.0/), which permits use, sharing, adaptation, distribution and reproduction in any medium or format, as long as you give appropriate credit to the original author(s) and the source, provide a link to the Creative Commons license and indicate if changes were made.

The images or other third party material in this chapter are included in the chapter's Creative Commons license, unless indicated otherwise in a credit line to the material. If material is not included in the chapter's Creative Commons license and your intended use is not permitted by statutory regulation or exceeds the permitted use, you will need to obtain permission directly from the copyright holder.

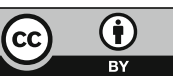




\title{
Chapter 14 \\ Impoverishment and Social \\ Fragmentation in Housing Estates \\ of the Paris Region, France
}

\author{
Christine Lelévrier and Talia Melic
}

\begin{abstract}
This chapter provides a historical overview of the construction and renewal programmes of large housing estates in Paris and its surrounding suburbs. We examine neighbourhood level data on two large housing estates to provide insight into the processes of poverty and ethnic concentration within these sites. We also examine the impact of urban renewal programmes on demographic and physical change. We argue that while the urban form of the large housing estate is gradually disappearing from the housing landscape, poverty and ethnic concentration have not disappeared, and micro-fragmentation between different social levels has become more pronounced. By including individual residential trajectories and mobilities in our analysis - and going beyond the traditional gentrification/ displacement nexus - we demonstrate that current renewal policies are at risk of creating new peripheries of exclusion and segregation at a regional level. At the same time, examination of the two case studies allows for a more nuanced perspective, which suggests that housing estates continue to play an important role in providing affordable housing and residential opportunities for local residents.
\end{abstract}

Keywords Fragmentation - Housing estates - Paris, France · Poverty Social mixing

\subsection{Introduction}

In France, the term 'grands ensembles' is widely used to describe large-scale social housing estates, built after World War II in order to house both workers and those who had been displaced from the old, derelict slums of the country's city centres (Droste et al. 2014; van Kempen et al. 2005). Between 1953 and 1973, the number

\author{
C. Lelévrier $(\bowtie) \cdot T$. Melic \\ University of Paris-Est, Lab’Urba, UPEC, Marne-la-Vallée, France \\ e-mail: lelevrier@u-pec.fr \\ T. Melic \\ e-mail: talia.melic@gmail.com \\ (C) The Author(s) 2018 \\ D. B. Hess et al. (eds.), Housing Estates in Europe, The Urban Book Series,


of social housing units in France increased from less than 500,000 to more than 3 million (Tomas et al. 2003; Le Goullon 2010). 43\% of the estates built during this period were situated within the Île-de-France region-one of the 18 regions of France and including the city of Paris - predominantly beyond the periphery of the city, in its suburbs. This chapter analyses the evolution of these housing estates within the Île-de-France region.

Although the grands ensembles were initially welcomed as a major step forward in housing quality and living standards, by the 1970s the planning principles underpinning the grands ensembles were beginning to be seriously questioned. In the mid-1970s, the first efforts were undertaken to renovate estate buildings. By the 1980s, housing estates were widely perceived as places that concentrated poverty and social problems, and many had become synonymous with the notion of a 'deprived neighbourhood'.

Since 2003, major demolition and tenure diversification programmes have sought to deconcentrate poverty within housing estates. These efforts have taken on greater significance in the wake of France's riots of November 2005, which brought into focus the extent to which the spatial concentration of poverty, and the structural dimensions of ethnic discrimination are real problems with profound social consequences (Dikec 2017).

Despite 15 years since their initial implementation, current policy approaches to urban renewal and social mixing remain strongly debated amongst academics and officials - as to what extent they represent viable and efficient responses to poverty concentration in public housing estates (Blanc 2010; Bolt et al. 2010; Levy-Vroelant 2007; Goulard and Puponni 2010). Given these divergent opinions, we seek to provide greater insight into the demographic and physical changes taking place within housing estates targeted by urban renewal programmes. We have chosen to focus on two housing estates located in the suburbs of Paris, in the Île-de-France region, in consideration of the following questions: What insights do historical and contextual factors provide into the process of poverty concentration within these housing estates? Have urban renewal programmes managed to reduce the concentration of social and ethnic groups within each estate? How have the changes in demographics and in the built environment, resulting from these programmes, transformed the urban landscape? How should such changes be theorised, and are the concepts 'gentrification' and 'displacement' sufficiently nuanced to capture the complexity of change taking place within these estates? What contextual factors might account for differences in residential trajectories across the two sites?

As these estates are grounded in their specific historical and regional contexts, in the first part of this chapter, we provide an overview and analysis of the concentration and degradation processes within large housing estates in France, including how perceptions and policies have evolved over time.

In the second part of the chapter, we examine neighbourhood level data from two housing estates in different suburbs of Paris, in order to provide a nuanced picture of their respective trajectories and the approaches pursued by each municipality to improve the built environment and social life. The first site, the 
'4000' housing estate, comprises 4000 units and is located in the suburban municipality of La Courneuve, in the northeast of Paris. The '4000' estate alone represents $26.6 \%$ of La Courneuve's total housing stock. The second site

is located in the suburban municipality of Orly, in the south of Paris, and comprises 5400 units. The estate represents $58.6 \%$ of Orly's total housing stock.

In the final part of the chapter, we draw on these cases to critically analyse the impact of urban transformation on social outcomes, highlighting common trends and diverging trajectories of change, ranging from impoverishment to micro-fragmentation.

In pursuing these questions, we come up against three major data limitations. First, in relation to housing, no official data on 'housing estates' is collected in France. Historians agree upon a general set of criteria for the grands ensembles, but it remains a rather loose definition. Though their boundaries have shifted as a result of various policy changes, our analysis will be based around the concept of 'priority neighbourhoods', as defined by France's City Policy—a social and urban policy that has specifically targeted housing estates since the 1980s.

Second, in relation to individuals, comprehensive data on income levels in France has only been available since 2002, making it difficult to accurately establish trends in poverty levels over time. Furthermore, very little of this data is disaggregated to a neighbourhood level. Therefore, as indicators of poverty levels, we draw on unemployment and social welfare allocation figures. Third, there is a lack of official data regarding ethnicity: in accordance with France's 'colour-blind' approach, ethnic origin is not recorded in its census nor in other major surveys (Alba and Silberman 2002). The census does collect comparable data on 'nationality', a legal category that distinguishes 'foreigners' from 'French citizens', and in some cases data on 'immigrants', defined as being born a foreigner in a foreign country. In light of this limitation, we draw on various data sources to examine ethnic segregation in housing estates.

\subsection{Producing and Improving Housing Estates: State-Led Policy in a Regional Context}

The evolution of housing estates in the Paris region is closely tied to France's national urban policy framework. A timeline, consisting of five main periods, can be constructed as follows for France's housing estate development in the post-World War Two era:

1953: The beginning of large-scale housing estate production, seen as a symbol of progress and modernity, and supported through financing tools from the State and private companies.

1958: Advances in land regulation, planning and funding tools to produce large housing estates through the creation of Priority Zones to be Urbanised; the 
beginning of the first major urban renewal programme targeting private tenure housing in city centres.

1973: The number of housing estates built reaches its peak. In the same year, the construction of estates larger than 500 units is formally halted, following the release of the 'Guichard circular'.

1977: Housing policies are significantly reformed, a home ownership programme is introduced which leads to the large-scale departure of middle-class housing estate residents.

1983-2003: A period of successive urban and social policies target housing estates, now seen as sites of poverty concentration and social problems.

2003: Major demolition and reconstruction programmes are launched, targeting large housing estates.

Though there is no formal definition of housing estates in France, many academics agree upon a classification based on their form as well as the methods used in their production; a relatively autonomous residential unit of collective buildings constructed rapidly, according to master plans that include a mix of high-rise buildings (tours) and tower blocks (barres) with local facilities (e.g. schools, shopping malls and stadiums). However, there is less agreement on the minimum threshold for defining a housing estate, which can vary from 500 units in some studies (Vieillard-Baron 2004) to 1000 units in others (Lacoste 1963). Most housing estates contain predominantly social housing (though not exclusively). The State has been heavily involved in both the production of these estates as well as the policies that have targeted them, by defining policy objectives and tools and by financing successive programmes of construction and renewal.

The term grands ensemble was first evoked to describe the Cité de la Muette. Built between 1931 and 1935 in Drancy, a northeastern suburb of Paris, historians and architects consider it to be France's first large housing estate, and indeed in 2001 it was classified as a historical monument. La Muettte comprised 1250 units and was designed by architects Eugène Beaudoin and Marcel Lods. However, it was the construction of housing estate Lochères, in Sarcelles (on the periphery of Paris) in 1954-just after the national plan Courant of 1953 - that launched the twenty-year post-war period of large-scale housing estate construction. Lochères comprised 12,368 units, representing a significant increase in the size and scale of these estates compared to the past.

\subsubsection{Suburban Housing Estates in the Paris Region: Population Growth and the Urban Renewal of Paris}

France embarked on its post-war period of housing construction as a response to a severe housing shortage. Following the damage brought about by the war, very little effort had gone into reconstruction. The Paris region was hit particularly hard. 
As a centre of industrial development, it had to accommodate a growing population comprising both domestic rural as well as international migrants, including a large flow of people from Algeria following its independence. During this time, the population of the Paris region grew from 7.2 million (1954) to 9.2 million (1968).

France's approach to constructing housing estates was enshrined in a 1958 law, which created Priority Zones for Urban Development (Zones à Urbaniser en Priorité/ZUP) and conferred power to the state to build massive, standardised social housing estates within these sites. Researcher estimates of the number of housing estates constructed throughout France during this period vary from 193 to 197 (ZUP) to 300-350, the last figure comprising 1.3 million units (Fourcaut 2006). Estates represent less than one-third of the total number of social housing units produced during this same period (Tomas et al. 2003). 26 of the 193 ZUP were built in the Paris region representing 150,000-170,000 housing units (Le Goullon 2010). These efforts were also driven by the goal of 'housing all employees' in social and collective housing and, as such, companies were major financial contributors. New government loans and subsidies were also created to fund their construction.

The conception and design of these estates were driven by a modernist vision that prevailed throughout the 1960s, inspired by the 'Athens Charter' of renowned architect Le Corbusier, and adapted to a Fordist economy and a situation of emergency housing. The grands ensembles were widely perceived as symbols of social progress, ushering residents into modernity and providing light and comfort in secure and sanitary suburbs far from the polluted inner-cities (Murie et al. 2003). It was assumed that within these estates, social groups would mix seamlessly to create new relations characterised by social harmony (Chombart De Lauwe 1965).

Aside from the availability of vacant agricultural land, there were a number of strategic reasons for building Paris's housing estates in its suburban areas beyond the periphery of the city-known in France as the banlieue. First, the 1958 urban renewal programme targeted inner-city 'slum' areas, largely made up of degraded private housing. The newly built estates of the city's peripheries served to relocate large immigrant populations of the working-class 13th and 19th districts of Paris, as well as those who had been displaced by the 1970s demolition of Paris's surrounding slums. The resulting processes of gentrification and the destruction of working-class lifestyles and networks attracted major criticism at the time (Coing 1966).

The second strategy employed sought to address land use and to control urban growth. In anticipation of Paris's impending population growth, in 1960, the Ministry of Reconstruction and Planning created a master plan (PADOG), which set directives for urban renewal, the production of housing estates and industrial decentralisation. It is within the framework of this plan that most ZUP estates were built, initially within the innermost suburbs of the Paris region to avoid overly extending the agglomeration. In 1965, as urban growth continued, a subsequent regional master plan provided a wider framework to create new development hubs located further away from Paris (15-50 kms). Today, France's social housing estates are largely concentrated within the Île-de-France region, housing $43 \%$ 
(around 150) of the estimated 350 sites built in France, including 26 of the 195 ZUPs (Fourcaut 2006).

\subsubsection{From Housing Estates to Deprived Neighbourhoods: 40 Years of Urban Policy}

The events that unfolded in Paris in 1968, and the emergence of social critics condemning these estates as a feature of a 'capitalist' mode of production (Lefebvre 1970), shattered the modernist vision that had initially inspired the grands ensembles. Furthermore, popular media had begun to expound a negative image of these places, beginning with a documentary film broadcast on national television in 1963, coining what became the notorious term 'sarcellite' - the depressive 'disease' suffered in the Lochères estate of Sarcelles. Before long, housing estates were widely condemned as sites that led to social isolation, boredom and petty crime. The rapid physical degradation of buildings that had been hurriedly constructed utilising poor-quality, prefabricated materials, only added to this diagnosis. As a result, in 1973, a famous policy circular abruptly halted the production of large housing estates above 500 housing units. This officially marked the end of the construction of large housing estates in France.

In official reports, these urban spaces were declared dysfunctional for a number of reasons. From a planning perspective, mono-functional use and a sparsity of local economic activity were seen to lead to a sense of urban isolation. The presence of open outdoor spaces that were difficult to secure led to a public perception of estates as being 'uncontrollable', despite the existence of resident ownership of these places. In addition, certain areas had become neglected due to a lack of clear boundaries between public and private space and resulting uncertainty over who was responsible for their management.

These perceptions were strongly influenced by emerging representations of the housing estates of the banlieue as dangerous, following periodic violent incidents that occurred in 1971 and 1981 in the suburbs of Lyon and Paris. Following these, the prevailing future image of these places seemed to have been decided: the 'deprived neighbourhoods' label entered public discourse, and successive urban policies have since focused on solving what is now framed as the 'banlieue problem'.

While these representations of the Paris banlieue estates do prevail, they have been criticised by many academics, who caution against reducing these sites to incidents such as the November 2005 riots. Recent analysis frame these actions as a plea from excluded young people to be included in French society (Moran 2017), bringing to light the broader, systemic context within which the concentration of poverty and ethnic groups is grounded. These representations have been reinforced in the wake of the multiple terrorist attacks committed in France: Islamophobic sentiment appears to have increased, making the large number of North African and 
Muslim people residing in these estates particularly vulnerable to discrimination (Moran 2017; Mondon and Winter 2017). This compounds further their spatial exclusion and, in some opinions, their exclusion from Republican narratives of the citizen.

Another assumption that is highly debated throughout Europe - and one that underpinned many of the renewal programmes that followed-is that a concentration of low-income and unemployed people leads to negative 'neighbourhood effects' that exacerbate their exclusion from society. Symptoms of these effects were presented as school failure, chronic unemployment and poverty, but also petty crime, conflict and drug trafficking. In the 1970s, sociologists had already begun to object to the hasty connections being made between the built environment and social problems, pointing out that such problems existed throughout society, and in all kinds of spaces (Huguet 1971).

Against this background, France's City Policy (Politique de la ville) has, since 1983, implemented a series of programmes that combine socio-economic measures with the restructuring of the built environment and public space. The City Policy targets a selection of deprived neighbourhoods, classed as priority neighbourhoods. While not all of neighbourhoods consist solely of housing estates, a number of the more specific urban restructuring programmes that have been implemented since the 1990s through the framework of this policy, have de facto targeted housing estates. Throughout this period and until the early 2000s, a soft rehabilitation that sought to avoid displacing workers was pursued. This was largely in response to the criticism received over the major displacement caused by the slum demolitions of the 1970s in Paris.

Like in many other European countries, social mixing through housing diversification remains a central objective of these programmes (Kleinhans 2004). Described as a means by which to reduce levels of poverty concentration and to prevent urban social enclaves, social mixing is primarily implemented through the demolition of high-rise social housing buildings, which are in many cases replaced by private dwellings in a bid to attract middle-class residents. In theory, demolition is undertaken according to the 'one to one' principle - one unit rebuilt for every unit demolished - so that the absolute number of social housing units remains stable.

The City Policy was significantly revised in 2014. The current policy runs until 2020 and includes the following components:

- City contracts between the state, regions and cities, which set out concrete actions that are to be pursued in each priority neighbourhood according to three central pillars: housing, living conditions and urban renewal; social cohesion; and economic development and employment. To date, 438 contracts targeting 1292 priority neighbourhoods (QPVs) have been signed.

- Urban renewal programmes. Included as part of the city contracts, these programmes focus on transforming the urban form and on diversifying housing tenure. They concern 400 priority neighbourhoods. 
- The extension of a specific legislative arrangement initiated in 2000 , which aims to create social mixing by requiring municipalities with less than $25 \%$ of social housing to take measures to reach this target.

Finally, three specificities of French urban policy have greatly influenced housing estate policies and planning. First, despite a major decentralisation process in 1982 and an increase in private funding since 2014, policies targeting housing estates remain strongly driven by national programmes. Second, the French concept of social housing is universal, rather than being reserved exclusively for low-income people. Third, the state's continued pursuit of social mix policies goes hand in hand with the value (and rhetoric) of 'territorial equality', in spite of ongoing criticism of these approaches. Area-based policies presented as a means to reduce the 'gaps' between territories allow public authorities to tackle ethnic concentration without naming it as such (Escafré-Dublet and Lelévrier 2014).

\subsection{Location, the Built Environment and Demographic Shifts in Housing Estates in the Paris Region}

The Paris region has 12 million inhabitants, of which 2.2 million live within the city of Paris. Prior to 2016, it was made up of eight departments, with four departments located each in both the region's first and second rings (Fig. 14.1). The official creation of the 'Greater Paris Metropolis' in 2016 amalgamated Paris and three surrounding departments, containing the inner suburbs of the region (Seine-Saint-Denis, Hauts-de-Seine and Val-de-Marne), and comprising 6.9 million inhabitants.

\subsubsection{Housing Estate Locations Reflect a Historical Regional Divide}

The spatial distribution of social housing (Fig. 14.2) and of renewed housing estates (Fig. 14.3) is linked to historical regional structures and policies. The first visible trend is the concentration of this type of housing in the northeastern part of the region (17.1\% of the region's overall social housing, $34.5 \%$ of all housing estates in Seine-Saint-Denis), where poverty and unemployment rates are highest. This reflects a historical social division between the East and the West of the region. While the East has traditionally been an industry hub for trade work, mainly housing the working class and a large number of immigrants, the West is made up of large residential areas and ample green space and has historically been home to the middle and upper classes. Other major housing estate sites are situated along the Seine river in close proximity to the motor industry (South and West), and are dispersed across less urbanised areas located 20-40 kms from Paris. 


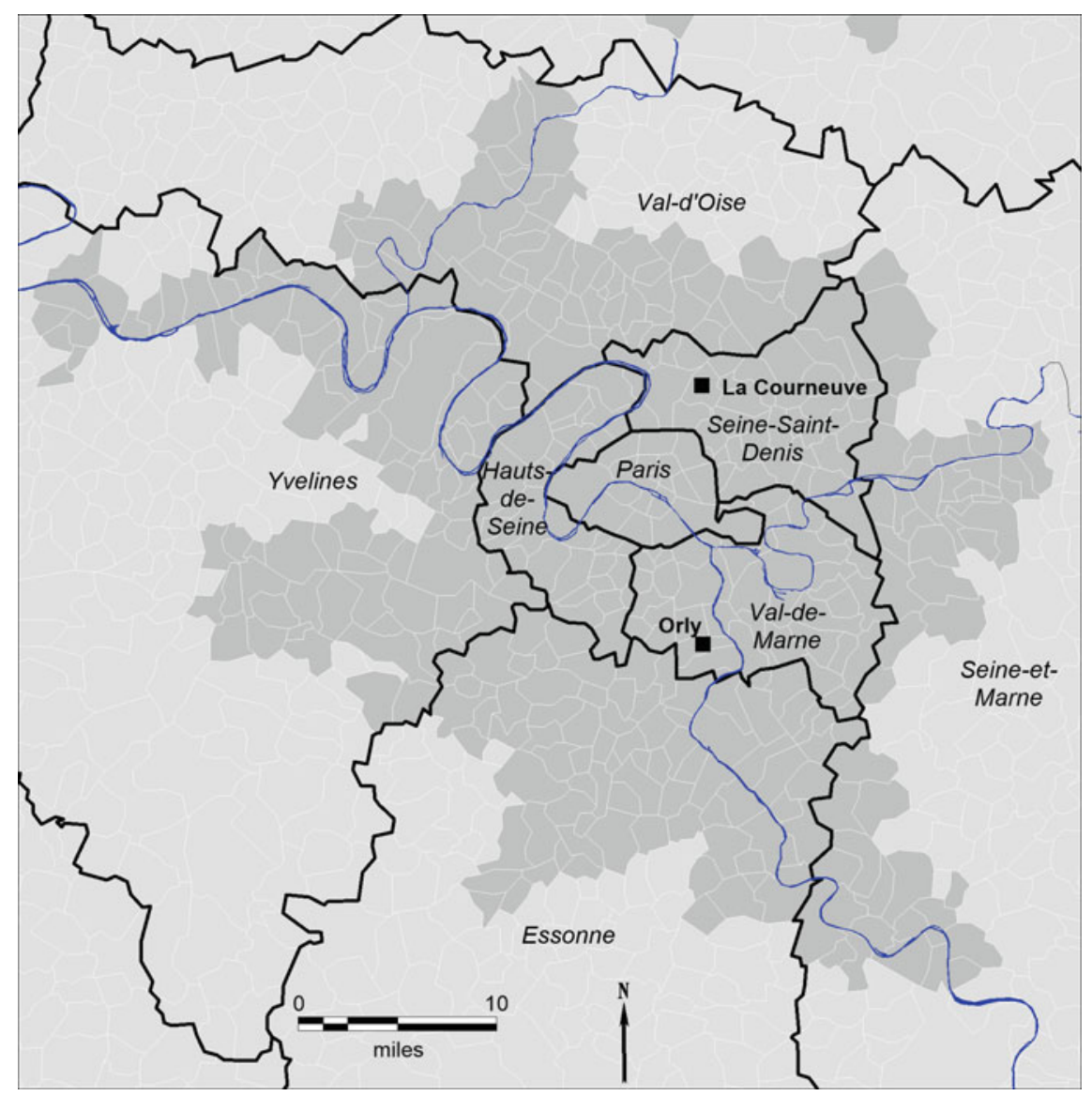

Fig. 14.1 Departments in the Ile-de-France region and location of Orly and La Courneuve municipalities

The traditional narrative regarding the demographic shifts occurring within housing estates states that an initially socially mixed population was gradually replaced by a majority of people in situations of immigration and unemployment. This demographic shift was encouraged by homeownership programmes established by the government as part of its 1977 housing reform policies. The programme provided affordable loans and individualised housing assistance. Following the resultant mass-departure of middle-income residents from housing estates all over the country, social housing was freed up for migrants and their families-who up until this point had been living in slums or temporary dwellings. Although in 1974, immigration laws had to curtail the intake of new migrants, they made allowances for families to be reunited. As such, newly arrived family members joined their relatives in homes within these vacated estates. 


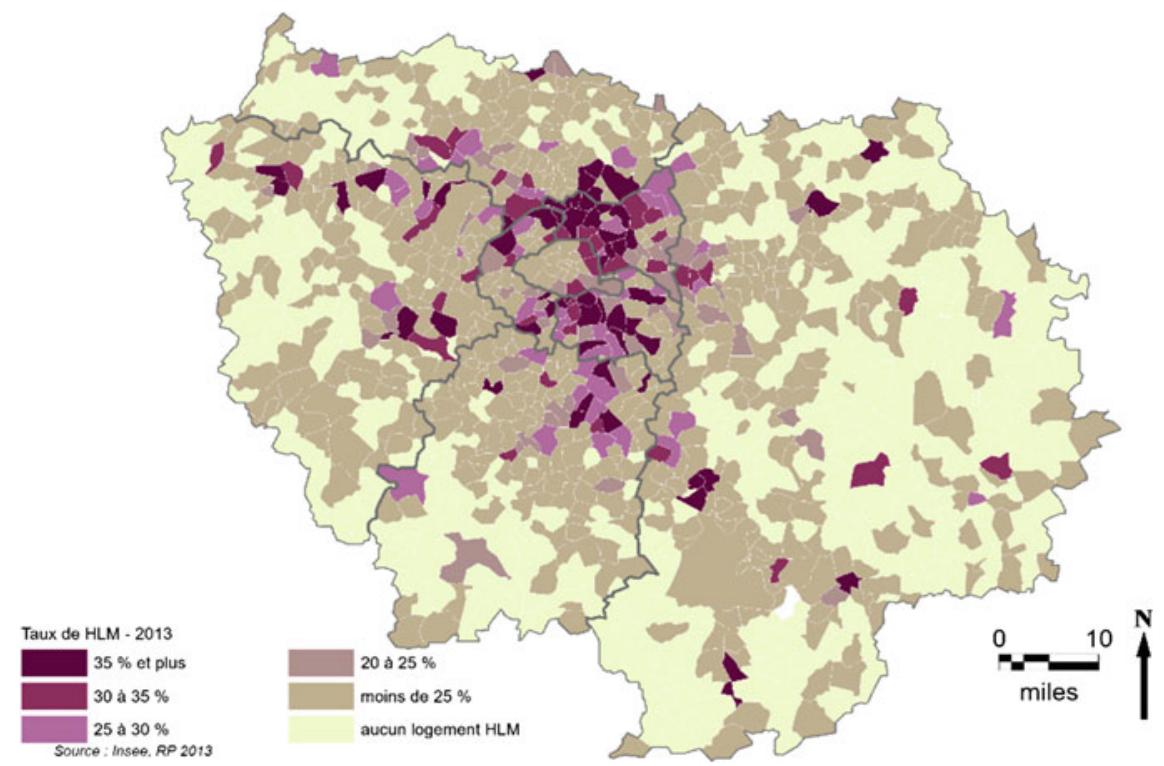

Fig. 14.2 Percentage of social housing (HLM) across municipalities of the Paris Region. Source Insee, Census 2013, IAU

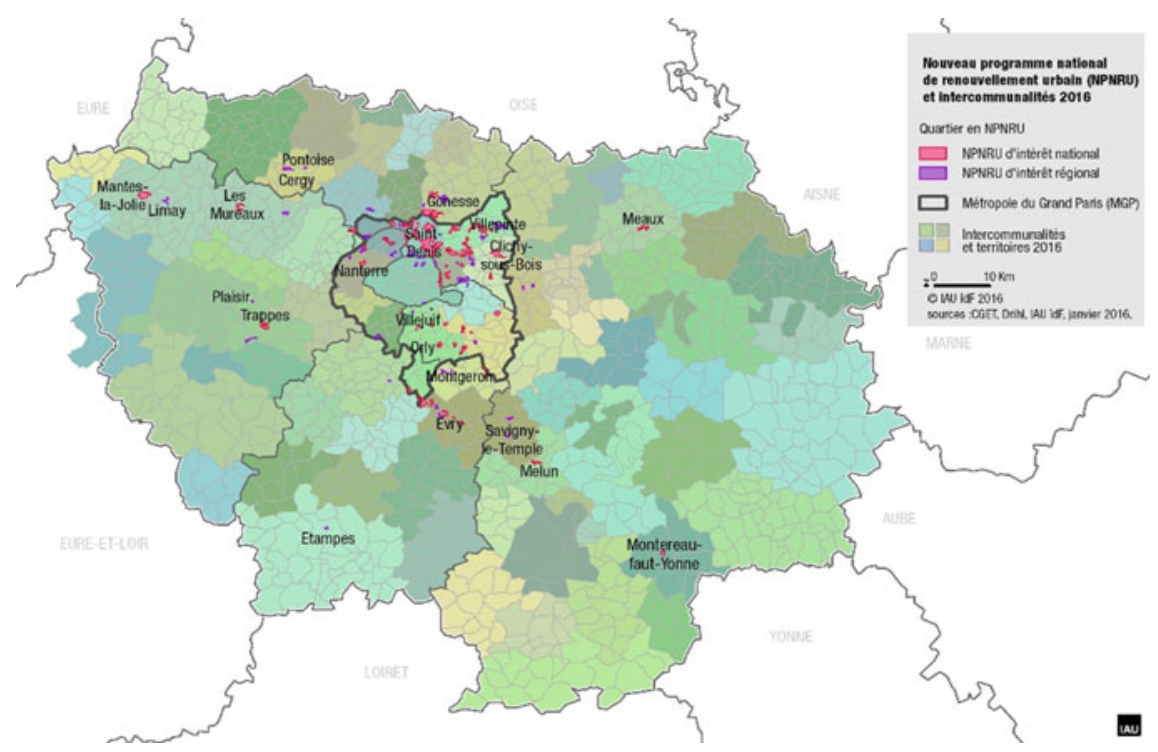

Fig. 14.3 Renewed neighbourhoods in the Paris region. Source General Committee for territorial Equality (CGET), IAU, 2016 
Despite this prevailing narratives, close examination of the data reveals that many of the estates that are now being targeted by programmes of demolition and reconstruction did not undergo such a demographic transformation, but have always housed low-income and migrant families. These families were relocated from degraded sites in Paris or worked in local companies that provided social housing support. A more significant demographic shift was in the impoverishment of many families already living in such estates as a result of economic changes. The 1974 oil crisis set in motion a process of economic precariousness and escalating unemployment. Examination of two large housing estate sites located in Orly and La Courneuve provides further insight into these processes.

\subsubsection{Internal Segmentation in Two 1960s Housing Estates: Orly and La Courneuve}

Located in medium-sized municipalities within Paris's first suburban ring, the 4000 housing estates in La Courneuve and the large housing estate in Orly share many common features. They were both built during the 1960s, and both have a large number of housing units (4900 in the La Courneuve estate, 5492 in Orly), representing at least half of the total population of each municipality, respectively. This translates into a population of 15,251 people in the 4000 and 13,298 in Orly's large housing estate (according to 2006 census data). Both sites are less than half an hour from the centre of Paris by train and are close to international airports, regional economic centres, basic amenities and large shopping centres. The architecture and planning of both are typical of a modernist conception of housing estates. A large number of high-rise buildings (in La Courneuve, 35 high-rise buildings ranging from 4 to 26 floors; and in Orly, various buildings ranging from 4 to 16 floors) represent what was conceived as a whole 'unit' of life, incorporating green spaces, and separating pedestrian areas from those of cars (Fig. 14.4).

Both sites housed those who had been displaced from the city centre by Paris's 1958 urban renewal programmes, people repatriated from Algeria following its 1962 independence, and those who worked in nearby factories or the Orly airport. They were initially managed remotely by the Seine public office before oversight was transferred to local public housing offices in the 1980s.

Internally, both estates are segmented, contradicting standard visions of housing estates as homogenous places. In Orly's housing estate, many of the poor and immigrant households relocated from Paris were provided housing of inferior quality to mainstream social housing because they could only afford low rents. On the same sites, workers from the nearby international airport had access to more standard social housing buildings. Inequalities in rent and in quality introduced an internal social division - today the site consists of five different sub-sectors, according to the funding structure, architectural design, building quality and rent levels. Many of the taller buildings (4-16 stories) are concentrated towards the heart 

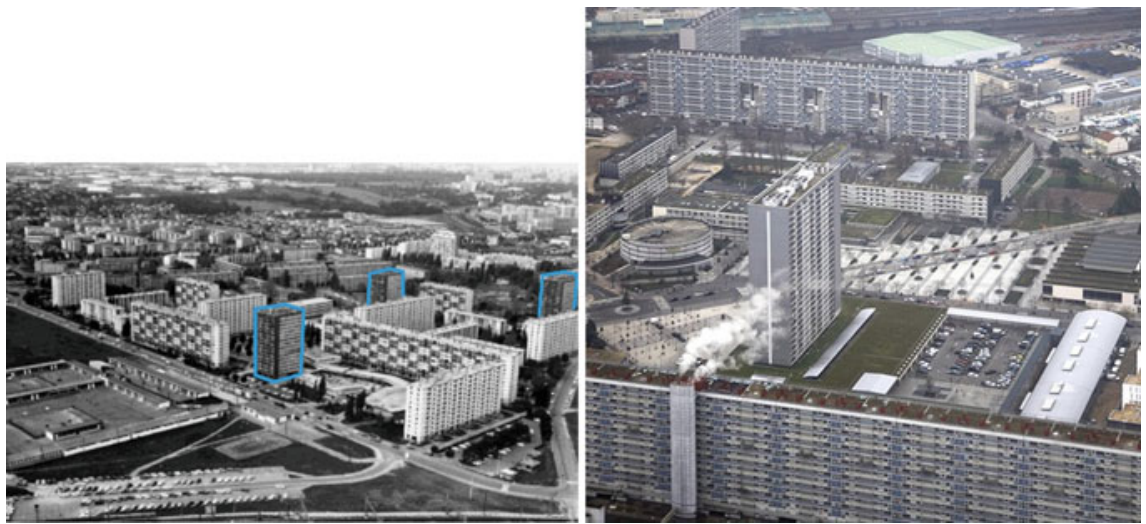

Fig. 14.4 Built environment and urban form of large housing estates Orly and La Courneuve, 1960s. Source Orly (city) and La Courneuve (blog. 40 quartiers, website, see La Courneuvephotojpg)

of the estate. They were rehabilitated in the 1980s and are currently in the process of being demolished.

In La Courneuve's 4000, the housing estate comprises two complexes in the north and the south. The tallest, poorest quality buildings with the largest apartments and the cheapest rents are concentrated in the south, while the north comprises smaller buildings, has a more residential setting, and is closer to the city centre. Unsurprisingly, it is the buildings within the southern area that have been targeted for demolition under urban renewal programmes (Fig. 14.5).

This internal spatial differentiation demonstrates how France's housing estates are the products of multiple housing interventions catering to diverse categories of the population. Different entities including the State, municipality and private companies have set allocation quotas that determine access to social housing, resulting in the presence of a variety of social groups in any given estate, often with
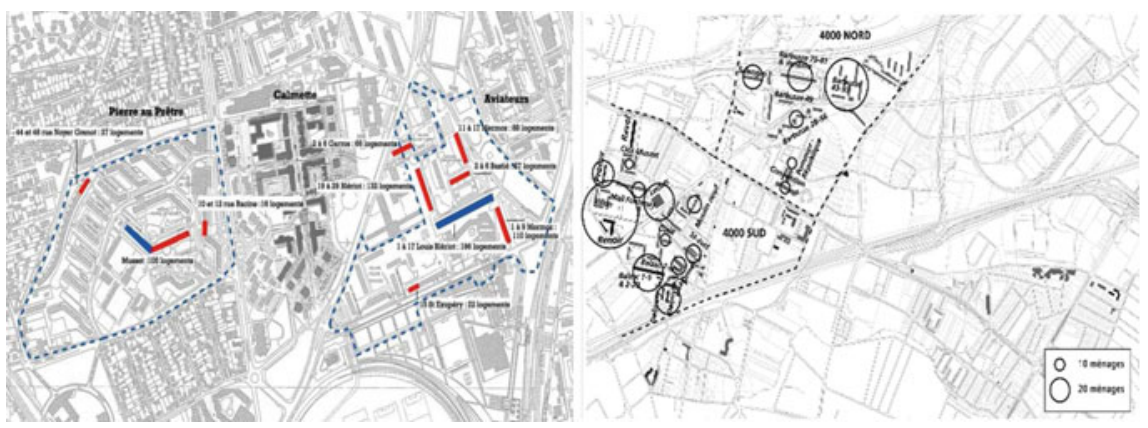

Fig. 14.5 Sub-sectors and demolitions (2003 urban renewal) of large housing estates in Orly and La Courneuve. Source Relocation board, April 2010; City/Valophis housing corporation 
divergent residential trajectories. For those middle-class residents who found their way into the estates through their respective companies, their stay was typically one of transition within the residential trajectory. For low-income groups, in contrast, the housing estate tended to represent the end of their residential trajectories, becoming their permanent residence (Chamboredon and Lemaire 1970).

\subsection{Social Change: Increasing Social Gaps and Spatial Differentiation}

The official category 'priority neighbourhoods' is not an exactly synonymous with 'housing estates' and the data available on these varies from programme to programme. Despite this limitation, by drawing from data at a regional level, and using the two housing estate case studies of La Courneuve and Orly, we are able to gain insight into the main trends taking place within these housing estates.

\subsubsection{A Growing Concentration of Large Families and Immigrants in Northeast and Peripheral Areas of Paris}

In 2006, those living within the 157 'priority neighbourhoods' (ZUS's) of the Paris region represented $11 \%$ of the regional population (above the national French average of 7.2\%) (Insee-Première 2010). When this category was extended in 2014 to cover 272 neighbourhoods, ZUS's accounted for 1,570,000 residents, or $13 \%$ of the regional population.

The most recent population data available (from 2006 and 2012) from Île-de-France reveals an increasing social gap between these priority neighbourhoods and the rest of the urban unit. In 2006, these neighbourhoods comprised a higher proportion of immigrants (36.2 vs. $22 \%$ in their urban units), half of them originating from Maghreb countries. They also contained twice as many large households (defined as five or more people) and had a higher proportion of young people alongside a lower proportion of elderly people (Table 14.1). However, figures on ethnic concentration would likely jump significantly if 'descendants of immigrants' were taken into account. A 2012 national survey found that an average of $52 \%$ of priority neighbourhood residents originated or had a parent that originated from another country, compared to just $22 \%$ of the population in the surrounding agglomerations (ONZUS 2012).

There is a significant income gap between people living in priority neighbourhoods and the surrounding urban unit. Within the Paris region, a recent study shows a higher median living standard (1140 €/month) and a lower percentage of people living under the poverty line compared with priority neighbourhoods located in 
Table 14.1 Sensitive Urban Zones (ZUS), 2006: comparison of France/Paris region (RIF) and ZUS/Urban environment (UU, urban units)

\begin{tabular}{l|l|l|l|l}
\hline Indicators & France ZUS & France UU & RIF ZUS & RIF UU \\
\hline Number of ZUS & 751 & & 157 & \\
\hline Total population & $4,361,000$ & & $1,278,300$ & \\
\hline People $<20$ & 31.6 & 24.9 & 32.5 & 25.7 \\
\hline People $>60$ & 14.8 & 19.8 & 11.6 & 16.6 \\
\hline Foreigners & 17.5 & 8.2 & 23.0 & 13.3 \\
\hline French (acquisition) & 10.2 & 5.9 & 13.2 & 8.7 \\
\hline Single-parent family & 25.7 & 15.8 & 24.7 & 16.4 \\
\hline Households 5 and + & 12.7 & 6.6 & 15.4 & 7.9 \\
\hline Home ownership & 20.0 & 47.0 & 19.5 & 44.6 \\
\hline Flats 5 rooms and + & 16.9 & 26.2 & 11.3 & 18.9 \\
\hline Vacant flats & 6.7 & 6.3 & 5.6 & 6.3 \\
\hline
\end{tabular}

Source Census 2006 (annual estimation surveys) - Insee Première, 2010

other regions of France. However, there are significant differences between priority neighbourhoods and the rest of the Paris region: $710 € /$ month below the region's median living standard, with $37 \%$ of people living under the poverty line in priority neighbourhoods (Insee-Analyses 2017).

Further analysis reveals patterns of segregation across the Paris region, as demonstrated (Table 14.2) by average foreign population numbers (1999) and income levels (2004). The data illustrates two marked discrepancies: poor housing estates in disadvantaged areas within the inner suburbs, in addition to pockets of poverty within more affluent outer suburban areas. In the housing estates of Paris's northeastern departments (Seine-Saint-Denis, Val d'Oise), foreigners and low income households are overrepresented. Meanwhile, the gap between these same indicators in some housing estates in the region's more affluent West (Yvelines) is significantly more pronounced: 28.5 versus $8.9 \%$ for foreigners and 9,990 versus $22,275 €$ in the median income.

A recent study identified six types of neighbourhoods among the 272 deemed 'priority' in the Paris region, based on surface area, population and income data (Insee-Analyses 2017). Two of these types correlate with housing estates. 'Large neighbourhoods of vulnerable families located far from Paris' (type D) tend to be located 20-30 kms from Paris and have the poorest standard of living - around 43\% of their population live under the poverty line. These areas are excluded from the new Greater Paris metropolis, and this will likely widen existing gaps. 'Historical City Policy neighbourhoods' (type E) include renewed neighbourhoods. The case study housing estates in Orly and La Courneuve fall under this category. Approximately $39 \%$ of the population of type E neighbourhoods live under the poverty line (Table 14.3). These two categories combined comprise 73 large housing estates-more than $55.3 \%$ of the population of Paris's priority neighbourhoods. 
Table 14.2 Foreign population and income levels in housing estates (renewed neighbourhoods) and suburban departments of the Paris region

\begin{tabular}{l|l|l|l|l}
\hline & \multicolumn{2}{l}{ Housing estates (ANRU) } & \multicolumn{2}{l}{ Departments } \\
\cline { 2 - 5 } & $\begin{array}{l}\text { Median } \\
\text { income/UC/ } \\
\text { year (€) }\end{array}$ & $\begin{array}{l}\text { Foreign } \\
\text { population } \\
(1999)(\%)\end{array}$ & $\begin{array}{l}\text { Median } \\
\text { income/UC/ } \\
\text { year }(€)\end{array}$ & $\begin{array}{l}\text { Foreign } \\
\text { population } \\
(\%)\end{array}$ \\
\hline Hauts-de-Seine & 12,713 & 19.7 & 22,088 & 11.5 \\
\hline Seine-Saint-Denis & 9,096 & 28.1 & 13,719 & 18.9 \\
\hline Val-de-Marne & 11,850 & 17.6 & 18,936 & 11.8 \\
\hline Seine-et-Marne & 10,092 & 19.4 & 18,800 & 7.7 \\
\hline Yvelines & 9,900 & 28.5 & 22,275 & 8.9 \\
\hline Essonne & 11,323 & 19.3 & 20,272 & 8.2 \\
\hline Val d'Oise & 9,923 & 22.8 & 18,066 & 10.8 \\
\hline Region & 10,432 & 23.4 & 19,402 & 11.9 \\
\hline
\end{tabular}

Source DGI 2004; RGP 1999

Table 14.3 Comparison of two types of priority neighbourhoods in the Paris region

\begin{tabular}{l|l|l|l}
\hline Indicators & Type D & Type E & $\begin{array}{l}\text { Priority regional neighbourhoods } \\
(\mathrm{QPV})\end{array}$ \\
\hline Number & 31 & 42 & 272 \\
\hline Population & 137,000 & 731,000 & $1,547,000$ \\
\hline$\%$ of the pop. QPV & 9 & 47 & $(13 \%$ region pop. $)$ \\
\hline Households 5+ (\%) & 21 & 21 & 19 \\
\hline Annual median income & 28,800 & 31,100 & 30,900 \\
\hline Welfare beneficiary (\%) & 68 & 65 & 64 \\
\hline $\begin{array}{l}50 \% \text { income = welfare } \\
\text { benefits (\%) }\end{array}$ & 79 & 70 & 67 \\
\hline $100 \%=$ welfare benefits $(\%)$ & 47 & 44 & 41 \\
\hline Poverty rate (\%) & 43 & 39 & 37 \\
\hline
\end{tabular}

Source Filosofi 2012; Insee Analyses 2017

\subsubsection{Poverty Concentration Enhanced by Parallel Trajectories of Mobility and Long-term Tenancies}

Recent data demonstrates that the concentration of poverty and immigrant populations within housing estates is increasing rather than decreasing. A significant limitation of this data is that while it measures how spatial concentration has evolved, it ignores the processes that produce this concentration and the diverging trajectories of the populations concerned. Examining these processes, rather than the ratios, reveals a different picture of the evolution of these estates.

For instance, census data on increasing poverty does not reflect population turnover. A 2005 national survey reveals that in $1999,40 \%$ of priority 
neighbourhood residents had moved to the neighbourhood within the past 10 years. Studies suggest that those recently arrived residents are younger and have lower incomes than those who are leaving. There is a causal link between this process of mobility (where people move in and out of these neighbourhoods) and that of impoverishment. This mobility raises additional questions about interpreting the causes of changes in poverty levels within these estates - how do we determine the contribution of policies to such changes? How do we evaluate policies that may have positive effects on people's individual trajectories but do not alter the spatial concentration of poverty within housing estate sites?

In parallel, solitary elderly people are becoming trapped - or choosing to remain -in large apartments, even if their incomes have long since decreased. In 2003, when buildings containing large apartments were designated for demolition to disperse families across renewed housing estates, the actors involved were surprised to discover a high proportion of elderly residents living in large apartments (Lelévrier 2013a). They were long-standing tenants who simply did not have enough resources to leave the neighbourhood, or who wanted to stay and hold onto their flats after their children had left. The proportion of elderly residents remaining in these housing estates defied expectations. Even though France's population as a whole is undergoing an ageing process, the discourse surrounding housing estates in the media and amongst officials focuses predominantly on young people. As such, these elderly residents have been less visible. In Orly, this ageing process has become significantly more pronounced since 1990 (Table 14.4). Greater awareness of the location of elderly residents would improve how local needs are defined and what services and supports are put in place to meet them.

\subsection{Spatial and Social Effects of Policies and Planning Strategies}

While the data suggests that segregation has not decreased, 40 years of public policies have changed the urban form of a great number of housing estates in the Paris region and, as such, have affected the spatial and social configuration of this segregation. The first 25 years of these policies were devoted to rehabilitation, infrastructure improvement and socio-economic measures, most of them targeting children and unemployed people. However, the greatest social impact has been that of urban restructuring and housing diversification through urban renewal programmes.

The first urban renewal programme of the Paris region has not yet been completed. However, in its first decade (2003-2013), 23,000 social housing units have already been demolished (out of a total 38,200 planned demolitions); 10,100 new social housing units have been built (of 20,700 planned) and 5,700 private dwellings have been developed (of a planned 21,600). At the end of this first stage, $10 \%$ of the housing stock of targeted estates has been renewed. Ten years into this 
Table 14.4 Characteristics of population change, Orly and La Courneuve, 1982, 1990, 1999

\begin{tabular}{l|l|l|l|l|l|l|l}
\hline Indicators & $\begin{array}{l}1982 \\
\text { Orly }\end{array}$ & 1990 & 1999 & $\begin{array}{l}1982 \\
\text { Courneuve }\end{array}$ & 1990 & 1999 & $\begin{array}{l}1999 \\
\text { ZUS-ANRU } \\
\text { region }\end{array}$ \\
\hline Population & 19,458 & 17,203 & 14,413 & 13,246 & 12,293 & 15,553 & \\
\hline $\begin{array}{l}\text { People/ } \\
\text { household }\end{array}$ & 3.24 & 2.98 & 2.76 & 3.54 & 3.44 & & \\
\hline Under 20 years & 36.5 & 33.1 & 30.8 & 40.6 & 37.9 & 36.2 & \\
\hline Above 60 years & 8.7 & 12 & 15.4 & 7.9 & 8.7 & 11.7 & \\
\hline Households 6+ & 10.9 & 9.1 & 7.0 & 20.2 & 15.6 & 12.6 & 8.7 \\
\hline $\begin{array}{l}\text { Foreign } \\
\text { population }\end{array}$ & 19.3 & 19.5 & 15.7 & 20.8 & 28.7 & 26.0 & 23.4 \\
\hline Unemployed & 15.8 & 17.7 & 24.7 & 27.5 & 29.4 & 28.3 & 21.3 \\
\hline $\begin{array}{l}\text { Without diploma } \\
55.9\end{array}$ & 44.8 & 39.2 & 60.8 & 50.4 & 39.4 & 31.1 \\
\hline Single-parent & 16.7 & 16.4 & 19.8 & 15.6 & 19.1 & 17.5 & 15.8 \\
\hline $\begin{array}{l}\text { Employees } \\
\text { clerical } \\
\text { workers) }\end{array}$ & 39 & 36.6 & 38.6 & 39.8 & 36.6 & 38.3 & 21.7 \\
\hline $\begin{array}{l}\text { Workers } \\
\text { (Blue-collar) }\end{array}$ & 43.9 & 44.9 & 37.4 & 41.0 & 45.8 & & 30.1 \\
\hline $\begin{array}{l}\text { Median income/ } \\
\text { UC (2002) }\end{array}$ & & & 10,428 & & & 7,333 & \\
\hline
\end{tabular}

programme, some general patterns of urban and social effect can be identified, with varying local trajectories.

\subsubsection{Improvement of the Built Environment and the End of Housing Estates}

Significant public investment has been injected into the infrastructure of $1960 \mathrm{~s}$ housing estates through successive public policies. The condition of the urban environments in which these estates are located has also improved through regional development efforts, with better transport and access to local facilities.

A 2013 evaluation found that the public space of renewed housing estates was of higher quality and more sustainable (CES-ANRU 2013). These estates have been transformed from a functional, modernist design into a postmodern conception embodying new urbanism principles. These principles include connecting roads, a mixture of car and foot traffic, subdivision of plots of land to build smaller residential units (40-150 dwellings up to six stories high), public squares and streets designed as places of encounter with mixed functions (e.g. shops, services) and tenure mix. The French 'résidentialisation' process has implemented defensible space theories, gating-off new and existing buildings with the purpose of reducing 
vandalism, separating public and private space (for easier management) and creating housing that looks more 'private and residential'. The underlying assumption driving this urban design is that such changes will improve the image of the area, attracting more affluent newcomers and promoting greater social diversity. This urban transformation leading to more ambiguous and controversial effects (Fig. 14.6).

Urban change is most visible in the large housing estates of the 1960s, which have been subject to demolition and reconstruction since the 1980s. In the La Courneuve 4000 estate, seven buildings comprising 1500 housing units have been demolished since 1986, representing $37.5 \%$ of the housing stock. In the Orly case, urban renewal began in 1976, when the oldest transitory buildings were demolished. From 1976 to 2013, nine buildings containing 1631 housing units were replaced by a mix of social (800) and private (633) housing units. By 2020, 30\% of the housing stock will have been renewed. After 40 years of urban renewal processes, it can be said that the 'large housing estate' no longer exists as an urban form.

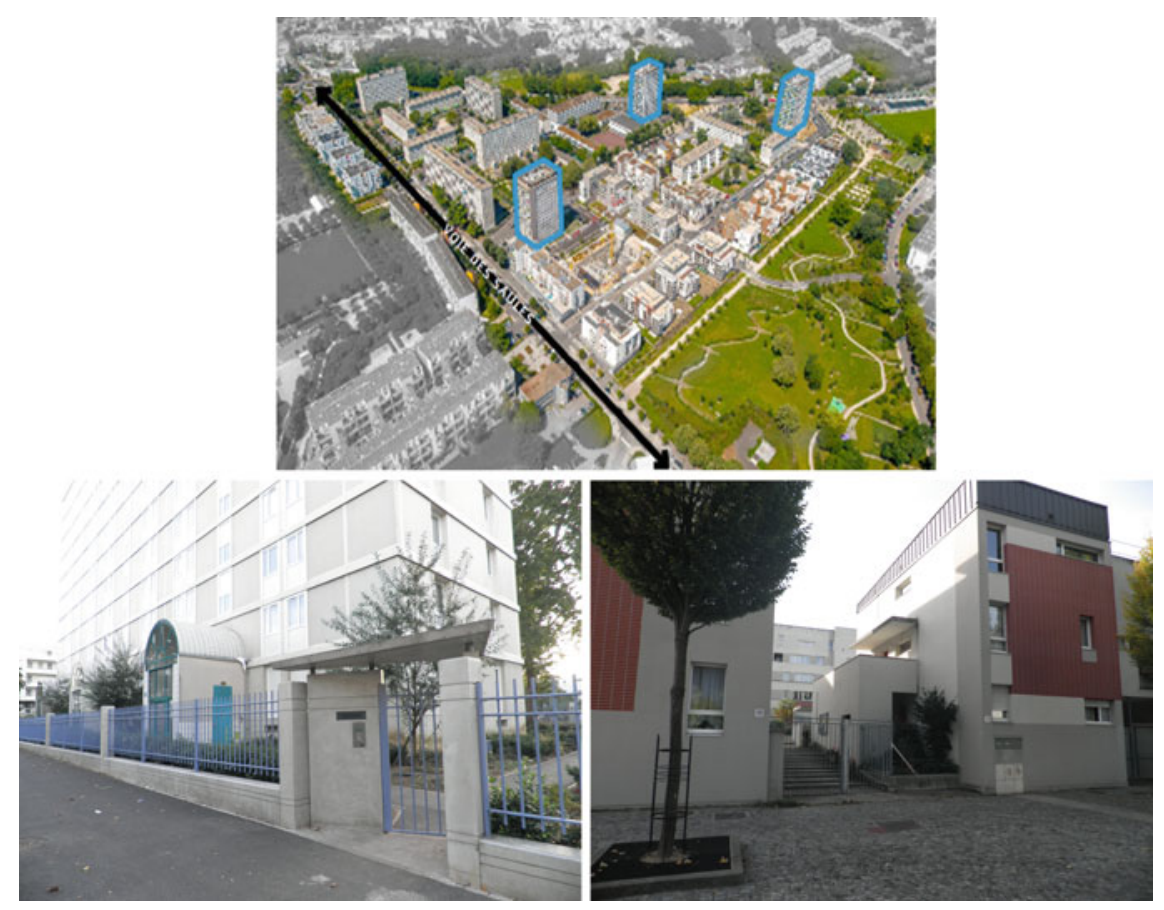

Fig. 14.6 'Gating' of existing buildings and new housing developments in Orly 


\subsubsection{The Paradoxical Effects of Urban Renewal}

France's City Policy and renewal programmes aim to improve living standards by reducing segregation and promoting the 'return' of middle-class groups into spaces in which poverty is concentrated. However, after ten years of urban renewal, public evaluations find that while these efforts have transformed the built environment, the socio-economic living conditions of the populations that these policies have intended to benefit have remained relatively unchanged, and poverty remains as concentrated as ever (Cour des Comptes 2012; CES-ANRU 2013).

We have identified four main reasons for this trend. First, the changes brought on by area-based policies have been marginal in comparison to the impacts of wider urban social and economic transformation. The economic situation of low-qualified residents of the housing estates in Paris's old industrial areas remains dire after many companies have closed down, leading to widespread job loss. Poverty levels have increased among social housing residents, both within but also beyond housing estates. Second, between 2003 and 2013, social measures and support for local initiatives have been drastically reduced in favour of interventions in the built environment. Third, even when renewed estates have managed to attract more affluent households into new developments, the number of households remains too marginal to alter the social structure and to affect poverty concentration levels. Finally, urban renewal seems to have produced the 'paradoxical effects' (Blanc 2010; Lelévrier 2013b) of reconcentration through relocation. This finding is explored in more depth below.

\subsubsection{A Reconcentration of Relocated Households}

Rather than being dispersed across the Paris region, residents of demolished buildings have been primarily relocated within the same neighbourhoods. According to national evaluation, $60 \%$ of relocated residents remained within the same neighbourhood and $89 \%$ within the same municipality. This national trend can be explained in part by the preference of many residents to remain in their neighbourhoods, demonstrating an attachment to these outwardly stigmatised areas. However, these figures are also representative of residents' limited housing options. The poorer and older a household, the more likely its residents will be relocated into the same type of building and neighbourhood. This 'reconcentration phenomenon' (Lelévrier and Noyé 2012) is particularly pronounced within the Paris region.

In La Courneuve, $93.4 \%$ of residents of demolished buildings remained in the same municipality, and $73 \%$ continued to live in the poorer, southern part of the estate. The housing choices available to these relocated households were extremely limited $-78.8 \%$ of them lived on less than $20 €$ a day, and more than half were large immigrant families. Few other apartments in the region were large enough, and low enough in rent, to meet their needs. Furthermore, social housing corporations from 
neighbouring municipalities were often reluctant to host families relocated from a once stigmatised housing estate.

In Orly, $98.5 \%$ of those who were relocated remained in the same municipality, and $50 \%$ within the same sub-sector of the housing estate. Compared to $\mathrm{La}$ Courneuve, relocated households were much smaller in size and also older (38\% were aged over 60 vs. $17 \%$ nation-wide) and had higher incomes (only $34.4 \%$ lived on less than $20 €$ per day). As a result, it was easier to disperse households among the different sub-sectors of the estate and beyond.

\subsubsection{New Housing Developments: Opportunities for Upper Working-class Residents}

New housing developments were intended to promote social mixing by attracting more affluent residents. The available data and local surveys highlight two main trends within the Paris region in this regard. First, there have been far fewer private developments than planned, and where they have been created, such developments tend to take the form of small apartments built on the fringes of existing housing estates. Second, although less visible in the data, the internal social configuration of housing estates is changing. Newcomers in private housing do tend to earn higher incomes than former residents, indicating that some form of social mixing is taking place. Their social profiles stand in contrast to the majority of residents-relatively small-sized households, young couples and families with jobs and average salaries. However, many of these 'newcomers' are, in fact, existing residents, who were already living in the neighbourhood or within social housing in another part of the same municipality (Lelévrier 2013b). Furthermore, local surveys find that approximately $50 \%$ of these private housing residents are immigrants or the descendants of immigrants. For these residents, their entry into private residency can be considered a step forward in their housing careers. For local officials, it can be seen as a form of internal social mixing, though it is reserved for the estate's most privileged. From the perspective of poverty reduction, this internal reconfiguration has no effect on the absolute poverty levels of the neighbourhood and actually reinforces internal segregation and differentiation between buildings with different tenures and social profiles.

\subsubsection{Impoverishment in La Courneuve, Urban and Social Fragmentation in Orly}

Urban renewal in the La Courneuve and Orly housing estates reveals two distinct trajectories as a result of differing local contexts and approaches. 
In La Courneuve, urban renewal was not able to alter the course of continued impoverishment nor remove the negative stigma associated with housing estates. Poor households and large migrant families have been relocated into other degraded high-rise buildings, or into new social housing programmes, with two-thirds concentrated within three sub-sectors of the estate. These household trajectories reveal a pattern of displacing stigmatisation and poverty from one demolished building to another, and as such, outsiders have been discouraged from moving in, despite substantial renewal efforts.

Prior to renewal, Orly's population was already diverse, containing a large number of medium-sized apartments. The local strategy pursued by both the municipality and the social housing corporation promoted social mixing by offering improved public services and opportunities for existing residents to upgrade their residences. This encouraged them to remain in the neighbourhood even if other options were accessible to them. A survey conducted demonstrated that new affordable home ownership programmes attracted young adult children of local Algerian families, who tended to be more highly educated and employed. This resulted in social diversity within the renewed estates (though not ethnic diversity). However, as of 2006, the average income of those living within housing estates had not increased, despite increases within the municipality of Orly as a whole. A 2011 survey also revealed wide gaps in poverty rates between the five different sub-sectors of the estate, ranging from $25 \%$ in renewed areas compared to $40 \%$ in remaining areas.

In addition to urban de-concentration policies, actions have been undertaken to promote training and employment, to prevent crime and to better manage public space. However, the funding for these important initiatives is low and precarious, and the small local associations that implement them are not able to respond to the challenges described. Furthermore, a failure to formally recognise ethnic discrimination leads to strong feelings of injustice (Hancock et al. 2016).

Socio-economic policies have been implemented differently in the respective municipalities, according to their financial resources-illustrating how housing estates are embedded within a local context and within structural regional inequalities. For example, the entire Seine-Saint-Denis department, in which La Courneuve is housed, has a high concentration of poverty. In 2009, the mayor of La Courneuve filed a complaint to the HALDE (France's supreme authority to fight discrimination) against territorial discrimination. He sought to alert public authorities to the damaging effects of the stigmatisation of housing estates and the injustice being inflicted as a result of inferior public services and discriminatory employment processes (Hancock et al. 2016). Orly, on the other hand, is located in a more privileged department. These strong regional and territorial inequalities are not taken into account in most analyses, and yet these findings make a strong case for redistribution and positive discrimination. 


\subsection{Conclusion}

When constructed in the 1960s, France's housing estates were conceived as an urban and social utopia, embodying ideals of modernity and decent living standards. Yet, by the 1970 s, they were rejected as sites seen to produce urban dysfunction and social isolation. While initially conceived as socially mixed places in which different social groups would be able to live in harmony, over time, France's grands ensembles came to symbolise 'ghettos' that concentrated poverty and crime and reflected the failure of the French Republican model (Sala-Pala 2005).

To address what was now considered a public problem, between 1977 and 1990, public authorities implemented a lightweight programme to renovate buildings and common spaces, accompanied by micro-social interventions addressing school failure, access to employment and delinquency. At this stage, these 'problems' were considered to be temporary, and it was thought that testing a few policies in a small number of estates would provide a formula for remedying them. One of the main reasons for pursuing this approach was to avoid a repeat of the major 1958 urban renewal programme, through which many of Paris's poorest residents had been displaced. Indeed, prior to the end of the 1990s, the very notion of demolition was deemed taboo, even though a small number of post-war housing estate demolitions had occurred in 1986. Officials also felt that larger scale renovation should only commence once the loans taken out to finance the construction of these estates had been fully repaid.

Nevertheless, over the past few decades, the buildings of these estates have been refurbished through a massive national urban renewal programme. The rationale for such a large-scale intervention was based on the perceived failings of socio-economic measures to reduce poverty and delinquency, and the view that the urban form of the high-rise estate had become obsolete and ill-adapted to the standards expected by the mainstream population. Between 2003 and 2013, over $10 \%$ of France's overall social housing stock was demolished. As low-rise replacement housing - both social and private - is built in its place, the urban form of the large housing estate is gradually disappearing from the housing landscape, in an effort to improve the built environment and connections to the city centre. New utopian visions have resurfaced through the pursuit of a new social mix via housing diversification and 'colour-blind' area-based policies, aiming to tackle social inequality. However, the conception of housing and urban design inspired by new urbanism and its value of defensible space could appear to be just as standardised as the modernist housing programmes of the 1960s. It has had minimal impact on reducing inequality or delinquency rates. Despite these changes in the urban form, poverty and ethnic concentration have not disappeared, because urban space and housing tenure are not the primary causes of segregation.

In contrast to much analysis forecasting gentrification and displacement as the main effects of urban renewal (Lees 2008), the majority of residents relocated from the demolished housing estates of the Île-de-France region have remained in the same neighbourhoods. The higher the level of poverty concentration in an estate 
before renewal, the more likely such concentration levels persist post renewal. Furthermore, data on the housing estates in La Courneuve and Orly illustrate two divergent trajectories: one of impoverishment, through the reconcentration of poverty; and the other of urban and social fragmentation, with increasing differentiation between the layout, design and tenure of various housing programmes. The concentration of poverty and ethnic groups that has long characterised housing estates has not disappeared, but rather has been reconcentrated into other sub-sectors, with only some select places undergoing micro-gentrification. This process of micro-fragmentation could be perceived as a failure of social mixing policies (Blanc 2010). However, from a household perspective, this trend aligns with local strategies of municipalities and social housing corporations that seek to maintain an already existing social diversity by encouraging local, upper working-class people from inside the housing estate to take a step upwards in their housing careers and to remain in the neighbourhoods, rather than leaving (Lelévrier 2013a). This outcome has also been demonstrated in research into regenerated Dutch housing developments (Bolt et al. 2010).

Over the long-term, housing estates of the Paris region have provided affordable and comfortable homes for a large number of low-income people, a crucial role that is often underappreciated and forgotten (Dufaux and Fourcaut 2004; Levy-Vroelant 2007). Today, at the regional level, the major challenge facing the Paris region is the ongoing disappearance of affordable large flats as a result of the demolition of 1960s-era high-rise buildings under urban renewal programmes and the rising costs of land, which makes it increasingly unaffordable for the government to acquire new property for social purposes. In a region where prices and rents are forever on the rise, socio-territorial disparities are growing rather than declining.

Thought needs to be given to finding ways by which to maintain existing rent prices in new social housing developments, so that the lowest income residents are not once again displaced from their neighbourhoods, and can be provided with opportunities to improve the socio-economic conditions of their lives.

The significant shortage of new and existing social housing units for those most in need suggests that it is timely for France to reconsider its approach to providing this housing. Recent laws passed in France potentially hold some promise. For example, the 2007 Right to Oppose Housing law enables residents who have been on social housing waiting lists for extended periods of time to be prioritised in the allocation process. Furthermore, France's 2017 Equality and Citizenship law increases the transparency of how social housing units are allocated and to whom. These policies seek to shift focus from diversification and the provision of new housing to increasing access to the existing public stock, including by attempting to overcome issues of discrimination.

France has also begun to reconsider its universal approach to public housing provision, to allow those who are most disadvantaged to have priority access, while devising appropriate mechanisms to support people who are able to access the private market. However, this remains a tough political discussion, as it brings into question the 'right to stay' principle enshrined into France's approach to social housing, and will likely lead to a reduction in levels of social mix. 
These challenges highlight the value in paying further attention to social innovations around the provision of affordable housing for France's lowest income people. One of the main shortcomings of traditional social mixing policies-aside from their inefficiency - is the uncertainty around how the poorest populations benefit from this approach. Housing initiatives of local authorities and non-governmental organisations can provide insight into different ways of mixing and producing housing, based on relations of social reciprocity as opposed to mere spatial proximity. For example, one model provides affordable accommodation to students in renewed housing estate areas in exchange for their engagement in social actions with residents (Lelévrier et al. 2016). Another approach pursues housing diversification strategies that assist local residents to advance in their housing careers within their own neighbourhoods (Lelévrier et al. 2016). Yet another approach consists of relocating low-income people into areas that concentrate wealthier residents, with the support of non-governmental organisations, in contexts where social mix is voluntarily chosen.

These findings challenge what has been depicted as one long, unfolding process of urban policy in France. They suggest that mobility is a pertinent concept for analysing poverty concentration and that it is time to reopen the debate between place and people-oriented policies. This would lead to more redistributive and socially-oriented policies that target the poorest housing estates, implying that social mix - at least in its current conception-would no longer be so central to urban policy, or would be reconceived in light of emerging innovations. This departs quite significantly from current national approaches, as well as from regional policies in Île-de-France, which are at risk of creating new peripheries of exclusion and segregation.

Acknowledgements The authors acknowledge assistance in acquiring data and maps from Mariette Sagot (IAU), Anne-Claire Davy (IAU), and Delphine Jacquier (Valophis).

\section{References}

Alba R, Silberman R (2002) Decolonization immigration and the social origins of the second generation: the case of North Africans in France. Int Migrat Rev 36(4):1169-1193

Blanc M (2010) The impact of social mix policies in France. Housing Stud 25:257-272

Bolt G, Philips D, Van Kempen R (2010) Housing policy, (de)segregation and social mixing: an international perspective. Housing Stud 25(2):129-135

CES-ANRU (2013) Changeons de regard sur les quartiers. Vers de nouvelles exigences pour la rénovation urbaine. Rapport, Janvier.

Chamboredon JC, Lemaire M (1970) Proximité spatiale et distance sociale. Les grands ensembles et leur peuplement. Revue française de sociologie 11(1):3-33

Chombart De Lauwe PH (1965) Des hommes et des villes. Payot, Paris

Coing H (1966) Rénovation urbaine et changement social. Éditions Ouvrières, Paris

Cour des Comptes (2012) La politique de la ville, une décennie de réformes. Cour des comptes, Paris

Dikec M (2017) Urban rage, the revolt of the excluded. Yale University Press, New Haven 
Droste C, Lelévrier C, Wassenberg F (2014) Urban regeneration in Dutch, French and German social housing areas. In: Scanlon K, Whitehead C, Fernandez Arrigoitia M (eds) Social housing in Europe. Wiley Blackwell, pp 368-388

Dufaux F, Fourcaut A (2004) Le monde des grands ensembles. France, Allemagne, Pologne, Russie, République tchèque, Bulgarie, Algérie, Corée du Sud, Iran, Italie, Afrique du Sud. Créaphis,

Escafré-Dublet A, Lelévrier C (2014) Governance arrangements and iniatives in Paris: divercities. UPEC, Paris

Fourcaut A (2006) Qu'elle était belle la banlieue. Histoire 315 (décembre)

Goulard F, Puponni F (2010) La république impuissante. Comité d'évaluation et de contrôle des politiques publiques sur l'évaluation des aides aux quartiers défavorisés. Assemblée nationale, Paris

Hancock C, Lelévrier C, Ripoll F, Weber S (2016) Discriminations territoriales, entre interpellation politique et sentiment d'injustice des habitants. l'œil d'or, Paris

Huguet M (1971) Les femmes dans les grands ensembles, de la représenta-tion à la mise en scène. CNRS, Paris

Insee-Analyses (2017) Les quartiers de la politique de la ville en Région Ile-de-France. vol 27

Insee-Première (2010) La population des ZUS. 328. décembre

Kleinhans R (2004) Social implications of housing diversification in urban renewal: a review of recent literature. J Housing Built Environ 19:367-390

Lacoste Y (1963) Un problème complexe et débattu: les grands ensembles. Bulletin de l'association des géographes français, 318-319

Le Goullon G (2010) Les grands ensembles en France: genèse d'une politique publique (19451962). thèse. Paris-1 Sorbonne

Lees L (2008) Gentrification and social mixing: towards an inclusive urban renaissance? Urban Stud 45(12):2449-2470

Lelévrier C (2013a) Forced relocation in France: how residential trajectories affect individual experiences. Housing Stud 28(2):253-271

Lelévrier C (2013b) Social mix neighbourhood policies and social interaction: the experience of newcomers in three new renewal developments in France. Cities 35:409-413

Lelévrier C, Noyé C (2012) La fin des grands ensembles? In: Donzelot J (ed) A quoi sert la rénovation urbaine?. PUF, Paris, pp 185-221

Lelévrier C, Rivière C, Escafre-Dublet A, Shokry G (2016) Divercities: dealing with urban diversity. University of Paris-Est-Créteil, Paris, The case of Paris

Levy-Vroelant C (2007) Urban renewal in France. Eur J Social Sci Res 20(2):109-318

Mondon A, Winter A (2017) Articulations of Islamophobia: from the extreme to the mainstream? Ethnic Racial Stud 40(13):2151-2179

Moran M (2017) Terrorism and the banlieues: the Charlie Hebdo attacks in context. Modern Contemp France 25(3):315-332

Murie A, Knorr-Siedow T, van Kempen R (2003) Large housing estates in Europe: general developments and theoretical backgrounds. Utrecht University, Utrecht, Faculty of Geosciences

ONZUS (2012) ONZUS rapport

Sala-Pala V (2005) The French republican integration model from theory to practice. The case of housing policy. In: Honohan I, Jennings J (eds) Republican theory, republican practice. Routledge, London, pp 186-198

Tomas F, Blanc JN, Bonilla M (2003) Les grands ensembles, une histoire qui continue. Université de Saint-Etienne, France

van Kempen R, Dekker K, Hall S, Tosics I (2005) Restructuring large housing estates in Europerestructuring and resistance inside the welfare industry. Policy Press, University of Bristol, Bristol

Vieillard-Baron H (2004) Sur l'origine des grands ensembles. In: Dufaux F, Fourcaut A (eds) Le monde des grands ensembles. France, Allemagne, Pologne, Russie, République tchèque, Bulgarie, Algérie, Corée du Sud, Iran, Italie, Afrique du Sud. Créaphis, Paris 
Open Access This chapter is licensed under the terms of the Creative Commons Attribution 4.0 International License (http://creativecommons.org/licenses/by/4.0/), which permits use, sharing, adaptation, distribution and reproduction in any medium or format, as long as you give appropriate credit to the original author(s) and the source, provide a link to the Creative Commons license and indicate if changes were made.

The images or other third party material in this chapter are included in the chapter's Creative Commons license, unless indicated otherwise in a credit line to the material. If material is not included in the chapter's Creative Commons license and your intended use is not permitted by statutory regulation or exceeds the permitted use, you will need to obtain permission directly from the copyright holder.

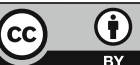




\title{
Chapter 15 \\ Long-term Development and Current Socio-Spatial Differentiation of Housing Estates in Prague, Czechia
}

\author{
Martin Ouředníček, Petra Špačková and Lucie Pospíšilová
}

\begin{abstract}
The housing estate is perceived to be one of the main symbols of the socialist regime in the former Eastern Bloc. Immediately after the Velvet Revolution, housing estates were to some extent rejected by the general public as well as neglected in spatial planning and policies. At the same time, Prague's housing estates contained more than $40 \%$ of the city's population, thus representing the most important part of the built environment within the city. The main aims of this chapter are to evaluate the specific development of Prague's housing estates in the second half of the twentieth century, and then to explore the finer details of their inherent socio-spatial differentiation. The role of state and local housing policy is evaluated as the crucial factor in the current and future development of housing estates. The results are similar to those for many other CEE cities, and confirm that the transformation period had little impact on social structures within these residential areas and that the social mix sustains the main attribute of Prague's housing estates. New housing construction and ethnic differentiation are the most important processes to have changed the social environment of housing estates in Prague during the post-transformation period.
\end{abstract}

Keywords Housing estates · Housing policy • Socio-spatial differentiation Prague

M. Ouředníček $(\bowtie) \cdot$ P. Špačková · L. Pospíšilová

Faculty of Science, Department of Social Geography and Regional Development,

Charles University, Prague, Czechia

e-mail: martin.ourednicek@natur.cuni.cz

P. Špačková

e-mail: petra.spackova@natur.cuni.cz

L. Pospíšilová

e-mail: lucie.pospisilova@natur.cuni.cz

(C) The Author(s) 2018

D. B. Hess et al. (eds.), Housing Estates in Europe, The Urban Book Series,

https://doi.org/10.1007/978-3-319-92813-5_15 


\subsection{Introduction}

Housing estates (sídliště) represent an integral part of the physical and social environment in cities, towns and even small villages within the whole of Czechia. Behind the single term-sídliště-various structures are hidden. Czech housing estates comprise huge settlements of panel apartment houses that constitute a considerable part of the urban housing stock on the one hand, and solitary houses on the peripheries of small villages (bytovka) on the other. Like the sickle and hammer, the red stars, and the communist slogans on the streets, housing estates are icons of the socialist era. The symbols of the previous era may have disappeared from public space almost immediately after the revolution, but housing estates are still one of the most prominent structures in Czech cities (Novotná 2010). Today, they comprise approximately one-third of the housing stock in Czechia and more than $40 \%$ of that in Prague.

The size of this proportion is itself sufficient to legitimise the social and scientific relevance of the research on housing estates. However, since sociologist Jiří Musil and his colleagues wrote the famous Lidé a sídliště (People and Housing Estates) in 1985, no similar focused work has been published in Czechia ${ }^{1}$ and only a few authors have subjected the question of housing estates in Prague to international debate (Temelová et al. 2011; Temelová and Slezáková 2014; Ouředníček 2016). Others published only in the Czech language (e.g. Maier 2003; Barvíková 2010; Špaček 2012), focus on the development of the whole of Prague, where housing estates are only part of the discourse (Špačková et al. 2016), or evaluate only selected Prague housing estates as a part of a broader analysis covering the whole of Czechia (Špačková and Pospíšilová 2017).

With this in mind, the main aim of this chapter is to evaluate and explain the development of Prague's housing estates in the second half of the twentieth and the beginning of the twenty-first centuries. Specifically, we intend to discuss the impact of changing state and city policies on the social structure of residents of housing estates, and its spatial differentiation. To this end, three periods of housing estate development are evaluated in the text. The first part relates to the description and explanation of state and local policies enacted in Czechoslovakia over the period 1948-1993, which saw the construction of housing estates in Prague and the development of the socio-spatial differentiation of housing estates, using the data from population censuses on location, size, tenure structure and population. The period after the Velvet Revolution (after 1989) is divided into two parts, namely, transformational and contemporary development, in which we again discuss specific policies and strategies, and the development of socio-spatial differentiation in housing estates in Prague.

\footnotetext{
${ }^{1}$ Several recently published works focus mainly on architecture and urbanism in selected housing estates (e.g. Zarecor 2011; Zadražilová 2013; Skřivánková et al. 2017).
} 


\subsection{History of Housing Estates in Prague}

Although the main ideas behind housing estates were developed well before World War II (Zadražilová 2013), the history of large housing estates in Czechoslovakia is strongly tied to the post-war period and the ideology of the Communist Party. For the delimitation of the subject of study, we refer to 'socialist housing estates', keeping in mind certain limitations of this term. Prague's first post-war (pre-socialist) housing estate, Solidarita, was built in 1947-1949, based on the regulatory plan of 1938. Several houses of the most recent generation (e.g. Černý Most II) were finished in 1993, 4 years after the Velvet Revolution. However, the vast majority of estates originate from the socialist period.

The general development of housing construction in Czechoslovakia was determined by national strategies; among them industrialisation and urbanisation strategies. These strategies led to heavy investment in industrial centres, and from the 1960s, the creation of the Central Settlement System (středisková soustava osidleni) supporting selected centres of newly established administrative districts (76 districts-okres). Planning at the national level was based on a combination of specific housing policy and a marked shortage of flats (Hampl and Kühnl 1993). Unlike many other cities, Prague sustained only slight damage during the war years. Early post-war housing construction was focused more on the restoration of damaged housing stock and construction on prepared plots, rather than on new larger projects (Borovička and Hrůza 1983). A major turning point in the development of Prague was the communist coup in February 1948. The relatively favourable housing situation compared to other cities in Czechoslovakia, supported by the migration of Prague residents to border regions from which the Germans had been expelled, together with the release of houses occupied by the Germans during the war, caused a shift of investment from housing to industry and to industrial cities other than Prague during the post-war period (Kohout and Vančura 1986; Matějů 1977).

The Communist Party soon began to promote specific policies reflecting efforts to reduce social disparities. Attempts were made to reduce differences in society via several measures such as the nationalisation of most apartment houses, rent regulation, the division of large housing units into several smaller ones and the abolition of the land market and the introduction of regulated or fixed land prices (Musil 2005a). The main objective was to improve conditions for working-class families in overcrowded apartments (Votrubec 1965); later, the aim was to solve the housing shortage (Matějů et al. 1979). Socialist housing construction was oriented towards homogenisation and elimination of differences either between regions within Czechoslovakia (in particular, between the Czech and Slovak parts of the Republic) or even between neighbourhoods within cities (Steinführer 2003). State and cooperative housing construction were financially supported and rationing of apartments was introduced. Initial redistribution of apartments aimed at the elimination of class inequality that took place within the existing housing stock, which then stagnated until the early 1960s (Matějů 1980). 
During the 1950s and 1960s, the socialist regime succeeded, through restrictions on housing construction, in controlling residential mobility, and at least to some extent, population growth in Prague (Matějů et al. 1979; Musil 2006). The real housing crisis came soon afterwards, primarily as a result of higher fertility rates and growing immigration to Prague (Matějů et al. 1979), but also as a consequence of the restrictive policies described herein. However, the construction of housing estates, which grew in the mid-1960s and was in full swing during the 1970s and 1980s, brought with it new dynamics in terms of population development (Matěju 1977; Matějů et al. 1979). This construction significantly changed the physical and social fabric of the city (Musil 2005b).

As early as the 1950s, a tendency towards standardisation and industrialisation appeared in housing construction, and the first prefabricated houses were built in Prague during the 1960s. This type of construction became dominant in new housing during the socialist period (Borovička and Hrůza 1983). The policy of Comprehensive Housing Construction (komplexní bytová výstavba) represented a planning tool to manage the construction of housing estates centrally at the national level. The aim of the policy was to enhance the integrity of the process of both project planning and construction (Zadražilová 2013). New industrial methods of housing construction, prefabrication and standardisation were introduced. The outcome of the socialist housing construction was a comprehensive housing estate providing residential buildings and civic amenities, whose scope was determined using so-called technical-economic indicators. This followed the Soviet concept of residential areas as smaller organisational units (Zadražilová 2013). The implementation of the policy of Comprehensive Housing Construction brought changes at the institutional level and led to the concentration of planning and construction in large-state institutions_-project institutes (projektové ústavy) and large construction companies.

During the years 1961-1970, a 16\% increase in the number of dwelling units was recorded in Prague, which was significantly lower than it was in the other main cities of Czechoslovakia (Borovička and Hrüza 1983). The attention of the government and Communist Party then turned to Prague during the 1970s because it lagged behind other socialist capitals due to a lack of investment (Kohout and Vančura 1986). The government approved plans for extensive construction of housing estates on the outskirts of the city and the most extensive housing construction in Prague took place during the 1970s. Newly designed residential units exceeded the administrative borders of the city, which was partly the reason for the expansion (Hrůza 1989). The city's development was also made possible due to the construction of the subway (metro) with the first line coming into operation in 1974 (Fig. 15.1).

Two concentric rings of housing estates rose up around the city centre (Fig. 15.1 and Table 15.1). Older housing estates from the 1950s and 1960s were often connected to the city centre by tramways (Fig. 15.2). The newer estates were built as greenfield developments and were much larger than similar projects in capitalist cities (Musil 2005b; Temelová et al. 2011). The construction of so-called 'new towns' created three large complexes of relatively autonomous settlements: North 


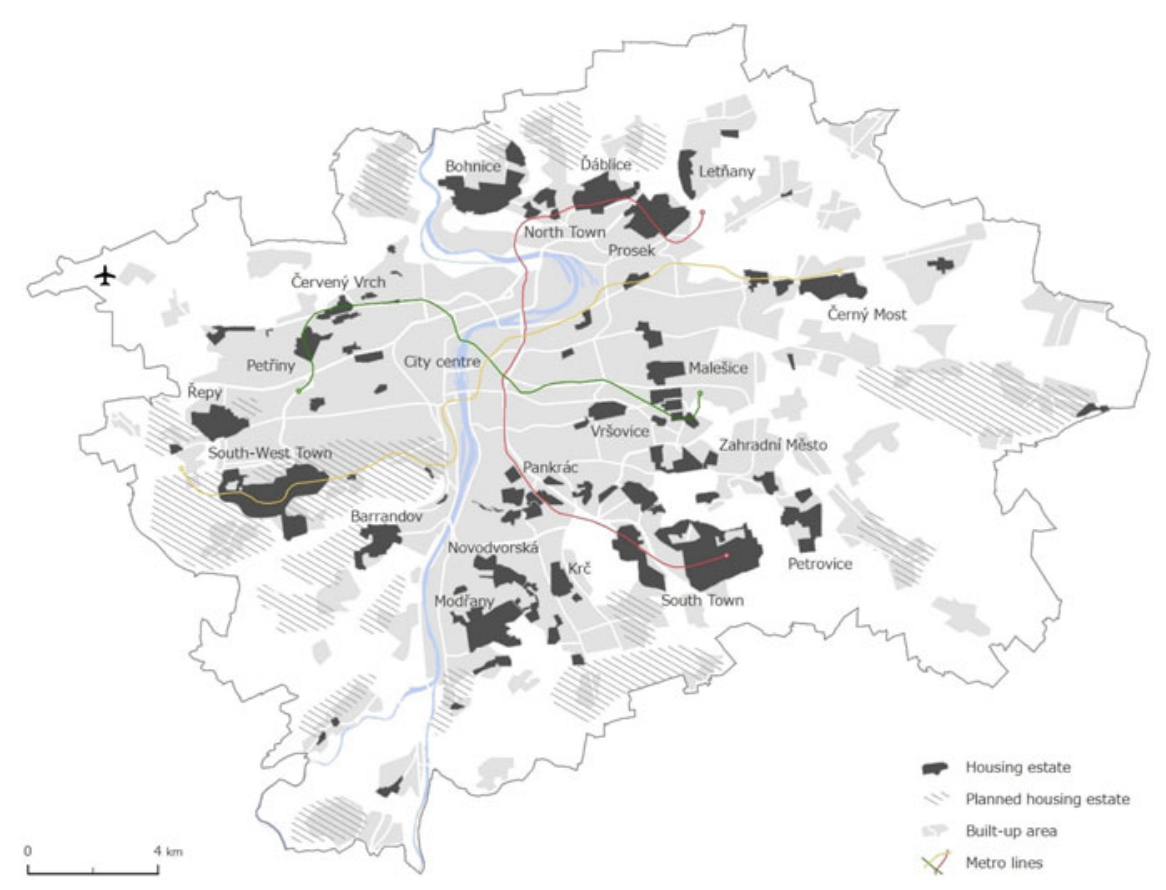

Fig. 15.1 Spatial pattern of housing estates in Prague. Source Jiří Nemeškal, 2017

Town (Severní Město), South Town (Jižni Město) and South-West Town (Jihozápadní Město). Metro lines serve these towns today, but in the early years, they suffered from a lack of social and cultural facilities and jobs. Housing estates erected on the outskirts then served as city dormitories with tens of thousands of people commuting every day to work, shopping and leisure activities in other parts of the city (Hrůza 1994; Maier et al. 1998). Several housing estates were never realised on the outskirts (see Fig. 15.1).

The proportion of the housing estate population has remained stable over the post-socialist period, ranging from 43 to $46 \%$ (Table 15.1). A large number of housing estates have experienced slow and gradual population loss via out-migration and a decrease in the average size of households. In other cases, positive net migration is a result of several new housing projects being built in these areas (Přidalová et al. 2015). In general, the number of inhabitants decreased by $20 \%$ in housing estates built prior to the 1970s. The percentage is even higher in the case of some older estates where the first residents are dying out (e.g. $40 \%$ for the Pankrác housing estate). Contrary to this development, estates built during the 1980s show a population increase connected to new housing construction in the form of infill development or larger complexes of new residential buildings (Fig. 15.2). 


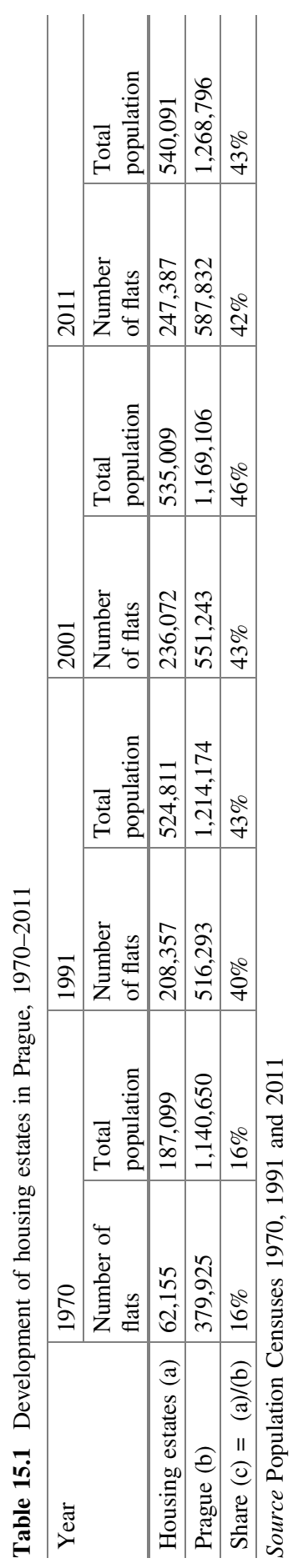



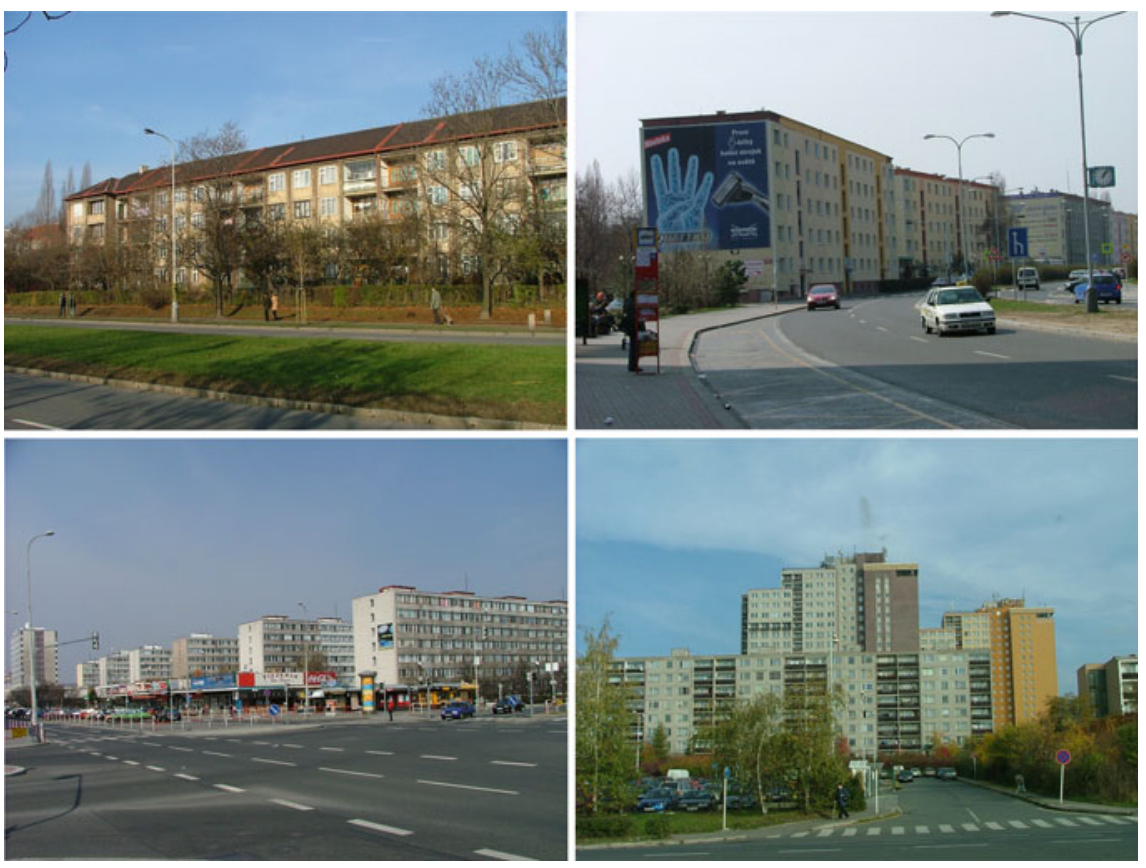

Fig. 15.2 Examples of housing estates in Prague: from top left, Solidarita (built during 19471949), Antala Staška (1954-1955), Pankrác (1964-1970) and South Town (1972-1992). Source Martin Ouředníček

\subsection{Development of Socio-Spatial Structure Within Socialist Housing Estates}

Socialist housing existed in Prague in four basic types of housing ownership: (i) state housing; (ii) socialist enterprise housing; (iii) cooperative housing and (iv) private housing (Musil 1987). State and enterprise construction was financed completely by public funds and mainly served employees of the socialist sector. Rent control and a policy of low rents were consistently applied (Musil 1987). Cooperative housing was based on a state grant and a low-rate loan together with families' private funds and was affordable for people who were able to contribute to the cost of house-building. All types of housing estates existed in the same place and there were no 'pure' cooperative or state estates, as there were in some other socialist countries (Musil 1987).

Allocation of individual apartments was fully in the hands of housing commissions (bytová komise), operated under national committees (Národní výbor), with building maintenance organised by District Housing Services Corporations (Obvodni podnik bytového hospodárství-OPBH). Through the national committees and other public institutions, the state regulated the use and construction of 
housing stock to limit the development of growing inequality in housing levels with regard to classes, social layers, social or demographic categories of the population, and also in respect to particular geographical areas (Musil 1987, p. 37). During the whole of the socialist era, the system of waiting lists (poradniky) for individual apartments was established as in many other socialist countries (compare Gentile and Sjöberg 2013). However, this system provided the opportunity for corruption (Musil 2002b; Lux and Sunega 2014). Among preferred groups with privileged positions were employees of industrial companies, working-class people, young households with children and households of employees in socially prominent organisations (e.g. police, army).

During the 1960s and 1970s, a significant proportion of new residents were former inhabitants of houses destroyed as a consequence of inner-city reconstruction programmes (Musil 2002b). In the 1970s, the strategy of Comprehensive Housing Construction compensated for the needs of Prague inhabitants in particular, but in the mid-1980s, a substantial part of the migration into the new residential areas seemed to consist of people moving from other parts of the Republic (Přidalová et al. 2015). This development was in accordance with the changing strategy of the Communist Party and the growing support of investment and relocation of the workforce to Prague. During this period, many inhabitants who moved within the administrative territory of Prague had previously lived in inner-city tenement houses and also in older housing estates (see Fig. 15.3).

Homogeneity of the housing estate population was primarily related to demographic status, as predominantly young families with children moved to newly built apartments (Matějů et al. 1979; Musil 1987; Temelová et al. 2011). However, regarding social status, newer estates were heterogeneous (Matějů et al. 1979; Musil 2006). In the first phase of housing estate construction, it was mostly working-class people who came to the newly built areas - more than $75 \%$ of them were young working-class households (Musil 1987). Consequently, an increasing diversity of housing, together with financial participation in cooperative housing, led to a more heterogeneous socio-economic structure in housing estates (Matějů et al. 1979; Musil 1987). Some flats in better quality estates were preferentially allocated to non-manual groups, with others, by contrast, allocated to manual workers (Linhart et al. 1977).

This heterogeneity was evident within individual housing estates, as well as between housing estates. First, a remarkably high social mix of various occupational groups was a characteristic of many housing estates which, in turn, were more socially mixed than the older parts of the city. For example, a university professor, industrial worker and bus driver might live in the same apartment building (Musil 1985). Second, we also observe significant differences in the social status of different housing estates. Although the housing estates showed average levels of both educational attainment and the proportion of employees in the secondary sector at the end of socialist period, a relatively high level of differentiation between individual housing estates was recorded (e.g. the proportion of university-educated ranged between 9.3 and $25.9 \%$ in 1991). Higher social status 


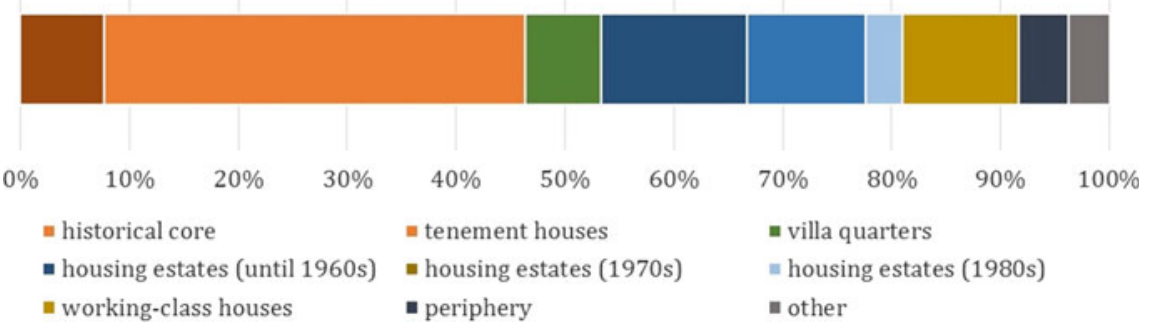

Fig. 15.3 Previous place of residence of new inhabitants of South Town and South-West Town, 1986-1988, N = 13470; Note tenement houses, villa quarters and estates from the 1960s are located within the inner-city and newer housing estates and working-class quarters are mainly in the outer city. Source IUD, 1989

was recorded in estates built up to the end of the 1960s (e.g. Pankrác, Petrriny) and also in the case of flats completed during the 1980s (e.g. Barrandov, Stodůlky).

On the other hand, lower socio-economic status as manifested both in low educational attainment and a high proportion of employees in the secondary sector of the economy was recorded in estates located in the eastern part of Prague (e.g. Černý Most, Kbely, Letňany). Apartments in these areas were preferentially allocated to factory employees. Therefore, we argue that spatial patterns of socio-economic structure perpetuated, to some extent, the pre-war status quo. Richer neighbourhoods were still located in western parts of the city, and poorer ones in the eastern parts of the city. This was partly due to the structure of local jobs and the proximity of industrial enterprises in the eastern part of the city, influenced by the prevailing westerly wind. Another reason was the area's flat terrain, which was more suitable for large-scale housing construction.

The role of ethnic groups was almost negligible in most housing estates during the socialist period. In general, the proportion of inhabitants with non-Czech ethnicity was low (only 4\%) and a majority of these were of Slovak ethnicity, i.e. citizens of Czechoslovakia. Selected estates accommodated higher numbers of Roma people (e.g. Repy, Stodůlky). However, their proportion in the population was generally lower than in inner-city neighbourhoods.

\subsection{Transformation Period: General Development and Socio-Spatial Differentiation}

The Velvet Revolution in November 1989 represents a 'break' point, after which fundamental changes took place, not only in politics and the economy but also in the spatial organisation of society and intra-urban spatial patterns (Musil 1993; Sýkora 1999; Hampl 2007). The first two decades of post-socialist urban development could be perceived as a period strongly influenced by transformation 
processes connected to transition from a socialist to a democratic society. These processes in Prague have been thoroughly described and evaluated (Eskinasi 1995; Sýkora 1999; Ouředníček and Temelová 2009), therefore we stress only those processes that directly influenced housing estate development in Prague. Among these, housing policy and dilution of public administration played crucial roles. Subsequent changes in ownership structure had a direct impact on the socio-spatial structures of the concerned housing estates.

All plans for new housing construction were halted almost immediately after the Velvet Revolution. The system of Comprehensive Housing Construction was terminated in 1993, and new housing construction was hindered by uncertainty about the restitution process, a real estate market that was developing slowly and the non-existence of financial tools to support housing. First attempts at humanising housing estates and their de-communisation in the form of simple changes were visible during early transformation period, particularly in streets, squares and institutional names (Kaltenberg-Kwiatkowska 2008). ${ }^{2}$ Housing estates were often negatively perceived, and were also presented in the media as communist symbols and so-called 'rabbit-hutches'; they were generally considered less attractive places to live. This all led to an uncertain future for housing estates, and a danger of stigmatisation and ghettoisation (Musil 2002a; Brade et al. 2009), which was strengthened by selective outflow of the well-off population during the first half of the 1990s (see below).

As highlighted by Musil (1993), housing policy in the early 1990s was very limited in that it did not aspire to provide state-controlled housing construction, social housing, or any reliance on large-state support for housing. This situation gradually changed during the mid-1990s with the establishment of a mortgage system, a new idea of building savings (stavebni spořeni), and restitution, which in combination helped to oil the wheels of the real estate market.

Decentralisation of self-government in Czechoslovakia was another important factor at the beginning of the 1990s. Prague itself changed from its former division of 10 administrative districts to 57 self-governed parts of the city. Several housing estate complexes on the outskirts became autonomous city parts, while older housing estates were incorporated into inner-city districts. In addition to the Prague City Assembly, each part of the city has its own assembly, council, mayor and independent budget, and also assumes some tasks in terms of state administration (Blažek et al. 1994). However, the scope of responsibilities of parts of the city is limited, with only poor control of urban planning and the economy of the city, which is in the hands of the Prague City Council. The role of self-government in city parts became especially important for housing policy. During the 1990s, it facilitated predominantly independent policies for the regeneration and privatisation of housing stock, which was transferred from the state to municipal ownership.

\footnotetext{
${ }^{2}$ As an example, the names of 12 stations on all three lines of the metro were changed.
} 
Privatisation of the formerly state and municipal housing stock was the core transformation process in housing estates. ${ }^{3}$ Each of Prague's 57 city parts devised its own privatisation policy because strategic decisions on the degree of privatisation were partly dependent on the political orientation of the ruling party. While more right-wing parties preferred privatisation of the entire housing stock, other city parts (e.g. К̌epy-social democratic) preferred to retain more housing units in municipal ownership (Musilová 2004). In the end, however, 90\% of former municipal housing stock was privatised (Burdová et al. 2012). Differences between city parts more or less levelled out, resulting in a proportion of non-privatised municipal houses of between 7 and $12 \%$, which is generally higher on housing estates than in other housing stock (Table 15.2).

Some city parts formulated their own regeneration strategies. At first, regeneration efforts focused on the built environment, namely on the revitalisation of housing stock. For example, Prague 11, comprising the South Town estate, commissioned an architectonic study to delimit the main principles of regeneration and guide particular renovation projects. Later, the focus also shifted more intensively to the revitalisation of public spaces. Among other initiatives, a pilot project based on participative planning was carried out in part of the Černý Most estate. At the same time, there was a larger impetus to promote community and cultural life, for example, Prague 14 (which includes the Černý Most and Hloubětín estates) created the organisation 'Praha 14 cultural' for these purposes. Last, there are no plans for the demolition of pre-fab houses; on the contrary, housing in these estates is in high demand, and new residential areas are quickly developing there.

More importantly, however, several state programmes specifically aimed at regeneration of housing estates were introduced at the dawn of twenty-first century. Most of the subsidy programmes coordinated by the Ministry of Regional Development and the Ministry of Environment focus on improving the state of buildings from a technical point of view, ${ }^{4}$ although some also cover the revitalisation of public spaces within housing estates (e.g. European Structural Funds, IPRM programme) (Šimáček et al. 2015). Thus, the remodelling of apartments, regeneration of panel houses, and revitalisation of public areas constituted the most common interventions within Czech housing estates (Šimáček et al. 2015). Enhancement of energy efficiency is the main motivation for the renovation of housing stock (Němec 2011). Most renovation activities are small-scale and are organised by individual owners and associations (private, cooperative and public).

According to analysis by the Institute of Planning and Development, most of the older housing estates in Prague have been completely regenerated (Ď́alice $68 \%$ of apartment buildings, Malešice 68\%, and Bohnice 67\%), while in younger estates sometimes fewer than $20 \%$ of apartment buildings have seen full reconstruction

\footnotetext{
${ }^{3}$ Today, some city authorities often sell apartments in housing estates to sitting tenants in Prague for one-third of the commercial value. During the 1990s, the prices were much lower, with flats being sold to tenants for about 2,000 CZK per m² (Kostelecký 2000, p. 188).

${ }^{4}$ Examples of building improvements include repairs of defects in panel buildings (1998-2005), new panel installation (2002-2015), and a new Green Savings Programme (2009-2020).
} 


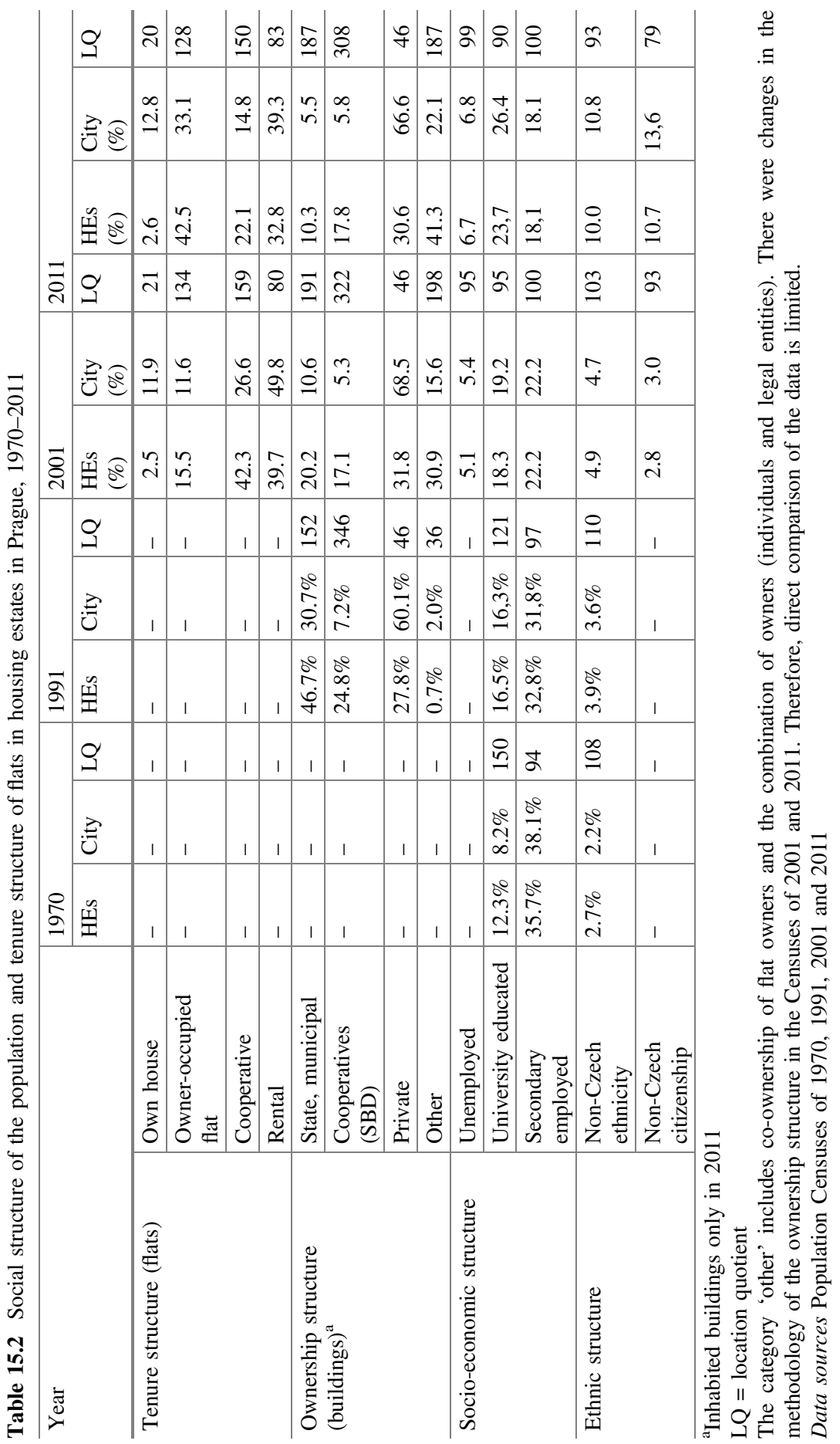


(Němec 2011). Because the sum of the average proportions of completely regenerated (42\%) and partly regenerated (48\%) apartment buildings is high, we might contend that in general they are well maintained by their owners. In this context, Němec (2011) argues that cooperative ownership results in the highest proportion of reconstructed dwellings. This could be explained by the greater ability of larger cooperatives to gain professional help in the renovation process (Karasek and Ubralova 2012).

Development of tenure structure in housing estates reflects the development of the housing market in Prague as a whole. We observe an increase in the number of owner-occupied flats connected with the transformation of housing cooperatives (bytové družstvo) into associations of owners (společenství vlastnikü) and with the large-scale privatisation of the housing stock from the public (state or municipal) into private hands (Table 15.2). Therefore, the proportion of flats that are rented has seen a slight decrease, and the composition of landlords has changed (from state and city into private flat owners). Former tenants, thus, remained in their dwellings, and as homeowners they started to invest in modernisation of their homes, thereby maintaining the attractiveness of estates. Such behaviour helped to maintain a relatively favourable social composition of the population in housing estates and, to some extent, the social mix as well, at least for a few decades. Indeed, housing estates in which the flats are occupied by their owners show a generally higher level of socio-economic status of their populations (compared to housing estates with higher proportions of rented housing).

The proportion of public housing is relatively low in Prague. According to the most recent census data from 2011, only 5.5\% of all inhabited houses were owned by the municipality or by the state in Prague, with $10.3 \%$ on housing estates (Table 15.2). It is interesting to note that more than 25 years after the fall of the communist regime, there is no legislation defining social housing (sociální bydleni) at the national level in Czechia. The policy of social housing is, therefore, in the hands of municipalities (or municipal districts), which approach it rather differently, with social allowances being the main tool to support low-income groups in paying housing rent.

In general, with the higher proportion of flats in public ownership, the socio-economic status of housing estate populations tends to be lower (i.e. a higher proportion of unemployed and lower proportion of university-educated residents). Indeed, in some units with higher concentrations of municipal housing, we observe a relatively low level of socio-economic status of the populations (Černý Most and Lehovec estates). In other units, however, socio-economic status is average compared with the general population (or even above-average). Despite a higher share of municipal housing stock in housing estates compared to the average for Prague, only part of it is used for social housing. Other flats are inhabited by tenants who have been living in their flats ever since the socialist period or are leased out by city authorities for market rent.

Considering the socio-economic patterns of the transformation period, analysis shows a gradual process of social degradation of housing estates as expressed by the educational structure of the population in comparison with development of the 
city. Dynamics of the increase in educational attainment show that it is lower than the city average, which results in a lower proportion of university-educated people. However, the proportion of unemployed, and employed in the secondary sector of the economy, is slightly less than the city average (Table 15.2).

Moreover, we observe different dynamics in variations in educational and employment structures. First, housing estates already experienced a sharp decrease in the proportion of secondary-sector employed residents during the 1990s; this change was tied to the transformation of the city's economy together with rapid deindustrialisation. Second, in the case of educational structure, the increase in the level of education was relatively slow in the 1990s compared with the period between 2001 and 2011 (in housing estates as well as in the city as a whole). In some housing estates, we even observe a slight decrease in the proportion of university-educated people (e.g. Modřany, Hostivař-Košík, Řepy and LibušPísnice). Although part of this change can be ascribed to the 'nest-emptying' process, some better-off people who could afford to move from housing estates gradually out-migrated from these areas during this period. Suburbanisation was one of the new processes that supported this out-migration (Ouředníček 2007).

Faster growth in educational attainment after 2001 was caused by greater availability of university education (increasing numbers of students at public and private universities), the age structure of Prague's population in which there was a high proportion of inhabitants born in the 1970s who had just finished their university studies, and the general attractiveness of Prague for young, educated people from other parts of the country. Nonetheless, growth in educational attainment was lower in housing estates than in other parts of the metropolitan region.

The process of relatively slow degradation, however, is not exclusively connected with the post-socialist transformation. It is possible to see the worsening of the educational structure even before the end of socialism. Even in 1991, the zone of housing estates showed 'only' average educational attainment compared with the rest of the city (Table 15.2). The rate of decrease of educational attainment is relatively stable over time. Besides other factors such as the out-migration of the better-off to other parts of the metropolitan region, it can be ascribed to the natural ageing of the local population.

When analysing spatial patterns, we observe a relative inertia following the end of the socialist period. Two groups of housing estates show worse educational and economic structure of the population. These estates, first, are located on the outskirts of the city, some with poor transportation accessibility, built either in the 1970s (Modřany, Lehovec and South Town) or in the 1980s (Černý Most and Horní Měcholupy-Petrovice). Second, populations with lower social status live in older housing estates with a high proportion of senior citizens (Zahradní Město, Malešice and Novodvorská). On the other hand, housing estates with excellent accessibility and location within the city remain an attractive residential choice for the better-off population and retain their higher social status despite a higher proportion of senior citizens (Petřiny, Červený Vrch, Pankrác and Solidarita). Similarly, estates with new housing construction attract economically stronger populations (e.g. Barrandov and Hostivař-Košík). 
The proportion of the foreign-born population is relatively low in housing estates compared to the city average. There are also considerable differences in the structure of the foreign population according to the country of origin. While better-off foreigners from the Western world tend to seek flats in the city centre and suburbs, comparatively cheaper housing estates attract post-Soviet and Asian foreigners (Přidalová and Ouředníček 2017). Ukrainians, Russians and Vietnamese are the most common ethnic groups. Interestingly, foreign nationals tend to create ethnic enclaves in some housing estates. For example, a Vietnamese minority is concentrated in Libuš-Písnice nearby the Vietnamese market SAPA, and Russian-speaking foreigners are over-represented in the South-West Town (Přidalová 2017).

\subsection{Post-transformation Development}

As we previously argued elsewhere (Ouředníček and Pospíšilová 2016), in Czechia the era of large transformation processes and systematic changes in the legislative, administrative, and other norms formed under the socialist regime is now at an end. The transformation processes - including restitution, privatisation, rent regulation, administrative, and legislative changes - can also be regarded as complete in Prague. By the end of 2012, rent regulation had ceased, and privatisation had finished in most city parts by around 2015. Post-transformation development in housing estates cannot be described using census data (the last census took place in 2011). However, we aim to illustrate the contemporary position of housing estates in Prague's residential environment using spatial patterns of new housing construction and house prices, both of which significantly influence the socio-economic status of the populations of housing estates.

The location of new residential construction is one of the most important factors in the socio-spatial differentiation of Prague. It might be surprising in some respects that after the Velvet Revolution many areas of new residential development were located in neighbourhoods that had previously been socially poor, in formerly neglected suburbs (Ouředníček 2007; Špačková and Ouředníček 2012) and inner-city working-class neighbourhoods (Ilík and Ouředníček 2007; Temelová 2007; Špačková and Sýkora 2017). A similar development was seen on housing estates (Ouředníček 2016; Špačková et al. 2016), where several examples of new housing construction were realised on the edges of estates (Fig. 15.4). Developers have been attracted to these parts of the city because housing estates provided building plots, coming with technical and social infrastructure and good transportation to the city centre. For example, $43 \%$ (48 out of all 111 residential projects) of new housing development were located within housing estate zones in 2014 (Němec 2014). Because the prices of apartments in pre-fab panel houses and newly built apartments differ considerably, a specific type of micro-spatial polarisation of new housing occurred. It is an open question, however, whether this supports more of a social mix in housing estates, or social polarisation or micro-segregation of new and old residents. 
Housing prices characterise quite well the position of housing estates within the real estate market in Prague, as well as the relative socio-economic status of housing estates. Wagner (2017) documents that apartments in housing estates today occupy the cheapest segment of Prague's real estate market. The same finding was described at the micro level of individual neighbourhoods (Ilík and Ouředníček 2007; Wagner 2017). The largest of Prague's housing estates, South Town, is now the cheapest place to live in Prague (when we exclude dormitories and other non-standard housing). However, as we argue elsewhere (Ouředníček 2016; Špačková et al. 2016), in relation to other housing estates within Czechia but also in relation to suburban housing, even the flats in the cheapest housing estates in Prague are still very expensive.

Prague's housing market extends far beyond the administrative boundary of the city and covers a large part of Central Bohemia. Commuting is still an important part of daily mobility, with long commuting distances extending beyond the boundaries of Central Bohemia. Prices of housing estates in smaller towns within the Prague metropolitan region are much lower. This is one of the factors actively protecting social downgrading of housing stock in Prague and subsequent large-scale deprivation in housing estates. This is also why it is hard to find deprived parts of Prague's housing estates (Kostelecký et al. 2012; Ouředníček 2016; Špačková et al. 2016). On the other hand, there are strong social problems in other parts of Czechia, and areas of social exclusion are often located within housing estates (Temelová et al. 2011; Čada et al. 2015).

\subsection{Conclusion and Discussion of Future Developments}

While the transformation period was typified by top-down development, contemporary changes in the housing estate environment are more spontaneous and market-driven. In other words, during the transformation period programmes aimed towards privatisation (small properties and housing), and the regeneration of houses and public places were managed under state and municipal policies. Rather than large regeneration projects, nowadays commercial forces and the free market influence the rapid development of residential and commercial areas within housing estates in Prague. Generally, policies aimed at regeneration are not seen as being among the top priorities of the city as a whole or in any of its parts. This was confirmed by Kostelecký et al. (2012) who analysed the results of 23 in-depth interviews with local politicians and officers. We argue that this situation is partially influenced by considerably lower (and decreasing) levels of socio-spatial disparity within the city and also by the belief of local actors that social and physical conditions in Prague will change for the better without significant efforts by anyone in the public sphere. As a result, no specific policy for housing estates is now articulated at the level of Prague. The new Metropolitan Plan of Prague concentrates on the protection and liveability of green public spaces (parks), but no other topics for housing estates are mentioned. On the other hand, the new strategic plan 


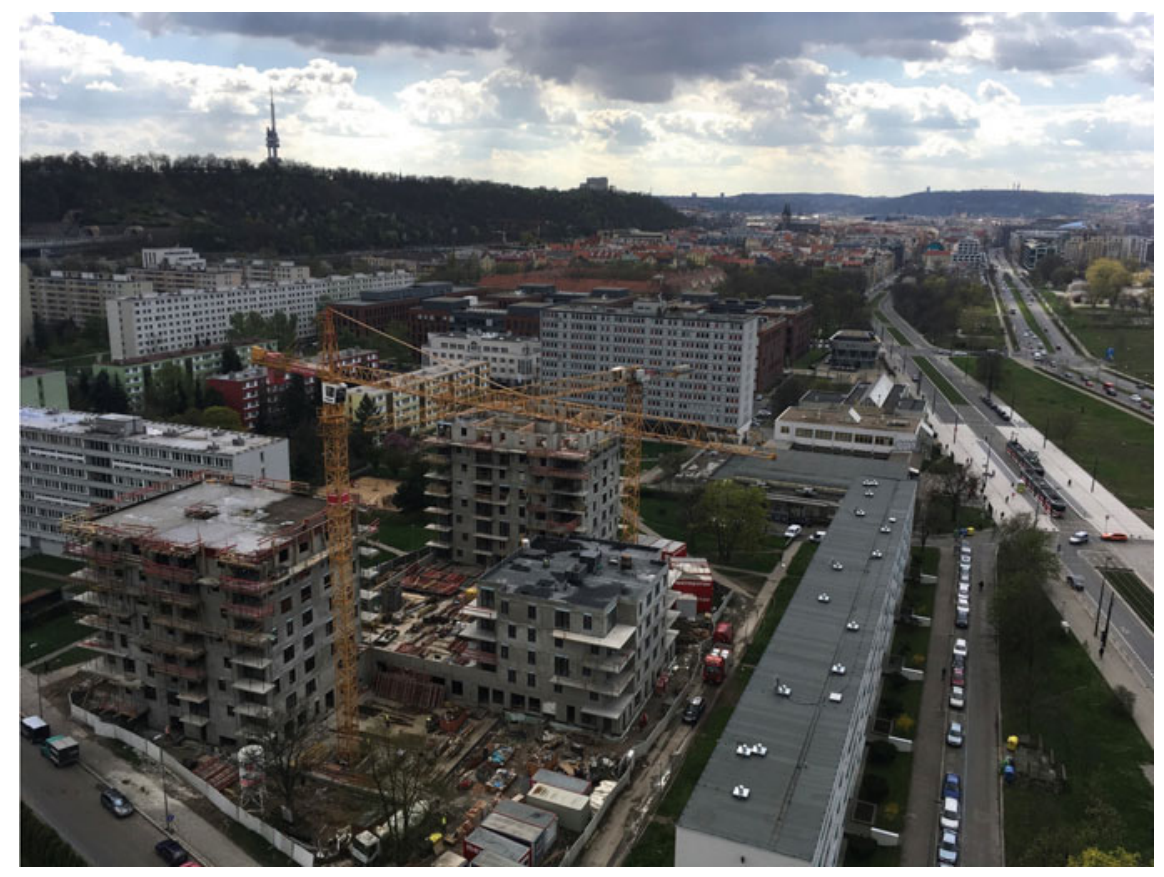

Fig. 15.4 Karlín Park, a new residential project on the site of a former kindergarten, is located in the core of the Invalidovna housing estate. Source Martin Ouředníček

contains several suggestions of activities to improve the quality of life specifically aimed at housing estate neighbourhoods.

Today, most of the housing estates in Prague can be evaluated as non-problematic residential areas. They are very stable parts of the metropolis, with the lowest fluctuation of people among all other types of residential areas (Přidalová and Ouředníček 2017), with a growing diversification of functional use, different types of housing and socio-economic differentiation. Housing estates have very low segregation tendencies (Ouředníček et al. 2016), although there are a number of enclaves of foreigners from the post-Soviet regions and Asia. Many estates are preferred for new investment and are in-demand places to live (Temelová et al. 2011). Although several localities with deteriorating social structure can be found in Prague, these are more the outcome of specific policies (e.g. the intentional movement of specific groups into these localities) (Matoušek and Seidlová 2010) than a sign of change for housing estates. The reasons for this can be seen in housing policies on the one hand (long-term rent regulation, large-scale privatisation, high share of flats in private hands, programmes for housing estate regeneration) and a prevailing reluctance to change the typical place of residence for the Czech population on the other (Lux et al. 2005).

Apart from residential functions, housing estates accommodate new services, offices and entertainment. Moreover, these functions have also brought a number of 
jobs with them, and selected housing estates have appeared as new centres of commuting themselves. Today, shopping malls such as Centrum Černý Most, Centrum Chodov, Metropole Zličín and others are retail centres of regional importance.

As discussed in the introduction, housing estates can be perceived as a symbol of the socialist era. Nevertheless, they are also living environments in which many Prague citizens grew up. Local playgrounds, schools, balconies, lifts and carpet beating stands are important places of memory and sentiment for all those people who have ever lived in housing estates, for whom the living environment there is perceived to be acceptable for starter apartments for their children. If we also take non-residents into consideration-other users of housing estate services, workplaces and entertainment - housing estates will increasingly become integral parts of the city as a whole, partly as an outcome of polycentric development and decentralisation policies. It seems that over the next few decades, the housing estates of Prague will constitute just one of the many historical layers of the housing stock of the city, just as houses from the Middle Ages and the industrial era are currently stable parts of the urban environment.

Acknowledgements This chapter was supported by the Czech Science Foundation grant number GA18-14510S, 'Contemporary changes of social environment within the Czech suburbs'.

\section{References}

Barvíková J (2010) Jak se žije na Jižním Městě z pohledu "Husákových dětí" (What's the Life Like in Housing Estate Jižní Město from the "Husák's children” Generation Point of View). Sociální studia 7(3):59-78

Blažek J, Hampl M, Sýkora L (1994) Administrative system and development of Prague. In: Barlow M, Dostál P, Hampl M (eds) Development and administration of Prague. Universiteit van Amsterdam, Amsterdam, pp 73-87

Borovička B, Hrůza J (1983) Praha. 1000 let stavby města. Panorama, Prague

Brade I, Herfert G, Wiest K (2009) Recent trends and future prospects of socio-spatial differentiation in urban regions of Central and Eastern Europe: a lull before the storm? Cities 26 (5):233-244. https://doi.org/10.1016/j.cities.2009.05.001

Burdová B, Chlupová D, Polešáková M, Rohrerová L (2012) Výsledky dotazníkové akce o změnách v obecním bytovém fondu ve vybraných městech $(2010,2011)$

Čada K, Büchlerová D, Korecká Z, Samec T, Ouředníček M, Kopecká Z (2015) Analýza sociálně vyloučených lokalit v ČR. GAC, Ministry of Labour and Social Affairs, Prague

Eskinasi M (1995) Changing housing policy and its consequences: the Prague case. Housing Stud 10(4):533-548. https://doi.org/10.1080/02673039508720836

Gentile M, Sjöberg Ö (2013) Housing allocation under socialism: the Soviet case revisited. Post-Soviet Affairs 29(2):173-195. https://doi.org/10.1080/1060586X.2013.782685

Hampl M (2007) Regionální diferenciace současného socioekonomického vývoje v České republice. Sociologický časopis/Czech Soc Rev 43(5):889-910

Hampl M, Kühnl K (1993) Migratory trends in former Czechoslovakia. Acta Universitatis Carolinae-Geographica 28(1):53-71

Hrůza J (1989) Město Praha. Odeon, Prague 
Hrůza J (1994) Historical development of Prague. In: Barlow M, Dostál P, Hampl M (eds) Development and administration of Prague. Universiteit van Amsterdam, Amsterdam, pp $15-28$

Ilík J, Ouředníček M (2007) Karlín a jeho proměny v souvislostech postsocialistické transformace Prahy. Geografie 112(3):292-314

Kaltenberg-Kwiatkowska E (2008) Street names between sign and symbol. The case of Poland and the Czech Republic. In: Strubelt W, Gorzelak G (eds) City and region. Papers in Honour of Jiří Musil. Budrich UniPress, Opladen, Farmington Hills, pp 157-192

Karasek J, Ubralova E (2012) Czech Republic: energy efficiency increasing in the housing stock. In: Nieboer N, Tsenkova S, Gruis V, van Hal A (eds) Energy efficiency in housing management. Policies and Practices in Eleven Countries. Routledge, London, pp 176-194

Kohout J, Vančura J (1986) Praha 19. a 20. století. Technické proměny. SNTL, Prague

Kostelecký T (2000) Housing and its influence on the development of social inequalities in the post-communist Czech Republic. Czech Sociol Rev 8(2):177-193

Kostelecký T, Patočková V, Illner M (2012) Problémové rezidenční čtvrti a politiky k jejich regeneraci v postsocialistickém městě—studie Prahy. Sociologický časopis/Czech Sociol Rev 48(1):39-63

Linhart J, Rak V, Voženílek J (1977) Sociální aspekty ekologické zónace hlavního města Prahy. Sociologický časopis/Czech Sociol Rev 13(1):94-115

Lux M, Sunega P (2014) Public housing in the post-socialist states of Central and Eastern Europe: decline and an open future. Housing Stud 29(4):501-519. https://doi.org/10.1080/02673037. 2013.875986

Lux M, Sunega P, Kostelecký T, Čermák D, Montag J (2005) Standardy bydlení 2004/05. Financování bydlení a regenerace sídlišt'. Sociological Institute, Prague

Maier K (2003) Sídliště: problém a multikriteriální analýza jako součást př́ípravy k jeho řešení. Sociologický časopis/Czech Sociol Rev 39(5):653-666

Maier K, Hexner M, Kibic K (1998) Urban development of Prague: history and present issues. Czech Technical University in Prague, Prague

Matějů P (1977) Sociologické aspekty vývoje bydlení v Praze. Sociologický časopis/Czech Sociol Rev 13(1):39-58

Matějů P (1980) Vývoj sociálně prostorové struktury Prahy v letech 1930-1970 ve světle faktorové analýzy. Sociologický časopis/Czech Sociol Rev 16(6):572-591

Matějů P, Večerník J, Jeřábek H (1979) Social structure, spatial structure and problems of urban research: the example of Prague. Int J Urban Reg Res 3(1-3):181-202. https://doi.org/10.1111/ j.1468-2427.1979.tb00785.x

Matoušek R, Seidlová M (2010) Residenční segregace v Česku: Praha-Černý Most. In: Sýkora L (ed) Rezidenční segregace. Charles University in Prague and Ministry of Regional Development, Prague, pp 112-116

Musil J (1985) Lidé a sídliště. Svoboda, Prague

Musil J (1987) Housing policy and the sociospatial structure of cities in a socialist country: the example of Prague. Int J Urban Reg Res 11(1):27-36. https://doi.org/10.1111/j.1468-2427. 1987.tb00033.x

Musil J (1993) Changing urban systems in post-communist societies in Central Europe: analysis and prediction. Urban Stud 30(6):899-905

Musil J (2002a) Co se děje s českými městy dnes. In: Horská P, Maur E, Musil J (eds) Zrod velkoměsta. Urbanizace českých zemí a Evropa, Paseka, Prague, Litomyšl, pp 298-331

Musil J (2002b) Urbanizace českých zemí a socialismus. In: Horská P, Maur E, Musil J (eds) Zrod velkoměsta. Urbanizace českých zemí a Evropa. Paseka, Prague, Litomyšl, pp 237-297

Musil J (2005a) City development in Central and Eastern Europe before 1990: Historical context and socialist legacies. In: Hamilton FEI, Andrews KD, Pichler-Milanović N (eds) Transformation of cities in Central and Eastern Europe: towards globalization. United Nations University Press, Tokyo-New York, pp 22-43 
Musil J (2005b) Prague returns to Europe. In: Hamilton FEI, Andrews KD, Pichler-Milanović N (eds) Transformation of cities in Central and Eastern Europe: towards globalization. United Nations University Press, Tokyo-New York, pp 281-317

Musil J (2006) Prague, present meets past. Int Rev Sociol 16(2):243-272. https://doi.org/10.1080/ 03906700600708840

Musilová M (2004) Regenerace panelových sídlišt’: př́iklad pražských sídlišt' Řepy, Letňany a Opatov. Charles University in Prague, Faculty of Science, Prague

Němec M (2011) Analýza stavu oprav a rekonstrukcí bytových domů alokovaných ve velkých sídlištních celcích hl. m. Prahy. Institute for Planning and Development, Prague

Němec M (2014) Domovní a bytový fond $\mathrm{v}$ detailu pražských městských částí z pohledu statistických ukazatelů. Institute for Planning and Development, Prague

Novotná B (2010) Panelák jako symbol a místo paměti Sociální studia 7(3):127-131

Ouředníček M (2007) Differential suburban development in the Prague urban region. Geografiska Annaler: Human Geography 89B(2):111-125

Ouředníček M (2016) The relevance of "Western" theoretical concepts for investigations of the margins of post-socialist cities: the case of Prague. Eurasian Geogr Econ 57(4-5):545-564. https://doi.org/10.1080/15387216.2016.1256786

Ouředníček M, Pospíšilová L (2016) Editorial: urban dynamics and neighbourhood change in cities after transition. Sociologický časopis/Czech Sociol Rev 52(6):787-794

Ouředníček M, Pospíšilová L, Špačková P, Kopecká Z, Novák J (2016) The velvet and mild: socio-spatial differentiation in Prague after transition. In: Tammaru T, Marcińczak S, van Ham M, Musterd S (eds) Socio-economic segregation in European capital cities: east meets west. Routledge, Abingdon, New York, pp 261-286

Ouředníček M, Temelová J (2009) Twenty years after socialism: the transformation of Prague's inner structure. Studia Universitatis Babes-Bolyai, Sociologia 54(1):9-30

Přidalová I (2017) Cizinci a lokální sociální prostředí: př́ípadová studie Hůrka. In: Ouředníček M, Jíchová J (eds) Sociální prostředí Prahy: město na prahu 21. století. Academia, Prague, pp 120 149

Přidalová I, Ouředníček M (2017) Role zahraniční migrace v měnící se sociálně-prostorové diferenciaci Prahy. Sociologický časopis/Czech Sociol Rev 53(5):659-692. https://doi.org/10. 13060/00380288.2017.53.5.360

Přidalová I, Ouředníček M, Nemeškal J (2015) Historical aspects of migration in Prague. Specialized map. Charles University in Prague, Faculty of Science, Department of Social Geography and Regional Development, Prague

Skřivánková L, Švácha R, Novotná E, Jirkalová K (2017) The Paneláks: twenty-five housing estates in the Czech Republic. The Museum of Decorative Arts in Prague, Prague

Steinführer A (2003) Sociálně prostorové struktury mezi setrvalostí a změnou. Historický a současný pohled na Brno. Sociologický časopis/Czech Sociol Rev 39(2):169-192

Sýkora L (1999) Processes of socio-spatial differentiation in post-communist Prague. Housing Stud 14(5):679-701. https://doi.org/10.1080/02673039982678

Šimáček P, Szczyrba Z, Andráško I, Kunc J (2015) Twenty-five years of humanising post-socialist housing estates: from quantitative needs to qualitative requirements. Geographica Polonica 88 (4):649-668. https://doi.org/10.7163/GPol.0038

Špaček O (2012) Česká panelová sídliště: faktory stability a budoucího vývoje. Sociologický časopis/Czech Sociol Rev 48(5):965-988

Špačková P, Ouředníček M (2012) Spinning the Web: New Social Contacts of Prague's Suburbanites. Cities 29(5):341-349

Špačková P, Pospíšilová L (2017) Diferenciace českých panelových sídlišt' z hlediska vzdělanosti jejich obyvatel: stav a dlouhodobý vývoj. Historická geografie 43(2):171-190

Špačková P, Pospíšilová L, Ouředníček M (2016) The long-term development of socio-spatial differentiation in socialist and post-socialist Prague. Sociologický časopis/Czech Sociol Rev 52 (6):821-860. https://doi.org/10.13060/00380288.2016.52.6.288

Špačková P, Sýkora J (2017) Kontrasty sociálních světů v dolních Holešovicích. In: Jíchová J (ed) Sociální prostředí Prahy: město na prahu 21. století. Academia, Prague, pp 92-119 
Zadražilová L (2013) Když se utopie stane skutečností. Panelová sídliště v Československu 19531989. Arbor Vitae, The Museum of Decorative Arts in Prague, Prague

Zarecor KE (2011) Manufacturing a socialist modernity: housing in Czechoslovakia, 1945-1960. University of Pittsburgh Press, Pittsburgh

Temelová J (2007) Flagship developments and the physical upgrading of post-socialist inner city: the golden angel project in Prague. Geografiska Annaler: Human Geogr 89B(2):169-181

Temelová J, Novák J, Ouředníček M, Puldová P (2011) Housing Estates after socialism: various trajectories and inner differentiation. Urban Stud 48(9):1811-1834. https://doi.org/10.1177/ 0042098010379279

Temelová J, Slezáková A (2014) The changing environment and neighbourhood satisfaction in socialist high-rise panel housing estates: the time-comparative perceptions of elderly residents in Prague. Cities 37:82-91. https://doi.org/10.1016/j.cities.2013.12.002

Wagner M (2017) Ceny bydlení v Praze. Charles University, Faculty of Science, Prague

Votrubec C (1965) Praha-zeměpis velkoměsta. SPN, Prague

Open Access This chapter is licensed under the terms of the Creative Commons Attribution 4.0 International License (http://creativecommons.org/licenses/by/4.0/), which permits use, sharing, adaptation, distribution and reproduction in any medium or format, as long as you give appropriate credit to the original author(s) and the source, provide a link to the Creative Commons license and indicate if changes were made.

The images or other third party material in this chapter are included in the chapter's Creative Commons license, unless indicated otherwise in a credit line to the material. If material is not included in the chapter's Creative Commons license and your intended use is not permitted by statutory regulation or exceeds the permitted use, you will need to obtain permission directly from the copyright holder. 


\title{
Chapter 16 \\ The Stockholm Estates-A Tale of the Importance of Initial Conditions, Macroeconomic Dependencies, Tenure and Immigration
}

\author{
Roger Andersson and Åsa Bråmå
}

\begin{abstract}
In this chapter, we define the concept of housing estates in the Swedish context and provide some information about Stockholm and the historical background to the construction of post-war housing estates. The core research question will then be whether and to what extent initial conditions play a key role for later developments of an estate. Approaching this question, we first provide a statistical overview of developments from 1990 onwards, and then use examples from two estates in Stockholm, one built in the mid-1960s (Bredäng) and one built a few years later (Rinkeby), which now have similar problems of ethnic and socio-economic segregation but have arrived at this situation through very different trajectories. We will analyse these trajectories and identify the key moments leading up to present day convergence in terms of the social challenges facing the estates. Until 1990, the socio-economic situation in the 49 estates we analysed was not very different from the average situation in the Stockholm region. However, the economic crisis of the early 1990s had profound effects and initiated diverging trajectories where some estates continued to do well while others did not. We explain this diverging development with reference to tenure composition, geographical context and building period, all important for also understanding the geography of refugee settlement. This set of explanations is based both on the more structural analysis of all 49 estates and on the more detailed study of our two cases. We end the chapter with a discussion of 40 years of recurrent interventions and of how contemporary challenges are perceived and addressed.
\end{abstract}

Keywords Stockholm • Housing estates · Tenure - Segregation Immigration • Planning

R. Andersson $(\bowtie) \cdot \AA$. Bråmå

Institute for Housing and Urban Research, Uppsala University,

Box 256, 75105 Uppsala, Sweden

e-mail: roger.andersson@ibf.uu.se

Å. Bråmå

e-mail: asa.brama@liu.se

(C) The Author(s) 2018

D. B. Hess et al. (eds.), Housing Estates in Europe, The Urban Book Series,

https://doi.org/10.1007/978-3-319-92813-5_16 


\subsection{Introduction}

In Sweden, the label 'large housing estate' has primarily been associated with multifamily housing constructed during the so-called Million Programme, when one million dwellings were built in 10 years (1965-1974). During this period, the projects were larger and the industrial efficiency of the construction process further driven than in earlier decades, resulting in metropolitan areas in very large estates with little mixing in terms of housing tenure and dwelling sizes. The resulting estates were also the first, in the modern Swedish context, to be associated with problems of ethnic and socio-economic segregation.

In this chapter, we define the concept of housing estates in the Swedish context and provide a brief historical background. We give an account of the location and demographic and socio-economic characteristics of Stockholm County's housing estates in 1990, a year when all estates we include in the analyses were completed. We then follow the estates forward to 2014 and document their heterogeneous development but also the emergence of concentrated poverty, declining employment levels and the role they have in residential sorting and segregation processes. These later developments are partly well-researched but there are important questions to be asked regarding the early years of the estates' development - Why do many of the estates today display similar kinds of problems? Is the answer to be found in issues related to design and architecture, in their location, in their tenure structure or in wider contextual matters such as economic and political developments? The core research question will be whether and to what extent initial conditions play a key role for later developments of an estate. Approaching this question, we use examples from two estates in Stockholm, one built mostly before (Bredäng) and one in the middle of the Million Programme period (Rinkeby), which now both have problems of ethnic and socio-economic segregation but have arrived at this situation through very different trajectories. We will analyse these trajectories and identify the key moments leading up to the present situation, in terms of the social challenges facing many of the estates.

Using longitudinal individual-level data from a combination of census and register data going back to 1960 , we will trace the population development of the two cases back to about 5 years after construction, showing who the early residents were and where they came from, and how this has shaped later developments of the estates. Accounts of the post-1990 period are primarily based on data from the Geosweden dataset, comprising longitudinal and geocoded annual microdata of the entire population of Sweden. These data are owned by the Institute for Housing and Urban Research, Uppsala University, but originate from a range of Statistics Sweden's registers (population, income, education and employment (LISA), real estate and property, dwellings registry).

As in many other countries, large-scale housing estates in Sweden have been much discussed politically since the 1970s and discussions have intensified as social conditions have deteriorated in many of them, triggering housing and urban policy responses and area-based interventions. We allocate one section of the paper 
to these interventions and reflect upon the current challenges facing Stockholm's estates. This section is partly based on field visits and interviews in the two estates selected for the long-term analysis.

\subsection{Housing Estates in Sweden-A Background}

Housing developments and planning for housing show broader international as well as country-specific characteristics. While architectural and design ideas have travelled easily across national borders, the social and political national realities always put severe constraints on both the when and how questions related to the physical manifestations of such ideas. In Sweden, as in many other countries, the philanthropic reactions to the slum housing created in the wake of industrialisation and urbanisation in the nineteenth century gradually shifted into politically induced change in regulations and planning practices. Step by step, the politically organised working class gained influence over housing developments and city planning. By the mid-1930s the Social Democratic Party (SAP) controlled government and did so for 40 years thereafter. Although some key organisations-like municipal rental housing and cooperative housing companies-were sometimes established already before World War II, it was not until after the war that they became instrumental for modernising housing for the working class. The State developed the financial means and laws regulating planning, building and rent setting, but it was the municipalities - most of them governed by Social Democrats - that were to become the key actors in planning for the new era.

Early on, Stockholm planning was internationally recognised for contributing with new visions regarding post-war urban development. The Stockholm City General Plan of 1945-1952, designed by Sven Markelius, envisioned 'a high-capacity highway network, designed especially to provide circumferential trips (...), to be supplemented by a brand-new subway system' (Hall 1988, 308). As pointed out by Hall, the new outer suburban units - Vällingby of 1950-4, Farsta of 1953-61, and Skärholmen of 1961-1968 - were developed as ABC units, meaning they were supposed to contain housing, workplaces and service. Vällingby and Farsta were well received but later developments faced a range of criticism.

Art Historian Lisbeth Söderqvist wrote her thesis in 1999 about 'The Record Years' (1960-1975) with a focus on multifamily large-scale housing in Sweden. She is not the only one to study this period of booming construction activity but her analyses of three particular cases in the Stockholm region convincingly sum up some key aspects we need to understand as background for approaching the Stockholm case. As housing shortage, along with poor conditions in most of the existing housing stock, were the main rationales for stepping up building activity after the war, the actual design of new housing and neighbourhoods was inspired by developments in the 1930s, such as the quest for modernism displayed not least at the influential 1930 Stockholm Exhibition, where a plea for acceptance of functionalism, standardisation and mass production as a cultural change was formulated 
(Pred 1995). In 1945, only $21 \%$ of the country's dwellings had a bathroom or a shower. This figure rose to 53\% in 1960 and 87\% in 1975 (Söderqvist 1999, p. 11). Modernistic design ideas along with a strong emphasis on technological advancements and industrial building methods formed the context of developments converging towards building massive amounts of new housing.

A State housing construction investigation was put in place in 1959 (Bostadsbyggnadsutredningen) and the experts estimated the need of new housing to be in the range of 1.5 million units for the 1960-1975 period (SOU 1965, p. 32). As noted by Söderqvist (1999, p. 12), the forthcoming politically formulated project 'The Million Programme' - meaning the construction of one million new dwellings between 1965 and 1974 — was therefore not dramatic, with these plans and forecasts already in place. All 1.5 million dwellings were also realised, truly making the 'Record Years' an appropriate label.

For a country with eight million people in 1970, the volume of new housing was indeed remarkable and it took more than new production methods to make it happen. The 1960s saw a range of economic reforms aiming to rationalise the building process. State investment funds for 'element factories' were one such new feature. Planning routines were also changed so that big projects (those with more than 1,000 new dwellings) could get a pre-decision from the planning authorities. The concept of 'total entrepreneur' - i.e. giving one company the responsibility for both project planning and construction-was introduced, further escalating the industrialisation of construction activity. Realising the new modernist housing projects was not possible on already built-up land, and the fact that Stockholm and other cities from the late nineteenth century onwards had bought substantial amounts of land on the outskirts provided another key factor in shaping the necessary conditions for large-scale housing construction. According to Söderqvist (1999, p. 161), municipal planning authorities had to develop general plans but these did not determine the real outcome. Instead, what later has become known as urban governance and public-private partnerships ('negotiating planning') characterised planning practices. Private actors had substantial influence while the State, primarily represented by the State Board of Construction and the provincial architect at the County administration, were rather weak and typically critical of high-rise developments (Söderqvist 1999, 164).

With the quantitative goals achieved by the mid-1970s, the debate immediately turned to questioning the more qualitative aspects of the new housing - the high-rise buildings, density, the repetitive character of buildings and layout, poor services and so on. Some blamed architects, others blamed developers and builders and most blamed politicians for failing to put the individual resident in focus. Rådberg (1988, 1997) argues that the modernist visions from the 1920s and 1930s, inspired by Le Corbusier and Walter Gropius but with strong involvement of Swedish modernist architects like Sven Markelius were realised in the 1960s and that architects had a great deal of responsibility for what took place. Markelius and a handful of other Swedish architects were affiliated with CIAM (Les Congreès Internationaux d'Archetecture Moderne), an organisation established in 1928 for discussing and promoting modern architecture (Söderqvist 2008, pp. 31-32). 
In a U.S.-Swedish comparative study, Popenoe (1977) argues that the construction of the subway (the political decision made in 1941) and the location of subway stations had a profound importance for the scale and density of new housing estates. Concentrating consumers to accommodate the economic interests of service providers also played a key role. It is clear that much of this makes sense but also that most of the criticism came later, after the completion of the estates.

Söderqvist concludes her thesis by stating: 'My interpretation (...) is (...) that the influence of state authorities on the design of the criticised large-scale housing estates was negligible. It was municipalities, developers, and building companies that, together with the architects, shaped the housing environments' (Söderqvist 2008, 185). However, sociologists Franzén and Sandstedt (1981) arrive at a somewhat different conclusion in terms of the state's overall influence. Applying Habermas' theory on the role of the state and the public sphere, they argue that the emergence of the modern social state meant a transition from a separation of the state and the private sphere to a situation where the state took over many more duties than earlier, and also that different interest groups gained more influence over the state. Their focus is on neighbourhood planning and housing construction but parallel developments took place in other policy fields, such as traffic planning and the control over retail businesses and location. This massive state expansion was made possible by a sustained period of post-war economic growth, but the notion of community planning did in fact not change much from before.

We conclude this background by noting that many circumstances aligned to produce foundations for and realisation of large-scale housing in Sweden. Therefore, explanations are offered at different levels of abstraction. It is clear that after the 'Record Years', overcrowding was more or less abolished, most people lived in high-standard modern housing and the debate soon shifted focus to issues related to those who were housed in the new housing estates. It is also with these issues we next engage.

\subsection{The Stockholm Estates}

We define a housing estate in the Stockholm context as a major concentration of multifamily housing constructed in the 1951-1990 period. We make our selection in 1990, at a time when all larger estates were built (only one was added after 1980). Our study area is Stockholm County and we define a 'major concentration' as a statistical area (SAMS) with at least 1,000 dwellings, where $75 \%$ or more of the residents are living in multifamily housing built during these four decades. We believe the definition is wide enough to capture the essence of the meaning of a large estate in our context but also narrow enough to avoid including areas that are seldom considered as being of an estate character. Naturally, all definitions of the concept 'housing estate' are somewhat arbitrary and the bulk of Swedish housing studies tend to focus instead on housing constructed during the Million Programme period. Although the Million Programme is a shorthand in the Swedish debate for 
discussing a range of housing related problems, it is less appropriate in this context for two reasons: (1) it is too narrow time-wise considering that housing construction was already industrialised and large-scale towards the end of the 1950s and that a similar type of planning (albeit somewhat adjusted) and housing construction continued throughout the 1970s and into the 1980s; (2) the Million Programme comprised not only multifamily housing but also a large proportion suburban single-family housing, produced fairly large-scale but without the characteristics of housing estates.

Although we use the SAMS neighbourhood division for identifying the estates, the data we provide refers to the multifamily section of each selected neighbourhood, i.e. the estates proper. When applying our definition, we find about 50 estates. We exclude one estate because it had an extended construction period (not resulting in a coherent housing estate). There are also a few estates further out in Stockholm County that we decided not to include. Some that are included from the 1950s are of a transitional character, in the sense that building methods were not as industrialised and design sometimes more varied than were later to follow in the 1960s. Our final selection of 49 estates is displayed in Fig. 16.1, and key data provided in Table 16.1 show the location and basic characteristics of Stockholm County's housing estates as of 1990. Many of the estates were built over a period of two to three years and in some cases, the construction period crossed a decade shift (such

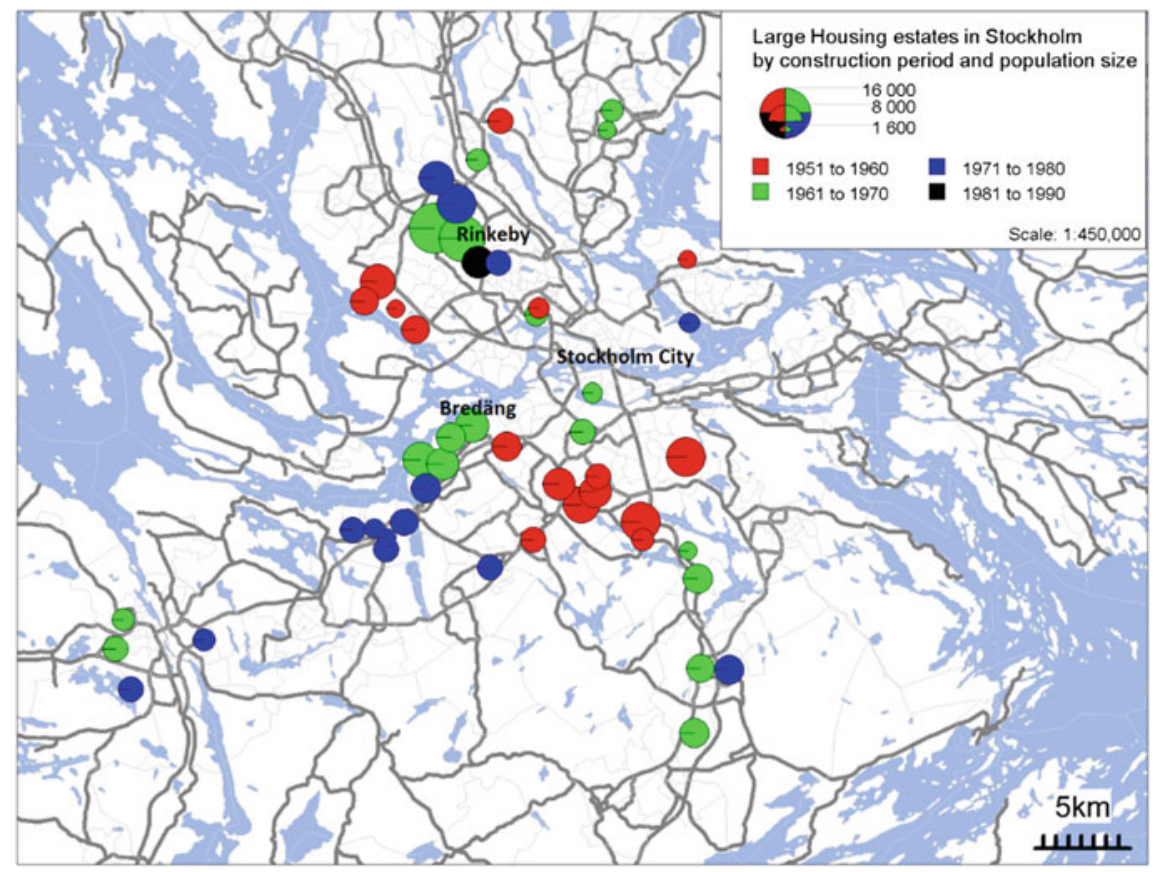

Fig. 16.1 Location of large housing estates in Stockholm by period of construction and population size in 1990 
as 1960s/1970s). The period of construction indicated in the map refers to the decade when at least half of the dwellings were completed and occupied. Most of the estates are located 10-20 km from the city centre and along subway lines and main highways. There is a tendency of later built projects to be located somewhat further away from the centre. Administratively, the 49 are dispersed over 10 municipalities (out of 26 in the county), but almost half of them (22) are located within the borders of Stockholm city, including our two cases Bredäng and Rinkeby. The proportion residing in these large housing estates varies across municipalities in 1990, from $36 \%$ in Sundbyberg to $11 \%$ in Täby and $24 \%$ in Stockholm.

\subsubsection{Key Data on Housing Estates in 1990 with an Overview of Subsequent Changes Until 2014}

As we will focus in particular on two of these 49 estates, data is provided separately for these two (Bredäng and Rinkeby). All 49 had about 264,000 multifamily-housed residents in 1990 (circa $16 \%$ of the county population and $25 \%$ of all living in multifamily housing) with an average of 5,400 people. Our two cases are in the upper range population-wise (7,000 and 13,000, respectively in 1990) but they share many housing and demographic characteristics with other estates from the same time period: most estates are heavily dominated by rental housing, and except for the 1970s estates, buildings are not very high but densities are still above mean for multifamily housing in the county (255 residents per hectare compared with 306 for our selection). Furthermore, three-room dwellings dominate, females are slightly over-represented and the immigrant proportion is clearly above mean values for neighbourhoods in the Stockholm region.

There are also differences between estates, related partly to the period of construction; there are fewer high-rise buildings from the 1950s and housing estates from this early period have fewer immigrants, and related to this, an older population and also smaller households. Overcrowding is very much discussed today but was not on the agenda in early 1990s, and on a group level, housing estates were only slightly more overcrowded than the wider Stockholm region. Estates from the 1960s and 1970s, however, did indeed house many that had to share a room with at least two other persons. These differences also apply for our two cases and Rinkeby's higher proportion of overcrowded households, younger population (including students), more immigrants and poorer socio-economic position are clearly displayed; the latter two indicators, in particular, stand out when compared to most other housing estates, including Bredäng and other early built estates.

We will extend our study period both backwards and forwards in time, asking: (1) Whether the socio-economic and ethnic differences visible in 1990 were established already when the estates were newly constructed, and (2) Whether developments after 1990 have converged towards Rinkeby's position and if so, why? The early period will be studied in detail using our two case study areas. 


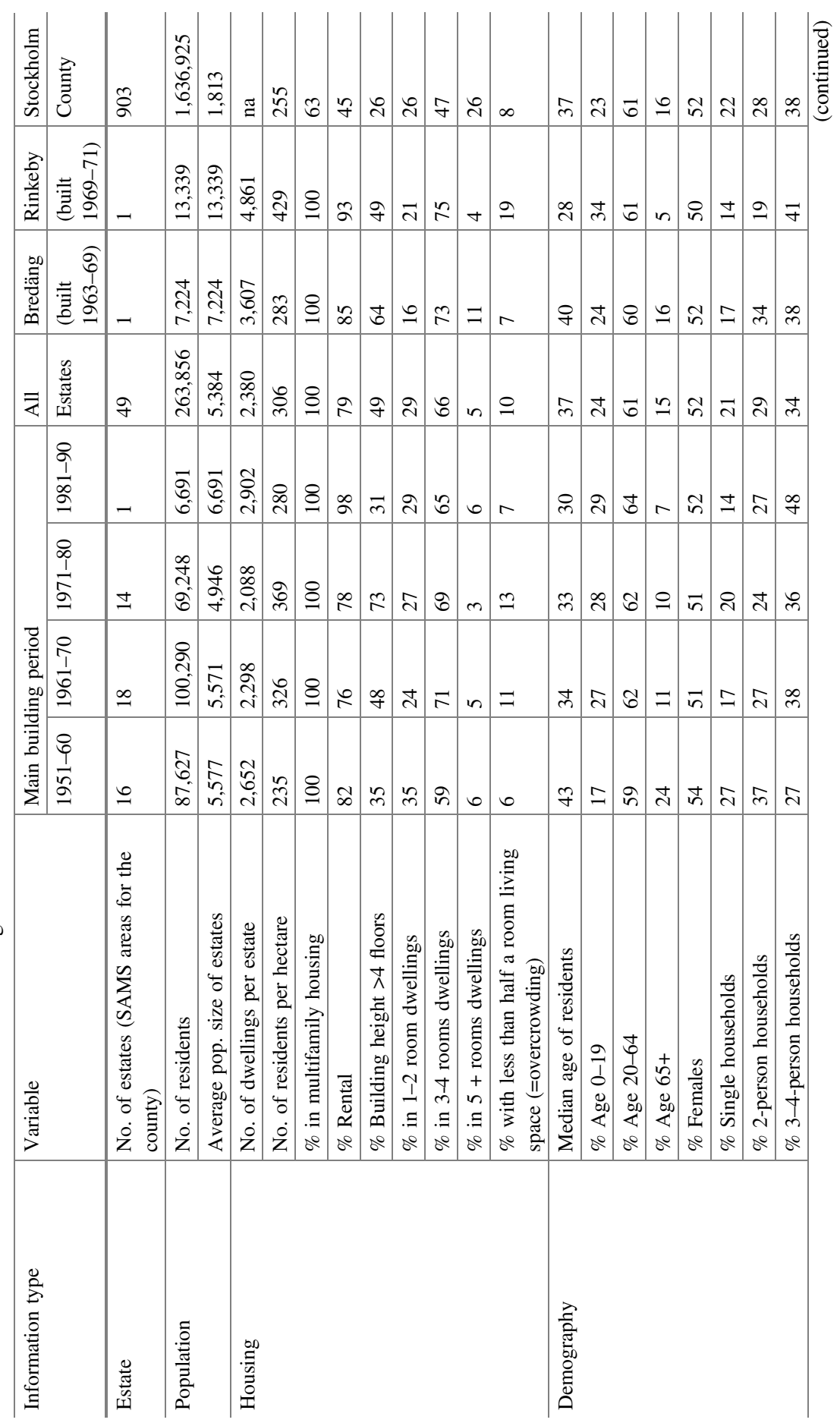


16 The Stockholm Estates-A Tale of the Importance ...

369

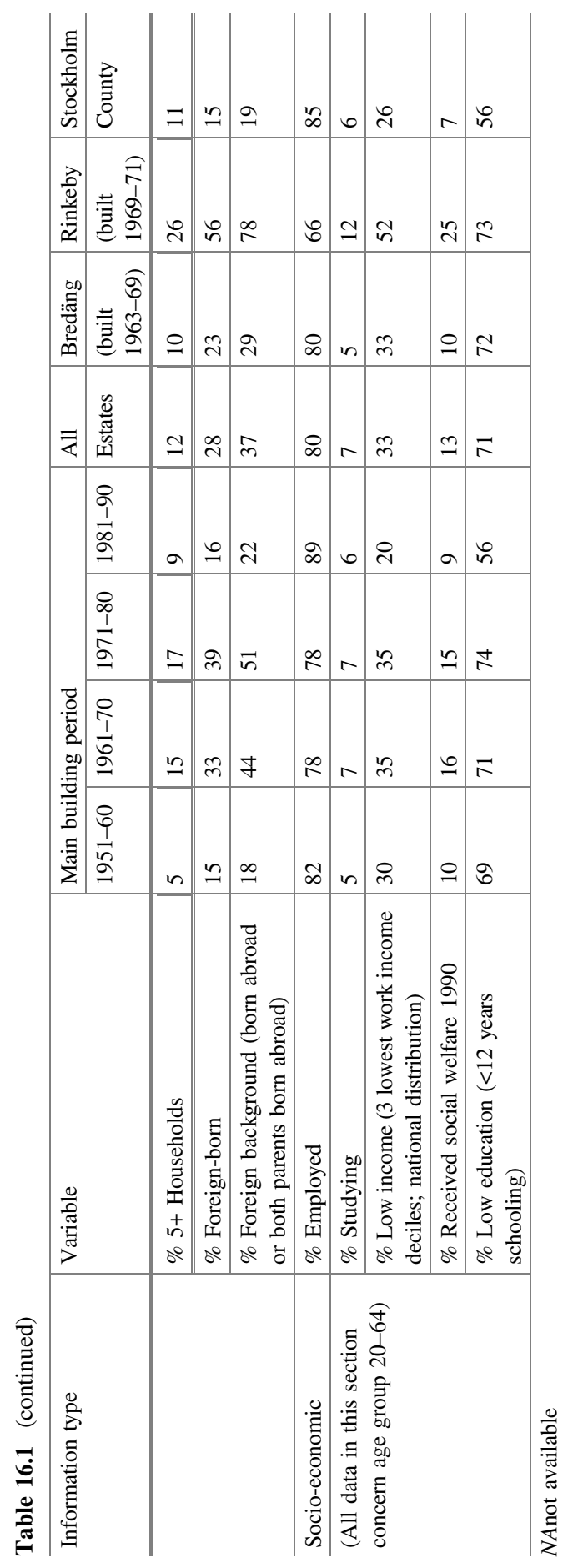


The more general development after 1990 is summarised in Table 16.2 and clearly indicates a more problematic situation today than in 1990 .

It is well known in Sweden that the large housing estates have faced a quarter-century of increasing signs of social exclusion and stigmatisation. Some argue that this is a consequence of increasing racialisation in the wake of the influx of non-European migrants (Molina 1997; Ericsson et al. 2002), while others have tended to primarily stress the geographically uneven effects of declining employment levels, housing policy change, and restructuring of the welfare state (Andersson and Hedman 2016; Andersson and Kährik 2015). All these explanations have relevance and isolating the effect of each component is indeed a very complex endeavour.

Table 16.2 follows the same general format as Table 16.1, but for brevity, we display data only for some key variables. There has been some post-1990 multifamily housing construction in 33 of the 49 estates but these additions explain less than half of the population increase (an additional 59,000 inhabitants in total). For Bredäng and Rinkeby, about one-third of the population increase from 1990 to 2014 comprises people living in post-1990 buildings. While overcrowding is generally not a problem in the Swedish housing market (and it has been further reduced in Stockholm County since 1990), it can be in some housing estates and certainly if an estate has seen in-migration of recently arrived refugee families. Rinkeby illustrates this; by 2014, close to one in four residents lived in dwellings where the available space was less than 0.5 rooms per person (kitchen excluded).

Other housing developments should also be noted. Stockholm has been a showcase for the liberal-conservative political parties' aims of introducing more market dynamics into the housing market. The primary instrument has been conversion of public rental housing to cooperative housing, and due to a parallel conversion - albeit not politically induced — of private rental housing to cooperative housing, Stockholm County has seen its stock of rental housing substantially reduced. While the overall reduction in Stockholm County is from 45 to $32 \%$ it has been very uneven; much more radical in Stockholm inner city while housing estates from the 1960s and 1970s (including Rinkeby) have been less affected (see Table 16.2). These tenure conversions have put extra pressure on the unaffected rental-dominated estates, effects that Andersson and Turner (2014) sum up using the concept of residualisation. Fewer rental units now have to cater to expanding numbers of people without much choice in the competitive housing market.

Besides some of these housing dynamics, three general developments stand out: (1) a radical reduction of the proportion of low-education persons in the region and across the estates; (2) a very fast increase of the immigrant population, following a general trend in the region (although the increasing proportions have been substantial in the housing estates, not least in estates with average proportions in 1990 - once again the early and late-built estates such as Bredäng) and (3) the negative employment change affecting many estates from all time periods. Most of the reduction occurred in the early 1990s but recovery has been modest since then (compare 2002 and 2014 in Table 16.2 and see Fig. 16.2). 


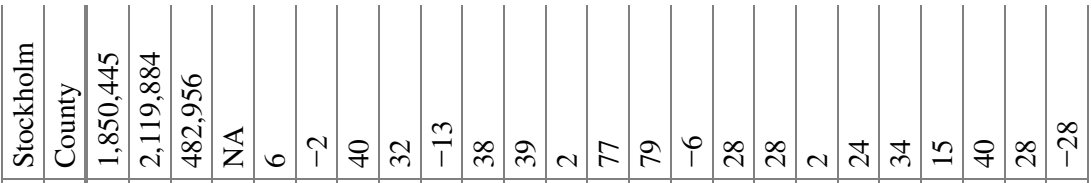

$\widehat{\approx}$

b

辛

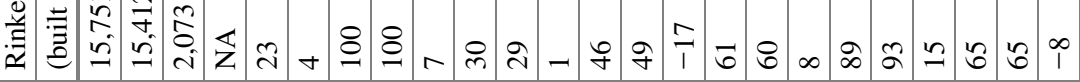

ชิ

ชู

离

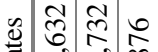

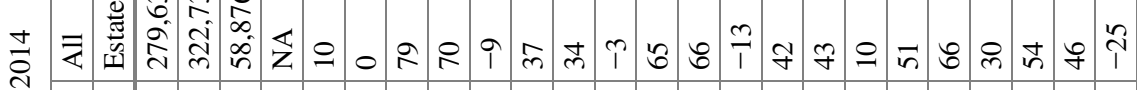

चี

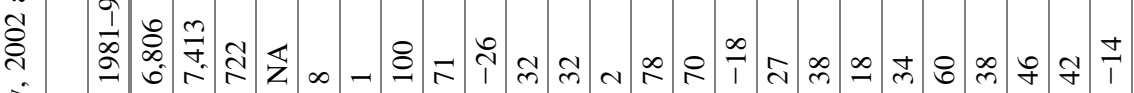

言

○

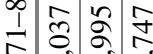

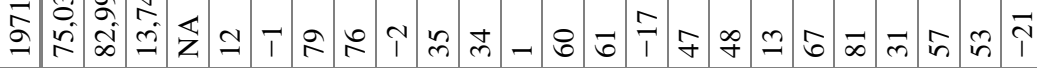

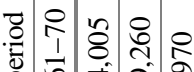

落

营

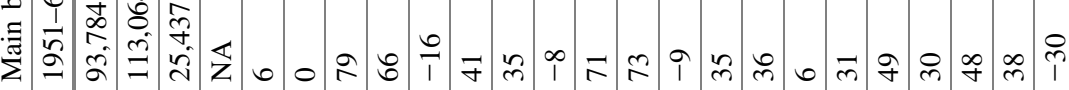

움

$\stackrel{Ð}{\Xi}$

4

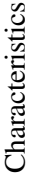

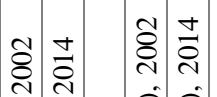

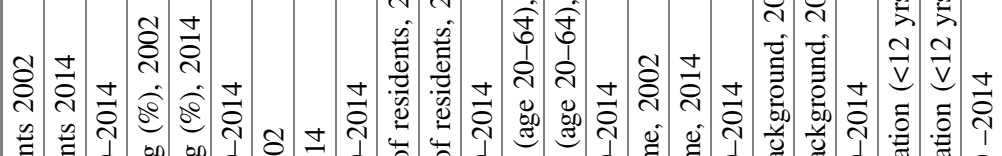

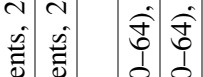

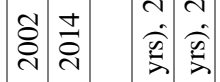

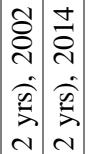

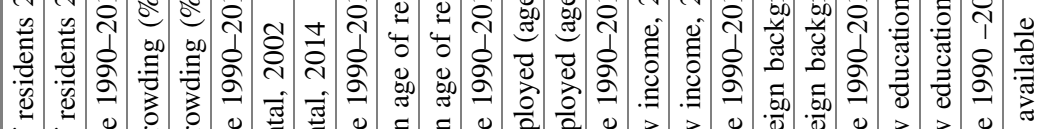

ஸ்

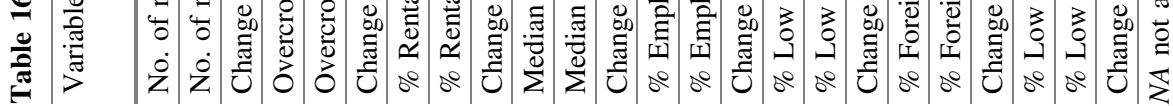




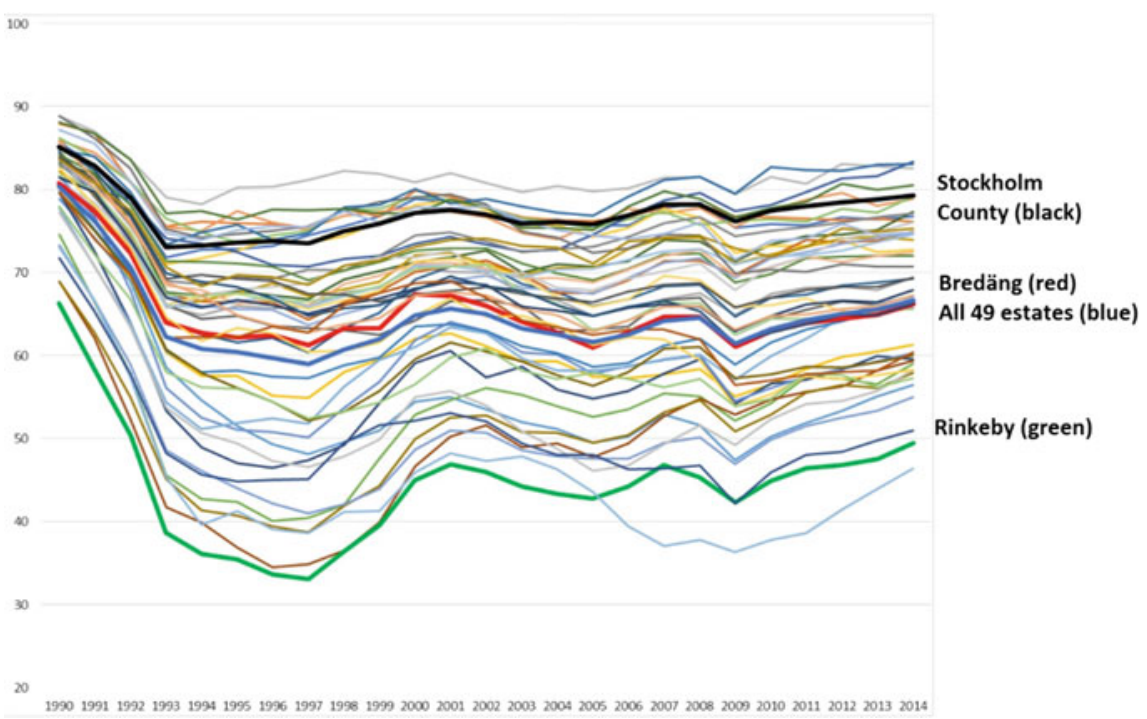

Fig. 16.2 Employment rates (\%) for residents in selected housing estates, 1990-2014. Note This figure is based on annual data for the 49 statistical units (SAMS) that frame the selection of housing estates. Some of the SAMS units thus contain housing other than the housing estate proper. It is clear that most estates follow the same trends (macroeconomic dependency) but also that developments in the estates radically diverged in the early 1990s and that the substantial spread established during the crisis remained for 15 years. Some convergence can be seen lately and preliminary data indicates that this has likely continued through 2017

Large housing estates may to a certain extent be similar in design, construction methods and building material but they exhibit big differences along the socio-economic dimension, for example, when it comes to employment. While some estates, like Rinkeby, now have employment rates around 50\%, some, in fact, do better than the county average of $79 \%$. These better performing estates, however, contain entirely or predominantly cooperative tenure, underscoring the key importance of tenure form, and primarily not architectural design, for post-1991 diverging developments.

The overall employment gap between cooperative dwellers and rental dwellers in 2014 was 77 versus $63 \%$ for the 49 estates, and housing estates with higher than estate average employment rate (above $66 \%$ ) had $45 \%$ cooperative tenants while those below had just $15 \%$. This explains a great deal of the inter-estate difference and sorting and, as argued, also explains where most immigrants end up. Such tenure-related employment differences did not exist when the estates were new, mainly because cooperative housing was not a market commodity until 1969 (Svensson 1998; Sørvoll 2013) and it took time and increasing housing shortage to establish the currently high entry costs associated with this tenure form. 


\subsection{Converging Fates? Bredäng and Rinkeby}

The two estates chosen for the case study illustrate how initial conditions at the time of construction can shape the development of the estate over decades but also how developments in society at large, such as the economic recession of the early 1990s and changes in role the municipal housing sector as a whole will put pressure also on the more successful estates. The first case, Bredäng, was built in the early 1960s when local demand for housing was very high and new housing was considered most welcome. When the second case, Rinkeby, was built only about 5 years later, conditions were radically different. Due to extensive construction in the intervening years, the local housing shortage was rapidly transforming into a housing surplus, and media attention had turned towards the more problematic aspects of industrialised housing construction and the resulting estates. Rinkeby has been one of the prime symbols of 'the segregated estate' in the public debate ever since it was built (Ericsson et al. 2002) while for Bredäng problems of socio-economic and ethnic segregation began to be noticed only in the mid-1990s.

First, a note on the data used in this section. Data for the period prior to 1990 comes from a combination of registry and census data, where the latter is only available for every fifth year. By using the property codes, we have been able to trace the multifamily properties of these two estates back to about five years after their construction. The choice of variables has mainly been guided by data availability; very few variables are available throughout the entire period from 1970 to 2014.

Bredäng was built in 1962-1967 and can be regarded as Stockholm's first large-scale housing estate, in the sense that the whole residential area of Bredäng was planned as one architectural unit (Fig. 16.3). Everything, from the street network and green spaces to the placement, form and volume of the buildings was regulated in the physical plan of the area. One governing principle in the physical planning of the estate was to let the landscape of the area guide the placement of streets and houses, and to keep as much as possible of the natural landscape. In order to achieve this, much of the housing had to be concentrated in large high-rise buildings, though there are also a number of low-rise multifamily houses. The result is an estate with winding streets and lots of green space, but where the large-scale concrete high-rise buildings, placed in parallel along the streets, form the dominant visual feature of the estate. In terms of building practices, the construction of Bredäng also marks the beginning of the era of industrialised building. Pre-fabricated building elements like stairs, balconies and some wall elements were delivered from a cement factory, along with cement used for in-place casting (Rittsél 2000).

The rented multifamily part of the housing stock, in total 3,900 dwellings built 1963-1965, was mostly owned by municipal housing companies, though private housing companies were (and are) also represented. Multifamily housing was supplemented with about 300 single-family dwellings in terraced housing in 1965-1967, some rented and some owner-occupied. Bredäng centrum, the centre 


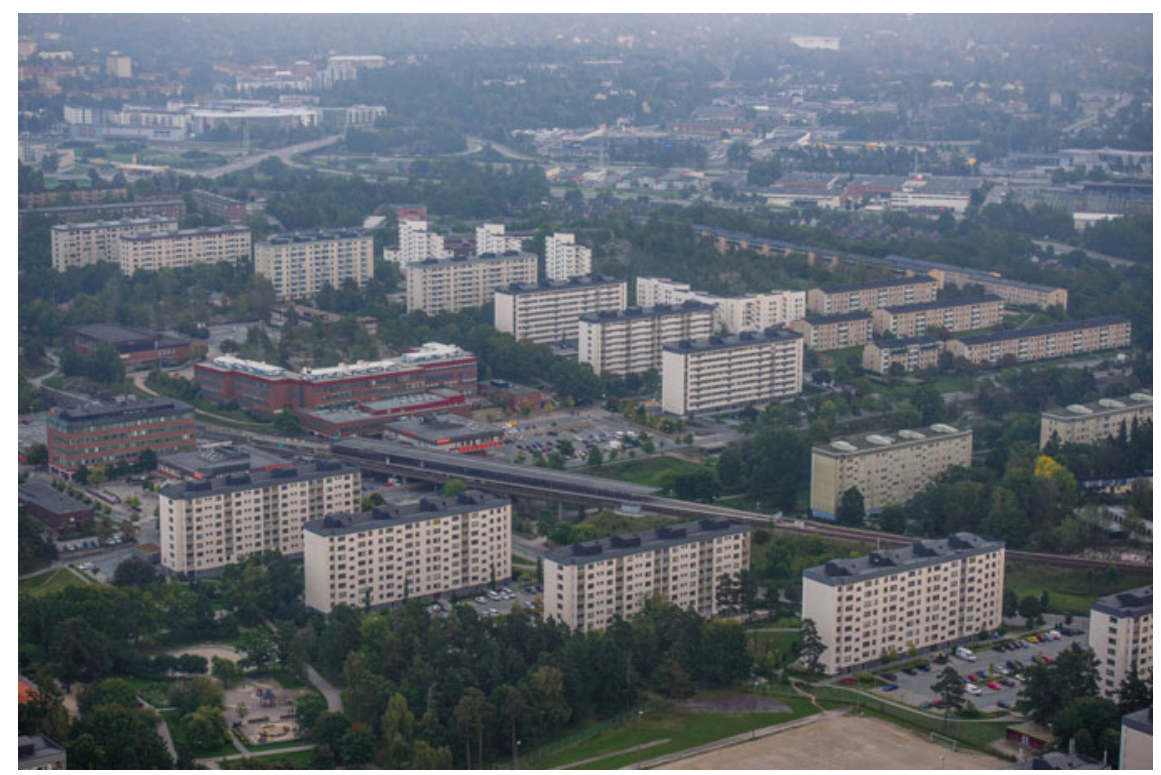

Fig. 16.3 Bredäng, 2014. Source Arild Vågen, Wikimedia Commons

where commercial and public services and the metro station are located, was opened in 1965 (Rittsél 2000). Later additions and changes to the housing stock have until recently been few. Currently, however, several new additions are planned for the coming years. About 500 new dwellings, in both rental and cooperative multifamily housing, are already under way, and another 1,000-1,500 are awaiting decision in the planning process (Stockholms stad: Fokus Skärholmen http:// vaxer.stockholm.se/omraden/skarholmen-fokus-skarholmen/). In the physical planning of these additions, the strategy has been to preserve the park-like character of the old, central parts of the estate and instead place new housing on the outskirts of the estate, especially to the east where the additions can help reduce the physical and mental gap between Bredäng and the small-scale single-family housing of neighbouring Mälarhöjden (Bredäng field visit).

In 1970, Bredäng had about 10,500 residents (Table 16.3). The age profile of the residents suggests a dominance of families with children. More than one-third (37\%) were children, and adults between ages 20 and 49 made up another $50 \%$. Only two percent of the residents were 65 years or older. About $92 \%$ were born in Sweden, which was slightly higher than the corresponding figure for the whole of Stockholm County. Further investigations into place of residence in 1960 of these early residents reveal that an overwhelming majority were 'locals'. Excluding children born after 1960, about $83 \%$ were living in Stockholm city and another four percent in other parts of Stockholm county.

Sweden in the 1970s and early 1980s is known as a society characterised by a high degree of economic equality (OECD 2011) and is obvious in our data that shows very 


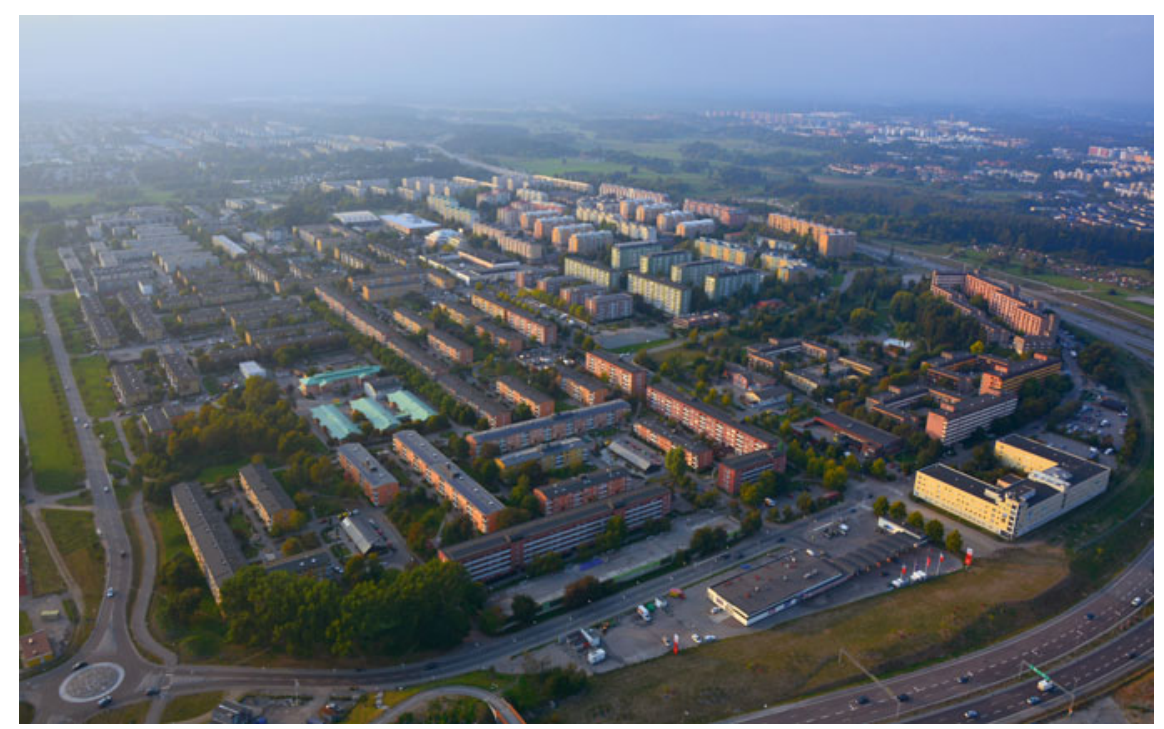

Fig. 16.4 Rinkeby, 2014. Source Johan Fredriksson, Wikimedia Commons

small income differences. Even so, available socio-economic indicators suggest that the early residents of Bredäng were rather well off. The average labour income was about six percent higher than the county average, and employment rates were higher, though the latter might be explained by the large proportion of young households, given higher employment rates among younger women than older.

When Rinkeby was built 1968-1971, together with neighbouring estate Tensta, planning ideals had shifted towards more urban forms (Fig. 16.4). That, and criticism in the public debate towards high-rise buildings resulted in lower but more densely placed buildings, interspersed by smaller, artificially landscaped green spaces (Söderström 2003). Originally, 13 different landlords, both public and private, were present on the estate, and 600 of nearly 4,900 dwellings in total were let as student flats.

Rinkeby and Tensta have received a lot of criticism over the years, for their large-scale and lack of variation in terms of tenure and housing types. At the time of construction, the critics were mainly focusing on the hurried construction process, with residents moving in while neighbouring houses were still being built and shops and other services were still lacking (Lundén 1999). Rinkeby centrum, with commercial and public services, was finished in 1971, but the accompanying metro station did not open until 1975 (Söderström 2003). The dense character of the estate has made further construction difficult, and very few additions have been made to the original housing stock. A small area of terraced housing was added in the early 2000s, but otherwise, all changes are alterations in the original housing stock. Worth mentioning is the conversion in 1993 of all student flats into ordinary private rental housing. 
Table 16.3 Socio-economic and demographic composition of early residents of Bredäng (1970) and Rinkeby (1975), in comparison with Stockholm county

\begin{tabular}{l|l|l|l|l}
\hline & \multicolumn{2}{l}{1970} & 1975 & \\
\cline { 2 - 5 } & Bredäng & $\begin{array}{l}\text { Stockholm } \\
\text { county }\end{array}$ & Rinkeby & $\begin{array}{l}\text { Stockholm } \\
\text { county }\end{array}$ \\
\hline $\mathrm{N}$ & 10,573 & $1,468,920$ & 12,720 & $1,489,865$ \\
\hline Percentage aged 0-19 & 37.3 & 26.7 & 35.4 & 26.3 \\
\hline Percentage aged 20-34 & 23.1 & 25.4 & 43.3 & 25.1 \\
\hline Percentage aged 35-49 & 26.2 & 18.4 & 12.9 & 17.3 \\
\hline Percentage aged 50-64 & 11.4 & 18.3 & 5.5 & 18.2 \\
\hline Percentage aged 65+ & 1.9 & 11.2 & 2.7 & 13.1 \\
\hline Percentage born in Sweden & 91.9 & 89.4 & 68.1 & 89.0 \\
\hline $\begin{array}{l}\text { Percentage w. Swedish } \\
\text { background }\end{array}$ & 90.2 & 88.0 & 61.3 & 87.0 \\
\hline $\begin{array}{l}\text { Percentage employed (age } \\
\text { 20-64) }\end{array}$ & 76.2 & 71.7 & 75.9 & 78.1 \\
\hline $\begin{array}{l}\text { Labour income, md. (age 20- } \\
\text { 64) }\end{array}$ & 25,000 & 23,600 & 34,700 & 38,300 \\
\hline
\end{tabular}

About 5 years after the construction, Rinkeby had 12,700 residents (Table 16.3). The age profile was exceptionally young, with nearly $80 \%$ younger than 35 , no doubt partly due to the presence of student flats on the estate. The population was arguably even more exceptional in terms of ethnic minority presence, with nearly one out of three residents born abroad. Data on country of birth reveal that the largest immigrant groups were from Finland (12\% of the residents), Greece and Turkey (just over $4 \%$ each). The socio-economic situation of the residents was rather good, with an employment rate near that of the whole county, and labour income only slightly below the Stockholm average. Thus, our data suggest that a large part of the early residents of Rinkeby were 'typical immigrants' of that time, i.e. labour immigrants from Finland and southern Europe. In contrast to Bredäng's early residents, the share of locals was very low. Only $47 \%$ of the 1975 residents were living in Stockholm county in 1965 (excluding children born after 1965).

So far, we have found a number of differences between the early residents of Bredäng in 1970 and those of Rinkeby in 1975. Though the Bredäng 'founders' had slightly higher average income, and their age profile was more mixed, the most striking difference had to do with the ethnic profile of the residents. And this aspect of the Rinkeby population was to become even more pronounced. The following 5 years saw a rapid decline in the number of residents with Swedish background and an equally rapid growth of the number of residents with foreign background (Fig. 16.5), resulting in a situation in 1980 where first- and second-generation immigrants constituted $60 \%$ of the residents. The transition continued rather rapidly until 1995 when $86 \%$ of the residents had foreign background. Since then, the number of residents with Swedish background has decreased at a much slower rate, from about 1,900 in 1995 to under 1,200 in 2014. 


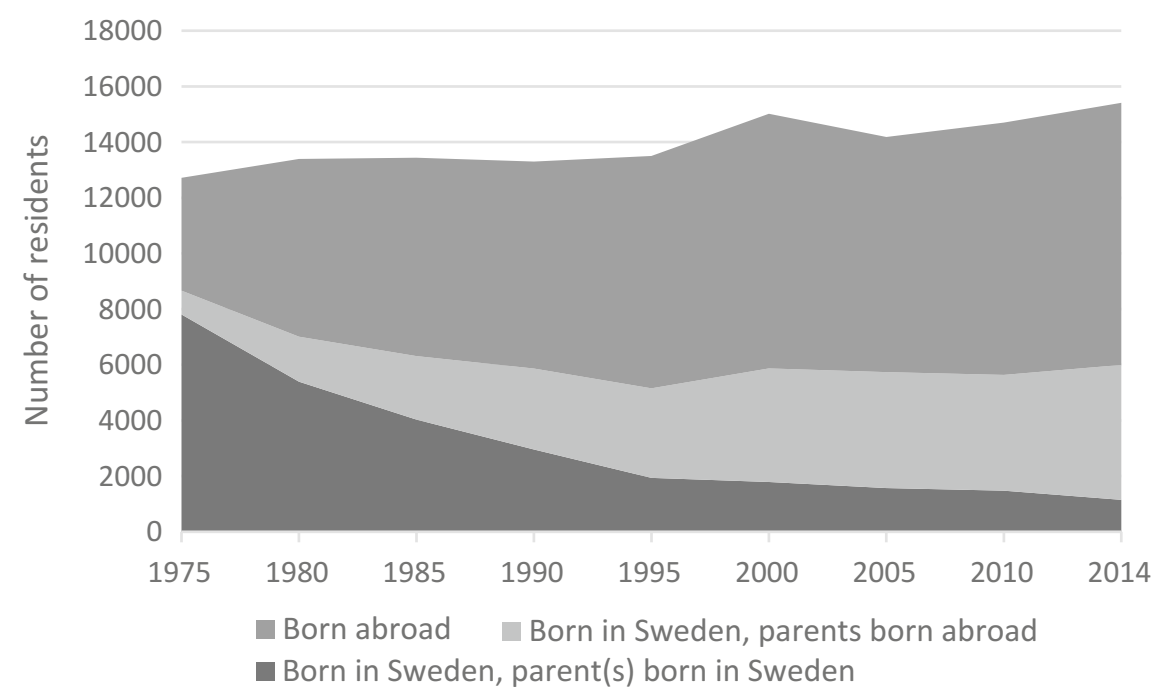

Fig. 16.5 Ethnic background of Rinkeby residents, 1975-2014

Although Bredäng can be considered 'immigrant-dense' now, with first- and second-generation immigrants constituting $72 \%$ of the population in 2014 (see Table 16.2), the transition process has been very different from that of Rinkeby. The transition started out much slower, and picked up pace only after 1990 (Fig. 16.6). Between 1990 and 2005 the share of residents with foreign background grew from 29 to $60 \%$. In terms of the development of the number of residents with Swedish background, however, the process resembles that of Rinkeby, but in Bredäng the decline in the native Swedish population was not accompanied by a corresponding growth of the immigrant population during the first decades. Thus, the total number of residents decreased, and only started to grow again after 1990, when the number of immigrants began to grow at a rate that could match the decline in the Swedish population. As of 2014, there are no signs yet of a stabilisation of the number of residents with Swedish background, though the decrease was slower in 2010 to 2014 than in earlier periods.

The development over time of the socio-economic indicators (Figs. 16.7, 16.8, 16.9) give a vivid illustration of the general tendency in Swedish society of increasing socio-economic inequality, and the effects of the economic recession of the early 1990s, in particular, are very striking, with rapidly falling employment rates and widening income gaps. Both estates were hit hard, but the negative effects were worse in Rinkeby where conditions had already begun to diverge from county averages (Fig. 16.7). The 1995-2000 period saw a general recovery of employment rates, but in the two estates the recovery was not nearly large enough to match the decline during the recession. From 2000, employment rates have stabilised at around $45 \%$ in Rinkeby and between 60 and $65 \%$ in Bredäng. 
12000

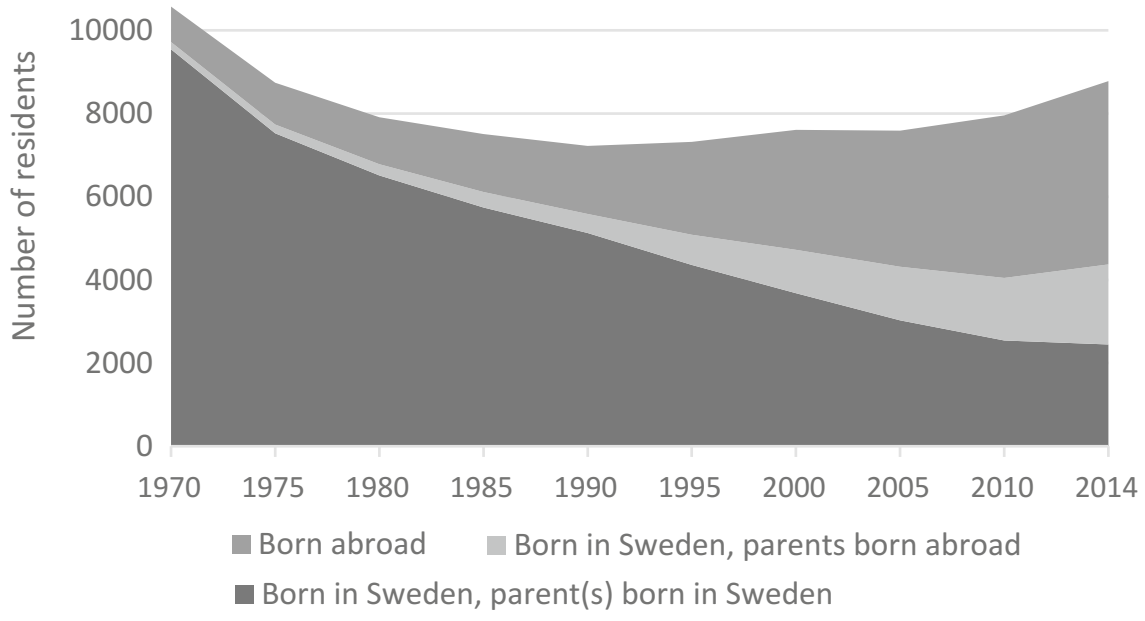

Fig. 16.6 Ethnic background of residents of Bredäng, 1970-2014

Widening gaps in employment rates are of course also visible in increasing differences in average labour incomes (Fig. 16.8, solid lines), from 1985 and onwards in Rinkeby and about 5 years later in Bredäng. But the income gaps between the residents of the estates and the county averages have also widened among those in employment (Fig. 16.8, dashed lines). Also in this respect, Rinkeby has been hit worse than Bredäng.

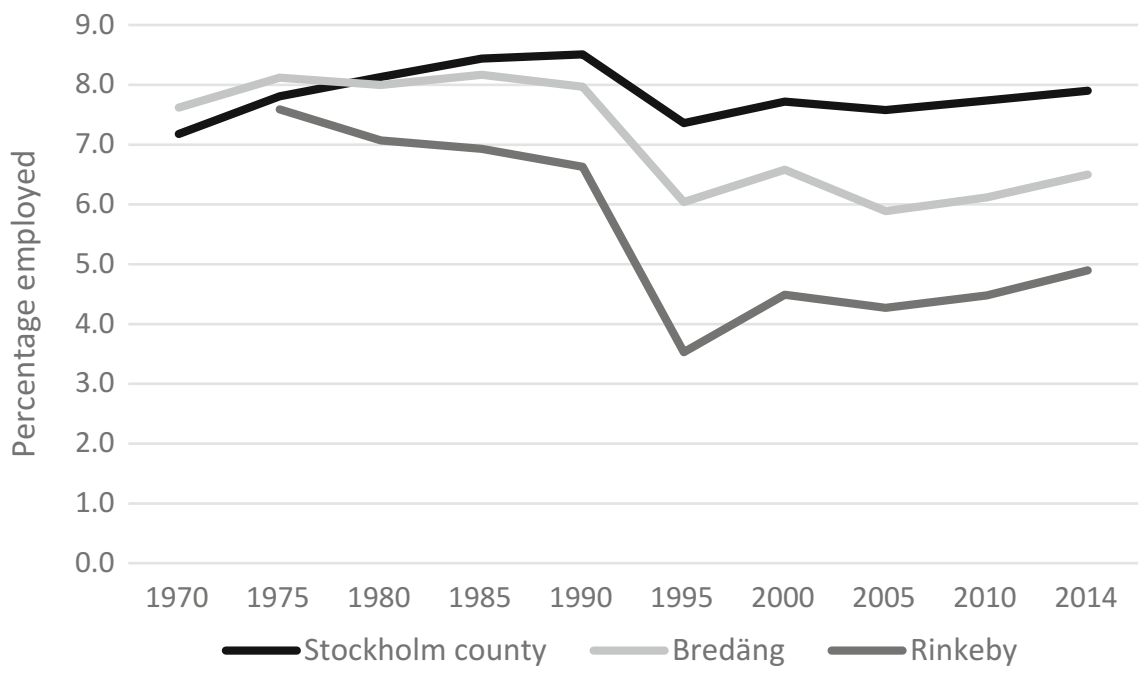

Fig. 16.7 Employment rates of residents aged 20-64 in Bredäng, Rinkeby and Stockholm county, 1970-2014 


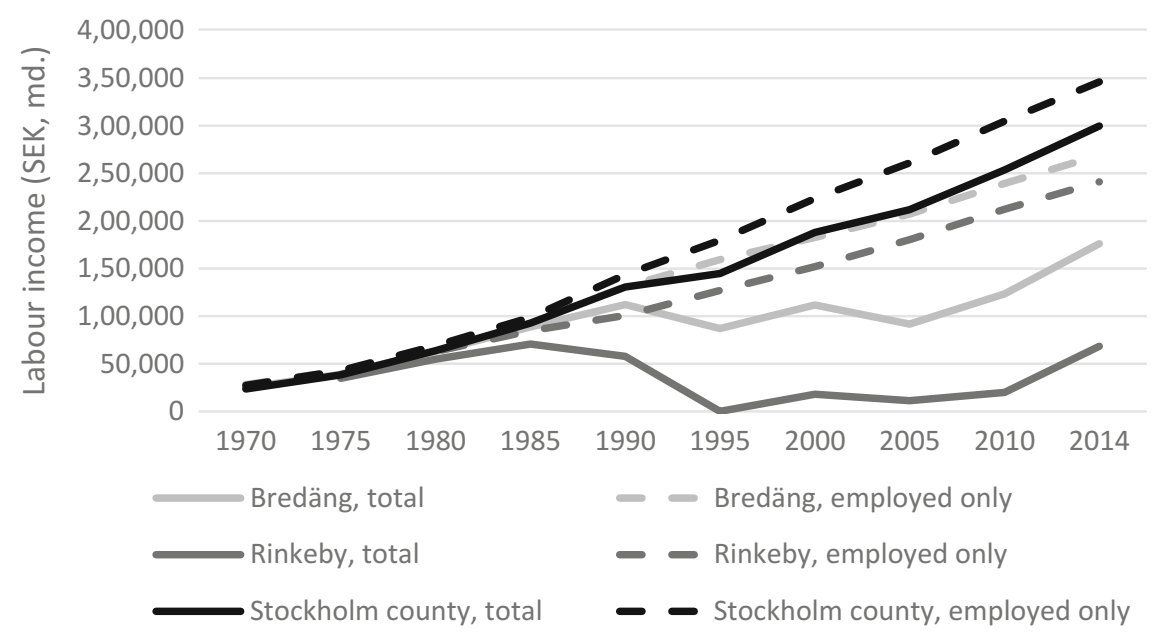

Fig. 16.8 Average labour income of residents aged 20-64 in Bredäng, Rinkeby and Stockholm County, 1970 to 2014

A further source of widening income gaps is visible also in the development of average disposable incomes (data available from 1980, see Fig. 16.9), where the county average starts to increase at" policy launched by the liberal-conservative government which meant lower taxes on labour a faster rate after 2005, most likely a result of the so-called "job tax deduction" policy launched by the liberal-conservative government which meant lower taxes on labour income. In addition, the property tax was abolished to be followed by a much lower annual fee.

In summary, both estates are now labelled 'segregated' in the public debate, but their trajectories towards the current situation have been very different. Rinkeby had a higher than average minority presence from the beginning and was labelled 'immigrant-dense' very early on. It is worth noting, though, that in the 1970s and early 1980s, when income differences were still small and refugee immigrants few, having a high proportion of foreign-born residents was not associated with poverty or deprivation. And as the socio-economic indicators have shown, income levels of the Rinkeby population followed the county averages at least until 1985. It was not until the economic crisis 1992-1993 that the association between immigrant-dense and socially deprived really became established, and this is clearly visible in both estates. As for Bredäng, the early 1990s marks the beginning of both socio-economic decline and ethnic transition. Socio-economic decline has not been as severe here as in Rinkeby, but it is uncertain how the socio-economic situation will be affected if ethnic transition continues and if labour market integration of refugee migrants remains poor. 


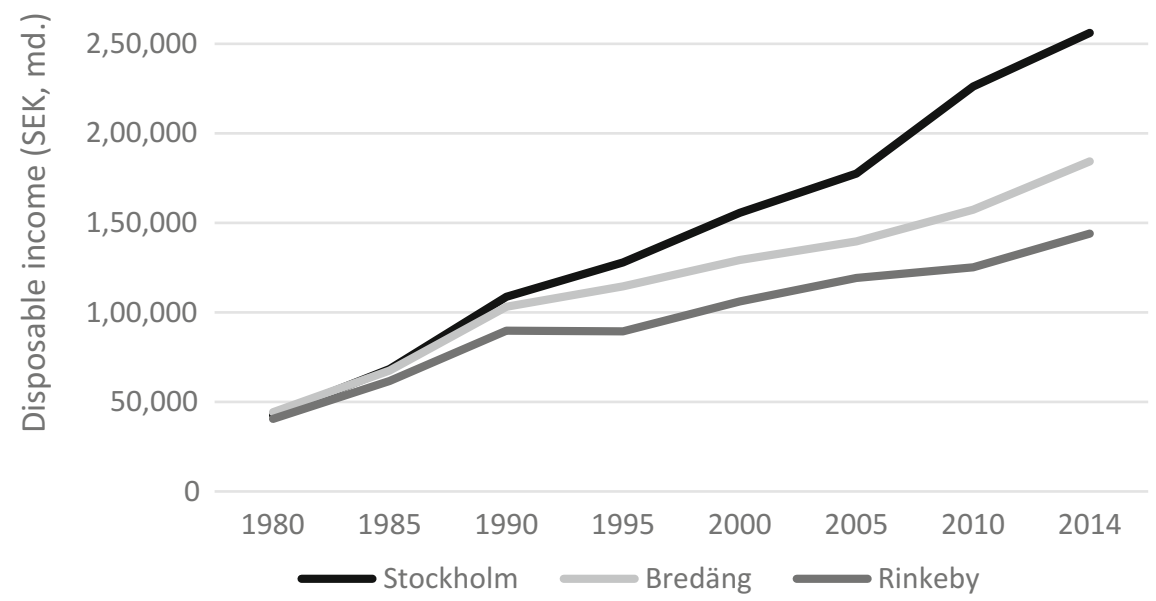

Fig. 16.9 Average disposable income of residents aged 20-64 in Bredäng, Rinkeby and Stockholm county, 1980-2014

\subsection{Interventions and Current Challenges}

We conclude our analysis of the early years by stating that ethnic segregation preceded socio-economic segregation, indicating that the downward spiral of decline is closely related to an overall integration failure (following a shift in origin countries as the migration type changed from labour market immigration to refugee immigration) which could be related to structural racism in combination with increasing human capital mismatch. The labour market has undergone dramatic shifts from Fordism to post-Fordism, and hence reduced the number of jobs available for people who are less educated and less experienced (affecting many immigrants but certainly also young natives without a higher education). The deteriorating situation was initially strongly triggered by the economic crisis in the early 1990s but recovery seems to have been slow or non-existent in many estates.

This, certainly, has not left political actors passive. On the contrary, the large housing estates have been the focus of a range of interventions starting soon after their completion and followed by others up to this date. Importantly, there have been no demolitions but otherwise, all kinds of measures have been used. Spells of no intervention are indeed few and brief and the format of this chapter makes it impossible to cover all types of interventions for this long time period. The most important ones are already well covered in earlier research, including in comparative European-funded research projects such as UGIS (Urban Governance, Inclusion and Sustainability), Restate (Restructuring Large housing estates in Europe) and Neighbourhood Governance-Capacity for Social Inclusion. (Andersson 1999, 2006; Andersson et al. 2010) provide analyses of the 
background, aims and outcomes of several of the State-funded initiatives and also references to other research (often published in Swedish) on the efforts to reverse the spiral of decline. A specific report within the Restate project summarises both physically and socially oriented state- and municipally funded efforts launched in the entire post-war era up to about 2004 (Öresjö et al. 2004; Lahti Edmark 2002)

A series of programmes were initiated, especially in the 1990s, and were to be followed by new initiatives in the new millennium. As pointed out, there have been no demolitions and most of the State and municipal interventions have been people-based rather than placed-based (physical) in character. Typically, these interventions focus on educational efforts (both in schools and for adults), improved matching of unemployed and labour demand, investments in health-related institutions, democratic participation and dialogue between residents and local authorities and supporting cultural life. Although often criticised for being time-limited project interventions, some have worked well. It has nevertheless proven difficult to break the underlying population dynamics, i.e. that more successful households move out to be replaced by newly arrived households (Andersson and Bråmå 2004). Rinkeby has been part of most interventions, more recently Järvalyftet, launched as a planning process in five housing estates in northwestern Stockholm city in 2007 and actively involving the city's public housing companies. The aims were formulated in terms of 'good housing in a more varied city environment', 'safety', 'improved education and language training' and 'more jobs and entrepreneurial activity'. This still-ongoing effort has a strong physical component, including major renovations of dwellings and maintenance of public space, but physical interventions sometimes include employment-related activities. The renovations, or 'renovictions' (renovation + eviction) as they are sometimes labelled, have in Stockholm and other Swedish cities been harshly criticised for forcing people to move and for striving for gentrification of neighbourhoods. It is argued that what is generally believed to be necessary renovations and energy efficiency improvements of the 50-60-year old estates, are in fact 'overdone' in order to increase rents beyond what is affordable for many households (Baeten et al. 2016).

\subsection{Looking Ahead: What Is on the Agenda?}

The 'renoviction' debate illustrates a growing problem in a context of abolished housing subsidies and a much less active State housing policy, but if a single word could condense and summarise today's dominating public discourse regarding the poor and immigrant-dense estates, it is safety. Safety has always been a relevant aspect and priority for those living in neighbourhoods experiencing unemployment and relative poverty, but it is now on top of the political agenda and it is strongly related to debates on immigration, refugees, radical Islam, gang violence and terrorism. The police have their own list of the worst and most dangerous places in Sweden, covering 61 estates across the country and 24 in Stockholm County, and many of our selected 49 housing estates are on this list. The government operates its 
own list of Urban 15, i.e. 15 housing estates in need of special attention and interventions. Rinkeby is on both lists while Bredäng is only on the police list.

Most social scientists do of course realise that the objective conditions created by neo-liberal policies and widening socio-economic gaps in a more segregated city provide fertile ground for social unrest. Particular events such as widespread car burnings and clashes between young men and the police attract national and international media attention and contribute to putting safety issues on top of the agenda. Many local residents do of course share the demands for more police presence, increased surveillance and other safety measures. However, available research on crime and safety finds crime rates dropping over time (2008-2014) and an overwhelming majority of residents find their neighbourhood to be safe (Stockholms Stad 2014). The overall proportion of people in Stockholm city reporting feeling unsafe in their own neighbourhood dropped from 10 to $8 \%$ in 2008-2014, but with variations across neighbourhoods (proportions are more than twice as high in socially disadvantaged estates such as Rinkeby and Bredäng). Complaints about damaged property, littering and arson are more common in areas dominated by housing estates compared to elsewhere. One in five residents in Stockholm city housing estates reports having felt anxious about violence over the past year (for comparison, see Kemppainen 2017, analysing disorder and insecurity in Finnish suburban housing estates). Clearly, even if such rates have not increased over time they are not satisfying, and Stockholm city along with the police have intensified their crime prevention activities. In Rinkeby and adjacent estates, the work is led by a security strategist who works in close cooperation with physical planners in order to make public space safer. The introduction of CCTV in May 2017 is another feature intended to make it easier to combat crime and gather evidence when a crime is committed (Rinkeby field visit).

It would, however, take a much more comprehensive social and housing reform agenda to combat the spiral of decline and reverse social exclusion tendencies. Such an agenda will likely not be politically agreed upon, but most share the view that employment is key and that improving school education is decisive for long-term improvements. The current left-green-feminist political majority in Stockholm city launched a new effort in 2015-The Commission on Socially Sustainable Development (Kommissionen för ett socialt hållbart Stockholm)—where a more holistic approach is taken towards current challenges, focusing not only on large housing estates but on planning and local policies more broadly. Priorities are listed under four headings: 'democracy and safety', 'work and income', 'housing and living environment' and 'childhood and education'. The commission works in close cooperation with the research community, but whether this new broader effort will result in changes on the ground remains to be seen.

It is clear that the severe housing shortage in Stockholm in some ways are seen by planners and politicians as an opportunity to also address problems related to the 'enclave' character of many estates. By means of new housing construction Rinkeby will have 600-1,000 new housing units with mixed tenure added to its housing stock. These will be located, for instance, on former parking sites in the estate but also on land freed up due to channelling passing traffic on the highway 
E18 underground and placing new housing above the tunnel. Other development plans aim at expanding housing on green land immediately south of the estate. Rinkeby will also be the location of a new large local police office employing approximately 300 people, serving all housing estates in northwestern Stockholm.

As mentioned earlier, new construction aiming at breaking down existing barriers to adjacent neighbourhoods is also planned near Bredäng. Breaking barriers by densification is a general ambition of politicians and of Stockholm city's planning office but such densification will likely also be contested because it reduces green space and constrains existing leisure activities. Balancing the need for more housing with rearranging accessibility patterns and conserving green space is indeed a challenge in a rapidly expanding urban region like Stockholm.

It is natural to expect municipalities and property owners to try to address what is believed to be problematic housing and neighbourhood conditions. But if anything, our analyses reveal the key importance of broader economic and political developments for what has taken place over the past 25 years. Absent a clearly formulated policy on refugee reception - for instance, regional and local placement policies - migrants have tended to cluster into a limited number of rental-dominated large housing estates. The economic crisis of the early 1990s saw some of these estates fall to the bottom in the rankings of many key neighbourhood indicators, employment being the most important. A better steering of newly arrived migrants' first housing and a more active education and labour market integration policy are measures more likely than area-based restructuring policies to be fruitful for combatting tendencies towards social exclusion in relation to the housing estates. Some might argue that as the cooperative segment of the estates is doing fine or at least better, why not convert remaining rental housing into ownership form? That might work for individual estates but the resulting gentrification will produce displacements and relocation of poor households elsewhere in the region or even beyond. We judge that the current level of rental housing, in particular, affordable rental housing, is already too low and too geographically concentrated for allowing enough people to move in and out of the Stockholm region and for sustaining a dynamic labour market.

\subsection{Conclusion}

Using earlier research, registry data and descriptive methods this chapter has provided an overview of the planning background and subsequent development of large housing estates in the Stockholm region. Despite criticism towards their standardised and dense layout, traffic separation, poor service level and other aspects, most estates did well socioeconomically until 1990. Our two cases, Bredäng and Rinkeby, had very different starts where Bredäng, as one of the early estates (finished by the mid-1960s) was populated with relocated, well established local households while Rinkeby (finished by the early 1970s) to a much higher extent was the destination for younger migrants from outside Stockholm and also 
from outside Sweden. We judge that these early conditions had a large impact on subsequent developments for more than 20 years.

Later on, Bredäng and many other formally successful estates seem to have undergone selective (in-)migration, where out-moving native-born Swedes, and employed people with higher incomes, have been replaced by successively larger proportions of new immigrants with weak attachment to the labour market. The dynamics of selective migration cannot be understood if not put in the context of the economic crisis occurring in the early 1990s. More than $12 \%$ of all jobs in the region disappeared in a few years' time, and newcomers in the labour market such as immigrants and young people-i.e. those that were concentrated in housing estates like Rinkeby-were among the worst hit. In addition, changes in the housing market have resulted in a reduction of affordable rental housing in many parts of the Stockholm region. With fewer rental units available, those remaining have to absorb even more of the forthcoming expansion of immigrated (refugee) households, reinforcing selective in-migration. Also at this stage, rental-dominated housing estates previously less affected by immigration and expansion of unemployed people, like Bredäng, become destinations, both for immigrants seeking relocation from the most immigrant-dense estates in the region and for those arriving directly from abroad.

In explaining which housing estates that followed this trajectory (converging towards Rinkeby's position) and which remained relatively unaffected, we can single out three important factors. First and foremost is tenure. Estates overwhelmingly consisting of rental housing have the potential to relatively quickly change their household composition, while estates with a larger proportion market-priced housing have lower turnover and exclude poorer households entirely from moving in. This does not mean that cooperative housing neighbourhoods are immune to selective migration, only that such dynamics will take longer time and that there are counter-balancing factors, especially when the housing market is tight and prices for entering are high. Second, housing estates located closer to existing clusters of poverty run a higher risk of being destinations for horizontal mobility from one area to another. This has to do with the very nature of residential mobility as very distance dependent. The bulk of movers tend to move over short distances because shorter moves have less transaction costs emotionally and socially. The third factor is building period, where the main difference seems not to be between Million Programme estates and non-Million Programme estates, but rather between early and late estates, where the dividing line seems to be around 1968. Our two cases illustrate a more general tendency that estates built later had less favourable initial conditions, i.e. lower local demand for housing and emerging stigmatisation of some estates.

Stockholm's housing estates face many challenges and the list of interventions by property owners, municipalities and the State is long and covers more than 40 years. Some interventions have targeted physical aspects, others socio-economic and wider cultural developments. To an increasing extent, these are now framed within a safety discourse. However, irrespective of the reason for political and management reactions and the objective needs to intervene and refurbish, we 
believe too much focus is placed on area-based reasoning and much too little on the wider social and political issues determining the fate also of particular estates.

Acknowledgements This research has received funding from the European Research Council under the European Union's Seventh Framework Programme (FP7/2007-2013)/ERC grant agreement no 324233, Riksbankens Jubileumsfond (DNR M12-0301:1), Forte research grant (DNR 2016-00837), and the Swedish Research Council (DNR 445-2013-7681) and (DNR 340-2013-5460).

\section{Field visits, hosts}

In Rinkeby, May 29, 2017:

Peter Lundevall, city planner at the planning office, Stockholm City.

Per Granhällen, manager Security-Crime prevention, The Rinkeby-Kista district, Stockholm City.

Ewa Jungstedt-Pilestål, community planner at the Rinkeby-Kista district, Stockholm City.

In Bredäng, May 30, 2017:

Eveliina Hafvenstein Säteri, city planner at the planning office, Stockholm City. Flor Luna, community planner, Skärholmen city district, Stockholm City. Love Örsan, community planner, Skärholmen city district, Stockholm City.

\section{References}

Andersson R (1999) 'Divided Cities' as a policy-based notion in Sweden. Hous Stud 14(5):601624. https://doi.org/10.1080/02673039982632

Andersson R (2006) 'Breaking segregation'-rhetorical construct or effective policy? the case of the metropolitan development initiative in Sweden. Urban Stud 43(4):787-799. https://doi.org/ $10.1080 / 00420980600597608$

Andersson R, Bråmå $\AA$ (2004) Selective migration in Swedish distressed neighbourhoods: can area-based urban policies counteract segregation processes? Hous Stud 19(4):517-539. https:// doi.org/10.1080/0267303042000221945

Andersson R, Bråmå Å, Holmqvist E (2010) Counteracting segregation: Swedish policies and experiences. Hous Stud 25(2):237-256. https://doi.org/10.1080/02673030903561859

Andersson R, Hedman L (2016) Economic decline and residential segregation: a Swedish study with focus on Malmö. Urban Geogr 37(5):748-768. https://doi.org/10.1080/02723638.2015. 1133993

Andersson R, Kährik A (2015) Widening gaps: segregation dynamics during two decades of economic and institutional change in Stockholm. In: Tammaru T, Marcińczak S, van Ham M, Musterd S (eds) Socio-economic segregation in european capital cities. East meets West, Routledge, London and New York, pp 110-131

Andersson R, Turner LM (2014) Segregation, gentrification, and residualisation: from public housing to market-driven housing allocation in inner city Stockholm. Int J Hous Policy 14 (1):3-29. https://doi.org/10.1080/14616718.2013.872949

Baeten G, Westin S, Pull E, Molina I (2016) Pressure and violence: Housing renovation and displacement in Sweden. Environ Plan A 49(3):631-651. https://doi.org/10.1177/ $0308518 \times 16676271$ 
Ericsson U, Molina I, Ristilammi PM (2002) Miljonprogram och media: föreställningar om människor och förorter. Integrationsverket and Riksantikvarieämbetet, Norrköping/Stockholm

Franzén M, Sandstedt E (1981) Grannskap och Stadsplanering. Om stat och byggande i efterkrigstidens Sverige (Neigbourhood and Town-planning. State and Housing Construction in Post War Sweden). Acta Universitatis Upsaliensis, Studia Sociologica Upsaliensia 17, Uppsala, Sweden

Hall P (1988) Cities of tomorrow. An intellectual history of urban planning and design in the twentieth century. Basil Blackwell, Oxford

Kemppainen T (2017) Disorder and insecurity in a residential context: a study focusing on finnish suburban housing estates built in the 1960s and 1970s, Helsingin kaupunki, Helsinki

Lahti Edmark H (2002) Förort i fokus - interventioner för miljoner. Nordisk översikt om interventioner i 'utsatta' bostadsområden - en kunskapsöversikt. Integrationsverkets rapportserie 2002:01. Norrköping

Lundén T (1999) Om staden: en Stockholmsgeografi. Studentlitteratur, Lund

Molina I (1997) Stadens rasifiering. Etnisk boendesegregation i Folkhemmet, vol 32. Geografiska regionstudier 32. Department of Social and Economic Geography, Uppsala University

OECD (2011) Divided we stand: why inequality keeps rising. Paris

Popenoe D (1977) The suburban environment: Sweden and the United States. University of Chicago Press, Chicago

Pred A (1995) pure and simple lines, future lines of vision: the stockholm exhibition of 1930. In: Recognizing European modernities: a montage of the present. Routledge, London

Rådberg J (1988) Doktrin och täthet i svenskt stadsbyggande 1875-1975. Statens råd för byggnadsforskning, Stockholm

Rådberg J (1997) Drömmen om Atlantångaren: utopier \& myter i 1900-talets stadsbyggande. Atlantis, Stockholm

Rittsél J (2000) Bredäng: starten för det stora seriebyggandet. Stockholms Stadsmuseum: Miljonprogram i Stockholm. Stockholms stadsmuseum, Stockholm, pp 90-101

Söderqvist L (1999) Rekordår och miljonprogram. Flerfamiljshus I stor skala. En fallstudiebaserad undersökning av politik, planläggning och estetik. Konstvetenskapliga institutionen, Stockholms universitet, Stockholm

Söderqvist L (2008) Att gestalt välfärd Från idé till byggd miljö. Forskningsrådet Formas och Riksantikvarieämbetet, Stockholm

Söderström G (2003) Stockholm utanför tullarna: nittiosju stadsdelar i ytterstaden. Stockholmia förlag, Stockholm

Sørvoll J (2013) The politics of cooperative housing in Norway and Sweden 1960-1990 (1945-2013) - The Swedish deregulation of 1968 and the Norwegian liberalization of the 1980s. PhD Dissertation, Faculty of Humanities, University of Oslo, Oslo

SOU (1965) Höjd bostadsstandard, vol 32, Stockholm

Stad Stockholms (2014) Trygghet i Stockholm 2014 Stockholms stad övergripande trygghetsmätning. Socialförvaltningen, Stockholm

Stockholms stad: Fokus Skärholmen. http://vaxer.stockholm.se/omraden/skarholmen-fokusskarholmen/

Svensson S (1998) Transformation of a tenure: the evolution of tenant-ownership in Sweden. Research Report 1998:3, Institute for Housing and Urban Research, Uppsala University, Uppsala

Öresjö E, Andersson R, Holmqvist E, Pettersson L, Siwertsson C (2004) Large housing estates in Sweden. Policies and practices. Restate report 3i. Urban and Regional Research Centre. Faculty of Geosciences. University of Utrecht, Utrecht 
Open Access This chapter is licensed under the terms of the Creative Commons Attribution 4.0 International License (http://creativecommons.org/licenses/by/4.0/), which permits use, sharing, adaptation, distribution and reproduction in any medium or format, as long as you give appropriate credit to the original author(s) and the source, provide a link to the Creative Commons license and indicate if changes were made.

The images or other third party material in this chapter are included in the chapter's Creative Commons license, unless indicated otherwise in a credit line to the material. If material is not included in the chapter's Creative Commons license and your intended use is not permitted by statutory regulation or exceeds the permitted use, you will need to obtain permission directly from the copyright holder.

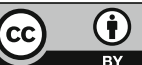




\title{
Chapter 17 \\ Population Shifts and Urban Policies in Housing Estates of Tallinn, Estonia
}

\author{
Kadri Leetmaa, Johanna Holvandus, Kadi Mägi and Anneli Kährik
}

\begin{abstract}
Housing estates in the Tallinn urban region are interesting objects of research in many respects. First, as in other post-socialist European cities, the proportion of the population residing in socialist-era apartments is extraordinarily high here. Second, residential units in housing estates were originally state-built and run but are almost fully privatised today. Third, post-Soviet housing estates tend to be multi-ethnic, much like similar residential districts in many other European cities. This chapter reveals that Tallinn housing estates are experiencing gradual social decline: within the first two decades of post-socialism, a remarkable ageing of the population has taken place, the proportion of people with low socio-economic status has increased dramatically in some estates while others have succeeded in remaining relatively stable in this respect, and patterns of ethnic and socio-economic segregation have increasingly overlapped. Interestingly, this silent social decline is not acknowledged by contemporary urban actors. In the early transition years, institutional rearrangements were made (privatisation, new housing management and urban planning rules), but this was followed by a period of political neglect until the late 2000s. Although recent interventions (e.g. social housing projects, densification of housing estates by private developers, support for the renovation of panel buildings and rising community activism) have been more targeted, these policies remain rather chaotic generally. No vision exists for how the efforts of different actors and sectoral policies should stabilise housing estates in the longer run. There seems to be a race against time - although investments and efforts are being made to improve the residential quality of housing estates, this is not sufficient to counterbalance their ongoing stigmatisation and population changes.
\end{abstract}

K. Leetmaa ( $₫)$ · J. Holvandus · K. Mägi · A. Kährik

Centre for Migration and Urban Studies, University of Tartu, Tartu, Estonia

e-mail: kadri.leetmaa@ut.ee

J. Holvandus

e-mail: johanna.holvandus@ut.ee

K. Mägi

e-mail:kadi.magi@ut.ee

A. Kährik

e-mail: anneli.kahrik@ut.ee

(C) The Author(s) 2018

D. B. Hess et al. (eds.), Housing Estates in Europe, The Urban Book Series,

https://doi.org/10.1007/978-3-319-92813-5_17 
Keywords Housing estates - Social degradation - Urban policies Post-Soviet cities

\subsection{Introduction}

Post-World War II housing estates have long been targets for urban policy-makers throughout Europe. Housing estates in formerly socialist countries are physically similar to those elsewhere in Europe (Glasze et al. 2012), meaning that assumptions about contemporary urban problems and suitable measures in these districts are sometimes made without sufficient critical reflection. This chapter broadens the scholarly knowledge of the ongoing population shifts and experimental interventions taking place in modernist housing estates in European cities by presenting the case of Tallinn, the capital of a former Soviet republic.

Housing estates in post-socialist Europe are a specific case because a high proportion of the population resides in socialist-era apartments and urban housing is in almost full private ownership. The majority of the dwellings in many former Soviet cities are located in housing estates. In East Central European cities, the estimated proportion is 20-40\% (Temelová et al. 2011). In the Tallinn urban region of today, half the residents live in housing estate apartments (Table 17.1). Privatisation of state-owned housing was launched in the early 1990s in Estonia and by the end of the decade almost all residential units belonged to private home owners. Generous public subsidies to maintain buildings and public spaces were then withdrawn and former public tenants lacked the skills and financial resources to act as owners.

Housing estates in former Soviet republics are also interesting areas of research because of their multi-ethnic (in Tallinn, Estonian-Russian) residential

Table 17.1 Population of housing estates in Tallinn and its surrounding municipalities, 19892011

\begin{tabular}{|c|c|c|c|c|c|c|}
\hline & \multicolumn{2}{|l|}{1989} & \multicolumn{2}{|l|}{2000} & \multicolumn{2}{|l|}{2011} \\
\hline & No. & $\%$ & No. & $\%$ & No & $\%$ \\
\hline \multicolumn{7}{|l|}{ Tallinn } \\
\hline Housing estates & 288,153 & 60.2 & 251,582 & 62.8 & 227,190 & 57.9 \\
\hline Other neighbourhoods & 190,821 & 39.8 & 148,770 & 37.2 & 165,476 & 42.1 \\
\hline \multicolumn{7}{|c|}{ Surrounding municipalities } \\
\hline Housing estates & 30,768 & 50.1 & 26,753 & 37.9 & 23,925 & 22.2 \\
\hline Other neighbourhoods & 30,693 & 49.9 & 43,907 & 62.1 & 84,002 & 77.8 \\
\hline \multicolumn{7}{|l|}{ Tallinn Urban Region } \\
\hline Housing estates & 318,921 & 59.0 & 278,335 & 59.1 & 251,115 & 50.2 \\
\hline Other neighbourhoods & 221,514 & 41.0 & 192,677 & 40.9 & 249,478 & 49.8 \\
\hline
\end{tabular}

Source Estonian Censuses 1989, 2000, 2011 
environments. In Tallinn, as in other European cities that have hosted large flows of immigrants, modernist housing estates were the destinations of arriving immigrants. The inflow of Russian-speaking populations accompanied the rapid industrialisation and allocation of Soviet military forces to Estonia. By the end of the 1980s, almost half of the population of Tallinn were Russian-speakers (1989 Census). The case of Tallinn, thus, illustrates the trajectories of mixed-ethnic housing estates in an almost fully privatised housing market where the housing estate apartment is the prevailing dwelling type.

In this chapter, we first explain how housing estates were planned and built in the Tallinn urban region during the socialist period and what position these districts acquired on the socio-spatial landscape of a Soviet city. Our empirical contribution is divided into two sections. First, we analyse the demographic and socio-economic trajectories of housing estates in the post-socialist period using cross-sectional individual data from the last three censuses $(1989,2000,2011)$ to demonstrate how mean age, proportion of low-social status inhabitants and Russian-speakers have changed in housing estate neighbourhoods. Second, we give an overview of how public policies have changed in response to these trends basing our analysis on expert interviews and the long-term field experience of the authors. Seven individual expert interviews and one focus group were used. The interviewees include planning officials in Tallinn today, former high officials in the field of planning and representatives of civic movements, apartment associations and private housing development projects.

\subsection{The Origin of Housing Estates in Soviet Cities}

Here, as well as elsewhere in Europe, large-scale housing construction in Estonia was a response to both a rapid industrial and population growth in Soviet cities and a severe post-World War II housing shortage. In the capital of Estonia, very intense immigration from Russia and other Soviet republics and internal migration made the housing shortage even more acute. During the first few Soviet decades, loyal workers were needed in administrative posts. In addition, military investments encouraged the immigration of military personnel. Throughout the Soviet period, Estonia's industrial capacity grew, which required an additional immigrant workforce, and later, family migration supported further immigration. With respect to internal migration, the former agricultural sector suffered from collectivisation and deportations in the 1940s and 1950s. At the same time, new industrial jobs made cities attractive destinations, even though special permission was needed to access urban housing.

The first large-scale housing construction programmes (using brick-technology, known as khrushchëvki) were launched in the late 1950s. These were mostly built as single in-fills or small groups of buildings on vacant plots close to the city centre. In Tallinn, for example, the development of Pelguranna district was initiated in this period. Since the 1960s, industrial housing construction (prefabricated panel 
technology) has become prevalent and construction activities in Tallinn have been concentrated in three larger master-planned housing estate districts: Mustamäe (30,500 apartments), Väike-Õismäe (14,500) and Lasnamäe (47,000) (Fig. 17.1).

In order to manage overcrowding, industrial investment was decentralised and directed to specialist industrial satellite towns adjacent to major Soviet cities (e.g. St. Petersburg, Moscow and Riga). In Tallinn, the initial decentralisation policies were less extensive. The largest satellite town established in the Tallinn agglomeration was Maardu (17,500 inhabitants, 2011 Census), which was the location of both the chemical industry and a port, and where all the historical layers of socialist housing can still be seen today.

It is noteworthy that prefabricated panel technology was also used in rural housing construction too. By the 1970s, collective agricultural enterprises in Estonia had become important producers. As a result, prestigious jobs now became available in rural settlements around Tallinn as well. To provide housing for agricultural workers, smaller rural housing estates were built. As the former Chief Architect of Tallinn commented: 'the fabrics of building materials were working, panels were steadily produced, they needed to be used.'

Figure. 17.1 presents the variety of housing estates in the Tallinn urban region. The peak of mass housing construction occurred in the 1970s and 1980s (in rural centres in the 1980s, the golden period of Soviet agriculture). Some projects were
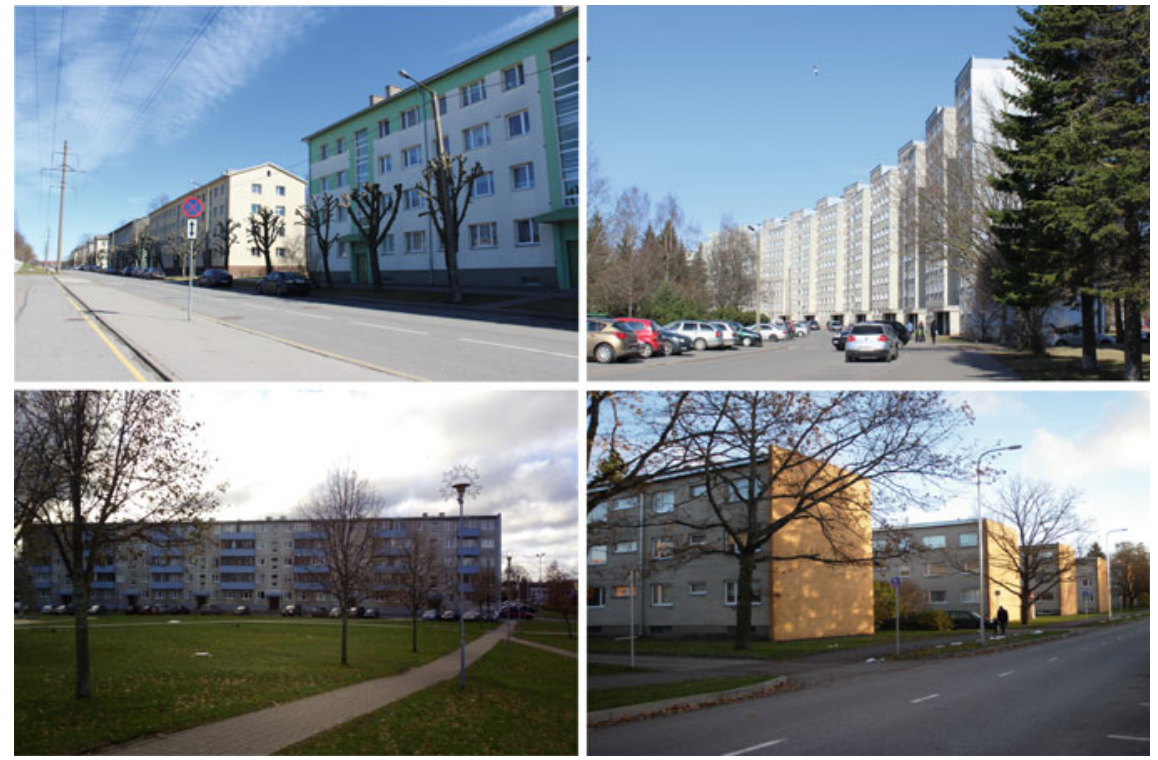

Fig. 17.1 Examples of housing estates in Tallinn urban region: (upper left photo) brick houses in Pelguranna/Tallinn (some buildings have new façades today); (upper right photo) prefabricated panel blocks in round-shaped Väike-Õismäe/Tallinn; (lower left photo) housing estates in Maardu satellite town; (lower right photo) smaller scale housing estates in the suburban-rural centre of Saku. Source Johanna Holvandus and Annika Väiko 
finalised in the early 1990s but had been initiated before that. By the end of the Soviet period (1989), $60 \%$ of the residents of Tallinn and $50 \%$ of the inhabitants of the surrounding municipalities (rural centres and satellite towns) lived in housing estate neighbourhoods (Table 17.1).

\subsection{Spatial and Socio-Spatial Reality in Soviet Housing Estates}

In addition to mass housing construction being a technological response to the housing shortage in Tallinn, as well as elsewhere in Europe, it was also envisaged to be in line with Soviet ideology as part of building a collective and just society. Theoretically, everyone was entitled to access to modern housing, and all new apartments were similar and equipped with contemporary modern facilities. The planning approaches of the time supported the equality principle as well. The main unit of the new residential districts became the mikrorayon, a self-contained neighbourhood with standardised high-rise apartment blocks. As for services and infrastructure, universal access was to be provided to amenities such as schools and childcare, personal services, car parks, public transport, greenery and recreation facilities.

Larger housing estate districts usually consisted of several mikrorayons and were carefully master-planned through prestigious architectural competitions (Metspalu and Hess 2018). Mustamäe is a good example in which we can follow the development of planning ideas from the initial more haphazard placement principles of residential buildings (as seen also in the older Pelguranna housing estate district: Fig. 17.1) to the more extensive application of the mikrorayon approach. In Väike-Õismäe, the mikrorayon idea was developed further with the residential buildings there placed in a circular fashion (Fig. 17.1) around the recreation area. Schools and kindergartens are located within the circle, and shops, services and public transport stops are on the main ring road. The master plan for Lasnamäe, the latest and the largest housing estate district of Tallinn, gives special attention to connections with the city centre (a fast tram line, although never finished, was envisaged) and to safe pedestrian roads (walkers' bridges). Some smaller housing estate districts depended on the infrastructure of the surrounding areas and were either built close to larger residential areas (Astangu in the 1980s next to VäikeÕismäe) or as in-fills in older districts. Because construction plans needed to be fulfilled, some districts were also built more spontaneously in more isolated locations. In the satellite town of Maardu, services and infrastructure were planned too, but residential construction was not as carefully organised there as it was in the larger housing estate districts of Tallinn. Compared to the large blocks of flats in Tallinn and Maardu, a more human-scale environment was built in rural centres, where the smaller housing estates were designed as extensions of existing settlements. 
The ideal of equality was never achieved, however, because in reality not everyone had access to new dwellings, and socialist-era planning ideas were never fully put into practice. Although administrative rules for allocating apartments were needs-based and families with children, for example, officially had priority (Kulu 2003), people waited for apartments for many years. In general, large industrial employers and the army were able to provide housing for their personnel more quickly. This shows the ethnic differentiation in access to housing as arriving immigrants who did not have alternative dwellings more easily received modern apartments (Hess et al. 2012). A similar shortage of resources existed in realising spatial plans. Because ever more housing was needed, when the residential buildings had been constructed in each housing estate, priorities typically shifted to new construction sites, and the infrastructure of the former sites remained unfinished.

Due to these unforeseen side effects, specific forms of segregation developed in Soviet cities. In a workers' society no salient upper or lower class emerged, and levels of socio-economic segregation, therefore remained modest. At the same time, ethnic segregation was noticeable. Some people had higher chances of receiving a new apartment (including the immigrant population) and others (most commonly Estonians) inhabited older housing areas that did not enjoy state subsidies and were due for demolition. Some districts were better equipped with infrastructure or better situated within the city in relation to, for example, public transport, workplaces, or environmental pollution. Micro-scale residential differentiation (a preferred floor in a building, or dwellings with better building material) also often existed.

Despite these shortcomings, the reputation of housing estates remained high until the end of Soviet period. There were, however, signs that a spatially monotonous mixed-ethnic built environment had lost its attraction, especially among native Estonians. For example, the phrase 'Stop Lasnamäe' from a popular song of the Singing Revolution became a symbol of the national independence movement of the late 1980s.

\subsection{Population Shifts in Housing Estates Since the Late Soviet Period}

Although equal distribution of social groups in urban space was the aim of socialist urban planning, no geographical microdata were made available to assess whether these aims were achieved. Today, almost 30 years after the collapse of the Soviet state, individual-level 1989 Census data are accessible to researchers. We are, therefore, able to compare the population composition of housing estates of the Estonian capital city region at the moment of the last Soviet census with the situations after the first (2000 Census) and second (2011 Census) transition decades.

We define neighbourhoods based on the spatial units used administratively in planning-related activities, and which are as a rule socially and spatially 
homogeneous areas. Among these units, we distinguish housing estates as: all neighbourhoods in Tallinn with at least 1000 inhabitants and in surrounding municipalities with at least 500 inhabitants where the majority of residents $(80 \%$ in Tallinn, $70 \%$ in the suburbs) live in Soviet-era apartments (this also includes buildings of the same type that were finished in the 1990s) according to the 2011 Census. Figure 17.2 presents the location of housing estates according to this definition in the Tallinn urban region. Pelguranna and Kopli (late 1950s and 1960s) are the oldest housing estate neighbourhoods, Mustamäe (1960s and 1970s), VäikeÕismäe (1970s and early 1980s), Lasnamäe (late 1970s and 1980s) are typical master-planned larger housing estate areas following the mikrorayon principle, and some smaller housing estates closer to the city centre are in-fills from different periods. In the surrounding municipalities, Maardu is a classic industrial satellite town and other housing estates are the central settlements of collective agricultural enterprises.

In the 1990s, considerable changes occurred in the economic structure and social stratification of the country. Many former industrial jobs disappeared, and people needed to adjust to the requirements of new branches of employment. The position of the Russian-speaking population changed from being a majority population in the Soviet Union to a minority ethnic group in the country. State funding to build new housing and to maintain publicly owned housing stock ended and new

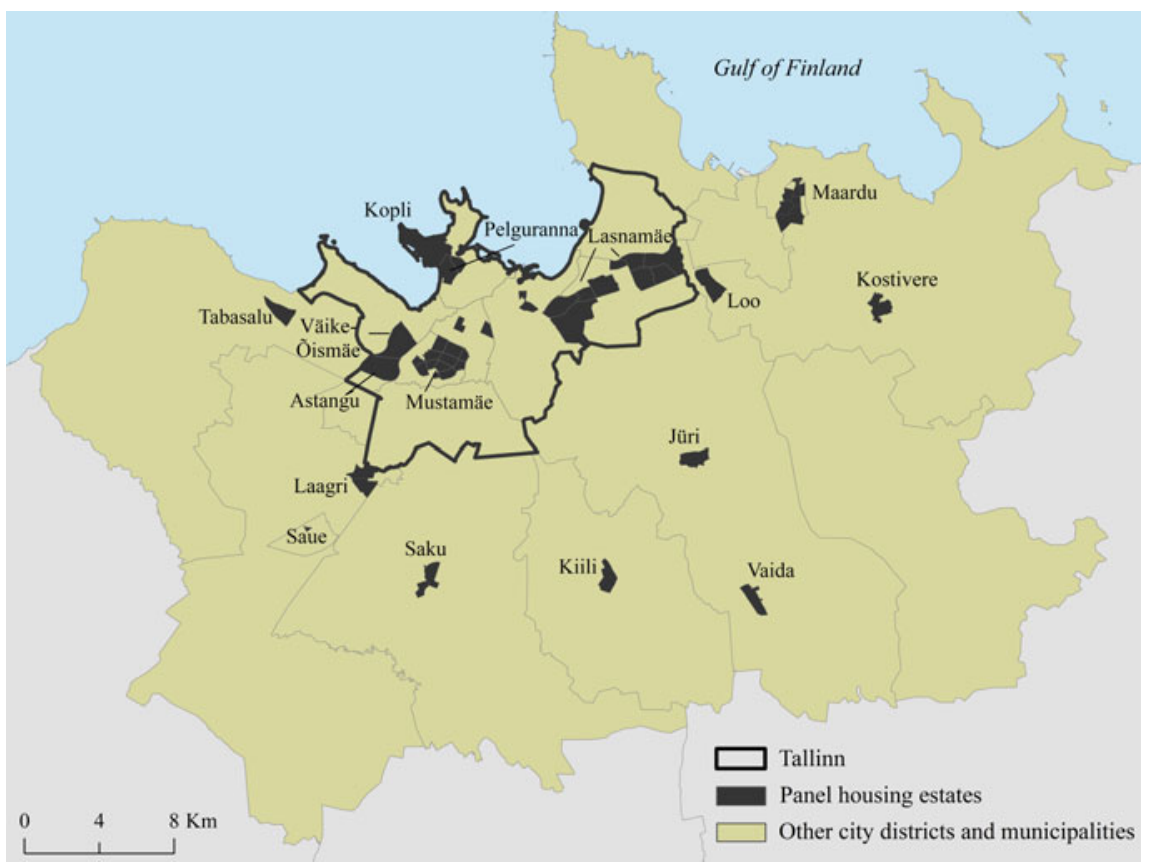

Fig. 17.2 Location of housing estates in the Tallinn urban region. Data Source Estonian Censuses 1989, 2000, 2011 
attractive choices gradually developed in the metropolitan housing market (gentrifying inner-city apartments, new suburban single-family homes, new privately developed apartment buildings, former summer homes as potential permanent dwellings, etc.). These trends started to affect the relative position of housing estates.

Only minor changes were seen in the proportions of people living in housing estate neighbourhoods within the capital city (60\% in 1989 and 58\% in 2011). At the same time, the ongoing construction of suburban housing has created many alternative choices in the surrounding municipalities. The proportion of inhabitants in housing estate neighbourhoods in suburban municipalities fell from 50 in 1989 to $22 \%$ in 2011 (Table 17.1).

The mean age (Table 17.2) of housing estate inhabitants increased in both urban and suburban housing estate neighbourhoods (in Tallinn from 35 in 1989 to 42 in 2011, in suburban municipalities from 29 to 38, respectively). Although population ageing is a general trend in the Tallinn urban region, ageing foremost characterises housing estates. It is noteworthy that the population of housing estates was on average younger than the population of other neighbourhoods in 1989, both within the city and in surrounding areas. This situation had reversed by 2011.

Figure 17.3 demonstrates how the populations of housing estates built in different decades gradually became older. In 1989 (Fig. 17.3), the mean age was below 35 in most of the housing estates in Tallinn, in Maardu, and also in rural centres. Only in Pelguranna and Mustamäe was the population relatively older (3540). The mean age of the population was also slightly higher in Väike-Õismäe, in older parts of Lasnamäe, in some newer housing estates in Northern Tallinn and in Maardu (30-35). The population was youngest in Astangu, in the newer neighbourhoods of Lasnamäe, and in all rural housing estates where peak construction was in the 1980s. Figure 17.3 illustrates how the ageing process follows the chronology of construction of respective housing estates. By 2011, only some housing estate neighbourhoods within the city had a mean age of lower than 40 . Industrial satellite Maardu and rural housing estates in Saku and Jüri also resembled the urban housing estates in 2011. The population of other rural housing estates, Astangu and some Lasnamäe neighbourhoods were relatively younger.

We estimated socio-economic differentiation on the basis of the proportion of the working-age population (18-64) who were either unemployed or working in low-status occupations. We used occupational groups defined in the international ISCO-classification and defined ISCO groups 5-9 as low-status jobs (service and sales workers; skilled agricultural and fishery workers; craft and related trades workers; plant and machine operators and assemblers; elementary occupations). In 2000 and 2011, we also merged unemployed people with this group, whereas in 1989 unemployment was almost non-existent and, therefore, not identified in the data. We admit that the interpretation of occupational groups in different years is somewhat controversial. Industrial employment was high at the end of the Soviet period and low-skilled jobs were not necessarily low-status jobs in terms of salary levels and prestige. 


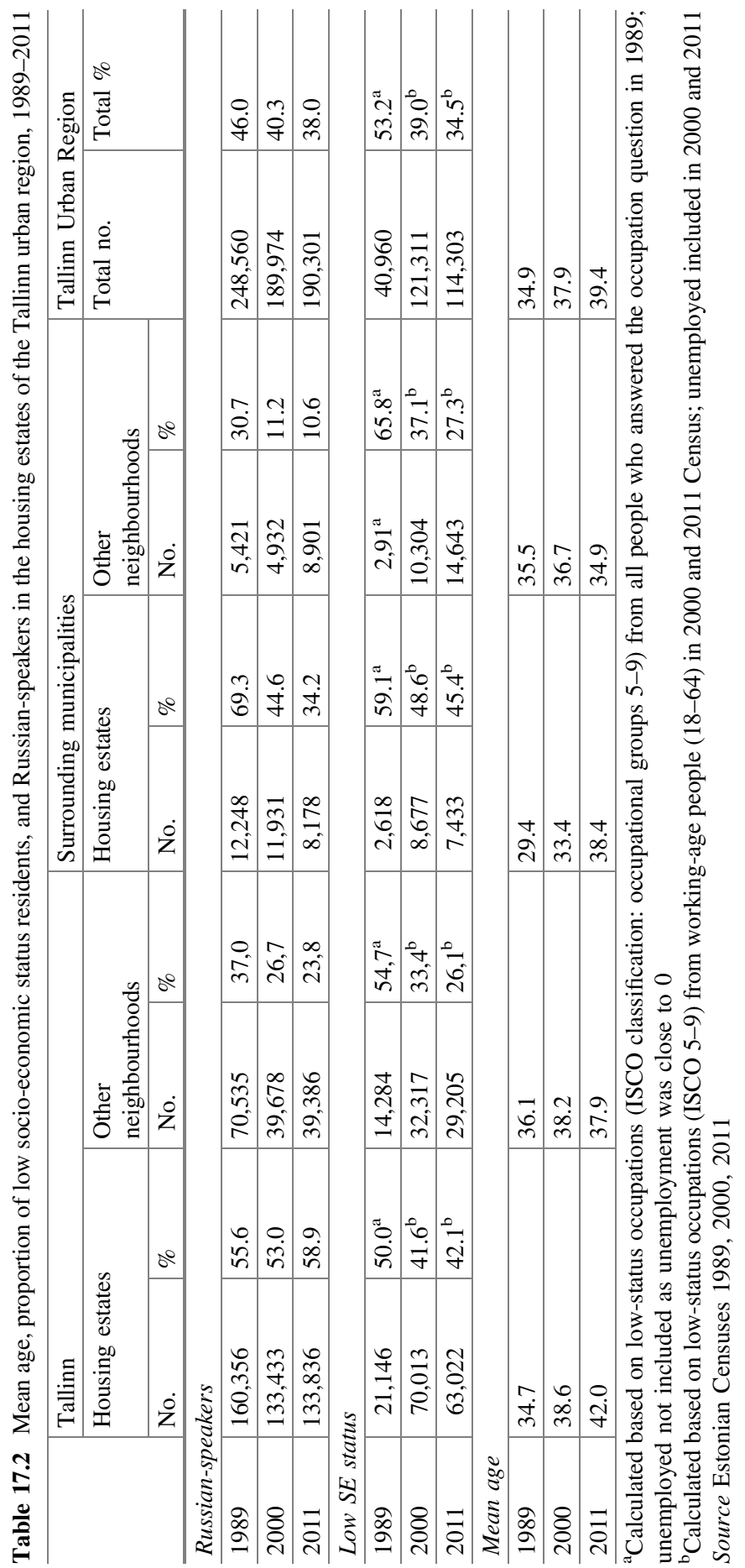



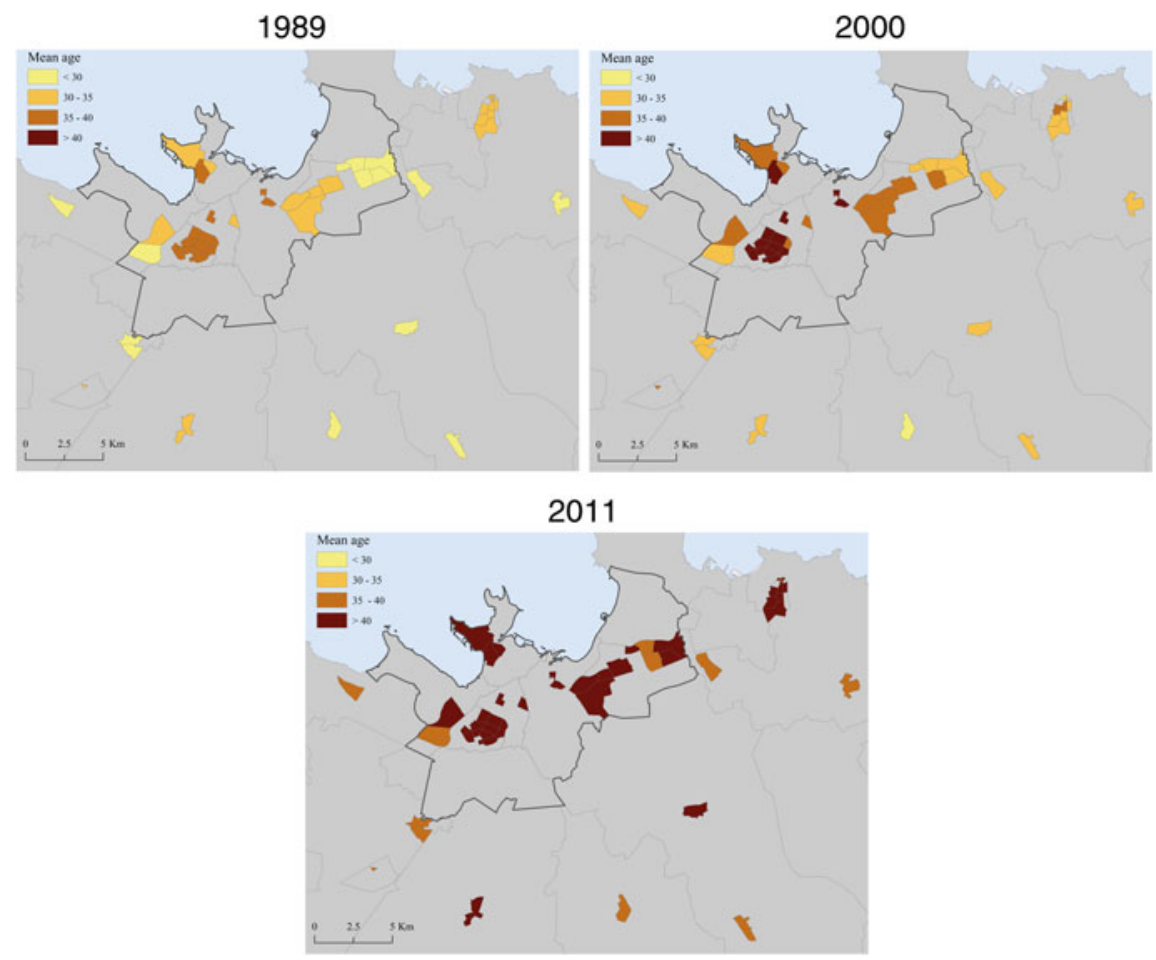

Fig. 17.3 Mean age of population living in housing estates in the Tallinn urban region, 1989, 2000, 2011. Data Source Estonian Censuses

In 1989, more than half the working-age population of the urban region worked in lower level positions (Table 17.2). In general, in housing estate neighbourhoods the share of people with low socio-economic status was slightly smaller than in other neighbourhoods (for example, 50\% in urban housing estates compared to 55\% in other urban neighbourhoods). In line with former studies (Tammaru and Leetmaa 2007), our study confirmed that the proportion of people working in low-status jobs was higher in the surrounding municipalities than in the city in 1989 (59\% in housing estates and $66 \%$ in other suburban neighbourhoods). The occupational structure changed after the collapse of the Soviet economy and, therefore, the proportion of people working in ISCO 5-9 occupations had fallen everywhere in the region by the end of the first transition decade (2000). At the same time, the position of housing estates and other neighbourhoods were reversed-now the share of lower status occupational groups was higher in housing estates.

Comparing different housing estates in the agglomeration (Fig. 17.4), the highest proportion of people working in low-status occupations in 1989 were in older housing estate districts in Northern Tallinn, some Lasnamäe neighbourhoods, housing estates in Maardu, and most of the rural housing estates (since agricultural jobs were included in the low-status categories). By 2000, Mustamäe and Väike- 
Õismäe, with the exception of Astangu (an extension of Väike-Õismäe built in the 1980s, which lost its initial high-status position during the transition decades), had improved their overall socio-economic positions, despite the high proportion of older inhabitants in these districts. Today, Mustamäe's attractiveness is influenced by the Tallinn Technical University campus, which is located in the district. Public and private investments into services and recreation facilities around Väike-Õismäe have been extensive, and this also has an effect on the attractiveness of socialist-era housing. Housing estates in suburban municipalities are today more heterogeneous than they were in the late Soviet years, whereas in housing estates in Maardu the proportion of low-status population was the highest in the region in 2011 (Fig. 17.4).

Although correlation between occupational differentiation and ethnic segregation was already observable at the end of the 1980s, by the 2000 s ethnic and socio-economic segregation patterns clearly overlapped in the Tallinn urban region (Tammaru et al. 2016). While immigrants were prioritised in the Soviet housing allocation schemes, during the transition years it was Estonians who benefited from

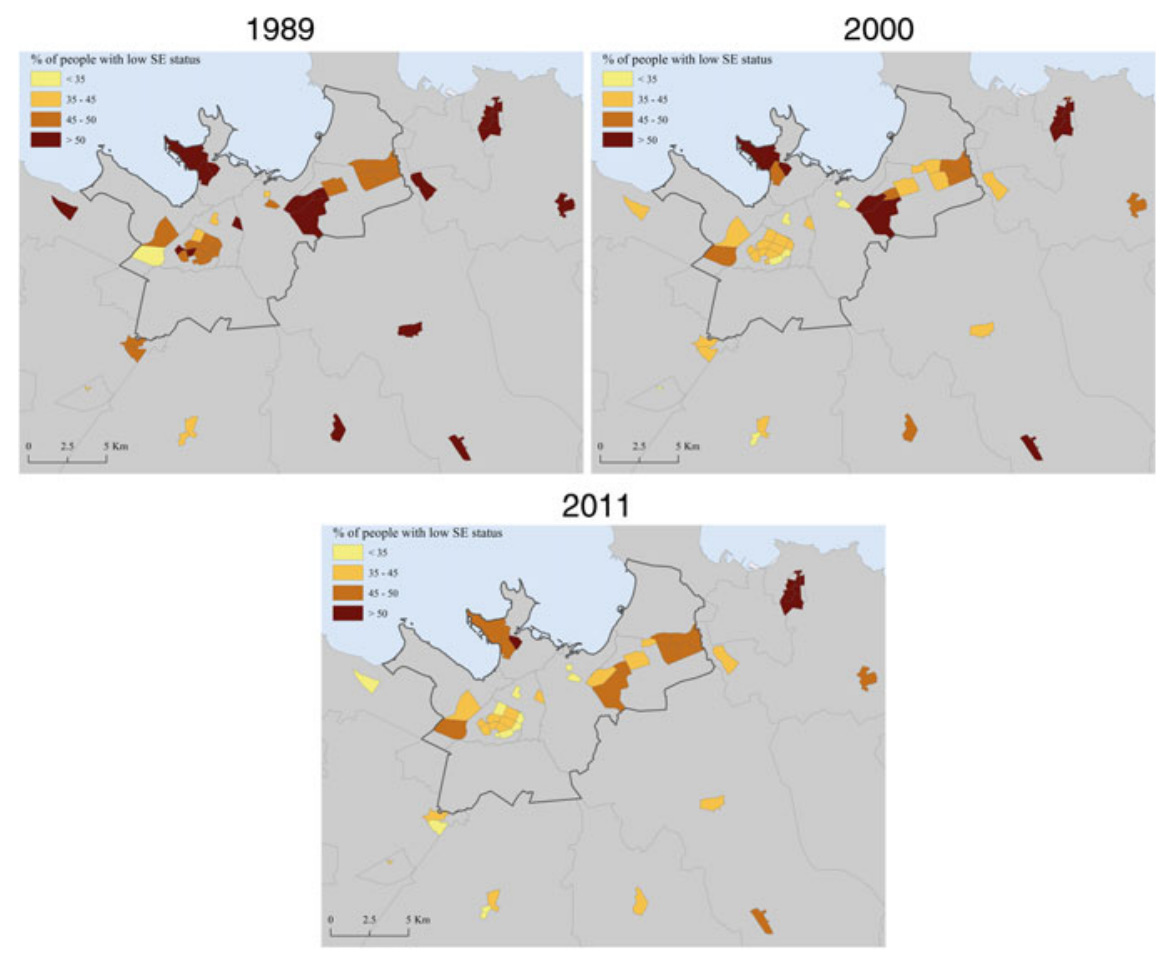

Fig. 17.4 Proportion of inhabitants with low socio-economic status* living in housing estates in the Tallinn urban region, 1989, 2000, 2011. *Proportion of people working in low-status occupations (ISCO 5-9) of the working-age (18-64) population. In 2000 and 2011, unemployed people are included also; in 1989, unemployment was almost 0. Data Source Estonian Censuses 

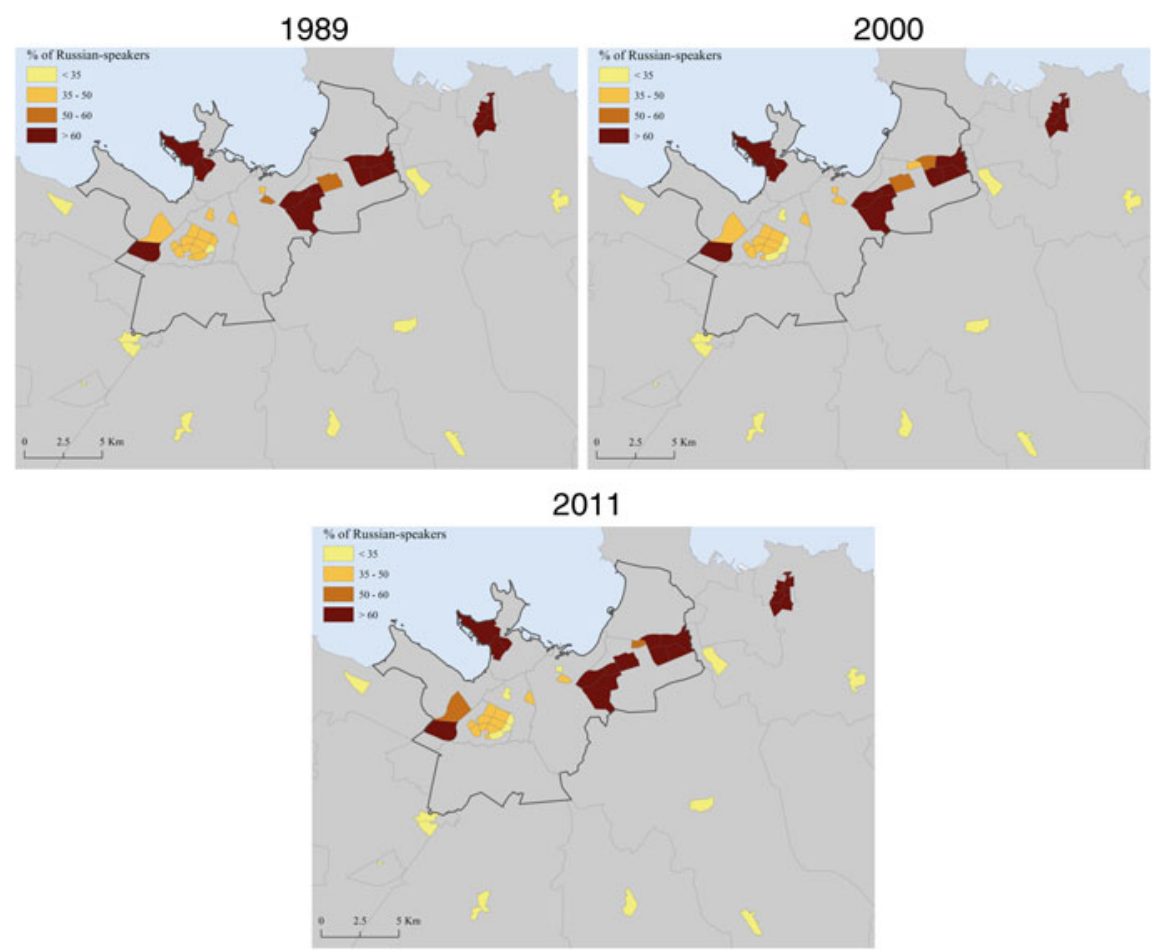

Fig. 17.5 Proportion of Russian-speakers in housing estates in the Tallinn urban region 1989, 2000, 2011. Data Source Estonian Censuses

social and economic transformations. As a result, Estonians were probably more able to improve their living conditions. Meanwhile, the reputation of different urban districts changed too. People could stay in the same neighbourhoods where they received their apartments years ago, but they now found themselves living in a low-image neighbourhood. Because it was Russian-speakers who mostly inhabited housing estates, it was their residential environments that suffered the most from worsened neighbourhood reputations.

On average, $56 \%$ of the residents of urban housing estates were Russian-speakers in 1989 (Table 17.2, Fig. 17.5). In residential districts built in the last Soviet decade, for example, Lasnamäe and Astangu, the proportion of Russian-speakers were even higher, since immigration during their construction period was extremely intensive. Many Russians, especially low-skilled industrial workers, inhabited Northern Tallinn's older housing estate neighbourhoods. Our analysis shows that despite the fact that the average proportion of Russian-speakers in the metropolitan population decreased in the early 1990s (many Russian-speakers, including those in the army, returned to Russia and other former Soviet republics), the housing estates of Tallinn became even more Russian-by 2011 the share of Russian-speakers in urban housing estate neighbourhoods 
reached 59\% on average. The satellite town Maardu seems to represent the case of hyper-segregation. Whilst in the city, the housing estate neighbourhoods were mixed, in Maardu's housing estates the proportion of Russian-speakers was already close to $80 \%$ in 1989, and in 2000 and 2011 this proportion continued to increase. Because rural housing estates were the destination of native Estonians in the 1970s and 1980s, the proportion of Russian-speakers remained mostly below 10 per cent there in 1989 as well as later on.

We can conclude that in general in the Tallinn urban region, the modernist neighbourhoods of the Soviet era have gradually lost their attractive status. This finding differs from the argument that post-socialist housing estates have experienced relative social stability (Kährik and Tammaru 2010). As discussed in former research (Temelová et al. 2011), we also find that an obvious differentiation occurs among housing estate neighbourhoods within the same urban region: the speed of ageing and social degradation varies and some housing estates have managed to preserve their appeal more than the others.

\subsection{Key Contemporary Challenges: Acknowledging Social Degradation and Combating Stigmatisation}

Considering that the speed with which new dwellings are constructed remains insufficient to replace housing estate apartments as a prevailing dwelling type in the region, the main challenge today is to preserve the social stability of housing estate neighbourhoods. Interestingly, although there is plenty of publicly discussed evidence (Leetmaa 2017; Tammaru et al. 2016) that the relative position of housing estates is weakening, and the interviewed experts were in general aware of the ageing process and selective in- and out-migration taking place, none of them explicitly acknowledged that the increase in segregation is a huge problem. They emphasised, on the contrary, that the living conditions in housing estates are constantly improving - the majority of the electorate lives in housing estate districts and, therefore, much investment is directed to these areas. It was pointed out that housing estate districts serve as the main 'migration pump' for the city; people first enter these districts and move on later when their family and professional career develops. Housing estate apartments are a vital and affordable choice for the student renters or a 'springboard' for young families. There is also evidence that new immigrants who arrive in Estonia from the former Soviet countries today tend to settle in housing estates (Leetmaa 2017).

Interviewees also unanimously condemned public discussions that stigmatise living in housing estate neighbourhoods - an additional challenge that housing estates are facing today. They were of the view that 'no objective arguments' exist to prove that housing estates are losing their value. Rather, they defended the living environment in housing estates with the arguments that all necessary services are at 
hand in these neighbourhoods, and the connections to the rest of the city are good too. Even though the fears of these experts regarding unfair stigmatisation are justified, a situation in which the proven signs of social degradation are not acknowledged is also somewhat alarming.

\subsection{Urban Policies Related to Housing Estate Neighbourhoods in the Tallinn Urban Region}

Because public expenditure was generally limited in Eastern and Central European countries after the change of system, it is to be expected that housing estate related policies remained underfinanced too, certainly compared to the generous Soviet state, but also in comparison to the ambitious urban and housing policies of Western and Northern European countries. The passive position of public bodies was, however, characteristic not only of the early transition years. Even later on, no clear vision existed for the future role of housing estates in the housing market. It is occasionally argued that housing estates have been ignored by public policies in the post-socialist period. We argue also that neglect has been an active policy choice with both expected and unexpected effects. We first introduce the institutional rearrangements of the 1990s that have determined the path of housing estates in subsequent years. This is followed by a summary of actions undertaken by the public, private and non-profit sectors in the 2000s and 2010s in housing estates.

\subsubsection{Privatisation of Housing Estate Apartments in the 1990s}

Without any doubt, the most influential post-socialist public intervention has been the decision to privatise housing estate apartments. At the beginning of the 1990s, nobody was yet able to foresee the consequences of privatisation. New plans were even developed to learn from contemporary Finnish housing construction models and to build more human-scale, but still master-planned, residential districts to address the persisting housing shortage. Ownership reform was implemented in the early 1990s, dwellings that had been built in the Soviet years were sold under favourable terms to sitting tenants and pre-World War II housing was restituted. By 2000 , the vast majority of dwellings (98\%) in the Tallinn urban region were already in private hands. A high rate of home ownership was considered a cornerstone of the market economy in the 1990s. Today, many experts admit retrospectively that an excessive burden was placed on individual apartment owners and that the new housing management system was applied within too short a period.

When compared to housing estates in many Western cities, it is obvious that opportunities for urban renewal are inevitably different in a fully privatised society 
where the preferences and rights of single owners need to be coordinated. Urban land was also almost entirely privatised, giving the strategic power over new housing and commercial projects to private developers. At the same time, local governments were left with only limited options when deciding the location of social housing or public facilities.

\subsubsection{Building the System of Apartment Associations}

The formation of apartment associations (non-profit organisations that collect contributions and organise the maintenance and renovation of apartment buildings) since the late 1990s has brought new order into the initial chaos in housing management. This new system was initially confusing. For example, the size of the plot that the apartment associations privatised around the buildings varied: some apartment associations privatised large plots and later had difficulty in caring for them, others privatised only a few metres around the buildings, optimising their budget initially, but later limiting their influence over their residential environment. In 1996, an umbrella organisation, the Estonian Union of Apartment Associations (EUAA) was founded with the mission of training the leaders of apartment associations. Apartment association leaders had been found among local residents, who as a rule had limited administrative skills and only vague legal knowledge. Together with the Tallinn City Government, the EUAA has organised roundtable discussions, seminars and training for apartment association leaders (accounting, leadership, cooperation and legislation) both in Estonian and in Russian.

Today, apartment associations are considered the main citizen-level partners for the city government in relation to housing estates. For example, in a rather anonymous residential environment such as a housing estate, classical neighbourhood associations formed from the bottom up are a rare phenomenon (Holvandus and Leetmaa 2016). Apartment associations, although they must be non-profit organisations, have partly taken over this role. By renovating the buildings and tidying the adjacent private and semi-public spaces around houses, they raise the value of local living environments. The success of a particular block often depends on the skills and capabilities of apartment associations leaders. If the apartment association directorate manages to motivate homeowners to invest and is administratively able to communicate with its partners successfully (city officials, lending institutions) the respective blocks tend to be in better condition. Yet, there is no scheme to allow apartment associations to take responsibility in more general spatial planning issues, e.g. how to develop the public space around apartment blocks (in the so-called no man's land) or how to adjust infrastructure to the changing needs of housing estate districts. 


\subsubsection{New Approaches in Urban Planning}

The social context of spatial planning has also undergone thorough changes. Socialist master plans for the larger housing estate districts of Tallinn were created in the 1960s and 1970s. Both the Soviet austerity policy and technological development (e.g. car ownership) very soon made it necessary to update these initial plans with official Revision Plans. Compromises were often made in relation to pedestrian comfort, recreational opportunities, personal services and sometimes also in public transport, but schools and kindergartens were mostly completed as planned. In reality, the Soviet period ended before the revisions were fully implemented. As a result, even though new apartments were desirable residential destinations, the housing estate neighbourhoods of the late Soviet period tended to have an incomplete feel.

The 1990s witnessed a planning vacuum. The old planning system became morally discredited and uncertainty prevailed, especially with regard to which aspects of old general plans should be followed. The main locational principles (location of social infrastructure, service centres and transport corridors) were not questioned, but there was limited public expenditure so it was often not possible to build something according to the plans. The planned volume of residential construction was ignored too-neither state nor private developers were able to invest in housing. New contemporary master plans were developed for the whole city and also for the housing estate districts in the 2000s. Now the realisation of plans was not as direct as under the central planning system. New master plans defined the zones of building rights and determined general spatial principles (guidelines for densification, location of new objects). Because urban land was now mostly in private hands, the role of the city government was limited to balancing private and public interests. From the perspective of public representatives, private developers never wanted to keep their public obligations (to create public spaces or reserve land for public functions, for example) and private developers, in turn, complained that the contemporary planning system did not give them stability and that they always ran the risk of the municipality setting unreasonable requirements for their projects.

The investment capacity of the public sector increased in parallel with rises in living standards. The city government gradually started to complement the unfinished infrastructure of the housing estates: building medical centres and sport facilities, renovating schools and kindergartens, reconstructing parks and green areas and improving streets and public transport. Private developers invested in shopping malls and service centres. As a result, the housing estate districts now became relatively better equipped with services and infrastructure. Nevertheless, some miscalculations were made too. The city sold former public facilities and land, even when it would have been more reasonable to keep them for future public purposes. In a privatised society, municipalities also behaved as market actors by reducing expenditures related to unused buildings and earning money by selling them. New shopping malls were placed next to major arterial streets, providing 
access to cars rather than to pedestrians and public transport users. This even caused closures of former mikrorayon service centres; thus, the proximity and accessibility that were original benefits of housing estate areas suffered as a result (Hess 2018).

Since the 2010s, interest has again grown in finding new planning solutions for housing estates. It seems, however, that interest in larger spatial scales ended with the socialist period. Contemporary planning thought is more focused on smaller spatial scales. Younger architects and other young urbanists engage themselves in redesigning public areas in housing estates by converting former anonymous space between the buildings into places with a more human scale. Although these small and rather low-cost interventions do not propose comprehensive new visions for housing estates, they enable experimentation with new good practices that could be applied more widely later on.

\subsubsection{Municipal and National Initiatives for Housing Renovation}

New housing construction was almost non-existent in the 1990s and housing renovation was limited to minor repair works of single households. By the 2000s, the economy had recovered, financial institutions were interested in offering loans, and incomes of households and investment capabilities of municipalities had recovered. More active apartment associations now started to apply for funding from commercial banks to finance their first larger scale renovation works. Tallinn City Government developed a more active position as well. Under the municipal programme 'Repair the façade' associations were given the opportunity to apply for municipal co-funding for making their building more energy efficient or improving its external appearance. Another municipal funding scheme 'Tidy up the yard' supported efforts to revitalise the common spaces between buildings. In addition, the city government has taken on the obligation to maintain (mowing the lawn, snow clearing) larger public spaces between the blocks that have not been privatised by apartment associations. Although these measures are still insufficient in the context of the huge revitalisation needed in physically ageing housing estates, they certainly help to build a responsible homeowners' community.

Since the end of the 2000s, major renovation works in housing estate neighbourhoods have been carried out with state subsidies mediated through a special funding agency, KredEx. The agency provides financial support for housing renovation projects when a complete renovation project exists for the building and when considerable improvement in energy efficiency is expected (Fig. 17.6). Apartment associations usually apply for KredEx funding in parallel with taking out mortgages from commercial banks. This support scheme, therefore, functions competitively. Banks only approve loans to projects that seem as if they will be able to pay back the mortgage. Also, the application process requires that apartment association leaders have considerable administrative capacities. As a result, 
better-managed blocks, often concentrated spatially in better urban districts, benefit. For example, the distribution of KredEx-supported projects in Tallinn reveals that relatively fewer renovation projects are located in Lasnamäe (Hess et al. 2018). Still, KredEx-renovated projects balance negative views that question whether the technical condition of housing estate buildings allows them to be renovated systematically. In fact, several analyses made by building experts have confirmed that competent renovation could keep the houses in a good condition for a very long period (Tallinn Technical University 2009). Municipal care of public spaces and national funding for renovating buildings, in combination, have visibly improved the technical state and aesthetic look of housing estates in the Tallinn urban region.

\subsubsection{Public and Private Actors in New Housing Construction in Housing Estates}

Privatisation created a society of homeowners. Until today, in many Estonian cities, the construction of social housing was a taboo topic as there were other priorities in which municipalities preferred to invest. The Tallinn urban region is the only region in Estonia where the municipalities enjoy population growth and considerable increases in budgets; therefore, the investment capacity of municipalities is also greater here. Since the second half of the 2000s, the Tallinn City Government has

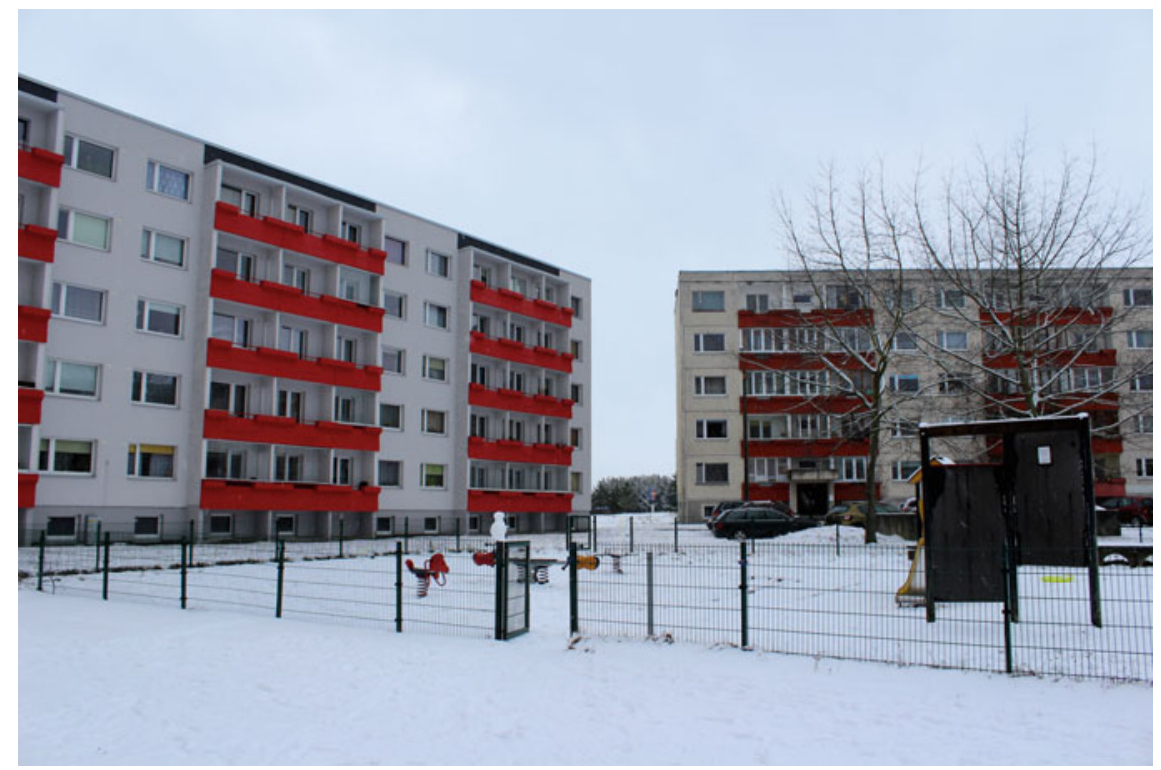

Fig. 17.6 Apartment building after undergoing KredEx-funded renovations on the left vs. an unrenovated apartment building on the right. Source Annika Väiko 
been a pioneer in contemporary construction of social housing, also sometimes attracting condemnation for turning back the clock by intervening in the market.

The first target groups for municipal housing were socially less secure groups and residents who had to find new homes after leaving restituted houses (often older people). Even though political opinions vary over whether or not building new social housing is sound urban policy, the most criticised aspect of the construction of social housing in Tallinn has been related to the choices of location (Kährik and Kõre 2013). Initially, several social housing projects were located in Northern Tallinn, a district where the proportion of people with low social status has traditionally been high. Recently, larger groups of social housing have been erected in Lasnamäe (e.g. the Raadiku and Meeliku neighbourhoods). Given that social housing itself is a stigmatised institution in the post-socialist ultraliberal society, there is always a risk that local residents will block the implementation of these projects. Locating these projects in Lasnamäe was partly related to the fact that the city owned appropriate plots there. In addition, in housing estate districts, community movements are typically weaker and the risk that such projects would be resisted in these districts is small. At the same time, placing social housing projects in districts that already suffer social degradation amplifies the moral downgrade of that residential environment even more.

Another problem is that as the stock of social housing is still very small, and the city has not been able to separate target groups with different needs: former prisoners, young adults leaving orphanages, people with specific medical needs (groups that may need an assisted living service), elderly people originating from restituted houses, large families and others. The concentration of less fortunate people as well as people from very different backgrounds in social housing fosters social conflict and misunderstandings. Criticisms have also been made that so far no good management models exist for social housing (TTÜ and TEMA 2008): there are neither typical apartment associations where homeowners can make their voice heard nor are there any other tools that inhabitants can use to influence their residential environment.

In the 2010s, the city of Tallinn has extended the construction of municipal housing for groups of various valued specialists in the city (nurses, teachers) whose low salary does not enable them to enter the housing market. The initial projects in Lasnamäe and Mustamäe have attracted rather positive feedback, although doubt still exists today regarding whether intervention should be made in the free market.

Contrary to new municipal housing projects in housing estate districts, private developers target more affluent residents. These developers take the view that although Soviet-era residential buildings are out-of-date from the perspective of existing infrastructure (plans of apartments, design of common spaces within and outside buildings) housing estates are still relatively good locations for new apartment houses. The new residents are expected to come from older housing estate apartments; for example, younger residents starting their housing career. The Russian community is extensive, therefore, in some cases, developers borrow ideas from new projects in Moscow or St. Petersburg that are well known in the local Russian community via Russian media channels. The new housing projects in 


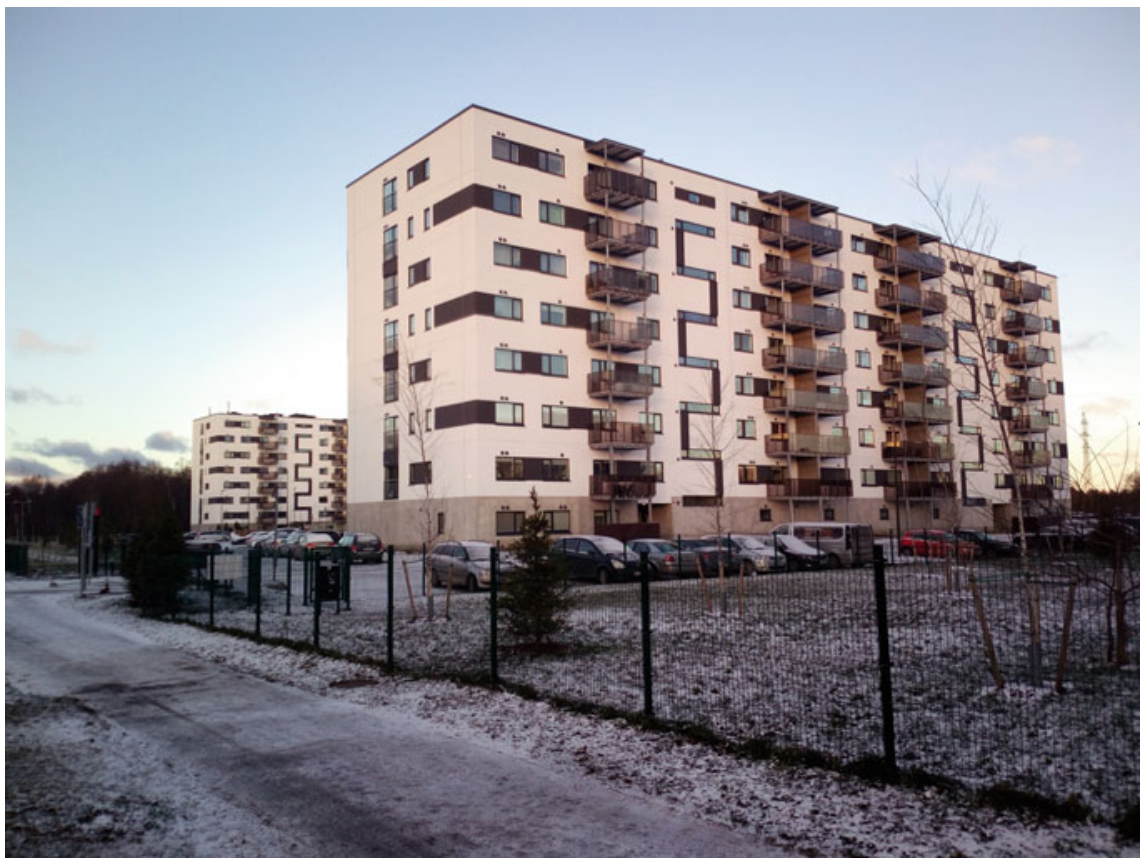

Fig. 17.7 An example of in-fill development in Astangu housing estate, Tallinn. Source Johanna Holvandus

housing estate districts are price-sensitive since on the one hand, they need to act as alternatives to old housing estate apartments and on the other hand, they need to discourage residents leaving the district. While this type of densification stablises housing estate districts socio-economically, it creates micro-scale segregation. Developers sell the surrounding environment (shops, kindergartens, public transport) in addition to the new apartments themselves but at the same time tend to add some of the elements of gated communities to their projects (Fig. 17.7).

\subsubsection{Rising Community Activism in Housing Estate Neighbourhoods}

Although generally housing estates are not considered to be favourable contexts for community activism, recently an inspirational flagship movement, the Lasna-idea, has been initiated in Lasnamäe. The first activities of the Lasna-idea were launched in 2014. As of 2015, the Lasna-idea is a non-profit organisation aiming to bring together citizens, local government, and civil and business organisations under the common goal of building a better living environment in the district. The leaders of the movement are mostly young educated people or those interested in fields related 


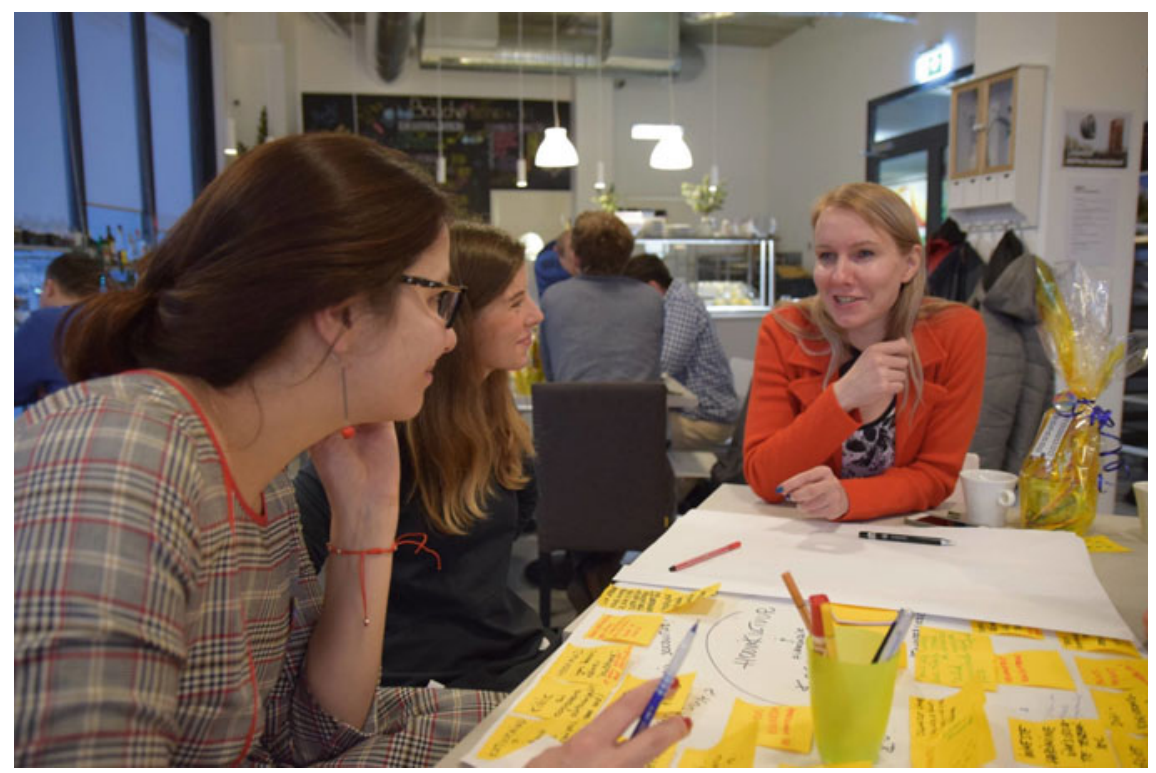

Fig. 17.8 Lasna-idea workshop, ‘Area-based community’. Source Janek Jõgisaar

to urban space. The first goal of the initiative was to change the image of Lasnamäe for both residents and outsiders. The main actions have been to organise different events (picnics, outdoor cinemas), workshops and public forums to bring together locals, both Estonian and Russian, but also to invest in place-making by organising something inspiring in otherwise grey and boring public spaces.

Today, Lasna-idea has gathered notable experience in networking with residents and other local actors. They seek to engage themselves in issues of planning and designing public space, and training people who have ideas regarding the living environment. Because collaboration with local government has been good, they plan to coordinate workshops and training courses to inspire people to take action themselves, rather than to expect everything to be done for them. One of their most interesting missions to date is the year-long project of community building in Raadiku social housing neighbourhoods, where the owner Raadiku Development Ltd. has invited the Lasna-idea people to organise workshops and activities that create a sense of belonging and ownership among the inhabitants (Fig. 17.8).

There are other civil initiatives in housing estates, for example, an initiative named Lasna-front mostly deals with cleanup issues, some housing estate districts have Facebook pages, and in the Haabersti district (which includes Väike-Õismäe) a Roundtable of the Haabersti Apartment Association (a non-governmental organisation) has been formed. Interesting place marketing efforts are being made by journalists, e.g. editing journal tabs on the history (including pre-socialist era) of housing estate districts. As such, civil initiatives try to counteract the stigmatisation of housing estates and to increase residential satisfaction. 


\subsection{Conclusion}

As in many other post-socialist cities, the housing estates of the Tallinn urban region form a remarkable segment of almost fully privatised housing stock. At the same time, similar to other ethnically diverse European cities, post-Soviet housing estates tend to have a mixed-ethnic nature. Our study revealed that in these circumstances housing estates in Tallinn are facing gradual ageing and social degradation. Among the housing estate neighbourhoods of Tallinn, some are suffering from serious social decline, whereas others have preserved their status relatively well. Much of this is dependent on when and how these estates were built. The older Mustamäe district is greener and more finished than the magnificently planned but unfinished Lasnamäe. Väike-Õismäe benefits even today from its carefully planned infrastructure. Some housing estates house a low-skilled industrial workforce who suffered the most from the economic transition. It is hard to argue to what extent contemporary interventions could redirect these path-dependent trajectories.

Two types of interventions can be recognised in the post-socialist period. First, in the 1990s major institutional rearrangements-privatisation, new planning principles, the formation of apartment associations-were launched. Other than this, a 'wait-and-see' (or 'neglect') period lasted until the late 2000s. Since then, new experiments have been initiated, e.g. municipal funding to improve facades and yards, national energy policy measures, municipal social housing projects and new private housing construction. In the 2010s, an increasingly younger generation of urban experts have engaged themselves in landscaping the public spaces of housing estates. Very possibly, we will see the effects of these latter efforts over the next few decades. However, the results of former research on targeted urban revitalisation policies are contradictory. For example, designating certain neighbourhoods as problem areas may even harm the reputation of whole districts (like Urban Sensitive Zones in Paris: Sari 2012). More powerful public interventions may indeed increase residential satisfaction (like in Leipzig/Grünau) but the reputation of housing estates largely depends on the availability of other residential alternatives in regional housing markets (Kovács and Herfert 2012). Therefore, even though no larger common vision exists in the Tallinn urban region regarding how these recent actions might stabilise housing estates, these undertakings could potentially at least increase the satisfaction of local residents.

The Tallinn experience proves that interventions, e.g. new housing construction that densifies housing estates, may both improve and damage the reputation of housing estates. Even when private developers distance themselves from the Soviet image of housing estates and at the same time use socialist residential benefits to their advantage, they still diversify dwelling types in these districts and potentially improve the image of the areas. The current problem that social housing projects face is the low reputation of social housing per se. This situation can only change when more population groups have access to affordable municipal apartments in the future and/or better management models for public rental houses are elaborated. 
A challenge for future policies is to find a balance between policies related to buildings and policies related to people. A good example of how emerging communities of homeowners can be empowered is the efforts of the Estonian Union of Apartment Association to invest in the capabilities of apartment associations. Associations that function as professional housing management agencies have also been more successful in applying for funding for housing improvement. Remarkable initiatives for people-based policies have originated in the non-profit sector. The non-governmental organisation Lasna-idea, has been able to support local inhabitants to become more responsible for their surroundings and offer more professional partnerships to the municipality and private developers.

Interestingly, there is no common conviction among contemporary urban actors that housing estates are truly losing their social status. It seems that this also hinders the creation of common visions regarding how to keep this large segment of housing stock stable in the future. However, taking into account that the challenges related to housing estates are today almost synonymous with general housing issues in many post-socialist cities, it seems that more ambitious and better-integrated policies are needed.

Acknowledgements This research received funding from the following sources: Institutional Research grant No. IUT2-17 of the Ministry of Education and Science Estonia, Grant No. 9247 of the Estonian Science Foundation; the European Research Council under the EU FP7 Programme (FP/2007-2013), ERC Grant Agreement No. 615159 (ERC Consolidator Grant DEPRIVEDHOODS, Socio-spatial inequality, deprived neighbourhoods and neighbourhood effects); the Marie Curie IEF programme within the 7th European Community Framework Programme, grant No. 332265. The authors also owe special thanks to Raivo Aunap for his cartographic advice, to Annika Väiko for her help with data management, and to the editors for their valuable comments.

\section{References}

Glasze G, Pütz R, Germes M, Schrimel H, Brailich A (2012) The same but not the same': The discursive constitution of large housing estates in Germany, France, and Poland. Urban Geogr 33(8):1192-1211

Hess DB (2018) Transport in mikrorayons: accessibility and proximity in centrally planned residential districts during the socialist era, 1957-1989. J Plan Hist 17(3):184-204. doi: https:// doi.org/10.1177/1538513217707082

Hess DB, Tammaru T, Leetmaa K (2012) Ethnic differences in housing in post-Soviet Tartu. Cities 29(5):327-333

Hess DB, Tammaru T, Väiko A (2018) Effects of new construction and renovation on ethnic and social mixing in apartment buildings in Estonia. Working paper, Centre for Urban and Migration Studies, University of Tartu, Estonia

Holvandus J, Leetmaa K (2016) The views of neighbourhood associations on collaborative urban governance in Tallinn. Est PlaNext 3:49-66

Kovács Z, Herfert G (2012) Development pathways of large housing estates in post-socialist cities: an international comparison. Hous Stud 27(3):324-342. https://doi.org/10.1080/02673037. 2012.651105

Kulu H (2003) Housing differences in the late Soviet city: the case of Tartu, Estonia. Int J Urban Reg Res 27(4):897-911 
Kährik A, Kõre J (2013) Estonia: Residualization of social housing and the new programs in social housing in transition countries. In: Hegedus J, Lux M, Teller N (eds) social housing in transition countries. Routledge, London, pp 163-179

Kährik A, Tammaru T (2010) Soviet prefabricated panel housing estates: areas of continued social mix or decline? The Case of Tallinn. Hous Stud 25(2):201-219. https://doi.org/10.1080/ 02673030903561818

Leetmaa K (2017) Place of residence as a measure of integration: changes in ethno-linguistic residential segregation. In: Tammaru $\mathrm{T}$, Kallas $\mathrm{K}$, Eamets $\mathrm{R}$ (eds) Estonian human development report 2016/17. Koostöökogu, Tallinn, pp 139-148

Metspalu P, Hess DB (2018) Revisiting the role of architects in planning large-scale housing in the USSR: the birth of three large housing estates in Tallinn, Estonia. Plan Perspect 33(3):335-361. doi: https://doi.org/10.1080/02665433.2017.1348974

Sari F (2012) Analysis of neighbourhood effects and work behaviour: evidence from Paris. Hous Stud 27(1):45-76

Tallinn Technical University (2009) Eesti eluasemefondi suurpaneel-korterelamute ehitustehniline seisukord ning prognoositav eluiga. Uuringu lõppraport (Study report on technical condition of panel buildings)

Tammaru T, Kährik A, Mägi K, Novák J, Leetmaa K (2016) The 'market experiment': increasing socio-economic segregation in the inherited bi-ethnic context of Tallinn. In: Tammaru T, Marcińczak S, van Ham M, Musterd S (eds) Socio-economic segregation in European capital cities: East meets West. Routledge, New York/London, pp 333-357

Tammaru T, Leetmaa K (2007) Suburbanisation in relation to education in the Tallinn metropolitan area. Popul Space Place 13(4):279-292

Temelová J, Novák J, Ouředníček M, Puldová P (2011) Housing estates after socialism: various trajectories and inner differentiation. Urban Stud 48(9):1811-1834. https://doi.org/10.1177/ 0042098010379279

TTÜ, TEMA (2008) Tallinn Technical University and Tallinn Housing Authority, Tallinna linna üürimajade elanike kvalitatiivne uuring. Uuringu lõpparuanne (Study report on municipal rental houses of Tallinn)

Open Access This chapter is licensed under the terms of the Creative Commons Attribution 4.0 International License (http://creativecommons.org/licenses/by/4.0/), which permits use, sharing, adaptation, distribution and reproduction in any medium or format, as long as you give appropriate credit to the original author(s) and the source, provide a link to the Creative Commons license and indicate if changes were made.

The images or other third party material in this chapter are included in the chapter's Creative Commons license, unless indicated otherwise in a credit line to the material. If material is not included in the chapter's Creative Commons license and your intended use is not permitted by statutory regulation or exceeds the permitted use, you will need to obtain permission directly from the copyright holder. 


\section{Index}

Note: Page numbers followed by " $f$ " and ' $t$ " refer to figures and tables.

A

Aalto, Alvar, 101

Ageing problem, in housing estates, 182, 279-283, 280t, 281f, 282f, $299 f$

Agnetapark, Delft, the Netherlands, 39

Agora Local Patriot Association, 211

À la française, 272

Alexandras Avenue, Athens

refugee housing estate on, $80 \mathrm{f}$

Ammelinckx S.A. estate, 148

Amsterdam

Bijlmer, 60, 61, 68, 69

local housing market, characteristics of, 63

population developments, 69

urban renewal, 68

Antala Staška housing estates, $345 f$

Apartment associations, building, 403

П-44 apartment buildings, $296 f$

Area for Reinforced Development of Housing and Renewal (Espace de

Développement Renforcé du Logement et de la Rénovation, EDRLR), 163

Arms Length Management Organisations (ALMOs), 125

Arrese, José Luis, 245

Asia Minor refugees, 79, 86, 94, 95

Association for the Centenarium Housing Estate, 211

Astangu housing estate, $408 f$

Athens, 5

large housing estates, 12, 77-97 allocation process and tenure, $86-88$ current challenges for housing estates, 95-97 demographics and social profile, 88-91, 90f, $92 f, 93 t$

distribution, $14 f$

from the early 1980 s to the present, 84 1920 s and 1930s, 78-79, 80f, $81 f$

from the 1950 s to the end of the $1970 \mathrm{~s}$, $81-83,82 f$

ongoing degradation and new planning initiatives, 92, 94-95

physical form, 84-86

population developments, 70

2004 Olympiako Chorio (Olympic Village), 78

See also Greece

Athens Charter, 60, 103, 317

Austerity, 176-178

Australia, 37

Austria, 36

Avant-garde style, 291

Azienda Lombarda Edilizia Residenziale

(ALER), 266, 274-276, 285, 286

\section{B}

Bahrdt, Hans Paul, 103

Balta Alba housing estate, 13, $174 f$

Baltic states recruitment of initial residents, 62

Barcelona local housing market, characteristics of, 63

Barona Village, 286

Barrio de la Estrella, $248 f$

Bauwochen (Building Fair), 107

BBPR, $273 f$

Beaudoin, Eugène, 316

D. B. Hess et al. (eds.), Housing Estates in Europe, The Urban Book Series,

https://doi.org/10.1007/978-3-319-92813-5 
Békásmegyer Church Foundation, 211

Belgium

urban renewal policies, 51

See also Brussels

Berlin, 5

large housing estates of, 99-118

distribution of, $14 f$

formation of, 101-103

and market liberalisation, 111-112

private ownership of apartments, 19

residential change in, 112-117, $114-117 f$

tenants, 104-105

See also East Berlin; Germany; West Berlin

Berlin Wall, 100

Bijlmer, 60, 61, 68, 69

Birmingham, 5, 121-143

Central Estates, 131-141, 132-139f

decline and fall of housing construction, $126-130,128 t, 130 t$

demolition of apartment buildings, 16, 17

distribution of housing estates, $14 f$

estates at the outset, 126

high-rise blocks and municipal dwellings, $125,126 t$

local housing market, characteristics of, 63 urban renewal, 68

wards and housing market area boundaries, $127 f$

See also United Kingdom (UK)

Birmingham Municipal Housing Trust, 130

Blades-style architecture, 180, $181 f$

Blocco eldilizio (the real estate block), 270

Bostadsbyggnadsutredningen, 364

Braem, Renaat, 41f, 147, 150

Brandenburg Gate, 107

Bredäng housing estates, 373-380, $374 f$

average disposable income, $380 f$

employment rates, $378 f, 379 f$

ethnic background of, $377 f$

socio-economic and demographic composition of, $376 t$

Brezhnevki, 294, 298, $299 f$

Brezhnev, Leonid, 294

Britain. See United Kingdom (UK)

Brunfaut Act of 1949, 147, 148

Brusselisation, 148

Brussels, 5

Brussels World's Fair (1958), 150

large housing estates, 12

configuration and physical aspects of, 149-151, 152f, $153 f$

definition and selection of, $148-149$, $150 f, 151 f$ distribution of, $14 f$

emergence and evolution of, 145-165

housing policies, 146-148

private large housing estates, 163

public large housing estates, 161-163

social composition of, 16

residential segregation

demographic and socioeconomic evolution of, 151-157, 154t, 155t, $157 f$

large housing estates' impact on ethnic and socioeconomic segregation, 157-160, 158f, 159f, 160t

See also Belgium

Brussels Capital Region, 161n4

Bucharest, 5

large housing estates, 13, 167-188

austerity, 176-178

challenges to, $180-187$

densification, 176-179, $176 f$

distribution of, $14 f$

gated communities, 178-179

high-quality small scale housing estates, implantation of, 171-172, 172f, 173f

land use and building age in, $170 f$

mass quality housing, 172-176,

174-178f, 178-179

physical layout of, 179-180

poor quality, 176-178, $177 f$

pre-1990 housing estates, location of, $171 f$

social composition of, 180-187

Master Plan of Bucharest (2014), 169

section profile of, $180 f$

Budapest, 5

distribution of housing estates, $14 f$

large housing estates, 191-212

challenges to, 207-211, 209t

evolution of, 192-200

1950s, 194, 195f

1960s, 194-196, $196 f$

1970s, 197-198, 197f, 198f

1980s, 199-200, $199 f$

post-socialist transition of, 207-211

socio-economic changes of, 204-207, 204t, 205f, $206 f$

weight and characteristics of, 202-203, $203 f$

weight and distribution of, at the national level, 200-202, 201f, 201t

local housing market, characteristics of, 64 Tér-Köz (Public-Space) programme, 211

See also Hungary

Building Act of 1959 (Finland), 217 
Building quality, 253

Built environment, improvement of, 329-330, $330 f$

Bulgaria population developments, 69

recruitment of initial residents, 62

C

Canyon-style architecture, 179f, 180, $181 f$

Castle Vale

Housing Action Trust funding for, 134-135

Central Estates, 131-141, 132-139f

Central Settlement System (středisková soustava osidleni), 341, 348

Černý Most housing estates, 349, 351

Chabolas (large squatter settlements), 245

CIAM (Les Congreès Internationaux d'Archetecture Moderne), 354

Cité de la Muette, 316

Civil War, 81

Colentina, 173

Colour-blind approach, 315

Comitato per l'Edilizia Residenziale (CER, Committee for Residential Building), 268

Commission on Socially Sustainable Development (Kommissionen för ett socialt hållbart Stockholm), 382

Common good, 216, 217

Communal life, 25

Communist Party of Spain, 245

Community activism in neighbourhoods, rising, 408-409, $409 f$

Comprehensive Housing Construction (komplexni bytová výstavba), 342, 346

Congrès Internationaux d'Architecture Moderne (CIAM) architects, 39-40, 46

Connectivity, 182

Connectivity-based policies, 23

Contemporary urban life, 25-26

Copenhagen

tenure, 65

Corviale, Rome, 65, 67

Council housing, 266, 278t, 279t

Craigmillar estate, 69, 70

Cvartal model, 171, 172f, $173 f$

Czechoslovakia

Central Settlement System (středisková soustava osídlení), 341

Communist Party, 341, 342, 346

Comprehensive Housing Construction (komplexní bytová výstavba), 342, 346, 348

Ministry of Environment, 349
Ministry of Regional Development, 349

population developments, 69

recruitment of initial residents, 62

Velvet Revolution, 340, 341, 347, 348, 353

See also Prague

\section{D}

Death and Life of Great American Cities, The (Jacobs), 46-47

Decent Homes Policy, 125, 129

Decline of large housing estates, 57-72

initial conditions

inadequate spatial planning, 60-61

poor physical design, 59

recruitment of initial residents, 61-62

weaknesses in urban design, 60-61

macro developments

employment, decline of, 70-71

population developments, $69-70$

management of

housing allocation, 67

maintenance, 66-67

relative depreciation

housing stock, size of, 63

local housing market, characteristics of, 63-64

tenure, 65-66

renewal, 68-69

DEGEWO, 101

De-industrialisation, 266

Demographic changes of housing estates

Athens, 88-91, 90f, 92f, 93t

Brussels, 151-157, 154t, 155t, $157 f$

Helsinki, 223-227, 224-226f, 227-228t, 229f, 229t, 230f, 231-232t

Demolition of housing estates, 4, 16, 209

Denmark, population developments, 69

Densification, 176-179, 176f, 184, $185 f$

Density, $184-186$

DEPOS, 94-95

Deprivedhoods, 20

Deprived neighbourhoods, 12 , 314, 318-320

De Taeye Act, 147

De-urbanisation, 266

die Platte, 100

Diffusion of large housing estates, 271-276, $271 f, 273-275 f$

Displacement, 314

Dissimilarity index (DI), 159-160, 160t

Distribution of housing estates, 200-202, 201f, $201 t, 203 f$

Do-it-yourself urbanism, 19

Drumul Taberei, 173, 174f, 176

Dutschke, Werner, 100 
Düttmann, Werner, 105

E

East Berlin

Hohenschönhausen estate, 100, 109-111

large housing estates, formation of, 103-104

Marzahn estate, 100, 101, 109-111, 116f, $117 f$

See also Berlin; Germany

East End estate, 69

Ebert, Wils, 100

Ecological footprints, 25

Educational stratification, 300

Electoral pattern of stratification, 300-302

Employment, decline of, 70-71

Energy efficiency, 182-183

Energy Saving Loan Program, 208

England. See United Kingdom (UK)

Equality and Citizenship law of 2017 (France), 335

Equity, 25

Estate Action (1985-1994), 124

Estates Renewal Challenge Fund (ERCF), 124, 131,135

Estonia

Estonian Union of Apartment Associations (EUAA), 403

population developments, 69

See also Tallinn

Ethnic diversity, 255-257

Ethnic segregation of large housing estates, 157-160, 158f, 159f, 160t, 276-279, $276-279 t$

Etrimo S.A. estate, 148

European Structural Funds, 349

European Union energy directives, 22

\section{F}

Falkenhagener Feld estate, 100, 103

Ferencváros Community Association

Fund for the József Attila Housing Estate, 211

15-Year Housing Development Plan (1960), 43

Finland

Building Act of 1959, 217

Planning Act (Asemakaavalaki) of 1931, 217

reputation of housing estates, 21

See also Helsinki

First wave of Soviet housing construction, 291

Fleig, Karl, 106
Fourth wave of Soviet housing construction, 294-296

France

City Policy (Politique de la Ville), 81, 319-320, 331

Equality and Citizenship law of 2017, 335

large housing estates, 37, 43

Ministry of Reconstruction and Planning, 317

'one million homes' in, 8

Priority Zones for Urban Development (Zones à Urbaniser en Priorité/ZUP), 317

private ownership of apartments, 20

Right to Oppose Housing law of 2007, 335

urban renewal, 68-69

Zones Urbaines Sensibles, 68-69

See also Paris

Francoism, 253

G

Gagès, Frenchman, 105

Gagès, René, 105, 106

Garden Cities, 13

healthier, 39

Gated communities, 178-179, 330f

GEHAG, 101

Gemeinnützige Wohnungsbaugesellschaften, 101

General Urban Development Plan 1944

(Madrid), 243

General Urban Development Plan 1963

(Madrid), 244-245

Gentrification, 15, 25, 59, 71, 89, 105, 138, 139, 143, 192, 300, 301, 304, 307, 313, $314,317,334,335,381,383$

Geographical data, 26-27

Germany

German Creditanstalt für Wiederaufbau, 208

high-rise estates, 46

large housing estates, 36

Plattenbau, 44

recruitment of initial residents, 62

Social Democratic Party, 101

Socially Integrative City (Soziale Stadt), 51

Wohnraumbewirtschaftungsgesetz (Law on the Management of Dwelling Space), 102

See also Berlin; East Berlin; West Berlin

Gescal (Gestione Case per Lavoratori, Institute for the Administration of Worker' Houses), 268, 272 
GESOBAU, 101

Gheorghi-Dej, Gheorghe, 172

Ginzburg, Moisei, 105

Glasgow

decline of large housing estates, management of, 67

East End estate, 69

Gorbals, the, 47

large housing estates, 38

Global financial crisis of 2008-2009, 297

Gloriette housing estate, $199 f$

Golden ghettos, 298

Government involvement, in large housing estates, 39

Grands ensembles, 313-317, 334

Gran San Blas, 60

Gratosoglio, 267, 273-275, 273-275f

Greece

Ministry of Public Works, 94

Ministry of Reconstruction, 94

Ministry of Social Care, 79, 80f, 82f, 83, 86, 94

population developments, 69

See also Athens

Grenfell Tower, 143

Gropiusstadt estate, 100, 103

Gropius, Walter, 100, 101, 364

Großsiedlung, 100

Grupo Marcelo Usera, $247 f$

Guardian, The, 4

Gubacsi housing estate, $195 f$

\section{H}

Haddon Tower, explosive demolition of, 134, $137 f$

Halle-Neustadt estate, 103

Hans-Loch-Viertel estate, 100

Havanna housing estate, $198 f$

Heinrichs, Georg, 100, 105, 106

Hellersdorf estate, 100

Helsinki, 5

distribution of housing estates, $14 f$

Neighbourhood Unit Plan, 218, $220 f$

Plan of a Decentralised Town, 218, $220 f$

population developments, 70

spatial social mixing in post-World War II

housing estates, 215-239

local social life, 229-230, 233-235, $234 f$

national interpretations of planning

ideologies, 218-222, 219-222f

planning and construction, 216-218, $218 f$ socio-economic and demographic changes, 223-227, 224-226f, 227-228t, 229f, 229t, 230f, 231-232t

tenure, 65

See also Finland

High-quality small scale housing estates, implantation of, 171-172, 172f, $173 f$

High-rise estates, 38, 43, 44, 44f, 46 problems associated with, $48 f$

High-rise Housing in Europe, 9

Hloubětín housing estates, 349

Hohenschönhausen estate, 100, 109-111

Home Loss and Disturbance Payments, 139

Honecker, Erich, 100, 104

Hong Kong high-rise estates, 46

Horizontal Property Act of 1960 (Spain), 245

Horseshoe Development, 100

Housing Action Trusts (1988-2007), 124

Housing Act of 1971 (Hungary), 198

Housing allocation, 67

Housing estates. See Large housing estates

Housing Law of 1993 (Hungary), 203

Housing Market Renewal (2002-2011), 124

Housing policies, 146-148

Housing renovation, municipal and national initiatives for, 405-406

Housing stock management of, 59 size of, 63

Howard, Ebenezer, 39

Hoyerswerda estate, 103

Hungary

Energy Saving Loan Program, 208

15 -year housing development programme, 195

Housing Act of 1971, 198

Housing Law of 1993, 203

Hungarian Central Statistical Office, 200

Hungarian Development Bank, 208

Ministry of Economy, 208

'one million homes' in, 8

'Panel Programme,' 208

population developments, 69

recruitment of initial residents, 62

See also Budapest

I

IAURIF, 270

Ideal Tower, $115 f$

Île-de-France region, 314, 317, $321 f$

Iliako Chorio (Solar Village), 84 
'Image of the City, The' (Lynch), 106

INA Casa (Istituto Nazionale Assicurazioni

Casa, Institute for Social Housing), 268

Income inequality, 25

Indefensible space, 61

Institute of Planning and Development, 349

International Monetary Fund (IMF)

debt repayment austerity, 176

International Standard Classification of Occupations (ISCO), 206

Intervention strategies, 22-25

IPRM programme, 349

Istituto Autonomo Case Popolari (IACP, Institute for Public Housing), 266-268, 272, 273, 285

Italy

high-rise estates, 46

See also Milan

Jacobsen, Arne, 101

Jacobs, Jane, 46-47

Jephcott, Pearl, 47

John Russell Court, 67

József Attila housing estate, 196f, 210, 211

$\mathbf{K}$

Karlín Park, $355 f$

Kazakhstan recruitment of initial residents, 62

Khrushchëvki housing estates, 290, 293-294, $294 f, 391$

demolition of, 304-306

reconstruction of, 304-306

renovation of, 304-306

social stratification of, 298, $299 f$

Khrushchëv, Nikita, 103, 290, 293

Kivinen, Olli, 218

Kombinate, 103

Komplexer Wohnungsbau, 109

KredEx, 405-406, $406 f$

Krupp estate, Berndorf, Austria, 39

$\mathbf{L}$

La Cité Moderne, $152 f$

La Courneuve estates, 323-325, 324f, 330, 331-332

impoverishment in, 332-333

Lakatos Street housing estate

Agora Local Patriot Association, 211

Land expropriation, 243

Land-for-flats system (antiparochi), 83

Large housing estates, 3-28

contemporary urban life, 25-26 critiques against, 46-47

definition of, 9,38

densities and location of, 15-17

distribution of, $14 f$

in Europe, formation of, 7-8

features of, 37-38

geographical data, 26-27

intervention strategies, 22-25

learning from mistakes, $27-28$

motives for building, 42-43

physical design and built environment of, $35-54$

position on housing ladder, 17-18

private ownership of, 18-20

reputation of, 20-22

roots of, 38-40

secrets of, $35-36$

universal problem of, 13-15

variations between countries, 11-13

Lasnamäe estate, 13

Latvia

local housing market, characteristics of, 64 population developments, 69

Lausanne Treaty (1923), 78

Le Corbusier, 40, 60, 105, 110, 317, 364

Le Creusot and Dolfus, Mulhouse, France, 39

Lee, Chen-Kuen, 105, $114 f$

Le Foyer Laekenois, 162

Lehovec housing estates, 351

Leipzig

local housing market, characteristics of, 64

Letchworth, 39

Lever's Port Sunlight, England, 39

Lidé a sídliště (People and Housing Estates), 340

Lithuania, population developments, 69

Local housing market, characteristics of, 63-64

Local social life on housing estates, 229-230, 233-235, $234 f$

Location of large housing estates, 15-17, 171f, 254, 256f, 271-276, 271f, 273-275f, $320-323,321 f, 322 f, 366 f$

Lochères, 316

Lods, Marcel, 316

\section{M}

Mac Mahon, 267

Madrid, 5

General Urban Development Plan 1944, 243

General Urban Development Plan 1963, 244-245

Gran San Blas, 60

large housing estates 
challenges to, 254

data and methods, 246-249, 247t

distribution of, $14 f$

diversity of trajectories of, 241-261

ethnic diversity, 255-257

evolution of, 243-246, 243f, $244 f$

political responses to, 254

social change, types of, 249-254, 250t,

$251 t$

social composition of, 16

social polarisation, 255-257

urban policies, 257-260, $259 f$

Social Urgency Plan 1957, 244

See also Spain

Madrid City Council, 258

Madrid Recovers Plan (MAD-RE), 258, 260

Markelius, Sven, 363, 364

Market liberalisation, 111-112

Märkisches Viertel estate, 100, 101, 103, 105-109, 109f, 110f, $114 f$

Marzahn estate, 100, 101, 109-111, 116f, 117f

Mass housing in 20th-21st centuries, evolution of, 291-297, 292f, 294-296f, 298f, $299 f$

Mass quality housing, $172-176,174-178 f$, 178-179

Master Plan of Bucharest (2014), 169

Mettewie buildings, $153 f$

Mikrorayons, 169n1, 175, 179, 181, 393, 395, 405

Milan, 5

large housing estates, 265-286

ageing problem, 279-283

critical points and challenges, 283 , 285-286

distribution of estates, $14 f$

genesis and evolution of, 266-270, 269t

geographical data, 26

location and diffusion of, 271-276,

271f, 273-275f

physical decay, 279-283

reputation of, 21

social and ethnic succession, 276-279,

276-279t

social segregation, 279-283, 280t, 281f, $282 f, 284 t$

See also Italy

Millions of homes, 40-42

Modernistic estates, traditional views of, $41 f$

Mortgage system, 348

Moscow, 5

"Comprehensive reconstruction of the areas

of five-storied apartment buildings," 305

contemporary urban life, 25

demolition of apartment buildings, 4, 16-17 distribution of housing estates, $14 f$

Khrushchëvki housing estates, demolition, reconstruction and renovation of, 304-306

mass housing in 20th-21st centuries, evolution of, 291-297, 292f, 294-296f

path-dependent development of mass housing, 289-308

socio-spatial stratification of, 297-304, $302 f, 303 f$

See also Russia

Motives, for building large housing estates, 42-44

Moving to Opportunity project, 23

Müller, Hans, 100

Musil, Jiří, 340

Mustamäe estate, 16

"My Street," 307

$\mathbf{N}$

Neighbourhood Governance-Capacity for Social Inclusion, 380

Neighbourhood Remodeling Plan (Spain), 245, 246, 253, 255, 260

Neighbourhoods

community activism in, rising, 408-409, $409 f$

construction procedure, 217

deprived, 12, 314

internal spatial structures of, 12-13

population composition of, 58-59

priority, $325,326,327 t$

renewed, $327 t$

scheme, 193, 218-220, 293

traditional, modern architects' view of, $41 f$ unit, 110

Neighbourhood Unite Scheme, 293

Neighbourhood Unit Plan, 218, $220 f$

Netherlands, the

Agnetapark, 39

Big City Policy (Grote Steden Beleid), 51

housing allocation, 67

large housing estates, 43

tenure, 66

New Deal for Communities (1998-2010), 124

New Lanark, Scotland, 39

New Town Movement, 39

Nokia, 222

Nordic Welfare State, 217

O

Obvodni podnik bytového hospodárství

(OPBH), 345

Olypiako Chorio estate, $82 f$ 
Optima Community Association, 131

Orly estates, 323-325, 324f, 330, 332 urban and social fragmentation in, 332-333

Oslo

housing stock, size of, 63

tenure, 65

Ostermann, Natan, 294

Outcomes, 47

$\mathbf{P}$

PADOG, 317

'Panel Programme,' 208

Pankrác housing estates, 343, $345 f$

Pantelimon, 173

Papageiensiedlung (Parrot Scheme), 106

Paris, 5

banlieues problem, 4, 318

deprived neighbourhoods, 318-320

large housing estates, 12, 13

built environment, improvement of, 329-330, 330f

demolition of, 16

distribution of, $14 f$

impoverishment and social

fragmentation in, 313-336

impoverishment in La Courneuve, 332-333

internal segmentation, 323-325, $324 f$

large families concentration, $326 t, 327 t$

location of, 320-323, 321f, 322f

poverty concentration, $327-328,329 t$

reputation of, 21

social gaps and spatial differentiation, 325-328

urban and social fragmentation in Orly, 332-333

population growth, 316-318

relocated households, reconcentration of, 331-332

upper-working class residents, opportunities for, 332

urban renewal, 316-318 paradoxical effects of, 331

See also France

Park Hill housing project, Sheffield, 70

People-based policies, 23-24

Periphery, 272, 286

Perry, Clarence, 40, 105, 110, 173, 193, 218-220, 293

Philanthropists, 38-39

Physical decay, 279-283, 280t, 281f, $282 f$

Physical layout of housing estates, 179-180

Piano Intercomunale di Milano (PIM,

Inter-municipal plan of Milan), 266, 276
Place-based policies, 23, 24-25

Planes de Barrio (Neighbourhood Plans), 258, $259 f, 260$

Planned neighbourhood, housing estates as, 40

Planning Act (Asemakaavalaki) of 1931

(Finland), 217

Plan of a Decentralised Town, 218, $220 f$

Plattenbau, 44

Poblado Dirigido de Orcasitas, $249 f$

Poblados de absorción (absorption settlements), 244

Poblados de gestión social (social urbanistic management settlements), 244

Poblados dirigidos (guided settlements), 244

Poblados mínimos (minimal settlements), 244

Points-style architecture, 180, $181 f$

Poland

population developments, 69

private ownership of apartments, 20

Policy/policies

interventions, 23-25

connectivity-based, 23

people-based, 23-24

place-based, 23, 24-25

urban renewal, 50-51

Political responses to large housing estates, 254

Poor physical design, 59

Poor quality, 176-178, $177 f$

Population change, characteristics of, $329 t$

Population developments, 69-70

Population shifts, 394-401, 395f, 397t, 398-400f

Post-privatisation condominium governance, 187

Post-socialist transformation, 192

Post-socialist transition of housing estates, 207-211

Post-Soviet period of construction, 296-297

Post-transformation development, 353-354

Post-war housing development, 205, 215-239, 390

Poverty, 327-328, 329t

Prague, 5

large housing estates in, 339-356 distribution of, $14 f$

future developments, 354-356

general development and socio-spatial differentiation, 347-353, 350t

history of, 341-343, 343f, 344t, $345 f$

post-transformation development, 353-354

socio-spatial structure within Socialist housing estates, development of, 345-347 
Metropolitan Plan of Prague, 354

Prague City Assembly, 348

Prague City Council, 348

See also Czechoslovakia

Prefabricated housing estates, 158, 207, 208, $212,218,318,391-392,392 f$

Principal components analysis (PCA), 248

Priority Estates Project (1979-1987), 124

Priority neighbourhoods, 325, 326, 327t

Priority Zones for Urban Development (Zones

à Urbaniser en Priorité/ZUP), 317

Private actors, in new housing construction, 406-408

Private housing developments, 253-254

Private large housing estates, 163

Private ownership of apartments, 16, 18-20

Privatisation of apartments, 402-403

Pruitt-Igoe housing estate, 168

Pruitt-Igoe Myth (documentary), 70

Public actors, in new housing construction, 406-408

Public housing developments, 254

Public large housing estates, 161-163

Public-private partnerships, 364

Q

Quality of schools, 22-23

Quartieri autonomi (selfsufficient neighbourhoods), 268

$\mathbf{R}$

Radiant City, 110

Real estate developers, weak planning biased toward, $186-187$

Reappraisal, 59

Recruitment of initial residents, 61-62

Refugee Care Fund (TPP), 79

Refugee Rehabilitation Committee (EAP), 79

Regional Federation of Neighbourhood

Associations of Madrid (FRAVM), 258

Relative depreciation, 58

housing stock, size of, 63

local housing market, characteristics of, 63-64

tenure, 65-66

Relocated households, reconcentration of, 331-332

Renewal, 52-53, 59, 68-69

Renewed neighbourhoods, $327 t$

Renoviction, 381

'Repair the façade,' 405

Reputation of housing estates, 20-22

Residential change, 112-117, 114-117f

Residential segregation, 25, 64, 146
Restate project, 4-6, 9, 242, 260, 380, 381

Restoration of urban space, 243

Riga

local housing market, characteristics of, 64

Right to Buy, 19, 124, 132, 203

Right-to-Buy Act of 1980 (UK), 65, 66, 69

Right to Oppose Housing law of 2007 (France), 335

Ring municipalities, 223

Rinkeby housing estates, 373-380, $375 f$ average disposable income, $380 f$ employment rates, $378 f, 379 f$ ethnic background of, $377 f$ socio-economic and demographic composition of, $376 t$

Romania population developments, 69 reputation of housing estates, 21

Roots of large housing estates, 38-40

Roundtable of the Haabersti Apartment Association, 409

Russia

contemporary urban life, 25

Russian Revolution of 1917, 290

See also Moscow

S

Salin, Edgar, 103

Salvisberg, Otto, 100

Sant Roc, 67 renewal of, 68

Sarcelles, 60

Sarcellite, 318

Scandinavia high-rise estates, 46

Scharoun, Hans, 105

Schudnagies, Karl, 106

Scotland high-rise estates, 61

New Lanark, 39

Second wave of Soviet housing construction, 291, 293

Segmentation, internal, 323-325, $324 f$

Segregation of large housing estates ethnic, 157-160, 158f, 159f, 160t, 276-279, 276-279t

residential, 25, 64, 146

social, 276-283, 276-279t, 280t, 281f, $282 f$

socioeconomic, 157-160, 158f, 159f, 160t

Self-governance of housing estates, 210

Sentinels, $138 f$

Sharing economy, 25

Sídliště, 340

Siedler, Wolf Jobst, 108 
Siedlungen, 36, 100

Siedlung Schillerpark, 100

Single Regeneration Budget (1994-2008), 124

Sink estates, 48-50

cycles of decline, 49

design of, 49-50

developments and deterioration, 48-49

Size distribution of large housing estates, $201 t$

Slovakia, population developments, 69

'Slum Quarter of Birmingham, The,' 131

Slums, $133 f$

Small housing companies, 234

Social apartment base, 222

Social change in large housing estates, types of, 249-254, 250t, 251t

Social cohesion, 257

Social composition of housing estates, 16, 18, 180-187, 253

Social degradation, 401-402

Social deprivation, 279, $280 t$

Social housing, 102-103

defined, 266-267

Social polarisation, $255-257$

Social rental housing, 233

Social segregation of large housing estates, 276-283, 276-279t, 280t, 281f, 282f

Social space, $43,45 f$

Social Urgency Plan 1957 (Madrid), 244

Social vulnerability, 242

Società Umanitaria, 267

Société du Logement de la Région de Bruxelles-Capitale (SLRB), 162

Sociétés Immobilières de Service Public (SISP), 162

Socio-economic changes of housing estates

Budapest, 204-207, 204t, 205f, $206 f$

Helsinki, 223-227, 224-226f, 227-228t, $229 f, 229 t, 230 f, 231-232 t$

Socio-economic Segregation in European Capital Cities, 9

Socioeconomic segregation, large housing estates' impact on, 157-160, 158f, 159f, $160 t$

Socioeconomic status, 250

Socio-spatial differentiation, 347-353, 350t

Socio-spatial stratification of Moscow, 297-304, 302f, 303f

educational stratification, 300

electoral pattern of stratification, 300-302

via property, 298, 300

Socio-spatial structure of housing estates, 393-394

within Socialist housing estates, development of, 345-347
Söderqvist, Lisbeth, 363-365

Sofia

local housing market, characteristics of, 64

Solidarita housing estates, $345 f$

South Town housing estates, $345 f, 347 f$

Soviet Union. See Russia

Spain

Communist Party of Spain, 245

high-rise estates, 46

Horizontal Property Act of 1960, 245

large housing estates, 37

Madrid Recovers Plan (MAD-RE), 258, 260

Ministry of Public Works, 245

Neighbourhood Remodeling Plan, 245, $246,253,255,257,260$

'one million homes' in, 8

Planes de Barrio (Neighbourhood Plans), 258, 259f, 260

population developments, 69

Special Plans of Investment and Intervention (PEIA), 258, 260

See also Madrid

Spatial disintegration, 238

Spatial distribution of large housing estates, $201 f, 203 f$

Spatial planning, inadequate, 60

Spatial social mixing, 215-239

Special Plans of Investment and Intervention (PEIA), 258, 260

Splintering urbanism, 182

Stalin baroque, 194

Stalinki, 291, 293

State-socialism, 197

Stefan, Hans, 100

Stein, Clarence, 218

Stigmatisation, 401-402

Stockholm, 5

large housing estates, 13, 361-385

agenda, 381-383

Bredäng and Rinkeby estates, 373-380, 374f, 375f, 376t, 377-380f

challenges to, 380-381

characteristics of, 367-372, 368-369t, $371 t, 372 f$

distribution of, $14 f$

housing stock, size of, 63

interventions of, 380-381

local housing market, characteristics of, 63

location of, $366 f$

tenure, 65,66

urban renewal, 68

population developments, 70 
Stockholm City General Plan of 19451952, 363

Stockholm Exhibition 1930, 363

See also Sweden

St. Petersburg

local housing market, characteristics of, 64

Surround-style architecture, 180, $181 f$

Sustainability, 25

Sweden

Commission on Socially Sustainable Development (Kommissionen för ett socialt hållbart Stockholm), 382

contemporary urban life, 25

geographical data, 26

housing estates in, 363-365

Metropolitan Development Initiative, 51

'Million Programme,' 4, 8, 12, 43, 63, 362, 364-366

Social Democratic Party (SAP), 363

State Board of Construction, 364

See also Stockholm

Sygrotima, 85

Systematisation, 172

\section{T}

Tallinn, 5

larger housing estates in, 389-411

apartment associations, building, 403

community activism in neighbourhoods, rising, 408-409, $409 f$

decline management, 66

distribution of, $14 f$

housing renovation, municipal and national initiatives for, 405-406

local housing market, characteristics of, 64

new approaches to urban planning, 404-405

origin of, 391-393, $392 f$

place-based policy interventions, 24

population of, $390 t$

population shifts, 394-401, 395f, 397t, 398-400f

private ownership of, 19

privatisation of apartments, 402-403

public and private actors in new housing construction, 406-408

social composition of, 16

social degradation, 401-402

spatial and socio-spatial reality in, 393-394

stigmatisation, 401-402

urban policies, 257-260, 259f, 402-409
Lasnamäe estate, 13

Mustamäe estate, 16

Tapiola Garden City, 218

Taut, Bruno, 100

Tenant Management Organisations (TMOs), 125

Tensta estate, 69

Tenure, 65-66, 86-88, 90f

diversification, 314

mixing, 221

structure, $350 t$

Tér-Köz (Public-Space) programme, 211

Thatcher, Margaret, 61

Third wave of Soviet housing construction, 293-294

Thomson, James, 40

'Tidy up the yard,' 405

Titan, 173, $174 f$

Total entrepreneur, 364

Traditional neighbourhoods, modern architects' view of, $41 f$

Trajectory of large housing estates, $256 f$

Trölitzsch, Gerhard, 110

$\mathbf{U}$

UGIS (Urban Governance, Inclusion and Sustainability), 380

Ukraine, high-rise estates, 46

Ulbricht, Walter, 100

Ungers, Oswald Mathias, 105, 106, $114 f$

Unité, 60

United Kingdom (UK)

demolition of apartment buildings, 4

high-rise estates, 46

housing allocation, 67

Lever's Port Sunlight, England, 39

mass housing in, 121-125

National Strategy for Neighbourhood

Renewal, 51

poor physical design, 59

Right-to-Buy Act of 1980, 65, 66, 69, 124, 132

tenure, 65

See also Birmingham

United States (USA)

high-rise estates, 46

large housing estates, 37

Upper-working class residents, opportunities for, 332

Urban design, weaknesses in, 60

Urban differentiation, 235

Urban governance, 364

Urban Housing Renewal Unit, 124 
Urban infrastructure, 182

Urbanism and Urban Design Guide (López de Lucio), 246

Urbanität durch Dichte (urbanity-through-density), 103

Urban planning, 404-405

Urban policies, 257-260, 259f, 402-409

Urban regeneration, 209

Urban renewal

in Birmingham, 68

in France, 68-69

paradoxical effects of, 331

in Paris, 316-318

policies, $50-51$

Urban revitalisation, 257

Urban vulnerability, 242

Urban Vulnerability Index, 242, 247, 250, 251t

'Utopia on Trial' (Coleman), 49, 61

\section{V}

Van Der Meeren, Willy, 147

Vele, Naples, 65, 67

Velvet Revolution, 340, 341, 347, 348

Victorian terraced housing, $132 f$

Vienna, large housing estates, 38

Vilnius local housing market, characteristics of, 64

Vnukovskoe settlement, $298 f$

W

Wagner, Martin, 100

Weak planning, biased toward real estate developers, 186-187

Wekerle garden-city, 193, $193 f$

Welfare policy, 199

Welwyn, 39

West Berlin

Märkisches Viertel estate, West Berlin, 100, 101, 103, 105-109, 109f, 114f

See also Berlin; Germany

West Berlin Hansaviertel, 101

White City, 100

Wohnraumbewirtschaftungsgesetz (Law on the Management of Dwelling Space), 102

Wohnsiedlungen, 36

Wood, Shadrach, 106

Workers' Housing Organization (OEK), 78, $83-85,87$

$\mathbf{Z}$

Zones Urbaines Sensibles, 68-69 